by

I. G. Wilson

Kevin I. Olson

Mary G. Wallace

M. D. Osborn
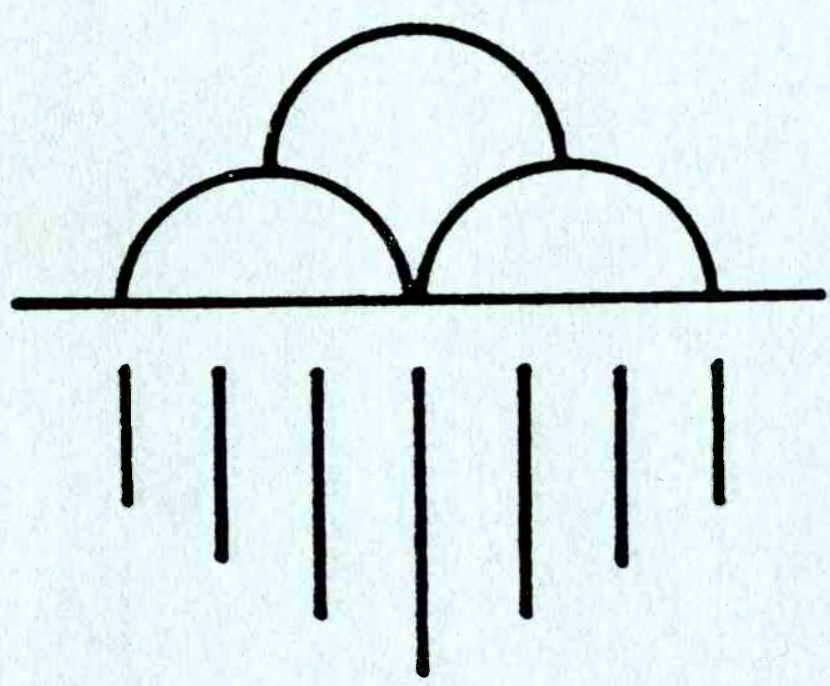

A Report by

The Water Resources Research Center

The University of Arizona, Tucson, Arizona

$$
\text { for }
$$

The Solar Energy Research Institute

1617 Cole Boulevard

Golden, Colorado 80401

(Subcontract No. XK-5-05083-1)

$$
\text { June 25, } 1986
$$




\title{
INVENTORY OF SOURCES OF AVAILABLE SALINE WATERS FOR MICROALGAE MASS CULTURE IN THE STATE OF ARIZONA
}

\author{
BY : \\ I.G. WILSON \\ KEVIN I. OLSON \\ MARY G. WALLACE \\ M.D.OSBORN
}

\section{A REPORT BY}

THE WATER RESOURCES RESEARCH CENTER

THE UNIVERSITY OF ARIZONA, TUCSON, ARIZONA

\section{FOR:}

THE SOLAR ENERGY RESEARCH INSTITUTE

1617 COLE BOULEVARD

GOLDEN, COLORADO 80401

(Subcontract No. XK-5-05083-1) 
This report comprises the results of an assessment of saline water resources in the state of Arizona potentially available for a microalgae biomass production facility. As a result of the assessment several surface water and ground-water resources were identified as being possibly suitable for subsequent detailed studies, involving both technical and legal-institutional considerations. Basic details on the follow-on studies are included in the report.

The authors wish to acknowledge the support and encouragement of the following individuals at the Solar Energy Research Institute: Mark Sorency, SERI Technical Staff and Bill Barclay, staff Algalogist. Other individuals who contributed to the completion of the report include Ms. Kay Warman, who assisted in word processing; Ms. Debbie Weller, who assisted in the compilation of data; Ms. Jean Clancy, who kept the books and records for the project; Rick Brokow, Kim Duffek, and Mary Jane Dupuy, who drafted the maps and related artwork for the project; George Smith with the United states Geological Survey who provided base maps and illustrations. Finally, the authors express special gratitude to Dr. Leo Leonhart for his technical review and valuable comments on the first draft of the manuscript. 
The Arizona water Resources Research Center was contracted by the Solar Energy Research Institute (SERI) to conduct an inventory of saline water resources within the state of Arizona. The purpose of this inventory was to identify on the basis of availability, chemistry, sustained yield, and institutional factors, the potential saline water supplies sufficient to maintain a microalgae production facility for eventual conversion of the algal biomass to synthetic fuel. Criteria for the inventory were specified by SERI. The six subtasks associated with the project are identified on the attached flow chart. The method of investigation involved a literature and data survey and interviews with key personnel in government or quasi-official agencies.

The principal data are included in the report together with a list of contacts. As a result of the survey conducted by the water Resources Research Center, six focal areas with saline ground-water resources were identified and ranked. The report includes a summary of the selection methodology, a description of the hydrogeology of each site and a thorough discussion of relevant institutional considerations, including permitting requirements under current ground-water associated laws in Arizona. Detailed maps are included of the saline surface water and ground-water sources. Recommendations are included for further evaluation by SERI of areas potentially suitable for a project.

\section{PRINCIPAL RESULTS}

The principal results of the study are as follows:

- Saline Surface Water

Thirty-four sources of saline surface water were identified. of these, only eight were adjudged to have a sufficient volume of water for a project. These sources included the Gila River, the Iittle Colorado River, and drainage from the Buckeye Irrigation District and from the Wellton-Mohawk Irrigation District. A future source in the Yuma area is brackish effluent from the reverse osmosis treatment plant near Yuma.

Total amount of saline surface water from the eight sources is estimated to be 3984 liters per day, or 13.4 million liters for a 10 year project.

\section{- Saline Ground-Water Areas}

Nineteen saline ground-water plumes were identified in the six focal areas as being capable of providing greater than 4 mgd. The following table includes a ranking of the focal areas as potential regions for a microalgae production facility, together with information on quantity of water in storage, water quality 


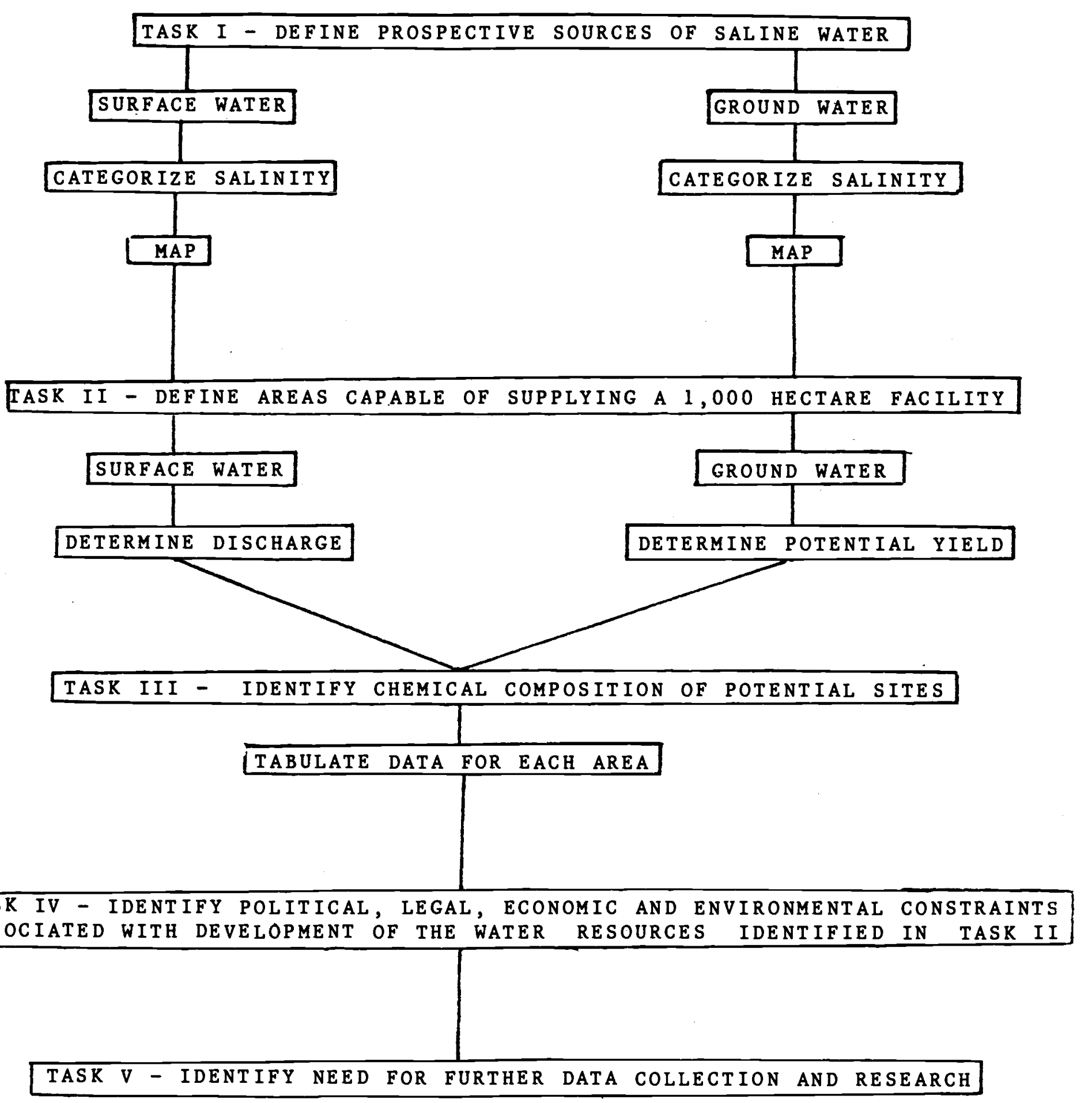

FLOW CHART SHOWING MAJOR TASKS ASSOCIATED WITH THE PROJECT TO INVENTORY SOURCES OF AVAILABLE SALINE WATER IN ARIZONA 
and institutional considerations:

\section{SUMMARY OF SALINE GROUND-WATER AREAS}

\begin{tabular}{|c|c|c|c|c|c|}
\hline $\begin{array}{l}\text { Area } \\
\text { (by } \\
\text { rank) }\end{array}$ & Location & $\begin{array}{l}\text { Number } \\
\text { of } \\
\text { Plumes }\end{array}$ & $\begin{array}{l}\text { Total } \\
\text { Quantity } \\
\text { (liters) }\end{array}$ & $\begin{array}{l}\text { Water } \\
\text { Type }\end{array}$ & $\begin{array}{l}\text { Institutional } \\
\text { Considerations }\end{array}$ \\
\hline
\end{tabular}

\begin{tabular}{|c|c|c|c|c|c|}
\hline II & Yuma & 2 & $1.4 \times 10^{13}$ & $\mathrm{NaCl}$ & $\begin{array}{l}\text { Outside of } \\
\text { Active } \\
\text { Management } \\
\text { Area; Gila } \\
\text { River } \\
\text { litigation }\end{array}$ \\
\hline III & Buckeye & 5 & $1.2 \times 10^{13}$ & $\mathrm{NaCl}$ & $\begin{array}{l}\text { Within } \\
\text { Phoenix } \\
\text { AMA }\end{array}$ \\
\hline VI & $\begin{array}{l}\text { Plateau } \\
\text { Uplands }\end{array}$ & 4 & $4.1 \times 10^{13}$ & $\mathrm{NaCl}$ & $\begin{array}{l}\text { Outside } \\
\text { of an } \\
\text { AMA; on } \\
\text { Navajo } \\
\text { Indian } \\
\text { Reservation }\end{array}$ \\
\hline
\end{tabular}

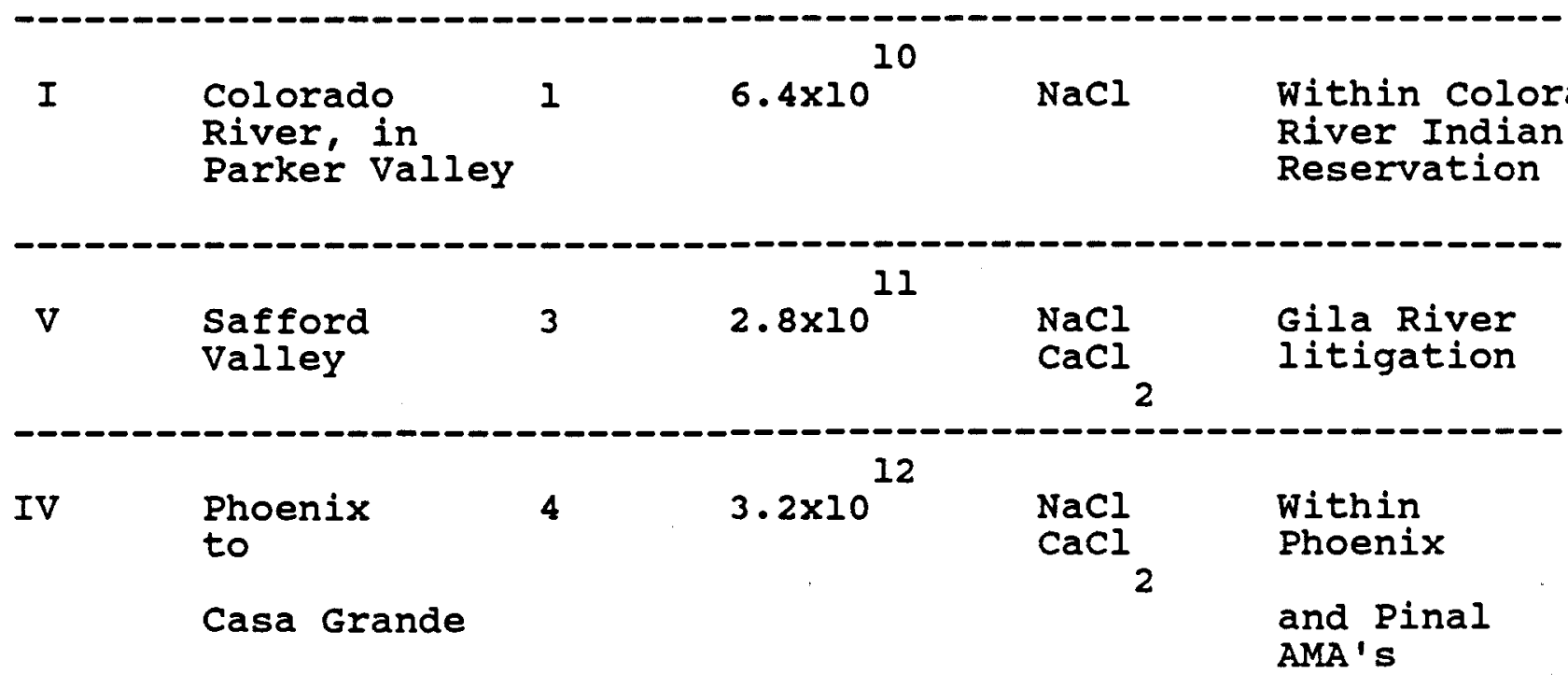

TOTAL $7.1 \times 10^{13}$ liters 
- Institutional Considerations

A microalgae production facility constructed in Arizona will require a permit from the Arizona Department of Environmental Quality, which will be an institutional entity in Arizona after July 1, 1987. Before a permit will be issued, it must be demonstrated that operation of a project will not adversely affect the quality of the underlying ground water. To ensure this protection, all ponds must be lined and monitoring wells must be installed. Additionally, if the project is located on state or federal lands, and if Federal environmental impact statement will be required. 
1.0 Introduction................................ 1

1.1 Background.............................

1.2 Project objectives.......................... 2

2.0 Water Resources of Arizona........................ 4

2.1 Hydrogeologic setting....................... 4

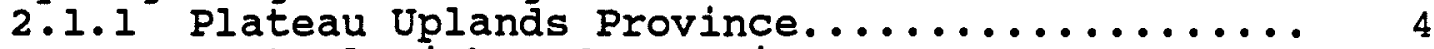

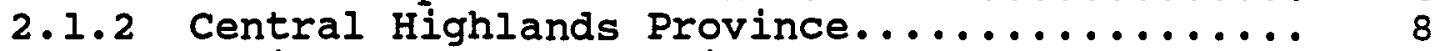

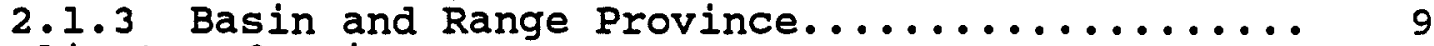

2.2 Climate of Arizona......................... 14

3.0 Methods................................... 15

3.1 Preliminary Inventory..................... 15

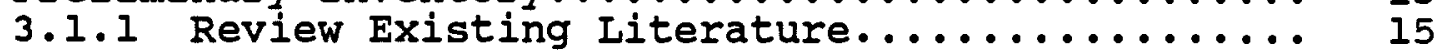

3.1.2 Contact Individuals and Agencies........... 15

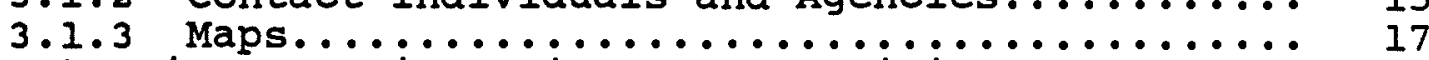

3.2 Determine Sustained yield of Identified Sources.... 17

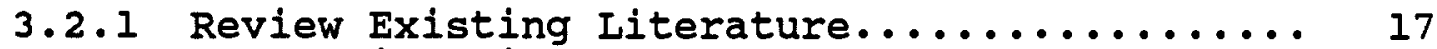

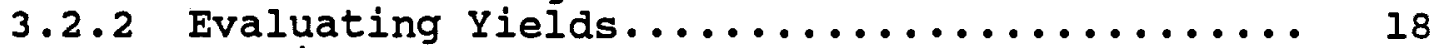

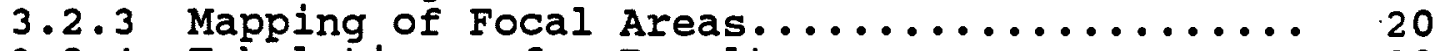

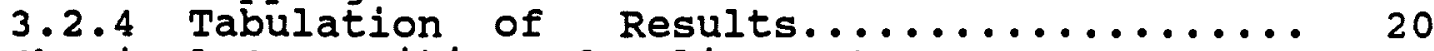

3.3 Chemical Composition of saline water sources...... 20

3.3.1 Obtain and Review Existing Water

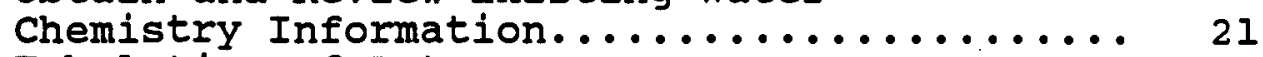

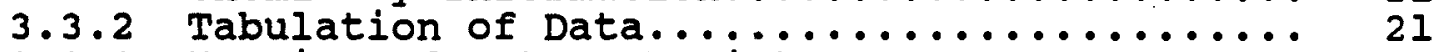

3.3.3 Mapping of Water Chemistry.............. 21

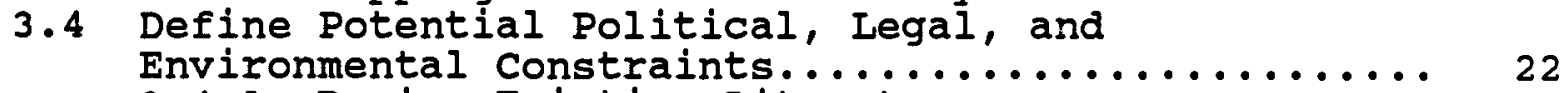

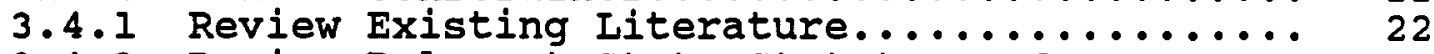

3.4.2 Review Relevant state statutes and

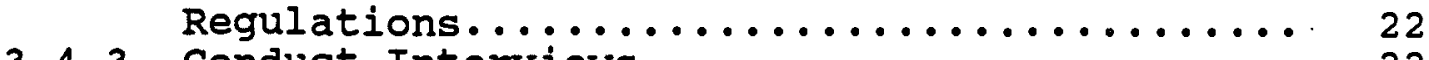

3.4 .3 Conduct Interviews.................... 22

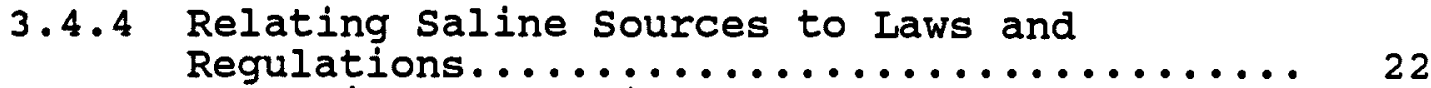

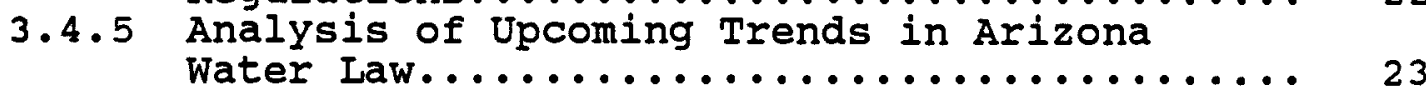

4.0 Results for Tasks I, II, and III.................. 24

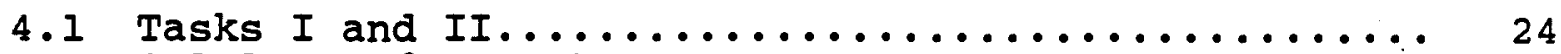

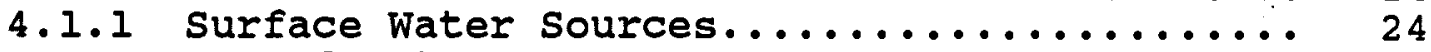

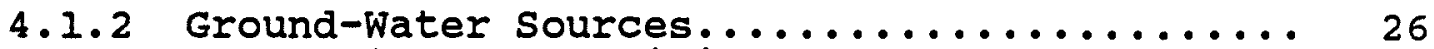

4.2 Task III, Chemical composition of sources......... 42

4.2 .1 surface water........................ 42

4.2 .2 Ground-Water sources.................. 46 
5.0 Institutional-Environmental Considerations............

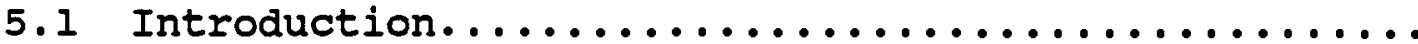

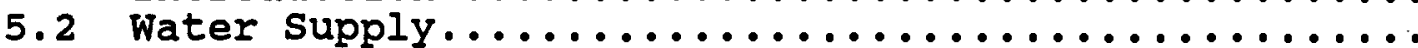

5.3 Arizona water Law.......................... 48

5.3 .1 Surface Water.................... 48

5.3 .2 Ground water................... 49

5.3.2.1 Arizona Groundwater Management

Act....................... 49

5.3.2.1.1 Grandfathered Rights... 50

5.3.2.1.2 Ground Water

Withdrawal Permits.....

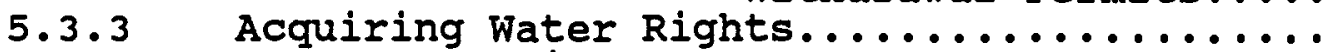

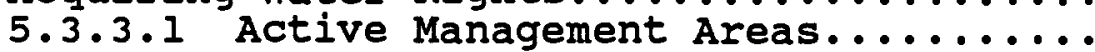
5.3.3.2 Purchasing Water Rights in an AMA.

5.3 .3 .3 Surface water Rights............

5.3.3.4 Ground water outside of AMA's.....

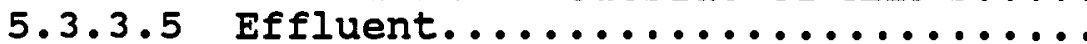

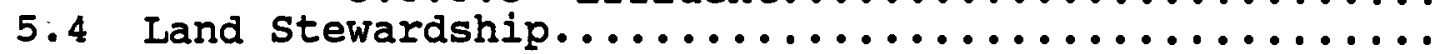

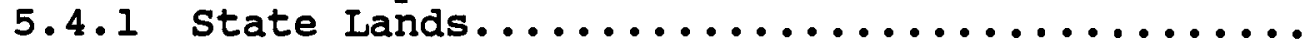

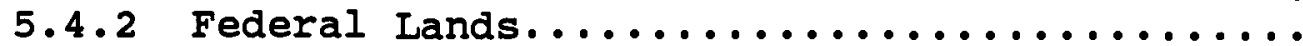

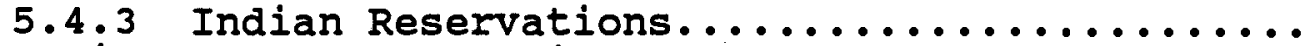

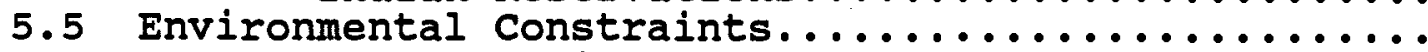

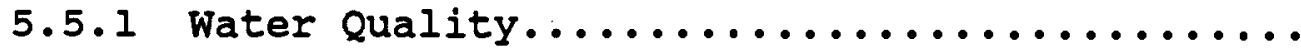

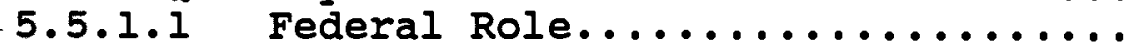

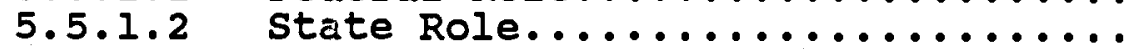

5.5.1.2.1 Permit Process.........

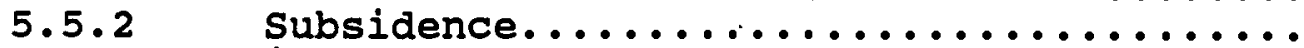

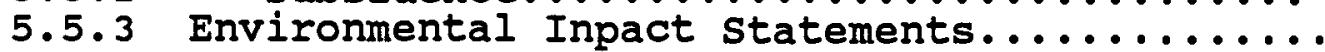

6.0 Focal Areas for a Possible Project................

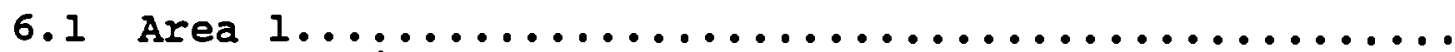

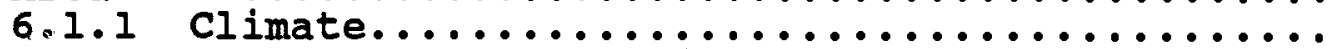

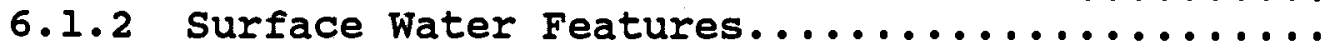

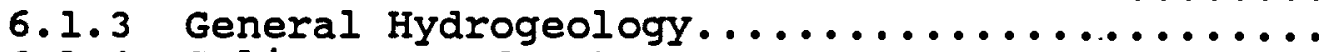

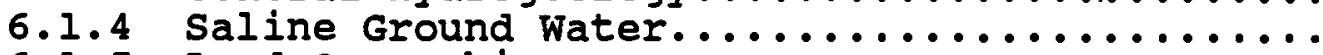

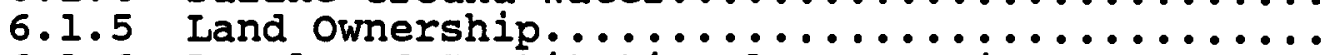

6.1.6 Legal and Institutional Constraints.........

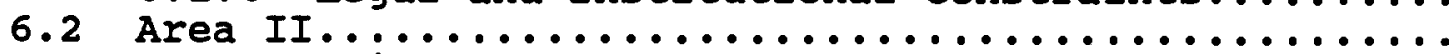

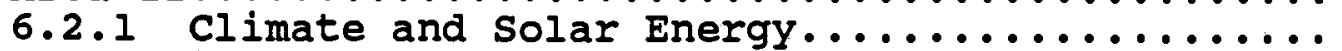

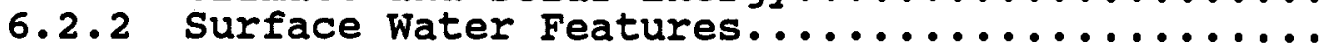

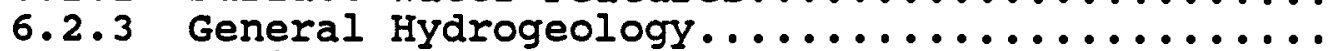

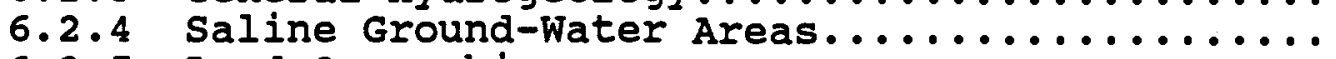

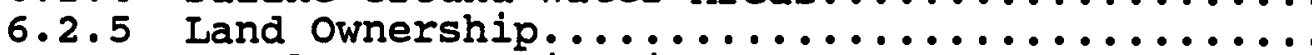

6.2 .6 Legal and Institutional Factors............

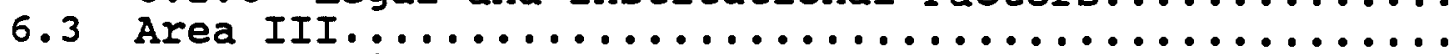

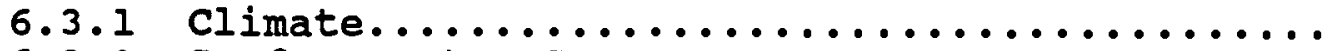

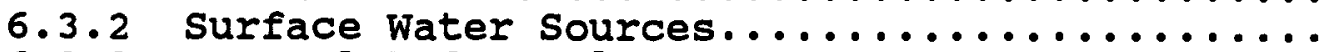

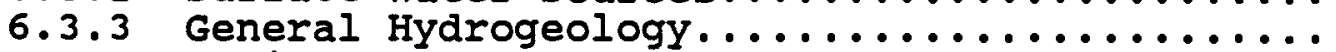

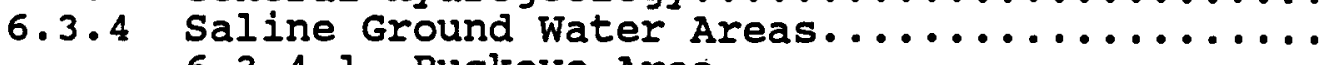

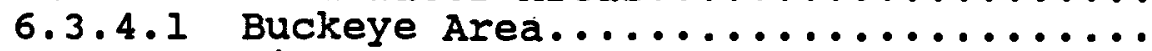

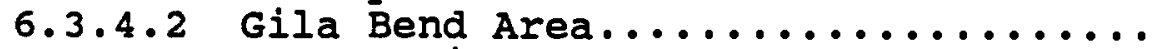
6.3.4.3 Rocky Point and Hyder Areas......... 
6.3.6 Legal and Institutional Factors.......... 85

6.4 Area IV................................ 87

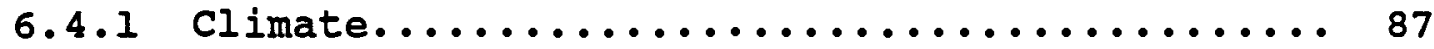

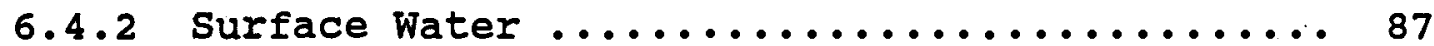

6.4 .3 Hydrogeology....................... 87

6.4 .4 Saline Ground-Water Areas............... 88

6.4 .4 .1 West Chandler Plume............. 88

6.4 .4 .2 South Mountains Area............ 89

6.4 .4 .3 Casa Grande Area................ 89

6.4 .4 .4 The Coolidge Area................ 90

6.4 .5 Land Ownership....................... 90

6.4 .6 Legal and Institutional Factors........... 90

6.5 Area V.................................. 93

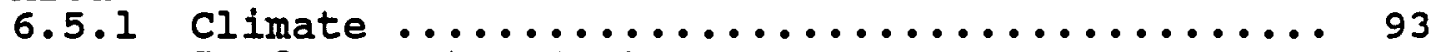

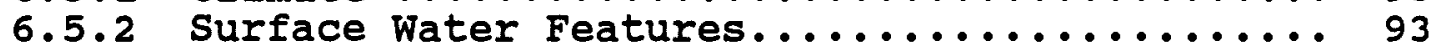

6.5 .3 General Hydrogeology.................... 94

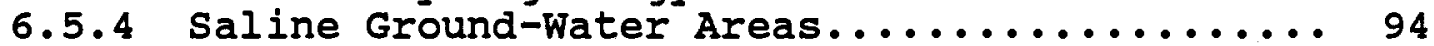

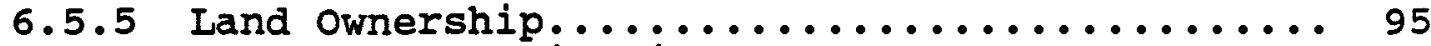

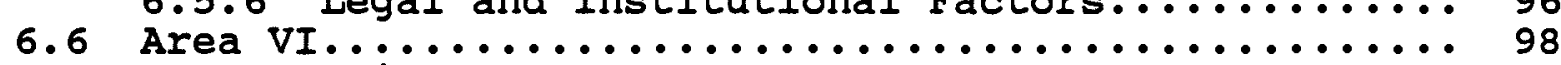

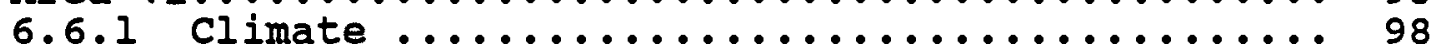

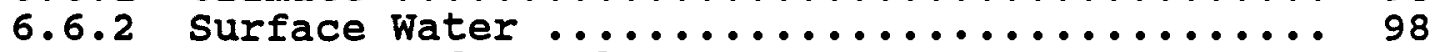

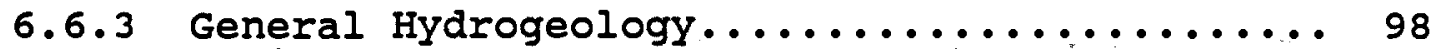

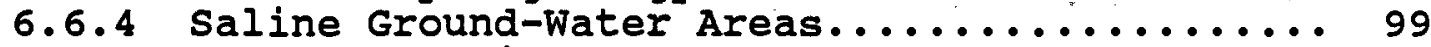

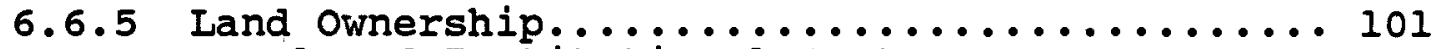

6.6 .6 Legal and Institutional Factors........... 101

7.0 Recommendations for Future work................... 103

7.1 Technical Activities........................ 103

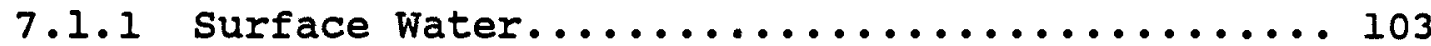

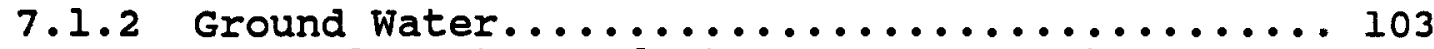

7.1.2.1 Water Budget and Ground Water

Flow Modeling................... 104

7.1.2.2 Well Design and Construction....... 105

7.1.2.3 Ground-Water Sampling for

Chemical quality................ 106

7.1.3 Conjunctive Use of Surface Water and

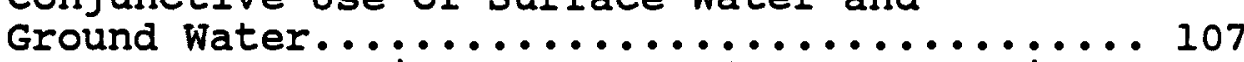

7.1.4 Effect of a Project on Ground-Water Quality.. 107

7.2 Institutional Activities.................... 107

8.0 Conclusions................................... 109

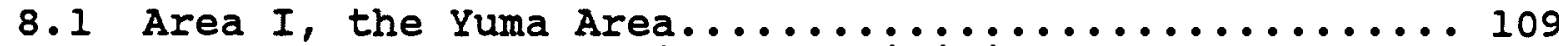

8.1.1 Water Production Capabilities............. 109

8.1.2 Institutional Considerations............. 109

8.2 Area III, The Buckeye Area................... 110

8.2.1 Water Production Capabilities............. 110

8.2.2 Institutional Considerations............. 110

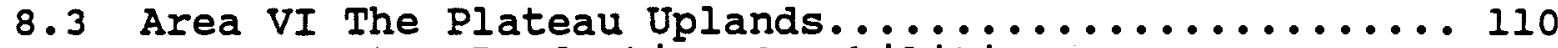

8.3.1 Water Production Capabilities.............. 110

8.3.2 Institutional Considerations.............. 110

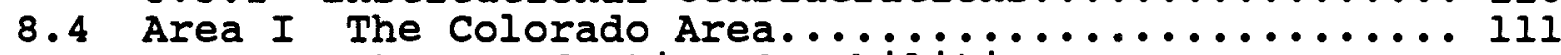

8.4.1 Water Production Capabilities............. 11l 

8.5
8.4.2 Institutional Considerations.............111
Area $V$ The Safford Valley Area................. III

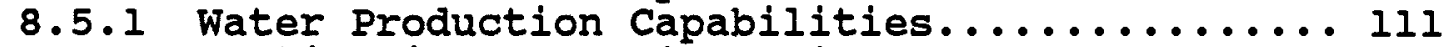

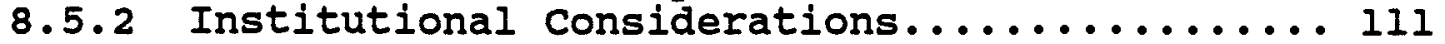

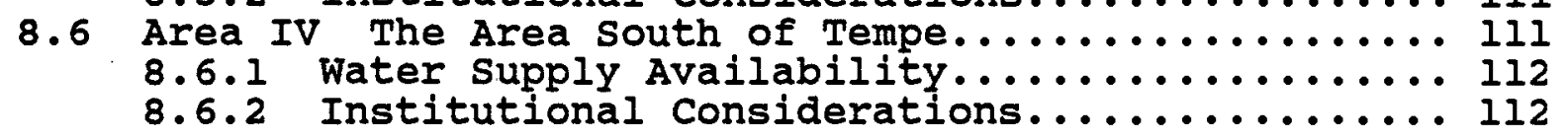

9.0 References.................................. 113 


\section{LIST OF FIGURES}

Page

2-1 Water Provinces in Arizona..................5

2-2 Ground-Water Basins in Arizona as

Designated by the U.S. Geolgoical survey..........6

2-3 Diagrammatic section showing the General

Quality of water from the $D, N$, and $C$

Multiple-Aquifer systems in the Plateau

Uplands Province (Davidson, 1979)...............

2-4 Categories of Geohydrologic Basins Based

on Regional Patterns of Aquifer Lithology

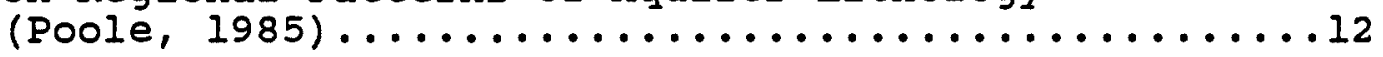

2-5 Generalized Basin struture and stratigraphy

within the Five Geohydrologic Categories of

Alluvial Basins in Arizona (Poole, 1985)..........13

3-1 Flow Chart Showing Major Tasks Associated

with the Project to Inventory sources of

Available Saline Water in Arizona..............16

4-1 Focal Areas and Designated Ground-Water Basins.....27

5-1 Map of Arizona Showing Location of

Active Management Areas and Irrigation

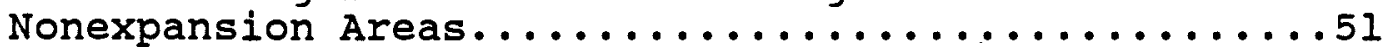

\section{LIST OF TABLES}

4-1 Saline surface water sources..................25

4-2 Possible Ground-Water Areas for a Project.........29

4-3 Sites with Insufficient Data to Determine Yield....35

4-4 Sites Unsuitable for Development...............36

4-5 Yield and Quantity Data...................43 


\section{IIST OF APPENDICES}

$\underline{\text { APPENDIX }}$

A

B

C

D
TITLE

Bibliography

List of contacts

Surface water Chemistry

Ground-Water Chemistry 
PIATE I Map Showing Total Dissolved Solids Content and Average Annual Yield for Saline surface Water Resources in Arizona

PIATE II Map Showing Total Dissolved Content of Saline Ground-Water Resources in Arizona

PLATE III AREA I - Map Showing Location and Chemical Composition of Saline Ground-Water Resources and Landownership along the Colorado River South of Poston, Arizona

AREA II - Map showing Location and Chemical Composition of Saline Ground-Water Resources and Landownership along the Gila River near Yuma, Arizona

PLATE IV AREA III - Map showing Location and Chemical Composition of Saline Ground-Water Resources and Landownership along the Gila River near Gila Bend, Arizona

PLATE V AREA IV - Map Showing Location and Chemical Composition of Saline Ground-Water Resources and Landownership along the Gila River near Casa Grande, Arizona

AREA V - Map Showing Location and Chemical Composition of Saline Ground-Water Resources and Landownership along the Gila River between Safford and Calva, Arizona

PIATE VI AREA VI - Map Showing Location and Chemical Composition of Saline Ground-Water Resources in the Coconino sandstone and Landownership in the Region near Winslow and St. John's Arizona 
SECTION 1.0

INTRODUCTION

\subsection{BACKGROUND}

The Solar Energy Research Institute (SERI) is conducting research on the development of microalgae biomass systems for the production of liquid fuels. Particularly appealing at this time is the idea of using indigenous resources of the southwest for large-scale production of microalgae. Such resources include flat land, saline water, and high incident solar radiation. $A$ current research emphasis is on the development of systems that would utilize inland saline waters (including ground waters and irrigation return flows) of the southwestern states where these biomass production systems would be located. Information on the quantity, quality, and location of available saline water resources will assist SERI in assessing the economic and technical potential of biomass systems and in the location of project sites. Similarly an assessment of water-related and environmental legislation, as well as institutional constraints, will define the legal, institutional and environmental impediments for a project.

A resource study conducted by Maxwell, et al. (1984) estimated that potentially 33 million acres are available for microalgae production in the southwest. This study was a broad-brush assessment and raised important questions. An analysis by Hill et al. (1984), evaluating the technical and economic feasibility of producing microalgae in the southwest, indicated that the availability of saline water could be the natural resource most likely to limit the extent to which this technology is developed. The study of Maxwell et al. (1984) indicated the presence or absence of aquifers with saline ground water, but did not attempt to develop data on potential yields from the aquifers or chemical composition of their waters. The analysis by Hill et al (1984) found that a saline water requirement of between 8 and 13 million gallons per day would be required for a 1,000 ha facility. The lower figure represents the water requirement of enclosed ponds (lower evaporation), whereas the higher figure is for open ponds. The analysis further indicated that wells should be less than 250-400 ft in depth and should be situated less than 10 miles from the facility boundary to meet cost feasibility requirements. The major issue raised by the analysis was whether there is enough saline water in the southwest to support extensive ( 1 quad or more) adoption of microalgae for fuels technology and continual production without harmful environmental impacts and at stable costs.

Maxwell et al (1984) addressed other constraints on practical and economic microalgae production, including annual insolation and growing season, the desert ecosystem, institutional factors relating to land and water ownership, land availability, and 
nutrient availability.

Among the southwestern states, Arizona closely matches the physical requirements for successful microalgae production. As pointed out by Osborn and Huddy (No Date), Arizona, in the heart of the sunbelt, offers ideal conditions for solar research and development. For example, Tucson averages approximately 1900 BTU's of solar energy per square foot per day, which is nearly $40 \%$ more than typical midwestern cities, and receives about 4000 hours of sunshine annually. Saline irrigation return flows exist, most notably in the Yuma and Buckeye areas. similarly, saline ground waters are present throughout the state, as documented by Kister (1973), Daniel (1981), and Thompson et al. (1983). Saline ground-water areas in the Colorado Plateau, in the Phoenix area, and in the safford Valley coincide with extensive salt deposits (Pierce, 1981).

Ample vacant land exists in the state, in proximity to saline water sources, including extensive holdings owned by the Federal government and by the state of Arizona. Extensive areas also reside in private ownership and within indian reservations. Both private landowners and indian governments may welcome the opportunity to develop saline water resources. Similarly, in some locations, farmers may be willing to lease their lands for a project.

Impediments to a project should also be noted. For example, extraction of ground water in certain designated areas may be constrained by the requirements of the 1980 Arizona Groundwater Management Act. Development of a project may also be affected by the requirements of recently-enacted ground-water quality legislation in the state, and by permitting requirements to protect ground-water quality.

\subsection{PROJECT OBJECTIVES}

The purpose of this report is to present the results of an inventory of saline water resources in the state of Arizona. The inventory was undertaken by the Water Resources Research Center, University of Arizona, for the Solar Energy Research Institute. The major objective of the study was to develop a more detailed assessment of the availability of saline water in Arizona for establishment of a microalgae production facility and to identify potential institutional and environmental constraints.

Specific objectives were as follows:

1. Task I, delineate areas with saline aquifers having static water levels within $500 \mathrm{ft}$ of the land surface (or deeper if economically feasible) and areas with large amounts of saline surface water, including irrigation return flows. For the purposes of this study, "saline" waters are those containing greater than $3,000 \mathrm{mg} / 1$ dissolved solids. 
2. Task II, establish areal classifications, as defined in the first objective, according to the following rates: less than 4 miliion gallons per day (MGD), 4-13 MGD, and greater than 13 MGD. Estimate aquifer life at these depletion rates.

3. Task III, define the chemical composition (major ions and nutrients) of the sources capable of yielding in excess of 4 MGD, as defined by the first and second objectives.

4. Task IV, define possible legal and environmental constraints to the utilization of these saline water resources.

5. Task $V$, identify needs for future research that will be required to refine site selection for a microalgae production facility. 


\subsection{HYDROGEOLOGIC SETTING}

According to Fenneman's (1931) classification, Arizona is situated within two of the major physiographic provinces of the southwestern United states: the colorado Plateau and the Basin and Range. From a hydrological perspective the state is divided into the following three water areas: the Plateau Uplands province, the Central Highlands province, and the Basin and Range Lowlands province (see Figure 2-1). The United States Geological Survey has further subdivided these provinces into subareas based primarily on hydrological distinctions, but in some cases on political boundaries (see Figure 2-2).

\subsubsection{Plateau Uplands Province}

According to Ligner et al. (1969), the Plateau Uplands Province occupies the northern 40 percent of the land surface in Arizona. Elevations range from $12,000 \mathrm{ft}$ in the San Francisco mountains to 4,000 to 5,000 ft along the Colorado River. Because of the relatively small amounts of rainfall each year, the high rate of evaporation, and water seepage, the surface runoff is minimal. Most water courses are dry except during times of heavy rainfall. Most surface water use occurs in the eastern end of the Mogollan Rim area along a few headwater streams. The area is sparsely populated with the Navajo Reservation covering much of the land area. Major land uses include cattle grazing and timber production.

The entire province is underlain by consolidated sedimentary rocks. These rocks consist mainly of a sequence of sandstone, siltstone, claystone and limestone. Alluvial deposits occur mainly along the major drainages. The principal drainage in the province is the Little Colorado River, which originates in New Mexico and empties into the colorado River.

The consolidated sedimentary rocks constituting the aquifers of this province comprise fine-grained sandstone units which generaliy do not yield water readily (Ligner et al.,1969). A generalized cross-section of the Plateau Uplands ground-water system is included as Figure 2-3. Limestone units store and transmit water, but the siltstone and claystone units act as confining layers. Multi-aquifer systems are common. The three principal aquifer systems are the $C$ (for Coconino sandstone), the $\mathrm{N}$ (for Navajo Sandstone) and the $\mathrm{D}$ (for Dakota Sandstone) multiaquifer systems. In contrast to other water-bearing formations, the c-aquifer can yield up to 2500 gallons per minute (gpm) from wells. The thin deposits of alluvium along the major water courses also yield ground water. According to the United states Geological survey (1985), the use of ground water in this 


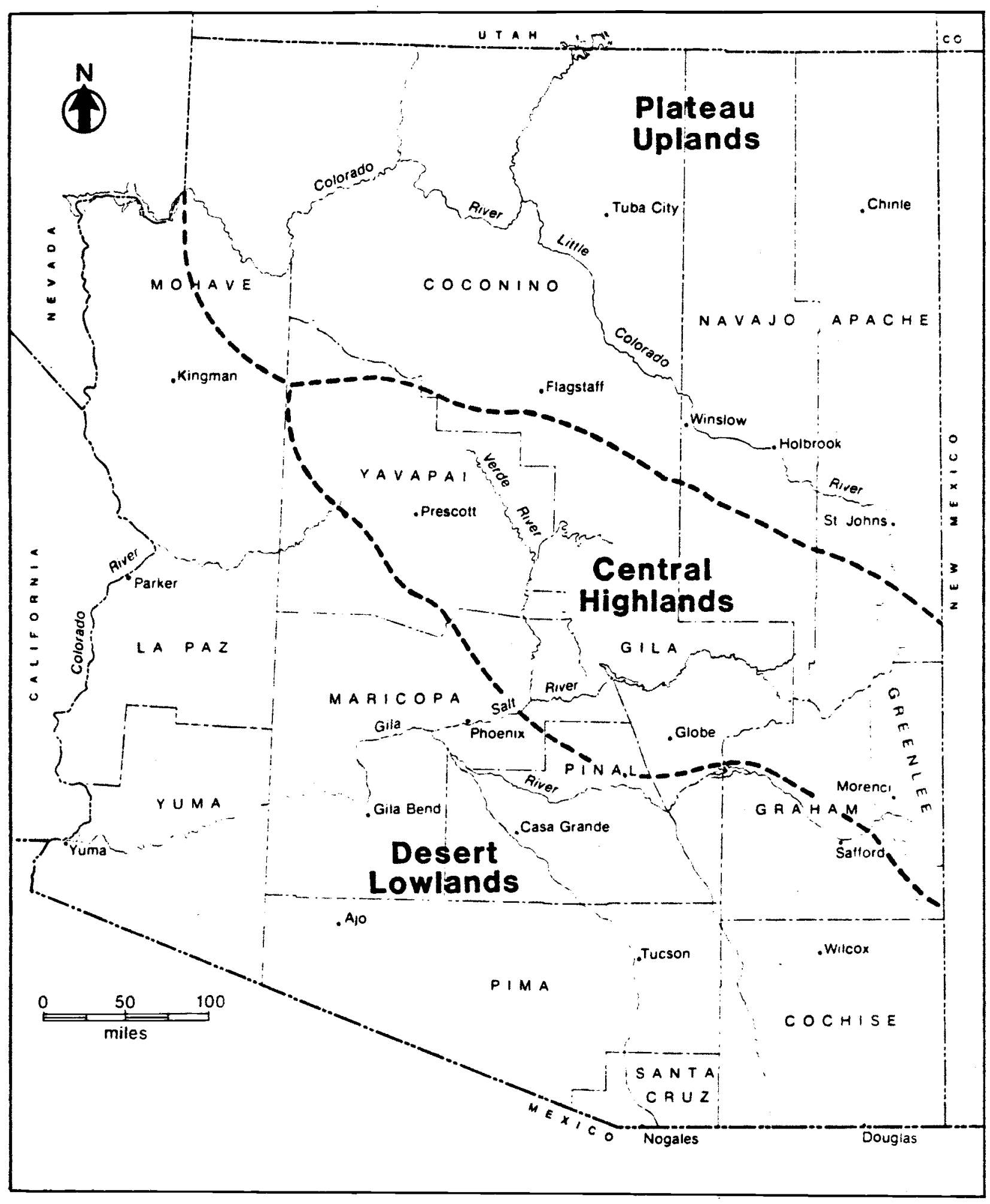

FIGURE 2-1. WATER PROVINCES IN ARIZONA 


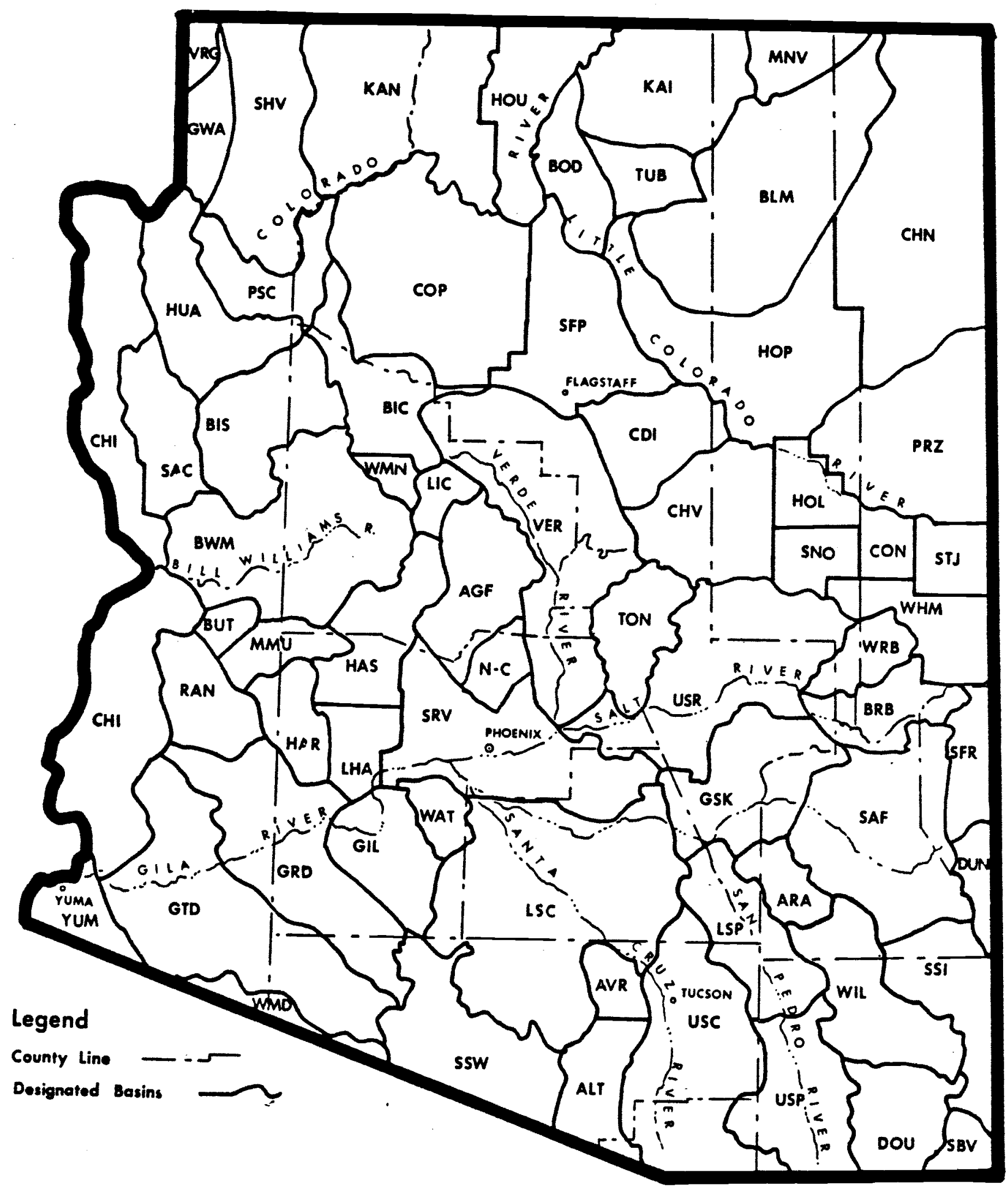

FIGURE 2-2. GROUND-WATER BASINS IN ARIZONA AS

DESIGNATED BY THE U.S. GEOLOGICAL SURVEY 


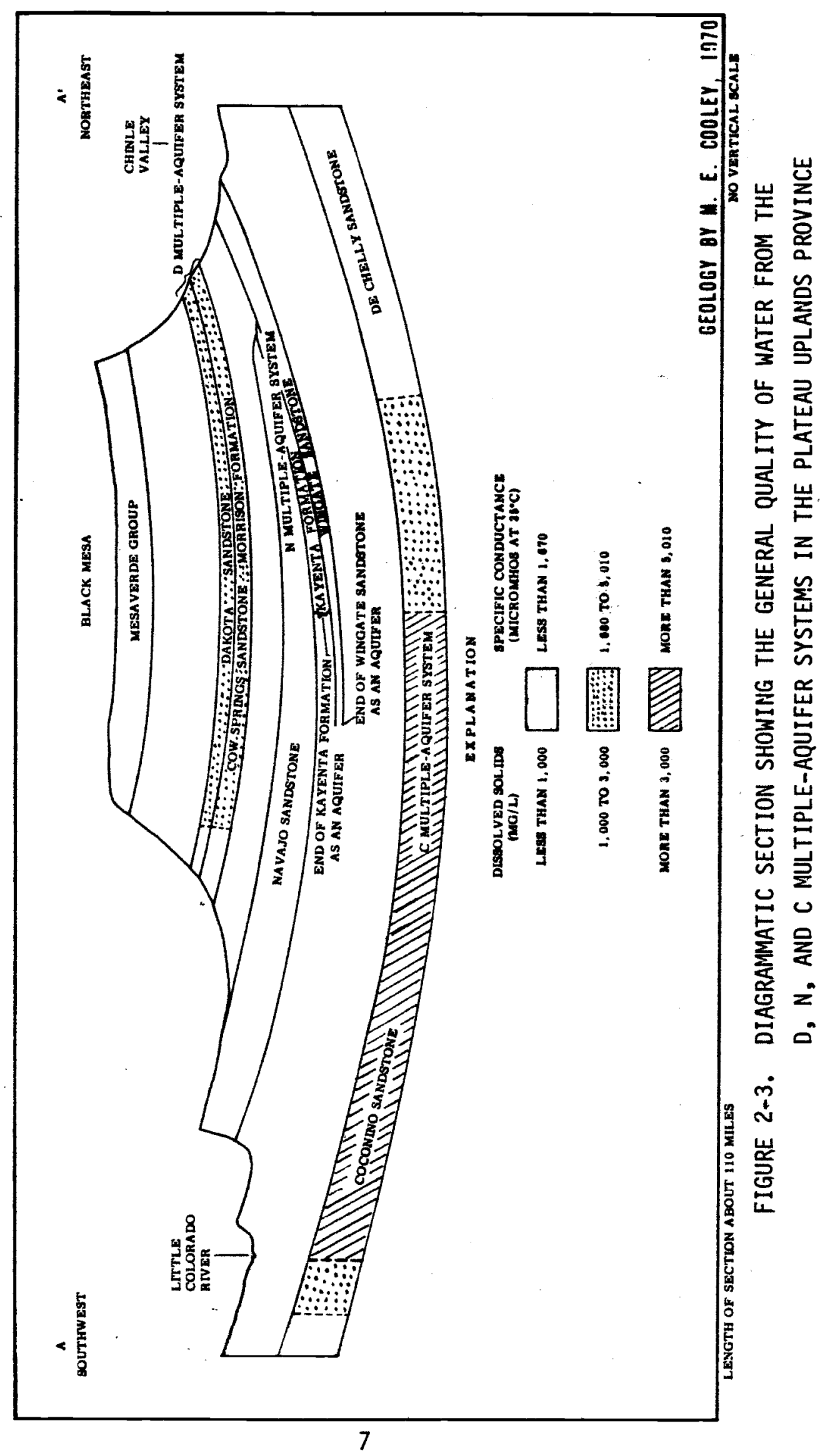


province is limited to supplying scattered farms and homesteads, industrial and utility sites, and a few major population centers, including Flagstaff. In 1983 approximately 92,000 acre-feet of ground water was withdrawn (USGS, 1985).

Ground water recharge occurs during precipitation on the upturned rocks exposed on the highlands. According to ligner et al (1969) the recharge areas are generally above 6000 ft where annual precipitation exceeds 15 inches.

An interesting geological feature of the province from the viewpoint of salinity is the presence of an extensive salt deposit in the Holbrook Basin. According to Peirce (1981), salt beds or layers within the supai Formation occurs in the subsurface of southern Navajo and Apache Counties beneath a region of about 2500 square miles in size. Sink holes have developed as a result of salt solution and surface collapse.

Kister (1973) reviewed the general ground-water quality in the Plateau Uplands Province. According to Kister, the lowest salinity ground water is present in the $N$ multiple aquifer system, where salinity levels are generally less than $1000 \mathrm{mg} / 1$. Total salinity in the $D$ multiple aquifer system ranges from 1000 to $3000 \mathrm{mg} / \mathrm{l}$. In the c multiple aquifer system, salinity ranges from 200 to $25,000 \mathrm{mg} / \mathrm{l}$. Ground waters having less than $500 \mathrm{mg} / \mathrm{l}$ are classified as calcium bicarbonate or sodium bicarbonate, whereas water with salinity levels exceeding $500 \mathrm{mg} / \mathrm{l}$ is classified as sodium sulfate, calcium sulfate, or sodium chloride types (Kister, 1973).

\subsubsection{Central Highlands Province}

As shown on Figure 2-1, the central Highlands Province is a transition region between the Plateau Uplands Province to the north and the Basin and Range Province to the south and west. The Central Highlands Province comprises about $15 \%$ of the total land area of the state. Most of Arizona's surface water supply, its few perennial streams, originate in this area. In fact, these streams, fed by rain and snowmelt, supply the state with more than 50\% of its surface water supply (Arizona Water Commission, 1975) and much of the ground-water recharge of the Desert Lowlands Province. This area is also sparsely populated, with grazing and timber the primary land uses.

Nations and stump (1981) described the geology of the Central Highlands Province as follows:

(This Province is )...characterized by rugged mountains of igneous, metamorphic and deformed sedimentary and volcanic rocks of Precambrian age, with erosional remnants of Paleozoic age. The elevations are generally lower and the crustal rocks have been more severely faulted than in the plateau province. The general absence of Mesozoic and cenozoic rocks indicates a 
longer period of erosion and/or nondeposition of sedimentary rocks such as are found in the other provinces.

According to Peirce (1981) there are two salt deposits in the province just south of Lake Mead. These deposits are the Detrital Valley deposit and the Red Lake deposit.

According to Ligner et al. (1969), the prominent feature of the province is the Mogollon Rim, an escarpment comprised of Paleozoic sedimentary rocks such as sandstone, siltstone, claystone, and limestone.

In most areas, the Mogollon Rim approximates the surface water divide between the little colorado River and the salt River systems (Ligner et al.,1969). Among the prominant river systems draining this province are the salt and verde Rivers. Springs along the Mogollon Rim and in other locations are the primary source of the perennial flow in the Gila, salt and Verde Rivers (Kister, 1973).

As described by the United States Geological Survey (1984), ground water in the Central Highlands Province is obtained from thick alluvial deposits in limited areas; from layered sandstone, limestone and conglomerate; from thin alluvial deposits along the major streams; and locally from fractured crystalline and sedimentary rocks. According to Kister (1973), volcanic rocks which crop out in much of the area are permeable, allowing water to recharge the underlying ground water reservoirs. Agricultural production and demands on ground water are accordingly small. In 1983 only about 45,000 acre-feet were withdrawn (USGS, 1984).

Kister (1973) specified that ground-water quality is generally excellent, with total dissolved solids (tds) concentrations less than 1,000 ppm. However, several springs discharge saline water to streams. For example, clifton Hot springs produces water from alluvium along the san Francisco River with a tds exceeding 9,000 $\mathrm{mg} / 1$. Kister (1973) also reported tds values of more than 37,000 $\mathrm{mg} / 1$ from the salt Banks on the Salt River, and $8000 \mathrm{mg} / 1$ from the White River salt springs. These waters are generally of the sodium chloride type.

\subsubsection{Basin and Range Province}

The Basin and Range province, located in southwestern Arizona, occupies approximately 45 percent of the state land area stretching across the bottom half of the state and up the western boundary to the Hoover Dam area. This area has a diverse topography ranging in elevation from $100 \mathrm{ft}$ above sea level in the Yuma area to over 10,000 ft in some upland areas. The southwestern region is primarily desert with little precipitation and flat, sandy soils. The southeastern area is comprised of mountains, forest areas, and desert flatlands. 
This province is by far the largest user of both surface and ground water. Most of the surface water flows from the central Highlands Province through the salt and Gila Rivers, yielding between .75 and 0.85 million acre-ft annually. Additionally, the Colorado and Gila Rivers together yield another $2.5 \mathrm{million}$ acreft annually (Martin, et al., 1985). Water use in this region accounts for over 958 of the total water use in the state. This region also contains over $85 \%$ of the state's population, $95 \%$ of the irrigated land, and also $90 \%$ of the employment. The state's principal metropolitan areas, Phoenix and Tucson, are located in this province.

As described by Ligner et al. (1969), the province is comprised of broad alluvial-filied basins bounded by high mountain ranges. The alluvial-filled basins were created during the structural disturbance that occurred 10 to 15 milition years ago (Anderson, 1985). The movement along high-angle faults in the vicinity of the basin edges formed a series of generally north to northwest trending basins and mountain ranges. Results of a gravity modelling project by oppenheimer and sumner (1980), showed that several basins contain as much as 10,000 feet of sediment.

Nations and stump (1981) described the structural and geological framework of the province as follows:

The mountains consist of tilted and sometimes structurally deformed, blocks of Precambrian, Paleozoic, Mesozoic, and Cenozoic rocks that are bounded by faults and that have been severely eroded. The Paleozoic rocks are predominantly marine limestones, shales and sandstones that were deposited on a shallow marine shelf in the Early Paleozoic and deeper basins in the Late Paleozoic. The Early Mesozoic rocks are predominantly volcanic or plutonic, and those of the cretaceous age are primarily marine sandstones, shales and carbonates, but also include Laramide intrusives. Cenozoic rocks are largely volcanic but also include nonmarine fluvial and lacustrine sediments, and a small area of marine sediments along the southern colorado River. The valleys are intermontane depressions that have subsided thousands of feet, and are filled with cenozoic volcanics, alluvium, and lacustrine sediments.

Extensive salt deposits are present in the salt River valley, in the Picacho Basin, and in the safford Valley (Peirce, 1981).

The principal drainage system in the province is the Gila River and tributaries including the santa cruz River, and the San Pedro River.

The recently completed Southwest Alluvial Basin Regional Aquifer System Assessment (SWAB/RASA) of the United states Geological survey incorporates alluvial basins in the central Highlands and 
Basin and Range Provinces. For the purposes of the study, the area was divided into 72 basins representing virtually separate hydrological entities (Anderson, 1985). Based on aquifer geology and geohydrology, the basins were grouped into five categories, as follows: central, west, southeast, Colorado River, and highland (see Figure 2-4).

Poole (1985) presented generic cross-sections for the five classes of basins (see Figure 2-5). For a typical cross-section, the main structure of the basins is a graben that has been downthrown along steeply-angled normal faults (Poole, 1985). Bedrock pediments are common along the basin margins. Alluvium which has backfilled the graben is called basin fill. The basinfill sediments are the most widespread and dominant water-bearing unit in the alluvial basins. As shown on Figure 2-5, distinct lithological differences exist between the five classes of basins. The central, west and southeast basins are underlain by upper and lower basin fill deposits and by mudstone and evaporite deposits. Saline ground water occurs in the evaporite deposits because of the presence of halite, gypsum and anhydrite (Smith et al., 1982). In some cases fine-grained layers within the basin fili units may act to confine underlying water bearing formations. The mudstone and evaporite deposits are typically absent from the colorado River basins and from the highland basins.

Ground water extraction in the Basin and Range Province has been extensive to support irrigated agriculture, the mining industry, and the growth of the Phoenix and Tucson metropolitan areas. By the end of 1983 an estimated 191 million acre-ft had been extracted from the basins in the province (United states Geological survey, 1984). Inasmuch as ground-water extractions have exceeded recharge, water levels have declined in the basins. Anderson (1985) cites water level declines of 400 ft in the Phoenix area and nearly $500 \mathrm{ft}$ in an agricultural area between Phoenix and Tucson. A consequence of the decline in ground water levels has been the occurrence of land subsidence and earth fissuring. According to Schumann et al. (1985), land subsidence and fissuring caused by ground-water withdrawals has affected more than 3000 square miles in southern Arizona.

Ground-water replenishment occurs from natural recharge processes, such as the infiltration of runoff along the principal stream channels, infiltration along mountain fronts, and from underflow from adjacent basins. Recharge also occurs from anthropogenic sources including deep percolation of irrigation water, and artificial recharge of reclaimed wastewater.

Kister (1973) indicated that the salinity of ground water in mountainous regions of the Basin and Range Province is generally less than $1000 \mathrm{mg} / \mathrm{l}$, although saline springs exist. The TDS of ground water in alluvium ranges from less than $100 \mathrm{mg} / \mathrm{l}$ to more than 100,000 mg/l (Kister, 1973). Saline ground water mainly occurs in the areas along and in the vicinity of the Gila River from safford to Yuma, along the southern most reach of the 


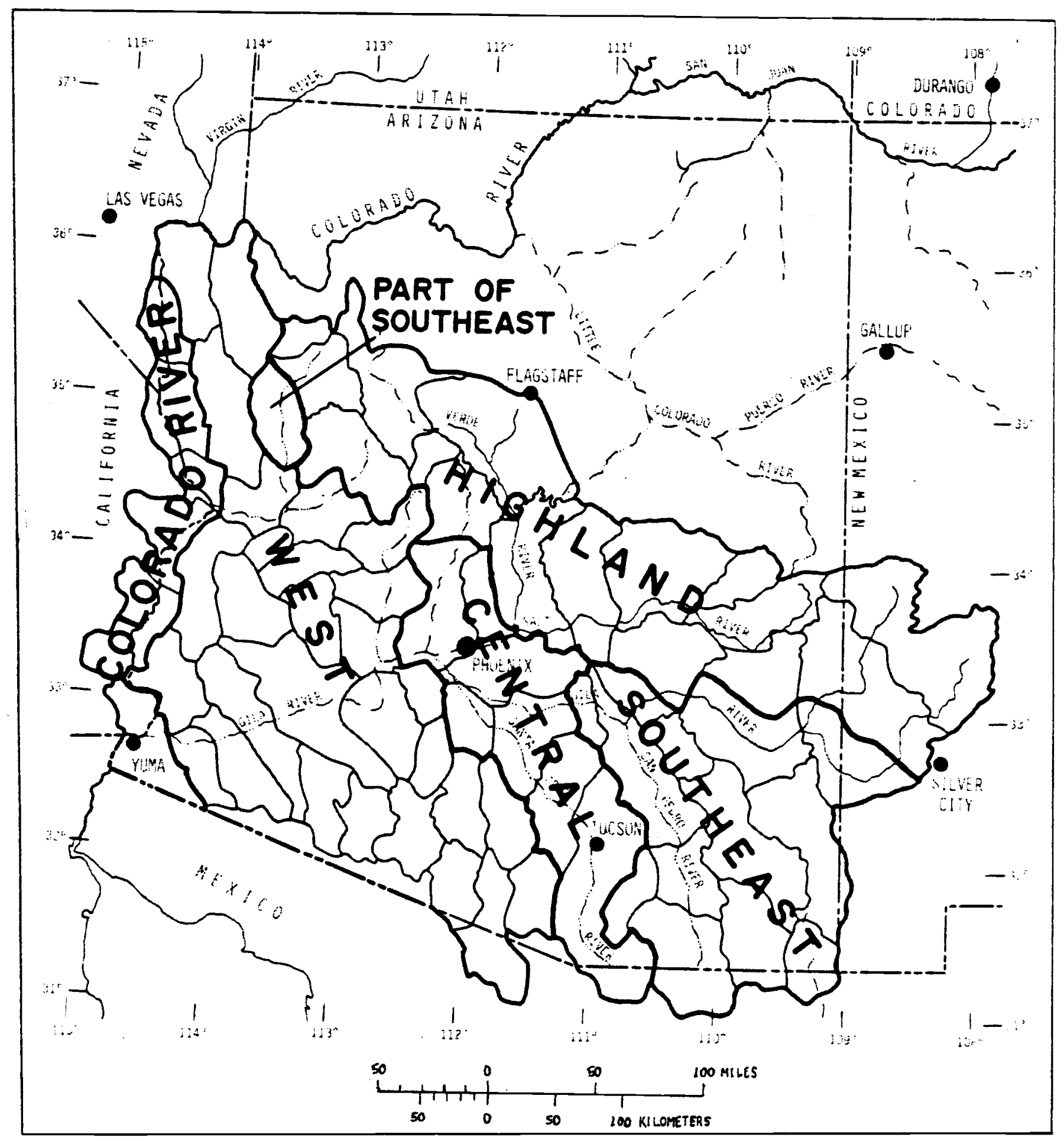

FIGURE 2-4. CATEGORIES OF GEOHYDROLOGIC BASINS BASED ON REGIONAL PATTERNS OF AQUIFER LITHOLOGY FROM POOLE 1985 


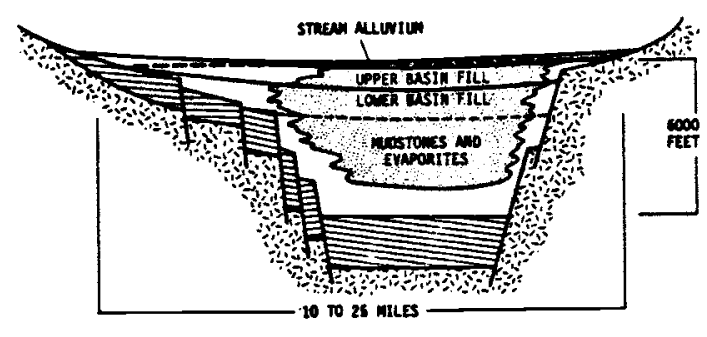

a. contan usins

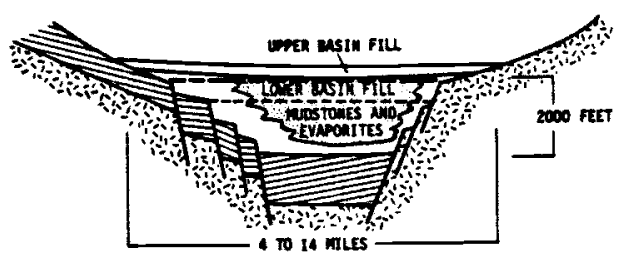

อ. vest usius

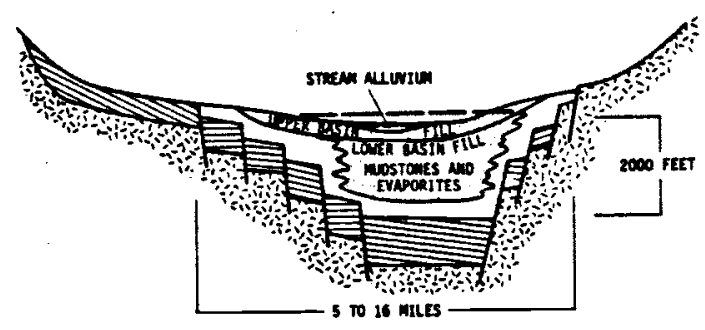

c. sounest usins

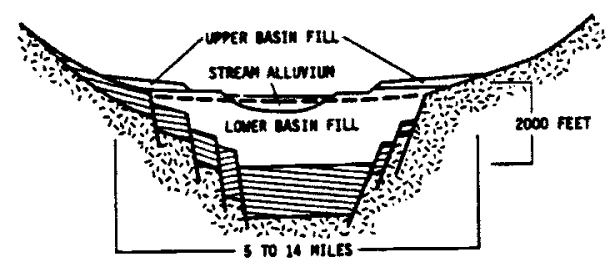

D. cocanoo kiver ussins

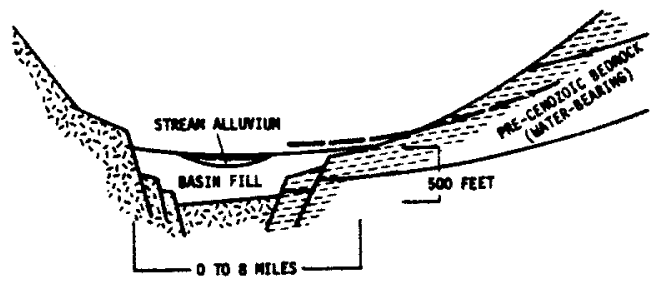

c. Hieven ensins

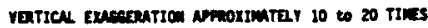

EXPLAMATION

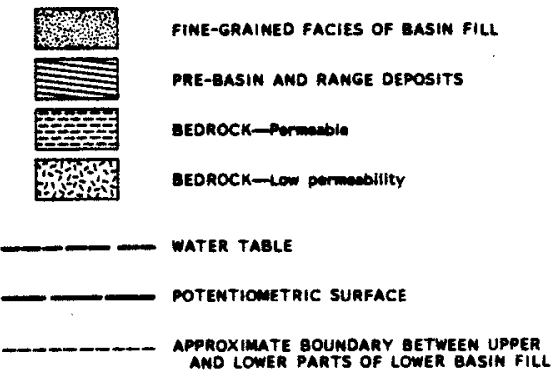

FIGURE 2-5. GENERALIZED BASIN STRUCTURE AND STRATIGRAPHY WITHIN THE FIVE CATEGORIES OF GEOHYDROLOGIC BASINS IN ARIZONA (POOLE 1985) 
Colorado River, and near Willcox, Casa Grande and Tucson (Kister, 1973). In some locations, salinity levels increase with depth, whereas in other locations the reverse is true. According to Robertson (1985) concentrations of fluoride, barium, arsenic and chromium may exceed state and Federal contaminant levels in ground waters from some alluvial basins.

\subsection{Climate of Arizona}

Solar and weather information for the state of Arizona is assembled in a report by osborn and Huddy (No Date). The report includes tables of daily solar data (mean), climatic data, and daily solar radiation on tilted surfaces for climate zones in Arizona. These data will be summarized for the focal saline water areas described in section 6.0 .

The climate of Arizona is also summarized in an excellent report by sellers and Hill (1974). This report includes information on extreme climatic events. 
SECTION 3.0

METHODS

The sequence of steps used to complete each of the project tasks are shown on the flow diagram, included as Figure 3-1.

\subsection{PRELIMINARY INVENTORY}

The overall goals of this task were to identify and collect existing information on sources of saline water in Arizona and to delineate saline surface water and shallow (i.e., water tables less than 500 ft from land surface) saline aquifers, on maps. Saline surface-water sources include springs, irrigation return flows, and power plant discharges. The basic approaches used to accomplish this task were as follows:

\subsubsection{Review Existing Literature}

As it turns out, there are a number of excellent references dealing with the overall water resources in Arizona, and several have identified saline water sources. For example, the United states Geological survey publishes an annual report on the quality of water releases into the Colorado River. Saline groundwater regions have been identified by Kister (1973), Daniel (1981), and Thompson et al. (1984). The bibliographies in each of these reports were used as the basis for the collection of further relevant references. The report of Thompson et al. (1984) is particularly valuable in that it delineates the TDS concentrations of ground water within 500 feet of the lands surface on a map for the SWAB/RASA (Southwest Alluvial Basin Regional Aquifer system Assessment) program. Other important references are the Water Resources Investigations and Hydrologic Map Series issued by the United States Geological survey and the Arizona Department of Water Resources. These map reports generally cover a basin, or part of a basin in the state, and contain information about the ground-water resource, including water quality. All references are listed in Appendix A.

\subsubsection{Contact Individuals and Agencies}

At the outset of the project, a letter was sent to each of the University of Arizona's Agricultural Extension offices in the state requesting information on saline irrigation return flows in each county. Subsequently letters were sent to the operators of 35 power plants in Arizona requesting information on the quantity and salinity of power plant discharges. Similar letters were sent to 24 irrigation districts for information on the quantity and 


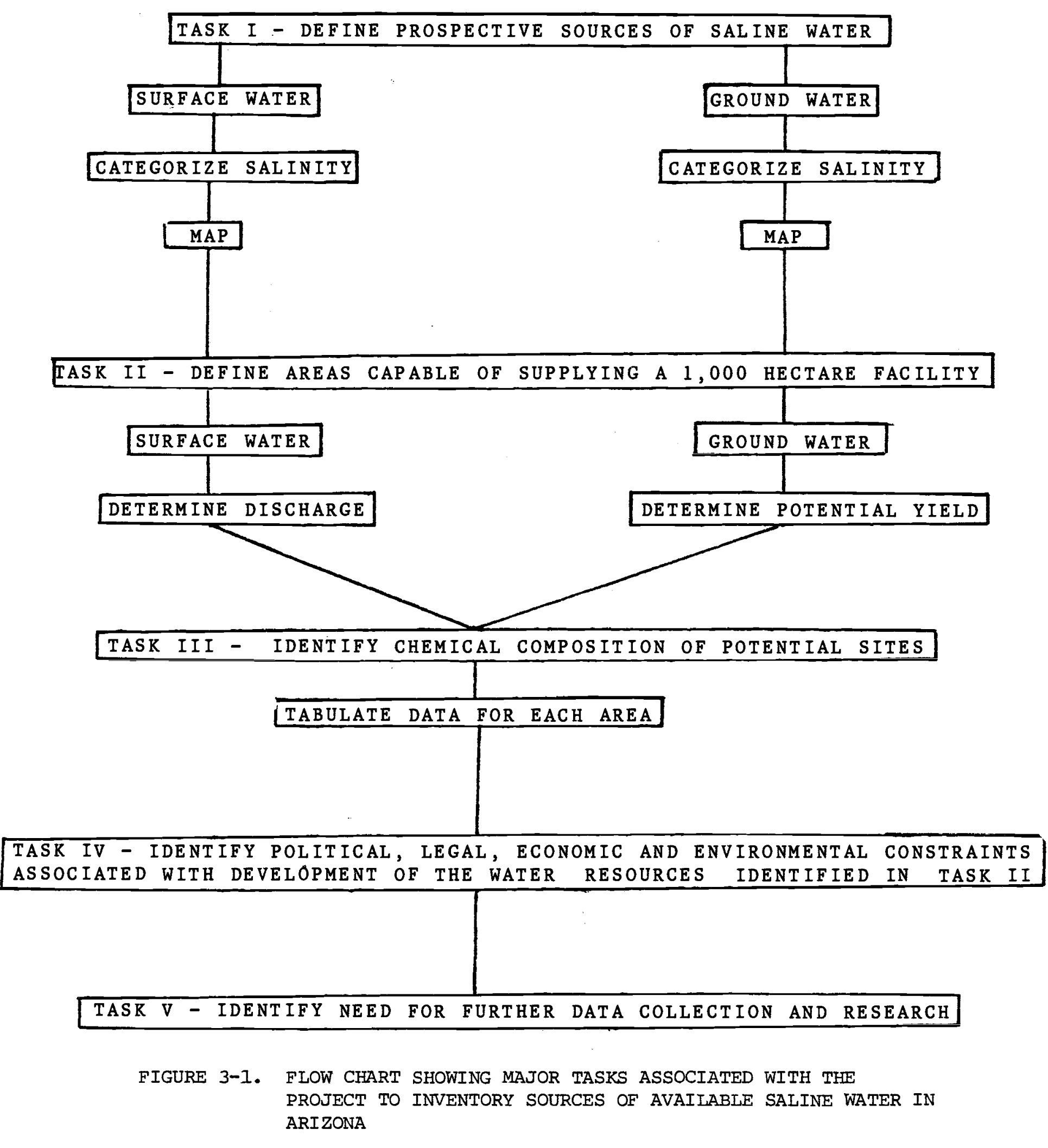


quality of irrigation return flows. To facilitate these requests, questionnaires were developed for each source type and included with the cover letters. Follow up telephone calls were made when necessary. A list of the agencies contacted during the study is included in Appendix B.

State and Federal agencies approached during the study included the Arizona Department of Water Resources, The Arizona state Land Department, the Arizona Department of Health Services, the United States Geological Survey, and the United states Bureau of Reclamation. These agencies were contacted for copies of relevant reports and water quality data from computer files. Leonard Halpenny, principal hydrologist with the Water Development corporation, was also contacted for information on specific areas.

A list of contacts is included in Appendix B.

\subsubsection{Maps}

Salinity data obtained during the information gathering phase were mapped onto working base maps of the state, at a scale of 1:1,000,000. Subsequently, separate maps of saline surface water sources and saline ground-water sources were prepared at the same scale from the working map. Saline surface water sources, including saline springs and streams, power plants, irrigation return flows, and saline areas along the Gila River, are delineated on the map of the saline water sources. The map of the saline ground-water sources was used to show contoured salinity levels from 3,000 to $5,000 \mathrm{mg} / 1,5,000$ to $10,000 \mathrm{mg} / 1$, and greater than $10,000 \mathrm{mg} / \mathrm{l}$. The levels of uncertainty in data with respect to salinity level and location are included on the maps.

\subsection{DETERMINE SUSTAINED YIELD OF IDENTIFIED SOURCES}

The basic goal of this task was to identify from among the areas defined during Task I, specific areas capable of providing sufficient water to supply one or several 1000 ha or larger microalgae facilities. For purposes of screening, the criteria used to identify suitable areas was that a sustained yield of greater than 4 million gallons per day should be available for a time period of 10 or more years. To assist in rating the potential yield of ground-water systems, available information was collected on aquifer properties and recharge.

The approaches used during this phase of the project were as follows:

\subsubsection{Review Existing Information}

The information collection activities for this task were carried 
out simultaneously with the parallel activities during Task I. An initial screening of areas capable of yielding greater than 4 million gallons per day utilized published information. The annual report on water resources data for Arizona, published by the United states Geological survey (e.g., White and Garrett, 1984) is a particularly valuable source of information on surface water supplies in Arizona. The USGS also publishes an annual summary of ground-water conditions in Arizona, which includes a map showing potential well production for areas within the state. Also included in the document are data on changes in ground-water levels and estimates of ground-water pumpage. The USGS has also published several "Water Resources Investigation" maps for specific basins in the state with useful information on ground water resources including ground-water contours, ground-water flow directions, ground-water pumpage, and salinity of ground water. A parallel Hydrologic Map series published by the Arizona Department of Water Resources also shows ground-water conditions in various areas of the state. Recent reports from the SWAB/RASA project include information on ground-water levels, springs, and depth to ground water (Langer et al., 1984) and ground-water withdrawals in the SWAB/RASA study area (Bedinger et al., 1984).

In addition to the literature review activities, additional information was obtained by contacting agencies and individuals with water resources information. For example, the questionnaire sent out to irrigation districts and power plant operators during Task I activities, also included a request for information on water yields. The USGS was contacted for aquifer test information from their computer files.

\subsubsection{Evaluating Yields}

The available literature was searched for estimated yield values for surface water sources. For example, the report of Ianger et al. (1984) provided information on the discharge of springs in the SWAB/RASA area.

Given the lack of extensive information on the hydrology of many of the ground water basins in the state, it was not possible to develop a refined water balance for basins of the state that were identified during the study. Accordingly, several approximation methods were used to estimate the sustained yields in many of the identified saline areas. These approaches were as follows:

a. Estimates from published reports.

Reports were found occasionally with estimates of the maximum obtainable yield for certain areas. These estimates were generally based either on existing pump yields or on aquifer test results for the area. These data were generally regarded as being the most reliable for the purposes of the study. 
b. Pump yields.

In some areas, information on the discharge rates of large capacity municipal or irrigation wells was used to estimate sustained aquifer yield.

c. Comparison with other areas.

For saline ground-water areas which lacked well discharge information, yield data was transferred from hydrologically similar areas within the associated basins with good data bases.

d. Historical water withdrawals and water level declines.

In areas of the state where ground-water resources have been extensively developed, the United states Geological survey has prepared map reports showing annual declines in ground-water levels resulting from pumping. The volume of aquifer dewatered during a given period of time was calculated from the geometry of the water level decline contours. Estimates of aquifer storativity (generally about.15) were then used to estimate the volume of water withdrawn in the reported areas over a period of time. Knowing the yield from a system and the annual rate of water level declines, it was possible to estimate the ability of a system to yield at rates in excess of $4 \mathrm{mgd}$ for a period of 10 years or more.

\section{e. Cooper-Jacob Method}

For systems with data on aquifer hydraulic properties a worstcase scenario was developed using the Cooper-Jacob (1946) analysis. The scenario assumed that a single well was used to pump ground water at rates of 4 and $13 \mathrm{mgd}$, and the modified Jacob analysis was used to estimate the drawdown in the well for a 10 year period of pumping. The analysis is based on the following equation:

$$
\Delta h=(Q / 4 \pi T)[\ln (2.25 T t / r S)]
$$

where: $\Delta \mathrm{h}=$ drawdown

$Q=$ pump discharge rate

$T=$ transmissivity

$t=$ time

$r=$ distance from pumped well

$s=$ aquifer storativity

Values of transmissivity were obtained from the literature or from United states Geological survey (USGS) computer files. The values of storativity were either derived from reported results or estimated based on representative values for the areas of interest.

Following the analysis, if the depth to water in the pumping well 
(approximated at $r=2 \mathrm{ft}$ ) greatly exceeded $500 \mathrm{ft}$, then the aquifer did not meet the yield criteria ( either 4 mgd or 13 mgd). However, when the resulting depth to water was close to 500 ft, it was presumed that multiple wells would meet the required yield.

\subsubsection{Mapping of Focal Areas}

Based on the preliminary screening effort and the more detailed studies to determine sustained yields of saline water sources, five general regions in the state were selected as potential candidate regions for a microalgae facility. These regions are as follows: (a) the Gila River Valley between Yuma and Phoenix, (b) the region near Casa Grande, (c) the Gila River Valley between Safford and the San Carlos Reservoir, (d) the Colorado River Valley between Parker and Ehrenberg, and (e) the region in Apache and Navajo Counties south of the Navajo Indian Reservation that includes St. Johns, Holbrook, and Winslow (see Figure 2-1).

Base maps scaled at 1:125,000 (approximately 1/2 inch per mile) were prepared for each region from standard 1:250,000 scale United states Geological survey topographic maps ( 1 degree by 2 degrees Army series Maps). Two maps were prepared to cover the region between Yuma and Phoenix, and one map was constructed for each of the other regions. These maps were used to delineate the boundaries of the saline ground-water resources in greater detail.

\subsubsection{Tabulation of Results}

In addition to representing the saline water focal areas on maps, three tables were prepared to summarize relevant information on saline ground- water resources. The following information is included in the tables: location of saline aquifer, depth to water, surface area overlying the saline plume, yield of sources, criteria used to estimate potential yield, reliability of yield estimate, references, and remarks. (These tables are included as Tables 4-2, 4-3, and 4-4, in a later section of the report.)

\subsection{CHEMICAI COMPOSITION OF SALINE WATER SOURCES}

The general purpose of this task was to determine the concentrations of the major ions and nutrients in the saline water sources. Major ions include calcium, sodium, magnesium, chloride, bicarbonate, carbonate, and sulfate. Nutrients include nitrogen, phosphorus, and potassium. The approaches used during this task were as follows: 
This effort involved collecting and examining published information on the water chemistry of surface and ground waters in the state, with particular emphasis on data for the five focal areas identified during Task II. The annual report on water resources data for Arizona, published by the United states Geological survey (e.g., White and Garrett, 1984) contains chemical analyses for a number of saline surface water sources in the State. The Environmental Protection Agency was contacted for water chemistry data from the STORET data base. STORET is a computerized data base system operated by EPA for the storage and retrieval of data relating to the quality of the waterways within and contiguous to the United States. The United States Geological Survey was approached for water chemistry information compiled during the SWAB/RASA project. For purposes of the USGS retrieval system, a list of wells, including legal descriptions, was provided for each of the focal areas. The USGS data are particularly meaningful in that values are included for major ion, nutrients, and certain trace elements that may be of significance when considering microalage production. Surface water and ground-water data from the USGS are included as Appendix $C$ and Appendix D, respectively.

\subsubsection{Tabulation of Data}

The water chemistry data obtained for each of the focal areas are summarized and presented in section 4.0. Raw data, including trace element concentrations, are included in Appendix $c$ and Appendix $\mathrm{D}$. These data will be of value during follow-up studies when specific sites are examined as candidates for a microalgae production facility.

\subsubsection{Mapping of Water Chemistry Data}

Representative water chemistry analyses, selected from saline ground-water sources with adequate yield potential, were displayed on focal area maps by means of chemical quality pattern diagrams known as stiff diagrams (stiff, 1951). These diagrams use a system of three parallel horizontal axis and a central vertical axis. Concentration of cations, in milliequivalents per liter, are plotted to the left of the central axis, and anions are plotted to the right. The end values of the individual concentration are joined by a straight line to form an irregularshaped polygon. The distinctive shapes of the polygons for different areas allows for rapid comparison of water chemistry and aids in identifying water types. 
3.4 DEFINE POTENTIAL POLITICAL, LEGAL, AND ENVIRONMENTAL CONSTRAINTS

The general purpose of this task was to identify legal, environmental, and political constraints associated with the utilization of saline water in Arizona. Specifically, Arizona water law as applies to both surface and ground water, and relevant water quality statutes and regulations were examined. After this general analysis was completed, the areas identified in Task II were evaluated in terms of these constraints. The approaches used during this phase of the project are as follows:

\subsubsection{Review Existing Literature}

This literature review concentrated on legal analysis of water acquistion and use. A bibliographic review of the Legal Index revealed no sources that discussed saline water law in particular. However, a number of articles discussing water rights acquistions and trends in water use in the West proved significant.

3.4.2 Review Relevant State statutes and Regulations

Relevant state statutes, specifically the Arizona Groundwater Management Act of 1980, the Arizona Water code of 1919, and water-quality laws and regulations were reviewed and analyzed. These laws and regulations were scrutinized particularly for references to saline water. Examination revealed that saline water is not a special class of water under Arizona law except when a poor water quality permit is applied for under the Groundwater Act. The procedures for acquiring water under state law, and for complying with water quality regulations were explained in detail.

\subsubsection{Conduct Interviews}

In-depth personal interviews were conducted with a representative of the Arizona Department of Water Resources and the Arizona Department of Health Services. These officials were queried about the feasability of this type of project and about the application of state laws and the best possibilities, in terms of water and land availability, for the location of the project. In addition, phone interviews were conducted with officials from the Bureau of Reclamation, State Land Department, Active Management Areas, Arizona Public Service, Irrigation Districts, Indian reservations, and others knowledgeable about saline water use in the state.

3.4.4. Relating Saline Sources to Laws and Regulations

After the general analysis of Arizona water law was completed, 
this information was applied specifically to the five areas identified in tasks I and II. This analysis revealed that the most suitable areas for this type of project are areas located outside of Active Management Areas that have a large supply of saline ground water. However, other areas were also identified as possible locations for a project but would require compliance with more state laws.

3.4.5 Analysis of Upcoming Trends in Arizona Water Law

For this task, apparent trends in Arizona water law that may affect this project were examined. Primarily, the Gila River adjudication was identified as having a large impact on existing water rights and on the project. Also, Arizona is contemplating changes in the law on water transfers. Finally, the possibility of introducing specific legislation that would facilitate the development of this project were examined. 
SECTION 4.0

RESULTS FOR TASKS I,II, AND III

\subsection{TASKS I AND II}

The purpose of Task I was to determine the location of sources of saline surface and ground waters in Arizona, where the term "saline" is defined as a concentration greater than $3000 \mathrm{mg} / \mathrm{l}$. For ground-water sources a criterion for selection was that water levels should not exceed 500 feet from land surface. The purpose of Task II was to designate regions where the yields fall within the following ranges: less than $4 \mathrm{mgd}, 4-13 \mathrm{mgd}$, and greater than $13 \mathrm{mgd}$. The data required for these tasks were obtained from the literature and from contacts with Federal and state waterrelated agencies, from irrigation districts, and from power plant operators. A list of references and contacts is included in Appendix B.

\subsubsection{Surface Water Sources}

During the study, 34 sources of saline surface water were identified in Arizona, including springs, rivers and streams, irrigation return flows and power plants. The locations of saline water sources are shown on Plate $I$. Also included are data on the potential yields of these sources.

As shown on Plate I, a total of 19 saline springs were identified in the state, concentrated primarily in the northwest corner near the Colorado River, in the north central part of the state near the Kaibito Plateau, and in the east-central part of the state near the Salt and Gila Rivers. Discharge data are not available for all of the springs. However, the springs lacking discharge data probably yield less than 10 gallons per minute because these springs do not appear on the maps of Thompson et al. (1984) for the SWAB/RASA study, which used $10 \mathrm{gpm}$ as the lower limit for listing on maps. Springs near clifton and Indian Hot springs are currently used in pools and spas. Springs near white and Black Rivers are in an area of extreme topography on the san carlos Indian Reservation. Other springs are less than $4 \mathrm{mgd}$. Overall, it appears that springs cannot be considered as a reliable source for a microalgae production facility.

Five electrical generating stations were identified. In general these sources appear to be unsatisfactory for a microalgae facility because the yields are less than the requisite 4 mgd, and the discharge is generally treated with an algacide, which may restrict growth in a production facility. A possible exception may be the Palo Verde Nuclear generating plant, west of Buckeye. This plant has only recently come on line and the waste- 
water discharge rate is unknown at this time. However, further investigation is in order because the station appears to be underlain by a fairly shallow mound of saline perched ground water which might be used conjunctively with plant discharge water to obtain the desired yield.

The following table summarizes the other saline surface water sources identified on Plate I, together with their discharge rates:

\section{TABLE $4-1$}

SURFACE WATER SOURCES

Location

Average Discharge

Coalmine Wash

Little Colorado River near st. Johns

Gila River at Calva

Pinal Creek near Globe

Gila River above diversions at Gillespie Dam

Gila River below diversions at Gillespie Dam

Buckeye Irrigation District Drains

Wellton- Mohawk Irrigation District main drain

South Gila Pump outlet 3

South Gila Pump outlet 4

$$
\begin{gathered}
6.9 \\
6.6 \\
184 \\
5.6 \\
216 \\
33 \\
22 \\
130 \\
9.5 \\
3.8
\end{gathered}
$$

Except for Coalmine Wash and South Gila Pump outlet 4, all of these sources appear to be capable of yielding more than 4 mgd. As shown on plate I, the discharge data for these sources represent average values for time intervals ranging from 1 year to 53 years. High salinity values in the Gila River can be relied upon only during low-flow periods.

The discharge value for the Buckeye Irrigation District is an instantaneous measurement representing the sum of the discharges of nine drainage pumps used to drain an area subject to waterlogging. The drainage water is discharged either into the Arlington canal or into the Gila River (Jones, 1985). According to the Secretary-Manager of the District, Mr. T.H. Jones (1985), this waste water could be made available for a project. The drainage pumps extract ground water from a depth of about 15 feet, and cost of pumping is about $\$ 1.10$ per acre foot, because the district is a preferred customer for Hoover Power.

The three discharge values for the wellton-Mohawk system are for 1982. Actually, discharge data have been collected for many years but return flows have decreased steadily over the past 10 years 
from over 200,000 acre-feet per year (af/Y) to below 150,000 af $/ y$. There are no institutional impediments to the district pumping additional water for sale to a project, such as a microalgae production facility.

In 1974, the United States Congress passed the Colorado River Basin salinity control Act which authorized construction of a reverse osmosis desalting plant near Yuma. This plant will be completed in 1989. When the plant comes on line, the saline effluent may be a source for a microalgae production facility. Additional details on this possibility are included in the section of this report dealing with Task IV.

\subsubsection{Ground- Water Sources}

The locations of 61 ground-water areas in Arizona with salinity levels in excess of $3000 \mathrm{mg} / \mathrm{l}$ and with water levels within $500 \mathrm{ft}$ of land surface are shown on Plate II. These areas were identified during Task I. Most of these areas are located in five general regions of the state, namely: along the Gila River between Phoenix and Yuma; the region near Casa Grande; the Gila River between safford and the San Carlos River; the Colorado River between Parker and Ehrenberg; and in the east-central portion of Arizona near Holbrook, winslow and st. Johns. other saline areas occur at scattered locations throughout the state. The extent of the saline ground water resources along the Gila River are well-defined in the literature that was examined during the study (e.g., Daniel, 1981; Thompson et al., 1984). The area in the east-central part of the state is known to contain large plumes of saline ground water, but the boundaries of these plumes are poorly-defined. The degree of certainty of data in other saline ground-water areas depends on the degree of development of the ground-water resources. in each area.

For convenience, 33 of the principal saline ground-water regions passing the screening criteria for Task I were combined into six focal areas, shown on Figure 4-1. The general locations of these areas are as follows:

Area I : a region within the Colorado River valley between Parker and Ehrenberg.

Area II: a region of the Gila River Valley which extends from Yuma to slightly northeast of Dateland.

Area III: a region of the Gila River Valley extending from Area II to Glendale.

Area IV: a region extending southward from Phoenix to Casa Grande.

Area V: a region of the Gila River Valley between safford and the San Carlos Reservoir. 


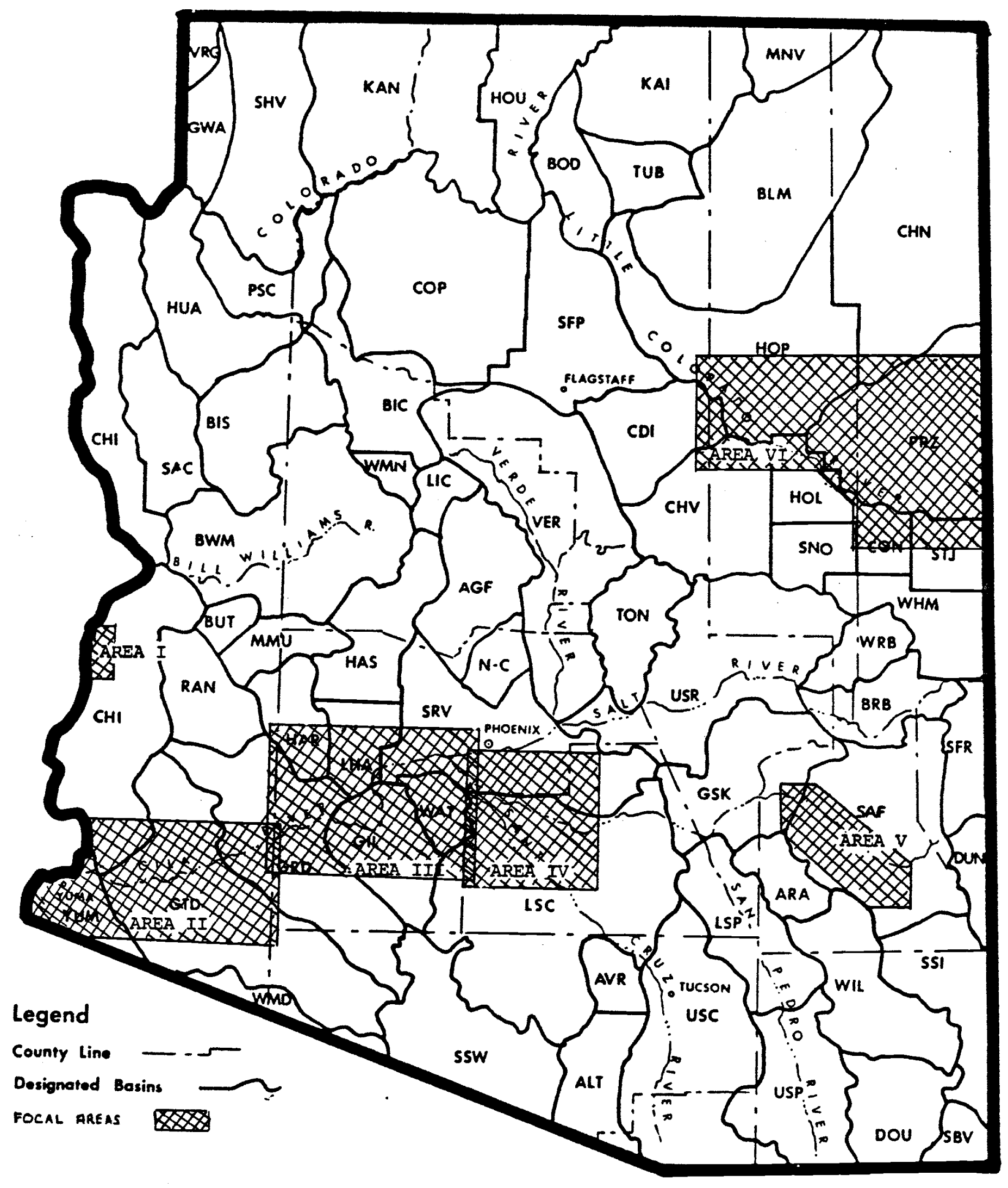

FIGURE 4-1. FOCAI AREAS AND DESIGNATED GROUND-WATER BASINS 
Area VI: a region in Apache and Navajo Counties south of the Navajo Indian Reservation that includes the communities of st Johns, Holbrook and Winslow.

As shown on Figure 4-1, Area $I$ is located entirely within the USGS designated area CHI ( Colorado River, Hoover Dam to Imperial Dam). Area II is within the following USGS designated areas: YUM (Yuma), GTD (Gila River from Texas Hill to Dome), CHI, and GRD (Gila River drainage from Painted Rock Dam to Texas Hili). Area III is within the following designated areas: GRD, HAR (Harquahala Plains), IHA (Lower Hassayampa), SRV (Salt River Valley), WAT (Waterman Wash), GII ( Gila Bend Basin), and ISC (Lower santa Cruz). Area IV is within elements of the following basins: SRV and ISC. Area $V$ is primarily within the SAF (Safford Basin), with a small section being in the GSK (Gila River from head of San Carlos Reservoir to Kelvin) area. Finally, Area VI is within the following designated areas: PRZ (Puerco-zuni), HOP (Hopi), CDI (Canyon Diablo), CHV (Chevelon), and HOL (Holbrook).

The total number of sites with the potential of satisfying the specified conditions for a microalgae production facility was further refined during the Task II screening process. As described in the methods section, a number of methods were used during Task II to eliminate ground-water sources not capable of providing at least four mgd. As a result of the final screening, 19 saline ground-water plumes were identified in the six focal areas as being capable of providing greater than $4 \mathrm{mgd}$ for $a$ microalgae production facility. An additional area was located outside of the focal areas with a potential yield of greater than $4 \mathrm{mgd}$. For seven areas there were insufficient data to determine the long term yield. Thirty four of the original 61 areas were determined to be incapable of providing greater than $4 \mathrm{mgd}$.

Most of the rejected areas are located in the northern and central part of the state where the aquifers generally consist of fine-grained sediments that yield less than 10 gallons per minute to wells. Also included were a few areas in the southern part of the state in fractured crystalline rocks that yield little or no water to wells.

The results of the screening process are summarized in Table 4-2 through Table 4-4. Table 4-1 designates possible sites for a project both within and outside the focal areas. The sites with insufficient data to determine yield are included in Table 4-3. Finally, the sites that are unsuitable for development are included in Table 4-4. Included in the tables are the following items for the various groups of saline ground-water areas: location, depth to water, surface area available for a project, estimated yield, criteria used to determine yield, reliability of the yield estimate ( in relative terms: good, fair or poor), remarks and pertinent references.

Criteria for rating the reliability of data were as follows: Data were considered to be "good" when the same values were reported 
TRBLE 4-2. POSSIBLE GROUND-HATER AREAS FOR A PROJECT

\begin{tabular}{|c|c|c|c|c|c|c|c|}
\hline \multicolumn{8}{|c|}{ POSSIBLE SITES - FOCAL AREA I } \\
\hline Location & $\begin{array}{l}\text { Depth to } \\
\text { Hater } \\
\text { (ft) }\end{array}$ & $\mid \begin{array}{l}\text { Surface } \\
\text { Area } \\
\text { (sq. -i.) }\end{array}$ & $\begin{array}{l}\text { Yield } \\
\text { (xeD) }\end{array}$ & $\begin{array}{l}\text { Criteria Used to } \\
\text { Determine Vield }\end{array}$ & $\begin{array}{l}\text { Reliability of } \\
\text { Vield Estinate }\end{array}$ & Rewarks & References \\
\hline $\begin{array}{l}8-5-21 \\
8-6-21 \\
8-7-21\end{array}$ & 12 & 5 & 113 & Published Reports & Fair & $\begin{array}{l}\text { Uithin the boundaries of the } \\
\text { Colorado River Indian Reser- } \\
\text { vation } \\
\text { Shallow zone contains } 2540 \text { to } \\
5780 \mathrm{mg} / 1 \mathrm{TDS} \\
\text { Gravel zone contains } 4520 \text { to } \\
6050 \mathrm{mg} / 1 \mathrm{TDS} \\
\text { Deep zone contains fresh water } \\
\text { Aquifer is hydraulically } \\
\text { connected to the Colorado River }\end{array}$ & $\begin{array}{l}\text { Netzger, et al., } \\
1973 \\
\\
.\end{array}$ \\
\hline \multicolumn{8}{|c|}{ PCSSIRE SITES - FDCAL AREA II } \\
\hline Location & $\begin{array}{l}\text { Depth to } \\
\text { Uater } \\
\text { (ft) }\end{array}$ & $\begin{array}{l}\text { Surface } \\
\text { Area } \\
\text { (sq. ai.) }\end{array}$ & $\begin{array}{l}\text { Yield } \\
\text { (MED) }\end{array}$ & $\begin{array}{l}\text { Criteria Used to } \\
\text { Deternine Yield }\end{array}$ & $\begin{array}{l}\text { Reliability of } \\
\text { Yield Estimate }\end{array}$ & Rewarks & References \\
\hline $\begin{array}{c}c-6-11 \\
\text { to } \\
c-6-13 \\
c-7-13 \\
\text { to } \\
c-7-21 \\
c-8-16 \\
\text { to } \\
c-8-20\end{array}$ & $2-25$ & 244 & 113 & $\begin{array}{l}\text { Published Reports } \\
\text { Modified Jacob } \\
\text { Pump Yields }\end{array}$ & Good & $\begin{array}{l}\text { Area includes Wellton-Hohank } \\
\text { Irrigation District }\end{array}$ & $\begin{array}{l}\text { US6S, 1985; } \\
\text { US6S, 1986; } \\
\text { Hal penmy, et al, } \\
1952\end{array}$ \\
\hline $\begin{array}{l}-4-25 \\
c-9-25\end{array}$ & 16 & 5 & 113 & $\begin{array}{l}\text { Modified Jacob } \\
\text { Published Reports }\end{array}$ & Fair & & $\begin{array}{l}\text { US65, 1985; } \\
\text { USES, 1986 }\end{array}$ \\
\hline
\end{tabular}


TABLE 4-2. PCSSIBLE GROUN-WATER AREAS FOR A PROJECT (ContinuEd)

\begin{tabular}{|c|c|c|c|c|c|c|c|}
\hline \multicolumn{8}{|c|}{ POSSIBLE SITES - FOCAL AREA III } \\
\hline Location & $\begin{array}{l}\text { Depth to } \\
\text { Uater } \\
\text { (ft) }\end{array}$ & $\begin{array}{l}\text { Surface } \\
\text { Area } \\
\text { (sq. ni.) }\end{array}$ & $\begin{array}{l}\text { Yield } \\
\text { (MSO) }\end{array}$ & $\begin{array}{l}\text { Criteria Used to } \\
\text { Determine Yield }\end{array}$ & $\begin{array}{l}\text { Reliability of } \\
\text { Yield Estimate }\end{array}$ & Rewarks & References \\
\hline $\begin{array}{l}A-1-1 \\
B-1-1 \\
\text { to } \\
B-1-4 \\
C-1-1 \\
\text { to } \\
C-1-5 \\
C-2-5 \\
D-1-1\end{array}$ & $10-200$ & 230 & 113 & $\begin{array}{l}\text { Published Reports } \\
\text { Modified Jacob } \\
\text { Puap Yields }\end{array}$ & Eood & $\begin{array}{l}\text { Yield decreases with depth } \\
\text { Hater levels have declined } \\
50 \text { to } 200 \text { feet since } 1923 \\
\text { in east part of area } \\
\text { for drainage }\end{array}$ & $\begin{array}{l}\text { Stulik, 1982; } \\
\text { Stulik and Twen } \\
\text { ter, } 1964\end{array}$ \\
\hline $\begin{array}{l}C-4-4 \\
C-5-4\end{array}$ & $(100-300$ & 18 & 113 & $\begin{array}{l}\text { Published Reports } \\
\text { Pump yields }\end{array}$ & Fair & & $\begin{array}{l}\text { Sebenik, 1979; } \\
\text { Halpenny, et al } \\
1952\end{array}$ \\
\hline $\begin{array}{l}C-4-7 \\
C-4-8 \\
C-5-8 \\
C-5-9\end{array}$ & 1100 & 53 & $4-13$ & $\begin{array}{l}\text { Published Reports } \\
\text { Comparison with } \\
\text { other areas }\end{array}$ & Poor & & $\begin{array}{l}\text { USE5, 1985; } \\
\text { Halpenmy, et al, } \\
1952\end{array}$ \\
\hline$c-4-10$ & 175 & 7 & 113 & $\begin{array}{l}\text { Published Reports } \\
\text { Modified Jacob }\end{array}$ & Fair & $\begin{array}{l}\text { Water levels declined } 30 \mathrm{ft} \\
\text { from } 1979 \text { to } 1984\end{array}$ & $\begin{array}{l}\text { Ueist, 1965; } \\
\text { LSES, 1985; } \\
\text { USES, } 1986\end{array}$ \\
\hline $0-4-1$ & 400 & 4 & 113 & $\begin{array}{c}\text { Historical declines } \\
\text { Comparison with } \\
\text { other areas }\end{array}$ & Poor & & Stulik, 1982 \\
\hline
\end{tabular}


TABLE 4-2. POSSIBLE GROWO-LATER AREAS FOR A PRDJECT (Contimued)

\begin{tabular}{|c|c|c|c|c|c|c|c|}
\hline \multicolumn{8}{|c|}{ POSSIELE SITES - FOCAL AREA IV } \\
\hline Location & $\begin{array}{l}\text { Depth to } \\
\text { Uater } \\
\text { (ft) }\end{array}$ & $\begin{array}{l}\text { Surface } \\
\text { Area } \\
\text { (sq. ni.) }\end{array}$ & $\begin{array}{l}\text { Yield } \\
\text { (1:Di) }\end{array}$ & $\begin{array}{l}\text { Criteria Used to } \\
\text { Deternine Yield }\end{array}$ & $\begin{array}{l}\text { Reliability of } \\
\text { Yield Estinate }\end{array}$ & Remarks & Referrences \\
\hline $\begin{array}{l}D-1-2 \\
D-2-2 \\
D-2-3\end{array}$ & $100-200$ & 42 & $4-13$ & $\begin{array}{l}\text { Published Reports } \\
\text { Madified Jacob }\end{array}$ & Fair & $\begin{array}{l}\text { Most of the area is on the } \\
\text { Gila River Indian Resemvation }\end{array}$ & $\begin{array}{l}\text { USES, 1985; } \\
\text { USES, } 1986\end{array}$ \\
\hline $\begin{array}{l}D-1-4 \\
0-1-5 \\
0-2-4 \\
\text { to } \\
0-2-6\end{array}$ & $1100-200$ & 39 & 113 & $\begin{array}{l}\text { Published Reports } \\
\text { Modified Jacob }\end{array}$ & Fair & $\begin{array}{l}\text { Perched water way be present } \\
\text { in southern part of area } \\
\text { Western part of area is on the } \\
\text { Gila River Indian Reservation } \\
\text { Most of area is irrigated }\end{array}$ & $\begin{array}{l}\text { USES, 1985; } \\
\text { LSES, } 1986\end{array}$ \\
\hline $\begin{array}{l}D-5-7 \\
D-5-8\end{array}$ & $300-500$ & 9 & $4-13$ & $\begin{array}{l}\text { Published Reports } \\
\text { rodified Jacob }\end{array}$ & Fair & $\begin{array}{l}\text { Extensive agricultural devel- } \\
\text { opment in area }\end{array}$ & $\begin{array}{l}\text { Konieczki and } \\
\text { English, 1979; } \\
\text { UsEs, 1986 }\end{array}$ \\
\hline $\begin{array}{l}D-6-5 \\
0-6-6 \\
0-7-6\end{array}$ & $100-400$ & 66 & $4-13$ & $\begin{array}{l}\text { Published Reports } \\
\text { Modified Jacob }\end{array}$ & Fair & $\begin{array}{l}\text { Depth to water increases } \\
\text { east to west }\end{array}$ & $\begin{array}{l}\text { Konieczki and } \\
\text { English, 1979; } \\
\text { USEs, 1986; } \\
\text { LSES, 1985 }\end{array}$ \\
\hline
\end{tabular}


TABLE 4-2. POSSIBLE GROND-WATER AREAS FOR A PROJECT (Continued)

\begin{tabular}{|c|c|c|c|c|c|c|c|}
\hline \multicolumn{8}{|c|}{ POSSIBLE SITES - FOCAL AREA V } \\
\hline Location & $\begin{array}{l}\text { Depth to } \\
\text { Mater } \\
\text { (ft) }\end{array}$ & $\begin{array}{c}\text { Surface } \\
\text { Area } \\
\text { (sq. wi.) }\end{array}$ & $\begin{array}{l}\text { Yield } \\
\text { (MED) }\end{array}$ & $\begin{array}{l}\text { Criteria Used to } \\
\text { Deternine Yield }\end{array}$ & $\begin{array}{l}\text { Reliability of } \\
\text { Yield Estimate }\end{array}$ & Remarks & References \\
\hline $\begin{array}{l}D-3-21 \\
D-3-22 \\
D-4-22 \\
D-4-23 \\
D-5-23 \\
D-5-24 \\
D-6-24 \\
D-6-25\end{array}$ & $10-40$ & 50 & $4-13$ & $\begin{array}{l}\text { Published Reports } \\
\text { Modified Jacob }\end{array}$ & Fair & $\begin{array}{l}\text { Yield listed is for mater } \\
\text { table aquifer (alluvium) } \\
\text { Yield for artesian aquifer } \\
\text { is less than } 4 \mathrm{MSD} \\
\text { Alluvium is hydraulically } \\
\text { comnected to the Gila River } \\
\text { Alluvium averages } 40 \text { to } 60 \\
\text { feet thickness }\end{array}$ & $\begin{array}{l}\text { LS65, 1985; } \\
\text { Hanson, 1972; } \\
\text { Laney, 1977; } \\
\text { Weist, 1971 }\end{array}$ \\
\hline $\begin{array}{l}0-6-26 \\
0-7-26\end{array}$ & $26-68$ & 5 & $4-13$ & $\begin{array}{l}\text { Published Reports } \\
\text { Comparison with } \\
\text { other areas }\end{array}$ & Fair & $\begin{array}{l}\text { Yield listed is for mater } \\
\text { table aquifer (alluvium) } \\
\text { Yield for artesian aquifer } \\
\text { is less than } 4 \text { noD } \\
\text { Alluvium is hydraulically } \\
\text { comected to the Gila River } \\
\text { Alluviun averages } 40 \text { to } 60 \\
\text { feet thickness }\end{array}$ & $\begin{array}{l}\text { US6S, 1985; } \\
\text { Hansom, 1972; } \\
\text { Laney, 1977; } \\
\text { Heist, 1971; }\end{array}$ \\
\hline $0-8-86$ & 40 & 3 & $4-13$ & $\begin{array}{r}\text { Comparison with } \\
\text { other areas }\end{array}$ & Poor & Insufficient information & \\
\hline
\end{tabular}


TABLE 4-2. POSSIBLE EROUD-MATER AREAS FOR A PROJECT (Continued)

\begin{tabular}{|c|c|c|c|c|c|c|c|}
\hline \multicolumn{8}{|c|}{ POSSIEL SITES - FLCAL AREA VI } \\
\hline Location & $\begin{array}{l}\text { Depth to } \\
\text { Water } \\
\text { (ft) }\end{array}$ & $\begin{array}{l}\text { Surface } \\
\text { Area } \\
\text { (sq. ni.) }\end{array}$ & $\begin{array}{l}\text { Yield } \\
\text { (mSo) }\end{array}$ & $\begin{array}{l}\text { Criteria Used to } \\
\text { Determine Yield }\end{array}$ & $\begin{array}{l}\text { Reliability of } \\
\text { Yield Estimate }\end{array}$ & Rewarks & References \\
\hline $\begin{array}{c}A-14-27 \\
A-14-28 \\
A-15-26 \\
\text { to } \\
A-15-29 \\
A-16-30\end{array}$ & $\begin{array}{c}\text { Flowing } \\
\text { to } \\
50\end{array}$ & 58 & $\begin{array}{c}\text { see } \\
\text { rewarks }\end{array}$ & Published Reports & Fair & $\begin{array}{l}\text { Area identified is Zuni River } \\
\text { Alluviu - insufficient data } \\
\text { is available to estimate yield } \\
\text { for the alluvium } \\
\text { Saline water nay exist in the } \\
\text { Coconino Sandstone - yield } \\
\text { for the Coconino is probably } \\
\text { greater than } 13 \text { ned } \\
\text { Flowing wells penetrate the } \\
\text { Coconino Sandstone }\end{array}$ & $\begin{array}{l}\text { Mann 1977; } \\
\text { Marn, } 1976\end{array}$ \\
\hline $\begin{array}{c}A-16-23 \\
\text { to } \\
A-16-27 \\
A-17-21 \\
\text { to } \\
A-17-27 \\
A-18-21 \\
\text { to } \\
A-18-27 \\
A-19-21 \\
\text { to } \\
A-19-26 \\
A-20-22 \\
\text { to } \\
A-20-25\end{array}$ & $\begin{array}{c}\text { Flowing } \\
\text { to } \\
500\end{array}$ & 500 & 113 & $\begin{array}{l}\text { Published Reports } \\
\text { Punp Yields }\end{array}$ & Good & $\begin{array}{l}\text { Coconino Sandstone } \\
\text { Saline area continues to the } \\
\text { north and east; however, depth } \\
\text { to water exceeds } 500 \text { feet } \\
\text { Flowing wells occur along the } \\
\text { Little Colorado River. Depth } \\
\text { to water increases to the } \\
\text { northeast } \\
\text { Yield varies vertically and } \\
\text { areally, depending on } \\
\text { fracture density. Generally, } \\
\text { yield increases with depth. } \\
\text { Petrified National Forest Park } \\
\text { is within the boundaries of } \\
\text { the saline area. }\end{array}$ & $\begin{array}{l}\text { Marn, 1977; } \\
\text { Davis, 1986; } \\
\text { Mann, 1976 }\end{array}$ \\
\hline
\end{tabular}


TABCE 4-2. POSSIBLE GROUND-4ATER AREAS FOR A PROJECT (Contimued)

\begin{tabular}{|c|c|c|c|c|c|c|c|}
\hline \multicolumn{8}{|c|}{ PLSSIBLE SITES - FUCAL AREA VI (Continued) } \\
\hline Location & $\begin{array}{l}\text { Depth to } \\
\text { Water } \\
\text { (ft) }\end{array}$ & $\begin{array}{l}\text { Surface } \\
\text { Area } \\
\text { (sq. vi.) }\end{array}$ & $\begin{array}{l}\text { Yield } \\
\text { (msd) }\end{array}$ & $\begin{array}{l}\text { Criteria Used to } \\
\text { Determine Yield }\end{array}$ & $\begin{array}{l}\text { Reliability of } \\
\text { Yield Estiunte }\end{array}$ & Remarks & References \\
\hline $\begin{array}{c}A-18-15 \\
\text { to } \\
A-18-18 \\
A-19-15 \\
\text { to } \\
A-19-17 \\
A-20-15 \\
\text { to } \\
A-20-17 \\
A-21-14 \\
\text { to } \\
A-21-17 \\
A-22-14 \\
A-22-15\end{array}$ & $150-200$ & 300 & 113 & Published Reports & Fair & $\begin{array}{l}\text { Coconino Sandstone } \\
\text { Yield varies vertically and } \\
\text { areally, depending on frecture } \\
\text { density. Eenerally, yield } \\
\text { increases with depth. } \\
\text { Northern part of area is on } \\
\text { the Navajo Indian Reservation }\end{array}$ & $\begin{array}{l}\text { Nimn, 1976; } \\
\text { Alers, 1964; } \\
\text { Davis, 1986; } \\
\text { Manin, 1977 }\end{array}$ \\
\hline$A-18-19$ & 40 & 29 & 113 & Published Reports & Fair & $\begin{array}{l}\text { Coconiro Sandstone } \\
\text { Yield varies vertically and } \\
\text { areally, depending on fracture } \\
\text { density. Generally, yield } \\
\text { increases with depth. }\end{array}$ & $\begin{array}{l}\text { Mann, 1976; } \\
\text { Akers, 1964; } \\
\text { Davis, 1985; } \\
\text { Ham, } 1977\end{array}$ \\
\hline \multicolumn{8}{|l|}{. } \\
\hline \multicolumn{8}{|c|}{ PISSIELE SITE - OUTSIDE FOCAL AREAS } \\
\hline Location & $\begin{array}{l}\text { Depth to } \\
\text { Hater } \\
\text { (ft) }\end{array}$ & $\begin{array}{l}\text { Surface } \\
\text { Area } \\
\text { (sq. wi.) }\end{array}$ & $\begin{array}{l}\text { Yield } \\
\text { (ISD) }\end{array}$ & $\begin{array}{l}\text { Criteria Used to } \\
\text { Determine Yield }\end{array}$ & $\begin{array}{l}\text { Reliability of } \\
\text { Yield Estinate }\end{array}$ & Rewarks & References \\
\hline $\begin{array}{l}c-18-1 \\
c-18-2 \\
c-19-1 \\
c-19-2\end{array}$ & 214 & 16 & 113 & $\begin{array}{l}\text { Punp Yields } \\
\text { Modified Jacob }\end{array}$ & Fair & $\begin{array}{l}\text { Area lies within the } \\
\text { boundaries of the Papago } \\
\text { Indian Reservation }\end{array}$ & Hollet, 1981 \\
\hline
\end{tabular}


TARLE 4-3. SITES UITH INSUFFICIENT DATA TO DETERMINE YIED

\begin{tabular}{|c|c|c|c|c|c|c|c|}
\hline Location & $\begin{array}{l}\text { Depth to } \\
\text { Mater } \\
\text { (ft) }\end{array}$ & $\begin{array}{l}\text { Surface } \\
\text { Area } \\
\text { (sq. mi.) }\end{array}$ & $\begin{array}{l}\text { Yield } \\
\text { (WSD) }\end{array}$ & $\begin{array}{l}\text { Criteria Used to } \\
\text { Determine Yield }\end{array}$ & $\begin{array}{l}\text { Reliability of } \\
\text { Yield Estimate }\end{array}$ & Remarks & References \\
\hline $\begin{array}{l}B-25-15 \\
B-25-16 \\
B-26-16 \\
B-26-17 \\
B-27-16 \\
B-27-17\end{array}$ & $200-500$ & 65 & $4-13$ & $\begin{array}{l}\text { Published Reports } \\
\text { Mell Yields } \\
\text { Modified Jacob }\end{array}$ & Poor & $\begin{array}{l}\text { Includes Red Lake (dry) } \\
\text { No infornation available } \\
\text { southeast of Red Lake } \\
\text { Red Lake consists of fine- } \\
\text { grained lacustrine deposits } \\
\text { Well yields up to } 2.2 \text { nos } \\
\text { west of Red Lake }\end{array}$ & $\begin{array}{l}\text { USES, 1985; } \\
\text { USES, 1986 }\end{array}$ \\
\hline $\begin{array}{l}8-39-16 \\
8-40-16\end{array}$ & $17-310$ & 12 & $?$ & - & - & $\begin{array}{l}\text { Area is adjacent to saline } \\
\text { areas in Nevada. Saline area } \\
\text { extends to at least the Lake } \\
\text { Mead area. } \\
\text { Surface area listed does not } \\
\text { include area in Nevada. }\end{array}$ & Kister, 1973 \\
\hline $\begin{array}{l}{[-7-11} \\
{[-7-12}\end{array}$ & 211 & 7 & $?$ & - & - & Possibly perched water & - \\
\hline $\begin{array}{l}0-8-32 \\
0-9-32\end{array}$ & $?$ & 6 & ? & - & - & $\begin{array}{l}\text { Saline water occurs in } \\
\text { unconfined alluvial aquifer. } \\
\text { Confined aquifer contains fresh } \\
\text { water. } \\
\text { Yield for confined aquifer is } \\
\text { greater than } 13 \text { Mgd. }\end{array}$ & \\
\hline $\begin{array}{l}0-13-31 \\
0-14-31\end{array}$ & 65 & 13 & $?$ & - & - & $\begin{array}{l}\text { Unconfined alluvial aquifer. } \\
\text { Depth of alluvium approxinately } \\
100 \text { feet. } \\
\text { Depth to bottom of confining } \\
\text { bed approximately } 500 \text { feet }\end{array}$ & \\
\hline
\end{tabular}


TABLE 4-3. SITES HITH INSUFFICIENT DATA TO DETERMINE YIELD (Continued)

\begin{tabular}{|c|c|c|c|c|c|c|c|}
\hline Location & $\begin{array}{l}\text { Depth to } \\
\text { Hater } \\
\text { (ft) }\end{array}$ & $\begin{array}{l}\text { Surface } \\
\text { Area } \\
\text { (sq. ni.) }\end{array}$ & $\begin{array}{l}\text { Yield } \\
\text { (MED) }\end{array}$ & $\begin{array}{l}\text { Criteria Used to } \\
\text { Deternine Yield }\end{array}$ & $\begin{array}{l}\text { Reliability of } \\
\text { Yield Estiunte }\end{array}$ & Rewarks & References \\
\hline $\begin{array}{l}0-14-12 \\
0-15-12\end{array}$ & $200-700$ & 2 & ? & - & - & - & - \\
\hline $\begin{array}{l}0-23-26 \\
0-23-27\end{array}$ & $\$ 100$ & 9 & ? & - & - & $\begin{array}{l}\text { Saline mater occurs in uncon- } \\
\text { fined alluvial aquifer. Con } \\
\text { fined aquifer contains fresh } \\
\text { mater. } \\
\text { Hater levels have declined up } \\
\text { up to } 35 \text { feet between } 1966 \text { and } \\
\text { 1977 }\end{array}$ & - \\
\hline
\end{tabular}

TARLE 4-4. SITES LNSUITAREE FOR DEVELOPNEN

\begin{tabular}{|c|c|c|c|c|c|c|c|}
\hline Location & $\begin{array}{l}\text { Depth to } \\
\text { Hater } \\
\text { (ft) }\end{array}$ & $\begin{array}{l}\text { Surface } \\
\text { Area } \\
\text { (sq. ai.) }\end{array}$ & $\begin{array}{l}\text { Yield } \\
\text { (MGD) }\end{array}$ & $\begin{array}{l}\text { Criteria Used to } \\
\text { Determine Yield }\end{array}$ & $\begin{array}{l}\text { Reliability of } \\
\text { Yield Estiwate }\end{array}$ & Remarks & References \\
\hline$A-1-15$ & $?$ & 2 & 14 & Modified Jacob & Fair & & L565, 1986 \\
\hline$A-13-4$ & 50 & 2 & 14 & $\begin{array}{l}\text { Puap Yields } \\
\text { Modified Jacob }\end{array}$ & Good & $\begin{array}{l}\text { Martin Formation } \\
\text { Saline water generally } \\
\text { occurs in wudstone facies, } \\
\text { is interfingered with the } \\
\text { liwestone aquifer. Hater } \\
\text { in the liwestone aquifer is } \\
\text { generally less than } 500 \mathrm{mg} / 1 \\
\text { TDS. } \\
\text { Within the boundaries of } \\
\text { Prescott National Forest }\end{array}$ & $\begin{array}{l}\text { Owen-Joyce, } \\
\text { 1984; Twenter } \\
\text { and Metzger, } \\
1963 \text {; Levings } \\
\text { and Manm, 1980 }\end{array}$ \\
\hline
\end{tabular}


TABLE 4-4. SITES LNSUITARE FOR DEVELOPWEN (Contimued)

\begin{tabular}{|c|c|c|c|c|c|c|c|}
\hline Location & $\begin{array}{c}\text { Depth to } \\
\text { Water } \\
\text { (ft) }\end{array}$ & $\begin{array}{c}\text { Surface } \\
\text { Arrea } \\
\text { (sq. ai.) }\end{array}$ & $\begin{array}{l}\text { Yield } \\
\text { (mas) }\end{array}$ & $\begin{array}{l}\text { Criteria Used to } \\
\text { Determine Yield }\end{array}$ & $\begin{array}{l}\text { Reliability of } \\
\text { Yield Estimate }\end{array}$ & Rewarks & References \\
\hline$A-13-5$ & 50 & 2 & $<4$ & $\begin{array}{l}\text { Pump Yields } \\
\text { Modified Jacob }\end{array}$ & Good & $\begin{array}{l}\text { Martin Fornation } \\
\text { Saline mater generally } \\
\text { occurs in mudstone facies, } \\
\text { is interfingered with the } \\
\text { limestone aquifer. Hater } \\
\text { in the limestone aquifer is } \\
\text { generally less than } 500 \mathrm{gg} / 1 \\
\text { TDS. } \\
\text { Uithin the boundaries of } \\
\text { Prescott Mational Forest }\end{array}$ & $\begin{array}{l}\text { Owen-Joyce, } \\
\text { 1984; Twenter \& } \\
\text { Metzger, 1963; } \\
\text { Levings and } \\
\text { Mam, } 1980\end{array}$ \\
\hline $\begin{array}{l}A-14-4 \\
A-14-5\end{array}$ & 50 & 2 & 14 & $\begin{array}{l}\text { Puep Vields } \\
\text { Modified Jacob }\end{array}$ & Good & $\begin{array}{l}\text { Mart in Formation } \\
\text { Saline mater generally } \\
\text { accurs in cudstone facies, } \\
\text { is interfingered with the } \\
\text { liwestone aquifer. Hater } \\
\text { in the liwestone aquifer is } \\
\text { generally less than } 500 \mathrm{gg} / 1 \\
\text { DS. } \\
\text { Within the boundaries of } \\
\text { Prescott National Forest }\end{array}$ & $\begin{array}{l}\text { Owen-Joyce, } \\
\text { 1984; Twenter } \\
\text { Metzger, 1963; } \\
\text { Levings and } \\
\text { Mann, } 1980\end{array}$ \\
\hline$A-15-4$ & 50 & 2 & $<4$ & $\begin{array}{r}\text { Comparison with } \\
\text { other areas }\end{array}$ & Fair & $\begin{array}{l}\text { Martin Formation } \\
\text { Saline water generally } \\
\text { occurs in mudstone facies, } \\
\text { is interfingered with the } \\
\text { limestone aquifer. Hater } \\
\text { in the limestone aquifer is } \\
\text { generally less than } 500 \mathrm{mg} / 1 \\
\text { TDS. } \\
\text { Uithin the boundaries of } \\
\text { Prescott National Forest }\end{array}$ & $\begin{array}{l}\text { Owen-Joyce, } \\
\text { 1984; Twenter } \\
\text { Metzger, 1963; } \\
\text { Levings and } \\
\text { Mann, 1980 }\end{array}$ \\
\hline
\end{tabular}


TARE 4-4. SITES LNSUITABLE FOR DEVELOPNENT (Continued)

\begin{tabular}{|c|c|c|c|c|c|c|c|}
\hline Location & $\begin{array}{l}\text { Depth to } \\
\text { Mater } \\
\text { (ft) }\end{array}$ & $\begin{array}{l}\text { Surface } \\
\text { Area } \\
\text { (sq. ni.) }\end{array}$ & $\begin{array}{l}\text { Yield } \\
\text { (mBD) }\end{array}$ & $\begin{array}{l}\text { Criteria Used to } \\
\text { Determine Yield }\end{array}$ & $\begin{array}{l}\text { Reliability of } \\
\text { Yield Estimate }\end{array}$ & Reuarks & References \\
\hline$A-13-28(1)$ & $?$ & 3 & 14 & Published Report & Good & $\begin{array}{l}\text { Diatreace in Bidahochi } \\
\text { Foration }\end{array}$ & Farrar, 1980 \\
\hline$A-13-28(2)$ & $?$ & 3 & 14 & Publisted Report & Good & $\begin{array}{l}\text { Diatrewe in Bidahochi } \\
\text { Formation }\end{array}$ & Farrar, 1980 \\
\hline$A-13-28(3)$ & 10 & 3 & 14 & Published Report & Fair & Coconino Sandstone & Mam, 1977 \\
\hline $\begin{array}{l}A-12-29 \\
A-13-29\end{array}$ & 183 & 3 & 14 & Published Report & Fair & Coconino Sandstone & Mann, 1977 \\
\hline$A-14-26$ & 35 & 4 & $\ll$ & Published Report & Fair & Coconino Sandstone & $\begin{array}{l}\text { Harper and } \\
\text { Anderson, } 1975\end{array}$ \\
\hline $\begin{array}{l}A-15-26 \\
\text { to } \\
A-15-2 B \\
A-16-27 \\
A-16-28\end{array}$ & 325 & 25 & 14 & Published Reports & 6ood & $\begin{array}{l}\text { Ohinle Fomation } \\
\text { (silts and clays) }\end{array}$ & $\begin{array}{l}\text { Mann, 1977; } \\
\text { US65, 1985 }\end{array}$ \\
\hline $\begin{array}{l}A-22-22 \\
A-22-23 \\
A-23-21 \\
\text { to } \\
A-23-23\end{array}$ & $?$ & 50 & 14 & Published Report & Good & $\begin{array}{l}\text { Bidahochi Formation } \\
\text { and alluvium }\end{array}$ & Farrar, 1980 \\
\hline $\begin{array}{l}A-23-31 \\
A-24-31\end{array}$ & $?$ & 11 & 14 & Published Report & Fair & $\begin{array}{l}\text { D-aquifer (fine grained } \\
\text { sand and silt) } \\
\text { Area is on Arizona-thew Mexico } \\
\text { border - way continue in New } \\
\text { Mexico. }\end{array}$ & $\begin{array}{l}\text { US6s, 1985; } \\
\text { Mann, 1977 }\end{array}$ \\
\hline$A-24-21$ & 74 & 5 & $\ll$ & Published Report & Good & $\begin{array}{l}\text { Diatrewe in Bidahochi } \\
\text { Formation }\end{array}$ & Farrar, 1980 \\
\hline
\end{tabular}


TABLE 4-4. SITES UNSUITABLE FOR DEVELOPEET (Continued)

\begin{tabular}{|c|c|c|c|c|c|c|c|}
\hline Location & $\begin{array}{l}\text { Depth to } \\
\text { Hater } \\
\text { (ft) }\end{array}$ & $\begin{array}{l}\text { Surface } \\
\text { Area } \\
\text { (sq. mi.) }\end{array}$ & $\begin{array}{l}\text { Yield } \\
\text { (Miso) }\end{array}$ & $\begin{array}{l}\text { Criteria Used to } \\
\text { Determine Yield }\end{array}$ & $\begin{array}{l}\text { Reliability of } \\
\text { Vield Estimate }\end{array}$ & Rewarks & References \\
\hline $\begin{array}{l}\text { Black } \\
\text { Mess } \\
\text { (Wavajo } \\
\text { and } \\
\text { Apache } \\
\text { Counties) }\end{array}$ & 100 & 50 & 14 & $\begin{array}{l}\text { Published Report } \\
\text { Modified Jecob }\end{array}$ & Good & D-aquifer & $\begin{array}{l}\text { Levings and } \\
\text { Farrar, 1970; } \\
\text { USES, 1985 }\end{array}$ \\
\hline $\begin{array}{l}\text { Carson } \\
\text { Mesa } \\
\text { (Apache } \\
\text { County) }\end{array}$ & $?$ & 12 & 14 & Published Report & Fair & . & USES, 1985 \\
\hline $\begin{array}{l}\text { Ventana } \\
\text { Mesa } \\
\text { (Apache } \\
\text { County) }\end{array}$ & $?$ & $B$ & $\ll$ & Published Report & Fair & & USES, 1985 \\
\hline $\begin{array}{l}\text { Lukachukai } \\
\text { Wash }\end{array}$ & $?$ & 20 & 14 & Published Report & Fair & & USES, 1985 \\
\hline $\begin{array}{l}A-26-9 \\
A-26-10 \\
A-27-9 \\
A-27-10 \\
A-28-9 \\
A-28-10 \\
A-29-9\end{array}$ & $100-700$ & 56 & 14 & $\begin{array}{l}\text { Published Reports } \\
\text { Modified Jacob }\end{array}$ & Fair & $\begin{array}{l}\text { Coconino Sandstone } \\
\text { Depth to water increases } \\
\text { to the south and west } \\
\text { Southern part of area is on } \\
\text { Wupatki National Monument }\end{array}$ & $\begin{array}{l}\text { Us65, 1985; } \\
\text { Appel and Bills, } \\
1980\end{array}$ \\
\hline $\begin{array}{l}B-40-7 \\
B-40-8\end{array}$ & $?$ & 37 & 14 & Published Reports & Good & $\begin{array}{l}\text { Moenkopi Formation } \\
\text { (siltstone) }\end{array}$ & $\begin{array}{l}\text { Us65, 1985; } \\
\text { Levings and } \\
\text { Farrar, } 1970\end{array}$ \\
\hline$B-33-15$ & $5-518$ & 8 & 14 & Publisthed Report & Fair & $\begin{array}{l}\text { Within the boundary of Lake } \\
\text { Mead National Recreation } \\
\text { Area }\end{array}$ & US65, 1985 \\
\hline$B-4-16$ & $200-250$ & 3 & 14 & Published Report & Fair & $\begin{array}{l}\text { Outside wain water bearing } \\
\text { unit }\end{array}$ & US6S, 1985 \\
\hline
\end{tabular}


TARE 4-4. SITES UNSUITABLE FOR DEVELOPNENT (Continued)

\begin{tabular}{|c|c|c|c|c|c|c|c|}
\hline Location & $\begin{array}{l}\text { Depth to } \\
\text { Water } \\
\text { (ft) }\end{array}$ & $\begin{array}{l}\text { Surface } \\
\text { Area } \\
\text { (sq. ni.) }\end{array}$ & $\begin{array}{l}\text { Yield } \\
\text { (1)60) }\end{array}$ & $\begin{array}{l}\text { Criteria Used to } \\
\text { Deternine Yield }\end{array}$ & $\begin{array}{l}\text { Reliability of } \\
\text { Yield Estiante }\end{array}$ & Remarks & References \\
\hline $\begin{array}{l}8-1-23 \\
C-1-23\end{array}$ & 20 & 18 & 14 & Publ ished Report & Fair & $\begin{array}{l}\text { Saline water occurs below the } \\
\text { main mater bearing zone in } \\
\text { fine-grained sediments. }\end{array}$ & $\begin{array}{l}\text { Metzger, et al, } \\
1973\end{array}$ \\
\hline $\begin{array}{l}8-2-8 \\
0-2-9 \\
0-1-8 \\
8-1-9\end{array}$ & $400-500$ & 35 & 14 & Published Report & Fair & $\begin{array}{l}\text { Fine grained alluvial } \\
\text { sediuents up to } 1000 \mathrm{ft} \text { thick }\end{array}$ & Metzger, 1957 \\
\hline $\begin{array}{l}9-16 \\
c-16\end{array}$ & 1100 & 4 & 44 & Published Reports & Fair & $\begin{array}{l}\text { Perched water } \\
\text { Area is on Arizona Public } \\
\text { Service Comission land } \\
\text { (Palo Verde Nuclear Power } \\
\text { Plant) }\end{array}$ & $\begin{array}{l}\text { Long, M.R., } \\
1983\end{array}$ \\
\hline $\begin{array}{l}c-4-5 \\
c-4-6 \\
c-5-6\end{array}$ & 1100 & 24 & 14 & $\begin{array}{l}\text { Puap Yields } \\
\text { Published Reports }\end{array}$ & Good & $\begin{array}{l}\text { May be perched mater } \\
\text { Fine-grained sediments up to } \\
900 \mathrm{ft} \text { thick in area }\end{array}$ & Sebinik, 1979 \\
\hline $0-4-2$ & $400-500$ & 13 & 14 & $\begin{array}{l}\text { Published Reports } \\
\text { Modified Jacob }\end{array}$ & 6ood & $\begin{array}{l}\text { Outside wain water bearing } \\
\text { unit }\end{array}$ & $\begin{array}{l}\text { USES, 1985; } \\
\text { USES, 1986 }\end{array}$ \\
\hline $\begin{array}{l}0-4-29 \\
0-4-30 \\
0-5-29 \\
0-5-30\end{array}$ & $?$ & 13 & 14 & Published Report & Fair & & US6S, 1985 \\
\hline $\begin{array}{l}D-5-6 \\
D-5-7\end{array}$ & $300-400$ & 5 & 14 & Published Report & Fair & $\begin{array}{l}\text { Outside wain water bearing } \\
\text { unit }\end{array}$ & USES, 1985 \\
\hline
\end{tabular}


TABLE 4-4. SITES USSUITABLE FOR DEVECOPHENT (Continued)

\begin{tabular}{|c|c|c|c|c|c|c|c|}
\hline Location & $\begin{array}{l}\text { Depth to } \\
\text { Water } \\
\text { (ft) }\end{array}$ & $\begin{array}{l}\text { Surface } \\
\text { Area } \\
\text { (sq. ai.) }\end{array}$ & $\begin{array}{l}\text { Yield } \\
\text { (MaD) }\end{array}$ & $\begin{array}{l}\text { Criteria Used to } \\
\text { Deterwine Yield }\end{array}$ & $\begin{array}{l}\text { Reliability of } \\
\text { Yield Estimate }\end{array}$ & Rewarks & References \\
\hline $0-13-20$ & $?$ & 6 & 14 & Published Reports & Good & $\begin{array}{l}\text { Outside main mater bearing } \\
\text { unit (6aliuro Hountains) }\end{array}$ & $\begin{array}{l}\text { USES, 1985; } \\
\text { Jones, } 1980\end{array}$ \\
\hline $\begin{array}{l}D-14-24 \\
D-14-25 \\
D-15-24 \\
D-15-25 \\
D-16-24\end{array}$ & $50-300$ & 48 & 14 & $\begin{array}{l}\text { Published Report } \\
\text { Modified Jacob }\end{array}$ & Eood & $\begin{array}{l}\text { Hilcox Playa } \\
\text { Fine-grained lacustrine } \\
\text { sediwents }\end{array}$ & $\begin{array}{l}\text { US65, 1985; } \\
\text { US65, } 1986\end{array}$ \\
\hline$D-16-20$ & 70 & 9 & 14 & $\begin{array}{l}\text { Published Report } \\
\text { Modified Jacob } \\
\text { Puwp Yields }\end{array}$ & Fair & $\begin{array}{l}\text { May be perched aquifer } \\
\text { Confined aquifer (below } 200 \\
\text { feet) contains fresh water }\end{array}$ & $\begin{array}{l}\text { Roeske and } \\
\text { Herrel, 1973; } \\
\text { US65, 1986 }\end{array}$ \\
\hline $\begin{array}{l}D-16-20 \\
D-17-20\end{array}$ & 65 & 8 & $\ll$ & $\begin{array}{l}\text { Published Report } \\
\text { Modified Jacob } \\
\text { Pup Yields }\end{array}$ & Fair & $\begin{array}{l}\text { May be percted aquifer } \\
\text { Confined aquifer (belou } 200 \\
\text { feet) contains fresh water }\end{array}$ & $\begin{array}{l}\text { Roeske and } \\
\text { Herrel, 1973; } \\
\text { USE5, } 1996\end{array}$ \\
\hline$D-17-4$ & 116 & 5 & 14 & $\begin{array}{l}\text { Publ ished Reports } \\
\text { Puep Yields }\end{array}$ & Good & $\begin{array}{l}\text { Outside main mater bearing } \\
\text { unit (Cosababi Mountians) }\end{array}$ & $\begin{array}{l}\text { USES, 1965; } \\
\text { Hollet, } 1981\end{array}$ \\
\hline
\end{tabular}


by independent sources. Date were considered to be "fair" when presented by a single source.. Finally data were considered to be "poor" when values were transferred from another region without independent corroboration in the area of interest.

The grouping of the potential areas within the focal areas according to possible yields was as follows:

- number of areas potentially yielding greater than 13 mgd $=12$

- number of areas capable of yielding from 4 to $13 \mathrm{mgd}=7$.

Estimated yields from each of the six focal areas are summarized in Table 4-5. Yield values over a 10 year period were calculated by multiplying the minimum daily yield by the number of 3650 , the approximate number of days in 10 years. Quantity in storage values were estimated from information on the depth of water in storage above $500 \mathrm{ft}$, the areal extent of the aquifer, and reported or estimated values of the formation drainable porosity. (The estimated value of drainable porosity was .15).

In addition to showing the locations of each of the focal areas on Figure 4-1 and on Plate II, base maps scaled at 1:125,000 were prepared for each region. These maps are included as plates III, which includes Areas I and II; Plate IV, for Area III; Plate $V$, for Areas $I V$ and $V ;$ and Plate VI, for Area VI. On these plates, the approximate locations of the saline ground-water plumes in each area are located within contours of equal salinity, with contour intervals being $3000 \mathrm{mg} / \mathrm{l}, 5000 \mathrm{mg} / \mathrm{l}$, and $10,000 \mathrm{mg} / 1$.

Relevant features of the six focal areas from the perspective of developing a microalgae facility are included in section 6.0 .

\subsection{TASK III, CHEMICAL COMPOSITION OF SOURCES}

\subsubsection{Surface Water}

Published data on the chemical quality of surface water sources germane to this project are included in Appendix $C$. These data are for water Year october 1981 to september 1982. Also included are water discharge records for these sources. Specific locations of these data are as follows:

- Iittle Colorado River above zion Reservoir, near St. Johns - Gila River at Calva, AZ 
TABLE 4-5

YIELD AND QUANTITY DATA

\section{FOCAL AREA I}

\begin{tabular}{|c|c|c|c|c|c|}
\hline Location & $\begin{array}{l}\text { Depth to } \\
\text { water } \\
\text { (ft) }\end{array}$ & $\begin{array}{l}\text { Surface } \\
\text { Area } \\
\text { (sq. mi.) }\end{array}$ & $\begin{array}{l}\text { Yield } \\
\text { (MGD) }\end{array}$ & $\begin{array}{c}\text { Yield } \\
\text { over lo years } \\
\text { (1iters) }\end{array}$ & $\begin{array}{l}\text { Quantity } \\
\text { in storage* } \\
\text { (liters) }\end{array}$ \\
\hline $\begin{array}{l}B-5-21 \\
B-6-21 \\
B-7-21\end{array}$ & 12 & 5 & $>13$ & $>1.8 \times 10^{11}$ & $6.4 \times 10^{10}$ \\
\hline \multicolumn{6}{|c|}{ FOCAL AREA II } \\
\hline Location & $\begin{array}{l}\text { Depth to } \\
\text { water } \\
\text { (ft) }\end{array}$ & $\begin{array}{l}\text { Surface } \\
\text { Area } \\
\text { (sq. mi.) }\end{array}$ & $\begin{array}{l}\text { Yield } \\
\text { (MGD) }\end{array}$ & $\begin{array}{l}\text { Yield } \\
\text { over 10 years } \\
\text { (liters) }\end{array}$ & $\begin{array}{l}\text { Quantity } \\
\text { in Storage* } \\
\text { (liters) }\end{array}$ \\
\hline $\begin{array}{l}c-6-11 \\
\text { to } \\
c-8-20\end{array}$ & $2-25$ & 244 & $>13$ & $>1.8 \times 10^{1.1}$ & $1.4 \times 10^{13}$ \\
\hline $\begin{array}{l}c-8-22 \\
c-9-22\end{array}$ & 16 & 5 & $>13$ & $>1.8 \times 10^{11}$ & $2.8 \times 10^{11}$ \\
\hline
\end{tabular}

\section{FOCAI AREA III}

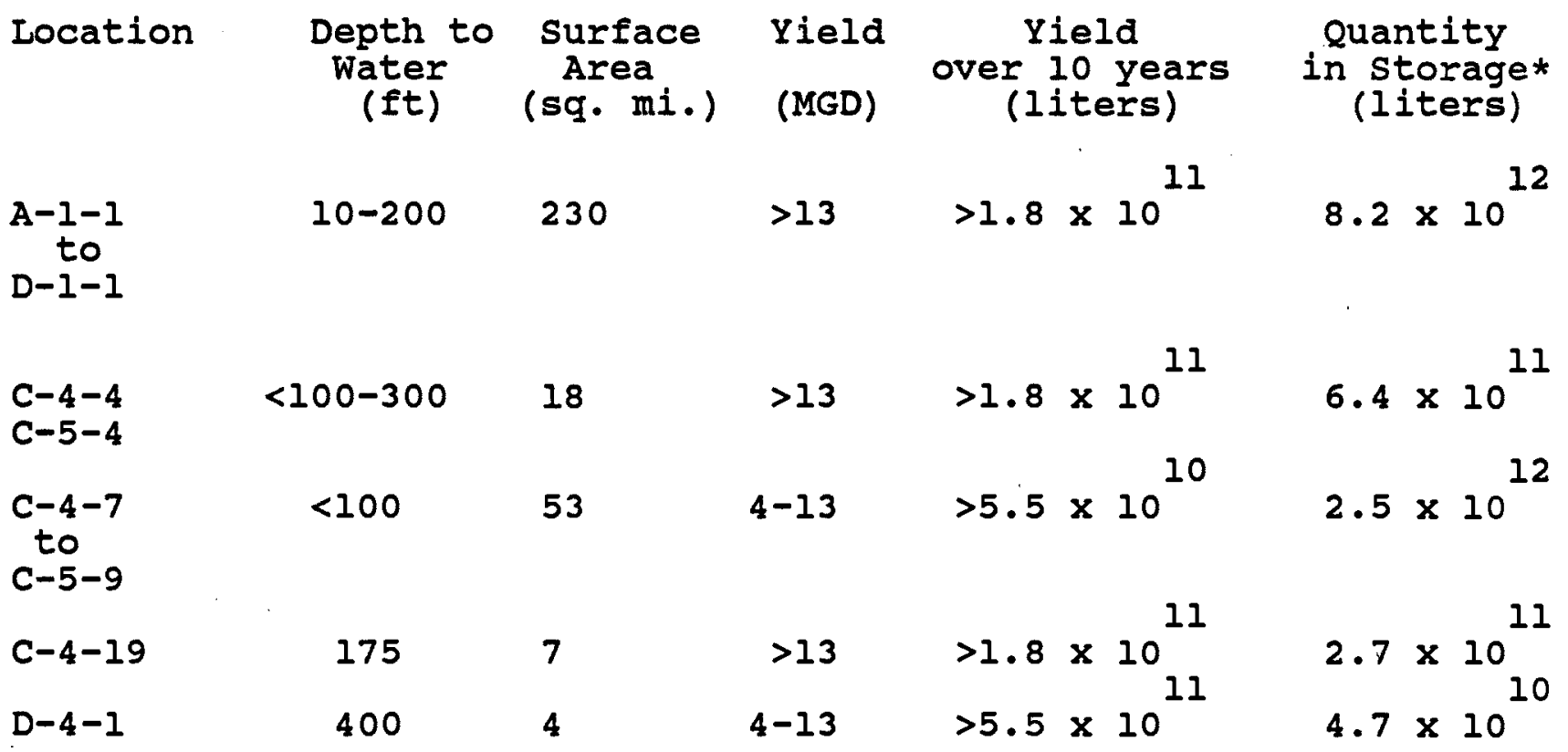


TABLE 4-5 (Continued)

FOCAL AREA IV

\begin{tabular}{|c|c|c|c|c|c|}
\hline Location & $\begin{array}{l}\text { Depth to } \\
\text { water } \\
\text { (ft) }\end{array}$ & $\begin{array}{l}\text { Surface } \\
\text { Area } \\
\text { (sq. mi.) }\end{array}$ & $\begin{array}{l}\text { Yield } \\
\text { (MGD) }\end{array}$ & $\begin{array}{c}\text { Yield } \\
\text { over 10 years } \\
\text { (1iters) }\end{array}$ & $\begin{array}{l}\text { Quantity } \\
\text { in Storage* } \\
\text { (liters) }\end{array}$ \\
\hline $\begin{array}{l}D-1-2 \\
D-2-2 \\
D-2-3\end{array}$ & $100-200$ & 42 & $4-13$ & $>5.5 \times 10^{10}$ & $1.5 \times 10^{12}$ \\
\hline $\begin{array}{l}D-1-4 \\
\text { to } \\
D-2-6\end{array}$ & $<100-200$ & 39 & $>13$ & $>1.8 \times 10^{11}$ & $1.4 \times 10^{12}$ \\
\hline $\begin{array}{l}D-5-7 \\
D-5-8\end{array}$ & $300-500$ & 9 & $4-13$ & $>5.5 \times 10^{10}$ & $1.1 \times 10^{11}$ \\
\hline $\begin{array}{c}C-6-5 \\
\text { to } \\
D-7-6\end{array}$ & $100-400$ & 66 & $4-13$ & $>5.5 \times 10^{10}$ & $1.5 \times 10^{11}$ \\
\hline
\end{tabular}

FOCAL AREA V

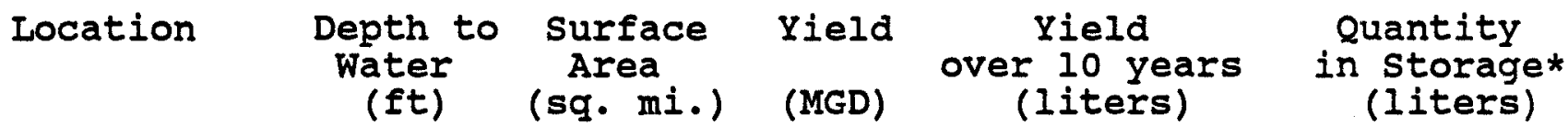

$\begin{array}{lllllll}\begin{array}{l}D-3-2 \\ \text { to } \\ D-6-25\end{array} & 10-40 & 50 & 4-13 & >5.5 \times 10^{10} & 2.4 \times 10^{11} \\ \begin{array}{l}D-6-26 \\ D-7-26\end{array} & 26-68 & 5 & 4-13 & >5.5 \times 10^{10} & 2.4 \times 10^{10} \\ \begin{array}{l}D-8-26 \\ D-5-8\end{array} & 40 & 3 & 4-13 & >5.5 \times 10^{10} & 1.4 \times 10^{10}\end{array}$


TABLE 4-5 (Continued)

\begin{tabular}{|c|c|c|c|c|c|c|c|}
\hline \multirow[b]{2}{*}{ Location } & \multicolumn{3}{|c|}{ FOCAL AREA VI } & & & & \\
\hline & $\begin{array}{l}\text { Depth to } \\
\text { water } \\
\text { (ft) }\end{array}$ & $\begin{array}{c}\text { Surface } \\
\text { Area } \\
\text { (sq. mi.) }\end{array}$ & $\begin{array}{l}\text { Yield } \\
\text { (MGD) }\end{array}$ & $\begin{array}{r}\text { Yie } \\
\text { over lo } \\
\text { (lit }\end{array}$ & $\begin{array}{l}\text { eld } \\
\text { years } \\
\text { eers) }\end{array}$ & $\begin{array}{l}\text { Quant } \\
\text { in sto } \\
\text { (lit }\end{array}$ & $\begin{array}{l}\text { Eity } \\
\text { orage* } \\
\text { ters) }\end{array}$ \\
\hline $\begin{array}{c}A-14-27 \\
\text { to } \\
A-16-30\end{array}$ & $\begin{array}{l}\text { Flowing } \\
\text { to } \\
50\end{array}$ & 58 & $>13 * *$ & $>1.8 x$ & $\times 10^{11}$ & $3.0 x$ & $\times 10^{12}$ \\
\hline $\begin{array}{l}A-16-23 \\
\text { to } \\
A-20-25\end{array}$ & $\begin{array}{c}\text { Flowing } \\
\text { to } \\
500\end{array}$ & 500 & $>13$ & $>1.8 x$ & $\times 10^{11}$ & $2.9 \times$ & $\times 10^{13}$ \\
\hline $\begin{array}{l}A-18-15 \\
\text { to } \\
A-22-15\end{array}$ & $150-200$ & 300 & $>13$ & $>1.8 x$ & $\times 10^{11}$ & $1.0 \mathrm{x}$ & $\times 10^{13}$ \\
\hline$A-18-19$ & 40 & 29 & $>13$ & $>1.8 x$ & $\times 10^{11}$ & $1.6 \mathrm{x}$ & $\times 10^{12}$ \\
\hline
\end{tabular}

OUTSIDE OF FOCAL AREAS

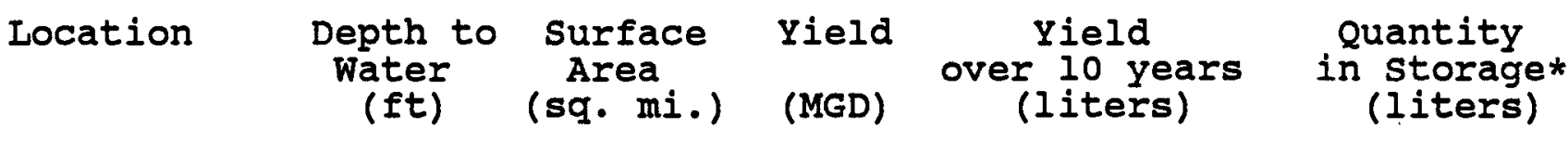

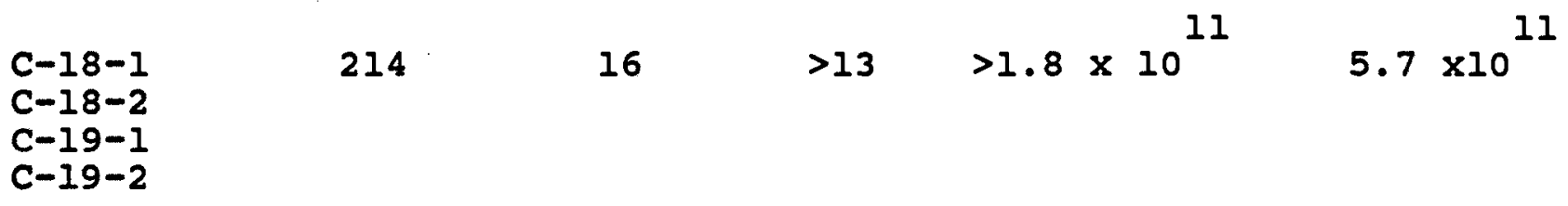

* Numbers do not include recharge, a significant factor along the Colorado River, and Plateau Uplands rerions. Recharge values are not quantified for specific areas of the state because of the uncertainty of existing data.

** Values are for the C-aquifer. Values for the alluvial aquifer are not known. 
- Pinal Creek at Inspiration Dam near Globe, AZ

- Gila River above diversions, at Gillespie Dam, AZ

- Gila River below Gillespie Dam, AZ

- Diversions and return flows at and below Imperial Dam

- Drainage water from the Buckeye Irrigation District

Examination of these data for the major constituents shows that the dominant type is sodium chloride, except for the inflows from Pinal creek, which are predominantly a calcium sulfate type. (For a discussion on chemical water types see Hem, 1959.)

The chemical data for these sources included in Appendix $C$, specifiy not only the major ionic constituents but also values for the trace constituents, including arsenic, barium, cadmium, chromium, cobalt, copper, iron, lead, manganese, mercury, nickel, selenium, silver, and zinc. From the viewpoint of microalgae production, the information on the concentrations of the major nutrients $(N, P$, and $K)$, and trace elements will be particularly helpful.

\subsubsection{Ground-Water Sources}

Data on the chemical composition of ground water within the identified plumes in the six focal areas are included in Appendix D. The data for focal areas II, III, IV, and VI were obtained from USGS computer files. The data for areas $I$ and $V$ are from the literature. The chemical analyses from the USGS mainly include the major chemical constituents, i.e., calcium, magnesium, sodium, potassium, chloride, sulfate, the nitrogen series, carbonate and bicarbonate, as well as $\mathrm{pH}$, temperature and specific conductance. Values for minor constituents are also reported when the results are available, including phosphate, fluoride, silica, arsenic, barium, beryllium, boron, cadmium, chromium, copper, iron, lead, manganese, molybdenum, nickel, strontium, vanadium, zinc, aluminum, lithium, and selenium.

Chemical quality pattern diagrams for selected wells in the saline ground-water plumes are included on the focal area maps, Plates III through VI. It is apparent from these diagrams and from an examination of the chemical quality data in Appendix $D$, that sodium chloride is the major water type. This is not surprising considering the extensive presence of salt deposits in the state (Peirce, 1981). Fairly substantial levels of bicarbonate are also present, which may be important from the viewpoint of microalgae production.

Additional details on water chemistry in the specific focal areas are included in section 6.0 . 
SECTION 5.0

INSTITUTIONAL-ENVIRONMENTAI CONSIDERATIONS

BY:

MARY WALLACE

\subsection{INTRODUCTION}

The West is entering a new era of water management and conservation (Wilkinson, 1985; Anderson, 1983). The emphasis is no longer on the large scale development of water supplies, but on better management and increasingly stringent conservation measures. One aspect of this trend toward better management is a growing recognition of water quality issues. There is a new focus in the West on protecting the quality of existing water supplies and on matching various qualities of water to appropriate uses.

New policies that reflect this quantity-quality link will be developed in the future in order that the growing demand for western water will be met. There will be an increase in the demand for now under utilized sources of water such as effluent, agricultural return flows, and highly saline waters.

This chapter reviews legal, political, economic and environmental constraints to the utilization of saline waters in Arizona for microalgae production systems. First, Arizona water law with respect to surface and ground water, including the Arizona Groundwater Management Act, will be analyzed. Second, requirements for acquiring different types of water rights available in the state are reviewed, including both initiating a new right and purchasing existing rights. Third, relevant groundwater quality statutes and regulations and other environmental constraints will be examined.

\subsection{WATER SUPPLY}

Arizona has three major sources of water: Surface water, including Colorado river water delivered via the Central Arizona Project, ground water, and effluent. Surface water supplies total approximately 2,500,000 acre-feet per year and accounts for over $40 \%$ of all water used in Arizona (Martin, et al., 1985) Except for the 1.2 million acre-feet of Colorado river water to be delivered by the Central Arizona Project (CAP), all surface waters in the state are developed and diverted for use. In fact in almost all regions, the surface water supply is over appropriated. with the expected completion of the CAP in 1991, the 1.2 million acre-feet of Colorado River water will also be 
Groundwater is Arizona's largest supply of water. In general, in most developed areas of the state, particularly the Desert Lowlands, the ground-water is stored in deep porous aquifers which yield large, easily pumped, quantities of water. However, since the 1940's, the rate of withdrawal has exceeded the rate of recharge. As a result, in some areas, specifically the Desert Lowlands, the groundwater tables have dropped by as much as 200 feet (Bush and Martin, 1984). Annual overdraft is currently 2.2 million acre-feet per year.

\subsection{ARIZONA WATER IAW}

\subsubsection{Surface Water}

Arizona water law recognizes three classes of water supply: surface water, water flowing in definite underground channels, and percolating groundwater. Both surface water and water flowing in definite underground channels are governed by the doctrine of prior appropriation (ARS 45-131a). The primary feature of this doctrine. is best expressed by the aphorism "first in time, first in right", or that the rights of prior uses are superior to any subsequent uses. In times of shortage, a water user with an earlier priority date will prevail over any other junior users.

All surface water and waters running in definite underground channels must be appropriated under the terms outlined in the Arizona water code which was promulgated in 1919. Under this code, the water is considered public in character and the basis and the limit and measure of a right is beneficial use (ARS 45131b). Permitted uses of appropriated water include domestic use, irrigation, stock watering, water power, recreation, wildlife including fish, for personal use or delivery to consumers. Surface water rights, once obtained, may be lost either through abandonment, which requires both an intent to give up the rights, and a cessation of use, or by nonuse for five years with constitutes a forfeiture of the right (ARS 45-131c).

Surface water rights are considered appurtenant, or attached to the land for which the appropriation was made. However, in 1962, amendments to the water code provided for transfers of water rights. A water right may be severed from the land for irrigation and other uses without a loss of priority if: 1) the transfer is approved by the Arizona Department of Water Resources (ADWR); 2) other vested water rights would not be injured; 3) the right itself has been perfected under Arizona law and not abandoned or forfeited (ARS 45-172, 1-4).

Further, if the water right is contained within the boundaries of an irrigation district or water users association, the entity 
must approve of the transfer. There is one other restriction to water transfers: the approval of irrigation districts and associations must be obtained if water from any watershed or drainage area that either supplies or contributes water for irrigated lands is to be transferred (ARS 45-172-5).

\subsubsection{Ground Water}

Many western States, including Arizona, have treated ground water differently from surface water supplies. While surface water has been classified as public in character with appropriation permits required, ground water has been viewed as a private resource. In a lengthy series of court cases, some contradictory, Arizona courts have applied a "rule of reasonable use" to the use of percolating ground waters. Under this rule, a landowner is allowed to pump any amount of ground water from underneath his property and utilize it for any beneficial and reasonable use on his land. However, the water cannot be transferred off the land from which it is pumped if a neighboring landowner is harmed.

However, this rule of reasonable use has been limited and even voided in some areas of the state during the last five years. First, in 1980, the Arizona Legislature passed the Arizona Groundwater Management Act (herein referred to as the Act). In this Act, four areas of the state were declared active management areas and an entirely new set of rules now govern ground water use in these areas (see following sections).

Second, in two cases, Cherry V. Steiner (543 F. Supp. 1270 (D. Ariz. 1982) and Town of Chino valley v. City of Prescott (638 P. 2d. $1324(1981))$, the rule of reasonable use was clarified. In these cases, both of which challenged the Arizona Groundwater Management Act (AGMA) on constitutional grounds, the court clarified the ownership of percolating ground water, holding that a landowner had no ownership to ground water until it was captured and put to beneficial use. The court also held that the AGMA was a proper exercise of the police powers of the state.

\subsubsection{Arizona Groundwater Management Act}

In 1980, the Arizona state Legislature enacted the Arizona Groundwater Management Act (herein referrred to as the Act). This law, a radical departure from previous policy concerning ground water, has been characterized as the most comprehensive ground water management plan of any western state. Basically, the Act is a comprehensive management plan that includes restrictions on new ground water uses, and also conservation requirements for existing water uses. Surface water uses are not affected.

The Act designates four Active Management Areas (AMA) and most provisions of the Act only apply to these four areas: 1) the Tucson area; 2) The Phoenix area; 3) the Prescott area; and 4) 
the Pinal area (see Figure 5-1). In these areas, the Act applies only to state and private lands andw ater use on the Indian reservations is not affected. The active mangement areas, however, contain over $80 \%$ of the state's population and over $69 \%$ of the total overdraft (Johnson, 1980). Additional AMA's may also be created either by the Director of the Arizona Department of Water Resources (ADWR) or upon petition by $10 \%$ of the voters in a proposed AMA. Once the petition is submitted, all registered voters may vote on the proposed AMA. In fact, the ADWR is currently investigating the possibility of creating an AMA in the Sierra Vista area, located in Cochise County (see Figure 2-1).

The Act also created three Irrigation Non-Expansion areas (INA), one in Douglass, one in the Harqualala Valley, and one in the Joseph City area (see Figure 2-1). In these areas, only those lands which were irrigated between 1975-80 may be irrigated presently. The Act also requires that all wells with pump capacities over $35 \mathrm{gpm}$ be measured and reported, but there are no restrictions on pumping.

The Act is administered by the Arizona Department of Water Resources, an agency created by the Act. This agency was delegated broad powers over most water resources matters, including the management of ground water and all surface water rights, except those decreed by a court, dam safety, flood control, the central Arizona Project, and also some aspects of water quality. The Director of the ADWR, who is appointed by the governor, has general responsibility over policy decisions, particularly the administration of all laws relating to ground water. In practice, however, the AMA offices have been relatively autonomous, with each utilizing different administrative procedures. In addition, the Arizona water Commission acts as an advisory committee to the Director, and local ground-water users adivisory councils assist the Directors of the AMAs.

The management goal for all AMAs is safe-yield by 2025 . In the Act, safe-yield is defined as a long term balance between ground water withdrawals and natural and artifical ground-water recharge (ARS 45-561-5). To achieve this goal, new ground-water uses are prohibited in AMAs except those which are granted a permit, and existing uses, which were "grandfathered", will be subject to increasingly stringent conservation requirements. Thus, in an AMA, there are two general classes of ground water rights grandfathered rights, or rights based on historical use, and permitted rights.

\subsection{Grandfathered Rights}

There are three types of grandfathered ground water rights within an AMA. First, irrigation grandfathered rights are rights to use ground water for commercial irrigation. With few exceptions, these rights could only be obtained for land that was irrigated between January 1,1975 and January 1, 1980. The quantity of the 


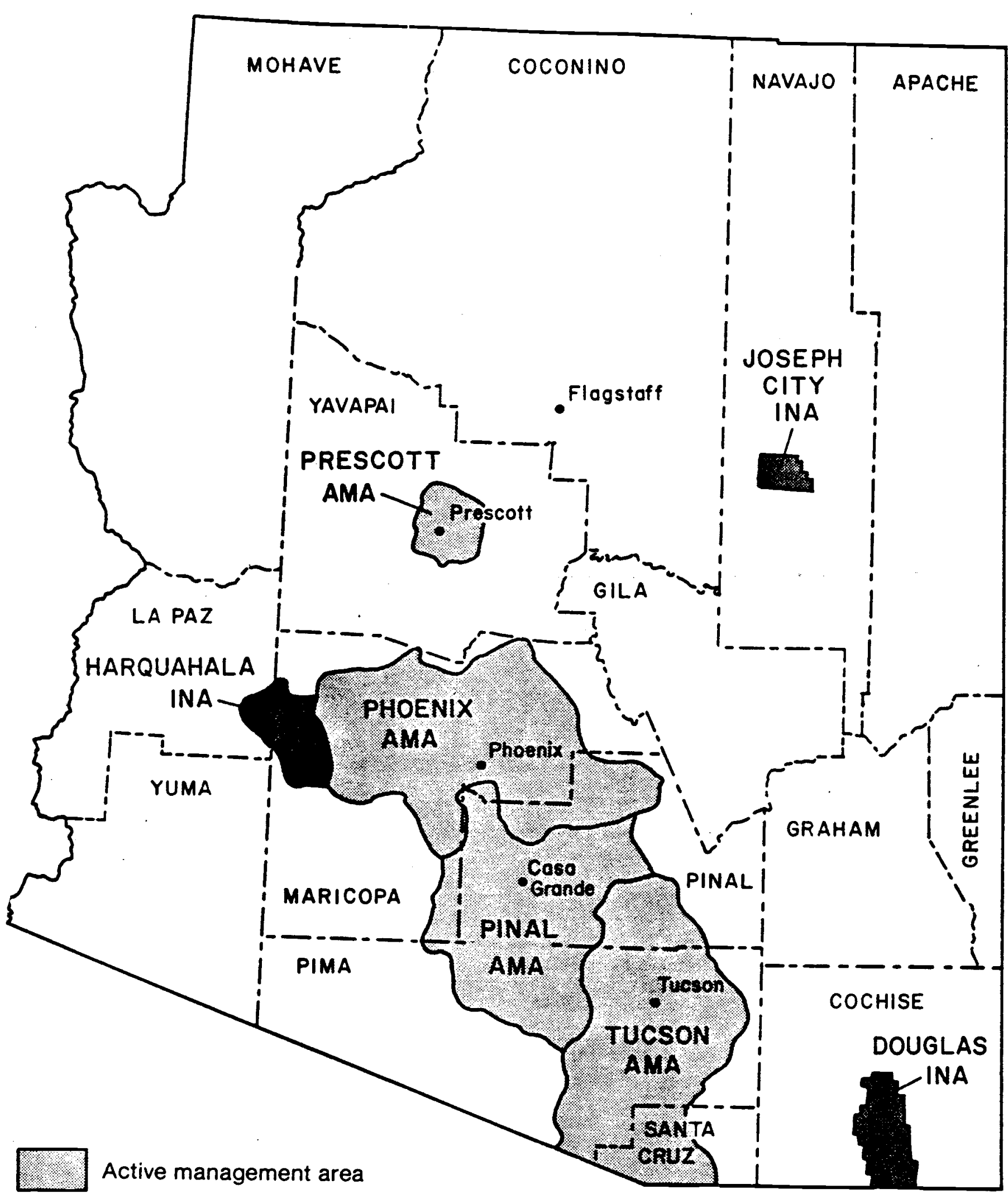

Irrigation nonexpansion area

FIGURE 5-1, MAP OF ARIZONA SHOWING LOCATION OF ACTIVE MANAGEMENT AREAS AND IRRIGATION NONEXPANSION AREAS 
rights was determined by an "irrigation water duty" which is the number of acre-feet per acre "that is reasonable to apply to irrigated land in a farm unit". This assigned duty is the maximum amount of water that may be applied to each acre on a farm. As successive management plans are promulgated in ten year increments, this quantity of water will be reduced.

Irrigation grandfathered rights are owned by the owner of the land to which it is appurtenant. It may be sold to others and converted to a non irrigations use, or continue to be used for agricultural purposes. However, the right may be sold or leased only with the irrigated land (ARS 45-472a).

Type I non Irrigation rights may be acquired when agricultural land is purchased and retired and the water used for nonagricultural purposes. The amount of this right is set at 3 acre-feet per acre, or the actual amount of water used on the land itself, whichever is less. These rights can be used for any purpose, except agricultural purposes. This type of right may be sold or leased only with the land it is appurtenant to. However, the land must not lie within the service area of a city, town, or private water company at the time the land is retired, or the right is extinguished. A service area is defined as the area that is actually being served water by one of these entities. Detailed maps of service areas are available at county recorders' offices.

The third type of grandfathered right is the Type II nonIrigation grandfathered right. Basically, these rights. were bestowed on all non-irrigation uses of ground water at the time the AMA was designated. The quantity of these rights was set at the maximum amount of water withdrawn during any year between 1975-80. These rights belong to the owner of the land from which the ground water was withdrawn and are transferable off the land anywhere within an AMA and may be sold for any purpose other than agricultural. The only restriction is that Type II rights that were used for mining can only be transferred to mining uses. In addition, these rights are "lumpy", they must be sold in whole, not in parts.

\subsection{Ground-Water withdrawal Permits}

In addition to the grandfathered rights, ground-water withdrawals in an AMA are also allowed by obtaining a permit. There are seven types of permits: 1) mine dewatering; 2) mineral extraction and processing; 3) general industrial use; 4) poor quality ground water; 5) temporary permits for electricity generation; 6) temporary dewatering permits; and 7) drainage permits. Permit applications are subject to public notice, hearings and appeals, and are only granted by the Director of the ADWR and only for permitted uses. The relevant permits for this project are discussed in detail in this section. 


\subsubsection{Acquiring Water Rights}

A prerequisite to any economic development in the west is a dependable and adequate supply of water. Generally, any new industry requiring water has two options: 1) to develop a new source of water; and 2) to purchase established water rights. To exercise either option will require "a combined analysis of water rights laws, hydrology, geology, engineering, and business judgement" (Phillips, 1984). In fact, a competent water lawyer and $a$ water resources hydrologist are necessary for any acquistion of water rights. As one attorney notes,

It is possible for a buyer to a pay a lot for nothing with respect to water rights, either because the seller does not have good marketable title or because the water rights will not produce much actual water or will not be useful for the client's purposes (Beebe, 1983).

In this section, the acquistion of water rights in different areas of the state will be examined.

\subsubsection{Active Management Areas}

Saline water sources have been identified in two active management areas: Phoenix and Pinal. This section will outline the possibilities and constraints of acquiring water in these areas.

Central to this discussion is whether a project by SERI will be considered an agriculutral use or industrial use of water. Under the AGMA, agricultural water use is defined as "the use of ground water on two or more acres of land to produce plants or parts of plants for sale or human consumption, or for use as feed for livestock, range, or poultry" (ARs 45-102-20). It is possible that if there is opposition to the project, that opponents would attempt to have the project construed as an agricultural use of water. This would only make a difference if the project is within an AMA or an INA. For this analysis, it will be assumed that a microalgae production system is an industrial use of water.

As stated earlier, there are seven types of permits for ground water withdrawals in AMA areas. Of these seven, three types of permits may be appropriate for this project. First, the AMAs offer a poor ground water quality permit. These permits may be issued by the Director of the ADWR to a non-irrigation user to withdraw poor quality ground water if he determines that the ground water to be withdrawn, because of its quality, has no other beneficial use at the present time. The withdrawal of such ground water must also be consistent with the management plan (ARS 45-516a). Based on the estimated life of the source of water, these permits may be issued for a period of up to thirtyfive years. However, the Director will monitor the withdrawals 
and has the authority to terminate the permit if another beneficial use is available for the water, or if he feels that it is inconsistent with the management plan for the AMA.

These permits are intended for those industries "which can use brackish or salt water that could not be used for drinking or irrigation", such as cooling for a power company. They are also intended to "help prevent the intrusion of brackish water into fresh water supplies" (Johnson, 1980 ). Additionally, these permits may be granted if the intent is to remedy industrial pollution of ground water.

To date, only a few poor ground water quality permits have been granted for water quality cleanup. For example, this type of permit was granted in the Tucson AMA to remedy a ground water pollution problem, the infiltration of TCE, an industrial solvent, into the ground water. Also, a number of permits are pending in the Phoenix AMA, applied for by power companies.

Another type of permit that may be acceptable for this project is a general industrial use permit. To date, these permits have been the most common type of permit granted in an AMA. The Director will only issue an industrial use permit if the ground water area lies outside of a service area of a municipal or private water company and if all of the following conditions apply: 1) uncommitted CAP and municipal water is not available; 2) other surface water and effluent is not available; 3) irrigation grandfathered rights cannot be purchased; 4) the use of the water is consistent with the management plan; 5) there is an assured water supply for the life of the project. These permits are granted for a period of up to 50 years, with the average running about 20 years. Also, if any other sources of water can be obtained at the cost of the ground water being withdrawn, the Director may require that this alternate source of water be used at any time during the life of the permit.

Before any permit is issued, DWR will require hydrologic studies to justify the issuance of the permit. The permit application forms require the following information:

1) names and addresses of the applicant and landowner.

2) the AMA and subbasin

3) a legal description of the land

4) the category of the permit

5) specific purpose for the ground water

6) the annual amount withdrawn in acre-feet per year

7) a description of the wells, whether existing or new including the location, diameter, and any other information the Director requires.

In addition, if any new wells will be constructed, a well spacing analysis will be required. 
A third type of permit that may be suitable for this project is a drainage water withdrawal permit. These permits may be issued by the Director if he determines that drainage of irrigated lands is necessary for reasonable economic return from agricultural production in respect to those lands. The withdrawal of such ground water must also be consistent with the management plan for the AMA (ARS 45- 519a). However, the Director will monitor any withdrawals of ground water under this permit and the permit will be terminated if the above conditions no longer apply. Permits can be renewed if these conditions are met.

\subsubsection{Purchasing Water Rights in an AMA}

Another option for acquiring water in an AMA is to purchase water rights. Three types of water rights are available for purchase: Type 1 and Type 2 non-Irrigation grandfathered rights and Irrigation grandfathered rights. Only the Type 2 non-Irrigation right may be transferred off the land; the other two types must be purchased with the land. While theoretically these rights could be a source of water for the project, for economic reasons, they would probably be unsuitable. For the Type 1 right and the irrigation grandfathered rights, the land would have to be purchased. The costs for this irrigation land would probably be prohibitive. The Type 2 rights are "lumpy" meaning that the entire right must be purchased, not just a part, also an expensive source of water.

The biggest impediment however is the price of the rights, a price that will only escalate over the next ten years. There is a rapidly growing market for these rights. Farm owners crowded by urbanization, land speculators hoping to make a profit, developers planning urban communities, and municipalities are all in the market for these rights or competing for them (Holub, 1986).

\subsubsection{Surface Water Rights}

A number of saline surface water supplies have been identified in the state. Another option for a water supply for a project would be to acquire surface water rights under the Arizona water Code. All appropriations for surface water must be made under the procedure outlined in ARS 45-142 entitled "Application for Permit to Appropriate Water".

The application to appropriate water must include the following information:

1) name and address of the applicant

2) the water supply from which the appropriation will be made including the nature and amount of the proposed use

3) the location, point of diversion, and description of 

works
4) proposed construction date and completion date of project works

Additionally, depending on the use, other information may be required including maps, drawings and data as required by the Director of the ADWR.

The Director of the DWR has the authority to reject any application if the proposed use "conflicts with vested rights, is a menance to public safety, or is against the interests and welfare of the public" (ARS 45-143a). If the diversion will exceed more than ten cubic feet per second, the Director may require a fact sheet on any corporations that are involoved in the project, or the name of the party constructing the works, and also proof that the diversion will not affect vested water rights.

Once an application is approved, a permit is granted and the applicant may construct the works, apply the water to a beneficial use and perfect the water right (ARS 45-148). Actual construction must begin within two years after the application is approved and must be completed within five years (ARS 45-150). However, extensions may be granted at the discretion of the Director, if justified by the magnitude of the works, physical difficulties, or the cost of work.

Once the works to appropriate the water have been completed and the water put to beneficial use, the Director issues a certificate of Wwater Rright. The certificate states the name and address of the owner of the right, the priority date, and extent and purpose of the right.

The primary obstacle to acquiring surface water rights in Arizona today is that most areas of the state are over-appropriated. All major surface water supplies have been developed and the few remaining headwater streams are for the most part unavailable because of earlier priority dates of downstream users. In fact, the only area where surface water may be uncommitted is some waters of the Iittle Colorado River (Arizona water Commission, 1975). But the status of all surface rights is uncertain until the General Adjudication of water Rights now underway is completed and all rights are ranked relative to priority and the Indian claims settled.

Another option for obtaining a water supply for this project is to purchase existing surface water rights. The Arizona Water code does permit the transfer of a surface water right from the land for which the original appropriation was made, and for a change in use. In order for the right to be transferred, the Director must give his approval and no vested or existing rights may be impaired. In addition, the amount transferred must not exceed the original right and it must also be a perfected right. Forfeited or abandoned rights may not be transferred. 
There are two restrictions on transfers however. First, no water right may be transferred from lands within the boundaries of irrigation districts, agricultural improvement districts, or water users associations without the written approval of the affected entity. Second, Arizona law contains one other rather sweeping restriction - "No right to the use of water on or from any watershed or drainage area which supplies or contributes water for the irrigation of lands within an irrigation district, agricultural improvement district, or water user association, shall be severed or transferred without the consent of the affected entity" (ARS 45-172). The statute provides that all such transfers must first be submitted to the governing bodies of these entities before an application is submitted to the Director of the ADWR, and within 45 days they must either accept or reject the transfer.

This provision of the law may have been mitigated by an Arizona Attorney General opinion issued in 1974 (Gould, 1980). In that opinion, the Attorney General held that these restrictions only apply to changes in place of use (Az. Atty. Gen. Op. No. 74-28-L (1974)). Changes in purpose of use only may be governed by another statute (ARS 45-146) that does not contain these restrictions. Additionally, court-decreed rights may also be free from these restrictions.

When considering purchasing surface water rights, a number of factors should be taken into consideration. Probably the most important factor is the priority date of the water right. The right must have sufficient seniority to provide a reliable source of water year round and in the event of shortage years on the river. In general, "the more junior the water right, the less reliable the supply" (Phillips, 1984).

This rule is especially true in Arizona. currently, the courts are adjudicating water rights and all rights wili be ranked according to priority dates. Given that most streams in Arizona are over-appropriated, it is likely that those individuals holding surface water rights with late priority dates will not receive water in shortage years. While the final decree for this adjudication will not be issued for at least 10-15 years, all purchasers of surface water rights and all new appropriators of surface water rights should exercise caution. The water right may prove to be little more than a paper water right, yielding little "wet" water.

Another factor to consider is the physical flow of the stream from which the water will be taken. A river must have enough flow to support a diversion that will supply a project with sufficient water. The flow rate is especially important on streams that may be overappropriated by agricultural users.

Three other factors to consider are the location of the water right, the validity of its title, and the way the amount of the right is measured. For location, it clearly must be located where it can be utilized. If a change of place of use is 
required, the effect of this change must not injure other vested water rights. It is also important to check the validity of the title to the water right, that the right has not been previously sold with land, or that it is not subject to forfeiture or abandonment. Finally, many irrigation rights are measured in cubic feet per second and are also offered as consumptive uses with some portion required to be returned to the river source.

\subsubsection{Ground Water Outside of AMA's}

Another option for a water supply for this project is saline ground water which is located outside of an AMA. This option is probably the best option in terms of cost, water availability, and legal requirements. As stated earlier in the section on ground water law outside an AMA, a rule of reasonable use is in effect. Any landowner may pump as much water as can be put to benefical use on their property. If the water is pumped and then transferred off the land, then the landowner could be subject to suits based on damages from neighboring landowners.

Some of the advantages to utilizing this source of water are as follows. First, a number of saline water sources have been identified in Tasks I and II that are outside of AMAs. Second, the only legal requirements required by the state is to register the wells, and follow well drilling guidelines set up by the state. Compared to the process that must be followed for obtaining a permit, or a surface water right, both these procedures are much less costly than following permit and appropriation procedures or purchasing existing water rights.

Third, in some of the identified areas, it would be an advantage to surrounding landowners and their water users to get the saline water out of the ground. In the Yuma area, the saline waters, if removed might improve the water quality in general in the area, and the farmers would probably be grateful, instead of opposing a new use of water in the area. Also, in the Buckeye area, the farmers are facing a water logging problem - there is too much ground water in the area.

However, a cautionary note concerning ground water must be issued. The Gila River adjudication may also adjudicate ground water. This has not yet been determined. The court may decide this issue in one of three ways: 1) all ground water will be included in the adjudication; 2) only ground water which is hydrologically connected to the surface water courses will be included; 3) or all ground water, except ground water which runs in definite underground channels, will be excluded.

Before purchasing land for its ground water, this factor must be 
taken into consideration. It is doubtful that all ground water will be included, but likely that the second option may be utlized by the court. Many of the ground-water sources identified for this project are in areas that are hydrologically connected to the surface water courses. If included in the adjudication, this water would probably also be assigned a priority date, with later priority dates forgoing use of water during shortage years on the river source.

\subsubsection{Effluent}

Presently, effluent is an underutilized water supply. For years, in both the Phoenix and Tucson areas, the effluent water was simply discharged into stream beds. But competition for this source of water is increasing. In fact, effluent discharged from the Tucson and Phoenix areas totals approximately 280,000 acrefeet a year (Arizona Town Hall, 1985). Increasingly, entities from agricultural users, to golf course owners, to power plants are either contracting for effluent from the cities, or are investigating contract possibilities.

In addition, the Active Management plans require the increased use of effluent in order for the areas to achieve safe-yield. Over $90 \%$ of the effluent in the Phoenix area is discharged from two plants, the 23 rd Avenue and 91 st Avenue plant. As part of the total return flows of water available in the Phoenix area, effluent is expected to increase from $17 \%$ in 1980 to $55 \%$ in 2025 .

In a recent suit, a superior court in Arizona ruled that effluent is a seperate class of water, falling neither under surface water provisions or the ground water code. This stance by the court has been opposed by the DWR. The case will probably be appealed and it is also possible the state legislature will clarify the legal status of effluent.

The price for the effluent varies greatly depending on when the contract for the effluent was negotiated. For example, Buckeye area farmers pay only $\$ 1.50$ per acre foot of effluent under a contract negotiated in 1967. Also, the Palo Verde Nuclear plant pays between $\$ 20$ and $\$ 30$ per acre-foot for up to 140,000 acrefeet of effluent a year under the terms of a contract negotiated in 1973. Conversely, the city of Tucson is charging $\$ 330$ per acre foot for effluent sold under recent contracts.

Competition for this resource will only grow. currently, a number of entities are vying for contracts, primarily because of the uncertain legal status of the water. If an entity can nail down a contract now, whatever the courts or legislature decides would not affect the status of these contracts. Additionally, farmers are looking to effluent as a source of water also. The effluent contains high levels of fertilizers and may be cheaper than CAP water. 


\subsection{LAND STEWARDSHIP}

\subsubsection{State Lands}

In Arizona, $13 \%$ of the land area is administered by the state, a total of 9.6 million acres (Arizona water Commission, 1975). The State land department is responsible for managing and administering these lands. The state does not own the land, but holds it in trust for a number of beneficiaries, primarily the state school system. The state Iand Department is not only responsible for the land, but also for all water and mining rights, and any other product linked to the land.

A majority of the trust land is leased to ranchers, farmers, developers, industry, and mining companies under one of approximately 70 leases. Presently, there are over 700 commercial leases and over 450 agricultural leases scattered throughout the state.

The leasing, selling, or exchanging of any state trust land or its products is governed by a federal law, the Arizona Enabling Act (36 stat. 557, 568-579). In this Act, it is required that "the granted land, its products, and proceeds be held in trust and be disposed of only for their true value (Kolsrud, 1986). In fact, "any disposition of trust assets not made in conformity with the Act is null and void" (Kolsrud, 1986). This enabling act, much stricter than the acts of other western states, must be complied with in any transaction involving state lands and its products.

The SERI project may be suitable for placement on state trust lands. It would require a commercial lease (Helms, 1986). Under a commercial lease, the lease holder secures a short term lease with a preferred right of renewal. A development plan for the land including land-use restrictions is prepared before the long term lease is bid on. This plan essentially protects the investment of the original lessee. As one lawyer notes, "A successful bidder who did not prepare the plan must cash out the existing leasee. Inevitably, the cost is so high that the bidding is chilled" (Kolsrud, 1986).

According to a state Land Department official, the major constraint on locating the SERI project on state land will be the cost of water. As stated earlier, the state Land Department must receive fair market value for the land and its products, including water. Consequently, the Agency charges approximately \$25 an acre-foot for ground water that is withdrawn from and used on trust lands (Helms, 1986). If the ground water is pumped from State land and then transported to another parcel of land, then the water must be bid on at a public auction. The price for water sold at an auction varies, depending on the area and competition. At a recent auction in Pinal county, the minimum 
value set was $\$ 45.00$ and acre-foot. Based on these prices, the cost of water for a SERI project on state land may be prohibitive. For example, 14,000 acre-feet of water would cost $\$ 350,000$ at the $\$ 25.00$ an acre-foot price.

However, this price may be negotiable. Project planners would have to file an application for a commercial lease and include a budget and a project proposal. State Land Department officials may be willing to negotiate the terms of the lease. Project planners could argue that the saline water is not worth $\$ 25.00$ an acre-foot. The key is that the water must be priced at fair market value and it may prove true that some saline ground water areas have low market value. The Commissioner of the state Land Department would have the final say.

\subsubsection{Federal Lands}

The federal government has substantial land holdings in the state of Arizona. In fact, $43.6 \%$ of the state is owned directly by the federal government, and another $26.7 \%$ is held in trust by the government for the Indian tribes. The federal land is administered primarily by the Bureau of Land Management and the Forest Service but the Defense Department, the National Park Service, and the Bureau of Reclamation (BIM) also all have responsibilities for federal land. The Bureau of Indian Affairs also has some responsiblity over Indian lands.

of the available federal lands in Arizona, probably only the lands administered by the BIM would be suitable for this type of project. Contact with the Phoenix area office revealed that while the BLM does lease land, primarily for agriculture and grazing, it is usually fairly small parcels, or the leases are long-term leases that the BLM "inherited". This agency is bound by a mandate to manage the public lands to maximize their potential for the public.

The BLM is reluctant to commit a large block of land for one use through a long-term lease. The realty specialist contacted suggested that if the parcel of BIM land is separate from other larger land holdings of the Agency, that it may consider selling the land. However, all sales of Federal land would have to be open to public bidding. Additionally, all water rights must be acquired in accordance with state law.

\subsubsection{Indian Reservations}

Another option for this project is obtaining water from the Indian reservations located in Arizona. In the state, there are nineteen Indian reservations encompassing more than 20 million acres of land, over $26 \%$ of the total land area of the state. The Indian people residing on the reservations are a diverse group, with distinct cultures. Due to high unemployment, poverty, and 
underutilization of natural interested in a microalgae economically self-sufficient.

resources, some tribes may be project in order to become more

Indian reservations in Arizona hold another type of water right, the reserved right, that is wholly seperate and different from water rights acquired under state law. These water rights have their basis in federal law and differ substantially from stateheld rights. The cornerstone of Indian water rights is the Winters Doctrine. First established in 1908 in Winters V. United States (207 U.S. 564,1980$)$ and later expanded through a $\frac{\text { unies }}{\text { series }}$ of court cases, it holds that when a reservation was established, enough water to fulfill the purposes of the reservation was implicitly reserved. The right is given a priority date of the time the reservation was established and the right is not measured by a criteria of beneficial use and cannot be lost through non- use.

The water rights of the Indian tribes in Arizona are largely unquantified. In 1963, in Arizona v. California, the Supreme Court awarded five tribes over 900,000 acre-feet of Colorado river water. Also, two other reservations, the Ak-Chin Community and the San Xavier district on the Papago (now the Tohono o'odham) Reservation, have had their rights quantified through legislative settlements. But the bulk of the tribes will have their rights quantified in the Gila River adjudication.

The quantification of Indian rights is a top priority for the State of Arizona. The early priority dates of the reservations' water rights, most dating back to the 1880's, predate the water rights held by most non-Indian water users. And until these rights are settled, the legal status of non-Indian rights with later priority dates is uncertain. Further, the magnitude of these rights is staggering. While it is unclear at this point what standard the Court will apply in the Gila River adjudication, if the "Practically Irrigable Acreage" standard, the method used by the supreme Court in Arizona v. California, is applied, some estimates place Indian water rights in the state at 30 million acr - feet of water (Western states Water Council, $1984)$.

There are still more questions than answers concerning Indian water rights in the west. Some of these questions are what standard should be used for quantification, whether reserved rights apply to ground water, and whether the rights can be leased for off-reservation use. But there is no question that the Indian tribes will have perfected rights with early priority dates to substantial amounts of water. The largest problem facing the tribes is how to put the water to use in an economically feasible way.

Indian tribes are sovereign powers, holding rights to selfgovernment, but also subject to the plenary powers of the Federal government. Reservation land is held in trust for the Indians by the Federal government. The land cannot be sold without Federal 
consent. However, under a law passed in 1955, tribal land can be leased upon the approval of the Secretary of Interior. The land can be leased for a variety of purposes including for the "development or utilization of natural resources in connection with operations under such leases" (25 U.S. Code Sec. 415). This provision has been interpreted as including water. In general, lease terms are restricted to twenty-five years although a number of Arizona tribes may lease land for up to ninety-nine years.

Water use on reservations is not under the jurisdiction of the state. The provisions of the Arizona Groundwater Management Act and state water code do not apply. Also, any state statutes and regulations concerning water quality do not apply on the reservations. In general, in the past there has been very little regulation of water use on the reservations. Recently, a number of tribes have developed water codes.

However, it is not always easy to place non-Indian economic development projects on reservations. First, negotiations must be conducted with tribal officials. A problem endemic to working with these tribal officials is that there is a high turnover rate. Second, Indian people must be given preference for jobs. Third, since it is federal land, environmental impact statements will be required. Fourth, there is often a cultural gap, one most non-Indians are unaware of. Fifth, the land itself cannot be used for collateral since it is held in trust by the federal government for the tribes.

\subsection{ENVIRONMENTAL CONTRAINTS}

In addition to legal constraints on the acquistion of water, there are also environmental constraints. In this section, some of these constraints and their significance to the microalgae project will be reviewed. First, the issue of water quality, and the current Arizona permitting process will be discussed. Second, land subsidence will be examined. Finally, requirements for preparing environmental impact statements will be reviewed.

\subsubsection{Water Quality}

For years in Arizona, there was little concern about water quality issues. Groundwater especially was considered "out of sight, out of mind and seemingly, out of harm's way" (Briggs, 1984). However, this misconception has been proven false as many areas of ground water contamination have been discovered. since 1980, gasoline and solvents, acids and heavy metal, cyanide, volatile organic chemical, agricultural pesticides, sulfates and nitrates have all been documented as contaminants of ground water.

In response to the discovery of these pollutants, public officials and the citizenry alike have begun to push for more stringent controls for water quality. Currently, there is an intiative drive to place a new water-quality law on the ballot in 
November, 1986. However, the initiative may be a dead issue now that the state Legislature has passed new ground-water quality legislation.

This bill, introduced into the Legislature at the end of April, 1986, is the result of weeks of closed-door negotiations between environmental groups, public officials, and representatives of affected industries. By means of this bill, Arizona will implement stricter standards for ground-water quality protection in the near future.

\subsubsection{Federal Role}

While three levels of government - Federal, local, and state all have responsibility for ground- water protection, the federal government does have a substantial role. Until the mid 1970's, there was little recognition on a national level of ground water contamination as a serious problem. The environmental legislation passed by Congress in the early 1970,s was aimed primarily at clean surface water and clean air. In the late 1970's, new legislation began to address the problem of ground water contamination.

Authority over ground-water protection is fragmented at the federal level. As one author notes, "It is not covered comprehensively by any one Federal law; nor is one Federal agency or office reponsible for overseeing or coordinating all ground water programs and activities" (Lofgren, 1984). In fact, sixteen federal laws and at least fourteen federal agencies have some effect on ground-water quality (Lofgren, 1984).

The Environmental Protection Agency (EPA), however, is the lead agency for both ground-water quality protection and regulation. The responsibilities of the EPA include: 1) administering a municipal sewage treatment program; 2) administering a financial assistance program to strengthen state water quality programs; 3 ) reviewing state regulation to ensure that they meet federal standards; 4) exercising regulatory authority where states fail to meet federal regulations (Arizona Town Hall, 1985).

The EPA has also recently developed a Groundwater Protection Strategy and formed a Groundwater Task Force to examine Federal legislation and State programs (Environmental Protection Agency, 1984). Under this policy, the states will assume primary responsibility for the protection and management of ground water. This strategy has four goals: 1) to build and enhance state programs for ground water protection; 2) address contamination from leaking storage tanks, landfills and other sources; 3) adopt guidelines for ground water protection and cleanup; 4) to strengthen EPA organization (Arizona Department of Health Services, 1984). 
While Federal law provides the context and often standards for water quality protection, the states have a primary role. Basically, the federal agency will develop the scientific data, technical standards and framework, and utilizing federal grants the states then set up their own programs in accordance with federal standards (Arizona Department of Health Services, 1984).

In fact, the Safe Drinking Water Act (SDWA), the clean Water Act (CWA), and the Resource Conservation and Recovery ACt (RCRA) are all federal programs that the states at their option can administer (Arizona Department of Health Services, 1984). Any State programs must be at least as stringent as the federal programs and must also be funded, through state monies and federal grants, at high enough levels to support the programs.

Arizona has also enacted its own water quality statutes, modeled after federal laws, and also implemented regulations. In 1967, the Iegislature adopted many of the provisions of the Federal Water Pollution Control Act of 1965 including providing for the "prevention, control and abatement of pollution of the waters of the State" (Briggs, 1984). While this statute was aimed primarily at surface water pollution, it also provides the authority to institute a similar program for ground water (A.R.S. 36-1851).

This statute also defines the reponsibilities and authority of the state for programs administered under the Federal water Pollution Control Act of 1972 and the clean water Act of 1977 . The Arizona Department of Health Services (ADHS) and its attendant water Quality Control Council (WQCC) was designated as the "State water pollution control agency" (ARS 63-1851).

It is unclear at this time whether the authority for ground water protection will remain with the Department of Health Services and the Water quality Control Council. The proposed initiative would abolish the WQCC and place all authority in the ADHS and the bill pending in the Legislature may create a new agency, a Department of Environmental Quality.

\subsection{Permit Process}

Water-quality standards are in a state of flux in Arizona now, but certainly the standards will become more, not less, stringent. In fact, the bill pending in the legislature would require that all of Arizona's aquifers be treated as sources of drinking water. Preliminary research has indicated that even under current Arizona standards, a microalgae production project will require a permit under the Arizona Groundwater Quality Protection Program (Brown, 1986). This section of the report will outline the permit application process that is currently in place, especially as it relates to the proposed microalgae project. This process should remain essentially intact with only 
a few minor changes, no matter what form of water quality legislation is passed. Under Arizona's Water Pollution Control Act (ARS 36-1851), the Arizona Department of Health Services (ADHS) has the authority to implement a ground water protection program. In 1984, to implement this program, the ADHS formulated a permitting system to control point source disposals of wastes or pollutants into the ground water (ACRR, ch. 2l). Non-point sources of pollution are not affected by this permitting process.

This permitting program specifically prohibits the discharge of hazardous and toxic materials to ground water and also outlines a detailed procedure for the issuance of permits for non-hazardous and toxic discharges to ground water. The permit process applies to "all facilities or activities that are point source dischargers which may impact ground water quality (Arizona Department of Health Services, 1984 ). These regulations apply to both new and existing facilities.

An interview with an ADHS official revealed that a microalgae production project would have to comply with this permitting process. While there are a number of exemptions to this process, the project does not fall under any of them. The permit would be required primarily because the highly saline water stored in the ponds would exceed the ambient ground water quality of the underlying aquifer (Brown, 1986).

The first step in the permit process is the filing of a "Notice of Disposal" (NOD). The purpose of a NOD permit is to allow very small dischargers to obtain a permit without having to go through the full permit process that will require hydrogeologic and disposal impact reports. In theory, the NOD permits are simply a way for the ADHS to gather information and assess whether the Application for Permit will be required (Brown, 1986). In practice, very few permits are granted on the basis on a NOD. Most applicants for NOD permits must also submit Applications for Permits.

Owners or operators of new facilities that may affect the ground water in Arizona must file a NOD with the ADHS at least 180 days prior to the date on which the discharge or disposal is to begin (ACRR: R9-20-205). The NOD should provide the ADHS with enough information of the nature of the disposal to allow a determination of whether $a$ NoD can be issued without the applicant having to go through the Application for Permit process.

This NOD must include the following information: 1) identification of the facility, and owner and operator; 2) topographic map detailing the facility location; 3) the type of facility and the nature of the activity; 4) date of expected operation; 5) operational lifetime of the facility; 6) a listing of any other environmental permits issued; 7) a description of disposal activities and control measures that are designed to protect ground water quality; 8) description of wastes and pollutants and flow rates, including an analysis of chemical, 
biological, and physical properties of the wastes; 9) a description of any ground water monitoring programs; and 10) any other information which the applicant believes will demonstrate that the facility should be permitted. (ACRR: R9-20-206).

Within 30 days, the Director of ADHS is required to notify the facility owner or operator that either a Permit will be issued, or that the applicant must submit to the permit application process, or that additional information is required. The ADHS may only issue a permit based on the NOD alone if it is found that there is "no adverse ground water quality impact" from the operation of the facility.

Under the regulations, adverse ground-water quality impact is defined as "any measurable change to the physical, chemical, or biological character of ground water" (ACRR: R9-20-203). This standard is met only if there is no migration of any wastes or pollutants to the ground water or vadose zone and if the disposal constituent concentrations are less than or equal to either the ambient ground water conditions or drinking water quality requirements.

In practice, these criteria are extremely difficult to meet. For example, the no migration standard is impossible to meet because no liner will prevent all migration. Secondly, very rarely will a discharge meet either drinking water standards or match the ambient ground water standards. Thus, most applicants for NoDs must also go through the Application for Permit process.

The permit application process is a lengthy, complex, and often expensive process. The ADHS will issue a permit based on the applications if it is determined that no wastes or pollutants will enter the aquifer or ground water in sufficient quantities to violate ground-water standards. In making this determination, the ADHS reviews the facility design, hydrogeologic charecteristics of the area, current and future uses of ground water in the area, the characteristics of the wastes, and the ambient ground-water quality in the area.

Before the application for a permit is. filled out, the operators of the facility must submit a proposal outlining the information that will be contained in the permit application. The ADHS must respond with an evaluation of this proposal within 60 days and meet with the applicant to discuss any additional work that must be done for the permit application.

The permit application itself requires a great deal of information. First, the application must include a hydrogeologic report. This report must include: 1) a description of the ambient ground water quality and an estimate of the quantity; 2) a description of ground water use in the area; 3) a description of the hydrogeologic and subsurface geologic charecteristics in the area.

The applicant must also provide a disposal impact assessment that 
includes: 1) a definition and description of the discharge impact area; 2) a description of the probable effects the facility will have on the ground water.

Finally, the ADHS can also require a monitoring plan and a description of a monitoring system that would be capable of detecting ground water contamination. Also, a contingency plan may be required that would require the applicant to provide information on how it will handle unintentional spills or leaks and a post-closure plan detailing how the facility will be shut down to prevent contamination.

Permit applications are approved if ADHS is satisfied that no wastes or pollutants will enter the aquifer or ground water in sufficient quantities to violate ground water quality standards. In assessing the permit application, ADHS looks specifically at the facility design, hydrogeologic factors, current and future uses of ground water and the present ground water quality, and characteristics of the wastes. The final permit is often the result of negotiations between ADHS and the applicant. Conditions on the permits vary for each facility.

An official contacted at ADHs felt that the microalgae production facility would have to go through the permit application process after the NOD is filed. He also stated that the Agency would probably require liners for the ponds, similar to hypalone liners that are about $30 \mathrm{~mm}$ or more in thickness. Finally, the Agency may require monitoring wells, probably four well monitors for each 10 acres of land, or at least 2-3 wells upstream, 5 wells downstream, and 3 on each side of the project, all set to the ground water flow.

\subsubsection{Subsidence}

Subsidence has been recognized as a problem in Arizona for many years. In some areas of the state, including the Buckhorn area and Paradise Valley area near Phoenix, approximately 5 feet of subsidence has occurred over the last 20 years. other areas including the Pinal AMA area have also experienced some subsidence.

Subsidence, the downward movement or sinking of land, is caused by both man-made and natural activities. In general, especially in Arizona, it is caused by the depletion of underground aquifers. Usually subsidence will occur in an area where underlying confined aquifers consisting of permeable sand or gravel of low compressibility are intermixed with clay strata of low permeability and high compressibility (Trelease, 1974). Once subsidence occurs, it cannot be reversed and the only solution is to reduce overdraft of the underlying ground-water table.

Subsidence in an area can cause damages to both man-made and natural structures resulting in high economic costs. In Arizona, subsidence of the land near Picacho in Pinal county has damaged 
the Picacho Reservoir, water wells, railroad lines, and irrigation systems (Arizona Water Commission, 1975). In the past, these costs have been borne by society, not the producer of the sudsidence. Under current laws, there is "no straightforward method by which the producer can be required to compensate others for damage to land resulting from ground water depletion" (Morris, 1980).

There are no statutes or even a body of law that address the problem of subsidence in Arizona. However, the DWR and other agencies have begun a subsidence monitoring and evaluation program. Also, under the Arizona Groundwater Management Act, any areas impacted by subsidence may be declared Active Management Areas and other provisions in the Act may act as a basis for administrative regulations for the control of subsidence (Morris, 1980).

However, a producer of subsidence could still be sued for damages. The court would probably be requested by the damaged party to create a legal right for landowners to be free from subsidence damage and impose a legal duty on the ground water pumper to not cause subsidence in an area (Morris, 1980). The court could rely on a number of legal theories, including negligence or nuisance law which is intended to protect a landowner's interest in his land in an unimpaired condition (Morris, 1980).

In conclusion, while there are no statutes or a body of law that specifically address the problem of subsidence, a landowner who is damaged by subsidence could probably successfully sue a groundwater pumper for damages. This is a new area of the law and has not been tested but a number of legal theories support the awarding of damages for subsidence. Further, the state of Arizona is increasingly aware of subsidence as a major problem and does have the authority under the Groundwater Management Act to establish administrative requlations to control subsidence.

\subsubsection{Environmental Impact Statements}

One other environmental constraint on the microalgae production facility is that if the project is located on federal lands, namely Bureau of Land Management land or an Indian reservation, an environmental impact statement (EIS) will be required.

The National Environmental Policy Act of 1969 (NEPA) established a national policy for the environment and also set up procedures that federal agencies must follow in assuring the protection of the environment. one of the most prominent features of the Act is section 102 (2) (c) which requires all federal agencies to prepare environmental impact statements for all federal actions that will affect the quality of the environment. 
The requirements for this environmental impact statement can vary from agency to agency. But it is important to realize that they can often be expensive reports to complete. It is advisable to contact the relevant federal agency and negotiate what is required for the report. For most federal lands, the Bureau of Iand Management would be the appropriate agency. For Indian lands, the Bureau of Indian Affairs would supervise any environmental impact statements required. Additionally, if SERI is the sponsor, there would probably be Federal involvement by virtue of using United states Department of Energy funds. 


\subsection{AREA I}

As shown on Plate III, this focal area is located in the Parker Valley immediately to the east of the Colorado River south of Poston, Arizona. From a physiographic perspective, the area is within the Parker Valley. The land area designated on Plate III is within the Colorado River Indian Reservation. An elongated plume of saline water is depicted on the Plate III extending in a northsouth direction paralleling the Colorado River. Ground water in the plume satisfies the screening criteria of Tasks I and II, namely, salinity in excess of $3,000 \mathrm{mg} / 1$, depth to ground water less than $500 \mathrm{ft}$ from land surface, and potential yields in excess of $4 \mathrm{mgd}$. Additional information on possible sites in this focal area is included in Table 4-2.

Relevant features of the area are described in the ensuing paragraphs.

\subsubsection{Climate}

The area is located within Zone 6a, Sonoran Desert (Low Desert), according to a classification of the Arizona solar Energy Commission (Osborn and Huddy, no date). Daily solar data, climate data, and data on daily solar radiation on tilted surfaces for the area are presented in the document of Osborn and Huddy (no date). According to Osborn and Huddy (No Date), summers in this region are long and hot. Temperatures in the afternoon reach 100 degrees $F$ on the average from June 10 to september 20. The average annual total horizontal insolation for the zone is about 1,924 BTU/ per square ft per day. The average annual temperature is 73.7 degrees F.

\section{1 .2 Surface water features}

Surface water drainage occurs directly into the nearby colorado River. There are no sources of saline surface water in the area.

\section{1 .3 General hydrogeology}

The area is within the system of basins classified by Anderson (1985) during the SWAB/RASA study as the Colorado River Basins. Anderson presented the following general description of these basins:

The aquifer system of the colorado River basins is totally dominated by the streamflow of the colorado River. Infiltration of streamflow is the principal source of inflow to the ground water system. outflow is almost entirely through consumptive use by 
phreatophytes and riparian vegetation and more recently by agricultural crops. The stream alluvium that underlies the flood-plain area is the principal water-bearing unit. older alluvium outside the floodplain is hydraulically connected to the stream alluvium and is part of the main aquifer. Ground-water flow occurs both laterally and longitudinally in the basins. A principal component of flow is away from the Colorado River toward the flood plain where discharge occurs.

Ground-water withdrawal in these basins will have minimal effects on the aquifer system because of the immensity of river leakage. Ground water pumped from the flood plain is river water that infiltrated. In places, minor quantities of water may be withdrawn from storage and evapotranspiration may decrease; however, lowering water levels will increase the water-level gradient resulting in more streamflow infiltration.

A representative cross-section through a Colorado River Basin is depicted in Figure 2-5.

\section{1 .4 Saline ground water}

As shown on Plate III; this focal area contains a plume of saline ground water extending for several miles in a direction paralleling the Colorado River. The source of the plume appears to be irrigation return flows to ground water. The TDS concentration within the plume is mainly betweem $3000 \mathrm{mg} / \mathrm{l}$ and $5000 \mathrm{mg} / \mathrm{l}$, except for a small plume with a salinity above 5000 $\mathrm{mg} / \mathrm{l}$. Two chemical quality pattern diagrams are included to illustrate representative water chemistry in the plumes. Except for absolute concentrations, the two diagrams are similar indicating the predominance of sodium and chloride in the anionic-cationic makeup of the water. sulfate is the second dominant anion and calcium is the second dominant cation. Additional information on the chemical composition of ground water in this area is included in Appendix D.

Hydrogeological features of the area which may affect groundwater development for a microalgae facility are described in the following paragraphs.

Tucci (1982) used the report of Metzger et al. (1973) to summarize the hydrogeologic system of the Parker valley, which includes the study area. Basically the area is underlain by three principal hydrologic units. The lowermost unit is a fanglomerate consisting of cemented sandy gravel. Ground water may be confined in this unit, and it is not being exploited as a major water source. Overlying the fanglomerate unit is the Bouse formation consisting of a basal limestone, a sand unit, and a tufa (Tucci, 1982). Metzger et al. (1973) describe this formation as a 
brackish water sequence. The average hydraulic conductivity of the upper zone of the Bouse formation is $30 \mathrm{ft} /$ day (Metzger et al., 1973). The lower zone is the confining layer for the underlying fanglomerate.

The Bouse formation is overlain by an alluvium formation. This formation is $125 \mathrm{ft}$ thick and its areal extent is confined to the floodplain (Tucci, 1981). The alluvium formation yields water eradily to wells with specific capacity values of more than 100 gpm/ft of drawdown (Tucci, 1982). The average hydraulic conductivity of the formation is $313 \mathrm{ft} / \mathrm{day}$.

Tucci (1982) simulated the ground-water flow system in the Parker Valley using a three-dimensional model. The three-dimensional modeliing approach was used to simulate and evaluate the flow between the alluvium unit and the upper layers of the Bouse formation.

According to the United States geological Survey (1984), wells in the area are capable of pumping rates in excess of $1000 \mathrm{gpm}$.

\subsubsection{Land ownership}

Land ownership is a critical factor in planning for a microalgae production facility. One of the goals of this project was to identify land ownership within a region extending up to 10 miles from identified sources. As shown on Plate III the saline groundwater plume is entirely within the colorado River Indian Reservation. To the east of the plume a major segment of land is managed by the Bureau of Land Management. This area is within 10 miles of the plume. Lands to the south of the plume are within the state Trust Lands, administered by the Arizona state Land Department. This land is also within 10 miles of the plume.

\subsubsection{Legal and Institutional Constraints}

The Colorado River Indian Tribe is one of the five Reservations whose water rights were quantified under Arizona $v$. California in 1963. In the final decree, the Indians of this reservation were awarded an annual allotment of Colorado River water. Currently, the Reservation is utilizing the majority of this water for agriculture. The only ground water pumped on the reservation is for drainage purposes. Crops grown include cotton, alfalfa, maize, barley and wheat.

In addition to the 8,000 acres of land farmed by the Tribe itself, and some small scale farming by individuals of the Tribe, a large portion of the agricultural land is leased to nonIndians. Terms for most leases run from one to five years, with the longer leases requiring some types of improvements to the land. The lease contracts contain jurisdiction clauses that are intended to end disputes that may arise and also contain preference clauses for Indian employment. The Tribe is currently encouraging non-Indians to lease land on the 
Reservation. By leasing land and water the Tribe hopes to increase revenue and protect their water rights. Further, the economic crisis that is affecting farming in general also has an impact on the Reservation, especially on cotton production. The Tribe is encouraging lessees to experiment with more lucrative specialty crops.

This reservation may be very interested in this type of project. The Indians have a large, dependable source of water and ample lands. They also have a drainage problem on the Reservation that this project could rectify. Finally, the Tribe is very interested in diversifying their economic development because of the falling market for cotton and other agricultural products (Laffoon, 1985). If the return on the lease was greater than what they presently make leasing that land for farming, it is likely they would consider this type of project.

The principal institutions that would approve and review a lease for this type of project are the Tribal Council, the Bureau of Indian Affairs, and the Bureau of Reclamation. Initially, the Tribal Council must approve the lease. The Bureau of Indian Affairs would probably require an environmental impact statement, but is also likely to approve the lease if the Tribes agree to the project. Finally, the Bureau of Reclamation, as manager of the Colorado river will monitor the withdrawals of ground water because the ground water is hydrologically connected to the Colorado River and must be charged to the Tribes' allotment. 
This focal area extends from the Palomas Plain along the Gila River to the City of Yuma. The area encompasses the extensive irrigated area in the Mohawk Valley. Details of Focal Area II are shown on Plate II and Plate III. On Plate II, four areas were identified as satisfying the screening screening criteria for Task I, i.e., salinity in excess of $3,000 \mathrm{mg} / \mathrm{l}$ and depths to ground water of less than 500 feet from land surface. During the Task II evaluation, only two of the four areas satisfied the criterion of potentially yielding more than $4 \mathrm{mgd}$. These plumes are shown on Plate III. one very large plume extends essentially as a unit along the Gila River from the Palomas Plain to the South Gila valley. A lesser plume is shown west of the larger plume. Details on possible sites for a microalgae production facility in this area are included in Table 4-2. As shown on the table, the total land area overlying the saline ground-water plumes is about 250 square miles. Information on the ground-water chemistry in this area is included in Appendix D.

Salient features of the focal area are summarized in the following paragraphs:

\subsubsection{Climate and Solar Energy}

According to Osborn and Huddy (no date), the focal area near Yuma is classified as Low Desert within the Sonoran Desert climatic zone. A detailed summary of daily solar data, climate data, and daily solar radiation on tilted surfaces is included in osborn's report. Average annual values of parameters of interest are as follows: total horizontal insolation is 1924 BTU per square ft per day and average monthly temperature is 73.7 degrees $F$.

\subsubsection{Surface Water Features:}

As shown on Plates I and III, this focal area is drained by the Gila River, which flows from the northeast corner to the westcentral part of the area. The Gila River flows into the colorado River near the City of Yuma. As discussed in a previous section, and shown on Plate $I$, the principal sources of saline surface water in the area include the Wellton Mohawk Main Drain, the South Gila Pump outlets 3 and 4 , and the Yucca steam generating station. When the Yuma desalination plant comes on line in 1989 there will be an additional source of saline surface water for a project (see Section 6.2.6).

\subsubsection{General hydrogeology}

The basins within Area II are primarily categorized as West Basins, according to the United States Geological survey's 
SWAB/RAS classification scheme. These basins are described by Anderson (1985) as follows:

The aquifer systems of the west basins include preBasin and Range sedimentary rocks and an overlying moderate- to coarse-grained facies of the lower basin fill, which forms the main water-bearing zone. An overlying fine-grained facies of the lower basin fill occurs near the basin centers. Upper basin fill consists of a thin layer of heterogeneous sediments thet generally lies above the water table. Stream alluvium occurs along the lower Gila River.

\begin{abstract}
Inflow to the west basins is small and is composed of minor mountain-front recharge and infiltrated streamflow. Outflow consists of evapotranspiration at the downstream end of the basins and underflow. The predevelopment potentiometric contours were virtually straight lines normal to the basin axis indicating that mountain front recharge is small. Ground-water pumpage is derived from removal of water from storage within the aquifer.
\end{abstract}

A representative cross-section through a west basin is shown on Figure 2-5.

\title{
6.2.4 Saline ground-water areas
}

As shown on Plate III the concentration of ground water in the elongated plume is generally about $3,000 \mathrm{mg} / \mathrm{l}$. Three lesser plumes with concentrations above $5,000 \mathrm{mg} / \mathrm{l}$ are also shown. According to Leake and clay (1979) salinity levels of more than $8,000 \mathrm{mg} / \mathrm{l}$ were fairly common in the Wellton-Mohawk area in the 1970's.

Hydrogeological features affecting the production of ground water for a microalgae facility in the area are summarized in the following paragraphs.

The hydrogeology of the area has been subdivided into the following subareas: (a) Painted Rock dam to Texas Hill (White et al., 1979), (b) Texas Hill to Dome area (Leake and Clay, 1979), and (c) in the Yuma area (Wilkins, 1978).

White et al. (1979) described the ground-water geology of the area from Painted Rock Dam to Texas Hill. The following discussion is abstracted from their report. Valley fill deposits constitute the main water bearing unit in the area. These deposits mainly consist of clay, silt, sand, and gravel deposits, and weakly consolidated mudstone and sandstone. The valley fill deposits have been divided into upper, middle, and lower units. The potential yield of wells in the alluvium exceed 1,000 gpm (USGS,1984), consequently yields in excess of $4 \mathrm{mgd}$ should be obtainable for a project. As shown on the chemical quality 
pattern diagram for this area, ground water is primarily of the sodium-chloride type.

The region between Texas Hill and the Dome area encompasses the Wellton-Mohawk area, which has been used extensively for irrigated agriculture since the 1920's (Leake and Clay, 1979). The geology of the area has been described by Leake and Clay as follows :

...the alluvium consists of an upper sandy unit and a lower gravel unit. The upper sandy unit contains sand, silt, clay, and some gravel lenses and ranges from 20 to $80 \mathrm{ft}$ in thickness. The lower gravel unit ranges from 10 to $70 \mathrm{ft}$ in thickness and overlies a clay layer. Extensive pumpage for irrigation in the early years caused a general lowering of water tables in the area. However, this trend was reversed with the importation of Colorado River water as an irrigation source beginning in 1952. By the early 1970's water levels were within 6 ft of land surface in most of the area. Since 1961 a series of about 70 wells were used to assist in the drainage of the waterlogged areas, pumping as much as 200,000 acre-ft per year.

Wells in the area are capable of yielding in excess of $1000 \mathrm{gpm}$ (USGS, 1984). Salinity levels in excess of $8000 \mathrm{mg} / \mathrm{l}$ are not uncommon. The chemical quality pattern diagrams show that ground water is generally of the sodium-chloride type. However, the sample from T8S, Rl6W was more of a mixed sodium-calciumchloride-bicarbonate type. Detailed chemical analyses for wells in this area are included in Appendix D.

According to wilkins (1978), the Yuma area is underlain by materials ranging from dense crystalline rocks to unconsolidated alluvium and windblown sand. The principal water-bearing unit in the area comprises the sedimentary deposits, thought to be hydraulically connected and forming a single aquifer (wilkins, 1978). The aquifer has been divided into the following three zones in descending order: upper fine grained zone, a coarse gravel zone, and the wedge zone. These zones were described by wilkins (1978) in the following way:

The upper fine-grained zone is composed mostly of sand and silt. The zone is about $100 \mathrm{ft}$ thick in the valley areas and $180 \mathrm{ft}$ thick beneath the Yuma Mesa. Most ground-water recharge and discharge take place through this zone. The coarse gravel zone is the principal production zone in the aquifer in the Yuma area and consists of gravel deposited by the Colorado and Gila Rivers... it ranges in thickness from 0 to more than $100 \mathrm{ft....} \mathrm{The} \mathrm{wedge} \mathrm{zone} \mathrm{consists} \mathrm{of} \mathrm{clay} \mathrm{to} \mathrm{gravel.}$

As in the Wellton-Mohawk area, water levels rose in the Yuma area following the importation of surface water, and extensive pumping was required to overcome water logging of the agricultural 
fields. According to wilkins (1978), 158,000 acre-ft was pumped in 1975 for drainage purposes. Wells in the area are capable of pumping at rates greater than 1000 gpm (USGS,1984). Ground water from one well in the area was reported to have a TDS of greater than 10,000 mg/l. As depicted on Plate III, the chemical quality pattern diagram for the area illustrates that ground water is predominantly of the sodium chloride type.

\subsubsection{Landownership}

Landownership in Area II is shown on Plate III. Within the plume, land ownership resides mainly in private hands and with the Bureau of Land Management (BIM). Only a small amount of the land is owned by the Arizona state Land Department (ASID). An extensive area to the north of the plume is within the Yuma Proving Ground. Similarly, the land to the south is within the Luke Air Force Range, except for regions near the saline groundwater boundary which are in private hands or owned by BLM and the ASID. The United States Marine Corps Air station is located at the western edge of the larger plume. The lands within the military reservations would not probably not be available for $a$ project.

Irrigation districts that are located within or near the plumes include the Wellton-Mohawk Irrigation and Drainage District, the Yuma Irrigation District, the Yuma-Mesa Irrigation and Drainage District, and the Yuma County Water User's Association.

\subsubsection{Legal and Institutional Factors}

In terms of legal constraints and land availability, this area may be the best area for a microalgae production project among the six focal areas examined during this project. First, it is not located within the boundaries of an Active Management area. For groundwater to be pumped, project planners would need only to construct the well according to state standards and register the well with the state. No permits or expensive hydrological studies would be needed. However, involving a trained hydrologist in the process is advisable. Secondly, there is a lot of private land available. Dr, Gordon Dutt (Department of Soils, Water and Engineering, The University of Arizona), an authority on the use of saline waters in this area, believes that there would be many opportunities to either lease or purchase private lands. Third, the presence of saline water in this area is a problem for the local farmers. While a few farms are using saline water, the majority do not.

However, there are some legal constraints on the use of this ground water and on the return flows of the irrigation districts. one factor to consider is the Treaty of 194.4 signed by the United states and Mexico. The Treaty apportioned the waters of the Rio Grande, Colorado, and Tijuana rivers. It allocated 1.5 million 
acre-feet of Colorado River water annually to Mexico. This quantity increases to 1.7 million acre-feet during surplus years and is reduced proportionaly during shortage years (Utton, 1982). While the high water levels over the last few years have resulted in much larger deliveries to Mexico than is required, during the shortage years on the river, this allotment to Mexico must be met first. The Bureau of Reclamation closely monitors ground-water pumping that is close to the river as this pumping is charged to Arizona's entitlement under Arizona v. California and because the Bureau is reponsible for meeting Mexico's entitiement of water.

Another federal law that is important in this region is the Colorado River Basin Salinity Control Act of 1974. In 1973, the United states and Mexico reached an agreement to limit the permissible levels of salinity of the water delivered to Mexico. Under this agreement, the water at Morelos dam must equal 155 parts per million, the salinity levels of the water stored in Imperial dam.

The Salinity Control Act was passed by Congress to implement this agreement. Primarily the Act authorizes construction of a reverse osmosis desalinization plant near Yuma, Arizona. But the Act also contains other provisions that affect water use in this area. First, each country must limit groundwater pumping within five miles of the Arizona - Sonora, Mexico border to 160,000 acre-feet of water. Each country has a well field along the border that pumps this maximum amount. The United states well field delivers water pumped to meet Treaty obligations. The Bureau of Reclamation operates a pumping field in this area and monitors groundwater withdrawals. Second, each county must consult with the other before undertaking any new developments of surface or groundwater resources, or modify existing development in the border region. Both of these provisions would have to be taken into account if the project was located in the border region.

Another factor to consider in this area is the Gila River water rights adjudication. As stated in the previous section, the court has not yet determined whether groundwater will be included in the adjudication. The court may rule that ground water that is hydrologically connected to the surface water flow of the Gila River will be adjudicated. This determination could affect the placement of the project because the court could assign priority dates to groundwater use in this area and those rights assigned later priority dates may lose the right to pump in a shortage year on the river so that senior surface water rights may be satisfied.

The surface water supplies identified in this region are also subject to some legal constraints. First, there are a number of irrigation districts in the area. Under Arizona law, these districts may be able to veto a transfer of surface water rights (See section 5.0). Second, the agricultural return flows of the districts are applied to the districts' entitlement of Colorado River water. The districts are given credit for water returned 
to the river, even if it is highly saline. While the welltonMohawk district has expressed interest in this project as a possible use for its return flows, it also cautioned that there is a "constraint on this water" (Gould, 1985). Another irrigation district or the Bureau of Reclamation might object to this transfer.

Interestingly, the desalinization plant itself will be a source of water for this project. The plant is under construction and will be completed in 1989. The brine effluent from the plant will average 25,000 to 35,000 acre-feet of water a year and will have a TDS of 9,000 to 10,000 (Boyer, 1986). The water is scheduled to be discharged into the santa clara slough, which empties into the Gulf of California. Presently, there are no indicated uses for this water. Negotiations with Bureau of Reclamation officials could be undertaken if this water is desired for the project. 
Focal Area III is depicted on Plate II and Plate IV. Principal municipalities in the area include Tolleson, Avondale, Buckeye, and Gila Bend. The Palo Verde Nuclear Generating station is located within this area west of the City of Buckeye. During Task I, eight distinct areas were identified with ground-water salinities above $3,000 \mathrm{mg} / \mathrm{l}$ and water levels within $500 \mathrm{ft}$ of the land surface. As shown on Plate IV, only five of the eight regions satisfied the screening criteria for Task II, namely potential yields in excess of $4 \mathrm{mgd}$. The largest plume is included within the Buckeye Valley and the Arlington Valley. other lesser plumes exist north of Gila Bend, south of Mobile, near Rocky Point, and in Hyder Valley. The legal descriptions of areas for possible project sites in this focal area are included in Table 4-2. The land area associated with the saline plumes is 312 square miles. Detailed information on the ground water chemistry in the area is included in Appendix D.

Relevant features of Area III are as follows:

\subsubsection{Climate.}

The area is within the Sonoran Desert climatic zone. Detailed solar and climatic information for the area is included in the document entitled: "Arizona solar and Weather Information", published by the Arizona Solar Energy Commission (Osborn and Huddy, no date) . This document includes the following items: daily solar data, climate data, and daily solar energy on tilted surfaces. Based on data for the Phoenix station, the average annual total horizontal insolation for this area is 1869 BTU per square foot per day, and the average monthly temperature is 70.3 degrees F.

\subsubsection{Surface water sources}

As shown on Plate $I$, the area is drained by the Gila River which cuts across the area from northeast to southwest. The saline surface water sources in the area, discussed in a previous section, include Gila River Diversion above and below Gillespie Dam, Drainage from the Buckeye Irrigation District, and possibly waste water from the Palo Verde Nuclear Generating station. Chemical quality data for saline water sources in this area are included in Appendix $c$.

\subsubsection{General Hydrogeology}

The basins within Area III are primarily categorized as west Basins, according to the United States Geological Survey's SWAB/RÁS classification scheme. These basins are described by Anderson (1985) as follows:

The aquifer systems of the west basins Basin and Range sedimentary rocks and include prean overlying 
moderate- to coarse-grained facies of the lower basin fill, which forms the main water-bearing zone. An overlying fine-grained facies of the lower basin fill occurs near the basin centers. Upper basin fill consists of a thin layer of heterogeneous sediments thet generally lies above the water table. stream alluvium occurs along the lower Gila River.

Inflow to the west basins is small and is composed of minor mountain-front recharge and infiltrated streamflow. Outflow consists of evapotranspiration at the downstream end of the basins and underflow. The predevelopment potentiometric contours were virtually straight lines normal to the basin axis indicating that mountain front recharge is small. Ground-water pumpage is derived from removal of water from storage within the aquifer.

A representative cross section through western basins is depicted on Figure $2-5$.

\subsubsection{Saline Ground Water Areas}

\subsubsection{Buckeye Area}

In the Buckeye area an extensive region contains ground water with a salinity in excess of $3,000 \mathrm{mg} / 1$, with two lesser plumes with concentrations of $5,000 \mathrm{mg} / \mathrm{l}$. According to the Arizona Department of Water Resources (1984), 10 of the 51 wells in the Buckeye Irrigation District pump ground water with salinities in excess of $4,000 \mathrm{mg} / 1$. The TDS of perched ground water in the vicinity of the Palo Verde Nuclear Generating station was found to range from about $3,000 \mathrm{mg} / 1$ to almost $19,000 \mathrm{mg} / \mathrm{l}$ (Long, 1983). A water quality pattern diagram for a well-water sample containing $4000 \mathrm{mg} / \mathrm{l}$ total salinity is included on Plate IV. This diagram was created using a representative analysis for the saline area, reported in Appendix D. According to this diagram ground water in this area is basically a sodium-chloride type. Bicarbonate represents the lesser anion. The Luke salt mass is located within this area (Peirce, 1981).

Hydrogeological considerations for extracting ground water for a microalgae production facility in the Buckeye area are described in the following paragraphs:

The hydrogeology of the western part of the salt River Valley was described in a USGS map report by Ross (1978). In this area, sedimentary deposits comprise the main water-bearing unit. These deposits include unconsolidated to weakly consolidated clay, silt, sand and gravel, locally containing thick deposits of evaporites. Thickness of the main water-bearing unit may be as much as 1,200 ft (Ross, 1978). The area is underlain by a thick 
widespread evaporite deposit consisting mainly of halite, ranging in depth from 880 to $1,500 \mathrm{ft}$ in depth. According to Ross's map, water levels in much of the Buckeye area are within 100 ft of land surface. The Arizona Department of Water Resources (1984) pointed out that wells in the Buckeye Irrigation District showed a rise in water levels during the period 1964 to 1983, and that 21 wells had an average water level increase of about 47 ft in this period. A reason for the increase was the increased release of sewage effluent into the area from the City of Phoenix's 92nd Ave. wastewater treatment plant.

Long (1983) described the hydrogeology in the Lower Hassayampa area, which includes a portion of the Arlington Valley, and the Palo Verde Nuclear Generating station. According to Long, the basin-fill sediments of the lower Hassayampa area are divided into three major units, including the upper, middle, and lower alluvium. In general, the upper alluvium is unsaturated except along the Hassayampa and Gila Rivers and in a perched zone underlying the Palo Verde Nuclear Generating station. The middle and lower alluvium are the main water bearing units except for some local volcanic and sedimentary bedrock units. According to Long, the upper alluvium is 30 to 60 feet in thickness, consisting of silty sands and gravelly sands with discontinuous stringers of silty clay and clay. The middle alluvium is 230 to 300 feet thick, mainly consisting of clay and silty clay. This unit contains the Palo Verde clay, described as a massive clay layer varying from 80 to 136 feet in thickness (Long 1983).

The middle alluvium acts as a perching layer beneath the Palo Verde Nuclear Generating station. According to Long, the depth to water in the perched layer ranged from 13 feet to 90 feet below land surface in 1982. Apparently, perched ground water developed when excess irrigation water percolated through the permeable upper alluvium, and accumulated on the less permeable middle alluvium unit. At this time the water levels in the perched system are declining because of the cessation of recharge and dewatering for the nuclear station. According to Long, the TDS of the perched ground water varies from 2856 to $18,990 \mathrm{mg} / \mathrm{l}$. Wells in the area are capable of production rates in excess of 1,000 gpm (USGS, 1984).

\subsubsection{Gila Bend Area}

The saline ground-water plume north of Gila Bend contains a pocket of ground water with a concentration in excess of 10,000 $\mathrm{mg} / \mathrm{l}$. The chemical quality pattern diagram for a well-water sample within the pocket shows that the TDS of the sample was $13,000 \mathrm{mg} / 1$. According to this diagram, ground water is predominantly a sodium-chloride type.

According to sebenik (1981), alluvial deposits in the Gila Bend area form the main water-bearing unit, consisting mostly of unconsolidated to moderately consolidated clay, silt, sand and gravel. The thickness of the unit ranges from a few tens of feet 
near the mountains, to more than 2,000 feet in the central part of the basin. The yield ranges from a few gallons per minute to several thousands of gallons per minute (Sebenik, 1981). Depths to ground water in the plume north of Gila Bend are generally less than 200 feet from land surface (sebenik, 1981).

\subsubsection{Rocky Point and Hyder Valley Areas}

Saline ground water in the plume near Rocky Point is generally about $3,000 \mathrm{mg} / \mathrm{l}$. In the representative sample used to plot the chemical quality pattern diagram, the TDS was $3,562 \mathrm{mg} / \mathrm{l}$. Again, the ground water is predominantly a sodium chloride type. TDS in the small pocket of saline ground water in the Hyder valley was generally about $3,000 \mathrm{mg} / \mathrm{l}$. According to the chemical quality pattern diagram, the sample was of a sodium chloride type.

The hydrogeology of the both areas is included in the map report of White et al. (1979), which covers the region of the Gila River drainage from Painted Rock Dam to the Texas Hill area. According to White et al. (1979), valley fill deposits constitute the main water bearing unit in the area. These deposits mainly consist of clay, silt, sand, and gravel deposits, and weakly consolidated mudstone and sandstone. The valley fill deposits have been divided into upper, middle, and lower units. Well yields in the plume should be sufficient to provide at least $4 \mathrm{mgd}$.

\subsubsection{Land Ownership}

Land ownership in Area III is shown on Plate IV. Within the large plume of saline ground water near Buckeye are the municipalities of Goodyear and Buckeye, and the Palo Verde Nuclear Generating station. Land ownership within the plume is mainly in private hands, with a small amount of property managed by the United States Bureau of land Management (BIM). Luke Air Force Base No. 6 is within the area, and the associated lands would probably not be available for a project. The Buckeye Water Conservation and Drainage District occupies a strip of land north of the Gila River and the Southern Pacific Railway line, east and west of Buckeye. The Roosevelt Irrigation District is within a strip of land north of the Buckeye Irrigation District. Within 10 miles of the plume boundary, land ownership is mainly in private hands or managed by BIM and the Arizona state Land Department. At the eastern edge of the plume is the Gila River Indian Reservation. The McMicken Irrigation District is located to the north of the community of Avondale.

The small plume near the City of Gila Bend is mainly in private ownership, although small parcels are within the state Trust. Some BLM land is also present. The Gila Bend Indian Reservation is located to the west of the plume. Otherwise, lands within 10 miles of the plume are managed by BLM and SLD or are in private hands. 
The small plume near Mobile encompasses privately owned land and an area managed by the BIM. Lands north of the plume are primarily privately owned, with BLM land predominating to the south.

Lands within the plume near Rocky Point are mainly managed by BIM, although about a quarter of the area is in private ownwership. Within 10 miles of the plume, the major landowner is BIM.

The small westernmost plume is entirely within an area of privately owned lands. Outside the plume area are privately owned lands and state Trust Land.

\subsubsection{Legal and Institutional Factors}

In this area, the Buckeye and Arlington Valleys and Mobile all lie within the boundaries of the Phoenix AMA. The other plumes near Hyder Valley, Gila Bend, and Rocky Point are located outside of the AMA. For the areas outside of the AMA, the legal constraints on the use of water are minimal, similar to Area 2. However, the Buckeye and Arlington valleys differ quite significantly from any other areas located within Active Management Areas. In fact, the primary problem in this area is not a shortage of groundwater, but an abundance of saline groundwater for which there is presently no use.

The Buckeye and Arlington Valleys may be an ideal location for the microalgae production facility. The area is considered water logged, with the groundwater table rising. As the project manager for the Buckeye Irrigation District stated, "Our problem is an oversupply of water, not a shortage" (Jones, 1986).

Large amounts of saline groundwater are pumped out of this area, specifically by the Buckeye Irrigation District, each year for drainage. Presently, the water is discharged into the Gila River and the Arlington Canal, and the Arlington Irrigation District uses part of it, but not all. Buckeye Irrigation District does not charge Arlington anything for the water. Arlington must simply maintain the canal.

The Phoenix AMA is currently conducting a study to determine whether the Buckeye and Arlington areas should be excluded from the Phoenix AMA. Under a directive from the legislature, the AMA will be assessing the effects of the Groundwater Management Act on this area over the next two years. It is likely that they will recommend that the area be removed from the AMA.

Even if the area does remain within the boundaries of the AMA, it will probably be easy to obtain a poor groundwater quality or a drainage permit. Gary Hansen, an AMA staff member, stated that 
the agency would support a viable use of this saline water and that a poor groundwater quality permit would be appropriate in this case. In fact, this area is a good example of an area where the pumping of the saline water would benefit the residents and the state.

Saline surface water supplies have also been identified in this area. Any use of these waters would require either purchasing existing rights, or initiating new rights under the Arizona Water code (See section 5.0). The adjudication of water rights that is presently being conducted in Arizona is a very significant factor for the Gila River system is the most over-appropriated source of water in the state. Once the adjudication is completed, any rights with very late priority dates may not receive the fuli quantity in shortage years. Also, any water rights considered for purchase would have to be carefully examined to see that they also would be viable rights after the completion of the adjudication (see section 5.0 ).

One other source of water is the waste water from the Palo Verde Nuclear Generating Plant. The Palo Verde Plant, under a contract negotiated in 1973, will receive up to 140,000 acre-feet of effluent from the 9 lst Avenue Treatment Plant in Phoenix. The term of this contract is until 2027. The plant will pay between $\$ 20$ and $\$ 30$ an acre-foot for this water, depending on the amount of effluent actually consumed. The plant will only take the water it needs with the excess to be discharged into the salt River. According to a Palo Verde plant engineer, this water is presently unclaimed (Rogers, 1986).

Palo Verde takes delivery of the water near the 91 st avenue plant and then pump it $361 / 2$ miles to the plant site. At the site, the water is treated through a cold lime softening process to replace the hard ions with soft ions. The ammonia is oxidized to nitrates and the $\mathrm{pH}$ of the water is controlled. The water is then run through a filter and stored in resevoirs until needed by the plant.

The TDS of this water is approximately $1000 \mathrm{ppm}$ when received by plant. The water is reused until it has been concentrated fifteen times, or has a TDS of approximately 15,000 ppm. The water is then stored and evaporated in a 200 acre on-site pond. The annual amount of water discharged to this pond is unknown at this time. Presently, the Plant has no plans for this water. Carter Robinson, plant engineer, is interested in alternative uses for this water. He emphasized that the company is always interested in more efficient and profitable methods of operation as a means to lower rates for its customers and that this type of project may be a suitable use of the waste water (Rogers, 1986). 


\subsection{AREA IV}

As shown on Plate II and Plate $V$, this focal area extends in a north-south direction from $T-1-N$ through $T-6-S$ and in an eastwest direction from $R-1-E$ through $R-9-E$. The area includes the cities of Tempe, Mesa, Casa Grande and Coolidge. During Task I five distinct ground-water plumes were determined to satisfy the screening criteria for the project, namely, salinities in excess of $3,000 \mathrm{mg} / \mathrm{l}$, and depths to ground water of less than $500 \mathrm{ft}$. During Task II, four out of the five areas satisfied the criterion of potentially being able to yield in excess of 4 MGD. These plumes are shown on Plate $V$. One extensive plume was delineated south of South Mountain. A second plume was determined to be near chandler. A third plume was found near coolidge, and the fourth was found near Casa Grande. The legal descriptions of potential areas for a project are included in Table 4-2. The estimated surface area overlying the saline plumes is 156 square miles.

Features of the area that are relevant for a potential microalgae production facility are discussed in the following sections.

\section{4 .1 Climate}

The focal area falls within zone 6a: Sonoran Desert (low desert), in the classification scheme of the Arizona solar Energy Commission. Detailed solar and climatic data for the Phoenix station of this zone are included in the report of osborn and Huddy (no date). In summary, the total horizontal solar insolation in the area averages 1,869 BTU per square ft per day on an annual basis. The average monthly temperature is 70.3 degrees F.

\subsubsection{Surface water}

The principal drainage channel in the area is the Gila river. Effluent from the ocotillo steam electric generating station is a source of saline surface water (see Plate I).

\subsubsection{Hydrogeology}

The ground-water basins in the area are classified among the Central Basins of the USGS' SWAB/RASA study (Anderson, 1985). According to Anderson (1985), the geohydrological features of these basins are as follows:

The aquifer systems in the central basins consist of as much as 5,000 ft of lower basin fill and generally less than 1,000 ft of upper basin fill. Basin-center deposits that have more than 60 percent fine-grained materials are common; the upper basin fill grades laterally to coarse material at the mountain fronts. 
stream alluvium along the major draianges is as much as 300 ft thick.

The inflow components consist of small to moderate amounts of mountain-front recharge and streamflow infiltration. Prior to development, outflow occurred principally as evapoptranspiration near the downstream end of the basins, but this has largely ceased owing to extensive pumping. The potentiometric contours are a broad U-shape, which indicates a mixture of inflow sources with no source particularly dominant.

Development has greatly decreased the amount of discharge that occurred as evapotranspiration and streamflow. Recharge through stream infiltration has probably increased. Reductions in ground water in storage have been large and future increases in pumpage will cause further depletion in storage.

\subsubsection{Saline Ground-Water Areas}

Hydrogeological features of the area affecting ground water development for a microalgae facility are reviewed in this section.

\subsubsection{West Chandler Plume}

As shown on Plate $V$ this plume includes the region from near Tempe south to the Maricopa-Pinal County line. The chemical quality pattern diagram for a representative ground-water sample illustrates that the water may be classified mainly as a calcium chloride type.

Ground water conditions in the area were examined by Laney, et al. (1978). According to these authors, sedimentary deposits form the main water-bearing unit in the area. These deposits consist mainly of unconsolidated and weakly consolidated clay, silt, sand and gravel. The unit varies in thickness from a few feet near the mountains to more than $1200 \mathrm{ft}$ in the central part of the basin (Laney, et al., 1978).

Aquifer tests in township DI-4, by the USGS, determined that transmissivity values were in the order of $40,000 \mathrm{gpd} / \mathrm{ft}$. The unit is capable of yielding in excess of $1,000 \mathrm{gpm}$ to wells. Laney et al. (1978) showed that in 1976 there was a ground water divide cutting across the western lobe of the plume. Ground water to the right of the divide flows east, while ground water to the left flows in a westerly direction. Perched ground water is common in this area and water levels may be less than 100 ft from land surface. 
This area is located immediately to the west of the West Chandler Area. A chemical quality pattern diagram is included on Plate $V$ for a ground-water sample with a total TDS of 4,000 $\mathrm{mg} / \mathrm{l}$. This sample is predominantly a sodium chloride type, with calcium and sulfate being the secondary ions.

This area shares similar ground-water condition to the area described in the previous section. However, perched ground water is not indicated on the maps of Laney et al. (1978). In the region near Lone Butte, water levels range from less than 100 ft from land surface to about $200 \mathrm{ft}$ below land surface. According to the results of aquifer tests by the United States Geological Survey in the townships $\mathrm{Dl}-2$ and $\mathrm{Dl}-3$, transmissivity values range from 26,000 gpd/ft to $171,000 \mathrm{gpd} / \mathrm{ft}$. Potential well yields are greater than 1000 gpm (Laney et al.,1978).

\subsubsection{Casa Grande Area}

As shown on Plate $V$, the plume in the vicinity of the City of Casa Grande occupies portions of $\mathrm{R}-5-\mathrm{E}$ and $\mathrm{R}-6-\mathrm{E}$ in $\mathrm{T}-6-\mathrm{S}$. Two chemical quality pattern diagrams are shown for this area. The diagram for a sample from a well near Arizola was primarily a calcium-sulfate type, with magnesium and chloride being of secondary dominance. The sample near Francisco Grande was mainly a magnesium-sulfate type, with calcium and chloride being of secondary importance. The water quality maps of Thompson et al. (1984) show that the ground water in Casa Grande area contains subareas of differing types, including sodium bicarbonate, sulfate, and chloride types. This area is included in a general discussion of ground water conditions in the Lower Santa Cruz area by Konieczki and English (1979). According to. these authors, the main water-bearing unit consists mainly of unconsolidated alluvial deposits, divided into the following four units: the upper sand and gravel unit, the silt and clay unit, the lower sand and gravel unit, and the local gravel unit. The upper and lower sand and gravel units are the main sources of ground water. In most of the area, the upper sand and gravel unit is at the land surface and ranges in thickness from 50 to $600 \mathrm{ft}$ below land surface. The silt and clay unit is from 100 to about $600 \mathrm{ft}$ below land surface and ranges in thickness from 0 to 2,000 ft. The lower sand and gravel unit is a mixture of sand, gravel and clay, and is generally more cemented than the upper unit (Konieczki and English, 1979). This unit varies in thickness from 0 to $2,000 \mathrm{ft}$. The local gravel unit varies in thickness from 0 to $1,000 \mathrm{ft}$.

In the area shown for the plume, water levels range from less than 100 ft to about $400 \mathrm{ft}$ from land surface (Konieczki and English, 1979). Well yields in excess of 1,000 gpm should be possible in the area (USGS, 1984). 


\subsubsection{The Coolidge Area}

The small ground water plume in this area is located west of the city of coolidge. The chemical quality pattern diagram for the plume shows that ground water is of the calcium-chloride type, with lesser concentrations of sodium and sulfate.

The discussion of ground-water conditions in the casa Grande area, covered in the previous section, is also germane to the plume in the coolidge area. In this area, ground water levels range from about $100 \mathrm{ft}$ to $400 \mathrm{ft}$ below land surface (Konieczki and English, 1979). Most wells in the area should be capable of supplying 1,000 gpm (USGS, 1984).

\subsubsection{Land Ownership}

Land ownership in Area IV is included on Plate V. About three fourths of the area within the plume encompassing West Chandler is privately owned. About one fourth of the area is within the Gila River Indian Reservation. A small segment of land in TI2S, R5E is within the Roosevelt water Conservation District. A segment within the northern part of the plume is within the salt River Project Agricultural Improvement and Power District. Within 10 miles of the saline ground-water boundary, ownwership resides mainly in private hands and in the Gila River Indian community. The plume is close to the Cities of Chandler and Tempe.

The plume in the South Mountains area is almost entirely within the Gila River Indian Community. Outside the plume the major land area is within the Gila River Indian Community except for a small parcel of state Trust land and land within the south Mountain Park.

Land within the plume near Casa Grande is entirely in private ownership, except for a small parcel of land within the state Trust. A similar breakdown of ownership exists within 10 miles of the plume. An area roughly south of Casa Grande is within the San Carlos Irrigation and Drainage District.

Land within the plume near coolidge are entirely in private ownership, as are the lands within 10 miles of the plume, except for a small segment of state Trust land. The area is within the San Carlos Irrigation and Drainage District and the Hohokam Irrigation and Drainage District.

\subsubsection{Legal and Institutional Factors}

Most of this area is located in two Active Management Areas: the Phoenix AMA and the Pinal AMA. As reviewed in section 6.3 , no new 
uses of groundwater are possible in an AMA unless either a permit is issued by the AMA or existing grandfathered rights are purchased. This latter option is probably too expensive for this type of project. However, But it may be possible to receive one of three types of permits: industrial use, poor water quality, or drainage permits.

Interviews with officials of both the Phoenix and Tucson AMA have revealed some obstacles to the granting of a permit for this type of project. Mainly, officials are concerned that the use of such a large quantity of water in open evaporation ponds would not be consistent with the management plan (Gessner, 1986; O'Hare, 1986). Also, officials are concerned about public perception of the project. In the past, city water officials and AMA staffs have utilized public education techniques to convince citizens to voluntarily conserve water. The emphasis of these campaigns has been on educating the public on the shortage of water in the state and on appropriate uses of water in the desert. Both officials contacted were concerned about the public perception of this type of project, i.e., that it would send out the wrong message.

If the AMA opposed the project, it would probably be on the grounds that this use of water would be inconsistent with the area plan. Further, there may be opposition to any large withdrawal of groundwater even if it is saline water and not presently utilized. But one staff member of the Department of Water Resources felt that this project would be a good use of saline water and that project planners would have to negotiate and even convince AMA staff to allow this use of water.

Clearly, under the Arizona Groundwater Management Act, the project could qualify for any one of three permits. But project planners will have to weigh the benefits and costs of placing the project within AMA boundaries. This option is decidedly more complex and expensive than locating the project outside of an AMA, but these costs may not be prohibitive. For example, before the permit is issued, the DWR can require extensive hydrologic studies and continued monitoring. Also, of the six areas identified in this report, land costs would undoubtedly be the highest in this area.

It is suggested that project planners contact and negotiate with the AMA staff very early in the planning process. The best tact to take would be to stress that there is no other use for the water and optimally, that this withdrawal would benefit the area. For example, if it could be shown that the withdrawal would prevent saline water intrusion into other higher quality aquifers, or would alleviate drainage pumping of agricultural return flows, the AMA staffs would be much more likely to support the issuance of a permit.

However, all of these restrictions and legal constraints could be avoided in this area by locating the project on one of the Indian reservations. Of the two reservations in this area, the Ak-Chin 
and the Gila River reservation, the Gila River community would probably be better suited for this type of project. The Ak-Chin reservation recently renegotiated the legislative settlement of their water rights and is eager to put this water to work. on their tribal farm. This tribe is one of the few reservations in the country that has an economically viable farming operation and they would probably not be interested in leasing land, preferring to develop the land themselves.

The Gila River Indian Community, however, may be very interested in a project of this type. First, it is a large reservation, encompassing more than 370,000 acres of land. Second, the Tribe is claiming a large amount of water in the adjudication, 1.8 million acre-feet, and is eager to put water to use on the reservation. Third, the primary use of water on the reservation is agriculture, including both a tribal farming enterprise and extensive leasing to non-Indians. While the Tribe will continue farming, it is also interested in uses of water that may bring a higher return than agriculture (Halleck, 1985). Finally, there is a Spirulina project on the reservation now that utilizes a similar project design, large open ponds. The Tribe may be very receptive to a microalgae project, especially if the spirulina project proves profitable. 


\subsection{AREA V}

Area $V$ is located within the safford Valley of southeastern Arizona (see Plate II and Plate V) extending to the San Carlos Reservation. The area includes the communities of safford, Thatcher, and Pima. The valley supports an economy based primarily on irrigated agriculture. Sources of water for irrigated agriculture include surface water from the Gila River and tributaries, and ground water. As shown on Plate II four distinct plumes of saline ground water within the area satisfied the screening criteria for Task $I$, i.e., salinities greater than $3,000 \mathrm{mg} / \mathrm{l}$ and depths to water of less than $500 \mathrm{ft}$. During Task II three of the areas satisfied the third criterion of potentially yielding greater than $4 \mathrm{mgd}$. These areas are identified on Plate $V$. One small plume in this area is located near Cactus Flat. A second area is located near safford, and a third, extensive plume, extends along the Gila River from near Central to Calva. The land surface area overlying the plumes is 58 square miles.

The legal descriptions of possible locations within the saline ground-water plumes for a microalgae production facility are specified in Table 4-2, which also includes values for depth to ground water, potential surface are, yield criteria, and information on reliability of the yield estimates. Information on the surface water chemistry in the area is included in Appendix c. Similarly, specific data on ground-water chemistry in the plumes is included in Appendix D. Factors affecting the development of a production unit are summarized in the following paragraphs.

\subsubsection{Climate}

The area is generally located within zone 6B: Sonoran Desert (mid-desert) in the classification scheme of the Arizona solar Energy Commission (Osborn and Huddy, no date). Daily solar data, climatic data, and data on daily solar radiation on tilted surfaces for the area are presented in the Osborn's report. The total horizontal insolation for the area averages 1,872 BTU per square ft per day, on an annual basis. The average monthly temperature is 67.8 degrees $F$.

\subsubsection{Surface Water Features}

The principal drainage for the area is the Gila River which cuts diagonally across the area from the southeast to the northwest. As shown on Plate I, there are several sources of saline surface water in the area. Four saline springs are identified between Pima and Fort Thomas. The spring near Pima was found to have a TDS of $16,000 \mathrm{mg} / \mathrm{l}$ in 1940. The salinity of the Gila River varies with discharge rates, being more saline during low flow periods. For example, during studies for the USGS along the Gila River above Calva, Laney (1977) observed that the salinity of river 
water ranged from about $300 \mathrm{mg} / \mathrm{l}$ during high flows to about 4,800 $\mathrm{mg} / \mathrm{l}$ during low flows. During his studies in the valley during the 1940's Hem (1950) found that the concentration of dissolved salts in river water leaving the valley was double that of the surface water entering the valley. According to Hem the increase in salinity is caused by the inflows of saline ground water, including irrigation return flows and natural saline sources. Hem observed that the main zones of ground-water inflow to the river are in the vicinity of Pima and Fort Thomas, i.e., in the area of saline springs.

\subsubsection{General Hydrogeology}

The Safford Valley is included among the southeast basins defined from the USGS's SWAB/RASA study. According to Anderson (1985), general ground-water features of these basins are as follows:

The aquifer systems in the southeast basins consist of at least two water-bearing units separated by a finegrained unit unit that consists of both lower and upper basin-fill sediments. The fine-grained sediments form a leaky confining layer that overlies the lower part of the aquifer. The lower water-bearing unit may include at least the upper part of the pre- Basin and Range sedimentary rocks.

The major inflow components are mountain-front recharge and stream infiltration; outflow consists of evapotranspiration and discharge to streamflow. The potentiometric contours are nearly V-shaped indicating inflow at the mountain fronts and discharge along the central axis of the basin....

A generalized cross-section through the southeast basins is shown on Figure 2-5.

\subsubsection{Saline Ground Water}

As indicated in the introductory comments for this area, three separate ground-water plumes were identified as meeting the screening criteria ( see Plate V). A minor plume of saline ground water is located near Cactus Flat. The TDS of ground water within this plume is greater than $3,000 \mathrm{mg} / \mathrm{l}$ but less than $4,000 \mathrm{mg} / 1$. According to the chemical-quality pattern diagram for a water sample from this plume, ground water is mainly a calcium chloride type, with lesser concentrations of sodium and sulfate. A second plume was located near the city of Safford. This plume contained a lesser plume in which the salinity exceeded $10,000 \mathrm{mg} / 1$. The chemical quality pattern diagram for this plume shows that the dominant chemical type is sodium chloride. The most extensive plume in the valley extends from near Central to Calva. This plume basically extends along the Gila River. one subplume is shown with salinities in excess of $5,000 \mathrm{mg} / \mathrm{l}$ and two additional 
subplumes were identified with TDS values above $10,000 \mathrm{mg} / 1$. Two chemical quality pattern diagrams for samples from the plume show that the predominant water quality type is sodium chloride. High boron concentrations are present.

Features of the ground-water system in the safford valley relevant to water production for a microalgae facility are discussed in the following paragraphs:

According to Weist (1971), Muller et al. (1973), and other authors, the ground-water system of the safford valley is hydrogeologically divided into two major systems: an artesian system occupying the lower extent of the basin fill unit and a surficial water table aquifer within Quaternary alluvial material. Weist (1971) indicated that the basin fill is the most widespread unit of the area and that the alluvial deposits along the Gila River are in a wide trough carved into the basin fill. The water in the artesian system is generally saline with electrical conductivity values of about $8 \mathrm{millimhos} / \mathrm{cm}$ (Muller, et al., 1973). High levels of salinity in the overlying groundwater system have been attributed by Feth (1952) and Mulier et al. (1973) to four possible sources, namely: localized upward seepage of saline water from the artesian system, return flows from irrigated field and canals, inflows from mineralized springs, and underflow from tributaries carrying mineralized flows. Peirce (1981) indicated that the safford valley could contain significant deposits of salts at depth in the valley fill.

Water levels in wells in the vicinity of the saline ground water plumes. ranged from 8 ft below land surface to $158 \mathrm{ft}$ below land surface in 1983 (USGS, 1984).

Based on the analysis of aquifer test data from within a 15-mile reach of the Gila River upstream of Calva, Hanson (1972) indicated that the average storage coefficient values for basin fill and alluvium are 0.0005 and 0.15 , respectively. Average transmissivity values for the area were $110 \mathrm{gpd} / \mathrm{ft}$ for the basin fill system and $210,000 \mathrm{gpd} / \mathrm{ft}$ for the alluvium system. Assuming that the high transmissivity values are also representative of those in the upstream aquifer system, it appears that there should be no difficulty in obtaining ample ground water for a microalgae facility. In fact, the United states Geological Survey's (1984) potential well production map for the valley shows that most wells in the area are capable of producing 1,000 gpm or more.

\subsubsection{Land Ownership}

Iand ownership within Area $\mathrm{V}$ is depicted on Plate $\mathrm{V}$. Land within the small saline ground-water plume near Cactus Flat is almost entirely privately owned, except for a small parcel of land within the state Trust. The plume is surrounded with state Trust land and privately owned land. Similarly, land within and 
adjoining the plume near safford is either in private ownership or managed by BIM.

The land area encompassing the large plume extending along the Gila River is primarily in mixed ownership, including both private holdings and BIM Iand. However, the entire region in the northwest is within the San Carlos Indian Reservation. A similar breakdown exists for the land area within 10 miles of the plume.

The Gila Valley Irrigation DIstrict extends along the Gila River, encompassing both the large plume and the lesser plume near safford.

\subsubsection{Legal and Institutional Factors}

The surface water supply identified in this area, the Gila River, is one of the most over appropriated river sources in the state. In fact, in most years the entire flow of the Gila river above the Ashurst-Hayden dam is diverted for agricultural purposes. Further, the stream flow and quality of the river water is highly variable. Between 1914 and 1973, the stream flow of the river varied from a minimum of 20 cfs to a maximum of $10,000 \mathrm{cfs}$.

Because the river is fully appropriated and the stream flows so variable, any new initiation of a water right or purchase of an existing right must be undertaken cautiously. Especially on this river system, it would be easy to acquire rights that are worth little in practice (see section 5).

This stretch of the Gila river will also be greatly affected by the Gila River adjudication. For one, as stated earlier this section of the Gila River is over-appropriated. Those individuals holding rights with late priority dates will certainly be affected by the final decree, probably not receiving their full entitlement of water during shortage years.

Secondly, the Gila River Indian Reservation is located downstream from this section of the river. This tribe is claiming rights to 1.8 million acre-feet of water in the adjudication. While it is physically impossible for the Tribe to be awarded the entire claim, they will receive a large amount of water in the adjudication. It is very likely that to satisfy this claim, other right holders will not receive their full entitlement during shortage years.

For purchase, probably the most secure rights would be those rights that were adjudicated in 1935 under the Globe Equity Decree No. 59, commonly known as the Gila Decree. Under this Decree, water rights were awarded to the Gila River Indian Reservation and to non-Indian irrigators in the area. The Decree also established rights and priorities for over 147,991 acres of land along the Gila river, including the safford valley. 
If this area were chosen for the microalgae project and surface water rights desired, it would be advisable to purchase this type of right - one already adjudicated under a court decree. The adjudication statute provides that all court decreed rights will be written into the final decree for the Gila River adjudication. While the court has not yet decided exactly how decreed rights will be handled, they are certainly more secure than rights that have not been previously decreed.

The groundwater sources identified in this area, especially the plume that runs along the Gila River from Central to Calva, will also be affected by the adjudication. As stated earlier, the court has not yet decided how groundwater will be included in the adjudication. A likely option is that the groundwater that is hydrologically connected to the surface flow of the river will be included in the adjudication. If this water were included, it could result in the assignation of priority dates to groundwater pumping, with those people who hold rights with late dates forced to shut down their pumps during shortage years. one option also available in this area is to locate the project on the san Carlos Apache Indian Reservation. This Reservation is large, encompassing more than 1,826,541 acres of land. The major water uses on the reservation are grazing and for recreational purposes. No land is leased for agricultural uses but in 1981 over 456,606 acres of land were leased to non-Indians for businesses and other purposes.

The Tribe then has quite a bit of experience in leasing land to non-Indians and may consider a project of this type. Also, this Tribe will have their water rights adjudicated in the Gila River adjudication and is also anxious to put water to use on the reservation. While the Tribal Council is currently undergoing some strife, this problem should be resolved over the next few years. 
Area VI, depicted on Plate VI, is located entirely within the Plateau Uplands physiographic province of Arizona. The area contains the cities of winslow and Holbrook, and portions of the Navajo Indian Reservation and the Painted Desert, as well as the Petrified National Forest Park. of 11 ground-water areas identified during Task I as having salinities in excess of 3,000 $\mathrm{mg} / \mathrm{l}$ and depths to water of less than $500 \mathrm{ft}$, only four remained after applying the yield criterion of $4 \mathrm{mgd}$ during Task II. One area is located in the southeastern portion of the area. A second, much larger area, occupies the central part of the area. A third, relatively small, area encompasing Joseph City, and a fourth, larger area, includes the city of winslow and part of the Painted Desert. The total land area overlying the saline groundwater plumes is almost 890 square miles.

The legal descriptions of possible locations for a microalgae production facility within the saline ground-water plumes in this area are specified in Table 4-2, which also includes values for depth to ground water, potential surface aree, yield criteria, and information on reliability of the yield estimates. similarly, specific data on ground-water chemistry in the plumes is included in Appendix D. Factors affecting the development of a production unit are summarized in the following paragraphs.

\subsubsection{Climate}

Area VI is located within zone 7, Basin and Range, in the classification scheme of the Arizona Solar Energy Commission (Osborn and Huddy, no date). According to osborn, clear sunny days are the rule, with an average of more than 270 days with clear or only partly cloudy skies. Large changes in diurnal temperature occur because of the higher elevation of the area. Summer days are warm and maximum temperatures of 90 degree F. or higher are reported between late May and mid-september (Osborn and Huddy, no date). Total horizontal insolation on an annual average basis is 1,802 BTU per square ft per day and the average monthly temperature is 55.3 degrees $F$ (Osborn, No Date). Other climatic and solar data for the area are included in osborn's report.

\subsubsection{Surface Water}

The area is drained by the Little colorado River, and there are several substantial washes in the area including the puerco River, Leroux Wash and Cottonwood Wash. There are no substantial sources. of saline surface water in the area, but the cholla Generating station is located a few miles southwest of Holbrook.

\subsubsection{General Hydrogeology}

The consolidated sedimentary rocks constituting the aquifers of 
this physiographic province comprise fine-grained sandstone units, many of which do not readily transmit water (Ligner, et al.,1969). The limestone units store and transmit water, but the siltstone and claystone units act as confining layers. Multiaquifer systems are common. The three principal aquifer systems are the $C$ (for Coconino sandstone), the $N$ (for Navajo sandstone) and the $D$ (for Dakota sandstone) multi-aquifer sustems. The thin deposits of alluvium along the major water courses also yield ground water.

\subsubsection{Saline Ground Water Areas}

Four principal saline ground water plumes were identified as meeting the screening criteria for the project (see Plate VI). The TDS of the elongated plume in the southestern corner of the area is generally above $3,000 \mathrm{mg} / \mathrm{l}$, but no minor plumes with salinities above $5,000 \mathrm{mg} / \mathrm{l}$ are shown. The chemical quality pattern diagram illustrates that ground water is mainly a sodiumchloride type. The salinity of ground water in the large central plume has a salinity mainly between 3,000 and $10,000 \mathrm{mg} / 1$. However, two isolated areas contain ground water with TDS values above 10,000 mg/l. The TDS of one sample was about $64,000 \mathrm{mg} / 1$. According to the chemical quality pattern diagrams, ground water is strongly of the sodium-chloride type. The third, smaller area near Joseph City contains ground water with TDS values between $3,000 \mathrm{mg} / 1$ and $5,000 \mathrm{mg} / 1$. In addition to encompassing an extensive plume of ground water where salinities are greater than $3,000 \mathrm{mg} / 1$, the fourth area contains a large region where salinities are above $5,000 \mathrm{mg} / \mathrm{l}$. A lesser plume with salinities above $10,000 \mathrm{mg} / \mathrm{l}$ is also apparent on Plate VI. As in the other subareas of Area VI, the chemical quality pattern diagram shows that ground water is strongly of the sodium-chloride type. Peirce (1981) indicated that the most extensive salt deposit in the Colorado Plateau Province occur near Holbrook. In fact, salt beds underly a region of about 2,300 square miles in area (Peirce, 1981).

Relevant features of the ground-water system from the viewpoint of extracting water for a microalgae production facility are reviewed in the following paragraphs:

The ground-water system in the eastern portion of the area is generally covered in a United States Geological survey map series report by Mann (1977). The system in the western part of the area is described in a second map series report by Farrar (1980). The information presented in this section is derived from these two reports. Proceeding in a depth-wise sequence from land surface downward, the principal water bearing formations are as follows: alluvium, the Bidahochi formation, the Toreva formation, the Daquifer, the N-aquifer, the chinle formation, the Moenkopi formation, and the Coconino sandstone.

Alluvium occurs mainly along the water courses. The alluvium consists of gravels, sand, silt and clay and may be as thick as $200 \mathrm{ft}$. Water levels generally fluctuate. The range in potential 
yield in wells within alluvium is from less than 1 gpm to greater than $1,700 \mathrm{gpm}$. Wells in alluvium units within the bounded areas on Plate VI are capable of providing saline water at the rates required for a microalgae facility.

The Bidahochi formation consists of three members, namely an upper member, a volcanic member, and a lower member. The upper member is of fluvial origin and the lower member is of lacustrine origin. Due to the fine-grained composition of the sandstones and siltstones comprising this member, the hydraulic conductivities are low. The middle, volcanic member contains diatremes, which are funnel-shaped volcanic vents filled with pyroclastic and tuffaceous materials. Well yields in diatremes range from $20 \mathrm{gpm}$ to more than $400 \mathrm{gpm}$, insufficient for a microalgae production unit.

The Toreva Formation also consists of three members, namely, an upper sandstone member, a middle carbonaceous member, and a basal sandstone member. Wells in this formation produce less than about $10 \mathrm{gpm}$. According this formation cannot be relied upon for supplying a microalgae facility.

The D-aquifer occurs in the northeastern part of the area. Member units of the D-aquifer include the Dakota sandstone, the Morrison Formation, the Cow-Springs Sandstone, the Entrada Sandstone, and the Carmel Formation. Wells in the D-aquifer are not capable of yielding water much in excess of $20 \mathrm{gpm}$, and would not be suited for a microalgae production facility.

The N-aquifer comprises fine-grained sandstone and siltstone units of the Navajo Sandstone, the Kayenta Formation, the Moenave Formation, and the wingate sandstone. Well yields do not exceed 45 gpm. Accordingly, this formation would be unsuitable for a microalgae production facility.

The Chinle Formation is ubiquitous in the area. The Formation includes the Church Rock, Owl Rock, Petrified Forest, and Shinarump members. Sandstone and conglomerate elements of the Shinarumo member are capable of yielding up to $30 \mathrm{gpm}$ in wells, which would not be enough for a microalgae facility.

The Moenkopi Formation is also ubiquitous throughout the area. Ground water occurs in sandstone and conglomerate units. However, because well yields are generally less than 10 gpm, this formation is not considered to be a resource for a microalgae producing unit.

The Coconino aquifer underlies the entire area. Components of the Formation are the Coconino sandstone, the supai Formation, the Kaibab Iimestone, and the Toroweap Formation. Well production depends on saturated thickness and amount of fracturing. Ground water occurs under both confined and unconfined conditions, and depths to water vary from land surface to hundreds of feet below land surface. Well yields are generally minimal but some wells may produce up to $2,500 \mathrm{gpm}$, which is adequate for a microalgae 
production unit, provided that the yields could be sustained for a long period of time.

\subsubsection{Land Ownership}

Land ownership in Area VI is shown on Plate VI. Within and near the elongated, southern plume, land ownership is mixed, with mainly private holdings and state Trust lands, and a small amount of BIM land. A similar mix of ownerships prevails within and near the central plume, except that the central part of the area is within the Petrified National forest. The western plume includes the City of winslow. The upper fourth of the area is entirely within the Navajo Indian Reservation. Otherwise ownership within and in the vicinity of the plume is a mixture of private holdings and state Trust lands.

\subsubsection{Iegal and Institutional Factors}

This area is similar to area II in that there are few legal constraints on the use of groundwater. There are no Active Management Areas in this part of the state and only one Irrigation Non-Expansion Area (INA). However, there are some factors that distinguish this area from other areas in Arizona. First, competition for water is relatively low in this area, especially when compared with the rest of the state. In fact, the Iittle Colorado River is probably the only river source in the state that is not fully appropriated.

Secondly, the water rights in this area are being adjudicated in the Littie Colorado River adjudication. While ground water may also be included in this adjudication, the ramifications are much less severe than in the Gila River adjudication. On the Gila River, large amounts of groundwater that is hydrologically connected to an over-appropriated surface water supply are being used. Any adjudication of surface rights will affect groundwater pumping. On the Little colorado river however, the stream is not fully appropriated and much of the groundwater pumping in this area does not affect the surface flow of the river.

There are restrictions on groundwater pumping in the Joseph City area. Under the Arizona Groundwater Management Act, this area was designated an Irrigation Non-Expansion Area (INA). In an INA, only land that had been irrigated between January 1, 1975 and January 1 , 1980, may be irrigated now. Also, all pumping from wells with a capacity of over $35 \mathrm{gpm}$ must be measured and reported annually. Since only new irrigation uses are prohibited, the microalgae project would not be affected by the legal constraints on water use in an INA, assuming that the project would be defined as industrial.

One other advantage to locating the microalgae product in this area, besides the few legal constraints on water use, is that the area is sparsely populated and land costs would be low. With the 
exception of the Petrified National Forest, the land in the area is either privately held or is BIM or state Trust land, or is part of the Navajo reservation. The land costs for the private land and the lease rentals would be much lower than in other areas of the state where there is a lot of irrigated land or urban land.

The Navajo Tribe may also be interested in a microalgae project. This reservation is the largest reservation in the United states, encompassing more than 15 million acres of land. While the tribe has leased very little land to non-Indians for agriculture, it has leased land for business and other purposes, and for mining. The tribe has also recently promulgated a water code and is also beginning to aggressively develop the water supplies on the reservation. The water rights of this reservation will be quantified in the Little Colorado adjudication. 


\author{
SECTION 7.0 \\ RECOMMENDATIONS FOR FUTURE WORK
}

During the course of this project a number of likely candidate sites for a microalgae production facility were identified from the perspective of the salinity and potential yield of surface and ground-water resources. In addition, the institutionalenvironmental constraints on projects at these sites were reviewed. Ostensibly, the next stage of the selection process will be to locate a specific site from among the choices presented from this study, and develop plans for a pilot study. A number of critical resource elements will need to be considered in the decision process, including annual insolation, length of growing season, and availability of enough land to meet the areal needs for a project. Site-specific technical, institutional and environmental considerations will also need to be addressed when finalizing site selection, including data on the hydrogeology, water-supply availability, and water chemistry at specific candidate sites and identification of potential legal, institutional and environmental impediments. The purpose of this section is to briefly review technical and institutional approaches for final site selection.

\title{
7.1 TECHNICAL ACTIVITIES
}

\section{1 .1 Surface Water}

Follow-on activities relating to the use of surface water for a project will be simpler than for a ground-water source. Information that will be required will include flow data and water chemistry. As described in section 4.0, waste waters from the Palo Verde Nuclear plant in the Buckeye area, and the desalting plant in the yuma areas may be ideal sources, along with agricultural drainage waters in both locations. All of these sources are or will be carefully monitored both for discharge rates and volumes and for water chemistry. Accordingly, a major activity of a follow-on project will be to ensure that flow records are adequate to allow predicting the long-time availability of the source. Similarly, chemical data should be monitored and if necessary additional samples should be taken to confirm the available analysis and to analyze for constituents that may not be determined routinely which may have an effect on algal growth (eg., trace metals). The sampling procedure and the laboratory analyses must be conducted using rigorous quality control abd quality assurance procedures.

\subsubsection{Ground water}

Three aspects are discussed, namely, conducting a water budget, designing wells, and water sampling for chemical analyses. 
7.1.2.1 Water Budget and Ground-Water Flow Modelling

Given that the water demands for a microalgae production project are great (i.e., flow rates greater than 4 mgd), it is particularly important to determine the long-term consequences of a project on the regional ground-water system. Ideally, a groundwater balance should be conducted for each site both to ensure that sufficient water will be available for the projected life of a project (10 years), and to ensure that the project will not have an unfavorable influence on potable water sources in the same basin.

A ground-water water balance study involves developing estimates of the components of the water budget for a basin. These components include inflows such as recharge and ground-water inflows from adjoining basins; outflows, including evapotranspiration, ground-water pumpage, and ground-water outflow; and changes in storage, usually determined by monitoring ground-water levels. Ground-water models are effective tools for using water budget information to predict the long-term stress of pumping on an aquifer system.

A detailed discussion of the requirements for a water balance is beyond the purview of this report. Several excellent references and texts review the topic and should be consulted for specific details. These references include texts by walton (1970), and Freeze and Cherry (1979). In addition it is highly recommended that a professional hydrogeologist be contracted to conduct the water balance studies and to interpret the results. Such studies will include collecting and examining ground-water related information for the region of interest, including data on stream flow losses, ground-water levels, vertical direction of groundwater motion, pumping data, cropping patterns and crop types, and other parameters required for a water budget.

Several excellent ground-water flow models are available to assist in determining the effect of various water use scenarios on the regional ground-water system. For example, the United states Geological Survey developed ground-water flow models for characteristic basins in the SWAB/RASA study area. The model of Tucci (1981) for Parker Valley, which includes Focal Area I, is an example of one of these models. Another excellent model is the McDonald-Harbaugh model developed for the United states Geological Survey. This model is capable of simulating three dimensional ground-water flow. This model is available for IBMPC. Again, a hydrogeologist with experience in modelling should be brought into a project to ensure that a suitable model is selected and that the chosen model is properly conceptualized, calibrated, validated and tested for the ground-water system of interest.

The effectiveness of ground-water models is limited by the availability of information on the hydraulic and chemical 
properties of the aquifer system. Hydraulic properties of interst are the transmisivity (T) and storativity (S). Although some values of $T$ and $S$ are available for the areas identified in section 6.0, in general there will not be enough data available to construct and run a model with a feeling of confidence in the results. Accordingly, site specific aquifer tests will be required, either using existing wells, or by constructing test wells. Methods for conducting and interpreting the results of aquifer tests are described by Lohman (1972). Aquifer testing is an expensive and technicaliy demanding process and again $a$ trained hydrologist should be involved in the planning and performance stages.

\subsubsection{Well Design and Construction}

Production wells at the site of a microalgae production facility should be constructed using approved methods under the supervision of an experienced hydrogeologist. Effective well siting and construction will be particularly important for a project in Focal Area 6 , in the Plateau Uplands province, where the success of a well depends on intercepting water yielding fractures. A recent article by Caswell (1981) describes techniques for pump testing in fractured-rock wells.

An excellent guide for designing and constructing wells is the "Manual of Water Well Construction Practices", issued by the U.S. Environmental Protection Agency (no date). Included in this document are specific details on the following elements of well construction:

- Constructing test holes for geophysical logging and formation sampling (this step will facilitate identifying productive layers in the aquifer, and provide background geological information)

- Well construction, including methods of construction

- casing selection ( of critical importance when pumping from highly saline aquifers; see Driscoll, 1986, p. 424)

- Well grouting

- Well screen and perforations

- Well plumbness and alignment

- Well development

- Well testing for performance

- Well disinfection

Selection of an experienced driller for this program is of 
critical importance. The goal should be to hire the most experienced and capable driller and not necessarily the lowest bidder.

In addition to careful well construction, the success of a well depends on tailoring the pumping plant to the particular conditions of each well site. The well testing program for performance will assist in developing the specifications of a pumping plant for site specific conditions. The selection of materials for a pumping plant will be an important factor when pumping saline ground water.

\subsubsection{Ground-Water Sampling for Chemical Quality}

As shown in Appendix D, there exists a sizeable amount of information on the ground-water chemistry of the focal areas. Nevertheless, it is highly recommended that samples be obtained at the site of a potential project to ensure that the quality is compatable with the needs of the project. The test well program described in the previous paragraphs provides an ideal opportunity of obtaining samples for chemical analyses. If possible, depth-wise samples should be obtained to characterize vertical stratification of water quality within water-bearing strata. The onsite sampling program should be supplemented with a sampling program to obtain a better perspective of the areal distribution of chemical constituents in the vicinity of the site. This information will be helpful when modelling the effect of the project on long-term salinity trends.

The sampling program should be based on a rigorous sampling protocol to ensure that, if necessary, the sampling results can be defended in a court of law. An effective protocol requires that the samples must be collected in an approved fashion, using approved containers, and stored and transferred using recommended techniques. A proper chain-of-custody procedure should be initiated.

An important aspect of well water sampling is to pump the well for a sufficient period of time to ensure that the well discharge is representative of the contributing water-bearing formations. A sample collected at that time will represent an "average" of the water quality in the region stressed by the pump. (In order to obtain samples from individual zones it will be necessary to install a packer assembly and submersible sampling pump.) Wood (1976) describes a method for determining the representativeness of well water samples using periodic checks on the levels of such unstable constituents as pH, specific electrical conductance, alkalinity, and redox potential. Other procedures for collecting representative water quality data from water wells are described by Gibb et al. (1981).

Laboratory selection is also of critical importance. The Arizona State Laboratory has a certifiction process for laboratories in the state, and it is recommended that only a certified laboratory 
should be selected for a project-related analytical program. Such a laboratory will emply an approved quality control, quality assurance program, and utilize EPA approved methods.

Although the purpose of an analytical program will be to identify the inorganic components in collected water samples, it may be worth while considering anayzing for a suite of the EPA priority pollutants, including the trace organics.

\subsubsection{Conjunctive Use of Surface Water and Ground Water}

In addition to concentrating on using either surface water or ground water for a project, it is recommended that consideration be give to conjunctively using surface and ground water to ensure a constant supply throughout the year. Thus in areas of saline irrigation return flows (eg., in the Buckeye and Yuma areas) the availability of the surface water supply will be seasonal. Accordingly, ground water could be extracted during the offseason to ensure constancy in the supply to a project. This approach will also be a means of augmenting the total available supply.

\subsubsection{Effect of a Project on Ground-Water Quality}

An essential consideration in planning for a project is to estimate the long-term effect of extracting large volumes of saline ground water on the regional ground-water quality. For example, prolonged pumping may induce a flow of fresh water into the area, diluting the project supply. Alternatively, the project may improve the fresh water supply by improving the overall salt balance in the area. Ground-water flow models which include a transport component will be useful in predicting long-term quality effects of a project.

\subsection{INSTITUTIONAL ACTIVITIES}

Recommendations for follow-on institutional activities are more general than for the technical studies described in the previous paragraphs. First, when the potential sites for a project are narrowed down to one or two alternatives, the legal and institutional elements of the area relative to obtaining water rights for a project must be researched, using guidelines set forth in section 5.0. Of particular importance is to itemize the requirements for a permit in an AMA, which may pose special problems. Similarly, a Notice of Disposal should be filed as soon as possible with the Arizona Department of Health Services once a final choice has been made. Second, contacts should be made with owners or caretakers of land on which a project may be developed. For example, specific details on the leasing requirements for each of the alternative Indian reservations should be determined. similarly, if leasing of state or Federal lands is being considered, contacts should be made with appropriate officials for details on leasing requirements. Third, an attempt should be 
made to have the status of the project clarified with the Arizona Department of water Resources (e.g., should the project be classified as an industrial or agricultural activity?).

Given the dynamic nature of water politics in Arizona, it is highly recommended that the information in section 5.0 be updated when definite plans are undertaken for a project. 
During this project a total of eight surface water sources were identified as having the potential of yielding large enough quantities (i.e., $>4$ mgd) of saline water for a microalgae facility. Similarly, 33 saline ground-water areas passed the screening criteria of the project. These areas were grouped into six focal areas. The technical and institutional features of each of these areas were discussed in detall in section 6.0. Based on an evaluation of the advantages and disadvantages of the separate areas from the viewpoint of both yield and institutional consideration, the following ranking, in descending order of importance, was developed:
1. Area II The Yuma area
2. Area III The Buckeye area
3. Area VI The Plateau Uplands area
4. Area I The Colorado River area
5. Area V The Safford Valley area.
6. Area IV The area south of Tempe

\subsection{AREA I THE YUMA AREA}

This area is depicted on Plate III.

\subsubsection{Water Production Capabilities}

This area was rated as the number one candidate for a project because it has two potentially large sources of saline surface water for a project, namely, drainage waters from the welltonMohawk Irrigation District and from the south Gila Valley Irrigation Districts, and effluent from the Yuma desalination plant, which will be coming on line in 1989. The brine outflow from the desalting plant is particularly desirable because it will be available in large quantities, and the supply is reliable and cheap. Undeveloped land is nearby. A disadvantage is that the effluent must be pumped because of the low elevation of the plant outfall. The abundant surface water resources in the area could be supplemented with saline ground water to ensure a reliable, constant source for a project.

\subsubsection{Institutional Considerations}

Another reason for rating this area at the top of the list is that there will be no legal restrictions on pumping ground water because the area is outside an AMA. A great deal of private land is available for a project and there will probably be a willingness on the part of farmers to cooperate in a project. A possible problem down the line is the ongoing water rights litigation by the Gila River Indians. 


\subsection{AREA 111 THE BUCKEYE AREA}

This area is depicted on Plate IV.

8.2.1 Water Production Capabilities

This area was rated high on the list of candidate areas because it also has an abundance of saline drainage water for a project, namely discharges from the Buckeye Irrigation District. This cheap abundant supply could be augmented with saline ground water to ensure a steady supply. Discharge from the Palo Verde Nuclear Generating Plant is also a possible source in the area.

\subsubsection{Institutional Considerations}

From an institutional viewpoint this area does not rank as high as the first choice because a portion of the area is located within an AMA, and the associated restrictions on pumping ground water. Inasmuch as the ongoing studies sponsored by the Arizona Department of Water Resources may remove the Buckeye area from the Phoenix AMA, obtaining ground water for a project may not be a problem in the future. Officials with the Buckeye Irrigation District have expressed interest in a project. Similarly, an arrangement could be made with the officials at the Palo verde generating plant with few legal constraints.

\subsection{AREA VI PLATEAU UPLANDS}

This area is shown on Plate VI.

\subsubsection{Water Production Capabilities}

A particular advantage of this area is that large expanses of land are available for a project. Similarly, large quantities of ground water are available. The area is not as highly rated as the first two areas because no large scale surface water resources are available for conjunctive use with ground water. In addition, a possible problem may arise when attempting to locate a well field for a facility because well yield depends on fracture spacing. Inasmuch as water production is tied to the uncertainty of locating water yielding fractures, the cost of a project may be quite high.

\subsubsection{Institutional Considerations}

A major advantage is that the area is outside an AMA with no legal constraints on pumping ground water. The Navajo Tribe may be interested in a project on their Reservation. Private land holdings are also available for a project. 
8.4 AREA I THE COLORADO RIVER AREA

This area is depicted on Plate III.

8.4.1 Water Production Capabilities

This area was also not rated at the top of the list because saline surface water sources are not available for conjunctive operation. Wells in the alluvium unit are good producers.

\subsubsection{Institutional Considerations}

An advantage of this area is that it is outside an AMA. The saline ground-water plume is entirely within the Colorado River Indian Reservation. Outside lands are within state Trust Iand and BLM managed areas. If the tribe were interested in a project, land could be leased for a 25 year period. The reservation officials have extensive leasing experience and less problems have arisen when dealing with this tribe than with others. The Tribe is also intersted in obtaining a higher return from their land than from regular agriculture.

\subsection{AREA $V$ THE SAFFORD VALLEY AREA}

This area is shown on Plate $V$

\subsubsection{Water Production Capabilities}

Although saline surface water is present in the area. the availability of this source is limited because the Gila River is over appropriated. Well yields in the alluvium are very favorable, producing in the range $4 \mathrm{mgd}$ to $13 \mathrm{mgd}$.

\subsubsection{Institutional Considerations}

Given the extensive agriculture in the area it may be difficult to obtain sufficient land in the area for a large-scale project. The Gila River adjudication will greatly affect the status of both surface and ground water in this area. The Gila River Indian Reservation is a possible location for a project because of the additional revenue that would be generated over that from farming. The reservation officials have extensive experience in leasing.

8.6 AREA IV THE AREA SOUTH OF TEMPE

This area is shown on Plate $\mathrm{V}$. 


\subsubsection{Water Supply Availability}

The presence of clay units increases the uncertainty of obtaining productive wells. The ground-water system is being heavily exploited. Subsidence is also recorded in the area.

\subsubsection{Institutional Considerations}

The principal reason for rating this area at the bottom of the list is that most of the area is within the Phoenix or pinal AMA's, and it is unlikely that the Arizona Department of water Resources would allow a new well field for microalgae production ponds because of concern over the public perception that well water was being used for a system of lakes. The expense of completeing the requirements for a permit would also be great. The most favorable location for a project would be on the Gila River Indian Reservation and there already is a spirulina project on the reservation that is similar to the proposed microalgae production facility. 


\section{SECTION 9.0}

REFERENCES

References cited within this report are included in the Bibliography, Appendix A. 

APPENDICES 

APPENDIX A

BIBLIOGRAPHY 
ACRR - Arizona Code of Rules and Regulations.

Akers, J.P., 1964, "Geology and Ground Water in the central Part of Apache County, Arizona", U.S. Geological Survey Water Supply Paper 1771.

Anderson, Terry, 1983, Water Crisis: Ending the Policy Drought, Baltimore, The John Hopkins University Press.

Anderson, T. W., 1985, "Hydrologic Setting, Objectives, and Approach of the Southwest Alluvial Basins, RASA study", submitted for Publication by the American water Resources Association.

Anderson T. W., 1985, "Geohydrology of the Southwest Alluvial Basins, Arizona", Submitted for publication by the American Water Resources Association.

Appel, C. I and Bills, D. J. 1980, "Map Showing Ground-Water Conditions in the Canyon Diablo Area, Coconino and Navajo Counties, Arizona - 1979", U.S. Geological Survey, Water Resources Investigations 80-747.

Arizona Department of Health Services, 1984, "Handout for Joint Meeting of The Water Quality Interim study committee of the Arizona state Senate, Phoenix, Arizona", Arizona Department of Health Services.

Arizona Department of Water Resources, 1984, "Management PlanFirst Management Period: 1980-1990", Tucson Active Management Area.

Arizona Department of Water Resources, 1984, "Management Plan, First Management Period 1980-1990", Phoenix Active Management Area.

Arizona Town Hall, 1985, "Managing Water quality in a Water Scarce state", Research Report Directed by school of Renewable Natural Resources, University of Arizona, Tucson, Arizona.

Arizona Water Commission, 1975, "Summary Phase I - Arizona State Water Plan, Inventory of Resource and Uses", Arizona Water Commission, Phoenix, Az.

Arizona Water Commission, 1975, "Arizona state water Plan: Inventory of Resource and Uses", State of Arizona.

Armstrong, C.A. and C.B. Yost, 1958, "Geology and Groundwater Resources of the Palomas Plain -Dendora Valley Area, Maricopa and Yuma Counties, Arizona", Arizona State Land Department. Water Resources Report Number 4 .

ARS - Arizona Revised Statutes.

Bedinger, M.S., T.W. Anderson and W. H. Langer, 1984, "Maps Showing Ground-Water Units and Withdrawal, Basin and Range Province, Arizona", U.S. Geological Survey, Water-Resources Report 83-4114-A.

Beebe R., 1983, "Water Rights - How to Avoid Getting in over Your Head", The Colorado Lawyer, Vol. 11, No. 8, pp. 2143 2145.

Boyer, T., 1986, Yuma Project Manager, Bureau of Reclamation, Phone Interview by Mary Wallace, April 18, 1986. 
Briggs, P.C., 1969, "Ground-Water Conditions in the Ranegras Plain Yuma County, Arizona", Arizona State Land Department, Water Resources Report No. 41.

Briggs, P., 1984, "Arizona's Groundwater Pollution Control Program", $\frac{\text { Proceedings }}{\text { of }}$ the $\frac{\text { Specialty }}{\text { Conference, }}$ Irrigation and Drainage Division, American Society of Civil

Briggs, P. and E. Nemecek, "Technical Aspects of Arizona Groundwater Law", unpublished paper.

Brown, S.G., H.H. Schumann, L.R. Kister and P.W. Johnson, 1963, "Basic Ground-Water Data of the Willcox Basin, Graham and Cochise Counties, Arizona", United States Geological Survey. Brown, A., 1986, Arizona Department of Health Services, Personal Interview by Mary $G$. Wallace, March $26,1986$.

Brown, S.G., and Schumann, H.H., 1968, "Geohydrology and Water Utilization in the willcox Basin, Graham and Cochise Counties, Arizona", U.S. Geological Survey Water-Supply Paper $1859-\mathrm{F}$.

Bush, D., and W. Martin, 1986, "Economic Benefits and Costs to Arizona Irrigation Districts Contracting for Central Arizona Project Water", Arizona Agricultural Experiment station Technical Bulletin.

Cooley, M.E., 1969, "Regional Hydrogeology of the Navajo and Hopi Indian Reservations", Arizona, New Mexico and Utah, U.S. Geological Survey Professional Paper 521-A.

Cooley, M.E., 1976, "Spring Flow from Pre-Pennsylvannian Rocks in the Southwestern Part of the Navajo Indian Reservation, Arizona", U.S. Geological Survey Professional Paper 52l-F.

Daniel, D.L., 1981, "Maps Showing Total Dissolved solids Content of Groundwater in Arizona", Arizona Department of Water Resources Hydrologic Map Series Number 2.

Davidson, E.S., 1979, "Summary Appraisal of the Nation's Groundwater Resources - Lower Colorado Region", U.S. Geological Survey Professional Paper 813-R.

Davis, S.N., 1986, Personal Communication with Kevin olson Regarding the C-Aquifer system in the Plateau Uplands, Arizona.

Decook, K. J., 1984, "Arizona Water Information Directory: Where to Find Water Information in Arizona", University of Arizona.

Denis, E.E., 1982, "Map showing Ground-water Conditions in the Tonto Basin Area, Gila County, Arizona - 1979", U.S. Geological Survey Water-Resources Investigations open File Report 82-116.

Denis, E.E., 1975, "Maps Showing Ground-Water Conditions in the Waterman Wash Area, Maricopa and Pinal Counties, Arizona1975", U.S. Geological Survey, Arizona Water Commission Hydrologic Map Series $\mathrm{H}-1$.

Driscoll, F.G., 1986, Groundwater and Wells, Johnson Division, st. Paul, Minnesota.

Dutt, G.R. and T.W. McCreary, 1970, "The Quality of Arizona's Domestic, Agricultural and Industrial Waters", University of Arizona, Agricultural Experiment Station, Report 256. 
Dutt, G., J. Stroehlein, R. Angus and T. Crawford, Jr., 1986, "Use and Reuse of Saline Waters for Irrigation and control of Salinity on River systems, Tucson, Arizona", Department of Soil and Water Science, pp. 1-13.

Environmental Protection Agency, 1984, "Groundwater Protection Strategy", Washington, D.C., office of Groundwater Protection.

Farrar C.D., 1979, "Map showing Groundwater conditions in the Bodaway Mesa, Coconino County, Arizona - 1977", U.S. Geological Survey Water Resources Investigations 79-1488.14.

Farrar, C.D., 1980, "Maps Showing Ground-Water conditions in the Hopi Area, Coconino and Navajo Counties, Arizona,-1977", U.S. Geological Survey Water-Resources Investigation 80-3.

Fenneman, N.M., 1931, Physiography of the Western United States, McGraw-Hili Book Co.

Feth, J.H., 1952, In: Halpenny, I.C. and others, "Ground Water in the Gila River Basin and Adjacent Areas, Arizona- A Summary", U.S. Geological survey, Tucson, AZ.

Freeze, R.A. and J.A. Cherry, 1979, Groundwater, Prentice-Hall, Inc.

Gessner, C., 1986, Staff, Phoenix Active Management Area, Phone Interview by Mary Wallace, April 2l, 1986.

Gould, G., 1980, "Conversion of Agricultural water Rights to Industrial Use" Rocky Mountain Mineral Law Institute, Vol. 27B, pp. 1791-1851.

Halleck, D., 1985, Tribal Planner, Gila River Indian Community, Personal Interview by Mary Wallace and Gary weatherford, March, 22, 1985.

Halpenny, I.C. and others, 1952, "Ground water in the Gila River Basin and Adjacent Areas, Arizona- A Summary", U.S. Geological survey, Tucson, Az.

Hansen, G., 1986, Staff, Phoenix Active Management Area, Phone Interview by Mary Wallace, April 22, 1986.

Hanson, Ronald I. and Brown, S.G. 1972, "Subsurface Hydraulics in the Area of the Gila River Phreatophtye Project, Graham County, Arizona, "U.S. Geological Survey Professional Paper $655-\mathrm{F}$.

Hardt, W.F., Cattany, R.E. and Kister, L.R. 1964, "Basic GroundWater Data for Western Pinal County, Arizona, "Arizona State Land Department, Water Resources Report No. 18 .

Harper and Anderson, 1975, Concho \& St. John Maps UsGs.

Helms, D., 1986, Staff, Arizona State Land Department, Telephone Interview by Mary Wallace, April, 15, 1986.

Holub, H., 1986, "Groundwater Rights in Arizona," Arizona Bar Journal, Vol. 21 , No. 4, pp. 8-14.

Hem, John D. 1950, "Quality of Water of the Gila River Basin Above Coolidge Dam Arizona," U.S. Geogical Survey WaterSupply Paper 1104 .

Hollett, Kenneth J., ig8l, "Maps Showing Ground-water conditions in the San Simon Wash area, Papago Indian Reservation, Arizona - 1979", United States Geological Survey WaterResources Investigations 81-530. 
Hould, C.L., 1985, Project Manager, Wellton-Mohawk Irrigation and Drainage District, Wellton, Arizona, Letter to L.G. Wilson, Hydrologist, Water Resources Research Center, University of Arizona, September, 11, 1985.

Johnson, J., 1980, "Summary of the 1980 Arizona Groundwater Management Act," State Bar of Arizona Continuing Legal Education, pp. 1-35.

Johnson, P.W. and R.B. Sanderson, 1968, "Springflow into the Colorado River - Lee's Ferrry to Lake Mead, Arizona", Arizona State Land Department water Resources Report \#34.

Jones, T., 1986, Project Manager, Buckeye Irrigation and Drainage District, Phone Interview by Mary Wallace, April, 25, 1986.

Jones, S.C., 1980, "Maps showing Ground-Water conditions in the Lower San Pedro Basin Area, Pinal, Cochise, Pima and Graham Counties, Arizona", U.S. Geological Survey Water-Resources Investigations 80-954.

Kam, William, H.H. Schumann, L.R. Kister, and F.E. Arteaga, 1966, "Basic Ground-Water Data from Western Salt River Valley, Maricopa County, Arizona", Arizona state Land Department Water Resources Report Number 27.

Kam, William, 1961, "Geology and Groundwater Resources of the McMullen Valley, Maricopa, Yavapai, and Yuma Counties, Arizona", Arizona state Land Department water Resources Report Number 8.

Kister, L.R. and Hatchett, J.L., 1963, "Selected Chemical Analyses of the Ground-Water, Part 2 of Geohydrologic Data in the Navajo and Hopi Indian Reservations, Arizona, New Mexico and Utah", Arizona state Land Department, Water Resources Report Number 12-B.

Kister, L.R., 1973, "Quality of Ground Water in Lower Colorado River Region, Arizona, Nevada, New Mexico, and Utah", U.S. Geological survey Hydrologic Investigations Atlas HA-478.

Kolsrud, R., 1986, "The Fox is Guarding the Hen House", Arizona Bar Journal, Vol. 21 , No. 4, pp. $16-22$.

Konieczki, A.D., 1980, "Maps showing Ground-water Conditions in the Upper San Pedro Basin Area, Pima, Santa Cruz, and Cochise Counties, Arizona-1978", U.S. Geological Survey Water Resources Investigation 80-i192.

Konieczki, A.D. and English, C.S. 1979, "Maps Showing GroundWater Conditions in the Lower Santa Cruz Area, Pinal, Pima, and Maricopa Counties, Arizona - 1977", U.S. Geological Survey Water-Resources Investigations 79-56.

Laffoon, Harry, 1986, Tibal Vice-President Colorado River Indian Tribes, Personal Interview, April 22, 1985.

Langer, W.H., D.A. Mulvihill, and T.W. Anderson, 1984,"Maps Showing Ground-Water Levels, Springs, and Depth to Ground Water, Basin and Range Province, Arizona", United States Geological Survey water Resources Investigations Report 83$4114-B$.

Laney, R.L., P.P. Ross and G. R. Littin, 1978, "Maps Showing Ground-Water Conditions in the Eastern Part of the Salt River Valley Area, Maricopa and Pinal Counties, Arizona1976," U.S. Geological Survey, Water Resources Investigations 78-61. 
Laney, R.I., 1977, "Effects of Phreatophyte Removal on Water Quality in the Gila River Phreatophyte Project Area, Graham County, Arizona", Geological Survey Professional Paper 655M.

Leake, S.A. and Clay, D.M., 1979, "Maps Showing Ground-Water Conditions in the Gila River Drainage from Texas Hill to Dome Area and in the Western Mexican Drainage Area, Maricopa, Pima and Yuma Counties, Arizona - 1977", U.S. Geological Survey Water-Resources Investigations 79-1540.

Levings, Gary $W$. and C.D. Farrar, 1979, "Maps Showing GroundWater conditions in the Virgin River, Grand wash, and Shivwits Area, Mohave County, Arizona-1976", U.S. Geologicial Survey, Water Resources Investigations 79-57.

Levings, G.W. and Farrar, C.D. 1977, "Maps Showing Ground-Water Conditions in the Northern Part of the Chinle Area, Apache County, Arizona - 1976", U.S. Geological Survey waterResources Investigations 77-35.

Levings, G.W. and Mann, L.J. 1980, "Maps showing Ground-Water Conditions in the Upper Verde River Area, Yavapai and Coconino Counties, Arizona - 1978", U.S. Geological Survey Water-Resources Investigations 80-726.

Levings, Gary W. and C.D. Farrar, 1978, "Map showing Ground-water Conditions in the House Rock Area, Coconino County, Arizona1976", U.S. Geologicial Survey, Water Resources Investigations 78-15.

Levings, Gary W. and C.D. Farr, 1977, "Maps showing Ground-water Conditions in the Monument Valley and Northern part of the Black Mesa Areas, Navajo, Apache, and Coconino Counties, Arizona-1976", U.S. Geologicial survey water Resources Investigations 77-44.

Ligner, J.J., N.W. White, L.R. Kister and M.E. Moss, 1969, "Water Resources", In:Mineral and Water Resources of Arizona, The Arizona Bureau of Mines, The University of Arizona, Tucson, Bulletin 180 .

Lofgren, S., 1984, "The Federal Role in Groundwater Protection", SAWARA Waterwords, Vol. 3, No. 12 , p. 13.

Lohman, S.W., 1979, "Ground-Water Hydraulics", U.S. Geological Survey Professional Paper 708.

Long, M.R., 1983, "Maps Showing Groundwater conditions in the Hassayampa Sub-basin of the Phoenix Active Management Area, Maricopa and Yavapai Counties, Arizona - 1982", Arizona Department of Water Resources Hydrologic Map Series Report Number 10.

Long, Austin, 1983, "Stable Isotopic Investigation of the Ground Water Quality and Transport systems in the Safford Valley, Arizona", University of Arizona, Department of Hydrology and Water Resources.

Mann, I.J., 1977, "Maps Showing Ground-Water Conditions in the Puerco-zuni Area, Apache and Navajo Counties, Arizona 1975", U.S. Geological Survey Water-Resources Investigations 77-5.

Mann, Larry J., Natlie D. White and R.P. Wilson, 1978, "Maps Showing Ground-water conditions in the Willcox.Area, Cochise and Graham Counties, Arizona-1975", U.S. Geologicial Survey, Water-Resources Investigations Open-File Report 78-60. 
Mann, Larry J., 1976, "Ground-water Resources and Water Use in Southern Navajo County, Arizona", Arizona Water Commission Bulletin 10 .

Martin, W., H. Ingram, D. Cory and M. Wallace, 1985, "Toward Sustaining a Desert Metropolis: Water and Land Use in Tucson, Arizona", Report prepared for World Resources Institute.

Maxwell E. L., A. G. Folger and S. E. Hogg, May 1985, Resource Evaluation and Site Selection for Microalgae production Systems, Solar Energy Research Institute.

McGavock, E.H., 1968, "Basic Ground Water Data for Southern Coconino County, Arizona", Water Resources Report Number Thirty-Three, Arizona state Land Department.

McGavock, E.H., R.J. Edmonds, E.L. Gillespie and I.C. Halpenny, 1966, "Geohydrologic Data in the Navajo and Hopi Indian Reservations, Arizona, Part 1-A-Supplemental Records of Ground-water supplies", Arizona state Land Department, Water Resources Report Number Twelve-E.

McGeorge, W.T., E.L. Brezeak, A. Mark Bliss, 1952, "The Salinity Problem Safford Experimental Farm Field Experiments", Agricultural Experiment Station, Technical Bulletin Number 124 .

Metzger, D.G., O.J. Loeltz and Burdge Irelan, 1973, "Geohydrology of the Parker-Blythe-cibola Area, Arizona and California", U.S. Geological Survey Professional Paper 486-G.

Metzger, D.G., 1957, "Geology and Ground-water Resources of the Harquahala Plain Area, Marricopa and Yuma Counties, Arizona", Arizona State Land Department Water-Resources Report Number 3 .

Morris, J., 1980, "Subsidence: An Emerging Area of Law", Arizona Law Review, Vol. 22 , pp. 899-917.

Mulle $\frac{\text { Law }}{A ., ~ I 973, ~ " S a f f o r d ~ V a l l e y ~-~ A n ~ A n a l y s i s ~ o f ~ t h e ~ W a t e r ~}$ Quality Problems of the Safford Valley, Arizona", University of Arizona, Department of Hydrology and Water Resources Report No. 15.

Muller, Anthony B., 1974, "Interdisciplinary Modelling in the Analysis of the Salinity Problems of the safford Valley".

Murphy, B.A. and J.D. Hedley, 1984, "Maps Showing Ground-Water Conditions in the Upper Santa Cruz Basin Area, Pima, Santa Cruz, Pinal and Cochise Counties, Arizona - 1982", Arizona Dept. of Water Resources, Hydrologic Map Series Report Number 11 .

Nations, Dale and Edmond Stump, 1981, Geology of Arizona, Dubuque, Iowa: Kendall/Hunt Publishing Company.

o'Hare, C., 1986, Staff, Tucson Active Management Area, Phone Interview by Mary Wallace, April 14, 1986.

oppenheimer, J.M. and J.S. Sumner, 1980," "Gravity Modeling of the Basins in the Basin and Range Province, Arizona", Arizona Geological Society Digest 13, Tucson, Arizona, pp. 111-115. osborn, Donald E. and P. Huddy (ed), 1982, "Arizona Solar and Weather Information", Phoenix: Arizona Solar Energy Commission.

Owen-Joyce, S.J., 1984, "Hydrology of a stream Aquifer system in the Camp Verde Area, Yavapai County, Arizona", Arizona Department of Water Resources Bulletin 3. 
Phillips, M., 1984, "Representing a Developer Purchaser of Water and water Rights, The Colorado Lawyer, Vol. 13, No. 4, pp. $627-629$.

Peirce, W. H., 1981, "Major Arizona Salt Deposits", Fieldnotes from the State of Arizona Bureau of Geology and Mineral Technology, Vol. II, No. 4 .

Peirce, Wesley and Thomas Gerrard, 1966, "Evaporite Deposits of the Permian Holbrook Basin, Arizona", Northern Ohio Geological society, second symposium on salt, $\frac{\mathrm{V} .1 . \mathrm{pp}}{1-\overline{10}}$

Poole, D.R.' 1985 , "Aquifer Geology of Alluvial Basins of Arizona", Submitted for Publication by the American Water Resources Association.

Reeter, R.W., 1982, "Maps Showing Ground-water conditions in the Avra/Altar Valley Area, Pima and Santa Cruz Counties, Arizona - 1981", Arizona Department of Water Resources, Hydrologic Map Series Report Number 7.

Remick, W.H., 1981, "Map Showing Ground-water Conditions in the Hualapai Basin Area, Mohave, Coconino and Yavapai Counties, Arizona - 1980", Arizona Department of Water Resources Hydrologic Map Series Report Number 4.

Robertson, F. N., 1985, "Occurrence and solubility controls of Trace Elements in Ground Water in Alluvial Basins of Arizona", Submitted for publication by the American Water Resources Association.

Roeski, R.H. and W.L. Werrell, 1973, "Hydrologic Conditions in the San Pedro River Valley, Arizona, 1971", Arizona Water Commission Bulletin \#4.

Rogers, C., 1986, Plant Engineer, Palo Verde Nuclear Power Plant, Phone Interview by Mary Wallace, April 17, 1986.

Ross, R.P., 1978, "Maps Showing Ground-Water conditions in the Western Part of the Salt River Valley Area, Maricopa County, Arizona - 1977", U.S. Geological Survey Water-Resources Investigations 78-40.

Schumann, H. H., R. I. Laney and L. S. Cripe, 1985, "Land Subsidence and Earth Fissures Caused by Ground-Water Depletion in Southern Arizona", Submitted for Publication by the American Water Resources Association.

Sebinik, P.G., 1979, "Maps Showing Ground-water conditions in the Gila Bend Basin Area, Maricopa County, Arizona-1979", Arizona Department of Water Resources Hydrologic Map Series Report Number 3.

Sellers, W.D. and R.H. Hill, 1974, Arizona Climate, University of Arizona Press, Tucson, Arizona.

Smith, H.V., G.E. Draper and W.H. Fuller, 1964, "The Quality of Arizona Irrigation Water", University of Arizona, Agricultural Experiment Station", Report 223.

Smith, H.V., G.E. Draper, T.F. Buehrer, W.H. Fuller and G.W. Marx, 1963, "Qualilty of Arizona's Domestic Waters", University of Arizona, Agricultural Experiment station, Report 217.

Stiff, H.A., 1951, "The Interpretation of Chemical Water Analysis by Means of Patterns", Journal of Petroleum Technology, V.3, No. 10, pp 15-17. 
stulik, R.S. and 0. Moosburner, 1969, "Hydrologic conditions in the Gila Bend Basin, Maricopa County, Arizona", Arizona State Land Department, Water Resources Report No. 39.

stulik, R.S. and F.R. Twenter, 1964, "Geology and Ground-water of the Luke Area, Maricopa County, Arizona", U.S. Geological Survey Water-Supply Paper 1779-P.

stulik, R.S. and Laney, R.L., l'976, "Maps Showing Ground-Water Conditions in the Lower Hassayampa Area, Maricopa County, Arizona - 1975", U.S. Geological Survey Water-Resources Investigations 76-35.

stulik, R.S., 1982, "Maps showing ground-water conditions in the Waterman Wash area, Maricopa and Pinal counties, Arizona 1982", Arizona Department of Water Resources, Hydrologic Map Series Report Number 8.

Thompson, Thomas H., Janet Nuter and T.W. Anderson, 1984, "Maps Showing Distribution of Dissolved solids and Dominant Chemical Type in Ground Water, Basin and Range Province, Arizona", U.S. Geological Survey Water Resources Investigations Report 83-4114-C.

Tucci, Patrick, 1982, "Use of a Three-Dimensional Model for the Analysis of the Ground-Water Flow System in Parker Valley, Arizona and California", $U$. S. Geological Survey, open-File Report 82-1006.

Twenter, F.R. and Metzger, D.G., 1963, "Geology and Ground-Water in Verde Valley - Mogollon Rim Region, Arizona", U.S. Geological Survey Bulletin 1177.

United States Bureau of Reclamation, 1976, "San Pedro-Santa Cruz Project", Concluding Report.

United States Bureau of Reclamation, 1981, "Saline water Use and Disposal Opportunities", Colorado River water Quality Improvement Program Special Report.

United States Environmental Protection Agency, No Date, "Manual of Water Well Construction Practices", Enironmental Protection Agency, office of Water Supply, EPA-570/9-75-001.

United States Geological Survey, 1974, "Dissolved-Solids Content of Ground-Water in the Phoenix Area, Arizona," U.S. Geological Survey Folio Map I-845-G.

United States Geological Survey, 1974, "Dissolved-Solids Content of Ground Water in the Tucson Area, Arizona," U.S. Geological survey Folio Map I-844-I.

United States Geological Survey, 1977, "Water Resources Data, Arizona, Water Year 1976", Water Data Report AZ-76-1.

United States Geological Survey, 1977, "Maps showing GroundWater Conditions in the southern Part of the Chinle Area, Apache County, Arizona - 1976", U.S. Geological Survey Water-Resources Investigations 77-50.

United States Geological Survey, 1977, "Maps Showing Ground-water Conditions in the Southern Part of the Black Mesa Area, Navajo, Apache, and Coconino Counties, Arizona - 1976", U.S. Geological Survey Water-Resources Investigations 77-41.

United States Geological Survey, 1978, "Water Resources Data for Arizona, Water Year 1977", U.S. Geologicial Survey Water-Data Report AZ-77-1. 
United States Geological Survey, 1979, "Maps Showing Ground-Water Conditions in the Kanab Area, Coconino and Mohave counties, Arizona - 1976", U.S. Geological Survey Water-Resources Investigations 79-1070.

United States Geological Survey, 1980, "Maps Showing Hydrologic Conditions in the San Francisco River Area, Greenlee County, Arizona, 1978 - A Reconnaissance Study", U.S. Geological Survey Water-Resources Investigations 80-441.

United States Geological Survey, 1981, "Maps Showing Ground-Water Conditions in the San Francisco Peaks Area, Coconino County, Arizona, - 1979", U.S. Geological Survey Water-Resources Investigations 81-914.

United States Geological Survey, 1984, "Annual Summary of Ground Water Conditions in Arizona, spring 1982 to spring 1983", Open File Report 84-428.

United States Geological Survey, 1985, "Annual Summary of Ground Water Conditions in Arizona, Spring 1983 to spring 1984", Open File Report 85-410.

United States Geological Survey, 1986, Unpublished Data on Aquifer Tests Conducted by Various Agencies in Arizona, Contact Mr. Tom Anderson, United States Geological Survey, Tucson office, 301 West Congress, Tucson, Az 85701.

Utton, A., 1982, "An Assessment of the Management of U.S.Mexican Water Resources: Anticipating the Year 2000", Natural Resources Journal, Vol. 22, No. 4, pp.1093-1117.

Walton, W.C., 1970, Groundwater Resource Evaluation, McGrawHill Book Co..

Weatherford, G., M. Wallace and I. Harold, 1986, "Leasing Indian Water: Upcoming Choices in the Colorado River Basin", Report Prepared for the John Muir Institute and the Conservation Foundation/World wildlife Fund with the support of the Ford Foundation, Publication Forthcoming in 1987.

Weist, W.G., Jr., 1965, "Geohydrology of the Dateland-Hyder Area, Maricopa and Yuma Counties, Arizona", Arizona state Land Department, water Resources Report No. 23.

Weist, William G., Jr., 1971, "Geology and Ground-Water system in the Gila River Phreatophyte Project Area, Graham County, Arizona", Geological Survey Professional Paper 655-D.

Western States Water Council, 1984, "Indian water Rights in the West", Report prepared for the Western Governor's Association, May 1984 .

White, N.D. and Clara R. Smith, 1965, "Basic Hydrologic Data for San Simon Basin, Cochise and Graham Counties, Arizona and Hildalgo County, New Mexico", Water-Resources Report Number Twenty-one, Arizona state Land Department.

White, N.D., Leake, S.A. and Clay, D.M., 1979," Maps Showing Ground-Water Conditions in the Northern Part of the Gila River Drainage from Painted Rock Dam to Texas Hill Area, Maricopa, Pima and Yuma Counties, Arizona - 1978", U.S. Geological Survey Water-Resources Investigations 79-1537.

White, N.D. and D. Childers, 1967, "Hydrologic Condition in the Douglas Basin, Cochise county, Arizona. Water-Resources Report Number 30", Arizona state Land Department. 
White, Natalie D. and Garrett, N.B., 1984, "Water Resources Data, Arizona, Water Year 1982", U.S. Geologicial Survey WaterData Report AZ-82-1.

Wilkinson, C., 1985, "Western Water Law in Transition", University of Colorado Law Review, Vol. 56, No. 3, pp. 317345 .

Wilkins, D.W., 1978, "Maps showing Ground-Water Conditions in the Yuma Area, Yuma County, Arizona - 1975", U.S. Geological Survey Water-Resources Investigations 78-62.

Wilson, R. P. and Natalie D. White, 1976, "Maps showing GroundWater Conditions in the San Simon Area, Cochise and Graham Counties, Arizona, and in Hildalgo County, New Mexico1975", U.S. Geological Survey, water Resources Investigations 76-89.

Wood, W.W., 1976, "Guidelines for Collection and Field Analysis of Ground-Water Samples for Selected Unstable Constituents", Techniques of Water Resources Investigations of the United States Geological Survey, Chapter D2, Book 1, Collection of Water Data by Direct Measurement, United states Geological Survey.

Yuma Mesa Irrigation and Drainage District and Yuma Natural Resources Conservation District, 1984, "Preauthorization Report Yuma Mesa Watershed", Yuma County, Arizona. 
APPENDIX B

LIST OF CONTACTS 
LIST OF CONTACTS AND SOURCES OF INFORMATION

\begin{abstract}
AGENCY
U.5. Geological Survey (Tucson)

U.S. Bureau of

Fecl amation

Arizona Department

of Health Services
\end{abstract}

Arizona Department of Water Fesources

Arizona State Land Department

Salt River Froject

Water Development Corporation

$\begin{array}{cll}\text { FEFSON } & \text { TELEFHONE } & \text { TYFE OF INFOFMATION } \\ \text { Tom Anderson } & 629-6266 & \begin{array}{l}\text { General Information } \\ \text { Aquifer Test Data }\end{array} \\ \text { Colleen Eabcoct: } & 629-6629 & \begin{array}{l}\text { Data Fetrieval } \\ \text { Computer SYstems } \\ \text { WATSTORE }\end{array} \\ \text { Natalie White } & 629-6850 & \text { Fublications } \\ \text { Les Kister } & 629-6564 & \text { Saline Water }\end{array}$

Dennis Watt

$726-2654$

Irrigation Frojects

Ed Swanson

$257-2362$

Tim Love

$257-2356$

Water Quality

STDFET

Jim Hedley

$255-1543$

Hydrologic Data

Craig D'Hare

$628-5858$

Water Fights

Fhil Briggs

$255-1554$

Water Law

Chucl: Constant $628-5480$

Trust Land

Gary Smal1

$236-2826$

Salt River Area

Leonard Halpenny 327-7412

Arizona Hydrology 
Wel 1 ton-Mohawt:

Irrigation District

Buckeye Irrigation

District

Gila Valley

Irrigation District

U.S. Department of Agricul ture
C.L. Gould

$785-3351$

Wel 1 ton-Mohawk

Travis Jones

$386-2196$

Buct:eye

Scott Pace

$428-3847$

Gila Valley

Extension Services

Local Information

Bill Cartes

Fichard Gibson

$628-5161$

$836-5221$

Mabel Flint

$359-2261$

Larry white

774-1860

F. Van Wilson

425-7179

Fobert Facicot

Fob Grumbles

Fichard Harris

524-6271

$753-3788$

287-4689

$669-8187$

$255-4456$

$445-6590$

$428-2611$

$357-2267$

384-3594

$783-8338$
Tucson

Casa Grande

Duncan

Flagstaff

Globe

Holbroot:

ringman

Nogales

Parlier

Fhoenix

Frescott

Safford

St. Johns

Wi I COK

Yuma 
The following irrigation districts were contacted for information regarding saline water.

Euckeye Water Conservation and Drainage District

Fit. 1 Box 69

Euckeye, Arizona 85326

Franklin Irrigation District Fifil, Box 51

Duncan, Arizona 85534

Maricopa-Stanfield Irrigation and Drainage District

Box 57

Maricopa, Arizona

Mohave Valley Irrigation and Drainage District

P.O. Box 5100

Mohave Vailey, Arizona 86440

New State Irrigation and Drainage District

F.O. BOX 1980

Fhoenix, Arizona 85001

Ocotillo Water Conservation

District

P. Q. Box 487

Chandler, Arizona 85224

Roosevelt Water Conservation

District

F.0. Box 168

Higley, Arizona 85236

San Tan Irrigation District

F. D. BOx $B$

Chandler Heights, Arizona 85227
Chandler Heights

Citrus Irrigation District

P.D. BoK 38

Chandler Heights, Arizona 85227

Hohokam Irrigation : Drainage District Eox 1244

Coolidge, Arizona 85228

McMicken Irrigation District

10451 W. Falmeras Dr.

Sun City, Arizona 85373

New Magma Irrigation

and Drainage District

3839 E. Altadena

Fhoenix, Arizona 85028

North Gila Valley Irrigation

District

1405 W. 16th Street

Yuma, Arizona 85364

Queen Creet: Irrigation District Fit 1. Box $20 \mathrm{~V}$

Queen Creet:, Arizona 85242

San Carlos Irrigation and

Drainage District

F.0. Box 218

Coolidge, Arizona 85228

Show Low Si l ver Creel: Water Conversation and Fower District Eox 121

Snowflake, Arizona 859:7 
St. David Irrigation District

St. David, Arizona 856:0

Tonopah Irrigation District 1730 N. Stapley Dr.

Mesa, Arizona 85205

Wenden Fecan Irrigation District 5050 N. 40th Street

Fhoenix, Arizona 85018

Woodruff Irrigation District Box 54

Woodruff, Arizona 85942
St. Johns Irrigation District

10209 w. Southern Avenue

Tolleson, Arizona 85S5S

Unit B Irrigation and Drainage District

FF 1 BOX $31 M$

Somerton, Arizona 85.50

Western Meadows Irrigation District 3934 W. Westcott Dr.

Glendale, Arizona 85308

Yuma Mesa Irrigation and Drainage District

143295 . Fourth Ave. Extension Yuma, Arizona 85365 
The following power plants were contacted for information regarding saline water resources.

Ajo Improvement Company

1 FIaza

Ajo, Arizona 85321

Citizens Utilities Company

Mohave Division

ringman, Arizona 86401

Morenci Water and Elec. Company F. O. Bo\% 68

Morenci, Arizona 85540

Mesa City Utilities

F. O. Eox 1466

Mesa, Arizona 85201

Thatcher Municipal Utilities

F.0. Box 670

Thatcher, Arizona 85552

Arizona Electric

Fower Cooperative, Inc.

F.D. Box 670

Benson, Arizona 85602

Graham County Electric

Cooperative

Drawer $\mathrm{B}$

Fima, Arizona 85543

Navopache Electric Co-op, Inc. F.o. Box 308

Lakeside, Arizona 85929

Trico Electric Cooperative, Inc. 5100 West Ina Fioad

Tucson, Arizona 85740

Arizona Fower Authority

1810 west Adams Street

Fhoenix, Arizona 85007
Arizona Fublic Service Company 411 North Central Avenue Fhoenix, Arizona 85004

Citizens Utilities Compàny Santa Cruz Division Nogales, Arizona 85621

Tucson Electric Fower Company 220 West 6th Street

Tucson, Arizona 85702

Safford Electric Department F.o. Box 272

Safford, Arizona 85546

Wickenburg Utilities System

Box 1269

Wickenburg, firizona 85358

Duncan Valley Electric Cooperative, Inc.

F.D. Box 0

Duncan, Arizona 85554

Mojave Electric

Cooperative, Inc.

F.0. EoK 1045

Bullhead City, Arizona 86430

Sulpher Springs Valley

Electric Cooperative, Inc.

F. O. Bax 820

Wilcox, Arizona 85643

US Bureau of Indian Affairs Department of the Interior San Carlos Irrigation Froject F.O. Box 456

Coolidge, Arizona 85228

Navajo Tribal Utility Authority F. 0 . Bax 170

Fort Defiance, Arizona 86504 
Fapago Tribal Utility Authority

F. D. Box 816

Sells, Arizona 856.34

Electrical District \#2

F.D. Box 548

Coolidge, Arizona 85228

Electrical District \#4

F.0. EOX 605

Eloy, Arizona 85231

Electrical District \#6 2845 East Camelback: Foad Suite 720

Fhoenix, AZ 85016

Cholla Fower Flant

F.D. BOX 188

Joeseph City, Arizona 86032

West Fhoenix Fower Flant 408 South 43rd Avenue

Phoenix, Arizona 85043

Falo Verde Nuclear Station

F.0. Box 53999

Fhoenix, Arizona 85072-3999
Electrical District \#1

Final County

711 East Cottonwood Lane

Casa Grande, Arizona 85222

Electrical District \#Z

711 East Cottonwood Lane Suite C

Casa Grande, Arizona 85222

Electrical District \#5 Box 8

Fied Fock, Arizona 85245

Childs and Irving Fower Flant Camp Verde, Arizona 86.322

\author{
Dcotillo Fower Flant \\ F. D. Box 1117 \\ Tempe, Arizona 85281 \\ Yucca Fower Flant \\ F. D. Box 1985 \\ Yuma, Arizona 85364
}


APPENDIX C

SURFACE WATER QUALITY 
09386030 LITTLE COLORADO RIVER ABOVE ZION RESERVOTR, MEAR ST. JOHNS, AZ

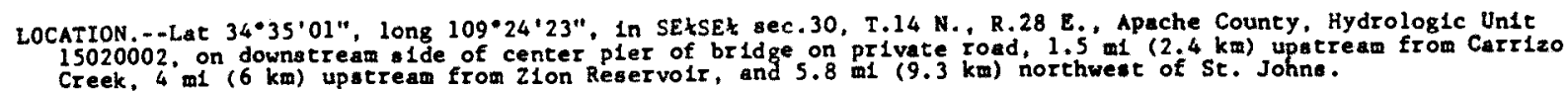
DRAINAGE AREA. - - -975 $\mathrm{mi}^{2} \cdot\left(2,525 \mathrm{~km}^{2}\right)$.

\section{WATER-DISCHARGE RECORDS}

PERIOD OF RECORD.--OCtober 1975 to current year.

GACE.--Hater-btage recorder. Altitude of gage $185,560 \mathrm{ft}(1,690 \mathrm{~m})$, from topographic map.

REMARKS.--Records falr except those for periods of no gage-height record, which are poor. Diversions above station for irrigation about 10,200 acres $\left(41.3 \mathrm{~km}^{2}\right)$, Including 1,500 acres $\left(6.07 \mathrm{~km}^{2}\right)$ gerved by Lyman Canal. Regulat1on by many reservolis above etation (combined capacity, 46,900 acre-ft or $57.8 \mathrm{hm}^{3}$ ). the largeat of which 1s Lyman Lake.

AVERAGE DISCHARGE.--7 years, $8.91 \mathrm{ft}^{3} / \mathrm{s}\left(0.252 \mathrm{~m}^{3} / \mathrm{s}\right), 6.460 \mathrm{acre-f \tau} / \mathrm{yr}\left(7.96 \mathrm{hm}^{3} / \mathrm{gr}\right)$.

EXIREMES FOR PERIOD OF RECORD.--Max1mum discharge, $453 \mathrm{ft} / \mathrm{s}\left(12.3 \mathrm{~m}^{3} / \mathrm{s}\right)$ Aug. 17,1982 , gage he1ght, $3.46 \mathrm{ft}$ (1.055 m); minimum da1ly, $0.04 \mathrm{ft} 3 / 8\left(0.001 \mathrm{~m}^{3} / \mathrm{s}\right)$ Aug. 2, Sept. 7. Oct. 16-20, 1978:

EXTREMES FOR CURRENT YEAR.--Maximum discharge, $453 \mathrm{ft}^{3} / \mathrm{s}\left(12.8 \mathrm{~m}^{3} / \mathrm{s}\right)$ Aug. 17 , gage he $1 \mathrm{ght}, 3.46 \mathrm{ft}$ $(1.055 \mathrm{~m})$; minimu daily, $0.09 \mathrm{ft}^{3} / \mathrm{s}\left(0.003 \mathrm{~m}^{3 / 8}\right)$ May 1 .

DISCHARGE, IN CUBIC FEET PER SECOND, WATER YEAR OCTOBER 1981 TO SEPTEMSER 1982

\begin{tabular}{|c|c|c|c|c|c|c|c|c|c|c|c|c|}
\hline DAY & OCT & nov & DEC & JAN & FEB & MAR & $A P R$ & MAY & JUN & JUL & AUG & SEP \\
\hline $\begin{array}{l}1 \\
2 \\
3 \\
4 \\
5\end{array}$ & $\begin{array}{l}2.0 \\
5.1 \\
39 \\
10 \\
3.4\end{array}$ & $\begin{array}{l}2.8 \\
2.5 \\
2.4 \\
2.4 \\
2.2\end{array}$ & $\begin{array}{l}3.8 \\
3.3 \\
1.8 \\
2.2 \\
2.1\end{array}$ & $\begin{array}{l}8.0 \\
9.0 \\
9.0 \\
8.0 \\
7.6\end{array}$ & $\begin{array}{l}6.5 \\
6.1 \\
7.9 \\
8.4 \\
8.8\end{array}$ & $\begin{array}{l}7.2 \\
4.2 \\
5.1 \\
4.8 \\
4.5\end{array}$ & $\begin{array}{l}3.1 \\
5.4 \\
6.5 \\
5.8 \\
5.1\end{array}$ & $\begin{array}{r}.09 \\
.18 \\
.41 \\
.18 \\
1.2\end{array}$ & $\begin{array}{l}1.3 \\
2.2 \\
2.4 \\
1.1 \\
2.9\end{array}$ & $\begin{array}{r}.50 \\
.50 \\
.50 \\
.50 \\
.32\end{array}$ & $\begin{array}{r}6.5 \\
13 \\
6.5 \\
5.8 \\
3.9\end{array}$ & $\begin{array}{r}12 \\
5.8 \\
4.8 \\
4.5 \\
5.1\end{array}$ \\
\hline $\begin{array}{r}6 \\
7 \\
8 \\
9 \\
10\end{array}$ & $\begin{array}{l}2.2 \\
2.2 \\
2.1 \\
2.0 \\
1.7\end{array}$ & $\begin{array}{l}2.1 \\
2.0 \\
2.0 \\
1.9 \\
2.5\end{array}$ & $\begin{array}{l}2.4 \\
2.2 \\
2.3 \\
2.4 \\
2.6\end{array}$ & $\begin{array}{l}7.6 \\
7.2 \\
6.5 \\
6.3 \\
6.2\end{array}$ & $\begin{array}{c}8.8 \\
11 \\
9.2 \\
10 \\
11\end{array}$ & $\begin{array}{l}3.9 \\
3.7 \\
3.4 \\
2.9 \\
2.4\end{array}$ & $\begin{array}{l}5.1 \\
4.8 \\
4.5 \\
4.5 \\
4.5\end{array}$ & $\begin{array}{l}1.0 \\
2.0 \\
2.2 \\
1.8 \\
1.2\end{array}$ & $\begin{array}{r}.41 \\
.32 \\
.32 \\
.32 \\
1.8\end{array}$ & $\begin{array}{l}.12 \\
.12 \\
.32 \\
.32 \\
.87\end{array}$ & $\begin{array}{r}14 \\
12 \\
8.0 \\
6.1 \\
4.5\end{array}$ & $\begin{array}{c}10 \\
4.2 \\
3.1 \\
3.1 \\
2.0\end{array}$ \\
\hline $\begin{array}{l}11 \\
12 \\
13 \\
14 \\
15\end{array}$ & $\begin{array}{l}1.6 \\
2.1 \\
2.0 \\
1.6 \\
1.8\end{array}$ & $\begin{array}{l}3.6 \\
3.2 \\
2.9 \\
2.7 \\
2.6\end{array}$ & $\begin{array}{l}2.8 \\
2.9 \\
2.7 \\
2.8 \\
2.8\end{array}$ & $\begin{array}{l}6.1 \\
5.5 \\
5.2 \\
5.0 \\
5.0\end{array}$ & $\begin{array}{l}14 \\
15 \\
11 \\
11 \\
11\end{array}$ & $\begin{array}{l}2.4 \\
4.2 \\
5.8 \\
8.0 \\
4.8\end{array}$ & $\begin{array}{l}4.5 \\
1.8 \\
.50 \\
3.7 \\
3.7\end{array}$ & $\begin{array}{l}1.2 \\
.46 \\
7.2 \\
5.1\end{array}$ & $\begin{array}{l}1.6 \\
1.1 \\
1.4 \\
3.1 \\
2.0\end{array}$ & $\begin{array}{l}2.2 \\
3.4 \\
1.1 \\
1.3 \\
1.4\end{array}$ & $\begin{array}{l}4.2 \\
37 \\
20 \\
19 \\
13\end{array}$ & $\begin{array}{l}24 \\
30 \\
16 \\
13 \\
12\end{array}$ \\
\hline $\begin{array}{l}16 \\
17 \\
18 \\
19 \\
20\end{array}$ & $\begin{array}{l}1.7 \\
1.8 \\
1.6 \\
2.0 \\
2.2\end{array}$ & $\begin{array}{l}1.9 \\
2.0 \\
2.4 \\
1.8 \\
1.8\end{array}$ & $\begin{array}{l}2.8 \\
2.9 \\
2.7 \\
2.5 \\
2.8\end{array}$ & $\begin{array}{l}5.5 \\
5.5 \\
6.0 \\
7.0 \\
8.0\end{array}$ & $\begin{array}{l}10 \\
10 \\
10 \\
10 \\
10\end{array}$ & $\begin{array}{l}3.4 \\
3.1 \\
3.1 \\
3.1 \\
3.1\end{array}$ & $\begin{array}{l}3.1 \\
3.4 \\
2.0 \\
1.8 \\
1.6\end{array}$ & $\begin{array}{l}4.4 \\
3.2 \\
2.4 \\
2.0 \\
2.0\end{array}$ & $\begin{array}{l}3.4 \\
4.8 \\
4.5 \\
4.2 \\
3.4\end{array}$ & $\begin{array}{l}1.3 \\
8.0 \\
1.6 \\
2.0 \\
2.2\end{array}$ & $\begin{array}{r}14 \\
191 \\
59 \\
21 \\
19\end{array}$ & $\begin{array}{r}8.8 \\
6.1 \\
5.8 \\
5.4 \\
.6 .5\end{array}$ \\
\hline $\begin{array}{l}21 \\
22 \\
23 \\
24 \\
25\end{array}$ & $\begin{array}{l}2.3 \\
2.2 \\
2.2 \\
2.4 \\
2.3\end{array}$ & $\begin{array}{l}1.7 \\
1.7 \\
1.5 \\
1.5 \\
1.3\end{array}$ & $\begin{array}{l}4.1 \\
5.3 \\
4.5 \\
4.0 \\
4.5\end{array}$ & $\begin{array}{l}9.2 \\
9.0 \\
8.0 \\
8.0 \\
8.5\end{array}$ & $\begin{array}{l}9.2 \\
10^{2} \\
10 \\
11 \\
13\end{array}$ & $\begin{array}{l}2.9 \\
2.9 \\
2.7 \\
2.7 \\
2.4\end{array}$ & $\begin{array}{l}2.7 \\
2.9 \\
2.4 \\
1.4 \\
1.3\end{array}$ & $\begin{array}{l}2.4 \\
2.7 \\
4.8 \\
3.9 \\
3.4\end{array}$ & $\begin{array}{c}2.4 \\
2.7 \\
1.8 \\
.41 \\
.41\end{array}$ & $\begin{array}{l}1.4 \\
1.3 \\
1.1 \\
1.0 \\
2.0\end{array}$ & $\begin{array}{l}71 \\
46 \\
29 \\
27 \\
33\end{array}$ & $\begin{array}{r}11 \\
6.5 \\
7.6 \\
8.0 \\
8.0\end{array}$ \\
\hline $\begin{array}{l}26 \\
27 \\
28 \\
29 \\
30 \\
31\end{array}$ & $\begin{array}{l}2.3 \\
2.5 \\
2.8 \\
2.6 \\
2.1 \\
2.1\end{array}$ & $\begin{array}{l}2.1 \\
3.1 \\
3.7 \\
4.2 \\
4.7 \\
-.-\end{array}$ & $\begin{array}{l}5.0 \\
6.0 \\
7.0 \\
6.0 \\
7.5 \\
8.2\end{array}$ & $\begin{array}{l}9.0 \\
9.6 \\
8.0 \\
6.8 \\
7.2 \\
7.2\end{array}$ & $\begin{array}{c}15 \\
13 \\
11 \\
-\ldots \\
- \\
-.-\end{array}$ & $\begin{array}{l}2.4 \\
2.9 \\
2.9 \\
3.1 \\
3.1 \\
3.1\end{array}$ & $\begin{array}{l}1.6 \\
.74 \\
1.0 \\
1.0 \\
.32 \\
-.00\end{array}$ & $\begin{array}{l}1.8 \\
1.8 \\
1.4 \\
3.7 \\
1.8 \\
1.4\end{array}$ & $\begin{array}{l}.50 \\
.50 \\
.41 \\
.50 \\
.74 \\
. .+\end{array}$ & $\begin{array}{l}14 \\
32 \\
7.5 \\
25 \\
38 \\
11\end{array}$ & $\begin{array}{r}48 \\
169 \\
45 \\
37 \\
35 \\
18\end{array}$ & $\begin{array}{l}7.2 \\
6.5 \\
5.4 \\
6.1 \\
5.8 \\
. . .\end{array}$ \\
\hline $\begin{array}{l}\text { TOTAL } \\
\text { MEAN } \\
\text { MAX } \\
\text { MIN } \\
\text { AC-FT }\end{array}$ & $\begin{array}{r}113.9 \\
3.67 \\
39 \\
1.6 \\
226\end{array}$ & $\begin{array}{r}73.2 \\
2.44 \\
4.7 \\
1.3 \\
145\end{array}$ & $\begin{array}{r}114.9 \\
3.71 \\
8.2 \\
1.8 \\
228\end{array}$ & $\begin{array}{r}224.7 \\
7.25 \\
9.6 \\
5.0 \\
446\end{array}$ & $\begin{array}{r}291.9 \\
10.4 \\
15 \\
6.1 \\
579\end{array}$ & $\begin{array}{r}114.2 \\
3.68 \\
8.0 \\
2.4 \\
227\end{array}$ & $\begin{array}{r}90.76 \\
3.03 \\
6.5 \\
+32 \\
180\end{array}$ & $\begin{array}{r}71.62 \\
2.31 \\
7.3 \\
i 09 \\
i 42\end{array}$ & $\begin{array}{r}52.94 \\
1.76 \\
4.8 \\
.32 \\
105\end{array}$ & $\begin{array}{r}162.87 \\
5.25 \\
38 \\
312 \\
323\end{array}$ & $\begin{array}{r}1035.5 \\
33.4 \\
191 \\
3.9 \\
2050\end{array}$ & $\begin{array}{r}254.3 \\
8.48 \\
30 \\
2.0 \\
504\end{array}$ \\
\hline
\end{tabular}

CAL YR 1981 TOTAL 1469.83 MEAN 4.03 MAX 50 MIN .07 AC-FT 2920 WTR YR 1982 SOTAL 2600.79 MEAN 7.13 MAX 191 MIN .09 AC-FT 5160

NotE.--No gage-helght record Dec. 24 to Jan. 6, Feb, 13 to Mar. 25. 
09386030 LITTLE COLORADO RIVER ABOVE ZION RESERVOIR, NEAR ST. JOHTS. AZ--CONT InUed WATER-QUALITY RECORDS

PERIOD OF RECORD.--1980 to current year.

WATER QUALITY DATA, WATER YEAR OCTOBER 1981 TO SEPTEMBER 1982

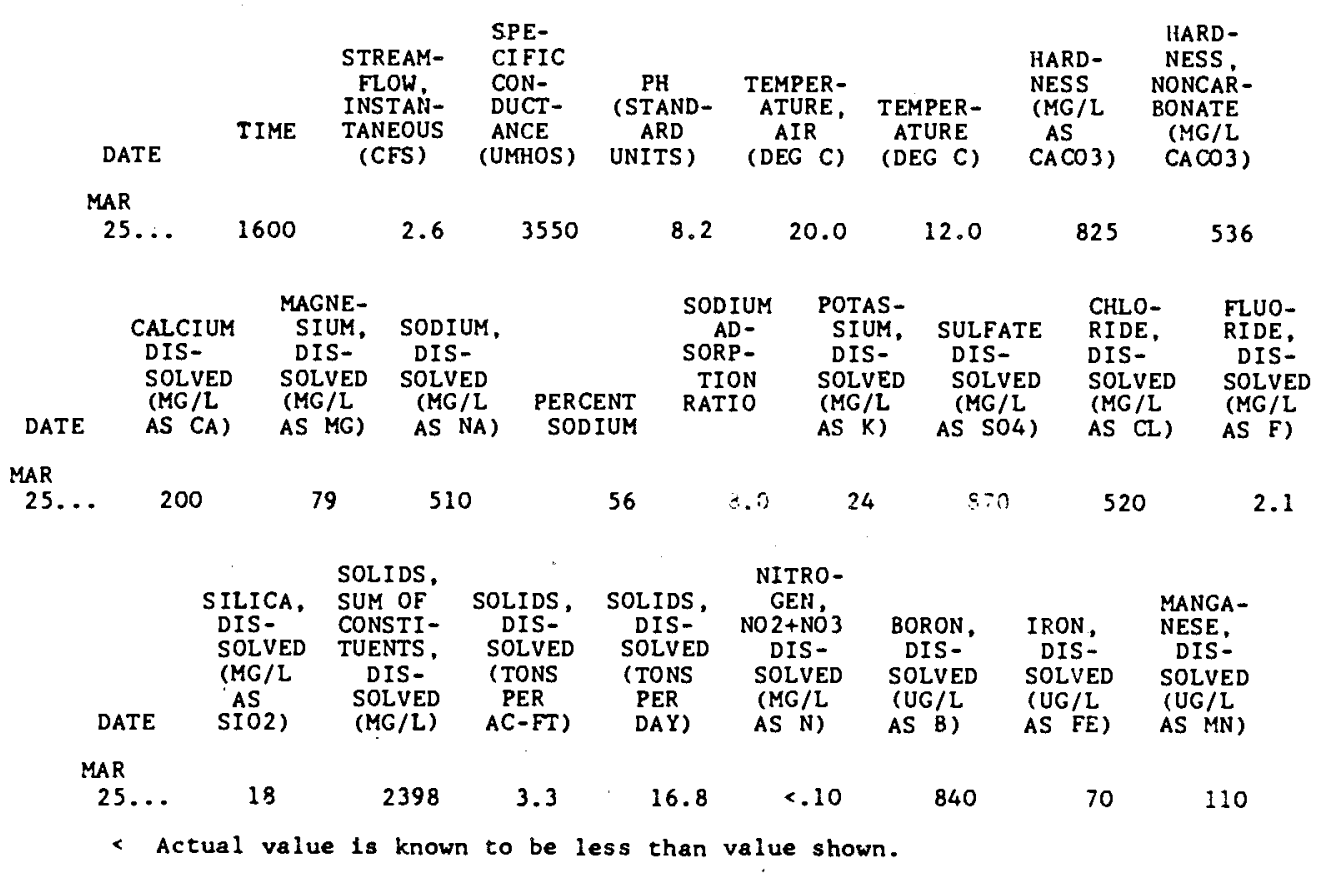




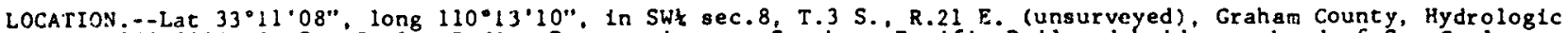
Unit. 15040005 , In San Carlos Indian Reservation, on Southern Pacific Railroad bridge at head of San Carlos Reservolr, $2.0 \mathrm{ml}(3.2 \mathrm{~km})$ west of Calva.

DRAINAGE AREA. $--11,470 \mathrm{~mL}^{2}\left(29.710 \mathrm{~km}^{2}\right)$.

WATFR-DISCHARGE RECORDS

PERIOD OF RECORD.--October 1929 to current year.

GAGF. - Hater-stage recoriter. Datum of gage is $2.517 .29 \mathrm{ft}$ (767.270 m) National Geodetic Vertical Datum of 1929. Prior to Aug. 24 , 1958 , at datum 5.52 ft (1.682 m) lower. Dec. 31, 1962, to Oct. 20, 1972 , at site $530 \mathrm{ft}$ (162 m) downstream at datur $3.65 \mathrm{ft}$ ( $1.113 \mathrm{~m})$ lower. Oct, 20,1972 , to Sept. 30 , 1974 , supplementary gage at bridge on U.S. Highway $70,6 . ? \mathrm{mi}(10.0 \mathrm{~km})$ upstream at datum $2,560.19^{\circ} \mathrm{ft}(780.346 \mathrm{~m}) \mathrm{NGVD}$.

REMARKS.--Records falr except those above $1,000 \mathrm{ft}^{3} / \mathrm{s}\left(24 \mathrm{~m}^{3} / \mathrm{s}\right)$, which are poor. Diversion above station for irrigation of about 69,000 acrea $\left(279 \mathrm{~km}^{2}\right)$, metallurgical creatment of ores, and municipal uses.

AVERAGE DISCHARGE.--53 years, $285 \mathrm{ft}^{3} / \mathrm{s}\left(8.071 \mathrm{~m}^{3} / \mathrm{s}\right), 206.500 \mathrm{acre-ft} / \mathrm{yr}\left(255 \mathrm{hm}^{3} / \mathrm{yr}^{2}\right)$ medlan of yearly mean discharges, $180 \mathrm{ft} / \mathrm{s}\left(5.10 \mathrm{in}^{3} / \mathrm{s}\right), 130,000$ acre-ft/yc $\left(16 \mathrm{~h}^{\mathrm{h}} \mathrm{h} / \mathrm{yr}\right)$.

EXTREMES FOR PERIOD OF RECORD.--Maximum discharge, $100.000 \mathrm{ft} / \mathrm{s}\left(2,830 \mathrm{~m}^{3} / \mathrm{s}\right) \mathrm{dec} .19,1978$, gage height, $15.20 \mathrm{ft}$ $(4.633 \mathrm{~m})$; no flow at times.

EXTREMFs OUTSIDE PERIOD OF RECORD.--Maximum discharge since at least 19l4, probably in excess of 100,000 ft3/s $\left(2.830 \mathrm{~m}^{3} / \mathrm{s}\right) \mathrm{Jan} .20,1916$, determined on basis of peak discharge at stations near Solomon and at kelvin.

EXTREMES FUK CURRENT YEAR. - Maximum discharge, $2.020 \mathrm{ft}^{3 / \mathrm{s}}\left(57.2 \mathrm{~m}^{3} / \mathrm{s}\right)$ Sept. 12 . $0800 \mathrm{hours}$, gage helght. $7.58 \mathrm{ft}$ $(2.310 \mathrm{~m})$, no peaks above base of $3.000 \mathrm{ft}^{3} / \mathrm{s}^{2}\left(85 \mathrm{~m}^{3} / \mathrm{s}\right)$; no flow July $14-17.20-25$.

DISCHAKGF, IN CUBIC FEET PER SECOND, WATER YEAR OCTOBER 1981 TO SEPTEMBER 1982

\begin{tabular}{|c|c|c|c|c|c|c|c|c|c|c|c|c|}
\hline DAY & $O C=$ & nov & DEC & JAII & FF.B & MAR & APR & MAY & Jut: & JUL & AUG & SEP \\
\hline $\begin{array}{l}1 \\
2 \\
3 \\
4 \\
5\end{array}$ & $\begin{array}{r}23 \\
41 \\
189 \\
1090 \\
420\end{array}$ & $\begin{array}{l}80 \\
81 \\
83 \\
83 \\
86\end{array}$ & $\begin{array}{l}133 \\
141 \\
149 \\
152 \\
145\end{array}$ & $\begin{array}{r}66 \\
70 \\
84 \\
97 \\
106\end{array}$ & $\begin{array}{l}168 \\
170 \\
170 \\
161 \\
163\end{array}$ & $\begin{array}{l}623 \\
539 \\
511 \\
462 \\
390\end{array}$ & $\begin{array}{l}315 \\
305 \\
275 \\
249 \\
225\end{array}$ & $\begin{array}{l}121 \\
118 \\
131 \\
170 \\
340\end{array}$ & $\begin{array}{l}48 \\
51 \\
46 \\
39 \\
35\end{array}$ & $\begin{array}{l}8.9 \\
8.1 \\
6.6 \\
5.5 \\
4.4\end{array}$ & $\begin{array}{r}55 \\
159 \\
76 \\
34 \\
25\end{array}$ & $\begin{array}{l}15 \\
15 \\
15 \\
10 \\
10\end{array}$ \\
\hline $\begin{array}{r}6 \\
7 \\
8 \\
9 \\
10\end{array}$ & $\begin{array}{l}275 \\
210 \\
154 \\
137 \\
135\end{array}$ & $\begin{array}{l}84 \\
84 \\
89 \\
91 \\
91\end{array}$ & $\begin{array}{r}135 \\
127 \\
119 \\
104 \\
98\end{array}$ & $\begin{array}{l}110 \\
118 \\
119 \\
123 \\
133\end{array}$ & $\begin{array}{l}161 \\
158 \\
158 \\
161 \\
154\end{array}$ & $\begin{array}{l}410 \\
415 \\
410 \\
350 \\
300\end{array}$ & $\begin{array}{l}191 \\
170 \\
158 \\
161 \\
182\end{array}$ & $\begin{array}{l}469 \\
476 \\
462 \\
441 \\
455\end{array}$ & $\begin{array}{l}33 \\
31 \\
29 \\
28 \\
27\end{array}$ & $\begin{array}{l}4.4 \\
6.2 \\
5.0 \\
3.6 \\
2.5\end{array}$ & $\begin{array}{l}25 \\
20 \\
20 \\
20 \\
18\end{array}$ & $\begin{array}{c}10 \\
10 \\
6.0 \\
10 \\
116\end{array}$ \\
\hline $\begin{array}{l}11 \\
12 \\
13 \\
14 \\
15\end{array}$ & $\begin{array}{r}125 \\
116 \\
102 \\
87 \\
73\end{array}$ & $\begin{array}{l}89 \\
87 \\
87 \\
91 \\
91\end{array}$ & $\begin{array}{l}89 \\
87 \\
84 \\
84 \\
84\end{array}$ & $\begin{array}{l}137 \\
154 \\
227 \\
163 \\
173\end{array}$ & $\begin{array}{l}237 \\
309 \\
614 \\
448 \\
434\end{array}$ & $\begin{array}{l}263 \\
235 \\
242 \\
366 \\
660\end{array}$ & $\begin{array}{l}235 \\
280 \\
270 \\
242 \\
249\end{array}$ & $\begin{array}{l}310 \\
235 \\
204 \\
185 \\
168\end{array}$ & $\begin{array}{l}24 \\
24 \\
23 \\
23 \\
23\end{array}$ & $\begin{array}{l}1.0 \\
.60 \\
.30 \\
.00 \\
.00\end{array}$ & $\begin{array}{l}18 \\
45 \\
97 \\
93 \\
50\end{array}$ & $\begin{array}{r}372 \\
1350 \\
472 \\
235 \\
170\end{array}$ \\
\hline $\begin{array}{l}16 \\
17 \\
19 \\
19 \\
20\end{array}$ & $\begin{array}{l}64 \\
61 \\
59 \\
68 \\
76\end{array}$ & $\begin{array}{l}93 \\
91 \\
93 \\
91 \\
91\end{array}$ & $\begin{array}{l}81 \\
78 \\
72 \\
66 \\
61\end{array}$ & $\begin{array}{l}191 \\
218 \\
214 \\
191 \\
182\end{array}$ & $\begin{array}{l}335 \\
330 \\
320 \\
270 \\
260\end{array}$ & $\begin{array}{r}798 \\
1010 \\
902 \\
798 \\
834\end{array}$ & $\begin{array}{l}275 \\
295 \\
280 \\
263 \\
235\end{array}$ & $\begin{array}{l}149 \\
137 \\
125 \\
116 \\
102\end{array}$ & $\begin{array}{l}22 \\
21 \\
20 \\
18 \\
16\end{array}$ & $\begin{array}{l}.00 \\
.00 \\
.40 \\
.20 \\
.00\end{array}$ & $\begin{array}{l}38 \\
60 \\
60 \\
50 \\
45\end{array}$ & $\begin{array}{r}130 \\
110 \\
100 \\
90 \\
86\end{array}$ \\
\hline $\begin{array}{l}21 \\
22 \\
23 \\
24 \\
25\end{array}$ & $\begin{array}{l}78 \\
79 \\
73 \\
89 \\
78\end{array}$ & $\begin{array}{r}93 \\
100 \\
108 \\
114 \\
112\end{array}$ & $\begin{array}{l}66 \\
69 \\
68 \\
66 \\
70\end{array}$ & $\begin{array}{l}179 \\
179 \\
191 \\
191 \\
191\end{array}$ & $\begin{array}{l}263 \\
280 \\
256 \\
242 \\
266\end{array}$ & $\begin{array}{l}822 \\
740 \\
553 \\
434 \\
370\end{array}$ & $\begin{array}{l}225 \\
221 \\
242 \\
260 \\
232\end{array}$ & $\begin{array}{l}89 \\
83 \\
79 \\
72 \\
64\end{array}$ & $\begin{array}{l}14 \\
13 \\
12 \\
11 \\
9.3\end{array}$ & $\begin{array}{l}.00 \\
.00 \\
.00 \\
.00 \\
.00\end{array}$ & $\begin{array}{r}205 \\
93 \\
53 \\
50 \\
50\end{array}$ & $\begin{array}{r}73 \\
102 \\
98 \\
104 \\
89\end{array}$ \\
\hline $\begin{array}{l}26 \\
27 \\
29 \\
29 \\
30 \\
31\end{array}$ & $\begin{array}{l}80 \\
85 \\
80 \\
80 \\
80 \\
90\end{array}$ & $\begin{array}{l}112 \\
116 \\
116 \\
123 \\
127 \\
\ldots\end{array}$ & $\begin{array}{l}81 \\
83 \\
83 \\
78 \\
70 \\
69\end{array}$ & $\begin{array}{l}168 \\
154 \\
149 \\
154 \\
158 \\
158\end{array}$ & $\begin{array}{l}315 \\
415 \\
587 \\
\ldots- \\
\ldots\end{array}$ & $\begin{array}{l}360 \\
345 \\
300 \\
270 \\
266 \\
300\end{array}$ & $\begin{array}{l}232 \\
194 \\
165 \\
147 \\
135 \\
-\infty\end{array}$ & $\begin{array}{l}57 \\
57 \\
56 \\
52 \\
49 \\
47\end{array}$ & $\begin{array}{l}8.1 \\
6.6 \\
5.2 \\
4.7 \\
6.2 \\
-.-0\end{array}$ & $\begin{array}{l}32 \\
69 \\
24 \\
18 \\
14 \\
21\end{array}$ & $\begin{array}{l}40 \\
40 \\
30 \\
30 \\
20 \\
20\end{array}$ & $\begin{array}{l}79 \\
79 \\
69 \\
57 \\
41 \\
-\end{array}$ \\
\hline $\begin{array}{l}\text { TOTAL } \\
\text { MLAN } \\
\text { MAX } \\
\text { MIN } \\
\text { AC-FT }\end{array}$ & $\begin{array}{r}438 \% \\
141 \\
1090 \\
23 \\
8090\end{array}$ & $\begin{array}{r}2877 \\
95.9 \\
127 \\
80 \\
5710\end{array}$ & $\begin{array}{r}2892 \\
93.3 \\
152 \\
61 \\
5740\end{array}$ & $\begin{array}{r}4758 \\
153 \\
227 \\
66 \\
9440\end{array}$ & $\begin{array}{r}7805 \\
279 \\
614 \\
154 \\
15480\end{array}$ & $\begin{array}{r}15288 \\
493 \\
1010 \\
235 \\
30320\end{array}$ & $\begin{array}{r}6908 \\
230 \\
315 \\
135 \\
13700\end{array}$ & $\begin{array}{r}5619 \\
181 \\
476 \\
47 \\
11150\end{array}$ & $\begin{array}{r}671.1 \\
22.4 \\
51 \\
4.7 \\
1330\end{array}$ & $\begin{array}{r}235.70 \\
7.60 \\
69 \\
.90 \\
468\end{array}$ & $\begin{array}{r}1639 \\
52.9 \\
205 \\
18 \\
3250\end{array}$ & $\begin{array}{r}4123.0 \\
137 \\
1350 \\
6.0 \\
8180\end{array}$ \\
\hline
\end{tabular}

CAL YR 1481 TITAL 31983.50 MEA: \$7.5 MAX 1090 MIII .00 AC-FY 03440 
09466500 GILA RIVER AT CALVA, AZ--Continued

WATER-QUALITY RECORDS

PERIOD OF RECORD.-October 1974 to curtent year.

WATER QUALITY DATA, WATER YEAR OCTOBER 1981 TO SEPTEMBER 1982

\begin{tabular}{|c|c|c|c|c|c|c|c|c|c|c|c|}
\hline DATE & TIME & $\begin{array}{l}\text { STREAM- } \\
\text { FLOW, } \\
\text { INSTAN- } \\
\text { TANEOUS } \\
\text { (CFS) }\end{array}$ & $\begin{array}{l}\text { SPE- } \\
\text { CIFIC } \\
\text { CON- } \\
\text { DUCT- } \\
\text { ANCE } \\
\text { (UMHOS) }\end{array}$ & $\begin{array}{c}\text { PH } \\
\text { (STAND- } \\
\text { ARD } \\
\text { UNITS) }\end{array}$ & $\begin{array}{c}\text { TEMPER - } \\
\text { ATURE, } \\
\text { AIR } \\
\text { (DFG C) }\end{array}$ & $\begin{array}{l}\text { TEMPER- } \\
\text { ATURE } \\
\text { (DEG C) }\end{array}$ & $\begin{array}{l}\text { TUR- } \\
\text { BID- } \\
\text { ITY } \\
\text { (NTU) }\end{array}$ & $\begin{array}{c}\text { OXYGEN, } \\
\text { DIS- } \\
\text { SOIVED } \\
(M G / L)\end{array}$ & $\begin{array}{l}\text { OXYCE:S } \\
\text { DEIIAID, } \\
\text { CHEM- } \\
\text { ICAL } \\
\text { (HI(;H } \\
\text { LFVEL) } \\
\text { (MG/L) }\end{array}$ & $\begin{array}{l}\text { COI.I - } \\
\text { FORM, } \\
\text { FECAL, } \\
0.7 \\
\text { UM-MF } \\
\text { (COLS.' } \\
100 \mathrm{ML} \text { ) }\end{array}$ & $\begin{array}{l}\text { STREP- } \\
\text { TOCOCCI } \\
\text { FECAL. } \\
\text { KF AGAR } \\
\text { (COLS. } \\
\text { PER } \\
100 \mathrm{ML} \text { ) }\end{array}$ \\
\hline $\begin{array}{r}\text { OCT } \\
21 \ldots\end{array}$ & 1100 & 79 & 3050 & 8.2 & 24.0 & 17.0 & 60 & 10.2 & 81 & 160 & 190 \\
\hline $\begin{array}{l}\text { DEC } \\
08 \ldots\end{array}$ & 1400 & 120 & 3400 & 8.3 & 18.0 & 14.0 & 96 & 10.4 & 85 & $\cdots$ & 710 \\
\hline & 0930 & 168 & 2800 & 8.8 & 8.0 & 10.0 & 76 & 10.2 & $\cdots$ & $K 16$ & 600 \\
\hline & 0930 & 191 & 2850 & 8.5 & 21.0 & 15.0 & 56 & 12.0 & 17 & 70 & 270 \\
\hline $\begin{array}{l}\text { JUN } \\
10 \ldots \\
\text { AUG }\end{array}$ & 1230 & 28 & 6200 & 7.8 & 32.0 & 28.0 & 11 & 7.8 & 44 & 50 & 200 \\
\hline $10 \ldots$ & 1300 & 18 & 3300 & 8.3 & 34.6 & 36.0 & 52 & 7.7 & 31 & 400 & 230 \\
\hline DATE & $\begin{array}{l}\text { HARD- } \\
\text { NESS } \\
(M G / L \\
\text { AS } \\
\text { CACO 3) }\end{array}$ & $\begin{array}{c}\text { HARD- } \\
\text { NESS } \\
\text { NONCAR- } \\
\text { BONATE } \\
\text { (MG /L } \\
\text { AS } \\
\text { CACO3) }\end{array}$ & $\begin{array}{l}\text { CALCIUM } \\
\text { DIS- } \\
\text { SOLVED } \\
\text { (MG/L } \\
\text { AS CA) }\end{array}$ & $\begin{array}{l}\text { MACNE- } \\
\text { SIUMA, } \\
\text { DIS- } \\
\text { SOLVED } \\
\text { (MG/L } \\
\text { AS M(;) }\end{array}$ & $\begin{array}{l}\text { SOUTUM, } \\
\text { DIS- } \\
\text { SOLVED } \\
\text { (MG/L } \\
\text { AS NA) }\end{array}$ & $\begin{array}{r}\text { PERCENT } \\
\text { SOIIUM }\end{array}$ & $\begin{array}{l}\text { SODIUM } \\
\text { AD- } \\
\text { SORP- } \\
\text { TIOH } \\
\text { RAIIO }\end{array}$ & $\begin{array}{l}\text { POTAS - } \\
\text { SIU:A, } \\
\text { DIS- } \\
\text { SOLVED } \\
\text { (MG/L } \\
\text { AS K) }\end{array}$ & $\begin{array}{c}\text { ALKA- } \\
\text { LINITY } \\
\text { LAB } \\
(\because G / L \\
\text { AS } \\
\text { CACO } 3)\end{array}$ & $\begin{array}{l}\text { SULFATE } \\
\text { DIS- } \\
\text { SOLVED } \\
\text { (IIG/L } \\
\text { AS SO4) }\end{array}$ & $\begin{array}{l}\text { CHLD- } \\
\text { RIDE, } \\
\text { DIS- } \\
\text { SOLVED } \\
\text { (MC/L } \\
\text { AS CI.) }\end{array}$ \\
\hline OCT & 540 & 296 & 150 & 39 & 490 & 66 & 9.6 & 11 & 240 & 320 & 740 \\
\hline $\begin{array}{l}\text { DEC } \\
08 \ldots\end{array}$ & 540 & 270 & 150 & 40 & 490 & 66 & 9.5 & 9.7 & 270 & 340 & 760 \\
\hline & 440 & 180 & 120 & 32 & 420 & 67 & 9.0 & 9.0 & 260 & 280 & 600 \\
\hline $\begin{array}{l}\text { APR } \\
06 \ldots\end{array}$ & 490 & 234 & 140 & 35 & 430 & 55 & 8.7 & 8.6 & 260 & 280 & 600 \\
\hline $10 \ldots$ & 920 & 697 & 230 & 85 & 1000 & 70 & 15 & 15 & 2.29 & 650 & 1500 \\
\hline $\begin{array}{l}\text { AUG } \\
10 \ldots\end{array}$ & 600 & 435 & 140 & 60 & 860 & 75 & 15 & 14 & 162 & 570 & 1309 \\
\hline DATE & $\begin{array}{l}\text { FLUO- } \\
\text { RIDE, } \\
\text { DIS- } \\
\text { SDLVED } \\
\text { (MG/L } \\
\text { AS F) }\end{array}$ & $\begin{array}{l}\text { SILICA, } \\
\text { DIS- } \\
\text { SOLVF.D } \\
\text { (IIG/L } \\
\text { AS } \\
\text { SIO2) }\end{array}$ & $\begin{array}{l}\text { SOLIDS, } \\
\text { RESIUUE } \\
A=1 B D \\
\text { DEG. C } \\
\text { DIS- } \\
\text { SOLVEO } \\
\text { (MG/L) }\end{array}$ & $\begin{array}{l}\text { SOLIDS, } \\
\text { SUM OF } \\
\text { CONSTI- } \\
\text { TUENTS, } \\
\text { DIS- } \\
\text { SOLVE) } \\
\text { (MG/L) }\end{array}$ & $\begin{array}{c}\text { SOLIDS, } \\
\text { UIS- } \\
\text { SOLVEI) } \\
\text { (TOIS } \\
\text { PER } \\
\text { AC-FT) }\end{array}$ & $\begin{array}{l}\text { SOLIDS, } \\
\text { DIS- } \\
\text { SOLVEI) } \\
\text { (TONS } \\
\text { PER } \\
\text { DAY) }\end{array}$ & $\begin{array}{l}\text { SOILIOS, } \\
\text { RESIOUE } \\
\text { AT lOS } \\
\text { DEG. C. } \\
\text { SUS- } \\
\text { PE:DEO) } \\
\text { (MG/H) }\end{array}$ & $\begin{array}{c}\text { NI TRJ- } \\
\text { (iE: } \\
\text { :O2+1NO3 } \\
\text { TOTAL } \\
\text { (:IG/L } \\
\text { AS NN) }\end{array}$ & $\begin{array}{c}\text { NITRO- } \\
\text { GE:! } \\
\text { :O2+iHO } 3 \\
\text { DIS- } \\
\text { SOLVED } \\
\text { (AG/L } \\
\text { AS HI) }\end{array}$ & $\begin{array}{l}\text { NITRO- } \\
\text { CEN, } \\
\text { ALMONIA } \\
\text { DIS- } \\
\text { SOLVED } \\
\text { (MG/L } \\
\text { AS (i) }\end{array}$ & $\begin{array}{l}\text { NITRO- } \\
\text { CEN, } \\
\text { AIMOHIA } \\
\text { DIS- } \\
\text { SOLVED } \\
\text { (MG/L } \\
\text { AS NH4) }\end{array}$ \\
\hline $\begin{array}{l}\text { OCT } \\
21 \ldots\end{array}$ & 1.6 & 36 & 1920 & 1930 & 2.6 & 410 & 125 & .71 & .65 & $<.060$ & .08 \\
\hline $\begin{array}{l}\mathrm{DEC} \\
08 \ldots\end{array}$ & 1.5 & 38 & 2760 & 1990 & 3.8 & 894 & $25 \%$ & 2.1 & 1.1 & .070 & .09 \\
\hline $\begin{array}{l}F E B \\
10 \ldots \\
A P R\end{array}$ & 1.7 & 36 & 1700 & 1660 & 2.3 & 771 & 172 & $i .0$ & .98 & $<.060$ & .08 \\
\hline JUN... & .50 & 36 & 1710 & 1690 & 2.3 & 882 & 218 & 1.3 & 1.3 & .070 & .09 \\
\hline AUG & .20 & 32 & 3560 & 3650 & 4.8 & 266 & 44 & .40 & .43 & .100 & .13 \\
\hline $10 \ldots$ & 1.7 & 32 & 3060 & 3080 & $4 . ?$ & 147 & -- & .26 & $.1 ?$ & .090 & .12 \\
\hline
\end{tabular}


WATER QUALITY DATA, WATER YEAR OCTOBER 1981 TO SEPTEMBER 1982

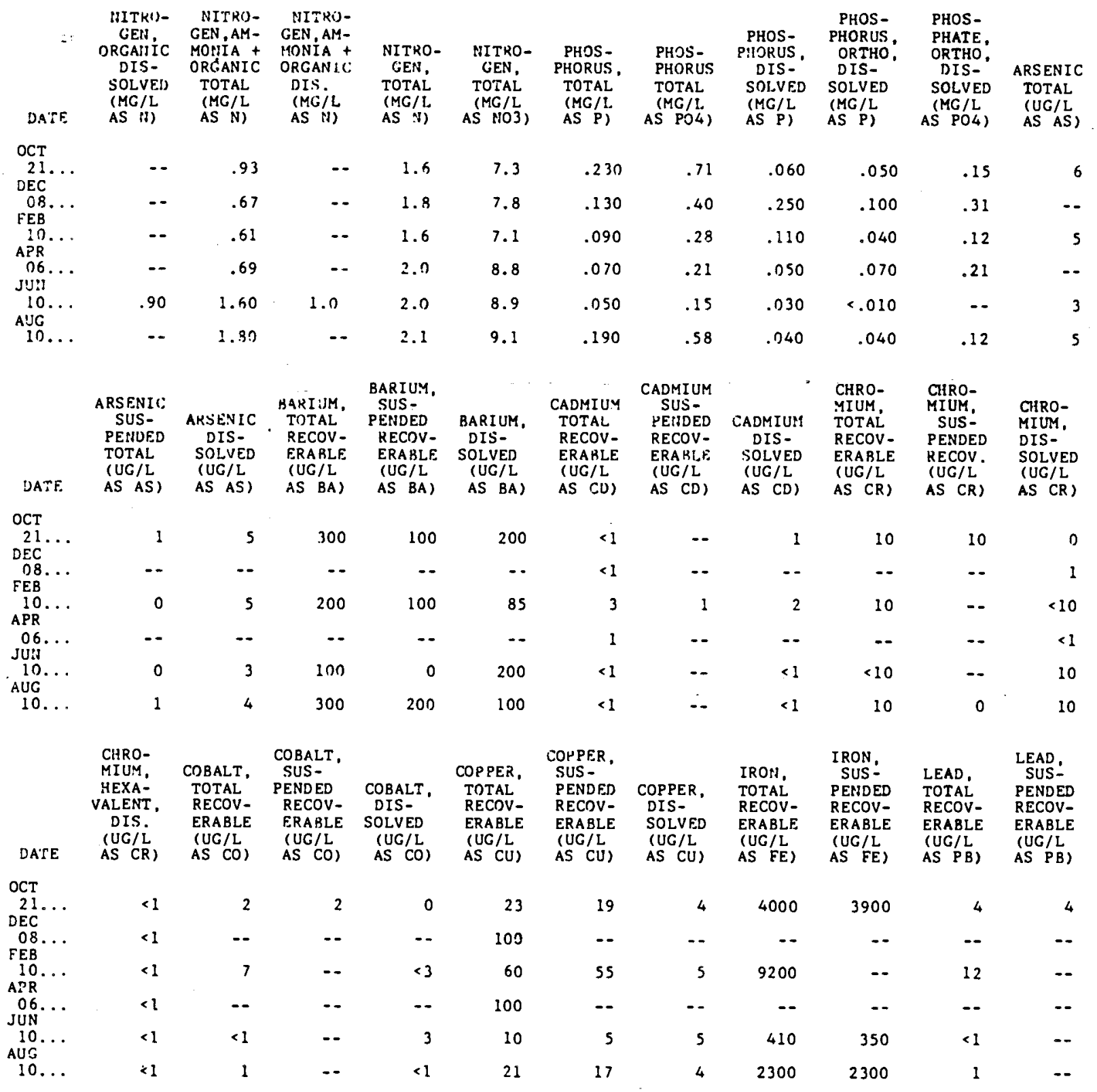

\footnotetext{
- Actual value is known to be less than value shown.
} 
09466500 CIILA RIVER AT CAL.VA, AZ--Continued

WATEK QUALITY DATA, WATER YEAR OCTOBTE 1981 TO SFPTF:IRI:K 1982

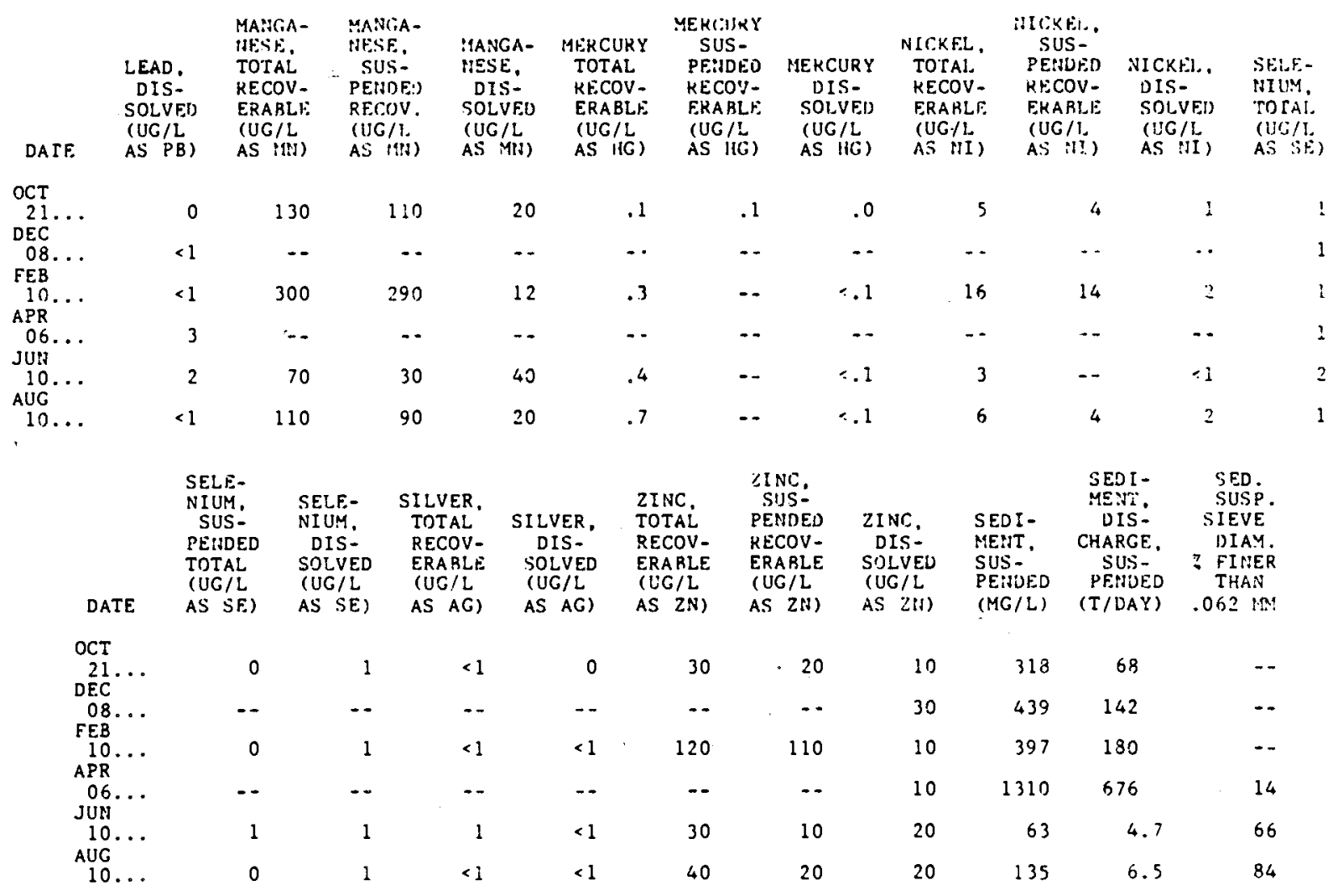

- Actual value is known to be less than value shown. 
LOCATION. - Lat $33^{\circ} 34^{\prime} 23^{\prime \prime}$, long $110^{\circ} 54^{\circ} 02^{\prime \prime}$, in NEtwWkSEt sec.26, T.3 N., R.14 E.. Gila County, Hydrologic Unit 15060103 , In Tonto National Forest, on right bank $20 \mathrm{ft}$ (6.I m) upstream from Inopiration Dam, $3.8 \mathrm{mi}$ (6.1 $\mathrm{km}$ ) upstream from mouth, and $14 \mathrm{mi}(22.5 \mathrm{~km})$ northeast of the town of Globe.

DRAINAGE AREA.--195 $\mathrm{mi}^{2}\left(505 \mathrm{~km}^{2}\right)$.

WATER-DISCHARGE RECORDS

PERIOD OF RECORD.--July 24,1980 to current year.

GAGE.--Water-stage recorder. Altitude of gage 13 about $2,800 \mathrm{ft}$ ( $853 \mathrm{~m}$ ) from topographic map.

REMARKS. - -Records poor.

EXTREMES FOR PERIOD OF RECORD.--Maximum discharge, 2,920 $\mathrm{ft}^{3} / \mathrm{s}\left(82.7 \mathrm{~m}^{3} / \mathrm{s}\right.$ ) July 9 , 1981 (from weather records), gage helght, $5.05 \mathrm{ft}(1.539 \mathrm{~m})$, from high-water mark by the gage; minimum da11y, $1.5 \mathrm{ft}^{3 / \mathrm{s}}\left(0.042 \mathrm{~m}^{3} / \mathrm{s}\right)$ Mar. $10-14 ; 1981$.

EXTREMES FOR CURRENT YEAR.--Maximum discharge (*) and peak discharges above base of $200 \mathrm{ft} / \mathrm{s}(5.66 \mathrm{~m} / \mathrm{s})$ :

\begin{tabular}{|c|c|c|c|c|c|c|c|c|c|c|c|c|}
\hline Date & \multirow{2}{*}{$\begin{array}{c}\text { Time } \\
\text { unknown } \\
1100 \\
1030 \\
0930\end{array}$} & \multicolumn{2}{|c|}{$\begin{array}{c}\text { Discharge } \\
\left(\mathrm{f} \mathrm{t}^{3 / \mathrm{s}}\right)\left(\mathrm{m}^{3} / \mathrm{s}\right)\end{array}$} & \multicolumn{2}{|c|}{$\begin{array}{l}\text { Gage height } \\
\text { (ft) (m) }\end{array}$} & \multicolumn{2}{|c|}{ Date } & \multirow{2}{*}{$\begin{array}{l}\text { Time } \\
1930 \\
2400 \\
0100 \\
1600\end{array}$} & \multicolumn{2}{|c|}{$\begin{array}{c}\text { Discharge } \\
\left(\mathrm{ft}^{3 / \mathrm{s}}\right)\left(\mathrm{m}^{3} / \mathrm{s}\right)\end{array}$} & \multicolumn{2}{|c|}{$\underset{(\mathrm{ft})}{\text { Gage helght }}(\mathrm{m})$} \\
\hline $\begin{array}{ll}\text { Oct. } & 3 \\
\text { Feb. I I } \\
\text { Mar. I } 3 \\
\text { Mar. I }\end{array}$ & & $\begin{array}{r}1.430 \\
277 \\
596 \\
224\end{array}$ & $\begin{array}{c}40.5 \\
7.84 \\
16.9 \\
6.34\end{array}$ & $\begin{array}{l}3.40 \\
1.65 \\
2.21 \\
1.55\end{array}$ & $\begin{array}{l}1.036 \\
0.503 \\
0.674 \\
0.472\end{array}$ & $\begin{array}{l}\text { July } \\
\text { Aug. } \\
\text { Aug. } \\
\text { Sept. }\end{array}$ & $\begin{array}{l}22 \\
18 \\
23 \\
11\end{array}$ & & $\begin{array}{r}1,080 \\
1,010 \\
885 \\
* 2,050\end{array}$ & $\begin{array}{l}29.5 \\
28.6 \\
25.1 \\
58.1\end{array}$ & $\begin{array}{l}2.89 \\
2.85 \\
2.67 \\
4.11\end{array}$ & $\begin{array}{l}0.881 \\
0.869 \\
0.814 \\
1.253\end{array}$ \\
\hline
\end{tabular}

Minimum daily, $4.9 \mathrm{ft}^{3} / \mathrm{s}\left(0.139 \mathrm{~m}^{3} / \mathrm{s}\right) \mathrm{July} 28$.

REVISIONS.--Revised daily discharges, In cubic feet per second, for the I98I water year, are given below. These figures supersede those published in the report for 1981.

DISCHARGE, IN CUBIC FEET PER SECOND, WATER YEAR OCTOBER 1980 TO SEPTEMBER 1981 MEAN VALUES

\begin{tabular}{|c|c|c|c|c|c|c|c|c|c|c|c|c|}
\hline DAY & OCT & NOV & DEC & JAN & FEB & MAR & APR & MAY & JUN & JUL & AUG & SEP \\
\hline $\begin{array}{l}1 \\
2 \\
3 \\
4 \\
5\end{array}$ & $\begin{array}{l}12 \\
11 \\
10 \\
10 \\
10\end{array}$ & $\begin{array}{l}10 \\
10 \\
10 \\
10 \\
10\end{array}$ & $\begin{array}{l}8.5 \\
8.5 \\
8.5 \\
8.5 \\
8.5\end{array}$ & $\begin{array}{l}9.0 \\
9.0 \\
9.0 \\
9.0 \\
9.0\end{array}$ & $\begin{array}{l}8.0 \\
8.0 \\
8.0 \\
8.0 \\
8.0\end{array}$ & $\begin{array}{l}9.5 \\
9.5 \\
9.5 \\
9.5 \\
9.5\end{array}$ & $\begin{array}{l}10 \\
10 \\
10 \\
10 \\
10\end{array}$ & $\begin{array}{l}7.9 \\
7.9 \\
7.9 \\
7.9 \\
7.8\end{array}$ & $\begin{array}{l}7.0 \\
7.0 \\
7.0 \\
7.0 \\
6.5\end{array}$ & $\begin{array}{l}4.5 \\
4.5 \\
4.5 \\
4.5 \\
4.5\end{array}$ & $\begin{array}{l}5.5 \\
5.5 \\
5.5 \\
5.5 \\
5.5\end{array}$ & $\begin{array}{l}5.0 \\
5.0 \\
5.0 \\
5.0 \\
5.0\end{array}$ \\
\hline $\begin{array}{r}6 \\
7 \\
8 \\
9 \\
10\end{array}$ & $\begin{array}{l}10 \\
10 \\
10 \\
10 \\
10\end{array}$ & $\begin{array}{l}9.5 \\
9.5 \\
9.5 \\
8.5 \\
9.5\end{array}$ & $\begin{array}{l}8.5 \\
8.5 \\
8.5 \\
8.5 \\
8.5\end{array}$ & $\begin{array}{l}9.0 \\
9.0 \\
9.0 \\
9.0 \\
9.0\end{array}$ & $\begin{array}{l}8.0 \\
8.5 \\
8.5 \\
8.5 \\
8.5\end{array}$ & $\begin{array}{l}9.5 \\
9.5 \\
9.5 \\
9.5 \\
9.5\end{array}$ & $\begin{array}{l}9.5 \\
9.5 \\
9.5 \\
9.5 \\
9.5\end{array}$ & $\begin{array}{l}7.8 \\
7.8 \\
7.8 \\
7.7 \\
7.7\end{array}$ & $\begin{array}{l}6.5 \\
6.5 \\
6.5 \\
6.0 \\
6.0\end{array}$ & $\begin{array}{r}4.5 \\
4.5 \\
4.5 \\
340 \\
40\end{array}$ & $\begin{array}{l}5.5 \\
5.5 \\
5.5 \\
5.5 \\
5.7\end{array}$ & $\begin{array}{l}5.0 \\
5.0 \\
5.0 \\
5.0 \\
5.0\end{array}$ \\
\hline $\begin{array}{l}11 \\
12 \\
13 \\
14 \\
15\end{array}$ & $\begin{array}{l}10 \\
10 \\
10 \\
10 \\
10\end{array}$ & $\begin{array}{l}9.5 \\
9.5 \\
9.5 \\
9.5 \\
9.5\end{array}$ & $\begin{array}{l}8.5 \\
8.5 \\
8.5 \\
8.5 \\
8.5\end{array}$ & $\begin{array}{l}8.5 \\
8.5 \\
8.5 \\
8.5 \\
8.5\end{array}$ & $\begin{array}{l}8.5 \\
8.5 \\
9.0 \\
9.0 \\
9.0\end{array}$ & $\begin{array}{l}10 \\
10 \\
10 \\
10 \\
10\end{array}$ & $\begin{array}{l}9.0 \\
9.0 \\
9.0 \\
9.0 \\
9.0\end{array}$ & $\begin{array}{l}7.7 \\
7.7 \\
7.6 \\
7.6 \\
7.6\end{array}$ & $\begin{array}{l}6.0 \\
6.0 \\
5.5 \\
5.5 \\
5.5\end{array}$ & $\begin{array}{l}5.5 \\
5.5 \\
5.5 \\
5.5 \\
5.5\end{array}$ & $\begin{array}{l}6.0 \\
6.0 \\
6.0 \\
6.0 \\
6.0\end{array}$ & $\begin{array}{l}5.0 \\
5.0 \\
5.0 \\
5.0 \\
5.0\end{array}$ \\
\hline $\begin{array}{l}16 \\
17 \\
18 \\
19 \\
20\end{array}$ & $\begin{array}{l}10 \\
10 \\
10 \\
10 \\
10\end{array}$ & $\begin{array}{l}9.0 \\
9.0 \\
9.0 \\
9.0 \\
9.0\end{array}$ & $\begin{array}{l}8.5 \\
8.5 \\
8.5 \\
8.5 \\
8.5\end{array}$ & $\begin{array}{l}8.5 \\
8.5 \\
8.5 \\
8.5 \\
8.5\end{array}$ & $\begin{array}{l}9.0 \\
9.0 \\
9.0 \\
9.5 \\
9.5\end{array}$ & $\begin{array}{l}10 \\
10 \\
10 \\
10 \\
10\end{array}$ & $\begin{array}{l}8.5 \\
8.5 \\
8.5 \\
8.5 \\
8.5\end{array}$ & $\begin{array}{l}7.6 \\
7.5 \\
7.5 \\
7.5 \\
7.5\end{array}$ & $\begin{array}{l}5.5 \\
5.0 \\
5.0 \\
5.0 \\
5.0\end{array}$ & $\begin{array}{l}5.5 \\
5.5 \\
5.5 \\
5.5 \\
5.5\end{array}$ & $\begin{array}{r}6.0 \\
6.0 \\
6.0 \\
11 \\
6.0\end{array}$ & $\begin{array}{l}5.0 \\
5.0 \\
5.0 \\
5.0 \\
5.0\end{array}$ \\
\hline $\begin{array}{l}21 \\
22 \\
23 \\
24 \\
25\end{array}$ & $\begin{array}{l}10 \\
10 \\
10 \\
10 \\
10\end{array}$ & $\begin{array}{l}9.0 \\
9.0 \\
9.0 \\
9.0 \\
8.5\end{array}$ & $\begin{array}{l}8.5 \\
8.5 \\
8.2 \\
8.5 \\
8.5\end{array}$ & $\begin{array}{l}8.0 \\
8.0 \\
8.0 \\
8.0 \\
8.0\end{array}$ & $\begin{array}{l}9.5 \\
9.5 \\
9.5 \\
9.5 \\
9.6\end{array}$ & $\begin{array}{l}10 \\
10 \\
10 \\
10 \\
10\end{array}$ & $\begin{array}{l}8.0 \\
8.0 \\
8.0 \\
8.0 \\
8.0\end{array}$ & $\begin{array}{l}7.4 \\
7.4 \\
7.4 \\
7.3 \\
7.3\end{array}$ & $\begin{array}{l}4.5 \\
4.5 \\
4.5 \\
4.0 \\
4.0\end{array}$ & $\begin{array}{l}5.5 \\
5.5 \\
5.5 \\
5.5 \\
5.5\end{array}$ & $\begin{array}{l}6.0 \\
6.0 \\
5.5 \\
5.5 \\
5.5\end{array}$ & $\begin{array}{r}5.0 \\
25 \\
8.0 \\
7.0 \\
6.8\end{array}$ \\
\hline $\begin{array}{l}26 \\
27 \\
28 \\
29 \\
30 \\
31\end{array}$ & $\begin{array}{l}10 \\
10 \\
10 \\
10 \\
10 \\
10\end{array}$ & $\begin{array}{l}8.5 \\
8.5 \\
8.5 \\
8.5 \\
8.5 \\
-.--\end{array}$ & $\begin{array}{l}9.0 \\
9.0 \\
9.0 \\
9.2 \\
9.0 \\
9.0\end{array}$ & $\begin{array}{l}8.0 \\
8.0 \\
8.0 \\
8.0 \\
8.0 \\
8.0\end{array}$ & $\begin{array}{l}9.5 \\
9.5 \\
9.5 \\
--- \\
--- \\
---\end{array}$ & $\begin{array}{l}10 \\
10 \\
10 \\
10 \\
10 \\
10\end{array}$ & $\begin{array}{l}8.0 \\
8.0 \\
8.0 \\
7.9 \\
7.9 \\
-.-\end{array}$ & $\begin{array}{l}7.3 \\
7.2 \\
7.0 \\
7.0 \\
7.0 \\
7.0\end{array}$ & $\begin{array}{l}4.0 \\
4.5 \\
4.5 \\
4.5 \\
4.5 \\
. .-\end{array}$ & $\begin{array}{l}5.5 \\
5.5 \\
5.5 \\
5.5 \\
5.5 \\
5.5\end{array}$ & $\begin{array}{l}5.0 \\
5.0 \\
5.0 \\
5.0 \\
5.0 \\
8.1\end{array}$ & $\begin{array}{l}7.0 \\
7.0 \\
7.0 \\
7.0 \\
7.0 \\
-. .\end{array}$ \\
\hline $\begin{array}{l}\text { TOTAL } \\
\text { MEAN } \\
\text { MAX } \\
\text { MIN } \\
\text { AC-FI }\end{array}$ & $\begin{array}{r}313 \\
10.1 \\
12 \\
10 \\
621\end{array}$ & $\begin{array}{r}276.0 \\
9.20 \\
10 \\
8.5 \\
547\end{array}$ & $\begin{array}{r}266.4 \\
8.59 \\
9.2 \\
8.2 \\
528\end{array}$ & $\begin{array}{r}263.0 \\
8.48 \\
9.0 \\
8.0 \\
522\end{array}$ & $\begin{array}{r}248.1 \\
8.86 \\
9.6 \\
8.0 \\
492\end{array}$ & $\begin{array}{r}305.0 \\
9.84 \\
10 \\
9.5 \\
605\end{array}$ & $\begin{array}{r}264.8 \\
8.83 \\
10 \\
7.9 \\
525\end{array}$ & $\begin{array}{r}233.3 \\
7.53 \\
7.9 \\
7.0 \\
463\end{array}$ & $\begin{array}{r}163.5 \\
5.45 \\
7.0 \\
4.0 \\
324\end{array}$ & $\begin{array}{r}531.5 \\
17.1 \\
340 \\
4.5 \\
1050\end{array}$ & $\begin{array}{r}181.8 \\
5.86 \\
11 \\
5.0 \\
361\end{array}$ & $\begin{array}{r}186.8 \\
6.23 \\
25 \\
5.0 \\
371\end{array}$ \\
\hline
\end{tabular}

WTR YK 1981 TOTAL 3233.2 MFAN 8.86 MAX $340 \quad$ MIN $4.0 \quad$ AC-FT 6410 
09498400 PINAL CREEK AT INSYIRATION DAM ISEAR GLOBE. AZ--Continued DISCHARGE, IN CUBIC FEET PEK SECOND, WATER YEAK OCTOBER 1981 TO SEPTEMBER 1982

\begin{tabular}{|c|c|c|c|c|c|c|c|c|c|c|c|c|}
\hline DAY & OCT & Nov & DEC & JAN & FEB & MAR & APR & MAY & JUN & JUL & AUG & SEP \\
\hline $\begin{array}{l}1 \\
2 \\
3 \\
4 \\
5\end{array}$ & $\begin{array}{l}7.0 \\
7.0 \\
40 \\
10 \\
8.0\end{array}$ & $\begin{array}{l}8.3 \\
8.4 \\
8.4 \\
8.4 \\
8.4\end{array}$ & $\begin{array}{l}8.8 \\
8.8 \\
8.8 \\
8.8 \\
8.8\end{array}$ & $\begin{array}{l}9.0 \\
9.0 \\
9.0 \\
9.0 \\
9.0\end{array}$ & $\begin{array}{l}6.3 \\
6.5 \\
6.5 \\
6.5 \\
6.5\end{array}$ & $\begin{array}{l}9.0 \\
9.0 \\
9.0 \\
9.0 \\
9.0\end{array}$ & $\begin{array}{l}10 \\
10 \\
10 \\
10 \\
10\end{array}$ & $\begin{array}{l}9.5 \\
9.5 \\
9.5 \\
9.5 \\
9.5\end{array}$ & $\begin{array}{l}5.5 \\
5.0 \\
5.0 \\
5.0 \\
5.0\end{array}$ & $\begin{array}{l}5.0 \\
5.0 \\
5.0 \\
5.0 \\
5.0\end{array}$ & $\begin{array}{l}5.0 \\
5.0 \\
5.0 \\
5.0 \\
5.0\end{array}$ & $\begin{array}{l}6.0 \\
6.0 \\
6.0 \\
6.0 \\
6.0\end{array}$ \\
\hline $\begin{array}{r}6 \\
7 \\
8 \\
9 \\
10\end{array}$ & $\begin{array}{l}8.0 \\
8.0 \\
8.0 \\
8.0 \\
8.0\end{array}$ & $\begin{array}{l}8.5 \\
8.5 \\
8.5 \\
8.5 \\
8.6\end{array}$ & $\begin{array}{l}8.8 \\
8.8 \\
8.8 \\
8.8 \\
8.8\end{array}$ & $\begin{array}{l}8.5 \\
8.5 \\
8.5 \\
8.5 \\
8.5\end{array}$ & $\begin{array}{l}7.0 \\
8.0 \\
9.0 \\
10 \\
16\end{array}$ & $\begin{array}{l}9.0 \\
9.0 \\
9.0 \\
9.0 \\
9.0\end{array}$ & $\begin{array}{l}10 \\
10 \\
10 \\
10 \\
10\end{array}$ & $\begin{array}{l}9.0 \\
9.0 \\
9.0 \\
9.0 \\
9.0\end{array}$ & $\begin{array}{l}5.0 \\
5.0 \\
5.0 \\
5.0 \\
5.0\end{array}$ & $\begin{array}{l}5.0 \\
5.0 \\
5.0 \\
5.0 \\
5.0\end{array}$ & $\begin{array}{l}5.0 \\
5.0 \\
5.0 \\
5.0 \\
5.5\end{array}$ & $\begin{array}{l}6.0 \\
6.0 \\
6.0 \\
6.0 \\
6.0\end{array}$ \\
\hline $\begin{array}{l}11 \\
12 \\
13 \\
14 \\
15\end{array}$ & $\begin{array}{l}8.0 \\
8.0 \\
8.0 \\
8.0 \\
8.0\end{array}$ & $\begin{array}{l}8.6 \\
8.6 \\
8.6 \\
8.7 \\
8.7\end{array}$ & $\begin{array}{l}8.9 \\
8.9 \\
8.9 \\
8.9 \\
8.9\end{array}$ & $\begin{array}{l}8.0 \\
8.0 \\
8.0 \\
8.0 \\
8.0\end{array}$ & $\begin{array}{r}69 \\
16 \\
9.0 \\
9.0 \\
9.0\end{array}$ & $\begin{array}{r}9.0 \\
9.0 \\
80 \\
9.0 \\
80\end{array}$ & $\begin{array}{l}10 \\
10 \\
10 \\
10 \\
10\end{array}$ & $\begin{array}{l}8.5 \\
8.5 \\
8.5 \\
8.5 \\
8.5\end{array}$ & $\begin{array}{l}5.0 \\
5.0 \\
5.0 \\
5.0 \\
5.0\end{array}$ & $\begin{array}{l}5.0 \\
5.0 \\
5.0 \\
5.0 \\
5.0\end{array}$ & $\begin{array}{l}5.5 \\
5.5 \\
5.5 \\
5.5 \\
5.5\end{array}$ & $\begin{array}{r}36 \\
6.0 \\
6.0 \\
6.0 \\
6.0\end{array}$ \\
\hline $\begin{array}{l}16 \\
17 \\
18 \\
19 \\
20\end{array}$ & $\begin{array}{l}8.0 \\
8.0 \\
8.0 \\
8.0 \\
8.0\end{array}$ & $\begin{array}{l}8.7 \\
8.7 \\
8.7 \\
8.7 \\
8.7\end{array}$ & $\begin{array}{l}8.9 \\
8.9 \\
8.9 \\
8.9 \\
8.9\end{array}$ & $\begin{array}{l}7.5 \\
7.5 \\
7.5 \\
7.5 \\
7.5\end{array}$ & $\begin{array}{l}9.0 \\
9.0 \\
9.0 \\
9.0 \\
9.0\end{array}$ & $\begin{array}{l}24 \\
10 \\
10 \\
10 \\
10\end{array}$ & $\begin{array}{l}10 \\
10 \\
10 \\
10 \\
10\end{array}$ & $\begin{array}{l}8.0 \\
8.0 \\
8.0 \\
8.0 \\
8.0\end{array}$ & $\begin{array}{l}5.0 \\
5.0 \\
5.0 \\
5.0 \\
5.0\end{array}$ & $\begin{array}{l}5.0 \\
5.0 \\
5.0 \\
5.0 \\
5.0\end{array}$ & $\begin{array}{r}5.5 \\
5.5 \\
6.5 \\
16 \\
6.0\end{array}$ & $\begin{array}{l}6.0 \\
6.0 \\
6.0 \\
6.0 \\
6.0\end{array}$ \\
\hline $\begin{array}{l}21 \\
22 \\
23 \\
24 \\
25\end{array}$ & $\begin{array}{l}8.0 \\
8.0 \\
8.0 \\
8.0 \\
8.0\end{array}$ & $\begin{array}{l}8.7 \\
8.7 \\
8.7 \\
8.7 \\
8.7\end{array}$ & $\begin{array}{l}9.0 \\
9.0 \\
9.0 \\
9.0 \\
9.0\end{array}$ & $\begin{array}{l}7.0 \\
7.0 \\
7.0 \\
7.0 \\
7.0\end{array}$ & $\begin{array}{l}9.0 \\
9.0 \\
9.0 \\
9.0 \\
9.0\end{array}$ & $\begin{array}{l}10 \\
10 \\
10 \\
10 \\
10\end{array}$ & $\begin{array}{l}10 \\
10 \\
9.8 \\
9.5 \\
9.5\end{array}$ & $\begin{array}{l}7.5 \\
7.5 \\
7.5 \\
7.5 \\
7.5\end{array}$ & $\begin{array}{l}5.0 \\
5.0 \\
5.0 \\
5.0 \\
5.0\end{array}$ & $\begin{array}{l}5.0 \\
9.5 \\
7.5 \\
5.0 \\
5.0\end{array}$ & $\begin{array}{r}6.0 \\
6.0 \\
39 \\
6.0 \\
6.0\end{array}$ & $\begin{array}{l}6.5 \\
6.5 \\
6.5 \\
6.5 \\
6.5\end{array}$ \\
\hline $\begin{array}{l}26 \\
27 \\
28 \\
29 \\
30 \\
31\end{array}$ & $\begin{array}{l}8.0 \\
8.0 \\
8.2 \\
8.2 \\
8.2 \\
8.2\end{array}$ & $\begin{array}{l}8.7 \\
8.7 \\
8.7 \\
8.7 \\
8.7 \\
---\end{array}$ & $\begin{array}{l}9.0 \\
9.0 \\
9.0 \\
9.0 \\
9.0 \\
9.0\end{array}$ & $\begin{array}{l}6.5 \\
6.5 \\
6.5 \\
6.5 \\
6.5 \\
6.5\end{array}$ & $\begin{array}{l}9.0 \\
9.0 \\
9.0 \\
-\ldots \\
\cdots \\
\cdots\end{array}$ & $\begin{array}{l}10 \\
10 \\
10 \\
10 \\
10 \\
10\end{array}$ & $\begin{array}{l}9.5 \\
9.5 \\
9.5 \\
9.5 \\
9.5 \\
.--\end{array}$ & $\begin{array}{l}7.5 \\
7.6 \\
7.5 \\
7.0 \\
6.5 \\
6.0\end{array}$ & $\begin{array}{l}5.0 \\
5.0 \\
5.0 \\
5.0 \\
5.0 \\
-.-\end{array}$ & $\begin{array}{l}5.0 \\
5.0 \\
4.9 \\
5.0 \\
6.0 \\
5.0\end{array}$ & $\begin{array}{l}6.0 \\
6.0 \\
6.0 \\
6.0 \\
6.0 \\
5.0\end{array}$ & $\begin{array}{l}7.0 \\
7.0 \\
7.0 \\
7.0 \\
7.0 \\
-.-\end{array}$ \\
\hline $\begin{array}{l}\text { TOTAL } \\
\text { l-EAN } \\
\text { MAX } \\
\text { MIN } \\
\text { AC-FT }\end{array}$ & $\begin{array}{r}280.8 \\
9.06 \\
40 \\
7.0 \\
557\end{array}$ & $\begin{array}{r}258.2 \\
8.61 \\
8.7 \\
8.3 \\
512\end{array}$ & $\begin{array}{r}276.0 \\
8.90 \\
9.0 \\
8.8 \\
547\end{array}$ & $\begin{array}{r}239.0 \\
7.71 \\
9.0 \\
5.5 \\
474\end{array}$ & $\begin{array}{r}311.3 \\
11.1 \\
69 \\
6.3 \\
517\end{array}$ & $\begin{array}{r}451.0 \\
14.5 \\
80 \\
9.0 \\
895\end{array}$ & $\begin{array}{r}296.3 \\
9.88 \\
10 \\
9.5 \\
588\end{array}$ & $\begin{array}{r}254.6 \\
8.21 \\
9.5 \\
6.0 \\
505\end{array}$ & $\begin{array}{r}150.5 \\
5.02 \\
5.5 \\
5.0 \\
299\end{array}$ & $\begin{array}{r}162.9 \\
5.25 \\
9.5 \\
4.9 \\
323\end{array}$ & $\begin{array}{r}216.5 \\
6.98 \\
39 \\
5.0 \\
429\end{array}$ & $\begin{array}{r}217.5 \\
7.25 \\
36 \\
6.0 \\
431\end{array}$ \\
\hline
\end{tabular}

CAL YR 1981 TOTAL 3192.8 MEAil $8.75 \quad$ MAX 340 MIN 4.0 AC-FT 6330 WTR YR 1982 TOTAL 3114.6 MEAN 3.53 MAX 80 MIH 4.9 AC-FT 6180 
PERIOU OF RECORD.--November 1979 to curcent year.

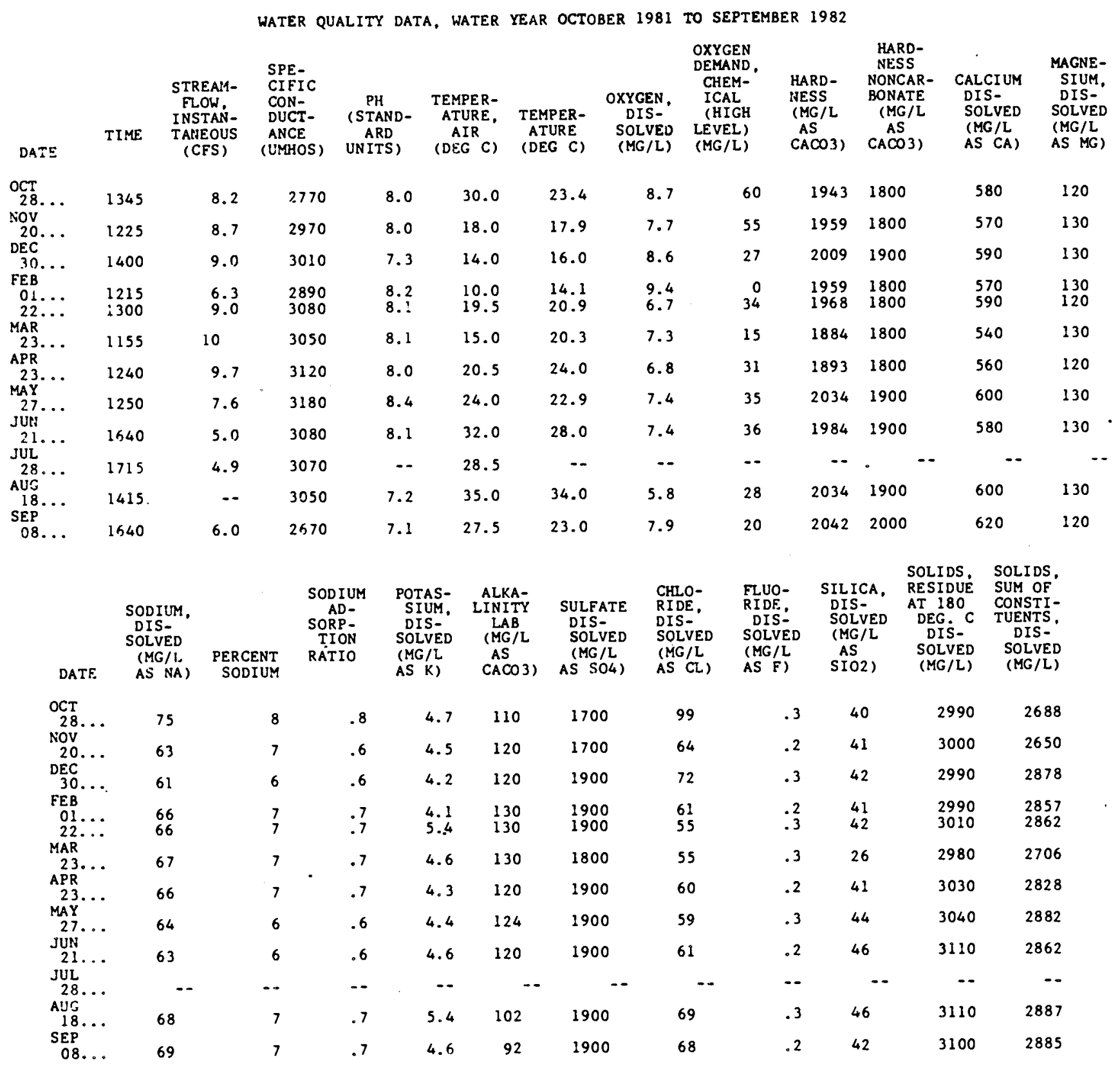


09498400 PINAL CREEK AI IMSPIRATION DAM NEAR GI.OAF. AZ--Continued

WATER QUALITY DATA, WATER YEAR OCTOBER 1981 TO SEPTEMBER 1982

\begin{tabular}{|c|c|c|c|c|c|c|c|c|c|c|c|}
\hline DATE & $\begin{array}{l}\text { SOLI IDS, } \\
\text { DIS - } \\
\text { SOLVED } \\
\text { (TONS } \\
\text { PER } \\
\text { AC-FT) }\end{array}$ & $\begin{array}{l}\text { SOLIDS, } \\
\text { DIS- } \\
\text { SOLVED } \\
\text { (TOHS } \\
\text { PER } \\
\text { DAY) }\end{array}$ & $\begin{array}{c}\text { NI TRO- } \\
\text { GEN } \\
: 102+N O 3 \\
\text { TOTAL } \\
\text { (MG/L } \\
\text { AS N) }\end{array}$ & $\begin{array}{l}\text { NITRO)- } \\
\text { CEN } \\
\text { NO2+NO3 } \\
\text { DIS- } \\
\text { SOLVED } \\
\text { (MG/L } \\
\text { AS N) }\end{array}$ & $\begin{array}{l}\text { NITRO- } \\
\text { GEN, AM- } \\
\text { MONIA + } \\
\text { ORGANIC } \\
\text { TOTAL } \\
\text { (MG/L } \\
\text { AS N) }\end{array}$ & $\begin{array}{l}\text { NITRO- } \\
\text { GEN, } \\
\text { TOTAL } \\
\text { (MG/L } \\
\text { AS N) }\end{array}$ & $\begin{array}{l}\text { NITRO- } \\
\text { GEN. } \\
\text { TOTAL } \\
\text { (MG/L } \\
\text { AS NO3) }\end{array}$ & $\begin{array}{l}\text { PHOS- } \\
\text { PHORUS. } \\
\text { TOTAL } \\
\text { (MG/L } \\
\text { AS P) }\end{array}$ & $\begin{array}{l}\text { PHOS- } \\
\text { PHORUS } \\
\text { TOTAL } \\
\text { (MC/L } \\
\text { AS POL) }\end{array}$ & $\begin{array}{l}\text { PHOS- } \\
\text { PHORUS, } \\
\text { ORTHO, } \\
\text { DIS- } \\
\text { SOLVED } \\
\text { (MC/L } \\
\text { AS P) }\end{array}$ & $\begin{array}{l}\text { PHOS- } \\
\text { PHATE, } \\
\text { ORTHO, } \\
\text { DIS- } \\
\text { SOLVED } \\
\text { (MC/L } \\
\text { AS PO4) }\end{array}$ \\
\hline $\begin{array}{l}\text { OCT } \\
28 \ldots \\
\text { NOV }\end{array}$ & 4.1 & 66.2 & $<.09$ & .11 & .58 & $\cdots$ & $\cdots$ & .050 & .15 & .020 & .06 \\
\hline DEC & 4.1 & 70.5 & .13 & .14 & 1.20 & 1.3 & 5.9 & .040 & .12 & $<.020$ & - \\
\hline $\begin{array}{l}30 \ldots \\
\text { FEB }\end{array}$ & 4.1 & 72.7 & .19 & .18 & .50 & .69 & 3.1 & .070 & .21 & .050 & .15 \\
\hline $\begin{array}{r}01 \ldots \\
22 \cdots \\
\text { MAR }\end{array}$ & $\begin{array}{l}4.1 \\
4.1\end{array}$ & $\begin{array}{l}50.9 \\
73.1\end{array}$ & .11 & $\begin{array}{l}.12 \\
.20\end{array}$ & $\begin{array}{l}.00 \\
.61\end{array}$ & $\begin{array}{l}.11 \\
.82\end{array}$ & 3.49 & $\begin{array}{l}.030 \\
.060\end{array}$ & $\begin{array}{l}.09 \\
.18\end{array}$ & $\begin{array}{l}.020 \\
.020\end{array}$ & $\begin{array}{l}.06 \\
.06\end{array}$ \\
\hline $\begin{array}{l}23 \ldots \\
A P R\end{array}$ & 4.1 & 82.9 & .23 & .23 & .58 & .81 & 3.6 & .040 & .12 & .030 & .09 \\
\hline $\begin{array}{l}23 \ldots \\
\text { MAY }\end{array}$ & 4.1 & 79.4 & .14 & .12 & .70 & .84 & 3.7 & .080 & .25 & .020 & .06 \\
\hline JU:N & 4.1 & 62.4 & $<.10$ & $<.10$ & .90 & -- & $=-$ & .050 & .15 & .010 & .03 \\
\hline $\begin{array}{l}21 \ldots \\
\text { JUL } \\
28\end{array}$ & 4.2 & 42.1 & $<.10$ & $<.10$ & .70 & -- & -- & .050 & .15 & .020 & .06 \\
\hline $\begin{array}{l}26 \ldots \\
\text { AUG } \\
18 \ldots \\
\text { SEP }\end{array}$ & 4.2 & 487 & .12 & .12 & .70 & .82 & 3.6 & $\cdots$ & .34 & .240 & .12 \\
\hline $08 \ldots$ & 4.2 & 50.2 & .10 & .10 & .70 & .80 & 3.5 & .210 & .64 & .040 & .12 \\
\hline DATE & $\begin{array}{l}\text { BORON, } \\
\text { DIS- } \\
\text { SOLVED } \\
\text { (UG/L } \\
\text { AS B) }\end{array}$ & $\begin{array}{l}\text { CADMIUM } \\
\text { TOTAL } \\
\text { KECOV- } \\
\text { ERABLE } \\
\text { (UG/L } \\
\text { AS CD) }\end{array}$ & $\begin{array}{l}\text { COPPER, } \\
\text { TOTAL } \\
\text { RECOV- } \\
\text { ERABLF } \\
\text { (UG/L } \\
\text { AS CU) }\end{array}$ & $\begin{array}{l}\text { IRON, } \\
\text { DIS- } \\
\text { SOLVED } \\
\text { (UG/L } \\
\text { AS FE) }\end{array}$ & $\begin{array}{l}\text { LEAD, } \\
\text { DIS- } \\
\text { SOLVED } \\
\text { (UG/L } \\
\text { AS PB) }\end{array}$ & $\begin{array}{l}\text { MAINGA- } \\
\text { NESE, } \\
\text { DIS - } \\
\text { SOLVED } \\
\text { (UC/L } \\
\text { AS MN) }\end{array}$ & $\begin{array}{l}\text { MERCURY } \\
\text { TOTAL } \\
\text { RECOV- } \\
\text { ERABLE } \\
\text { (UG/L } \\
\text { AS HG) }\end{array}$ & $\begin{array}{l}\text { SELE- } \\
\text { NIUM, } \\
\text { TOTAL } \\
\text { (UG/L } \\
\text { AS SE) }\end{array}$ & $\begin{array}{l}\text { ZINC, } \\
\text { DIS- } \\
\text { SOLVED } \\
\text { (UG/L } \\
\text { AS ZN) }\end{array}$ & $\begin{array}{l}\text { SEDI- } \\
\text { MENT. } \\
\text { SUS- } \\
\text { PENDED } \\
\text { (MG/L) }\end{array}$ & $\begin{array}{l}\text { SEDI - } \\
\text { MENT - } \\
\text { DIS - } \\
\text { CHARGE, } \\
\text { SUS - } \\
\text { PENDED } \\
\text { (T/DAY) }\end{array}$ \\
\hline $\begin{array}{l}\text { OCT } \\
28 . . \\
\text { NOV }\end{array}$ & 60 & $<1$ & 350 & 50 & 1 & 2800 & .1 & $<1$ & 20 & 345 & 7.6 \\
\hline $\begin{array}{l}20 \ldots \\
\mathrm{DEC}\end{array}$ & 50 & 1 & 200 & 90 & 3 & 5200 & .1 & $<1$ & 50 & 190 & 4.5 \\
\hline $\begin{array}{l}30 \ldots \\
\text { FEB }\end{array}$ & 60 & $<1$ & 50 & 30 & 1 & 6200 & $<.1$ & $<1$ & 30 & 86 & 2.1 \\
\hline $\begin{array}{r}01 \ldots \\
22 \ldots \\
\text { MAR }\end{array}$ & $\begin{array}{l}50 \\
60\end{array}$ & $\begin{array}{l}1 \\
1\end{array}$ & $\begin{array}{r}50 \\
150\end{array}$ & $\begin{array}{l}20 \\
50\end{array}$ & $\begin{array}{l}<1 \\
<1\end{array}$ & $\begin{array}{l}6200 \\
5500\end{array}$ & .1 & $<\frac{1}{1}$ & $\begin{array}{l}30 \\
20\end{array}$ & $\begin{array}{r}4 \\
265\end{array}$ & $\begin{array}{l}.07 \\
6.4\end{array}$ \\
\hline $\begin{array}{l}23 \ldots \\
\text { APR }\end{array}$ & 60 & 1 & 200 & 40 & 5 & 5400 & .1 & $<1$ & 20 & 405 & 11 \\
\hline $\begin{array}{l}23 \ldots \\
M A Y\end{array}$ & 60 & 3 & 120 & 50 & 3 & 4500 & $<.1$ & $<1$ & 20 & 294 & 7.7 \\
\hline$\underset{\text { JUN }}{27} \cdots$ & 60 & 2 & 70 & 40 & $<1$ & 6000 & $.1 \vdots$ & $<1$ & 30 & 130 & 2.7 \\
\hline$\underset{\text { JUL }}{21} \cdots$ & 60 & 1 & 30 & 60 & $<1$ & 5300 & .1 & $<1$ & 20 & 14 & .19 \\
\hline $\begin{array}{l}28 \ldots \\
\text { AUC }\end{array}$ & -- & $\cdots$ & 1490 & $\rightarrow$ & -- & $\cdots$ & -- & -- & -- & -- & -- \\
\hline $\begin{array}{l}18 \ldots \\
\text { SEP }\end{array}$ & 60 & 1 & 390 & 50 & 2 & 6800 & .1 & 1 & 20 & . 299 & -- \\
\hline $08 \ldots$ & 180 & 1 & 120 & 60 & $<1$ & 5600 & $<.1$ & 1 & 30 & 156 & 2.5 \\
\hline
\end{tabular}

< Actual value is known to be less than value shown. 
09518000 GILA RIVER ABOVF: DIVERSIONS, AT GILLESPIE DAM, AZ

(National stream-quality accounting network altd pesticide station)

LOCATION - - Lat $33^{\circ} 13^{\circ} 45^{\prime \prime}$, long $112^{\circ} 46^{\circ} 00^{\prime \prime}$, In SEknE sec. 28 , T.2 S., R.5 W. Maricopa County. Hydrologic Unit 15070101 at Gillespie Dam $8 \mathrm{mi}(13 \mathrm{~km})$ downstream from Hassayampa River. Gila Bend Canal diverts from left end, and Enterprise Canal diverts from right end of Gillespie Dam.

DRAINAGE AREA. $=-49,650 \mathrm{mi}^{2}\left(128,600 \mathrm{~km}^{2}\right)$.

\section{WATER-DISCHARGE RECORDS}

PERIOD OF RECORD --June 1935 to November 1939 (monthly discharge only published in WSP 1313 ). December 1939 to September 1971 (published with records for sta 09519500 . Gila River below Gillespie Dam). 1972 and 1973 (water year estimates only. Iisted in REMARKS for sta 09519500;, October 1973 to current year. Low-Elow records prior to October 1970 are not equivalent as leakage less than $5 \mathrm{ft}^{3} / \mathrm{s}\left(0.14 \mathrm{~m}^{3} / \mathrm{s}\right.$ ? is not included. 09518500 . Gila Bend Canal: May 1935 to September 1971, October 1973 to current year (s1nce 0ctober 1941, monthly discharge only).

09519000 Enterprise Canal: June 1935 to September 1939 (discharge measurements and monthly estimates only). October 1939 to September 1971. April 1974 to current year (since October 1941, monthly discharge only). Published as "Gillespie Canal" prior to 1951.

GAGE.--Gila Bend Canal: Water-stage recorder $200 \mathrm{ft}(60.9 \mathrm{~m})$ downstream from headgates. Enterprise Canal: Water-stage recorder $600 \mathrm{Et}(\mathrm{i} 80 \mathrm{~m})$ downstream from intake at dam.

REMARKS. - Records good except those below $1,000 \mathrm{ft}^{3} / \mathrm{s}\left(28.3 \mathrm{~m}^{3} / \mathrm{s}\right)$, which are fair. Record is obtained by combining on a daily basis, the flows of Gila Bend Canal, Enterprise Canal, and Gila River below Gillespie Dam (see . Some of the diversions to Gila Rend Canal in the 1981 water year were returned to the river below the gage.

Many large diversions above station for irrigation, municipal, and industrial use. Flow of Gila River and cributaries above this station is regulated by San Carlos Reservoir on Gila River - capacity, $1.073,600$ acre-ft $\left(1.320 \mathrm{hm}^{3}\right)$; by a series of reservoirs on Salt River - capacity, 1,755,000 acre-ft (2,160 inm $\left.{ }^{3}\right)$; by Bartlett and iorseshoe Reservoirs on Verde River - capacity, 317,700 acre-ft (392 hm); and by Lake Pleasant on Agua Fria River - capacity, 157,600 acre-ft $\left(194 \mathrm{hm}^{3}\right)$.

AVERAGE DISCHARGE. -47 years, $334 \mathrm{ft} 3 / \mathrm{s}\left(9.459 \mathrm{~m}^{3} / \mathrm{s}\right), 242,000$ acre-ft/yr $(298 \mathrm{hm} / \mathrm{yr})$ : median of yearly mean discharges, $66 \mathrm{ft} / \mathrm{s}\left(1.87 \mathrm{~m}^{3} / \mathrm{s}\right), 47,800$ acre-ft/yr $\left(59 \mathrm{hm}^{3} / \mathrm{yr}\right)$.

EXTREMES FOR PERIOD OF RECORD, - Maximum daily discharge, $124,000 \mathrm{ft} / \mathrm{s}(3,510 \mathrm{~m} / \mathrm{s}) \mathrm{Feb}$. 17 , 1980 ; no flow except for possible leakage of less than $5 \mathrm{ft}^{3} / \mathrm{s}\left(0.14 \mathrm{~m}^{3} / \mathrm{s}\right)$ thov. 24-27, 1966, July 14.1967.

EXTREMES FOK CURRENT YEAR.--Maximum dally discharge, $3,870 \mathrm{ft}^{3} / \mathrm{s}\left(110 \mathrm{~m}^{3} / \mathrm{s}\right) \mathrm{Mar}$. 18 ; minimum daily, $29 \mathrm{ft} / \mathrm{s}$ $\left(0.82: \mathrm{m}^{3} / \mathrm{s}\right)$ July 16 .

DISCHARGE, IN CUBIC FFET PER SECO:: WATER YEAR OCTOBER 1981 TO SFPTEMBER 1982

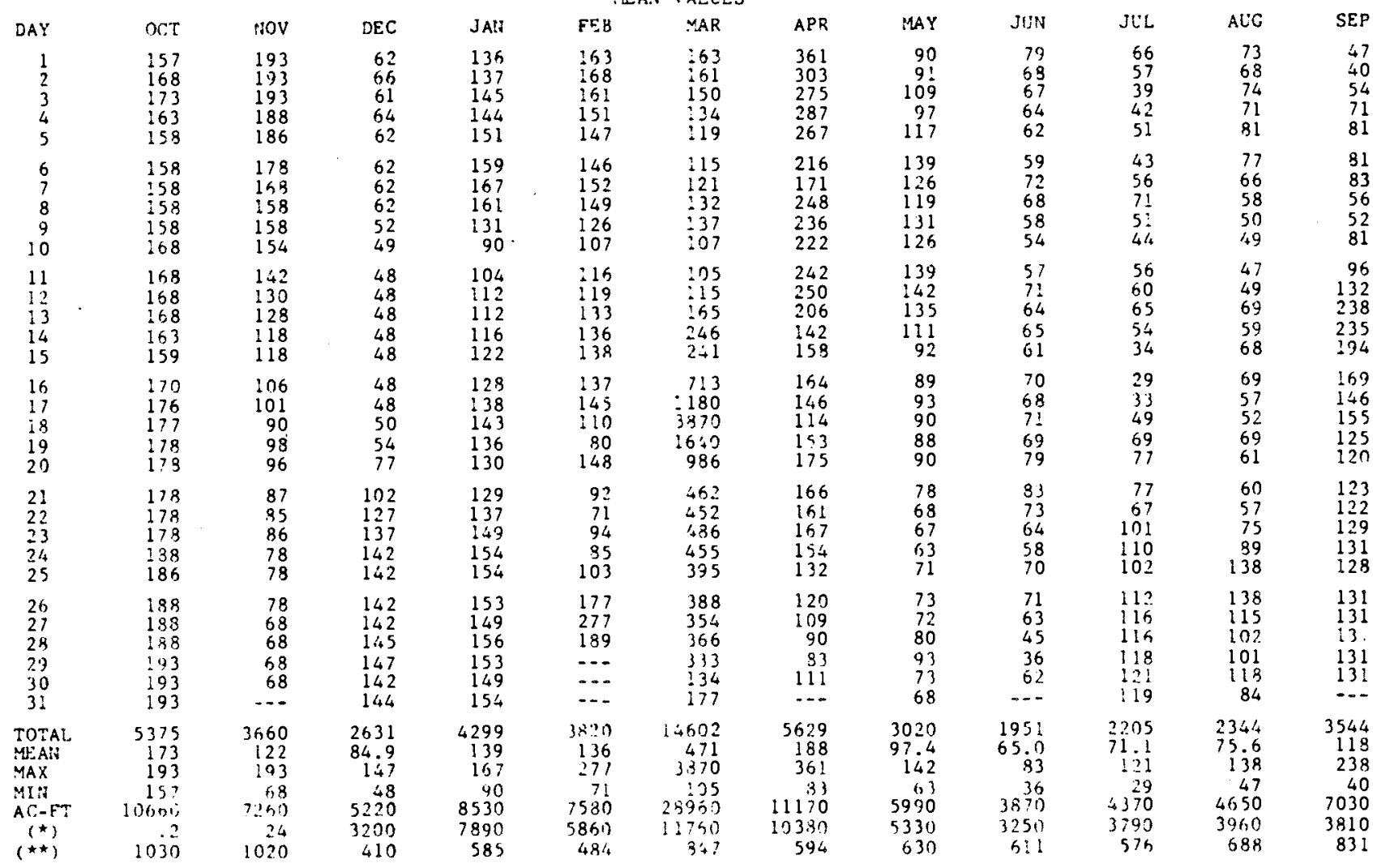

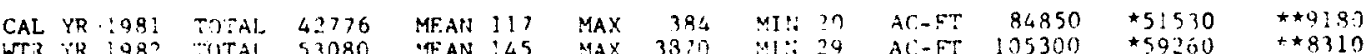

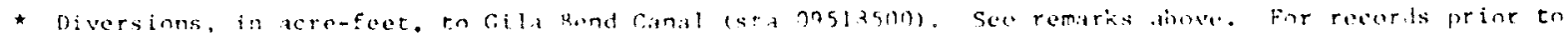

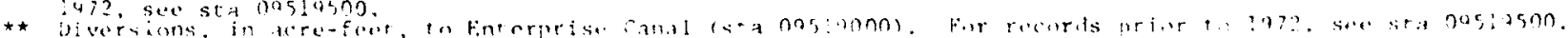




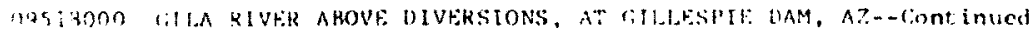

WATER-QUALITY RECOROS

PHRIOU OF RECOKD.--3. Cember 1950 to September 1971 , Mareh 1974 to curront year.

Prior to october 1967. puhlished as 09519500 . Gila River helow Gillespie Dam, Ariz.

PERIOD OF DAILY RECORD --

SPECIFIC CONDUCTANCE: October 1964 to September 1971, Apri1 1974 to September 1981.

WATER TEMPERATURES: December 1950 to September 1971. April 1974 to September 1981.

REMARKS,--Unpublished da 11 y specific conductance measurements for period December 1950 co September 1964 avallable from district office in Tucson, Ariz.

EXTREMES FOR PERIOD OF DAILY RECORD.--

SPECIFIC CONDUCTANCE: Maximum observed, 13,200 micromhos July 10,11, 1966; minimum observed, 236 micromhos

WATER TEMPERATURES: Maximum observed, $36.5^{\circ} \mathrm{C}$ July 8,1958 , July 22, 1959, Aug. 5, 8, 1966; minimum observed, $1.5^{\circ} \mathrm{C} \mathrm{Jan.1.1951.}$

-WATER QUALITY DATA. WATER YEAR OCTOBER 1981 TO SEPTEMBER 1982

\begin{tabular}{|c|c|c|c|c|c|c|c|c|c|c|c|}
\hline DATE & TIME & $\begin{array}{l}\text { STREAM- } \\
\text { RON } \\
\text { IISTAH- } \\
\text { TAIIEOUS } \\
\text { (CFS) }\end{array}$ & $\begin{array}{l}\text { SPE- } \\
\text { CIFIC } \\
\text { CON- } \\
\text { DUCT- } \\
\text { ANCE } \\
\text { (UMHOS) }\end{array}$ & $\begin{array}{c}\text { PH } \\
\text { (STAND- } \\
\text { ARD } \\
\text { UNITS) }\end{array}$ & $\begin{array}{c}\text { TEMPER- } \\
\text { ATURE, } \\
\text { AIR } \\
\text { (DEG C) }\end{array}$ & $\begin{array}{l}\text { TEMPER- } \\
\text { ATURE } \\
\text { (DEG C) }\end{array}$ & $\begin{array}{l}\text { TUR- } \\
\text { BID- } \\
\text { ITY } \\
\text { (ITU) }\end{array}$ & $\begin{array}{c}\text { OXYCEN, } \\
\text { DIS- } \\
\text { SOLVED } \\
\text { (MG/L) }\end{array}$ & $\begin{array}{l}\text { OXYGEN } \\
\text { DEMAND. } \\
\text { CHEM- } \\
\text { ICAL } \\
\text { (HIGH } \\
\text { LEVEL) } \\
\text { (MG/L) }\end{array}$ & $\begin{array}{l}\text { COLI- } \\
\text { FORM, } \\
\text { FECAL, } \\
0.7 \\
\text { UII-MF } \\
\text { (COLS. } \\
\text { IOO ML) }\end{array}$ & $\begin{array}{c}\text { STREP - } \\
\text { TOCOCCI } \\
\text { FECAL } \\
\text { KF AGAR } \\
\text { (COLS. } \\
\text { PER } \\
100 \mathrm{ML} \text { ) }\end{array}$ \\
\hline $\begin{array}{l}\text { OCT } \\
28 \ldots\end{array}$ & 0945 & 188 & 3740 & 8.0 & 19.0 & 17.5 & 13 & 8.1 & 110 & 500 & 650 \\
\hline $\begin{array}{l}\text { NOV } \\
24 \ldots . \\
\text { DEC }\end{array}$ & 0940 & 59 & 5690 & 8.4 & 10.0 & 12.0 & $\sim$ & 9.5 & 180 & 160 & 120 \\
\hline $\begin{array}{l}\text { DEC } \\
31 \ldots \\
\text { FEB }\end{array}$ & 1005 & $E 148$ & 4150 & 7.2 & 17.0 & 13.0 & 8.5 & 7.8 & 45 & 280 & 1200 \\
\hline $\begin{array}{r}02 \\
25 \ldots\end{array}$ & $\begin{array}{l}0915 \\
0955\end{array}$ & $\begin{array}{l}\text { E171 } \\
\text { E119 }\end{array}$ & $\begin{array}{l}4190 \\
5230\end{array}$ & $\begin{array}{l}8.1 \\
8.2\end{array}$ & $\begin{array}{r}4.0 \\
15.0\end{array}$ & $\begin{array}{l}10.5 \\
16.0\end{array}$ & $7 . \overline{4}^{-}$ & $\begin{array}{l}7.4 \\
9.1\end{array}$ & $\begin{array}{l}39 \\
54\end{array}$ & $\begin{array}{r}580 \\
2400\end{array}$ & $\begin{array}{r}910 \\
6900\end{array}$ \\
\hline $\begin{array}{l}\text { MAR } \\
25 \ldots \\
\text { APR }\end{array}$ & 1025 & 511 & 3770 & 7.9 & 18.0 & 17.5 & -- & 5.8 & 49 & $k 400$ & 2700 \\
\hline JUN $29 .$. & 1045 & E79 & 5100 & 8.8 & 30.5 & 24.0 & 36 & 16.0 & $<10$ & 74 & $\cdots$ \\
\hline $\begin{array}{l}02 \ldots \\
24 \ldots\end{array}$ & $\begin{array}{l}0855 \\
1040\end{array}$ & $\begin{array}{l}69 \\
55\end{array}$ & $\begin{array}{l}5360 \\
5280\end{array}$ & $\begin{array}{l}8.8 \\
8.9\end{array}$ & $\begin{array}{l}28.0 \\
34.0\end{array}$ & $\begin{array}{l}22.5 \\
26.0\end{array}$ & $16^{--}$ & $\begin{array}{r}8.8 \\
16.6\end{array}$ & $\begin{array}{r}82 \\
120\end{array}$ & $\begin{array}{r}100 \\
93\end{array}$ & 1200 \\
\hline $\begin{array}{l}\text { JUL } \\
29 . . .\end{array}$ & 1650 & 121 & 4000 & 8.5 & 35.0 & 29.0 & -- & 14.9 & 39 & -- & $\cdots$ \\
\hline $\begin{array}{l}\text { AUG } \\
24 \ldots \\
\text { SEP }\end{array}$ & 1800 & 98 & 2580 & 7.9 & 27.0 & 31.0 & 33 & 9.3 & -- & 1000 & -- \\
\hline $15 \ldots$ & 0945 & 199 & 3820 & 8.0 & 26.0 & 23.5 & -- & 5.6 & -- & 1100 & 2600 \\
\hline DATE & $\begin{array}{l}\text { HARD- } \\
\text { NESS } \\
(\mathrm{MG} / \mathrm{L} \\
\text { AS } \\
\text { CACO3) }\end{array}$ & $\begin{array}{l}\text { HARD- } \\
\text { NESS } \\
\text { NONCAR- } \\
\text { BONAIE } \\
\text { (MG/L } \\
\text { AS } \\
\text { CACO3) }\end{array}$ & $\begin{array}{l}\text { CALCIUM } \\
\text { DIS- } \\
\text { SOLVED } \\
\text { (MG/L } \\
\text { AS CA) }\end{array}$ & $\begin{array}{l}\text { MACNE- } \\
\text { SIUM. } \\
\text { DIS- } \\
\text { SOLVED } \\
\text { (MG/L } \\
\text { AS MG) }\end{array}$ & $\begin{array}{l}\text { SODIUM, } \\
\text { DIS- } \\
\text { SOLVED } \\
\text { (MG/L } \\
\text { AS NA) }\end{array}$ & $\begin{array}{r}\text { PERCENT } \\
\text { SODIUM }\end{array}$ & $\begin{array}{l}\text { SODIUM } \\
\text { AD- } \\
\text { SORP- } \\
\text { TION } \\
\text { RATIO }\end{array}$ & $\begin{array}{l}\text { POTAS- } \\
\text { SIUM, } \\
\text { DIS- } \\
\text { SOLVED } \\
\text { (MC/L } \\
\text { AS K) }\end{array}$ & $\begin{array}{c}\text { ALKA- } \\
\text { LINI TY } \\
\text { LAB } \\
\text { (MG/L } \\
\text { AS } \\
\text { CACO3) }\end{array}$ & $\begin{array}{l}\text { SULFATE } \\
\text { DIS- } \\
\text { SOLVED } \\
\text { (MG/L } \\
\text { AS SO4) }\end{array}$ & $\begin{array}{l}\text { CHLO- } \\
\text { RIDE, } \\
\text { DIS - } \\
\text { SOLVED } \\
\text { (MC/L } \\
\text { AS CL) }\end{array}$ \\
\hline $\begin{array}{l}\mathrm{OCT} \\
28 \ldots\end{array}$ & 670 & 428 & 150 & 71 & 540. & 63 & 9.4 & 12 & 240 & 460 & 800 \\
\hline $\begin{array}{l}\text { NOV } \\
24 \ldots \\
\text { DEC }\end{array}$ & -- & -- & -- & $\cdots$ & $\cdots$ & $\cdots$ & $-\infty$ & - & -- & - & 1300 \\
\hline FEB & 830 & 550 & 190 & 86 & 550 & 59 & 8.6 & 11 & 280 & 550 & 920 \\
\hline $\begin{array}{r}02 \ldots \\
25 \ldots\end{array}$ & 930 & $6 \ddot{49}$ & $220^{--}$ & $92^{-\infty}$ & $780^{-\infty}$ & 64 & $11^{-\infty}$ & $12^{--}$ & $280^{--}$ & $730^{\circ-}$ & $1200^{\circ}$ \\
\hline APR & $\cdots$ & $-\infty$ & -- & -- & - & $\cdots$ & $\cdots$ & $\cdots$ & - & $-\infty$ & - \\
\hline JUN 29. & 930 & 673 & 220 & 93 & 720 & 62 & 11 & 11 & 260 & 720 & 1100 \\
\hline $\begin{array}{l}02 \ldots \\
24 \ldots\end{array}$ & 860 & 698 & $180^{--}$ & $100^{-\infty}$ & $790^{--}$ & 66 & $12^{-\infty}$ & 9.9 & $164^{--}$ & $790^{--}$ & $\begin{array}{l}1200 \\
1200\end{array}$ \\
\hline $\begin{array}{l}\text { JUL } \\
29 \ldots \\
\text { AUG }\end{array}$ & $=$ & $\cdots$ & , $\quad=$ & $=0$ & $=$ & $=$ & $\cdots$ & $\cdots$ & $\cdots$ & $\cdots$ & $m-$ \\
\hline SEP & 540 & 394 & 130 & 52 & 390 & 61 & 7.5 & 9.6 & 145 & 380 & 620 \\
\hline $15 \ldots$ & - & -- & - & - & $-\infty$ & $=$ & $\cdots$ & $\cdots$ & - & - & - \\
\hline $\begin{array}{ll}\mathrm{K} & \mathrm{B} \\
< & \mathrm{AC} \\
\mathrm{E} & \mathrm{E}\end{array}$ & $\begin{array}{l}d \text { on } n \\
\text { al va } 1 \\
\text { mated. }\end{array}$ & $\begin{array}{l}\text { ideal } \\
\text { is knc }\end{array}$ & $\begin{array}{l}n y \text { co } \\
0 \text { be }\end{array}$ & 5 than & ue & & & & & & \\
\hline
\end{tabular}


09518000 GILA RIVER ABOVE DIVERSIONS, AT GILLESPIE DAM, AZ--Cont1nued

WATER QUALITY DATA, WATER YEAR OCTOBER 1981 TO SEPTEMBER 1982

\begin{tabular}{|c|c|c|c|c|c|c|c|c|c|c|c|}
\hline DATE & $\begin{array}{l}\text { FLUO- } \\
\text { RIDE, } \\
\text { DIS- } \\
\text { SOLVED } \\
\text { (MG/L } \\
\text { AS F) }\end{array}$ & $\begin{array}{l}\text { SILICA, } \\
\text { DIS- } \\
\text { SOLVED } \\
\text { (MG/L } \\
\text { AS } \\
\text { SIO2) }\end{array}$ & $\begin{array}{l}\text { SOLIDS, } \\
\text { RESIDUE } \\
\text { AT } 180 \\
\text { DEG. C } \\
\text { DIS- } \\
\text { SOLVED } \\
(M G / L)\end{array}$ & $\begin{array}{l}\text { SOLIDS, } \\
\text { RESIDUE } \\
\text { AT IOS } \\
\text { DEG. C, } \\
\text { DIS-' } \\
\text { SOLVED } \\
(M G / L)\end{array}$ & $\begin{array}{l}\text { SOLIDS, } \\
\text { SUM OF } \\
\text { CONSTI- } \\
\text { TUENTS, } \\
\text { DIS- } \\
\text { SOLVED } \\
\text { (MG/L) }\end{array}$ & $\begin{array}{c}\text { SOLIDS, } \\
\text { DIS- } \\
\text { SOLVED } \\
\text { (TONS } \\
\text { PER } \\
\text { AC-FT) }\end{array}$ & $\begin{array}{c}\text { SOLIDS, } \\
\text { DIS- } \\
\text { SOLVED } \\
\text { (TONS } \\
\text { PER } \\
\text { DAY) }\end{array}$ & $\begin{array}{l}\text { SOLIDS, } \\
\text { RESIDUE } \\
\text { AT IOS } \\
\text { DEG. C. } \\
\text { SUS- } \\
\text { PENDED } \\
\text { (MG/L) }\end{array}$ & $\begin{array}{l}\text { NITRO- } \\
\text { GEN, } \\
\text { NO2+NO3 } \\
\text { DIS- } \\
\text { SOLVED } \\
\text { (MG/L } \\
\text { AS N) }\end{array}$ & $\begin{array}{l}\text { NITRO- } \\
\text { GEN, } \\
\text { AMMONIA } \\
\text { DIS- } \\
\text { SOLVED } \\
\text { (MG/L } \\
\text { AS NH4) }\end{array}$ & $\begin{array}{l}\text { NITRO- } \\
\text { CEN, } \\
\text { AMMONIA } \\
\text { DIS- } \\
\text { SOLVED } \\
\text { (MG/L } \\
\text { AS N) }\end{array}$ \\
\hline $\begin{array}{l}\text { OCT } \\
28 \ldots \\
\text { NOV }\end{array}$ & 1.7 & 26 & 2250 & -- & 2220 & 3.1 & 1140 & 37 & 7.4 & 8.1 & 6.30 \\
\hline & $=$ & $\cdots$ & -- & -- & -- & $=-$ & -- & 20 & -- & $=-$ & -- \\
\hline & 1.7 & 26 & 2630 & $\cdots$ & 2520 & 3.6 & -- & 13 & 8.8 & 8.8 & 6.80 \\
\hline $\begin{array}{l}02 \ldots \\
25 \ldots \\
M A R\end{array}$ & .50 & $24^{--}$ & 3300 & $=$ & 3230 & $4.5^{-5}$ & $11 \overline{60}$ & $\begin{array}{l}46 \\
49\end{array}$ & $10^{--}$ & $1 . \overline{4}$ & $1.10^{-}$ \\
\hline $\begin{array}{l}25 \ldots \\
A P R\end{array}$ & $=$ & - & -- & 2250 & -- & -- & $-\infty$ & 75 & -- & -- & $=$ \\
\hline$\underset{\text { JUN }}{29} \ldots$ & 2.1 & 12 & 3190 & $\cdots$ & 3040 & 4.3 & $=$ & 22 & 9.0 & .13 & .100 \\
\hline $\begin{array}{l}02 \ldots \\
24 \ldots\end{array}$ & $2.2^{-=}$ & $5 . \overline{5}$ & $33 \overline{0}$ & $=-$ & $31 \overrightarrow{80}$ & $4.6^{--}$ & 499 & $\begin{array}{l}132 \\
162\end{array}$ & $7.3^{--}$ &.$\overline{13}$ & .100 \\
\hline $\begin{array}{l}\text { JUL } \\
29 \ldots \\
\text { AUG }\end{array}$ & $=-$ & -- & $\therefore$ & -- & -- & -- & $\cdots$ & 124 & -- & -- & -- \\
\hline & 1.0 & 16 & 1730 & -- & 1690 & 2.4 & 458 & 130 & -- & 1.1 & .890 \\
\hline $15 \ldots$ & -- & $=-$ & -- & 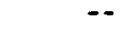 & $=$ & -- & -- & 210 & -- & $=-$ & -- \\
\hline DATE & $\begin{array}{l}\text { NITRO- } \\
\text { GEN,AM- } \\
\text { MONIA + } \\
\text { ORGAHIC } \\
\text { TOTAL } \\
\text { (MG/L } \\
\text { AS N) }\end{array}$ & $\begin{array}{l}\text { PHOS- } \\
\text { PHORUS, } \\
\text { TOTAL } \\
\text { (MC/L } \\
\text { AS P) }\end{array}$ & $\begin{array}{l}\text { PHOS- } \\
\text { PHORUS } \\
\text { TOTAL } \\
\text { (MC/L } \\
\text { AS PO4) }\end{array}$ & $\begin{array}{c}\text { PHOS- } \\
\text { PHORUS, } \\
\text { DIS- } \\
\text { SOLVED } \\
\text { (MC/L } \\
\text { AS P) }\end{array}$ & $\begin{array}{l}\text { PHOS- } \\
\text { PHATE, } \\
\text { ORTHO, } \\
\text { DIS - } \\
\text { SOLVED } \\
\text { (MG/L } \\
\text { AS PO4) }\end{array}$ & $\begin{array}{l}\text { PHOS- } \\
\text { PHORUS, } \\
\text { ORTHO, } \\
\text { DIS- } \\
\text { SOLVED } \\
\text { (MG/L } \\
\text { AS P) }\end{array}$ & $\begin{array}{l}\text { ARSENIC } \\
\text { TOTAL } \\
\text { (UG/L } \\
\text { AS AS) }\end{array}$ & $\begin{array}{c}\text { ARSENIC } \\
\text { SUS- } \\
\text { PENDED } \\
\text { TOTAL } \\
\text { (UG/L } \\
\text { AS AS) }\end{array}$ & $\begin{array}{c}\text { ARSENIC } \\
\text { DIS- } \\
\text { SOLVED } \\
\text { (UG/L } \\
\text { AS AS) }\end{array}$ & $\begin{array}{l}\text { BARIUM, } \\
\text { TOTAL } \\
\text { RECOV- } \\
\text { ERABLE } \\
\text { (UG/L } \\
\text { AS BA) }\end{array}$ & $\begin{array}{l}\text { BARIUM, } \\
\text { SUS - } \\
\text { PENDED } \\
\text { RECOV- } \\
\text { ERABLE } \\
\text { (UG / } \\
\text { AS BA) }\end{array}$ \\
\hline
\end{tabular}

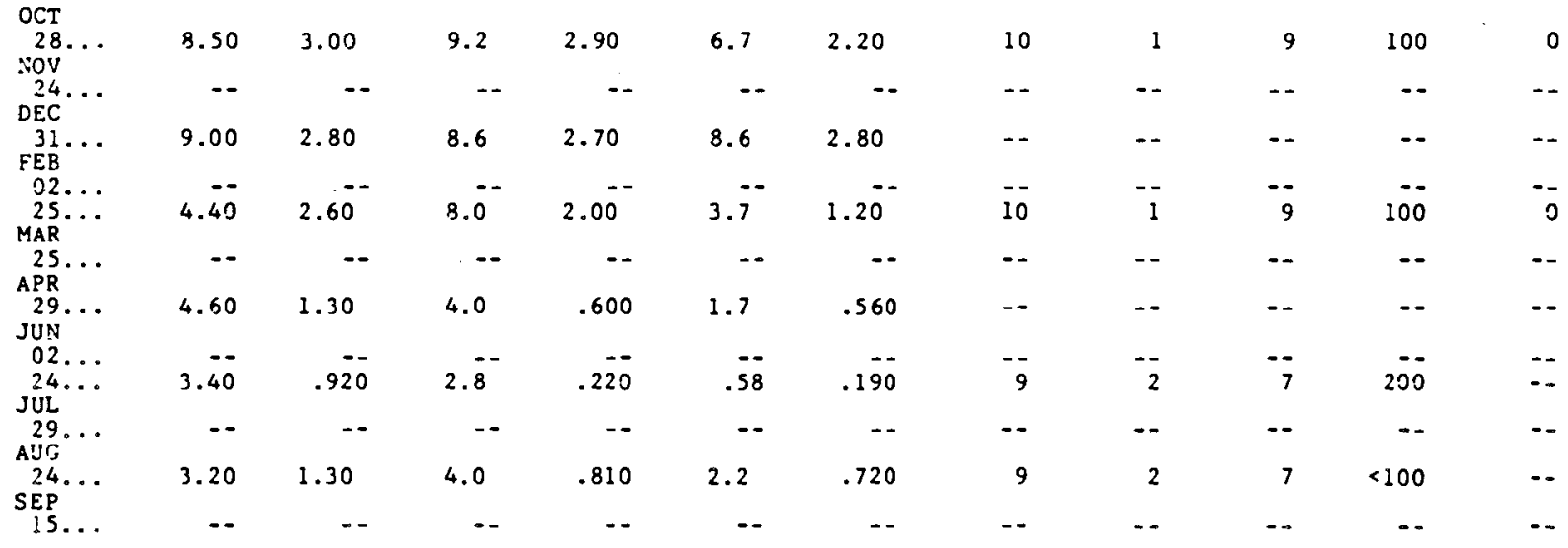

- Actual value is known to be less than value shown. 


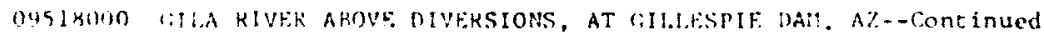

WATFR QIALITY DATA, WATER YEAR OCTOBER 198I TO SEPTEMBEK 1982

\begin{tabular}{|c|c|c|c|c|c|c|c|c|c|c|c|}
\hline DATE & $\begin{array}{l}\text { BARILM, } \\
\text { DIS- } \\
\text { SOLVED } \\
\text { (UG/L } \\
\text { AS BA) }\end{array}$ & $\begin{array}{l}\text { BOKON, } \\
\text { TOTAL } \\
\text { RECOV- } \\
\text { FRABLF, } \\
\text { (UG/L } \\
\text { AS B) }\end{array}$ & $\begin{array}{l}\text { CADYILY } \\
\text { TOTAL } \\
\text { RECOV- } \\
\text { ERABLE } \\
\text { (UG/L } \\
\text { AS CD) }\end{array}$ & $\begin{array}{c}\text { CADHIUM } \\
\text { SUS- } \\
\text { PENDFD } \\
\text { RECOV- } \\
\text { FRABLE } \\
\text { (UG/L } \\
\text { AS CD) }\end{array}$ & $\begin{array}{l}\text { CADHIUM } \\
\text { DIS- } \\
\text { SOLVED } \\
\text { (UG/L } \\
\text { AS CD) }\end{array}$ & $\begin{array}{l}\text { CIIRO- } \\
\text { MIUM, } \\
\text { TOTAL } \\
\text { RECOV- } \\
\text { ERABLE } \\
\text { (UG/L } \\
\text { AS CR) }\end{array}$ & $\begin{array}{l}\text { CHRO- } \\
\text { MIUH, } \\
\text { SUS- } \\
\text { PEHDED } \\
\text { RECOV. } \\
\text { (UG/L } \\
\text { AS CR) }\end{array}$ & $\begin{array}{l}\text { CHRO- } \\
\text { MIUM, } \\
\text { OIS- } \\
\text { SOLVED } \\
\text { (UG/L } \\
\text { AS CR) }\end{array}$ & $\begin{array}{l}\text { COBALT, } \\
\text { TOTAL } \\
\text { RECOV- } \\
\text { ERABLE } \\
\text { (UG/L } \\
\text { AS CO) }\end{array}$ & $\begin{array}{l}\text { COBALT, } \\
\text { SUS- } \\
\text { PENDED } \\
\text { RECOV- } \\
\text { ERABLE } \\
\text { (UG/L } \\
\text { AS CO) }\end{array}$ & $\begin{array}{l}\text { COBALT, } \\
\text { DIS- } \\
\text { SOLVED } \\
\text { (UG/L } \\
\text { AS CO) }\end{array}$ \\
\hline $\begin{array}{l}\text { DCT } \\
28 \ldots \\
\text { Nov }\end{array}$ & 200 & 1500 & 1 & 0 & 1 & 10 & 10 & $<10$ & 1 & 0 & 1 \\
\hline DEC & -+ & $\cdots$ & $<1$ & $\cdots$ & -- & -- & -- & -- & -- & $=-$ & $=$ \\
\hline FEB & $\cdots$ & -- & $<1$ & -- & $\cdots$ & -- & $=-$ & $=$ & - & $-=$ & $\infty$ \\
\hline $\begin{array}{l}02 \ldots \\
25 \ldots \\
\text { IAR }\end{array}$ & $10 \overline{0}$ & 2400 & $\begin{array}{l}1 \\
<1\end{array}$ & 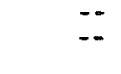 & $<1$ & 10 & $\overline{0}$ & $\overline{10}$ & $-\frac{-}{2}$ & $-\overline{0}$ & $-\frac{-}{3}$ \\
\hline$\underset{A P R}{25} \ldots$ & -- & -- & 2 & $=-$ & $-\infty$ & -- & -- & -- & $\cdots$ & -- & $\rightarrow$ \\
\hline JUN & $\cdots$ & $\cdots$ & $?$ & -- & -- & -- & -- & -- & -- & -- & $=$ \\
\hline $\begin{array}{l}02 \ldots \\
24 \ldots \\
\text { JUL }\end{array}$ & $10 \overline{0}$ & 2500 & ? & $=$ & $-\overline{1}$ & 20 & $\overline{10}$ & 10 & $-\overline{1}$ & -- & $-\overline{1}$ \\
\hline $\begin{array}{l}29 . \ldots \\
\text { AUG }\end{array}$ & - & $=$ & $\cdots$ & -- & $=$ & $=-$ & -- & $\cdots$ & - & $\cdots$ & $=$ \\
\hline $\begin{array}{l}24 \ldots \\
\text { SEP }\end{array}$ & 100 & 1300 & $<1$ & $\cdots$ & $<1$ & 10 & $-\cdot$ & $<10$ & 1 & $\cdots$ & $<1$ \\
\hline $15 \ldots$ & $\cdots$ & -- & $<!$ & -- & $\cdots$ & $\cdots$ & $\cdots$ & $\cdots$ & -- & $-\cdots$ & -- \\
\hline DATE & $\begin{array}{l}\text { COPPER, } \\
\text { TOTAL } \\
\text { RECOV- } \\
\text { ERABLE } \\
\text { (UG/L } \\
\text { AS CU) }\end{array}$ & $\begin{array}{l}\text { COPPER, } \\
\text { SUS - } \\
\text { PENDED } \\
\text { RECOV- } \\
\text { ERABLE } \\
\text { (UG/L } \\
\text { AS CU) }\end{array}$ & $\begin{array}{l}\text { COPPER, } \\
\text { DIS- } \\
\text { SOLVED } \\
\text { (UG/L } \\
\text { AS CU) }\end{array}$ & $\begin{array}{l}\text { IRON, } \\
\text { TOTAL } \\
\text { RECOV- } \\
\text { ERABLE } \\
\text { (UG/L } \\
\text { AS FE) }\end{array}$ & $\begin{array}{l}\text { IRON, } \\
\text { SUS- } \\
\text { PENDED } \\
\text { RECOV- } \\
\text { ERABLE } \\
\text { (UG/L } \\
\text { AS FE) }\end{array}$ & $\begin{array}{l}\text { IRON, } \\
\text { DIS- } \\
\text { SOLVED } \\
\text { (UC/L } \\
\text { AS FE) }\end{array}$ & $\begin{array}{l}\text { LEAD, } \\
\text { TOTAL } \\
\text { RECOV- } \\
\text { ERABLE } \\
\text { (UG/L } \\
\text { AS PB) }\end{array}$ & $\begin{array}{l}\text { LEAD, } \\
\text { SUS - } \\
\text { PENDED } \\
\text { RECOV- } \\
\text { ERABLE } \\
\text { (UG/L } \\
\text { AS PB) }\end{array}$ & $\begin{array}{l}\text { LEAD, } \\
\text { DIS- } \\
\text { SOLVED } \\
\text { (UG/L } \\
\text { AS PB) }\end{array}$ & $\begin{array}{l}\text { MANGA- } \\
\text { NESE } \\
\text { TOTAL } \\
\text { RECOV- } \\
\text { ERABLE } \\
\text { (UG/L } \\
\text { AS MN) }\end{array}$ & $\begin{array}{l}\text { MANGA- } \\
\text { NESE, } \\
\text { SUS- } \\
\text { PENDED } \\
\text { RECOV. } \\
\text { (UG/L } \\
\text { AS MN) }\end{array}$ \\
\hline$O C T$ & & & & & & & & & & & \\
\hline :OV & 14 & 9 & 5 & 1600 & 1600 & 50 & 5 & 5 & $<1$ & 120 & 40 \\
\hline DEC & 170 & $=$ & $=-$ & $\cdots$ & $=-$ & $=\infty$ & -- & $=-$ & 2 & -- & $\cdots$ \\
\hline FEB & so & $\cdots$ & $=-$ & $\cdots$ & $-\infty$ & $=-$ & -- & $=-$ & $<1$ & $\infty$ & $\cdots$ \\
\hline $\begin{array}{l}02 \ldots \\
25 \ldots\end{array}$ & $\begin{array}{l}50 \\
19\end{array}$ & $-\frac{-}{8}$ & 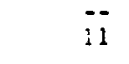 & 1000 & $9 \overline{80}$ & 20 & $-\overline{5}$ & 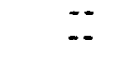 & $\begin{array}{r}<10 \\
<1\end{array}$ & $2 \overline{60}$ & 50 \\
\hline $\begin{array}{l}\text { MAR } \\
25 \ldots \\
\text { APR }\end{array}$ & 50 & $\cdots$ & -- & $\cdots$ & -- & $=-$ & $-\therefore$ & $\cdots$ & $<1$ & -- & - \\
\hline$\underset{\text { JUN }}{29} \ldots$ & 70 & -- & -- & $\cdots$ & $-\infty$ & -- & $\cdots$ & -- & $<1$ & $-\infty$ & $\infty$ \\
\hline $\begin{array}{l}02 \ldots \\
24 \ldots \\
\text { JUL }\end{array}$ & $\begin{array}{l}50 \\
16\end{array}$ & $\overline{10}$ & $-\overline{6}$ & 2200 & 2100 & 70 & $-\infty$ & $\ddot{0}$ & $\begin{array}{r}<1 \\
4\end{array}$ & 200 & 170 \\
\hline AUr. & 30 & $-\infty$ & $\cdots$ & -- & $\Rightarrow$ & -- & $\cdots$ & $\cdots$ & $\cdots$ & $-\infty$ & - \\
\hline $\begin{array}{l}24 \ldots \\
\text { SEP }\end{array}$ & 10 & 4 & 6 & 1800 & 1800 & 40 & 2 & $\cdots$ & $<1$ & 160 & 90 \\
\hline $15 \ldots$ & 30 & $-\infty$ & $=-$ & $\cdots$ & $\cdots$ & $\cdots$ & -- & $\cdots$ & $<1$ & $=-$ & $\cdots$ \\
\hline
\end{tabular}

- Actual value is known ro be less than value shown. 


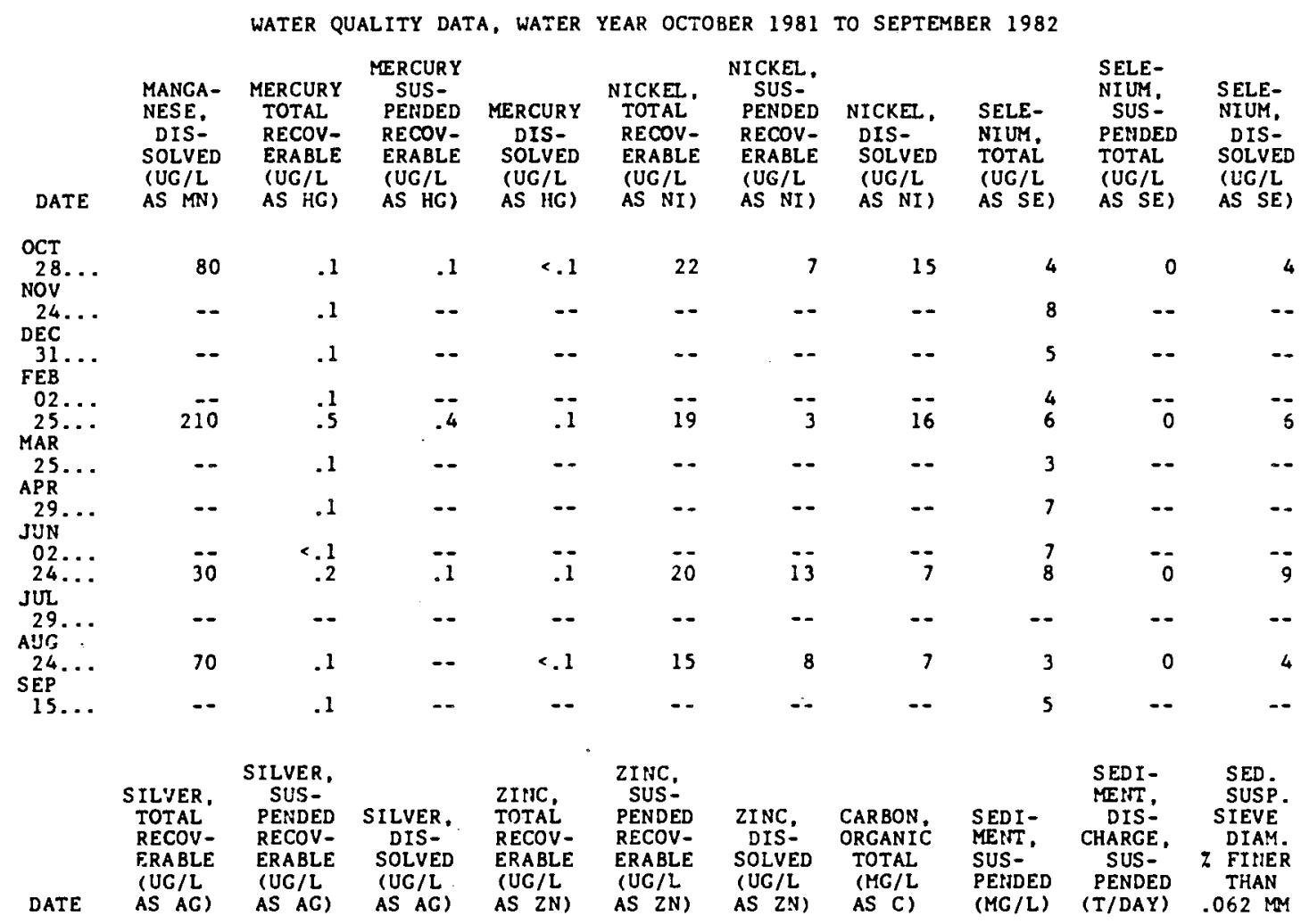

\begin{tabular}{|c|c|c|c|c|c|c|c|c|c|c|}
\hline $\begin{array}{l}\text { OCT } \\
28 \ldots\end{array}$ & 1 & 1 & $<1$ & 30 & 20 & 10 & 9.7 & 39 & 20 & -- \\
\hline $\begin{array}{l}\text { HOV } \\
24 \ldots\end{array}$ & - & $\cdots$ & - & $\cdots$ & -- & -- & -- & 33 & 5.3 & -- \\
\hline DEC & & & & & & & & & & 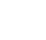 \\
\hline $\begin{array}{c}31 \\
\text { FEB }\end{array}$ & -- & -- & -- & -- & -- & -- & $\therefore$ & 21 & -- & -- \\
\hline $02 \ldots$ & -- & -- & -- & -- & -- & -- & -- & 61 & -- & -- \\
\hline$\underset{\text { MAR }}{25} \ldots$ & $<1$ & $\cdots$ & $<1$ & 30 & 10 & 20 & -- & 51 & -- & 85 \\
\hline$\underset{A P R}{25} \cdots$ & -- & -- & $\cdots$ & -- & $\cdots$ & $\cdots$ & -- & 143 & 197 & 56 \\
\hline $\operatorname{JUN}_{\text {JUN }}^{29}$ & -- & $\cdots$ & -- & -- & -- & -- & -- & 157 & $\cdots$ & 85 \\
\hline $\begin{array}{l}02 \ldots \\
24 \ldots\end{array}$ & $<1$ & $=-$ & $=-$ & 30 & $\overline{10}$ & 20 & $=-$ & $\begin{array}{l}123 \\
140\end{array}$ & $\begin{array}{l}23 \\
21\end{array}$ & $\begin{array}{l}86 \\
97\end{array}$ \\
\hline $\begin{array}{l}\text { JUL } \\
29 . \ldots\end{array}$ & $-\cdot$ & -- & -- & $\cdots$ & -- & $\cdots$ & -- & -- & -- & 93 \\
\hline $\begin{array}{l}\mathrm{AUC} \\
24 \ldots\end{array}$ & $<1$ & $=-$ & $<1$ & 30 & 0 & 30 & & 95 & 25 & \\
\hline SEP & & & 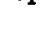 & 80 & 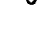 & (Jo & 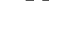 & 93 & 23 & 92 \\
\hline $15 \ldots$ & $\cdots$ & -- & -- & $=-$ & -- & -- & -- & 201 & 108 & 98 \\
\hline
\end{tabular}




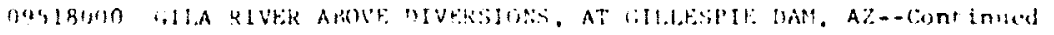

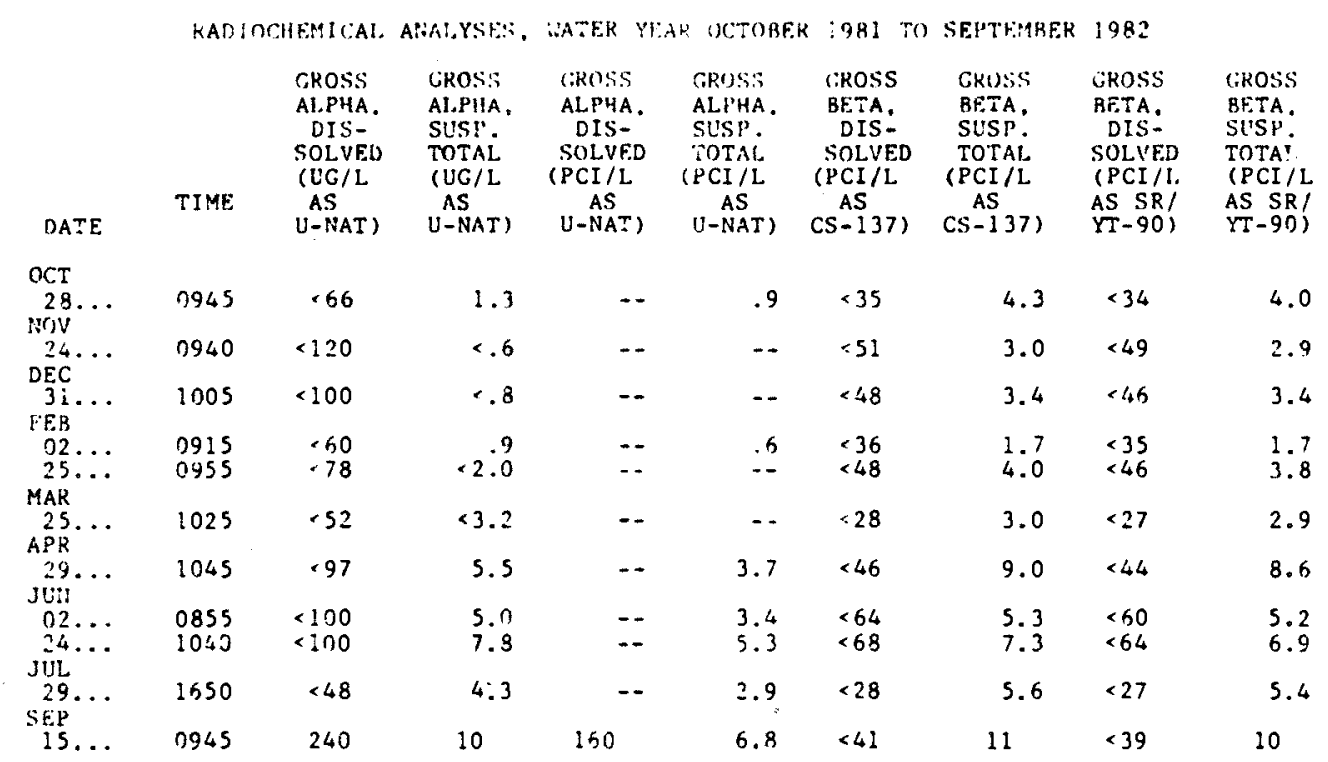

PESTICIDE ANALYSES, WATER YEAR OCTOBER I981 TO SEPTEMBER 1982

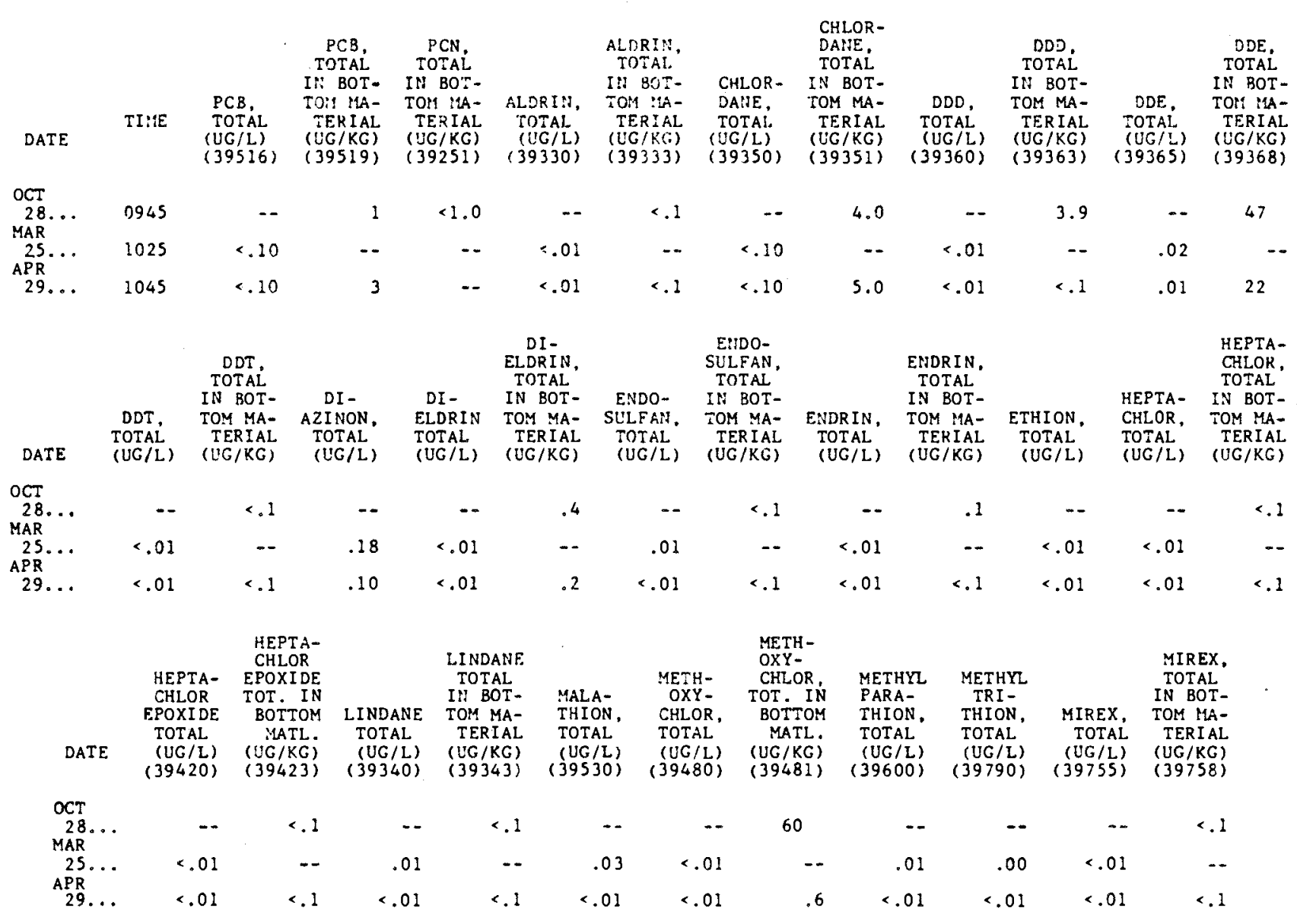

- Actual value is known to be less than value shown. 
GILA RIVER BASIN

09518000 GILA RIVER ABOVE DIVERSIONS, AT GILLESPIE DAM, AZ--Cont Inued

PESTICIDE ANALYSES, WATER YEAR OCTOBER 1981 TO SEPTEMBER 1982

\begin{tabular}{|c|c|c|c|c|c|c|c|c|c|c|c|}
\hline DATE & $\begin{array}{l}\text { NAPH- } \\
\text { THA- } \\
\text { LENES, } \\
\text { POLY- } \\
\text { CHLOR. } \\
\text { TOTAL } \\
\text { (UG/L) }\end{array}$ & $\begin{array}{l}\text { PARA- } \\
\text { IHION, } \\
\text { TOIAL } \\
\text { (UG/L) }\end{array}$ & $\begin{array}{l}\text { PER- } \\
\text { THANE } \\
\text { TOTAL } \\
\text { (UG/L) }\end{array}$ & $\begin{array}{l}\text { PER- } \\
\text { THANE } \\
\text { IN } \\
\text { BOTTOM } \\
\text { MATERIL } \\
\text { (UG/KG) }\end{array}$ & $\begin{array}{l}\text { TOX- } \\
\text { APHENE, } \\
\text { TOTAL } \\
\text { (UG/L) }\end{array}$ & $\begin{array}{l}\text { TOXA- } \\
\text { PHENE, } \\
\text { TOTAL } \\
\text { IN BOT- } \\
\text { TOM MA- } \\
\text { TERIAL } \\
\text { (UG/KG) }\end{array}$ & $\begin{array}{l}\text { TOTAL } \\
\text { TRI- } \\
\text { THION } \\
\text { (UG/L) }\end{array}$ & $\begin{array}{l}2,4-D, \\
\text { TOTAL } \\
\text { (UG/L) }\end{array}$ & $\begin{array}{c}2 \text { 4-DP } \\
\text { TOTAL } \\
\text { (UG/L) }\end{array}$ & $\begin{array}{l}2,4,5-T \\
\text { TOTAL } \\
\text { (UG/L) }\end{array}$ & $\begin{array}{l}\text { SILVEX, } \\
\text { TOTAL } \\
\text { (UG/L) }\end{array}$ \\
\hline $\begin{array}{l}\text { OCT } \\
28 . . . \\
\text { MAR }\end{array}$ & -- & $=$ & -- & $<1.00$ & -- & $<10$ & -- & -- & -- & -- & $-\infty$ \\
\hline APR & $<.10$ & -- & $<.10$ & - & $<1$ & -- & $<.01$ & $<.01$ & $<.01$ & $<.01$ & $<.01$ \\
\hline $29 \ldots$ & $<.10$ & $<.01$ & $<.10$ & $<1.00$ & $<1$ & $<10$ & $<.01$ & .08 & $<.01$ & $<.01$ & $<.01$ \\
\hline
\end{tabular}

- Actual value is known to be less than value shown. 
095:9500 IIIAA RIVEK HFI.OW (IILLESPIE BAM, AZ

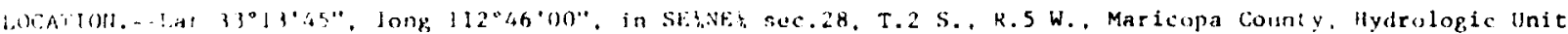
15070:01, तो lef: en! uf rillespie Dam, $8 \mathrm{mi}$ (:3 km) downsteam frum Hassayampa kiver.

DiRAINAGE AREA, $-49,650 \mathrm{mi}^{2}\left(128,600 \mathrm{~km}^{2}\right)$.

PËRIOO OF RSORB. - Aupist 1221 to currenc year. Low-flow records prior to October 1970 are not equivalent as leakaye of less than $5 \mathrm{ft} 3 / \mathrm{s}\left(0.14 \mathrm{~m}^{3} / \mathrm{s}\right)$ not included, and from October 1971 to September 1973 , when no leakage was included. Annial estimate of leakage was listed in REMARkS for the 1972 water year. Prior to 1939 , published as "ist Gillespie Dam."

REVISF. RECUKUS.--USP 1213: 1939. WSP 1243: 1924(M). WSP 1926: Drainage area.

GACE.--Water-stage recorder since July 28, 1924. Datum of gage is $9.95 \mathrm{ft}$ (3.033 m) be low average elevation of crest of $\mathrm{Aam}$, which is $753.46 \mathrm{ft}(229.655 \mathrm{~m})$ Hational Geodetic Vertical Datum of 1929 . Prior to Nov. 11 , 1924 . depth of water read on crest at left end of dam. Nov. 11, 1924, to July 22, 1932 datum of gage was at average ilevation of lam crest. July 23, 1932, to Apr. 27,1955 , datum of gage was $5.00 \mathrm{ft}$ (1.524 m) below average elevation of crest of dam. Since Apr. 2, 1974, supplementary water-stage recorder and concrete control 78 ft $(21.3 \mathrm{~m})$ downstream from erest of dam at datum $5.64 \mathrm{ft}(1.719 \mathrm{~m})$ lower than datum of base gage.

KEMARKS.--Records grod except those below $1,000 \mathrm{ft}^{3} / \mathrm{s}\left(28.3 \mathrm{~m}^{3} / \mathrm{s}\right)$, which are poor. Flow consists of water passing over the dam, and through the dam, but does not include water diverted to Gila Bend or Enterprise Canals. See sta 09518000 , Gila River above diversions, at Gillespie Dam, for cecords of flow reaching dam, and of diversions to Gila Rend and Enterprise Canals. For diversions and regulation above station, see REMARXS for sta 09518000.

EXTREMES FOK PFRIOD OF RECORD.--Maximum discharge, 178,000 $\mathrm{ft}^{3} / \mathrm{s}\left(5,040 \mathrm{~m}^{3} / \mathrm{s}\right) \mathrm{Feh}$. 16, 1980, gage height, 18.81 ft $(5.733 \mathrm{~m})$, present datun; probably no flow at imes.

EXIREMES OITSIDF PERIOD OF RECORD.--4aximun discharge since at least $1891,250,000 \mathrm{ft} / \mathrm{s}$ ( $7,100 \mathrm{~m} / \mathrm{s})$, estiuated, in February 1891 .

EXTREMES WOR CURRENT YEAR,--Maximm discharge, $5.630 \mathrm{ft}^{3} / \mathrm{s}\left(159 \mathrm{~m}^{3} / \mathrm{s}\right)$ Mar, 18 , $0945 \mathrm{hours,}$ gage height, $10.94 \mathrm{ft}$ $(3.335 \mathrm{~m})$; no flow for several days. DISCHARGE, IN CUBIC FEET PER SECOND, WATER YEAR OCTOBER 1981 TO SEPTEMBER 1982

\begin{tabular}{|c|c|c|c|c|c|c|c|c|c|c|c|c|}
\hline DAY & $O C:$ & nov & DEC & JAN & FEB & MAR & $A P R^{\circ}$ & MAY & JUN & JUL & AUG & SEP \\
\hline $\begin{array}{l}1 \\
2 \\
3 \\
4 \\
5\end{array}$ & $\begin{array}{l}150 \\
150 \\
155 \\
145 \\
140\end{array}$ & $\begin{array}{l}175 \\
175 \\
175 \\
170 \\
168\end{array}$ & $\begin{array}{l}44 \\
48 \\
43 \\
46 \\
46\end{array}$ & $\begin{array}{l}.42 \\
.42 \\
.53 \\
.53 \\
.53\end{array}$ & $\begin{array}{l}.15 \\
.15 \\
.11 \\
.11 \\
.11\end{array}$ & $\begin{array}{l}.71 \\
.53 \\
.53 \\
.53 \\
.48\end{array}$ & $\begin{array}{r}57 \\
6.9 \\
5.0 \\
4.0 \\
3.0\end{array}$ & $\begin{array}{l}.19 \\
.19 \\
.19 \\
.23 \\
.37\end{array}$ & $\begin{array}{l}.48 \\
.48 \\
.48 \\
.42 \\
.42\end{array}$ & $\begin{array}{l}.08 \\
.08 \\
.08 \\
.08 \\
.11\end{array}$ & $\begin{array}{l}.08 \\
.05 \\
.08 \\
.19 \\
.11\end{array}$ & $\begin{array}{l}.00 \\
.00 \\
.00 \\
.00 \\
.00\end{array}$ \\
\hline $\begin{array}{r}6 \\
7 \\
8 \\
9 \\
10\end{array}$ & $\begin{array}{l}140 \\
140 \\
140 \\
140 \\
150\end{array}$ & $\begin{array}{l}150 \\
150 \\
140 \\
140 \\
130\end{array}$ & $\begin{array}{l}46 \\
46 \\
46 \\
46 \\
46\end{array}$ & $\begin{array}{l}.53 \\
.53 \\
.53 \\
.53 \\
.53\end{array}$ & $\begin{array}{l}.11 \\
.11 \\
.11 \\
.11 \\
.11\end{array}$ & $\begin{array}{l}.48 \\
.48 \\
.42 \\
.28 \\
.23\end{array}$ & $\begin{array}{l}2.0 \\
1.6 \\
1.3 \\
1.3 \\
1.0\end{array}$ & $\begin{array}{l}.53 \\
.53 \\
.53 \\
.53 \\
.53\end{array}$ & $\begin{array}{l}.42 \\
.37 \\
.37 \\
.37 \\
.37\end{array}$ & $\begin{array}{l}.15 \\
.15 \\
.15 \\
.11 \\
.11\end{array}$ & $\begin{array}{l}.11 \\
.11 \\
.08 \\
.08 \\
.08\end{array}$ & $\begin{array}{l}.00 \\
.00 \\
.00 \\
.00 \\
.00\end{array}$ \\
\hline $\begin{array}{l}11 \\
12 \\
13 \\
14 \\
15\end{array}$ & $\begin{array}{l}150 \\
150 \\
150 \\
150 \\
150\end{array}$ & $\begin{array}{l}120 \\
110 \\
110 \\
100 \\
100\end{array}$ & $\begin{array}{l}46 \\
46 \\
46 \\
46 \\
46\end{array}$ & $\begin{array}{l}8.4 \\
1.4 \\
1.1 \\
1.0 \\
.91\end{array}$ & $\begin{array}{l}.11 \\
.11 \\
.11 \\
.11 \\
.11\end{array}$ & $\begin{array}{l}.23 \\
3.0^{23} \\
20 \\
25\end{array}$ & $\begin{array}{l}.84 \\
.65 \\
.53 \\
.37 \\
.23\end{array}$ & $\begin{array}{l}.53 \\
.53 \\
.53 \\
.53 \\
.53\end{array}$ & $\begin{array}{l}.32 \\
.32 \\
.32 \\
.28 \\
.28\end{array}$ & $\begin{array}{l}.15 \\
.11 \\
.08 \\
.01 \\
.00\end{array}$ & $\begin{array}{l}.08 \\
.08 \\
.08 \\
.08 \\
.08\end{array}$ & $\begin{array}{l}.00 \\
.00 \\
.00 \\
.00 \\
.00\end{array}$ \\
\hline $\begin{array}{l}16 \\
17 \\
18 \\
19 \\
20\end{array}$ & $\begin{array}{l}160 \\
160 \\
160 \\
160 \\
160\end{array}$ & $\begin{array}{l}90 \\
90 \\
80 \\
80 \\
80\end{array}$ & $\begin{array}{r}46 \\
46 \\
23 \\
1.7 \\
1.3\end{array}$ & $\begin{array}{l}.84 \\
.71 \\
.71 \\
.65 \\
.53\end{array}$ & $\begin{array}{r}.11 \\
.11 \\
10^{.11} \\
69\end{array}$ & $\begin{array}{r}501 \\
964 \\
3620 \\
1370 \\
702\end{array}$ & $\begin{array}{l}.28 \\
.28 \\
.32 \\
.42 \\
.53\end{array}$ & $\begin{array}{l}.53 \\
.53 \\
.53 \\
.53 \\
.53\end{array}$ & $\begin{array}{l}.28 \\
.23 \\
.23 \\
.23 \\
.19\end{array}$ & $\begin{array}{l}.03 \\
.01 \\
.01 \\
.01 \\
.01\end{array}$ & $\begin{array}{l}.08 \\
.08 \\
.11 \\
.11 \\
.11\end{array}$ & $\begin{array}{r}.00 \\
.00 \\
.00 \\
.00\end{array}$ \\
\hline $\begin{array}{l}21 \\
22 \\
23 \\
24 \\
25\end{array}$ & $\begin{array}{l}160 \\
160 \\
160 \\
170 \\
170\end{array}$ & $\begin{array}{l}70 \\
70 \\
70 \\
60 \\
60\end{array}$ & $\begin{array}{l}1.2 \\
1.1 \\
.91 \\
.78 \\
.65\end{array}$ & $\begin{array}{l}.53 \\
.42 \\
.42 \\
.37 \\
.37\end{array}$ & $\begin{array}{l}27 \\
30 \\
63 \\
65 \\
83\end{array}$ & $\begin{array}{r}167 \\
161 \\
175 \\
150 \\
92\end{array}$ & $\begin{array}{l}.53 \\
.53 \\
.53 \\
.53 \\
.53\end{array}$ & $\begin{array}{l}.48 \\
.48 \\
.48 \\
.48 \\
.48\end{array}$ & $\begin{array}{l}.19 \\
.19 \\
.15 \\
.15 \\
.15\end{array}$ & $\begin{array}{l}.01 \\
.23 \\
.65 \\
.18 \\
.01\end{array}$ & $\begin{array}{l}.11 \\
.08 \\
.03 \\
.01 \\
.00\end{array}$ & $\begin{array}{l}112 \\
112 \\
112 \\
112 \\
1: 2\end{array}$ \\
\hline $\begin{array}{l}26 \\
27 \\
28 \\
29 \\
30 \\
31\end{array}$ & $\begin{array}{l}170 \\
170 \\
170 \\
175 \\
175 \\
175\end{array}$ & $\begin{array}{r}60 \\
50 \\
50 \\
50 \\
50 \\
\cdots\end{array}$ & $\begin{array}{l}.53 \\
.53 \\
.48 \\
.42 \\
.42 \\
.42\end{array}$ & $\begin{array}{l}.23 \\
.23 \\
.23 \\
.19 \\
.15 \\
.15\end{array}$ & $\begin{array}{r}116 \\
134 \\
26 \\
\ldots \\
\ldots\end{array}$ & $\begin{array}{l}84 \\
53 \\
62 \\
3 ! \\
15 \\
41\end{array}$ & $\begin{array}{l}.53 \\
.48 \\
.19 \\
.19 \\
.19 \\
.-.\end{array}$ & $\begin{array}{l}.48 \\
.48 \\
.48 \\
.48 \\
.48 \\
.48\end{array}$ & $\begin{array}{l}.15 \\
.11 \\
.11 \\
.11 \\
.08 \\
. .-\end{array}$ & $\begin{array}{l}.00 \\
.00 \\
.00 \\
.01 \\
.05 \\
.08\end{array}$ & $\begin{array}{l}.00 \\
.00 \\
.00 \\
.00 \\
.00 \\
.00\end{array}$ & $\begin{array}{r}112 \\
112 \\
112 \\
112 \\
112\end{array}$ \\
\hline $\begin{array}{l}\text { TOTAL } \\
\text { MEAN } \\
\text { MAX } \\
\text { MIN } \\
\text { AC-FT }\end{array}$ & $\begin{array}{r}4855 \\
157 \\
175 \\
140 \\
9630\end{array}$ & $\begin{array}{r}3133 \\
104 \\
175 \\
50 \\
6210\end{array}$ & $\begin{array}{r}812.44 \\
26.2 \\
48 \\
.42 \\
1610\end{array}$ & $\begin{array}{r}24.62 \\
.79 \\
8.4 \\
.15 \\
49\end{array}$ & $\begin{array}{r}625.06 \\
22.3 \\
134 \\
1240\end{array}$ & $\begin{array}{r}8241.13 \\
266 \\
3620 \\
16350\end{array}$ & $\begin{array}{r}91.78 \\
3.06 \\
57 \\
119 \\
182\end{array}$ & $\begin{array}{r}14.40 \\
.46 \\
.53 \\
.19 \\
29\end{array}$ & $\begin{array}{r}8.25 \\
.28 \\
.48 \\
.08 \\
16\end{array}$ & $\begin{array}{l}2.74 \\
.088 \\
.65 \\
.00 \\
5.4\end{array}$ & $\begin{array}{l}2.09 \\
.067 \\
.19 \\
.00 \\
4.1\end{array}$ & $\begin{array}{r}1200.00 \\
40.0 \\
112 \\
.00 \\
2380\end{array}$ \\
\hline
\end{tabular}

CAL YR 1981 TOTAL 12813.34 MEAN 35.1 MAX 175 MIN .00 AC-FT 25420 $\begin{array}{lllllllll}\text { WTR YR } 1982 & \text { TOTAL } 19010.51 & \text { MEAN } 35.1 & \text { MAX } & 175 & \text { MIN } .00 & \text { AC-FT } & 25420 \\ \text { WEAN } 52.1 & \text { MAX } 3620 & \text { MIN } & .00 & \text { AC-FT } & 37710\end{array}$ 
LOCATION,--Lat $32^{\circ} 43^{\circ} 04^{\prime \prime}$, long $114^{\circ} 30^{\circ} 12^{\prime \prime}$, In NWkSEk sec. 22 , T. 8 S., R. 22 W. Yuma County, Hydrologic Unit 15070201 at gaging station $0.5 \mathrm{mi}(0.8 \mathrm{~km})$ upstream from out let to G1la River, and $6 \mathrm{ml}$ (10 km) east of Yuna. PERIOD OF RECORD.--October 1968 to current year.

PERIOD OF DAILY RECORD.--

SPECIFIC CONDUCTANCE: October 1978 to current year.

REMARKS.--Unpublished miscellaneous chemical analyses for water years $1965-68$ avallable from district office in Tucson, Ariz.

COOPERATION.--Dally specific conductance record furnished by, and water samples collected by, U.S. Bureau of Reclamation.

EXTREMES FOR PERIOD OF DAILY RECORD.--

SPECIFIC CONDUCTANCE: Maximum observed, 5,350 micromhos Sept. 12, 1981; minimum observed, 3,020 micromhos Nov. 7, 1979.

EXTREMES FOR CURRENT YEAR. -

SPECIFIC CONDUCTANCE: Maximum observed, 5,230 micromhos Jan. 19; minimum observed, 3,210 micromhos Dec. 2.

WATER QUALITY DATA, WATER YEAR OCTOBER 1981 TO SEPTEMBER 1982

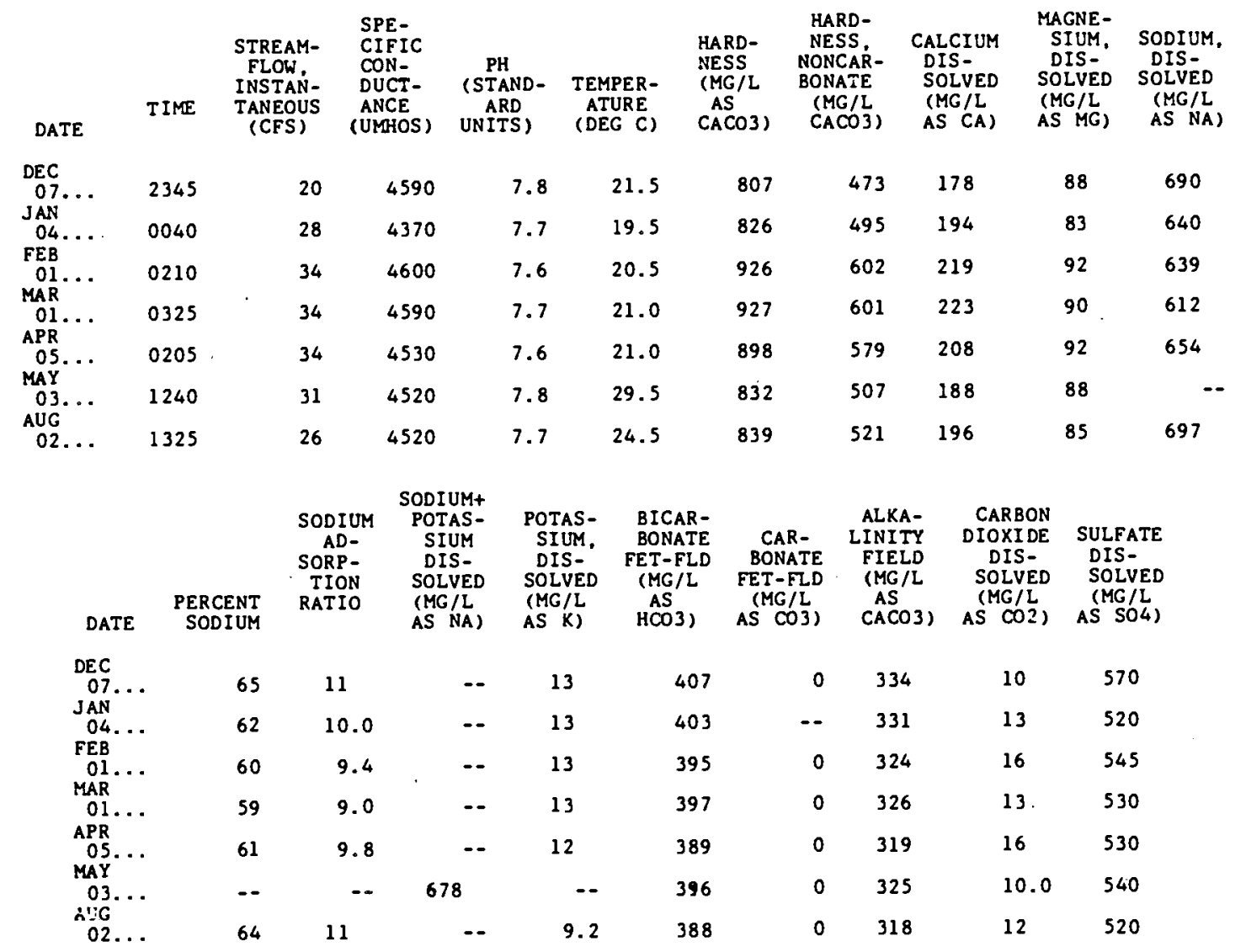


$09 \$ 29160$ SOUTH GILA PUMP OUTI.ET CHANNEL NO. 3 NEAR YUMA, AZ--Cont inued

WATER QUALITY DATA, WATER YEAR OCTOBER 1981 TO SEPTEMBER 1982

\begin{tabular}{|c|c|c|c|c|c|c|c|c|c|}
\hline & $\begin{array}{l}\text { CHLO- } \\
\text { RIDE, } \\
\text { DIS- } \\
\text { SOLVED } \\
\text { (MG/L } \\
\text { AS CL) }\end{array}$ & $\begin{array}{l}\text { FLUO- } \\
\text { RIDE, } \\
\text { DIS- } \\
\text { SOLVED } \\
\text { (MG/L } \\
\text { AS F) }\end{array}$ & $\begin{array}{l}\text { SILICA, } \\
\text { DIS- } \\
\text { SOLVED } \\
\text { (MG/L } \\
\text { AS } \\
\text { SIO2) }\end{array}$ & $\begin{array}{l}\text { SOLIDS } \\
\text { RES IDUE } \\
\text { AT } 180 \\
\text { DEG.C } \\
\text { DIS- } \\
\text { SOLVED } \\
(M G / L)\end{array}$ & $\begin{array}{c}\text { SOLIDS, } \\
\text { SUM OF } \\
\text { CONSTI- } \\
\text { TUEINIS, } \\
\text { DIS- } \\
\text { SOLVED } \\
\text { (MG/L) }\end{array}$ & $\begin{array}{c}\text { SOLIDS, } \\
\text { DIS- } \\
\text { SOLVED } \\
\text { (TONS } \\
\text { PER } \\
\text { AC-FT) }\end{array}$ & $\begin{array}{l}\text { SOLIDS } \\
\text { DIS- } \\
\text { SOLVED } \\
\text { (TONS } \\
\text { PER } \\
\text { DAY) }\end{array}$ & $\begin{array}{c}\text { NITRO- } \\
\text { GEN } \\
\text { NITRATE } \\
\text { DIS- } \\
\text { SOLVED } \\
\text { (MG/L } \\
\text { AS N) }\end{array}$ & $\begin{array}{c}\text { NITRO- } \\
\text { GEN } \\
\text { UITRATE } \\
\text { UIJ- } \\
\text { SOLVED } \\
\text { (MG/L } \\
\text { AS NO3) }\end{array}$ \\
\hline
\end{tabular}

\begin{tabular}{|c|c|c|c|c|c|c|c|c|c|}
\hline $\begin{array}{c}\text { DEC } \\
07 \ldots\end{array}$ & 990 & .8 & 27 & 2890 & 2761 & 3.9 & 156 & 1.00 & 4.4 \\
\hline $\begin{array}{l}\text { JAN } \\
04 \ldots\end{array}$ & 930 & .8 & 26 & 2740 & 2609 & 3.7 & 207 & .90 & 4.0 \\
\hline $\begin{array}{c}\text { FEB } \\
01 \ldots\end{array}$ & 1010 & .7 & 17 & 2990 & 2738 & 4.1 & 274 & 1.80 & 8.0 \\
\hline $\begin{array}{c}\text { MAR } \\
01 \ldots\end{array}$ & 1020 & .6 & 34 & 2980 & 2722 & 4.1 & 274 & 1.00 & 4.4 \\
\hline $\begin{array}{l}\text { APR } \\
\text { OS... } \\
\text { MAY }\end{array}$ & 1000 & .8 & 28 & 2910 & 2722 & 4.0 & 267 & 1.30 & 5.8 \\
\hline $03 .$. & 1000 & .7 & 29 & 2920 & 2720 & 4.0 & 244 & 1.40 & 6.2 \\
\hline $02 \ldots$ & 1000 & .7 & 23 & 2920 & 2724 & 4.0 & 205 & .63 & 2.8 \\
\hline
\end{tabular}

SPECIFIC CONDUCTANCE (MICROMHOS/CM AT 25 DEG. C), WATER YEAR OCTOBER 1981 TO SEPTEMBER 1982

\begin{tabular}{|c|c|c|c|c|c|c|c|c|c|c|c|c|}
\hline DAY & OCT & NOV & DEC & JAN & FEB & MAR & APR & MAY & JUN & JUL & AUG & SEP \\
\hline $\begin{array}{l}1 \\
2 \\
3 \\
4 \\
5\end{array}$ & & & $\begin{array}{l}3210 \\
4520 \\
4580 \\
4620\end{array}$ & $\begin{array}{l}4410 \\
4430 \\
4420 \\
4430 \\
4440\end{array}$ & $\begin{array}{c}4640 \\
\ldots- \\
\ldots- \\
\ldots\end{array}$ & $\begin{array}{l}4650 \\
4650 \\
4600 \\
4630 \\
4630\end{array}$ & $\begin{array}{l}4590 \\
4590 \\
4590 \\
4580 \\
4570\end{array}$ & $\begin{array}{r}4560 \\
4580 \\
4570 \\
\ldots- \\
\ldots\end{array}$ & $\begin{array}{l}4590 \\
4590 \\
4590 \\
4580 \\
4570\end{array}$ & $\begin{array}{r}4620 \\
4650 \\
4660 \\
\ldots \ldots \\
\ldots-\end{array}$ & $\begin{array}{l}4570 \\
4600 \\
4610 \\
4630 \\
4610\end{array}$ & $\begin{array}{l}-. \\
\cdots \\
\cdots- \\
\cdots-\end{array}$ \\
\hline $\begin{array}{r}6 \\
7 \\
8 \\
9 \\
10\end{array}$ & & & $\begin{array}{r}4630 \\
4650 \\
4670 \\
4350\end{array}$ & $\begin{array}{l}4440 \\
4450 \\
4450 \\
4450 \\
4480\end{array}$ & $\begin{array}{l}\cdots \\
\cdots \\
\cdots- \\
-\cdots \\
--\end{array}$ & $\begin{array}{l}4620 \\
4620 \\
4600 \\
4620 \\
4590\end{array}$ & $\begin{array}{l}4580 \\
4570 \\
4570 \\
4580 \\
4590\end{array}$ & $\begin{array}{l}\cdots- \\
--- \\
\cdots- \\
\cdots-\end{array}$ & $\begin{array}{l}4580 \\
4570 \\
4570 \\
4580 \\
4340\end{array}$ & $\begin{array}{l}\ldots \\
4640 \\
4640\end{array}$ & $\begin{array}{l}4620 \\
4610 \\
4610 \\
4610 \\
4590\end{array}$ & $\begin{array}{l}\cdots \\
\cdots \\
\cdots \\
\cdots\end{array}$ \\
\hline $\begin{array}{l}11 \\
12 \\
13 \\
14 \\
15\end{array}$ & & 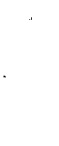 & $\begin{array}{l}4390 \\
4390 \\
4400 \\
4400 \\
4400\end{array}$ & $\begin{array}{r}4440 \\
4290 \\
=-0 \\
=--\end{array}$ & $\begin{array}{l}\ldots- \\
\cdots \\
\cdots \\
\cdots\end{array}$ & $\begin{array}{r}4530 \\
4610 \\
4600 \\
4600 \\
\ldots\end{array}$ & $\begin{array}{l}4580 \\
4580 \\
4600 \\
4590 \\
4560\end{array}$ & $\begin{array}{l}\cdots \\
\cdots \\
\cdots- \\
\cdots \\
\cdots\end{array}$ & $\begin{array}{l}4630 \\
4670 \\
4690 \\
4690 \\
4680\end{array}$ & $\begin{array}{l}4620 \\
4630 \\
4560 \\
4610 \\
4070\end{array}$ & $\begin{array}{r}4610 \\
4600 \\
4610 \\
4600 \\
-=-\end{array}$ & $\begin{array}{l}\cdots \\
\cdots \\
\cdots \\
\cdots\end{array}$ \\
\hline $\begin{array}{l}16 \\
17 \\
18 \\
19 \\
20\end{array}$ & & & $\begin{array}{l}4410 \\
4400 \\
4390 \\
4430 \\
4410\end{array}$ & $\begin{array}{l}5200 \\
5210 \\
5200 \\
5230 \\
4650\end{array}$ & $\begin{array}{l}4550 \\
4640 \\
4640 \\
4690\end{array}$ & $\begin{array}{l}\ldots \\
\ldots \\
\overline{4} \\
\overline{600}\end{array}$ & $\begin{array}{l}4570 \\
4580 \\
4580 \\
4580 \\
4570\end{array}$ & $\begin{array}{l}\cdots \\
\cdots \\
\cdots- \\
\cdots-\end{array}$ & $\begin{array}{l}4690 \\
4580 \\
4680 \\
4670 \\
4650\end{array}$ & $\begin{array}{l}4050 \\
4170 \\
4160 \\
4180 \\
4210\end{array}$ & $\begin{array}{r}-1-- \\
4540 \\
4190 \\
4210\end{array}$ & $\begin{array}{l}-\cdots \\
\cdots \\
\cdots\end{array}$ \\
\hline $\begin{array}{l}21 \\
22 \\
23 \\
24 \\
25\end{array}$ & & & $\begin{array}{l}4420 \\
4410 \\
4430 \\
4420 \\
4410\end{array}$ & $\begin{array}{l}4580 \\
4610 \\
4650 \\
4670 \\
4660\end{array}$ & $\begin{array}{l}4650 \\
4650 \\
4660 \\
4660 \\
4620\end{array}$ & $\begin{array}{l}4610 \\
4600 \\
4600 \\
4590 \\
4590\end{array}$ & $\begin{array}{l}4500 \\
4570 \\
4580 \\
4570 \\
4580\end{array}$ & $\begin{array}{l}\cdots \\
\ldots- \\
\cdots \\
\cdots \\
--\end{array}$ & $\begin{array}{l}4650 \\
4660 \\
4650 \\
4650 \\
4660\end{array}$ & $\begin{array}{l}4070 \\
4210 \\
4220 \\
4230 \\
4240\end{array}$ & $\begin{array}{r}3620 \\
3630 \\
3260 \\
3650 \\
\ldots\end{array}$ & $\begin{array}{l}4310 \\
3800 \\
4210 \\
4190\end{array}$ \\
\hline $\begin{array}{l}26 \\
27 \\
28 \\
29 \\
30 \\
31\end{array}$ & & & $\begin{array}{l}4430 \\
4430 \\
4440 \\
4430 \\
4460 \\
4470\end{array}$ & $\begin{array}{l}4640 \\
4650 \\
4660 \\
4650 \\
4660 \\
4660\end{array}$ & $\begin{array}{r}4630 \\
4620 \\
4660 \\
\ldots \\
\ldots\end{array}$ & $\begin{array}{l}4580 \\
4600 \\
4580 \\
4580 \\
4600 \\
4610\end{array}$ & $\begin{array}{r}4580 \\
4570 \\
4580 \\
4570 \\
4570 \\
\ldots\end{array}$ & $\begin{array}{l}\ldots- \\
\ldots- \\
\ldots- \\
\cdots \\
\cdots\end{array}$ & $\begin{array}{r}4640 \\
4640 \\
4630 \\
4640 \\
4630 \\
\ldots\end{array}$ & $\begin{array}{r}4230 \\
4240 \\
\ldots-0 \\
\ldots-0 \\
\ldots-\end{array}$ & $\begin{array}{l}\ldots- \\
\cdots \\
\cdots \\
\cdots \\
\cdots\end{array}$ & $\begin{array}{r}4170 \\
4190 \\
4140 \\
4120 \\
-\ldots \\
-\ldots-\end{array}$ \\
\hline $\begin{array}{l}\text { MEAN } \\
\text { MAX } \\
\text { MIN }\end{array}$ & & & $\begin{array}{l}4410 \\
4670 \\
3210\end{array}$ & $\begin{array}{l}4630 \\
5230 \\
4290\end{array}$ & $\begin{array}{l}4640 \\
4690 \\
4550\end{array}$ & $\begin{array}{l}4600 \\
4650 \\
4530\end{array}$ & $\begin{array}{l}4580 \\
4600 \\
4500\end{array}$ & $\begin{array}{l}4570 \\
4580 \\
4560\end{array}$ & $\begin{array}{l}4620 \\
4690 \\
4340\end{array}$ & $\begin{array}{l}4360 \\
4660 \\
4050\end{array}$ & $\begin{array}{l}4360 \\
4630 \\
3260\end{array}$ & $\begin{array}{l}4140 \\
4310 \\
3800\end{array}$ \\
\hline
\end{tabular}

WTR YR 1982 :EAIN 4510 MAX 5230 MIN 3210 
LOCATION (Revised).--Lat $32^{\circ} 44^{\circ} 33^{\prime \prime}$, long $114^{\circ} 26^{\prime} 10^{\prime \prime}$, In NEtWWt sec.17, T.8 S.. R. 21 W. Yuma County. Hydrolog1c Unit 15070201 , at gaging station. $7.8 \mathrm{mi}$ (12.6 km) upstream from out let to Gila River, and 11 mi (18 km) east of Yuma.

PERIOD OF RECORD. - - October 1968 to current year.

PERIOD OF DAILY RECORD.--

SPECIFIC CONDUCTANCE: October 1976 to current year.

WATER QUALITY DATA, WATER YEAR OCTOBER 1981 TO SEPTEMBER 1982

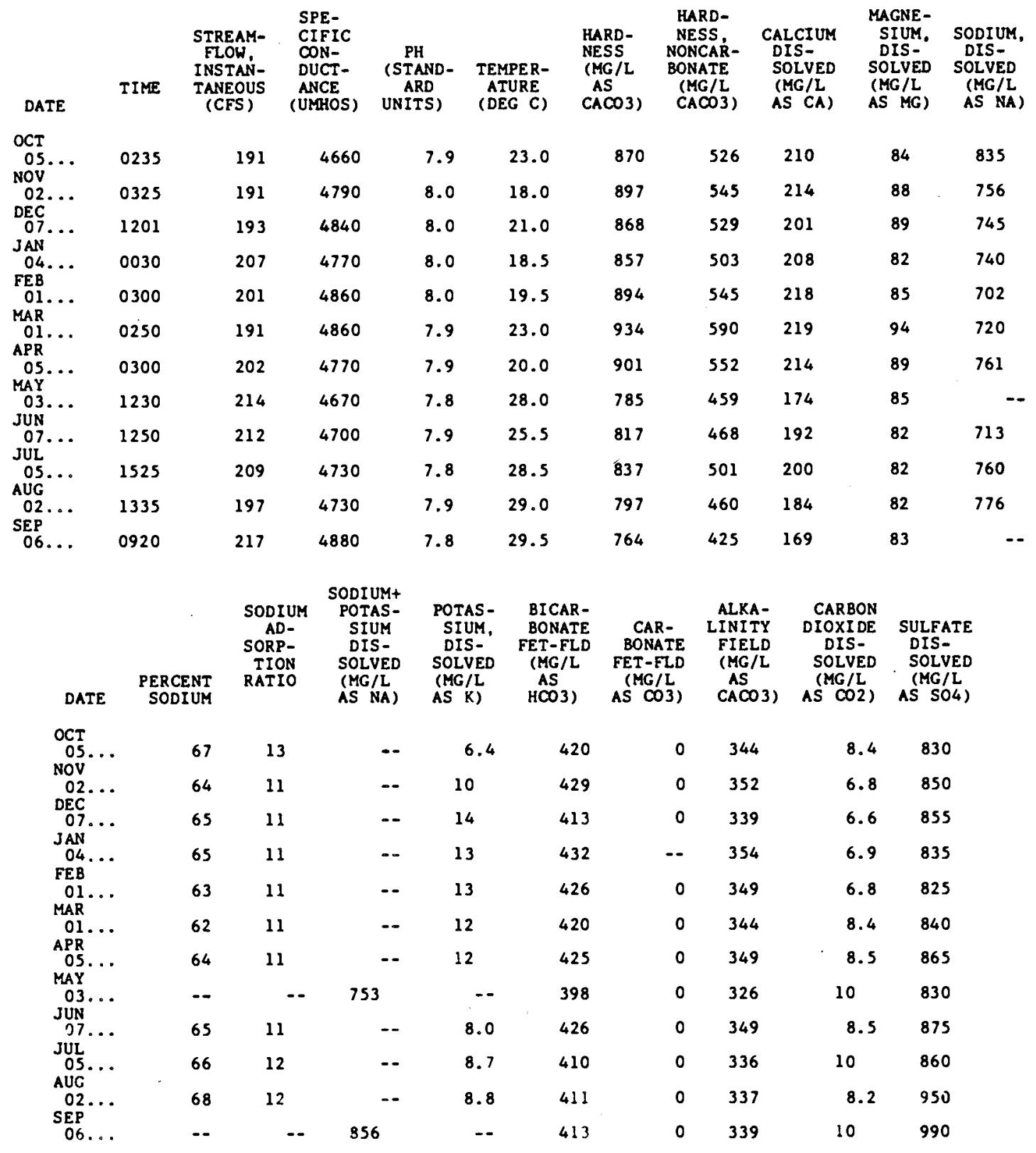


09529300 WELLTOH-MOHAWK MAII OUTLET DRAIN NEAR YUMA, AZ--CONT inued

REMARKS.- - Inpublished chemical analyses (continuing record) for water years $1961-68$ available fron district office in Tucson, Ariz. Prior to Dec. 1, 1974, samples collected at gage site 1,000 ft (304.8 m) upstream. COOPERATION, - Daily specific conductance record furnished by, and water samples collected by, U.S. Bureau of
Reclamation.

F.XTREMES FOK PERIOD OF DAILY RECORD...

SPECIFIC CONDUCTANCE: Maximam observed, 6,130 micromhos Mar. 20, 1977; minimum observed.4,550 Dec. 3, 1980.

F.XTREMES FOR CURRENT YEAR ...

SPECIFIC CONDUCTANCE: Maximum observed, 5,040 micromhos July 18 ; minisum observed, 4,570 nicromhos Dec. 10.

WATER QUALITY DATA, WATER YEAR OCTOBER 1981 TO SEPTEMBER 1982

\begin{tabular}{|c|c|c|c|c|c|c|c|c|c|}
\hline DATE & $\begin{array}{l}\text { CHLO- } \\
\text { RIDF, } \\
\text { DIS= } \\
\text { SOLVED } \\
\text { (MG/L } \\
\text { AS CL) }\end{array}$ & $\begin{array}{l}\text { FLUO- } \\
\text { RIDE, } \\
\text { DIS- } \\
\text { SOLVED } \\
\text { (MG/L } \\
\text { AS F) }\end{array}$ & $\begin{array}{l}\text { SILICA. } \\
\text { DIS- } \\
\text { SOLVED } \\
\text { (MG/L } \\
\text { AS } \\
\text { SIO2) }\end{array}$ & $\begin{array}{l}\text { SOLIDS, } \\
\text { RESIDUE } \\
\text { AT I80 } \\
\text { DEG. C } \\
\text { DIS- } \\
\text { SOLVED } \\
\text { (MG/L) }\end{array}$ & $\begin{array}{l}\text { SOLIDS, } \\
\text { SUM OF } \\
\text { CONSTI- } \\
\text { TUENTS, } \\
\text { DIS- } \\
\text { SOLVED } \\
\text { (MG/L) }\end{array}$ & $\begin{array}{c}\text { SOLIDS, } \\
\text { DIS- } \\
\text { SOIVED } \\
\text { (TONS } \\
\text { PER } \\
\text { AC-FT) }\end{array}$ & $\begin{array}{c}\text { SOLIDS, } \\
\text { DIS - } \\
\text { SOLVED } \\
\text { (TONS } \\
\text { PER } \\
\text { DAY) }\end{array}$ & $\begin{array}{c}\text { NITRO- } \\
\text { GEN, } \\
\text { NITRATE } \\
\text { DIS- } \\
\text { SOLVED } \\
\langle\text { MG/L } \\
\text { AS N }\rangle\end{array}$ & $\begin{array}{c}\text { NITRO- } \\
\text { GEN, } \\
\text { NITRATE } \\
\text { DIS- } \\
\text { SOLVED } \\
\text { (MG/L } \\
\text { AS NO3) }\end{array}$ \\
\hline $\begin{array}{l}\text { OCT } \\
05 \ldots \\
\text { NOV }\end{array}$ & 880 & 1.0 & 27 & 3000 & 3092 & 4.1 & 1550 & 2.70 & 12 \\
\hline $\begin{array}{l}02 \ldots \\
D E C\end{array}$ & 905 & 2.2 & 31 & 3080 & 3078 & 4.2 & 1590 & 2.50 & 11 \\
\hline $\begin{array}{c}07 . \\
\text { JANH }\end{array}$ & 910 & 2.0 & 24 & 3130 & 3051 & 4.3 & 1630 & 1.70 & 7.5 \\
\hline $\begin{array}{l}04 \ldots \\
\text { FEB }\end{array}$ & 900 & 1.9 & 26 & 3080 & 3021 & 4.2 & 1720 & .68 & 3.0 \\
\hline MAR & 920 & 3.4 & 24 & 3150 & 3015 & 4.3 & 1710 & 3.40 & 15 \\
\hline $\begin{array}{l}01 \ldots \\
\mathrm{APR}\end{array}$ & 910 & 1.8 & 30 & 3140 & 3045 & 4.3 & 1620 & 2.70 & 12 \\
\hline MAY & 900 & 2.1 & 29 & 3070 & 3095 & 4.2 & 1670 & 3.20 & 14 \\
\hline JUN $03 .$. & 860 & 1.9 & 20 & 3010 & 2940 & 4.1 & 1740 & 3.60 & 16 \\
\hline$\underset{\text { SUL }}{07 \ldots}$ & 860 & 1.9 & 29 & 3150 & 2977 & 4.3 & 1800 & 1.40 & 6.2 \\
\hline AUG & 8,0 & 2.4 & 28 & 3230 & 3019 & 4.4 & 1820 & 1.40 & 6.2 \\
\hline $\begin{array}{l}02 \ldots \\
\text { SEP }\end{array}$ & 870 & 4.0 & 23 & 3140 & 3109 & 4.3 & 1670 & 2.00 & 8.9 \\
\hline U6... & 880 & 2.0 & 25 & 3150 & 3220 & 4.3 & 1850 & 2.30 & 10 \\
\hline
\end{tabular}




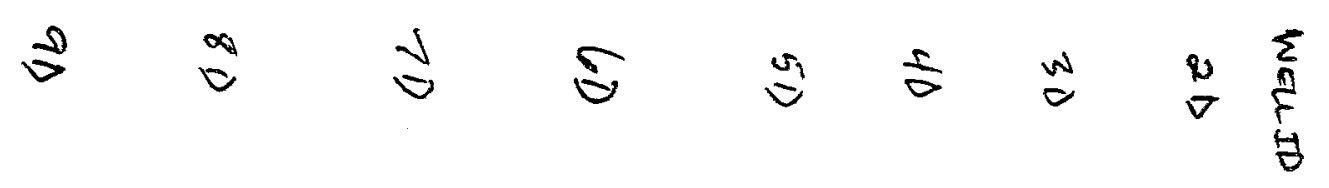

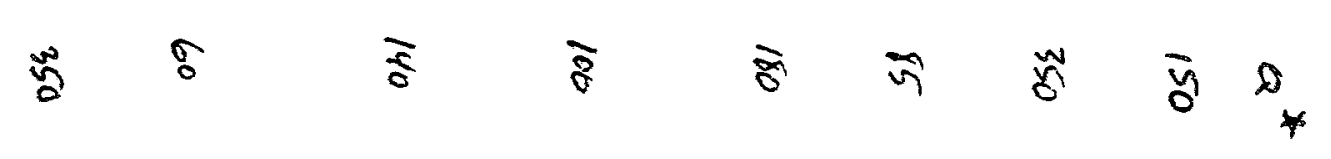

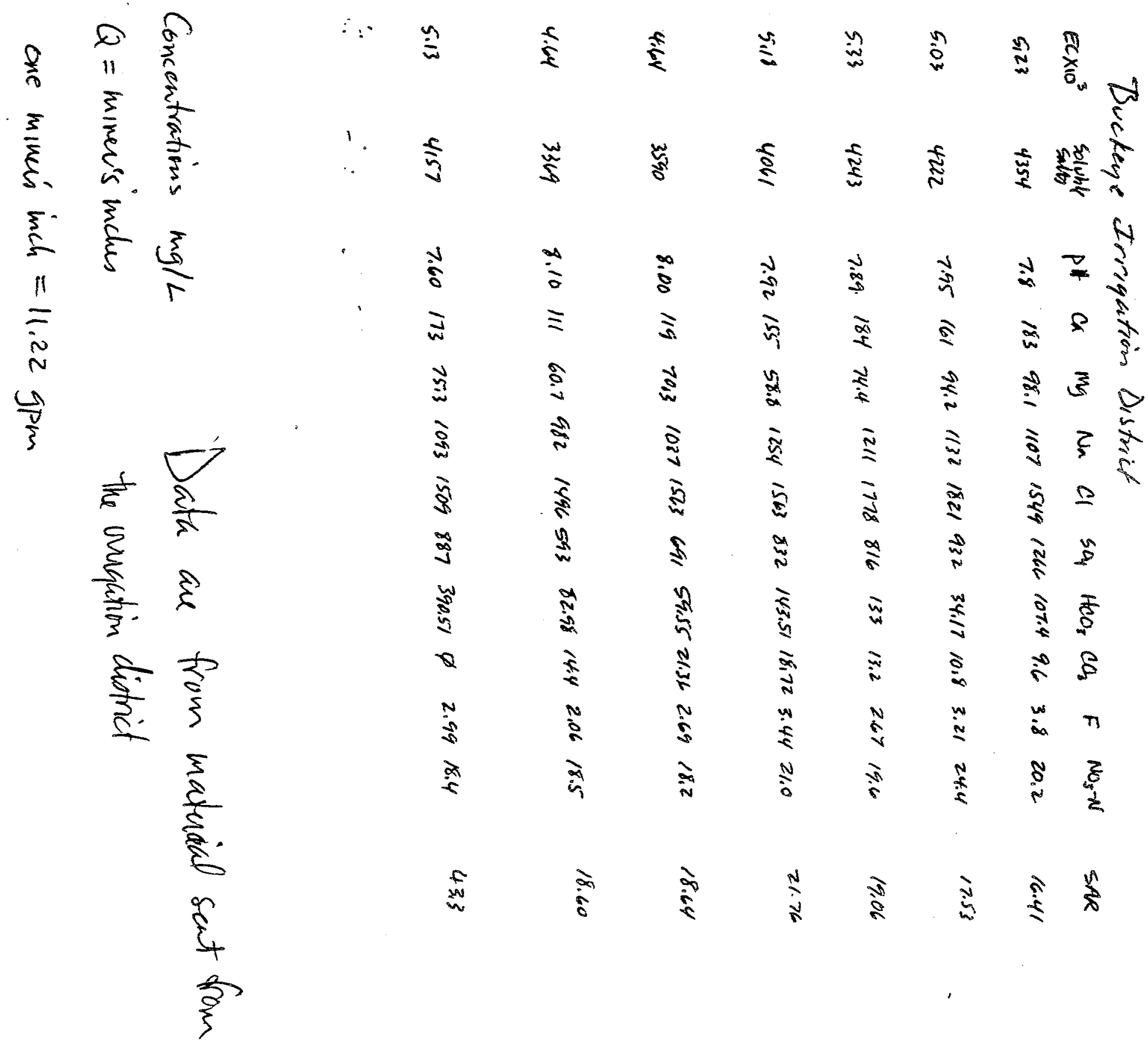


LOCATION.--Lat 32*42"46", long 114*35'50". in NWtNWk sec.26, T.8 S., R.23 W., Yuma County, Hydrologic Unit 15030107 , at gaging station, 1.5 mi $(2.4 \mathrm{~km})$ upstream from out let to Colorado River, and $1.5 \mathrm{mi}$ (2.4 $\mathrm{km})$ east of Yuma.

PERIOD OF RECORD.--October 1968 to current year.

PERIOD OF DAIIY RECORD.--

SPECIFIC CONDUCTANCE: October 1978 to current year.

REMARKS..-Unpublished miscellaneous chemical analyses for, warer years 1966-68 available from district office in Tucson, Ariz.

WATER QUALITY DATA, WATER VEAR OCTOBER 1981 TO SEPTEMBER 1982

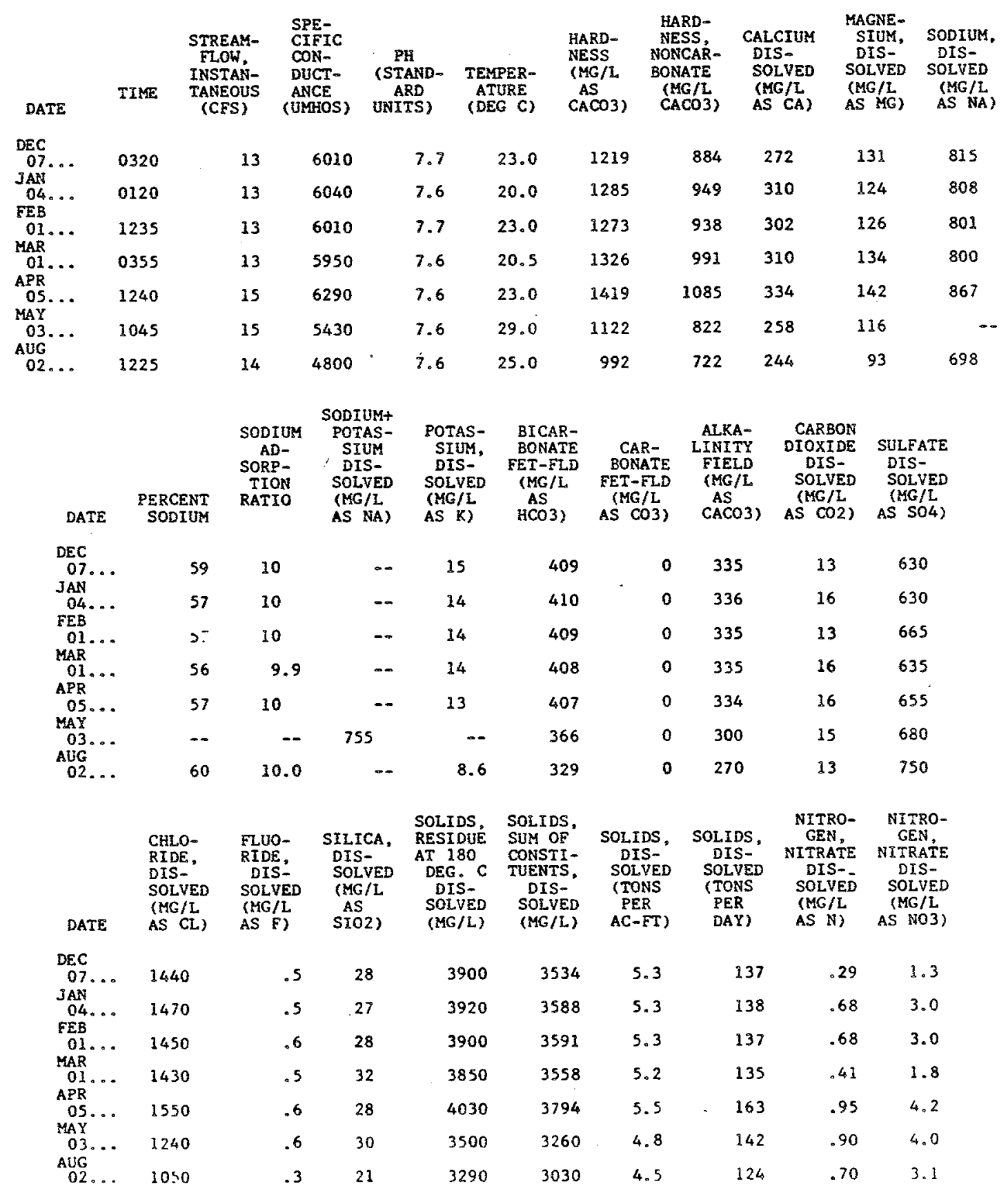


09529440 SOUTH GILA PUMP OUTLET CHANNEL NO. 4 NEAR YUMA, AZ--Continued

COOPERATION.--Wacer samples collected by U. S. Bureau of Reclamation.

EXTREMES FOR PERIOD OF DAILY RECORD.--

SPECIFIC CONDUCTANCE: Maximum observed, 8,700 micromhos Nov. 23, 1979: minimum observed, 3,800 micromhos July 3 , 1979.

EXTREMES FOR CURRENT YEAR.--

SPECIFIC CONDUCTANCE: Maximum observed, 6,450 micromhos Max, 28; minimum observed, 4,890 micromhos Aug. 1.

SPECTFIC CONDUCTANCE (MICROMHOS/CM AT 25 DEG. C). WATER YEAR OCTOBER 1981 TO SEPTEMBER 1982 SPECTFIC CONDUCTANCE (MICROMHOS/CM AT 25 DEG. C)
ONCE-DAILY

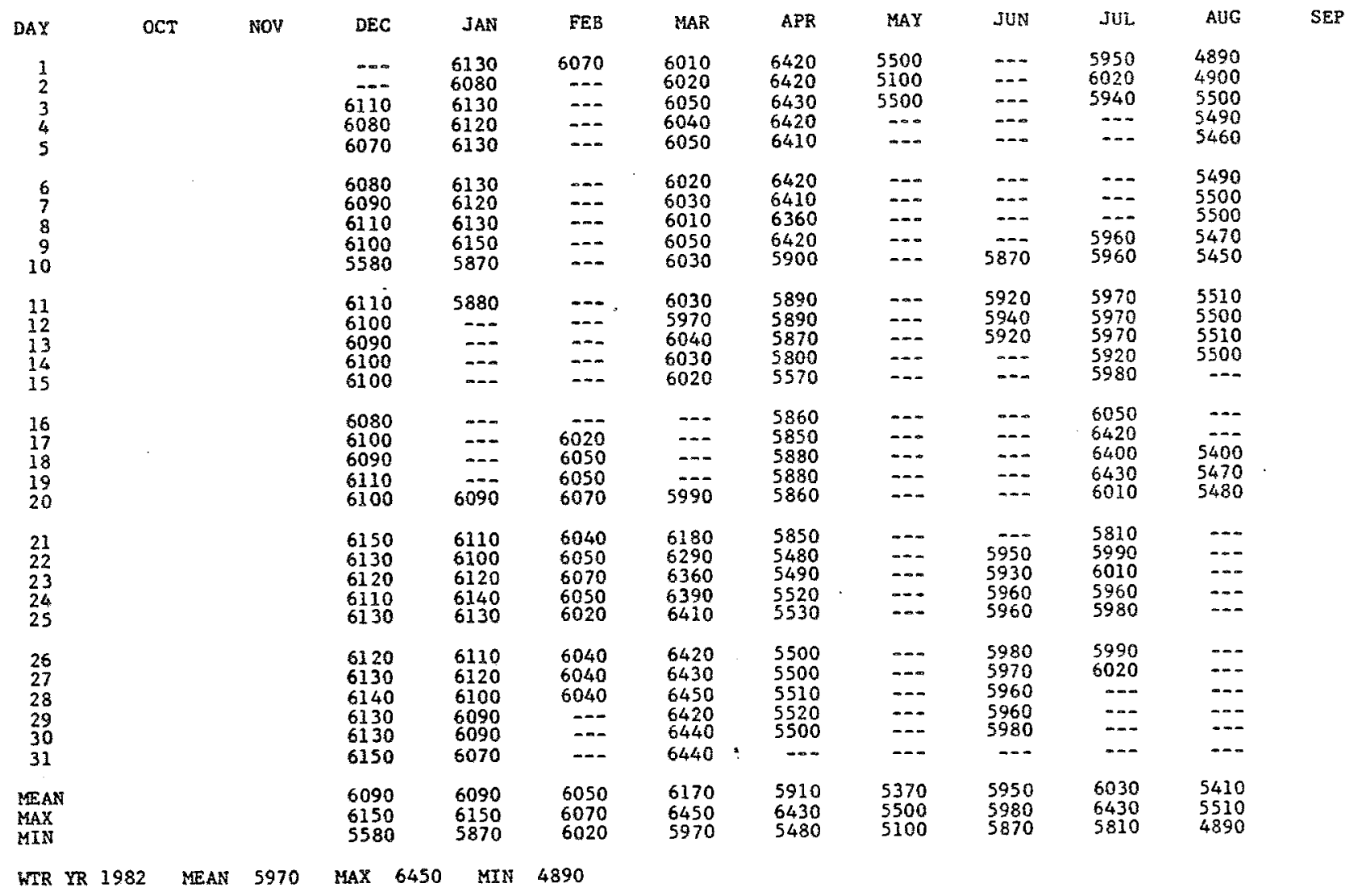


DIVERSTONS AND RETURN FLOWS AT AND BELOW IMPERIAL DAM

09529300 WELLTON-MOHAWK MATN OUTLET DRAIN NEAR YUMA, AZ--Continued

SPECIFIC CONDUCTANCE (MICROMHOS/CH AT 25 DEG. C). WATER YEAR OCTOBER 1981 TO SEPTEMBER 1982

SPECIFIC CONDUCTANCE (MICROMHOS/CK AT ONCE-DAILY

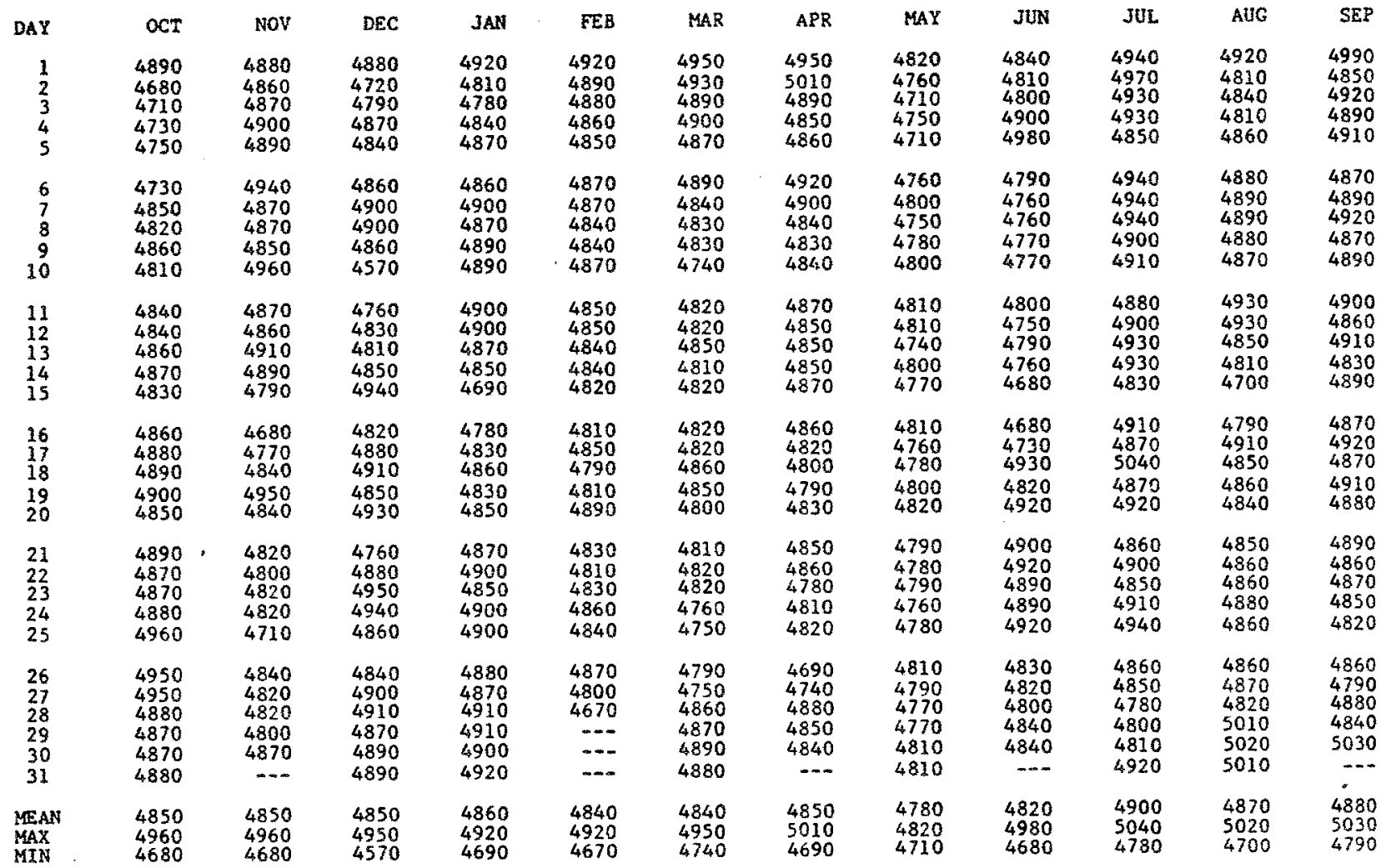

WLR YR 1982 MEAN 4850 MAX 5040 MIN 4570 
APPENDIX D

GROUND-WATER CHEMISTRY 
CHEHICAL ANAL YSES FOR SELECTED HELLS IN AREA I

(The following inforiation was obtained from ketzger, 1973)

\begin{tabular}{|c|c|c|c|c|c|c|c|c|c|c|c|c|}
\hline LDCATION & DATE & $\begin{array}{l}\text { SAMPLE } \\
\text { IWTERUAL } \\
\text { (FEET) }\end{array}$ & $\begin{array}{l}\text { HCOS } \\
\text { IMS/LI }\end{array}$ & $\begin{array}{c}\text { CO3 } \\
(N G / L)\end{array}$ & $\begin{array}{c}\mathrm{C} \\
(\mathrm{m}) / \mathrm{L})\end{array}$ & $\begin{array}{c}504 \\
(46 / L)\end{array}$ & $\begin{array}{l}\text { WA + K } \\
\text { (MG/L) }\end{array}$ & $\begin{array}{c}\text { CA } \\
\text { (WG/L) }\end{array}$ & $\begin{array}{c}M G \\
\text { MGG/L) }\end{array}$ & $\begin{array}{l}\text { MITRO- } \\
\text { GEN } \\
\text { IUG/L) }\end{array}$ & $\begin{array}{l}\text { PHDS- } \\
\text { PORDUS } \\
\text { (MG/L) }\end{array}$ & $\begin{array}{l}\text { TDS } \\
(n \in / L)\end{array}$ \\
\hline$B-5-21 \quad 218 B B$ & $03-28-33$ & $127-128$ & 316 & - & 1890 & 1250 & 931 & 572 & 188 & - & - & 4990 \\
\hline $\mathrm{B}-5-21$ OACCC & $03-28-33$ & $125-12 b$ & 428 & - & 3220 & 1850 & 1500 & 844 & 351 & - & - & 8000 \\
\hline $\mathrm{B}-6-21 \quad 02 \mathrm{BAB}$ & $03-28-63$ & $125-126$ & 560 & - & 1800 & 1800 & 1630 & $28 b$ & 167 & - & - & 6050 \\
\hline B-7-21 $23 A C D$ & $11-02-62$ & $113-114$ & 412 & - & 900 & 1050 & 325 & 334 & 123 & - & - & 3260 \\
\hline
\end{tabular}


CHEMICAL ANALYSES FOR SELERTED WELLS IN AREA II

The following infor sation was obtained from the U. S. Geological Survey, Tucson, Arizona)

LOCAL

IDENT-

I-

FIER

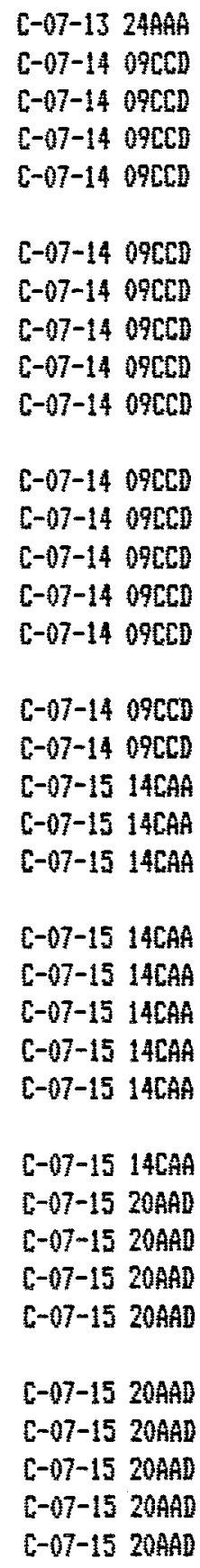

\begin{tabular}{|c|c|c|c|c|c|c|c|c|c|}
\hline $11-17-76$ & -- & 29.0 & - & -- & 4740 & -- & 7.9 & 0.6 & 26 \\
\hline $03-01-65$ & 1230 & -- & -- & -- & 7530 & -- & -- & -- & 267 \\
\hline $03-29-65$ & 1230 & $-\infty$ & -- & - & 6130 & - & - & - & 326 \\
\hline $07-06-65$ & 1230 & -- & - & - & 5980 & -- & - & - & 340 \\
\hline $08-30-65$ & 1230 & -- & -- & - & 5720 & -- & -- & -- & 335 \\
\hline $11-30-65$ & 1230 & -- & -- & -- & 5760 & -- & -- & -- & 331 \\
\hline $02-28-66$ & 1230 & -- & -- & -- & 5190 & - & -- & -- & 460 \\
\hline $07-05-66$ & 1230 & - & -- & -- & 5460 & -- & -- & -- & 345 \\
\hline $10-08-67$ & 1230 & -- & -- & - & 3350 & -- & -- & - & 288 \\
\hline $07-01-68$ & 1230 & -- & -- & -- & 3200 & -- & -- & -- & 310 \\
\hline $07-01-69$ & 1230 & -- & -- & -- & 2800 & -- & - & -- & 290 \\
\hline $09-02-71$ & 1230 & -- & -- & -- & 2090 & -- & 7.7 & 9.2 & 238 \\
\hline $07-03-72$ & 1230 & -- & -- & -- & 2160 & -- & 7.9 & 6.1 & 252 \\
\hline $09-0 b-73$ & 1230 & -- & -- & -- & 2650 & -- & 7.5 & 18 & 298 \\
\hline $05-30-74$ & 1230 & - & - & -- & 2690 & -- & 7.8 & 8.9 & 290 \\
\hline $06-03-75$ & 1230 & -- & - & -- & 2350 & -- & 7.8 & 8.8 & 285 \\
\hline $05-04-76$ & 1230 & - & -- & -- & 2420 & -- & 7.9 & 6.5 & 267 \\
\hline $12-0 b-67$ & 1230 & -- & - & -- & 22700 & - & -- & -- & 371 \\
\hline $07-01-68$ & 1230 & -- & -- & -- & 17800 & -- & - & -- & 360 \\
\hline $07-01-69$ & 1230 & -- & - & -- & 13000 & - & - & -- & 400 \\
\hline $09-04-70$ & 1230 & -- & - & -- & 11200 & -- & 7.8 & 11 & 365 \\
\hline $12-30-71$ & 1230 & -- & -- & -- & 9680 & -- & 7.9 & 10 & 418 \\
\hline $01-03-73$ & 1230 & -- & - & -- & 9430 & -- & 7.9 & 10 & 409 \\
\hline $01-02-74$ & 1230 & -- & - & -- & 8220 & -- & 0.0 & 8.0 & 412 \\
\hline $02-06-75$ & 1230 & - & -- & -- & 8520 & -- & 8.0 & 6.5 & 333 \\
\hline $01-29-76$ & 1230 & -- & -- & -- & 7770 & - & 7.6 & 20 & 407 \\
\hline $08-28-64$ & 1230 & - & - & - & 13800 & -- & -- & -- & 281 \\
\hline $03-29-65$ & 1230 & - & - & - & 13400 & -- & -- & -- & 276 \\
\hline $07-06-65$ & 1230 & $-\infty$ & $-\infty$ & - & 13800 & - & -- & - & 262 \\
\hline $12-17-65$ & 1230 & - & - & - & 13800 & - & - & - & 267 \\
\hline $03-24-67$ & 1230 & - & -- & - & 13600 & -- & $-\infty$ & - & 273 \\
\hline $10-01-67$ & 1230 & - & - & - & 14600 & - & -- & -- & 278 \\
\hline $10-24-68$ & 1230 & - & - & - & 14300 & -- & -- & - & 273 \\
\hline $10-01-69$ & 1230 & - & - & - & 13800 & - & -- & -- & 270 \\
\hline $11-03-70$ & 1230 & - & -- & -- & 13800 & -- & 7.8 & 8.3 & 270 \\
\hline
\end{tabular}




\begin{tabular}{|c|c|c|c|c|c|c|c|c|c|c|c|c|}
\hline DATE & $\begin{array}{c}\text { ACIDITY } \\
\text { (W6/L } \\
\text { AS } \\
\text { CACDS) } \\
\text { (00435) }\end{array}$ & $\begin{array}{c}\text { BICAR- } \\
\text { BONATE } \\
\text { FET-FLD } \\
\text { (WG/L } \\
\text { AS } \\
\text { HCDS) } \\
(00440)\end{array}$ & $\begin{array}{c}\text { CAR- } \\
\text { BONATE } \\
\text { FET-FLD } \\
\text { (HGLL } \\
\text { AS COS) } \\
\text { (00445) }\end{array}$ & $\begin{array}{c}\text { NITRO- } \\
\text { GEN, } \\
\text { TOTAL } \\
\text { (MG/L } \\
\text { AS N) } \\
\text { (00600) }\end{array}$ & $\begin{array}{c}\text { NITRO- } \\
\text { GEN, } \\
\text { ORGANIC } \\
\text { TOTAL } \\
\text { (MEAL } \\
\text { AS W) } \\
\text { (00605) }\end{array}$ & $\begin{array}{c}\text { MTTR- } \\
\text { GEN, } \\
\text { ORGANIC } \\
\text { DIS- } \\
\text { SDLVED } \\
\text { (HS/L } \\
\text { AS W) } \\
\text { (O0607) }\end{array}$ & $\begin{array}{c}\text { NITRO- } \\
\text { GEEN, } \\
\text { NITRATE } \\
\text { DIS- } \\
\text { SULVED } \\
\text { IMBA } \\
\text { AS N1 } \\
\text { (00618) }\end{array}$ & $\begin{array}{l}\text { WITRO- } \\
\text { GEN, } \\
\text { HITRATE } \\
\text { TOTAL } \\
\text { IMG/L } \\
\text { AS NI } \\
\text { (00620) }\end{array}$ & $\begin{array}{c}\text { NITRD- } \\
\text { SEN, } \\
\text { WD2+NO3 } \\
\text { DIS- } \\
\text { SQLVED } \\
\text { HEG } \\
\text { AS NI } \\
\text { (00631) }\end{array}$ & $\begin{array}{c}\text { PHDS- } \\
\text { PHATE, } \\
\text { ORTHD, } \\
\text { DIS- } \\
\text { SOLUED } \\
\text { (WG/L } \\
\text { AS PD4) } \\
\text { (00660) }\end{array}$ & $\begin{array}{c}\text { PHDS- } \\
\text { PHORIS, } \\
\text { OREANIC } \\
\text { TOTAL } \\
\text { IHG/L } \\
\text { AS PI } \\
\text { (OOO670) }\end{array}$ & $\begin{array}{l}\text { PHDS- } \\
\text { PHDRUS, } \\
\text { ORTH, } \\
\text { DIS- } \\
\text { SALUED } \\
\text { (MESL } \\
\text { AS PI } \\
\text { I00B71) }\end{array}$ \\
\hline $11-17-76$ & - & 32 & 0 & -- & -- & -- & -- & -- & 0.38 & 0.0 & -- & 0.01 \\
\hline $03-01-65$ & - & 330 & -- & -- & -- & - & -- & - & -- & -- & -- & -- \\
\hline $03-29-65$ & -- & 400 & $-\infty$ & - & - & - & -- & -- & -- & -- & -- & - \\
\hline $07-0 b-65$ & - & 410 & -- & -- & -- & - & -- & $-\infty$ & -- & -- & - & -- \\
\hline $08-30-65$ & -- & 410 & - & -- & -- & -- & -- & -- & -- & - & - & -- \\
\hline $11-30-65$ & - & 400 & - & - & -- & - & -- & -- & -- & -- & -- & - \\
\hline $02-28-66$ & -- & 560 & -- & -- & - & - & - & - & -- & - & - & -- \\
\hline $07-05-66$ & $-\infty$ & 420 & -- & -- & -- & -- & -- & - & -- & - & - & -- \\
\hline $10-08-67$ & - & 350 & -- & - & -- & -- & - & -- & -- & -- & - & -- \\
\hline $07-01-68$ & - & 380 & -- & -- & -- & - & -- & -- & -- & - & - & -- \\
\hline $07-01-69$ & - & 350 & - & -- & -- & -- & -- & - & -- & -- & -- & -- \\
\hline $09-02-71$ & -- & 290 & -- & - & - & - & -- & - & -- & - & -- & -- \\
\hline $07-03-72$ & -- & 310 & -- & - & - & $-\infty$ & -- & -- & -- & -- & -- & -- \\
\hline $09-106-73$ & -- & 350 & -- & - & -- & - & -- & - & -- & - & -- & -- \\
\hline $05-30-74$ & - & 350 & -- & -- & -- & - & - & - & - & - & -- & - \\
\hline $06-03-75$ & -- & 350 & -- & - & -- & -- & -- & - & -- & - & -- & -- \\
\hline $05-04-76$ & -- & 330 & -- & -- & -- & - & -- & -- & -- & - & -- & -- \\
\hline $12-06-67$ & $-\infty$ & 450 & $-\infty$ & - & -- & - & -- & - & -- & - & -- & -- \\
\hline $07-01-68$ & - & 440 & -- & -- & -- & -- & -- & - & - & - & -- & -- \\
\hline $07-01-69$ & -- & 500 & -- & -- & -- & - & - & - & -- & -- & - & - \\
\hline $08-04-70$ & -- & 450 & - & - & $-\infty$ & -- & -- & - & - & - & - & -- \\
\hline $12-30-71$ & -- & 510 & -- & -- & -- & - & - & - & $-\infty$ & -- & -- & - \\
\hline $01-03-73$ & -- & 500 & -- & -- & $-\infty$ & -- & - & - & -- & - & -- & -- \\
\hline $01-02-74$ & -- & 500 & -- & -- & -- & - & - & - & -- & -- & -- & -- \\
\hline $02-06-75$ & -- & 410 & - & - & - & - & - & - & -- & - & -- & -- \\
\hline $01-29-76$ & -- & 500 & -- & - & -- & - & - & $\infty$ & - & - & - & - \\
\hline $08-28-64$ & -- & 340 & - & - & -- & - & $\infty$ & - & - & - & $\infty$ & - \\
\hline $03-29-65$ & -- & 340 & -- & - & -- & -- & - & -- & -- & $-\infty$ & - & -- \\
\hline $07-06-65$ & -- & 320 & - & - & $-\infty$ & - & $-\infty$ & - & -- & - & -- & - \\
\hline $12-17-65$ & -- & 330 & -- & - & - & - & - & $-\infty$ & - & - & - & - \\
\hline $03-24-67$ & -- & 330 & - & - & - & - & $=$ & - & -- & - & -- & -- \\
\hline $10-01-67$ & -- & 340 & -- & -- & - & - & - & - & - & -- & - & -- \\
\hline $10-24-68$ & -- & 330 & -- & -- & -- & - & - & $-\infty$ & -- & - & -- & - \\
\hline $10-01-69$ & - & 330 & -- & -- & - & - & -- & - & -- & -- & -- & - \\
\hline $11-03-70$ & -- & 330 & - & - & -- & -- & -- & - & - & - & - & - \\
\hline
\end{tabular}




\begin{tabular}{|c|c|c|c|c|c|c|c|c|c|c|c|}
\hline DATE & $\begin{array}{c}\text { PHOS- } \\
\text { PHORUS, } \\
\text { ORGANIC } \\
\text { DIS- } \\
\text { SOLUED } \\
\text { (HEGL } \\
\text { AS P) } \\
(00673)\end{array}$ & $\begin{array}{l}\text { HARD- } \\
\text { NESS } \\
\text { (NG/L } \\
\text { AS } \\
\text { CACO3) } \\
\text { (00900) }\end{array}$ & $\begin{array}{c}\text { HARD- } \\
\text { UESS, } \\
\text { HONCAR- } \\
\text { BONATE } \\
\text { (NHGL } \\
\text { CACDS) } \\
\text { (00902) }\end{array}$ & $\begin{array}{l}\text { CALCIUH } \\
\text { DIS- } \\
\text { SOLVED } \\
\text { (MG/L } \\
\text { AS CA) } \\
\text { (00915) }\end{array}$ & $\begin{array}{c}\text { MAGNE- } \\
\text { SIUH, } \\
\text { DIS- } \\
\text { SOLUED } \\
\text { (NG/L } \\
\text { AS MG) } \\
(00925)\end{array}$ & $\begin{array}{l}\text { SODIUN, } \\
\text { DIS- } \\
\text { SOLUED } \\
\text { (MG/L } \\
\text { AS NA) } \\
\text { (O0930) }\end{array}$ & $\begin{array}{c}\text { SODLH } \\
\text { AD- } \\
\text { SORP- } \\
\text { TION } \\
\text { RATID } \\
\text { 1009311 }\end{array}$ & $\begin{array}{c}\text { PERCENT } \\
\text { SODIUI } \\
1009321\end{array}$ & $\begin{array}{c}\text { SODIUH" } \\
\text { POTAS- } \\
\text { SIUH } \\
\text { DIS- } \\
\text { SOLVED } \\
\text { (NG } \\
\text { AS NA) } \\
\text { (DOQS3) }\end{array}$ & $\begin{array}{l}\text { POTAS- } \\
\text { SHUM, } \\
\text { DIS- } \\
\text { SOLUED } \\
\text { (HE/L } \\
\text { AS K) } \\
(00935)\end{array}$ & $\begin{array}{l}\text { CHLO- } \\
\text { RIDE, } \\
\text { DIS- } \\
\text { SOLVED } \\
\text { IMGH } \\
\text { AS CL) } \\
\text { (OOOA40I }\end{array}$ \\
\hline $11-17-76$ & -- & 850 & 820 & 320 & 12 & 780 & 12 & 66 & -- & 6.4 & 670 \\
\hline $03-01-65$ & -- & 1900 & 1600 & 510 & 140 & 1000 & 11 & - & - & -- & 2000 \\
\hline $03-29-65$ & -- & 1500 & 1200 & 400 & 120 & 880 & 10 & - & -- & -- & 1500 \\
\hline $07-06-65$ & - & 1400 & 1100 & 390 & 110 & 850 & 10 & -- & -- & -- & 1400 \\
\hline $08-30-65$ & -- & 1300 & 990 & 380 & 94 & 810 & 10 & - & - & -- & 1300 \\
\hline $11-30-65$ & - & 1400 & 1000 & 370 & 110 & 900 & 10 & - & -- & -- & 1300 \\
\hline $02-28-66$ & -- & 1200 & 700 & 290 & 110 & 780 & 10 & -- & - & -- & 1100 \\
\hline $07-05-66$ & -- & 1300 & 920 & 340 & 100 & 790 & 10 & - & -- & - & 1200 \\
\hline $10-08-67$ & -- & 650 & 360 & 170 & 53 & 510 & 9 & -- & - & -- & 550 \\
\hline $07-01-68$ & -- & 640 & 330 & 170 & 51 & 470 & 8 & - & -- & -- & 490 \\
\hline $07-01-69$ & - & 530 & 240 & 150 & 41 & 420 & 8 & -- & -- & -- & 380 \\
\hline $09-02-71$ & -- & 390 & 140 & 110 & 23 & 340 & 8 & 65 & -- & 8.6 & 220 \\
\hline $07-0.3-72$ & - & 440 & 190 & 130 & 26 & 300 & 6 & 59 & -- & 8.6 & 220 \\
\hline $09-0 b-73$ & - & 560 & 270 & 170 & 35 & 380 & 7 & 59 & -- & 10 & 330 \\
\hline $05-30-74$ & -- & 600 & 310 & 170 & 44 & 390 & 7 & 58 & -- & 9.4 & $360^{\circ}$ \\
\hline $06-03-75$ & -- & 500 & 220 & 140 & 36 & 350 & 7 & 60 & -- & 7.4 & 290 \\
\hline $05-04-76$ & - & 510 & 240 & 120 & 50 & 320 & $b$ & 58 & - & 7.8 & 290 \\
\hline $12-06-67$ & -- & 4700 & 4400 & 1000 & 530 & 3900 & 25 & - & -- & - & 7200 \\
\hline $07-01-68$ & - & 3300 & 2900 & 690 & 370 & 3100 & 24 & -- & -- & $-\infty$ & 5000 \\
\hline $07-01-69$ & -- & 2100 & 1700 & 500 & 200 & 2400 & 24 & - & -- & - & 3400 \\
\hline $08-04-70$ & -- & 1600 & 1200 & 410 & 140 & 2100 & 24 & 74 & -- & 20 & 2600 \\
\hline $12-30-71$ & -- & 1400 & 960 & 360 & 110 & 1900 & 23 & 75 & -- & 17 & 2100 \\
\hline $01-03-73$ & - & 1100 & 720 & 270 & 110 & 1600 & 21 & 75 & -- & 16 & 1700 \\
\hline $01-02-74$ & -- & 1100 & 660 & 260 & 100 & 1500 & 21 & 75 & - & 15 & 1700 \\
\hline $02-06-75$ & -- & 1000 & 720 & 240 & 110 & 1600 & 22 & 76 & - & 25 & 1900 \\
\hline $01-29-76$ & - & 1000 & 610 & 220 & 110 & 1500 & 21 & 76 & -- & II & 1600 \\
\hline $08-28-64$ & $-\infty$ & 2200 & 2000 & 420 & 290 & 2500 & 23 & -- & -- & - & 4100 \\
\hline $05-29-65$ & -- & 2200 & 2000 & 420 & 290 & 2500 & 23 & $-\infty$ & -- & $-\infty$ & 4300 \\
\hline $07-06-65$ & - & 2200 & 2000 & 430 & 290 & 2500 & 24 & - & $\cdots$ & - & 4300 \\
\hline $12-17-65$ & -- & 2300 & 2000 & 440 & 280 & 2500 & 24 & - & $-\infty$ & - & 4300 \\
\hline $03-24-67$ & - & 2300 & 2000 & 430 & 290 & 2500 & 24 & - & -- & - & 4300 \\
\hline $10-01-67$ & - & 2300 & 2000 & 430 & 300 & 2500 & 23 & - & - & - & 4300 \\
\hline $10-24-68$ & -- & 2300 & 2000 & 430 & 290 & 2500 & 24 & -- & - & - & 4300 \\
\hline $10-01-69$ & -- & 2200 & 1900 & 480 & 240 & 2400 & 24 & - & - & -- & 4200 \\
\hline $11-03-70$ & - & 2200 & 1900 & 470 & 250 & 2400 & 22 & 70 & $-\infty$ & 9.4 & 4100 \\
\hline
\end{tabular}


SOLIDS, SOLIDS,

NITR0-

FLUD- SILICA, MANGA- RESIDUE SUM OF SDLIDS, SOLIDS, GEN,

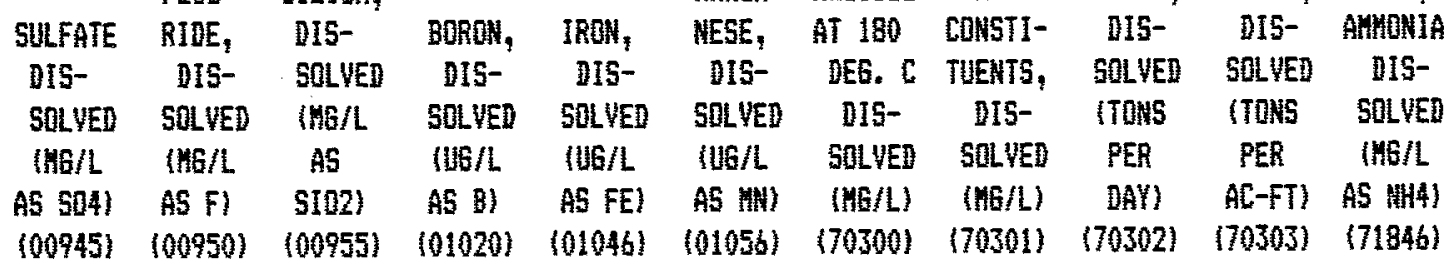

\begin{tabular}{|c|c|c|c|c|c|c|c|c|c|c|c|}
\hline $11-17-76$ & 1600 & 4.3 & 10 & 3300 & $<10$ & 30 & 3470 & 3400 & -- & 4.7 & - \\
\hline $03-01-65$ & 990 & -- & -- & -- & -- & -- & -- & 4800 & - & -- & - \\
\hline $03-29-65$ & 950 & - & -- & -- & -- & -- & - & 4100 & - & - & - \\
\hline $07-0 b-65$ & 950 & - & - & - & - & -- & - & 3900 & - & -- & -- \\
\hline $08-30-65$ & 910 & - & -- & - & -- & - & - & 3700 & - & - & -- \\
\hline $11-30-65$ & 910 & -- & -- & -- & -- & -- & -- & 3700 & - & -- & -- \\
\hline $02-28-66$ & 860 & - & -- & -- & - & - & - & 3400 & -- & -- & -- \\
\hline $07-05-66$ & 940 & -- & -- & -- & - & $-\infty$ & - & 3600 & - & - & -- \\
\hline $10-08-67$ & 660 & - & -- & -- & -- & - & - & 2100 & -- & -- & -- \\
\hline $07-0 !-68$ & 660 & -- & -- & -- & -- & -- & -- & 2000 & -- & -- & -- \\
\hline $07-01-6 ?$ & 600 & - & -- & - & -- & - & -- & 1800 & -- & -- & -- \\
\hline $09-02-71$ & 540 & -- & - & -- & - & -- & - & 1400 & -- & -- & -- \\
\hline $07-03-72$ & 480 & - & -- & -- & -- & - & -- & 1300 & -- & -- & -- \\
\hline $09-0 b-73$ & 620 & -- & 25 & - & -- & -- & - & 1700 & -- & 2.4 & - \\
\hline $05-30-74$ & 580 & - & 25 & -- & - & - & - & 1700 & -- & 2.4 & -- \\
\hline $0 b-03-75$ & 530 & -- & 24 & -- & -- & - & - & 1600 & -- & 2.1 & -- \\
\hline $05-04-76$ & 570 & - & 25 & - & - & -- & - & 1500 & -- & 2.1 & -- \\
\hline $12-06-67$ & 2600 & -- & - & $-\infty$ & - & -. & - & 15000 & - & -- & - \\
\hline $07-01-68$ & 2500 & - & -- & - & -- & -- & - & 12000 & - & -- & -- \\
\hline $07-01-69$ & 2100 & -- & - & -- & - & -- & - & 8900 & - & - & -- \\
\hline $08-04-70$ & 2000 & - & -- & - & - & - & - & 7500 & - & -- & - \\
\hline $12-30-71$ & 2000 & -- & -- & -- & -- & -- & $-\infty$ & 6800 & $-\infty$ & -- & -- \\
\hline $01-03-73$ & 1600 & - & -- & -- & - & $-\infty$ & - & 5600 & - & -- & -- \\
\hline $01-02-74$ & 1400 & -- & 45 & -- & - & - & -- & 5300 & -- & 7.2 & -- \\
\hline $02-0 b-75$ & 1400 & - & 42 & - & - & - & -- & 5500 & - & 7.5 & - \\
\hline $01-29-76$ & 1500 & -- & 48 & $-\infty$ & - & - & - & 5100 & - & 7.0 & - \\
\hline $08-28-64$ & 1400 & - & -- & $-\infty$ & -- & $-\infty$ & - & 8900 & - & -- & - \\
\hline $03-29-65$ & 1400 & $-\infty$ & - & $-\infty$ & - & - & $\infty$ & 9000 & - & - & $-\infty$ \\
\hline $07-0 b-65$ & 1400 & - & -- & - & - & -- & - & 9000 & - & - & - \\
\hline $12-17-65$ & 1300 & - & - & - & - & - & - & 9000 & - & - & $T$ \\
\hline $03-24-67$ & 1400 & - & - & - & - & -- & -- & 9100 & -- & -- & $-\infty$ \\
\hline $10-01-67$ & 1400 & - & -- & - & -- & - & -- & 9100 & -- & - & -- \\
\hline $10-24-68$ & 1400 & - & - & - & -- & -- & -- & 9100 & -- & -- & -- \\
\hline $10-01-69$ & 1300 & -- & $-\infty$ & -- & - & - & - & 8800 & -- & -- & -- \\
\hline $11-03-70$ & 1200 & -- & -- & -- & - & - & - & 8600 & - & - & -- \\
\hline
\end{tabular}




\begin{tabular}{|c|c|c|c|c|c|c|c|c|c|c|c|}
\hline DATE & $\begin{array}{c}\text { MITHO- } \\
\text { GEN, } \\
\text { MITRATE } \\
\text { TOTAL } \\
\text { (HE/L } \\
\text { AS HOS) } \\
\text { (7185D! }\end{array}$ & $\begin{array}{c}\text { NITRO- } \\
\text { GEN, } \\
\text { NITRATE } \\
\text { DIS- } \\
\text { SOLVED } \\
\text { (MGLL } \\
\text { AS NQ3) } \\
\text { (71851) }\end{array}$ & $\begin{array}{c}\text { NITRD- } \\
\text { GEN, } \\
\text { NITRITE } \\
\text { DIS- } \\
\text { SOLUED } \\
\text { (MSG/L } \\
\text { A5 MD2) } \\
\text { (71856) }\end{array}$ & $\begin{array}{c}\text { NITRO- } \\
\text { BEN, } \\
\text { TDTAL } \\
\text { (U6A } \\
\text { AS UDS) } \\
\text { (71887) }\end{array}$ & $\begin{array}{c}\text { ELEY. } \\
\text { OF LAND } \\
\text { SURFACE } \\
\text { DATUM } \\
\text { (FT. } \\
\text { ABOUE } \\
\text { NGUD) } \\
\text { (72000) }\end{array}$ & $\begin{array}{c}\text { DEPTH } \\
\text { OF } \\
\text { MELL, } \\
\text { TOTAL } \\
\text { (FEET) } \\
\text { (7200B) }\end{array}$ & $\begin{array}{c}\text { DEPTH } \\
\text { TO TOP } \\
\text { OF } \\
\text { SAYPLE } \\
\text { INTER- } \\
\text { VAL } \\
\text { (FT) } \\
\text { (72015) }\end{array}$ & $\begin{array}{c}\text { DEPTH } \\
\text { TO BOT- } \\
\text { TON OF } \\
\text { SANPLE } \\
\text { INTER- } \\
\text { VAL } \\
\text { (FT) } \\
\text { (72016) }\end{array}$ & $\begin{array}{c}\text { SEDI- } \\
\text { MENT, } \\
\text { DIS- } \\
\text { CHARGE, } \\
\text { SUS- } \\
\text { PENDED } \\
\text { (T/DAY) } \\
\text { (BO155) }\end{array}$ & $\begin{array}{l}\text { SEDI- } \\
\text { MENT, } \\
\text { DISCH, } \\
\text { SUSP = } \\
\text { BED HA- } \\
\text { IERIAL } \\
\text { (T/DAY) } \\
\text { (BOISG) }\end{array}$ & $\begin{array}{l}\text { ORAIN- } \\
\text { AGE } \\
\text { AREA } \\
\text { (SR. } \\
\text { MI.) } \\
\text { (B1024) }\end{array}$ \\
\hline $11-17-76$ & -- & -- & -- & -- & -- & - & -- & -- & -- & -- & -- \\
\hline $03-01-65$ & -- & -- & -- & - & $32 b$ & 53.00 & -- & - & -- & -- & -- \\
\hline $03-29-65$ & -- & - & -- & - & 326 & 54.00 & -- & - & -- & -- & - \\
\hline $07-06-65$ & -- & -- & -- & - & 326 & 54.00 & -- & - & -- & -- & -- \\
\hline $08-30-65$ & -- & - & -- & -- & 326 & 54.00 & -- & - & -- & - & - \\
\hline $11-30-65$ & -- & -- & -- & -- & 326 & 54.00 & -- & -- & -- & - & -- \\
\hline $02-28-66$ & -- & -- & -- & -- & 326 & 54.00 & -- & -- & -- & -- & -- \\
\hline $07-05-66$ & -- & - & - & -- & 326 & 54.00 & -- & - & - & -- & -- \\
\hline $10-08-67$ & -- & -- & -- & - & 326 & 54.00 & -- & -- & -- & -- & -- \\
\hline $07-01-68$ & -- & - & -- & -- & 326 & 54.00 & -- & -- & - & -- & -- \\
\hline $07-01-69$ & -- & -- & -- & -- & 326 & 54.00 & -- & -- & -- & -- & -- \\
\hline $09-02-71$ & -- & -- & -- & -- & $32 b$ & 54.00 & -- & -- & -- & -- & -- \\
\hline $07-03-72$ & -- & -- & -- & $-\infty$ & 326 & 54.00 & -- & -- & -- & -- & -- \\
\hline $09-06-73$ & -- & -- & - & - & 326 & 54,00 & -- & -- & -- & -- & -- \\
\hline $05-30-74$ & -- & -- & -- & - & 326 & 54.00 & -- & -- & -- & -- & -- \\
\hline $06-03-75$ & -- & -- & - & -- & $32 b$ & 54.00 & -- & -- & -- & -- & -- \\
\hline $05-04-76$ & -- & -- & -- & $-\infty$ & 326 & 54.00 & -- & -- & - & -- & - \\
\hline $12-06-37$ & $-\infty$ & -- & $\infty$ & -- & 315 & 70.00 & -- & - & -- & -- & -- \\
\hline $07-01-68$ & - & -- & -- & - & 315 & 70.00 & -- & -- & -- & -- & - \\
\hline $07-01-69$ & -- & -- & -- & -- & 315 & 70.00 & -- & -- & -- & - & - \\
\hline $08-04-70$ & -- & -- & - & - & 315 & 70.00 & -- & -- & -- & - & -- \\
\hline $12-30-71$ & -- & -- & -- & $=$ & 315 & 70.00 & -- & -- & -- & -- & -- \\
\hline $01-03-73$ & - & -- & - & -- & 315 & 70.00 & -- & -- & -- & - & - \\
\hline $01-02-74$ & -- & -- & - & -- & 315 & 70.00 & -- & -- & -- & - & - \\
\hline $02-06-75$ & -- & -- & - & -- & 315 & 70.00 & -- & -- & - & -- & -- \\
\hline $01-29-76$ & -- & -- & -- & - & 315 & 70.00 & -- & -- & -- & - & -- \\
\hline $08-28-64$ & -- & - & - & - & 304 & 77.60 & -- & -- & -- & - & -- \\
\hline $03-29-65$ & - & - & - & - & 304 & 77.00 & -- & - & -- & - & -- \\
\hline $07-06-65$ & -- & -- & - & -- & 304 & 77.00 & -- & -- & -- & - & -- \\
\hline $12-17-65$ & -- & - & -- & - & 304 & 77.00 & -- & -- & -- & - & -- \\
\hline $03-24-67$ & -- & -- & - & - & 304 & 77.00 & -- & - & -- & - & -- \\
\hline $10-01-67$ & -- & - & -- & - & 304 & 77.00 & - & - & $-\infty$ & - & -- \\
\hline $10-24-68$ & -- & -- & -- & - & 304 & 77.00 & - & - & - & - & -- \\
\hline $10-01-69$ & -- & - & $-\sim$ & -- & 304 & 77.00 & -- & - & -- & -- & -- \\
\hline $11-03-70$ & -- & - & -- & -- & 304 & 77.00 & -- & - & -- & -- & - \\
\hline
\end{tabular}


LOCAL

IDENT-

I-

FIER
C-07-15 20AAD

C-07-15 20AAD

C-07-15 20AAD

C-07-15 20AAD

C-07-15 20AAD

C-07-15 20AAD

C- $07-15$ 22CDD

C-07-15 22CDD

C-07-15 22CDD

C-07-15 22CDD

C-07-15 22CDD

C-07-15 22CDD

C-07-15 22CDD

C-07-15 22CDD

C- $-07-15$ 22CDD

C- $07-15$ 22CDD

C- $-07-15$ 22CDD

C-07-15 220DA

C- $07-15$ 22DDA

C-07-15 22DDA

C-07-15 22DDA

C-07-15 22DDA

C- $07-15$ 22DDA

C-07-15 220DA

C-07-15 220DA

C-07-15 220DA

C-07-15 25DDD

C-07-15 250DD

C-07-15 25DDD

C-07-15 25DDD

C-07-15 250DD

C-07-15 250DD

C-07-15 25DDD

C-07-15 25DDD

C-07-15 26CCB
OXYGEN,

AGENCY AGEMCY SPE- DIS- CARBON ALKA-

COL- ANA- CIFIC SOLVED

LECTING LYZING

CON- IPER-

SAMPLE TEMPER- SAMPLE SAMPLE DUCT- CENT ISTAND- SOLVED IMG/L

NUHBER ATURE (CODE ICODE

AHCE SATUR- ARD (MG/L AS

(DEG C) NUMBER) NUMBER) (US/CM) ATION) UNITS) AS CO2) CACD3)

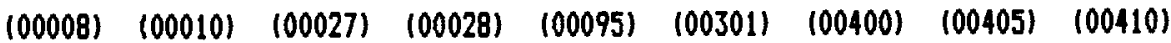

$\begin{array}{llllllllll}10-07-71 & 1230 & -- & -- & -- & 14800 & -- & 7.6 & 13 & 276\end{array}$

$\begin{array}{llllllllll}10-03-72 & 1230 & -- & - & -- & 14300 & -- & 7.6 & 13 & 267\end{array}$

$\begin{array}{llllllllll}03-27-73 & 1230 & -- & -- & -- & 14500 & -- & 7.7 & 15 & 385\end{array}$

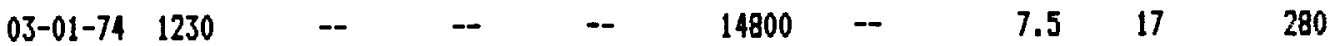

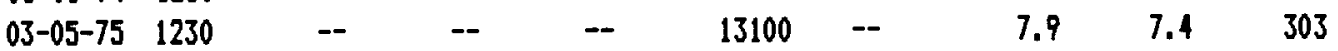

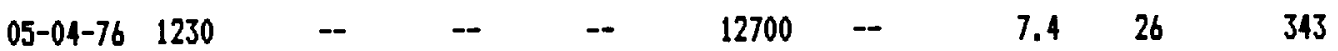

$\begin{array}{llllllllll}11-01-66 & 1230 & -- & -- & -- & 9990 & -- & -- & -- & 418\end{array}$

$\begin{array}{llllllllll}07-12-67 & 1230 & -- & -- & -- & 9750 & -- & -- & -- & 413\end{array}$

$\begin{array}{llllllllll}10-24-68 & 1230 & -- & -- & -- & 9290 & -- & -- & -- & 363\end{array}$

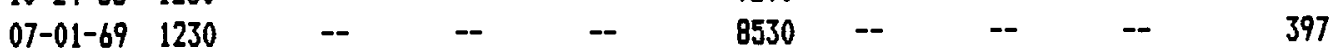

$\begin{array}{llllllllll}08-04-70 & 1230 & -- & -- & -- & 7570 & -- & 7.8 & 14 & 450\end{array}$

$\begin{array}{llllllllll}07-01-71 & 1230 & - & -- & -- & 7270 & -- & 8.1 & 5.7 & 367\end{array}$

$\begin{array}{llllllllll}06-01-72 & 1230 & -- & -- & -- & 7760 & -- & 7.8 & 13 & 435\end{array}$

$\begin{array}{llllllllll}07-02-73 & 1230 & - & -- & -- & 3130 & -- & 7.6 & 13 & 267\end{array}$

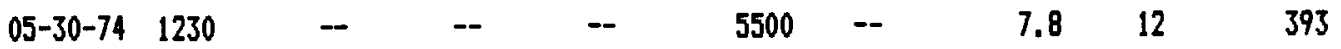

$\begin{array}{llllllllll}08-05-75 & 1230 & -- & -- & -- & 5200 & -- & 7.6 & 11 & 235\end{array}$

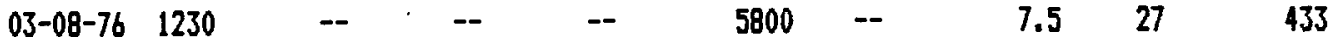

$\begin{array}{llllllllll}07-03-67 & 1230 & -- & -- & -- & 6340 & -- & -- & -- & 376\end{array}$

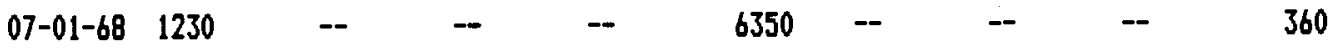

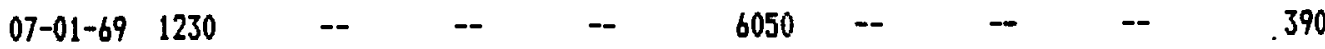

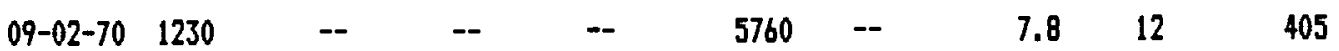

$\begin{array}{llllllllll}12-30-71 & 1230 & -- & -- & -- & 5570 & -- & 7.8 & 12 & 398\end{array}$

$\begin{array}{llllllllll}01-03-73 & 1230 & -- & -- & - & 5300 & -- & 7.7 & 17 & 430\end{array}$

$\begin{array}{llllllllll}01-02-74 & 1230 & - & -- & -- & 5130 & -- & 7.7 & 12 & 312\end{array}$

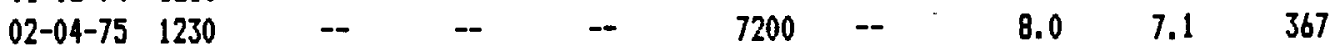

$\begin{array}{llllllllll}04-06-76 & 1230 & -- & -- & -- & 4770 & -- & 7.4 & 32 & 417\end{array}$

$\begin{array}{llllllllll}07-27-67 & 1230 & -- & -- & -- & 16000 & - & -- & -- & \cdot 200\end{array}$

$\begin{array}{llllllllll}11-04-68 & 1230 & -- & -- & -- & 19200 & -- & -- & -- & 170\end{array}$

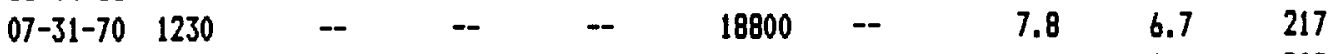

$\begin{array}{llllllllll}12-30-71 & 1230 & -- & -- & -- & 19400 & - & 7.6 & 10 & 208\end{array}$

$\begin{array}{llllllllll}01-03-73 & 1230 & -- & -- & -- & 18400 & -- & 7.5 & 12 & 203\end{array}$

$\begin{array}{llllllllll}01-02-74 & 1230 & -- & -- & -- & 22800 & -- & 7.6 & 11 & 224\end{array}$

$\begin{array}{llllllllll}02-06-75 & 1230 & -- & -- & -- & 22000 & -- & 7.7 & 8.9 & 230\end{array}$

$\begin{array}{llllllllll}01-29-76 & 1230 & -- & -- & -- & 19700 & -- & 7.3 & 23 & 240\end{array}$

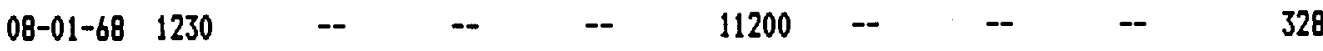




\begin{tabular}{|c|c|c|c|c|c|c|c|c|c|c|c|c|}
\hline DATE & $\begin{array}{c}\text { ACIDITY } \\
\text { (MG/L } \\
\text { AS } \\
\text { CACO3) } \\
(00435)\end{array}$ & $\begin{array}{c}\text { BICAR- } \\
\text { BONATE } \\
\text { FET-FLD } \\
\text { (MG/L } \\
\text { AS } \\
\text { HCO3) } \\
(00440)\end{array}$ & $\begin{array}{r}\text { CAR- } \\
\text { BONATE } \\
\text { FET-FLD } \\
\text { (K6/L } \\
\text { AS CO3) } \\
(00445)\end{array}$ & $\begin{array}{l}\text { NITRO- } \\
\text { GEN, } \\
\text { TOTAL } \\
\text { (MG/L } \\
\text { AS N) } \\
(00600)\end{array}$ & $\begin{array}{c}\text { NITRO- } \\
\text { GEN, } \\
\text { ORGANIC } \\
\text { TOTAL } \\
\text { (HG/L } \\
\text { AS N) } \\
(00605)\end{array}$ & $\begin{array}{c}\text { NITRO- } \\
\text { GEH, } \\
\text { OREANIC } \\
\text { DIS- } \\
\text { SOLVED } \\
\text { (HG/L } \\
\text { AS N) } \\
\text { (00607) }\end{array}$ & $\begin{array}{c}\text { NITRO- } \\
\text { GEN, } \\
\text { NITRATE } \\
\text { DIS- } \\
\text { SOLVED } \\
\text { (MG/L } \\
\text { AS N) } \\
\text { (00618) }\end{array}$ & $\begin{array}{c}\text { NITRO- } \\
\text { GEN, } \\
\text { NITRATE } \\
\text { TOTAL } \\
\text { (MG/L } \\
\text { AS N) } \\
(00620)\end{array}$ & $\begin{array}{c}\text { NITRO- } \\
\text { GEN, } \\
\text { NO2+NO3 } \\
\text { DIS- } \\
\text { SOLVED } \\
\text { (MG/L } \\
\text { AS N) } \\
\text { (00631) }\end{array}$ & $\begin{array}{c}\text { PHOS- } \\
\text { PHATE, } \\
\text { ORTHO, } \\
\text { OIS- } \\
\text { SOLVED } \\
\text { (MG/L } \\
\text { AS PO4) } \\
\text { (00660) }\end{array}$ & $\begin{array}{c}\text { PHOS- } \\
\text { PHORUS, } \\
\text { ORGANIC } \\
\text { TOTAL } \\
\text { (MG/L } \\
\text { AS P) } \\
(00670)\end{array}$ & $\begin{array}{c}\text { PHOS- } \\
\text { PHORUS, } \\
\text { ORTHO, } \\
\text { DIS- } \\
\text { SOLVED } \\
\text { (MG/L } \\
\text { AS P) } \\
\text { (00671) }\end{array}$ \\
\hline $10-07-71$ & -- & 340 & -- & - & -- & -- & -- & -- & -- & -- & -- & - \\
\hline $10-03-72$ & -- & 330 & -- & -- & -- & -- & -- & -- & -- & -- & -- & -- \\
\hline $03-27-73$ & -- & 470 & -- & - & -- & -- & -- & - & -- & -- & -- & -- \\
\hline $03-01-74$ & -- & 340 & -- & -- & -- & -- & -- & -- & -- & -- & - & -- \\
\hline $03-05-75$ & -- & 370 & -- & - & -- & -- & -- & -- & -- & -- & -- & -- \\
\hline $05-04-76$ & -- & 420 & -- & - & -- & -- & -- & -- & -- & -- & -- & -- \\
\hline $11-01-66$ & -- & 510 & -- & - & -- & -- & -- & - & -- & -- & -- & -- \\
\hline $07-12-67$ & -- & $500^{\circ}$ & -- & -- & -- & -- & - & -- & -- & -- & -- & -- \\
\hline $10-24-68$ & -- & 440 & -- & -- & -- & -- & -- & - & -- & -- & -- & -- \\
\hline $07-01-69$ & -- & 480 & -- & -- & -- & -- & -- & -- & -- & -- & -- & -- \\
\hline $08-04-70$ & -- & 550 & -- & -- & -- & - & -- & -- & -- & -- & -- & -- \\
\hline $07-01-71$ & -- & 450 & -- & -- & -- & -- & -- & -- & -- & -- & -- & -- \\
\hline $06-01-72$ & -- & 530 & -- & -- & -- & -- & -- & -- & -- & -- & -- & -- \\
\hline $07-02-73$ & -- & 330 & -- & -- & -- & -- & -- & -- & -- & -- & -- & -- \\
\hline $05-30-74$ & -- & 480 & -- & - & - & - & -- & -- & -- & - & -- & -- \\
\hline $08-05-75$ & -- & 290 & -- & -- & -- & -- & -- & -- & -- & -- & -- & -- \\
\hline $03-08-76$ & -- & 530 & -- & -- & -- & -- & -- & -- & -- & - & -- & -- \\
\hline $07-03-67$ & -- & 460 & -- & -- & -- & -- & -- & -- & -- & -- & -- & -- \\
\hline $07-01-68$ & -- & 440 & -- & - & -- & - & -- & -- & -- & - & -- & -- \\
\hline $07-01-69$ & -- & 480 & -- & -- & -- & -- & -- & - & -- & -- & - & -- \\
\hline $09-02-70$ & -- & 490 & -- & -- & -- & -- & -- & -- & -- & - & -- & -- \\
\hline $12-30-71$ & -- & 490 & -- & -- & -- & -- & -- & - & -- & -- & -- & -- \\
\hline $01-03-73$ & -- & 520 & -- & -- & -- & -- & -- & -- & -- & -- & -- & -- \\
\hline $01-02-74$ & -- & 380 & -- & -- & -- & -- & -- & -- & -- & -- & -- & - \\
\hline $02-04-75$ & -- & 450 & -- & - & -- & -- & -- & - & -- & -- & -- & - \\
\hline $04-06-76$ & -- & 510 & -- & -- & -- & -- & -- & -- & -- & -- & -- & -- \\
\hline $07-27-67$ & -- & 240 & -- & -- & -- & -- & -- & -- & -- & -- & -- & -- \\
\hline $11-04-68$ & -- & 210 & -- & -- & -- & - & -- & -- & -- & -- & - & -- \\
\hline $07-31-70$ & -- & 270 & -- & -- & -- & -- & -- & -- & -- & -- & -- & $\cdots$ \\
\hline $12-30-71$ & -- & 250 & -- & -- & -- & -- & -- & -- & -- & -- & -- & -- \\
\hline $01-03-73$ & -- & 250 & -- & -- & -- & -- & -- & -- & -- & -- & -- & -- \\
\hline $01-02-74$ & -- & 270 & -- & - & -- & -- & -- & -- & -- & -- & -- & -- \\
\hline $02-06-75$ & -- & 280 & -- & -- & -- & -- & -- & -- & -- & -- & -- & -- \\
\hline $01-29-76$ & -- & 290 & -- & -- & -- & -- & $-\infty$ & -- & -- & -- & -- & -- \\
\hline $08-01-68$ & -- & 400 & -- & -- & -- & -- & -- & -- & -- & -- & -- & -- \\
\hline
\end{tabular}




\begin{tabular}{|c|c|c|c|c|c|c|c|c|c|c|c|}
\hline DATE & $\begin{array}{c}\text { PHOS- } \\
\text { PHORUS, } \\
\text { ORGANIC } \\
\text { DIS- } \\
\text { SOLVED } \\
\text { (MGG/L } \\
\text { AS P) } \\
\text { (00673) }\end{array}$ & $\begin{array}{l}\text { HARD- } \\
\text { NESS } \\
\text { (MG/L } \\
\text { AS } \\
\text { CACO3) } \\
\text { (00900) }\end{array}$ & $\begin{array}{l}\text { HARD- } \\
\text { NESS, } \\
\text { MONCAR- } \\
\text { BONATE } \\
\text { (MG/L } \\
\text { CACDZ) } \\
\text { (00902) }\end{array}$ & $\begin{array}{l}\text { CALCIUH } \\
\text { DIS- } \\
\text { SOLVED } \\
\text { (MG/L } \\
\text { AS CA) } \\
\text { (00915) }\end{array}$ & $\begin{array}{l}\text { MAGME- } \\
\text { SIUH, } \\
\text { DIS- } \\
\text { SOLVED } \\
\text { (MG/L } \\
\text { AS MG) } \\
(009251\end{array}$ & $\begin{array}{l}\text { SODIUH, } \\
\text { DIS- } \\
\text { SOLVED } \\
\text { (MG/L } \\
\text { AS NA) } \\
(00930 \text { ) }\end{array}$ & $\begin{array}{c}\text { SODIUH } \\
\text { AD- } \\
\text { SORP- } \\
\text { TION } \\
\text { RATIO } \\
(00931)\end{array}$ & $\begin{array}{l}\text { PERCENT } \\
\text { SODIUH } \\
(00932)\end{array}$ & $\begin{array}{c}\text { SODIUH+ } \\
\text { POTAS- } \\
\text { SIUH } \\
\text { DIS- } \\
\text { SOLVED } \\
\text { (HG/L } \\
\text { AS NA) } \\
\text { (00933) }\end{array}$ & $\begin{array}{c}\text { POTAS- } \\
\text { SIUH, } \\
\text { DIS- } \\
\text { SOLVED } \\
\text { (HG/L } \\
\text { AS K) } \\
(00935)\end{array}$ & $\begin{array}{l}\text { CHLO- } \\
\text { RIDE, } \\
\text { DIS- } \\
\text { SOLVE } \\
\text { IHG/L } \\
\text { AS CL } \\
100940\end{array}$ \\
\hline $10-07-71$ & -- & 2300 & 2000 & 460 & 280 & 2600 & 24 & 71 & - & 19 & 4300 \\
\hline $10-03-72$ & -- & 2300 & 2100 & 510 & 260 & 2400 & 22 & 69 & - & 18 & 4100 \\
\hline $03-27-73$ & -- & 2300 & 1900 & 480 & 270 & 2500 & 24 & 70 & -- & 18 & 4300 \\
\hline $03-01-74$ & -- & 2400 & 2100 & 500 & 270 & 2500 & 23 & 69 & -- & 16 & 4300 \\
\hline $03-05-75$ & -- & 2000 & 1700 & 440 & 220 & 2300 & 23 & 71 & -- & 20 & 3700 \\
\hline $05-04-76$ & -- & 2100 & 1700 & 370 & 280 & 2000 & 20 & 68 & -- & 11 & 3300 \\
\hline $11-01-66$ & $-\infty$ & 2100 & 1700 & 510 & 190 & 1600 & 16 & -- & -- & - & 2800 \\
\hline $07-12-67$ & -- & 1900 & 1500 & 430 & 200 & 1600 & 16 & - & -- & -- & 2600 \\
\hline $10-24-68$ & -- & 1700 & 1400 & 430 & 160 & 1500 & 16 & -- & -- & -- & 2500 \\
\hline $07-01-69$ & -- & 1600 & 1200 & 400 & 140 & 1400 & 16 & - & -- & -- & 2200 \\
\hline $08-04-70$ & -- & 1400 & 960 & 360 & 120 & 1200 & 15 & 65 & -- & 16 & 1800 \\
\hline $07-01-71$ & -- & 1300 & 970 & 340 & 120 & 1200 & 14 & 65 & -- & 16 & 1800 \\
\hline $06-01-72$ & - & 1400 & 940 & 370 & 110 & 1200 & 15 & 66 & $-\infty$ & 19 & 1800 \\
\hline $07-02-73$ & -- & 430 & 160 & 140 & 20 & 520 & 11 & 72 & -- & 8.2 & 650 \\
\hline $05-30-74$ & - & 920 & 530 & 240 & 76 & 880 & 13 & 67 & -- & 15 & 1200 \\
\hline $08-05-75$ & -- & 740 & 500 & 180 & 72 & 920 & 15 & 73 & -- & 12 & 1200 \\
\hline $03-08-76$ & -- & 1200 & 770 & 310 & 110 & 900 & 12 & 62 & -- & 11 & 1200 \\
\hline $07-03-67$ & -- & 1400 & 1000 & 350 & 130 & 980 & 12 & -- & -- & -- & 1600 \\
\hline $07-01-68$ & -- & 1300 & 980 & 310 & 140 & 920 & 11 & -- & -- & -- & 1400 \\
\hline $07-01-69$ & -- & 1300 & 870 & 310 & 120 & 890 & 11 & -- & -- & -- & 1300 \\
\hline $09-02-70$ & - & 1300 & 890 & 330 & 110 & 840 & 11 & 58. & -- & 18 & 1200 \\
\hline $12-30-71$ & -- & 1200 & 840 & 370 & 75 & 850 & 11 & 60 & -- & 13 & 1100 \\
\hline $01-03-73$ & -- & 1200 & 750 & 300 & 100 & 780 & 10 & 59 & -- & 15 & 1000 \\
\hline $01-02-74$ & - & 1100 & 780 & 310 & 79 & 750 & 10 & 59 & -- & 15 & 1200 \\
\hline $02-04-75$ & -- & 1200 & 800 & 350 & 71 & 1200 & 16 & 69 & -- & 33 & 1700 \\
\hline $04-06-76$ & -- & 940 & 520 & 230 & 87 & 740 & 11 & 63 & -- & 11 & 850 \\
\hline $07-27-67$ & -- & 2300 & 2100 & 670 & 150 & 3000 & 29 & - & -- & -- & 4700 \\
\hline $11-04-68$ & -- & 2800 & 2600 & 800 & 190 & 3700 & 31 & -- & -- & -- & 5600 \\
\hline $07-31-70$ & -- & 2800 & 2600 & 890 & 150 & 3700 & 32 & 74 & -- & 22 & 5500 \\
\hline $12-30-71$ & -- & 2800 & 2600 & 900 & 140 & 3700 & 32 & 74 & -- & 22 & 5300 \\
\hline $01-03-73$ & -- & 2700 & 2500 & 820 & 160 & 3500 & 30 & 73 & - & 26 & 5100 \\
\hline $01-02-74$ & -- & 3500 & 3300 & 1100 & 190 & 4100 & 31 & 71 & -- & 33 & 7000 \\
\hline $02-06-75$ & -- & 3400 & 3200 & 980 & 230 & 4100 & 32 & 72 & -- & 54 & 6700 \\
\hline $01-29-76$ & -- & 2800 & 2600 & 800 & 200 & 3700 & 32 & 74 & -- & 19 & 5700 \\
\hline $08-01-68$ & -- & 1600 & 1200 & 420 & 130 & 2300 & 26 & -- & -- & -- & 3200 \\
\hline
\end{tabular}




\begin{tabular}{|c|c|c|c|c|c|c|c|c|c|c|c|}
\hline DATE & $\begin{array}{l}\text { SULFATE } \\
\text { DIS- } \\
\text { SOLVED } \\
\text { (MG/L } \\
\text { AS SO4) } \\
\text { (00945) }\end{array}$ & $\begin{array}{l}\text { FLUO- } \\
\text { RIDE, } \\
\text { DIS- } \\
\text { SOLVED } \\
\text { (HG/L } \\
\text { AS F) } \\
(00950)\end{array}$ & $\begin{array}{l}\text { SILICA, } \\
\text { DIS- } \\
\text { SOLVED } \\
\text { (II6/L } \\
\text { AS } \\
\text { SI02) } \\
\text { (00955) }\end{array}$ & $\begin{array}{c}\text { BORON, } \\
\text { DIS- } \\
\text { SOLVED } \\
\text { (U6/L } \\
\text { AS B) } \\
\text { (01020) }\end{array}$ & $\begin{array}{c}\text { IRON, } \\
\text { DIS- } \\
\text { SOLVED } \\
\text { (UG/L } \\
\text { AS FE) } \\
\text { (01046) }\end{array}$ & $\begin{array}{l}\text { MANGA- } \\
\text { NESE, } \\
\text { DIS- } \\
\text { SOLVED } \\
\text { (UG/L } \\
\text { AS WN) } \\
(01056)\end{array}$ & $\begin{array}{l}\text { SOLIDS, } \\
\text { RESIDUE } \\
\text { AT } 180 \\
\text { DEG. C } \\
\text { DIS- } \\
\text { SOLVED } \\
\text { (HE/L) } \\
(70300)\end{array}$ & $\begin{array}{c}\text { SOLIDS, } \\
\text { SUM OF } \\
\text { CONSTI- } \\
\text { TUENTS, } \\
\text { DIS- } \\
\text { SOLVED } \\
\text { (HG/L) } \\
(70301)\end{array}$ & $\begin{array}{c}\text { SOLIDS, } \\
\text { OIS- } \\
\text { SOLVED } \\
\text { (TONS } \\
\text { PER } \\
\text { DAY) } \\
(70302)\end{array}$ & $\begin{array}{c}\text { SOLIDS, } \\
\text { DIS- } \\
\text { SOLVED } \\
\text { (TONS } \\
\text { PER } \\
\text { AC-FT) } \\
(70303)\end{array}$ & $\begin{array}{l}\text { NITRO- } \\
\text { GEN, } \\
\text { AMMONI } \\
\text { DIS- } \\
\text { SOLVEI } \\
\text { (HG/L } \\
\text { AS NH4) } \\
(71846)\end{array}$ \\
\hline $10-07-71$ & 1400 & - & -- & -- & -- & -- & -- & 9200 & -- & -- & -- \\
\hline $10-03-72$ & 1300 & -- & -- & - & - & -- & -- & 8800 & -- & -- & -- \\
\hline $03-27-73$ & 1300 & - & -- & - & -- & -- & -- & 9100 & -- & -- & - \\
\hline $03-01-74$ & 1400 & -- & 66 & - & - & -- & -- & 9200 & -- & 12.5 & -- \\
\hline $03-05-75$ & 1300 & - & 46 & -- & -- & -- & -- & 8300 & -- & 11.2 & -- \\
\hline $05-04-76$ & 1500 & -- & 69 & - & - & -- & -- & 7800 & -- & 10.6 & -- \\
\hline $11-01-66$ & 1200 & - & -- & - & -- & -- & -- & 6500 & -- & -- & - \\
\hline $07-12-67$ & 1200 & -- & -- & -- & - & -- & -- & 6200 & -- & -- & - \\
\hline $10-24-68$ & 1100 & -- & -- & -- & - & -- & -- & 5900 & -- & -- & -- \\
\hline $07-01-69$ & 1100 & -- & -- & - & -- & -- & -- & 5400 & -- & -- & -- \\
\hline $08-04-70$ & 1000 & -- & -- & -- & -- & -- & -- & 4800 & -- & -- & -- \\
\hline $07-01-71$ & 990. & -- & -- & -- & -- & -- & -- & 4700 & -- & -- & -- \\
\hline $06-01-72$ & 1000 & -- & 29 & 2 & -- & -- & -- & 4900 & -- & 6.7 & -- \\
\hline $07-02-73$ & 370 & -- & 26 & -- & -- & -- & -- & 1900 & -- & 2.6 & -- \\
\hline $05-30-74$ & 760 & -- & 29 & -- & -- & -- & - & 3400 & -- & 4.7 & -- \\
\hline $08-05-75$ & 830 & - & 26 & -- & -- & - & -- & 3300 & -- & 4.5 & -- \\
\hline $03-08-76$ & 930 & -- & 27 & - & -- & - & -- & 3700 & -- & 5.1 & -- \\
\hline $07-03-67$ & 960 & -- & -- & -- & -- & - & -- & 4200 & -- & -- & -- \\
\hline $07-01-68$ & 940 & -- & -- & -- & -- & -- & -- & 4000 & -- & -- & -- \\
\hline $07-01-69$ & 930 & -- & -- & -- & -- & $\because$ & -- & 3800 & -- & -- & -- \\
\hline $09-02-70$ & 940 & - & -- & -- & -- & -- & -- & 3700 & -- & -- & -- \\
\hline $12-30-71$ & 1100 & -- & -- & -- & - & -- & -- & 3700 & -- & -- & -- \\
\hline $01-03-73$ & 930 & -- & -- & - & -- & - & -- & 3400 & -- & -- & - \\
\hline $01-02-74$ & 760 & -- & 37 & -- & -- & -- & -- & 3300 & -- & 4.5 & -- \\
\hline $02-04-75$ & 1000 & -- & 25 & - & -- & -- & -- & 4700 & - & 6.4 & -- \\
\hline $04-06-76$ & 910 & - & 28 & -- & -- & -- & -- & 3100 & -- & 4.2 & -- \\
\hline $07-27-67$ & 2100 & -- & -- & - & -- & -- & -- & 11000 & -- & -- & -- \\
\hline $11-04-68$ & 2500 & -- & -- & -- & -- & -- & - & 13000 & -- & -- & -- \\
\hline $07-31-70$ & 2600 & -- & -- & -- & -- & -- & -- & 13000 & -- & -- & $\cdots$ \\
\hline $12-30-71$ & 2900 & -- & -- & -- & -- & -- & -- & 13000 & -- & -- & -- \\
\hline $01-03-73$ & 2500 & -- & -- & - & -- & -- & -- & 12000 & -- & -- & -- \\
\hline $01-02-74$ & 2600 & -- & 60 & -- & -- & -- & -- & 15000 & -- & 20.6 & -- \\
\hline $02-0 b-75$ & 2500 & -- & 52 & -- & -- & - & -- & 15000 & -- & 20.1 & - \\
\hline $01-29-76$ & 2500 & -- & 60 & -- & -- & -- & -- & 13000 & -- & 17.9 & -- \\
\hline $08-01-68$ & 1700 & -- & -- & -- & -- & -- & -- & 7900 & -- & -- & -- \\
\hline
\end{tabular}




\begin{tabular}{|c|c|c|c|c|c|c|c|c|c|c|c|}
\hline DATE & $\begin{array}{c}\text { NITRO- } \\
\text { GEN, } \\
\text { NITRATE } \\
\text { TOTAL } \\
\text { (MG/L } \\
\text { AS NOJ) } \\
\text { (71850) }\end{array}$ & $\begin{array}{c}\text { NITRO- } \\
\text { GEN, } \\
\text { NITRATE } \\
\text { DIS- } \\
\text { SOLVED } \\
\text { (MGG/L } \\
\text { AS NO3) } \\
\text { (71851) }\end{array}$ & $\begin{array}{c}\text { NITRO- } \\
\text { GEN, } \\
\text { NITRITE } \\
\text { DIS- } \\
\text { SOLVED } \\
\text { (MGG/L } \\
\text { AS NO2) } \\
\text { (71856) }\end{array}$ & $\begin{array}{l}\text { NITRO- } \\
\text { GEN, } \\
\text { TOTAL } \\
\text { (NG/L } \\
\text { AS NO3) } \\
\text { (7L887) }\end{array}$ & $\begin{array}{c}\text { ELEV. } \\
\text { OF LAND } \\
\text { SURFACE } \\
\text { DATUH } \\
\text { (FT. } \\
\text { ABOVE } \\
\text { NGVD) } \\
\text { (72000) }\end{array}$ & $\begin{array}{l}\text { DEPTH } \\
\text { OF } \\
\text { MELL, } \\
\text { TOTAL } \\
\text { (FEET) } \\
\text { (72008) }\end{array}$ & $\begin{array}{c}\text { DEPTH } \\
\text { TO TOP } \\
\text { OF } \\
\text { SAMPLE } \\
\text { INTER- } \\
\text { VAL } \\
\text { (FT) } \\
\text { (72015) }\end{array}$ & $\begin{array}{c}\text { DEPTH } \\
\text { TO BOT- } \\
\text { TOH OF } \\
\text { SAMPLE } \\
\text { INTER- } \\
\text { VAL } \\
\text { (FT) } \\
(72016)\end{array}$ & $\begin{array}{c}\text { SEDI- } \\
\text { MENT, } \\
\text { DIS- } \\
\text { CHARGE, } \\
\text { SUS- } \\
\text { PENDED } \\
\text { (T/DAY) } \\
\text { (80155) }\end{array}$ & $\begin{array}{l}\text { SEDI- } \\
\text { HENT, } \\
\text { DISCH, } \\
\text { SUSP. + } \\
\text { BED HA- } \\
\text { TERIAL } \\
\text { (T/DAY) } \\
\text { (80156) }\end{array}$ & $\begin{array}{c}\text { DRAIH- } \\
\text { AGE } \\
\text { AREA } \\
\text { (SQ. } \\
\text { HI.) } \\
\text { (81024) }\end{array}$ \\
\hline $10-07-71$ & $\therefore$ & -- & -- & -- & 304 & 77.00 & -- & -- & -- & -- & -- \\
\hline $10-03-72$ & -- & - & -- & -- & 304 & 77.00 & -- & -- & -- & - & -- \\
\hline $03-27-73$ & -- & -- & -- & -- & 304 & 77.00 & -- & - & -- & -- & -- \\
\hline $03-01-74$ & -- & -- & -- & - & 304 & 77.00 & -- & -- & -- & -- & -- \\
\hline $03-05-75$ & -- & -- & -- & -- & 304 & 77.00 & -- & -- & -- & -- & -- \\
\hline $05-04-76$ & -- & -- & -- & -- & 304 & 77.00 & -- & -- & -- & -- & -- \\
\hline $11-01-66$ & -- & -- & -- & - & 306 & 66.00 & - & -- & -- & -- & -- \\
\hline $07-12-67$ & -- & -- & -- & -- & 306 & 66.00 & -- & -- & -- & -- & -- \\
\hline $10-24-68$ & -- & -- & -- & -- & 306 & 66.00 & -- & -- & -- & -- & -- \\
\hline $07-01-69$ & -- & -- & -- & -- & 306 & 66.00 & -- & -- & -- & -- & -- \\
\hline $08-04-70$ & -- & -- & -- & -- & 306 & 66.00 & -- & -- & -- & -- & -- \\
\hline $07-01-71$ & -- & -- & -- & -- & 306 & 66.00 & -- & -- & -- & -- & -- \\
\hline $06-01-72$ & -- & -- & -- & -- & 306 & 66.00 & -- & -- & -- & -- & -- \\
\hline $07-02-73$ & -- & -- & -- & - & 306 & 66.00 & -- & -- & -- & -- & -- \\
\hline $05-30-74$ & -- & -- & -- & -- & 306 & 66.00 & -- & -- & -- & -- & -- \\
\hline $08-05-75$ & -- & -- & -- & -- & 306 & 66.00 & -- & -- & -- & -- & -- \\
\hline $03-08-76$ & -- & - & -- & -- & 306 & 66.00 & -- & -- & -- & -- & -- \\
\hline $07-03-67$ & -- & -- & -- & -- & 301 & 96.00 & -- & -- & -- & -- & -- \\
\hline $07-01-68$ & -- & -- & -- & -- & 301 & 96.00 & -- & -- & -- & -- & -- \\
\hline $07-01-69$ & -- & - & -- & -- & 301 & 96.00 & -- & -- & -- & -- & -- \\
\hline $09-02-70$ & -- & -- & -- & -- & 301 & 96.00 & -- & -- & -- & -- & -- \\
\hline $12-30-71$ & -- & -- & -- & -- & 301 & 96.00 & -- & -- & -- & -- & -- \\
\hline $01-03-73$ & -- & -- & -- & -- & 301 & 96.00 & -- & -- & -- & -- & -- \\
\hline $01-02-74$ & -- & -- & -- & -- & 301 & 96.00 & -- & -- & -- & -- & -- \\
\hline $02-04-75$ & -- & -- & -- & -- & 301 & 96.00 & -- & -- & -- & -- & -- \\
\hline $04-06-76$ & -- & -- & -- & -- & 301 & 96.00 & -- & -- & -- & -- & -- \\
\hline $07-27-67$ & -- & -- & -- & -- & 311 & 94.00 & -- & -- & -- & -- & -- \\
\hline $11-04-68$ & -- & -- & - & -- & 311 & 94.00 & -- & -- & -- & -- & -- \\
\hline $07-31-70$ & -- & - & -- & -- & 311 & 94.00 & -- & -- & -- & -- & -- \\
\hline $12-30-71$ & -- & -- & -- & -- & 311 & 94.00 & -- & -- & -- & -- & -- \\
\hline $01-03-73$ & -- & - & -- & -- & 311 & 94.00 & -- & -- & -- & -- & -- \\
\hline $01-02-74$ & -- & - & -- & -- & 311 & 94.00 & -- & -- & -- & -- & -- \\
\hline $02-06-75$ & -- & -- & -- & - & 311 & 94.00 & -- & -- & -- & -- & -- \\
\hline $01-29-76$ & -- & -- & -- & -- & 311 & 94.00 & -- & -- & -- & -- & -- \\
\hline $08-01-68$ & -- & -- & -- & -- & 307 & 98.00 & -- & -- & -- & -- & -- \\
\hline
\end{tabular}


LOCAL

IDENT-

I-

FIER
C-07-15 26CCB

C-07-15 26CCB

C-07-15 26CCB

C-07-15 26CCB

C-07-15 26CCB

C-07-15 26CCB

C-07-15 26CCB

C-07-15 26CCB

C-07-15 29BAA2

C-07-15 29BAA2

C-07-15 29BAA2

C-07-15 29BAA2

C-07-15 30BDD

C-07-15 30BDD

C- $-07-15$ 30BDD

C-07-15 30BDD

C- $07-15$ 30BDD

C-07-15 30BDD

C- $07-15$ 30BDD

C-07-15 30BDD

C-07-15 30BDD

C-07-15 30BDD

C-07-15 30BDD

C-07-15 30BDD

C-07-16 25BCC

C-07-16 25BCC

C-07-16 25BCC

C-07-16 25BCC

C-07-16 25BCC

C-07-16 33CBB

C- $07-16$ 33CBB

C-07-16 33CBB

C-07-16 33CBB

C-07-16 33CBB

C-07-16 33CBB

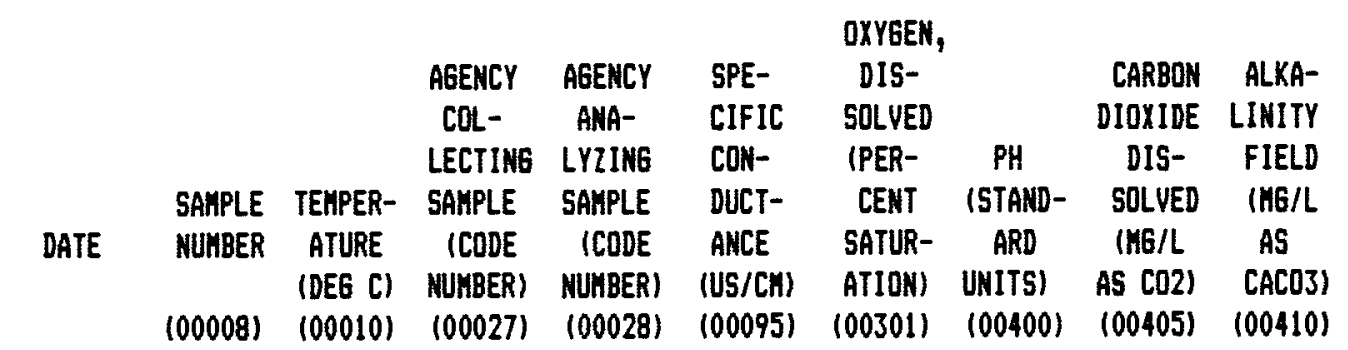

$\begin{array}{rlllllllll}10-01-69 & 1230 & -- & -- & -- & 10800 & - & -- & - & 317 \\ 10-01-70 & 1230 & -- & - & -- & 11100 & -- & 7.9 & 7.7 & 317 \\ 06-10-71 & 1230 & -- & - & -- & 10300 & -- & 8.1 & 7.9 & 515 \\ 05-01-72 & 1230 & -- & -- & -- & 9720 & -- & 7.8 & 9.6 & 312 \\ 03-27-73 & 1230 & -- & -- & -- & 8900 & -- & 7.9 & 8.7 & 355 \\ & & & & & & & & & \\ 02-14-74 & 1230 & -- & -- & -- & 9240 & -- & 7.7 & 14 & 351 \\ 02-04-75 & 1230 & -- & -- & -- & 8450 & -- & 8.0 & 5.4 & 276 \\ 01-29-76 & 1230 & -- & -- & -- & 7770 & -- & 7.9 & 8.5 & 350 \\ 04-03-72 & 1230 & -- & -- & -- & 3510 & -- & 7.9 & 8.7 & 355 \\ 05-01-73 & 1230 & -- & -- & -- & 7070 & -- & 7.9 & 10 & 423 \\ & & & & & & & & & \\ 05-08-74 & 1230 & -- & -- & -- & 7130 & -- & 7.8 & 11 & 372 \\ 05-01-75 & 1230 & -- & -- & -- & 7430 & -- & 7.6 & 20 & 414 \\ 07-03-67 & 1230 & -- & -- & 1076 & 11800 & -- & -- & -- & 390 \\ 01-02-68 & 1230 & -- & -- & 1076 & 12600 & -- & -- & -- & - \\ 08-01-68 & 1230 & -- & -- & 1076 & 12100 & -- & -- & -- & 383 \\ & & & & & & & & & \\ 01-06-69 & 1230 & -- & - & 1076 & 12000 & - & -- & -- & - \\ 08-07-69 & 1230 & -- & -- & 1076 & 12300 & -- & -- & -- & 376 \\ 01-05-70 & 1230 & -- & -- & 1076 & 12100 & -- & -- & - & -- \\ 08-04-70 & 1230 & -- & -- & 1076 & 11200 & -- & 7.8 & 13 & 426 \\ 12-30-71 & 1230 & -- & -- & 1076 & 11400 & -- & 7.7 & 18 & 463 \\ 06-05-73 & 1230 & -- & -- & 1076 & 10600 & -- & 7.7 & 19 & 482 \\ 09-06-74 & 1230 & -- & -- & -- & 9860 & -- & 7.7 & 15 & 378 \\ 09-05-75 & 1230 & -- & -- & -- & 9530 & -- & 7.5 & 32 & 516 \\ 06-04-76 & 1230 & -- & -- & -- & 9450 & -- & 7.7 & 18 & 469 \\ 07-01-68 & 1230 & -- & -- & 1076 & 6510 & -- & -- & -- & 403 \\ & & & -- & & & & & & \\ 02-01-73 & 1230 & -- & -- & 1076 & 5720 & -- & 7.8 & 12 & 387 \\ 02-14-74 & 1230 & -- & -- & 1076 & 5550 & -- & 7.8 & 12 & 398 \\ 02-04-75 & 1230 & -- & -- & -- & 5240 & -- & 8.1 & 5.9 & 385 \\ 01-29-76 & 1230 & -- & -- & -- & 5010 & -- & 8.0 & 7.5 & 385 \\ 12-05-63 & 1230 & -- & -- & -- & 5920 & -- & - & -- & 308 \\ 06-03-64 & 1230 & -- & -- & -- & 8100 & -- & -- & -- & 343 \\ 08-28-64 & 1230 & -- & -- & -- & 9250 & -- & -- & - & 340 \\ 03-01-65 & 1230 & -- & -- & -- & 12000 & -- & -- & -- & 348 \\ 12-17-65 & 1230 & -- & -- & -- & 9940 & -- & -- & -- & 328 \\ 02-28-66 & 1230 & -- & -- & -- & 10500 & -- & -- & -- & 331\end{array}$




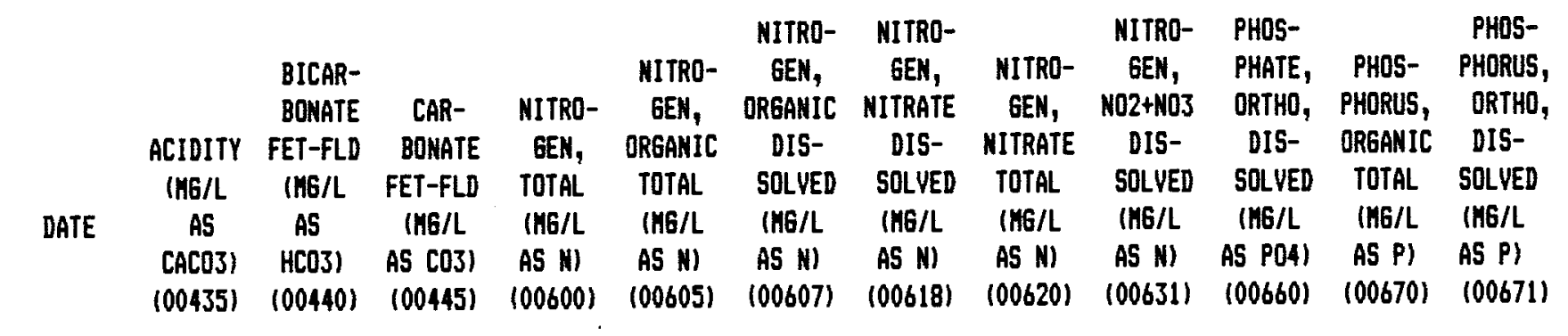

\begin{tabular}{|c|c|c|c|c|c|c|c|c|c|c|c|c|}
\hline $10-01-69$ & -- & 390 & -- & -- & -- & - & -- & - & -- & -- & -- & -- \\
\hline $10-01-70$ & -- & 390 & -- & -- & -- & -- & -- & -- & -- & -- & -- & -- \\
\hline $06-10-71$ & -- & 630 & -- & -- & -- & -- & -- & - & -- & - & -- & - \\
\hline $05-01-72$ & -- & 380 & -- & -- & -- & -- & -- & -- & -- & -- & -- & -- \\
\hline $03-27-73$ & -- & 430 & -- & -- & -- & -- & - & - & -- & -- & -- & -- \\
\hline $02-14-74$ & -- & 430 & -- & - & -- & -- & -- & -- & -- & -- & -- & -- \\
\hline $02-04-75$ & -- & 340 & -- & - & -- & -- & -- & -- & -- & -- & -- & -- \\
\hline $01-29-76$ & -- & 430 & -- & -- & -- & -- & -- & - & -- & - & -- & -- \\
\hline $04-03-72$ & -- & 430 & -- & -- & -- & -- & -- & -- & -- & -- & -- & -- \\
\hline $05-01-73$ & -- & 520 & -- & - & -- & - & -- & - & -- & -- & -- & -- \\
\hline $05-08-74$ & -- & 450 & -- & -- & -- & -- & -- & -- & -- & -- & -- & -- \\
\hline $05-01-75$ & -- & 510 & -- & -- & -- & -- & -- & -- & -- & -- & -- & -- \\
\hline $07-03-67$ & -- & 480 & & -- & -- & -- & -- & -- & -- & -- & -- & -- \\
\hline $01-02-68$ & -- & -- & -- & -- & -- & -- & -- & -- & -- & -- & -- & -- \\
\hline $08-01-68$ & -- & 470 & & -- & -- & -- & -- & -- & -- & -- & -- & -- \\
\hline $01-06-69$ & -- & -- & -- & -- & -- & -- & -- & -- & -- & -- & -- & -- \\
\hline $08-07-69$ & -- & 460 & & -- & -- & -- & -- & -- & -- & -- & -- & - \\
\hline $01-05-70$ & -- & -- & -- & -- & -- & -- & - & -- & -- & -- & -- & -- \\
\hline $08-04-70$ & -- & 520 & & -- & -- & - & -- & -- & -- & -- & -- & -- \\
\hline $12-30-71$ & -- & 560 & & -- & -- & -- & -- & -- & -- & -- & -- & -- \\
\hline $06-05-73$ & - & 590 & & -- & -- & -- & -- & -- & -- & -- & -- & -- \\
\hline $09-06-74$ & -- & 460 & -- & -- & -- & -- & -- & -- & -- & -- & -- & -- \\
\hline $09-05-75$ & -- & 630 & -- & -- & -- & -- & -- & -- & -- & -- & -- & -- \\
\hline $06-04-76$ & -- & 570 & -- & -- & - & -- & -- & -- & -- & -- & -- & -- \\
\hline $07-01-68$ & -- & 490 & & -- & - & -- & -- & -- & -- & -- & -- & -- \\
\hline $02-01-73$ & -- & 470 & & -- & -- & -- & -- & -- & -- & -- & -- & -- \\
\hline $02-14-74$ & -- & 490 & & -- & -- & -- & -- & -- & -- & -- & -- & -- \\
\hline $02-04-75$ & -- & 470 & -- & -- & -- & -- & -- & - & -- & -- & -- & -- \\
\hline $01-29-76$ & -- & 470 & -- & -- & -- & -- & -- & -- & -- & -- & -- & -- \\
\hline $12-05-63$ & -- & 380 & -- & -- & -- & -- & -- & - & -- & -- & -- & -- \\
\hline $06-03-64$ & - & 420 & -- & -- & -- & -- & -- & -- & -- & -- & -- & -- \\
\hline $08-28-64$ & -- & 410 & -- & - & -- & -- & -- & -- & -- & -- & -- & -- \\
\hline $03-01-65$ & -- & 420 & -- & -- & -- & -- & -- & -- & -- & -- & -- & -- \\
\hline $12-17-65$ & -- & 400 & -- & -- & -- & -- & -- & -- & -- & -- & -- & -- \\
\hline $02-28-66$ & -- & 400 & -- & -- & -- & -- & -- & -- & -- & - & -- & -- \\
\hline
\end{tabular}




\begin{tabular}{|c|c|c|c|c|c|c|c|c|c|c|c|}
\hline DATE & $\begin{array}{c}\text { PHOS- } \\
\text { PHORUS, } \\
\text { ORGANIC } \\
\text { DIS- } \\
\text { SOLVED } \\
\text { (HG/L } \\
\text { AS P) } \\
(00673)\end{array}$ & $\begin{array}{l}\text { HARD- } \\
\text { MESS } \\
\text { (HG/L } \\
\text { AS } \\
\text { CACO3) } \\
(00900)\end{array}$ & $\begin{array}{c}\text { HARD- } \\
\text { NESS, } \\
\text { NOMCAR- } \\
\text { BONATE } \\
\text { (MG/L } \\
\text { CACO3) } \\
\text { (00902) }\end{array}$ & $\begin{array}{l}\text { CALCIUH } \\
\text { DIS- } \\
\text { SOLVED } \\
\text { (HG/L } \\
\text { AS CA) } \\
(00915)\end{array}$ & $\begin{array}{c}\text { MAGNE- } \\
\text { SIUH, } \\
\text { DIS- } \\
\text { SOLVED } \\
\text { (ME/L } \\
\text { AS HG) } \\
\text { (00925) }\end{array}$ & $\begin{array}{c}\text { SODIUH, } \\
\text { DIS- } \\
\text { SOLVED } \\
\text { (HG/L } \\
\text { AS NA) } \\
(00930)\end{array}$ & $\begin{array}{c}\text { SODIUH } \\
\text { AD- } \\
\text { SORP- } \\
\text { TION } \\
\text { RATIO } \\
\text { CO0931I }\end{array}$ & $\begin{array}{c}\text { PERCENT } \\
\text { SODIUH } \\
\text { (00932) }\end{array}$ & $\begin{array}{c}\text { SODIUH+ } \\
\text { POTAS- } \\
\text { SIUH } \\
\text { DIS- } \\
\text { SOLVED } \\
\text { (MG/L } \\
\text { AS NA) } \\
\text { (O0933) }\end{array}$ & $\begin{array}{c}\text { POTAS- } \\
\text { SIUH, } \\
\text { DIS- } \\
\text { SOLVED } \\
\text { (HE/L } \\
\text { AS KI) } \\
\text { (00935) }\end{array}$ & $\begin{array}{l}\text { CHLO } \\
\text { RIDE, } \\
\text { DIS- } \\
\text { SOLVE } \\
\text { IMG / } \\
\text { AS CI } \\
100940\end{array}$ \\
\hline $10-01-69$ & -- & 1400 & 1000 & 380 & 97 & 2000 & 25 & -- & -- & - & 2900 \\
\hline $10-01-70$ & -- & 1400 & 1000 & 400 & 88 & 2000 & 25 & 76 & -- & 9.0 & 2900 \\
\hline $06-10-71$ & - & 1600 & 1100 & 410 & 150 & 1800 & 20 & 71 & -- & 16 & 2600 \\
\hline $05-01-72$ & -- & 1200 & 850 & 320 & 87 & 1800 & 23 & 77 & -- & 16 & 2300 \\
\hline $03-27-73$ & -- & 1100 & 760 & 310 & 82 & 1700 & 22 & 76 & -- & 16 & 2100 \\
\hline $02-14-74$ & -- & 1200 & 860 & 360 & 76 & 1700 & 22 & 75 & -- & 16 & 2300 \\
\hline $02-04-75$ & -- & 1000 & 750 & 290 & 73 & 1500 & 21 & 76 & -- & 15 & 2100 \\
\hline $01-29-76$ & -- & 990 & 640 & 270 & 79 & 1400 & 21 & 76 & -- & 11 & 1800 \\
\hline $04-03-72$ & -- & 560 & 200 & 150 & 48 & 580 & 11 & 69 & -- & 9.0 & 590 \\
\hline $05-01-73$ & -- & 1300 & 890 & 370 & 95 & 1200 & 14 & 65 & -- & 17 & 1500 \\
\hline $05-08-74$ & -- & 1200 & 870 & 310 & 110 & 1200 & 15 & 67 & -- & 18 & 1600 \\
\hline $05-01-75$ & -- & 1300 & 900 & 310 & 130 & 1200 & 15 & 66 & -- & 13 & 1600 \\
\hline $07-03-67$ & -- & 2000 & 1600 & 430 & 230 & 2300 & 23 & 71 & -- & - & 3400 \\
\hline $01-02-68$ & -- & - & -- & - & - & - & -- & -- & -- & -- & -- \\
\hline $08-01-68$ & -- & 2000 & 1600 & 420 & 230 & 2200 & 22 & 71 & -- & -- & 3300 \\
\hline $01-06-69$ & -- & - & -- & -- & -- & - & -- & -- & -- & -- & -- \\
\hline $08-07-69$ & -- & 2000 & 1600 & 440 & 220 & 2200 & 22 & 70 & -- & -- & 3300 \\
\hline $01-05-70$ & -- & -- & $\therefore$ & - & - & - & -- & -- & -- & -- & -- \\
\hline $08-04-70$ & -- & 1900 & 1500 & 490 & 170 & 2100 & 22 & 71 & -- & 18 & 3000 \\
\hline $12-30-71$ & -- & 1900 & 1500 & 450 & 190 & 2100 & 21 & 70 & -- & 20 & 2900 \\
\hline $06-05-73$ & -- & 1600 & 1100 & 350 & 180 & 1900 & 21 & 72 & -- & 22 & 2500 \\
\hline $09-06-74$ & -- & 1400 & 970 & 300 & 140 & 1800 & 22 & 74 & -- & 22 & 2300 \\
\hline $09-05-75$ & -- & 1300 & 830 & 350 & 120 & 1700 & 21 & 73 & -- & 15 & 2100 \\
\hline $06-04-76$ & -- & 1400 & 950 & 310 & 150 & 1700 & 20 & 72 & -- & 15 & 2100 \\
\hline $07-01-68$ & -- & 830 & 430 & 180 & 95 & 1200 & 18 & 76 & -- & -- & 1300 \\
\hline $02-01-73$ & -- & 850 & 460 & 190 & 89 & 1000 & 15 & 72 & -- & 13 & 990 \\
\hline $02-14-74$ & -- & 750 & 350 & 200 & 61 & 1000 & 17 & 74 & -- & 13 & 960 \\
\hline $02-04-75$ & -- & 700 & 320 & 160 & 73 & 900 & 15 & 73 & -- & 13 & 910 \\
\hline $01-29-76$ & -- & 640 & 250 & 140 & 71 & 920 & 16 & 75 & -- & 10 & 820 \\
\hline $12-05-63$ & -- & 1400 & 1100 & 340 & 130 & 800 & 10 & -- & -- & -- & 1400 \\
\hline $06-03-64$ & -- & 1900 & 1600 & 470 & 190 & 1200 & 12 & -- & -- & -- & 2200 \\
\hline $08-28-64$ & -- & 2200 & 1900 & 530 & 220 & 1300 & 13 & -- & -- & -- & 2600 \\
\hline $03-01-65$ & -- & 3000 & 2700 & 740 & 290 & 1800 & 14 & -- & -- & -- & 3700 \\
\hline $12-17-65$ & -- & 2400 & 2100 & 590 & 230 & 1500 & 14 & -- & -- & -- & 2900 \\
\hline $02-28-66$ & -- & 2500 & 2100 & 590 & 250 & 1500 & 14 & -- & -- & -- & 3000 \\
\hline
\end{tabular}




\begin{tabular}{|c|c|c|c|c|c|c|c|c|c|c|c|}
\hline DATE & $\begin{array}{l}\text { SULFATE } \\
\text { DIS- } \\
\text { SOLVED } \\
\text { (MG/L } \\
\text { AS SO4) } \\
\text { (00945) }\end{array}$ & $\begin{array}{l}\text { FLUD- } \\
\text { RIDE, } \\
\text { DIS- } \\
\text { SOLVED } \\
\text { (MG/L } \\
\text { AS F) } \\
(00950)\end{array}$ & $\begin{array}{l}\text { SILICA, } \\
\text { DIS- } \\
\text { SOLVED } \\
\text { IMG/L } \\
\text { AS } \\
\text { SI02) } \\
(00955)\end{array}$ & $\begin{array}{l}\text { BORDH, } \\
\text { DIS- } \\
\text { SOLVED } \\
\text { (UE/L } \\
\text { AS B) } \\
(01020)\end{array}$ & $\begin{array}{c}\text { IRON, } \\
\text { DIS- } \\
\text { SOLVED } \\
\text { (UG/L } \\
\text { AS FE) } \\
(01046)\end{array}$ & $\begin{array}{l}\text { MANGA- } \\
\text { NESE, } \\
\text { DIS- } \\
\text { SOLVED } \\
\text { (UG/L } \\
\text { AS HN) } \\
\text { (01056) }\end{array}$ & $\begin{array}{c}\text { SOLIDS, } \\
\text { RESIDUE } \\
\text { AT IBO } \\
\text { DEE. C } \\
\text { DIS- } \\
\text { SOLVED } \\
\text { (MG/L) } \\
(70300)\end{array}$ & $\begin{array}{l}\text { SOLIDS, } \\
\text { SUH OF } \\
\text { CONSTI- } \\
\text { TUENTS, } \\
\text { DIS- } \\
\text { SOLVED } \\
\text { (MG/L) } \\
\text { (70301) }\end{array}$ & $\begin{array}{c}\text { SOLIDS, } \\
\text { DIS- } \\
\text { SOLVED } \\
\text { (TONS } \\
\text { PER } \\
\text { DAY) } \\
(70302)\end{array}$ & $\begin{array}{c}\text { SOLIDS, } \\
\text { DIS- } \\
\text { SOLVED } \\
\text { (TONS } \\
\text { PER } \\
\text { AC-FT) } \\
(70303)\end{array}$ & $\begin{array}{c}\text { NITRO- } \\
\text { GEN, } \\
\text { AHHONIA } \\
\text { DIS- } \\
\text { SOLVED } \\
\text { (MG/L } \\
\text { AS NH4) } \\
\text { (71846) }\end{array}$ \\
\hline $10-01-69$ & 1400 & -- & -- & -- & - & -- & -- & 7000 & - & -- & -- \\
\hline $10-01-70$ & 1400 & -- & - & -- & -- & - & - & 7000 & -- & - & - \\
\hline $06-10-71$ & 1400 & - & -- & -- & -- & -- & - & 6700 & -- & - & -- \\
\hline $05-01-72$ & 1300 & -- & -- & -- & -- & -- & -- & 6000 & -- & -- & -- \\
\hline $03-27-73$ & 1200 & - & -- & -- & -- & -- & -- & 5600 & -- & -- & -- \\
\hline $02-14-74$ & 1200 & -- & 32 & - & -- & -- & - & 5800 & -- & 7.9 & - \\
\hline $02-04-75$ & 890 & - & 34 & -- & -- & -- & -- & 5000 & -- & 6.9 & -- \\
\hline $01-29-76$ & 1000 & - & 37 & -- & -- & -- & -- & 4900 & - & 6.7 & -- \\
\hline $04-03-72$ & 590 & -- & 28 & 1 & -- & -- & -- & 2200 & -- & 3.0 & -- \\
\hline $05-01-73$ & 1200 & -- & 31 & - & -- & -- & -- & 4600 & - & 6.2 & -- \\
\hline $05-08-74$ & 1200 & -- & 27 & -- & - & -- & -- & 4600 & -- & 6.3 & -- \\
\hline $05-01-75$ & 1200 & -- & 27 & -- & -- & -- & -- & 4800 & -- & 6.5 & -- \\
\hline $07-03-67$ & 1700 & -- & -- & -- & -- & -- & -- & 8300 & -- & 11.7 & - \\
\hline $01-02-68$ & -- & -- & -- & -- & -- & -- & -- & 8500 & - & 11.5 & -- \\
\hline $08-01-68$ & 1700 & - & -- & -- & -- & -- & -- & 8100 & -- & 11.4 & - \\
\hline $01-06-69$ & -- & -- & -- & -- & -- & - & -- & 8400 & -- & 11.4 & - \\
\hline $08-07-69$ & 1700 & - & - & -- & -- & -- & -- & 8100 & -- & 11.7 & -- \\
\hline $01-05-70$ & -- & -- & -- & -- & -- & -- & -- & 8400 & -- & 11.4 & -- \\
\hline $08-04-70$ & 1600 & -- & -- & -- & -- & - & -- & 7600 & -- & 10.8 & -- \\
\hline $12-30-71$ & 1900 & - & - & -- & -- & -- & -- & 7800 & -- & 10.7 & -- \\
\hline $06-05-73$ & 1700 & -- & 14 & -- & - & -- & -- & 6900 & -- & 9.4 & -- \\
\hline $09-06-74$ & 1500 & - & 31 & -- & -- & -- & -- & 6400 & -- & 8.7 & -- \\
\hline $09-05-75$ & 1500 & - & 29 & -- & -- & -- & -- & 6100 & -- & 8.4 & -- \\
\hline $06-04-76$ & 1600 & -- & 30 & -- & -- & -- & -- & 6200 & -- & 8.5 & -- \\
\hline $07-01-68$ & 1200 & - & -- & -- & -- & -- & -- & 4200 & -- & 5.9 & -- \\
\hline $02-01-73$ & 1100 & -- & -- & -- & -- & -- & -- & 3700 & -- & 5.0 & -- \\
\hline $02-14-74$ & 1100 & -- & 28 & -- & -- & -- & -- & 3600 & -- & 4.9 & -- \\
\hline $02-04-75$ & 1200 & -- & 29 & -- & -- & -- & -- & 3600 & -- & 4.9 & -- \\
\hline $01-29-76$ & 1100 & - & 31 & -- & -- & -- & -- & 3300 & -- & 4.5 & -- \\
\hline $12-05-63$ & 870 & -- & -- & -- & -- & -- & -- & 3700 & -- & -- & -- \\
\hline $06-03-64$ & 1100 & -- & -- & - & -- & -- & -- & 5300 & -- & -- & -- \\
\hline $08-28-64$ & 1200 & - & -- & -- & -- & -- & -- & 6100 & -- & -- & -- \\
\hline $03-01-65$ & 1400 & -- & -- & -- & -- & -- & -- & 8100 & -- & -- & -- \\
\hline $12-17-65$ & 1200 & -- & -- & -- & -- & -- & -- & 6600 & -- & -- & -- \\
\hline $02-28-66$ & 1200 & - & -- & - & -- & -- & -- & 6700 & -- & - & -- \\
\hline
\end{tabular}




\begin{tabular}{|c|c|c|c|c|c|c|c|c|c|c|c|}
\hline & $\begin{array}{c}\text { NITRO- } \\
\text { GEN, } \\
\text { NITRATE } \\
\text { TOTAL } \\
\text { (MGG/L } \\
\text { AS NO3) } \\
(71850)\end{array}$ & $\begin{array}{c}\text { NITRD- } \\
\text { GEN, } \\
\text { NITRATE } \\
\text { DIS- } \\
\text { SOLVED } \\
\text { (MG/L } \\
\text { AS NO3) } \\
\text { (71851) }\end{array}$ & $\begin{array}{c}\text { NITRO- } \\
\text { GEN, } \\
\text { NITRITE } \\
\text { DIS- } \\
\text { SOLVED } \\
\text { (IIG/L } \\
\text { AS NO2) } \\
\text { (71856) }\end{array}$ & $\begin{array}{c}\text { NITRO- } \\
\text { GEN, } \\
\text { TOTAL } \\
\text { (NG/L } \\
\text { AS NO3) } \\
\text { (71887) }\end{array}$ & $\begin{array}{c}\text { ELEV. } \\
\text { OF LAND } \\
\text { SURFACE } \\
\text { DATUH } \\
\text { (FT. } \\
\text { ABOVE } \\
\text { NEVD) } \\
(72000)\end{array}$ & $\begin{array}{l}\text { DEPTH } \\
\text { OF } \\
\text { MELL, } \\
\text { TOTAL } \\
\text { (FEET) } \\
\text { (72008) }\end{array}$ & $\begin{array}{c}\text { DEPTH } \\
\text { TO TOP } \\
\text { OF } \\
\text { SAKPLE } \\
\text { INTER- } \\
\text { VAL } \\
\text { (FT) } \\
\text { (72015) }\end{array}$ & $\begin{array}{c}\text { DEPTH } \\
\text { TO BOT- } \\
\text { TOK OF } \\
\text { SAMPLE } \\
\text { INTER- } \\
\text { VAL } \\
\text { (FT) } \\
\text { (72016) }\end{array}$ & $\begin{array}{c}\text { SEDI- } \\
\text { MENT, } \\
\text { DIS- } \\
\text { CHARGE, } \\
\text { SUS- } \\
\text { PENDED } \\
\text { (T/DAY) } \\
\text { (BO155) }\end{array}$ & $\begin{array}{c}\text { SEDI- } \\
\text { MENT, } \\
\text { DISCH, } \\
\text { SUSP. + } \\
\text { BED VA- } \\
\text { TERIAL } \\
\text { (T/DAY) } \\
\text { (80156) }\end{array}$ & $\begin{array}{l}\text { DRAIN- } \\
\text { AGE } \\
\text { AREA } \\
\text { (SE. } \\
\text { HI.) } \\
\text { (81024) }\end{array}$ \\
\hline
\end{tabular}

\begin{tabular}{|c|c|c|c|c|c|c|c|c|c|c|c|}
\hline $10-01-69$ & -- & -- & -- & -- & 307 & 98.00 & -- & - & -- & -- & -- \\
\hline $10-01-70$ & -- & - & -- & -- & 307 & 98.00 & -- & -- & -- & -- & -- \\
\hline $06-10-71$ & -- & -- & -- & -- & 307 & 98.00 & -- & - & -- & -- & - \\
\hline $05-01-72$ & - & - & -- & - & 307 & 98.00 & -- & -- & -- & -- & - \\
\hline $03-27-73$ & -- & -- & -- & -- & 307 & 98.00 & -- & -- & -- & -- & -- \\
\hline $02-14-74$ & -- & - & -- & - & 307 & 98.00 & -- & - & -- & -- & -- \\
\hline $02-04-75$ & - & -- & -- & - & 307 & 98.00 & -- & -- & -- & -- & -- \\
\hline $01-29-76$ & -- & -- & -- & -- & 307 & 98.00 & -- & -- & -- & -- & -- \\
\hline $04-03-72$ & - & $\ldots$ & -- & -- & 297 & 100.00 & -- & -- & -- & -- & -- \\
\hline $05-01-73$ & - & - & -- & -- & 297 & 100.00 & -- & -- & -- & -- & -- \\
\hline $05-08-74$ & -- & -- & -- & -- & 297 & 100.00 & -- & - & -- & -- & -- \\
\hline $05-01-75$ & -- & -- & -- & -- & 297 & 100.00 & -- & -- & -- & -- & -- \\
\hline $07-03-67$ & -- & -- & -- & -- & 293 & 142.00 & - & -- & -- & -- & -- \\
\hline $01-02-68$ & -- & -- & -- & - & 293 & 142.00 & -- & -- & -- & -- & -- \\
\hline $08-01-68$ & -- & -- & -- & -- & 293 & 142.00 & -- & -- & -- & -- & -- \\
\hline $01-06-69$ & - & -- & -- & -- & 293 & 142.00 & -- & -- & -- & - & -- \\
\hline $08-07-69$ & -- & -- & -- & -- & 293 & 142.00 & -- & -- & -- & -- & -- \\
\hline $01-05-70$ & - & -- & -- & -- & 293 & 142.00 & -- & -- & -- & -- & -- \\
\hline $0 B-04-70$ & - & -- & -- & -- & 293 & 142.00 & -- & -- & -- & -- & -- \\
\hline $12-30-71$ & -- & -- & -- & -- & 293 & 142.00 & -- & - & -- & -- & -- \\
\hline $06-05-73$ & -- & - & -- & -- & 293 & 142.00 & -- & -- & -- & -- & -- \\
\hline $09-06-74$ & - & - & -- & - & 293 & 144.00 & -- & -- & -- & -- & -- \\
\hline $09-05-75$ & -- & -- & -- & -- & 293 & 144.00 & -- & -- & -- & -- & -- \\
\hline $06-04-76$ & -- & -- & -- & - & 293 & 144.00 & -- & -- & -- & -- & -- \\
\hline $07-01-68$ & -- & -- & -- & -- & 286 & 144.00 & -- & -- & -- & -- & -- \\
\hline $02-01-73$ & -- & -- & -- & -- & 286 & 144.00 & -- & -- & -- & $\therefore$ & -- \\
\hline $02-14-74$ & -- & -- & -- & -- & 286 & 144.00 & -- & -- & -- & -- & -- \\
\hline $02-04-75$ & -- & - & - & - & 286 & 144.00 & -- & -- & -- & -- & -- \\
\hline $01-29-76$ & - & - & -- & -- & 286 & 144.00 & -- & -- & -- & -- & -- \\
\hline $12-05-63$ & -- & -- & -- & -- & 275 & 89.00 & -- & -- & -- & -- & -- \\
\hline $06-03-64$ & -- & -- & -- & -- & 275 & 89.00 & -- & -- & -- & -- & -- \\
\hline $0 B-2 B-64$ & -- & -- & - & -- & 275 & 89.00 & -- & -- & -- & -- & - \\
\hline $03-01-65$ & -- & -- & -- & -- & 275 & 89.00 & - & - & -- & -- & -- \\
\hline $12-17-65$ & -- & - & -- & -- & 275 & 89.00 & -- & -- & -- & -- & -- \\
\hline $02-28-66$ & -- & -- & -- & -- & 275 & 89.00 & -- & -- & -- & -- & -- \\
\hline
\end{tabular}


LOCAL

IDENT-

I-

FIER
C-07-16 33CBB

[- $-07-16$ 33СBB

C-07-16 33CBB

C-07-16 34BBB

C-07-16 34BBB

C-07-16 348BB

C-07-16 348BB

C-07-16 34BBB

C $-07-16 \quad 348 B B$

C-07-16 348BB

C $-07-16 \quad 348 B B$

C-07-16 34BBB

C-07-17 3400D

C-07-17 3400D

C-07-17 340DD

C-07-17 3400D

C-07-17 3400D

C-07-17 3400D

C-07-17 3400D

C-07-17 34DDD

C-07-17 340DD

C- $07-1734000$

C-07-17 340DD

C- $-07-1734000$

C-07-17 3400D

C-07-17 3400D

C $-08-16$ 01BCC

C-08-16 01BCC

C-08-16 01BCC

C-08-16 01BCC

C-08-16 01BCC

C-08-16 01BCC

C-08-16 01BCC

C-08-16 01BCC

C-08-16 01BCC

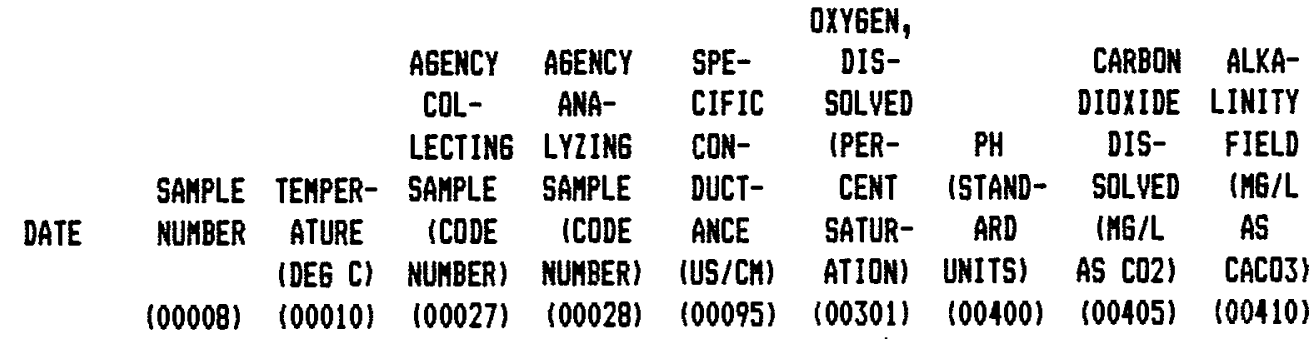

\begin{tabular}{|c|c|c|c|c|c|c|c|c|c|}
\hline $03-28-74$ & 1230 & -- & - & -- & 12400 & -- & 7.5 & 24 & 388 \\
\hline $03-05-75$ & 1230 & -- & -- & -- & 10100 & -- & 7.5 & 24 & 398 \\
\hline $05-04-76$ & 1230 & -- & - & -- & 9410 & -- & 7.4 & 32 & 415 \\
\hline $01-06-69$ & 1230 & -- & - & 1076 & 9670 & -- & -- & -- & -- \\
\hline $10-01-69$ & 1230 & -- & -- & 1076 & 9390 & -- & -- & -- & 461 \\
\hline $01-02-70$ & 1230 & -- & -- & 1076 & 8540 & -- & -- & -- & -- \\
\hline $10-01-70$ & 1230 & -- & -- & 1076 & 7850 & -- & 8.0 & 8.8 & 455 \\
\hline $10-07-71$ & 1230 & -- & -- & 1076 & 7010 & -- & 7.7 & 17 & 428 \\
\hline $10-03-72$ & 1230 & '-- & -- & 1076 & 6490 & -- & 7.8 & 13 & 415 \\
\hline $10-04-73$ & 1230 & -- & -- & 1076 & 6100 & -- & 7.8 & 14 & 445 \\
\hline $10-01-74$ & 1230 & -- & -- & -- & 5950 & -- & 8.0 & 11 & 566 \\
\hline $10-06-75$ & 1230 & -- & -- & -- & 5590 & - & 7.7 & 17 & 440 \\
\hline $08-28-64$ & 1230 & -- & -- & -- & 12800 & -- & -- & -- & 335 \\
\hline $03-30-65$ & 1230 & -- & - & -- & 11900 & -- & -- & -- & 338 \\
\hline $07-07-65$ & 1230 & -- & -- & -- & 11800 & -- & -- & -- & 335 \\
\hline $06-20-66$ & 1230 & -- & -- & -- & 10500 & -- & -- & -- & 343 \\
\hline $09-19-67$ & 1230 & -- & -- & -- & 10200 & -- & $\because$ & -- & 360 \\
\hline $10-24-68$ & 1230 & -- & - & -- & 9290 & -- & - & - & 360 \\
\hline $10-02-69$ & 1230 & -- & -- & -- & 8680 & -- & -- & -- & 359 \\
\hline $10-05-70$ & 1230 & -- & -- & -- & 7040 & -- & 8.1 & 5.7 & 371 \\
\hline $10-08-71$ & 1230 & -- & -- & -- & 7710 & -- & 7.8 & 11 & 355 \\
\hline $02-02-72$ & 1230 & -- & -- & -- & 8470 & -- & 7.6 & 17 & 358 \\
\hline $02-05-73$ & 1230 & -- & -- & -- & 8500 & -- & 7.7 & 14 & 367 \\
\hline $03-01-74$ & 1230 & -- & -- & -- & 7140 & -- & 7.8 & 12 & 376 \\
\hline $05-01-75$ & 1230 & -- & -- & -- & 8150 & -- & 7.6 & 19 & 385 \\
\hline $06-03-76$ & 1230 & -- & -- & -- & 7530 & -- & 7.7 & 16 & 403 \\
\hline $12-05-63$ & 1230 & -- & -- & -- & 3630 & -- & -- & -- & 349 \\
\hline $02-27-64$ & 1230 & -- & -- & -- & 4160 & -- & -- & -- & 367 \\
\hline $08-28-64$ & $123 \theta$ & -- & -- & -- & 4210 & -- & -- & -- & 353 \\
\hline $03-01-65$ & 1230 & -- & -- & -- & 4430 & -- & -- & -- & 371 \\
\hline $08-30-65$ & 1230 & -- & -- & -- & 4290 & -- & -- & -- & 360 \\
\hline $12-01-65$ & 1230 & -- & -- & -- & 4290 & -- & -- & -- & 358 \\
\hline $02-28-66$ & 1230 & -- & - & -- & 4550 & -- & -- & -- & 390 \\
\hline $07-01-66$ & 1230 & -- & -- & -- & 4420 & -- & -- & -- & 393 \\
\hline $07-03-67$ & 1230 & -- & -- & -- & 4550 & -- & -- & -- & 323 \\
\hline
\end{tabular}




\begin{tabular}{|c|c|c|c|c|c|c|c|c|c|c|c|c|}
\hline DATE & $\begin{array}{c}\text { ACIDITY } \\
\text { (HG/L } \\
\text { AS } \\
\text { CACO3) } \\
\text { (00435) }\end{array}$ & $\begin{array}{c}\text { BICAR- } \\
\text { BONATE } \\
\text { FET-FLD } \\
\text { (MG/L } \\
\text { AS } \\
\text { HCO3) } \\
(00440)\end{array}$ & $\begin{array}{c}\text { CAR- } \\
\text { BONATE } \\
\text { FET-FLD } \\
\text { (MG/L } \\
\text { AS CO3) } \\
(00445)\end{array}$ & $\begin{array}{l}\text { NITRO- } \\
\text { GEN, } \\
\text { TOTAL } \\
\text { (HGG/L } \\
\text { AS N) } \\
(00600)\end{array}$ & $\begin{array}{c}\text { NITRO- } \\
\text { GEN, } \\
\text { ORGANIC } \\
\text { TOTAL } \\
\text { (MG/L } \\
\text { AS N) } \\
\text { (00605) }\end{array}$ & $\begin{array}{c}\text { MITRO- } \\
\text { GEN, } \\
\text { ORGANIC } \\
\text { DIS- } \\
\text { SOLVED } \\
\text { (MG/L } \\
\text { AS N) } \\
(00607)\end{array}$ & $\begin{array}{c}\text { NITRO- } \\
\text { GEN, } \\
\text { NITRATE } \\
\text { DIS- } \\
\text { SOLYED } \\
\text { (MG/L } \\
\text { AS N) } \\
(00618)\end{array}$ & $\begin{array}{c}\text { NITRO- } \\
\text { GEN, } \\
\text { NITRATE } \\
\text { TOTAL } \\
\text { (MG/L } \\
\text { AS N) } \\
(00620)\end{array}$ & $\begin{array}{c}\text { NITRO- } \\
\text { GEN, } \\
\text { NO2+NO3 } \\
\text { DIS- } \\
\text { SOLVED } \\
\text { (MG/L } \\
\text { AS N) } \\
\text { (00631) }\end{array}$ & $\begin{array}{c}\text { PHOS- } \\
\text { PHATE, } \\
\text { ORTHO, } \\
\text { DIS- } \\
\text { SOLVED } \\
\text { (MG/L } \\
\text { AS PO4) } \\
\text { (00660) }\end{array}$ & $\begin{array}{c}\text { PHOS- } \\
\text { PHORUS, } \\
\text { ORGANIC } \\
\text { TOTAL } \\
\text { (MG/L } \\
\text { AS P) } \\
(00670)\end{array}$ & $\begin{array}{l}\text { PHOS- } \\
\text { PHORUS, } \\
\text { ORTHO, } \\
\text { DIS- } \\
\text { SOLVED } \\
\text { (HG/L } \\
\text { AS P) } \\
(00671)\end{array}$ \\
\hline $03-28-74$ & -- & 470 & -- & -- & -- & -- & -- & -- & -- & -- & -- & - \\
\hline $03-05-75$ & -- & 470 & -- & -- & -- & -- & -- & -- & -- & -- & -- & -- \\
\hline $05-04-76$ & -- & 510 & -- & -- & -- & -- & -- & -- & -- & -- & -- & -- \\
\hline $01-06-69$ & -- & -- & -- & -- & -- & - & -- & -- & -- & -- & -- & - \\
\hline $10-01-69$ & -- & 560 & 0 & -- & -- & -- & -- & -- & -- & -- & -- & -- \\
\hline $01-02-70$ & -- & -- & -- & -- & -- & - & -- & -- & -- & -- & -- & -- \\
\hline $10-01-70$ & -- & 560 & 0 & -- & -- & -- & -- & -- & -- & -- & -- & -- \\
\hline $10-07-71$ & -- & 520 & 0 & -- & -- & - & -- & -- & -- & -- & -- & - \\
\hline $10-03-72$ & -- & 510 & 0 & -- & -- & -- & -- & -- & -- & - & -- & -- \\
\hline $10-04-73$ & -- & 540 & 0 & -- & -- & - & -- & -- & -- & - & -- & -- \\
\hline $10-01-74$ & -- & 690 & -- & -- & -- & - & -- & -- & -- & -- & -- & - \\
\hline $10-06-75$ & -- & 540 & -- & -- & -- & - & -- & -- & -- & -- & -- & -- \\
\hline $08-28-64$ & -- & 410 & -- & -- & -- & -- & -- & -- & -- & -- & -- & -- \\
\hline $03-30-65$ & -- & 410 & -- & -- & -- & - & -- & -- & -- & -- & -- & -- \\
\hline $07-07-65$ & -- & 410 & -- & -- & -- & -- & -- & -- & -- & -- & -- & -- \\
\hline $06-20-66$ & -- & 420 & -- & -- & -- & - & -- & -- & - & -- & -- & -- \\
\hline $09-19-67$ & -- & 440 & -- & -- & -- & - & -- & -- & - & -- & -- & -- \\
\hline $10-24-68$ & -- & 410 & 14 & -- & -- & -- & -- & -- & -- & -- & -- & -- \\
\hline $10-02-69$ & -- & 440 & -- & -- & -- & -- & -- & -- & -- & -- & -- & -- \\
\hline $10-05-70$ & -- & 450 & -- & -- & -- & - & -- & -- & -- & -- & -- & -- \\
\hline $10-08-71$ & -- & 430 & -- & -- & -- & -- & -- & -- & -- & -- & -- & -- \\
\hline $02-02-72$ & -- & 440 & -- & -- & -- & -- & -- & -- & -- & -- & -- & -- \\
\hline $02-05-73$ & -- & 450 & -- & -- & -- & -- & -- & -- & -- & -- & -- & -- \\
\hline $03-01-74$ & -- & 460 & -- & -- & -- & -- & -- & -- & -- & -- & -- & - \\
\hline $05-01-75$ & -- & 470 & -- & -- & -- & -- & -- & - & -- & -- & -- & -- \\
\hline $06-03-76$ & -- & 490 & -- & -- & -- & -- & -- & -- & -- & -- & -- & -- \\
\hline $12-05-63$ & -- & 430 & -- & -- & - & -- & -- & - & -- & -- & -- & -- \\
\hline $02-27-64$ & -- & 450 & -- & -- & -- & -- & -- & -- & -- & -- & -- & -- \\
\hline $08-28-64$ & -- & 430 & -- & -- & -- & - & -- & -- & -- & -- & -- & -- \\
\hline $03-01-65$ & -- & 450 & -- & -- & -- & - & -- & -- & -- & -- & +- & -- \\
\hline $08-30-65$ & -- & 440 & -- & -- & -- & -- & -- & -- & -- & -- & -- & -- \\
\hline $12-01-65$ & -- & 440 & -- & -- & -- & -- & -- & -- & -- & -- & -- & -- \\
\hline $02-28-66$ & -- & 480 & -- & -- & -- & -- & -- & -- & -- & -- & -- & -- \\
\hline $07-01-66$ & -- & 480 & -- & -- & -- & -- & -- & -- & -- & - & -- & -- \\
\hline $07-03-67$ & -- & 390 & -- & -- & -- & -- & -- & -- & -- & -- & -- & -- \\
\hline
\end{tabular}




\begin{tabular}{|c|c|c|c|c|c|c|c|c|c|c|c|}
\hline DATE & $\begin{array}{l}\text { PHOS- } \\
\text { PHORUS, } \\
\text { ORGANIC } \\
\text { DIS- } \\
\text { SOLVED } \\
\text { (HIG/L } \\
\text { AS P) } \\
(00673)\end{array}$ & $\begin{array}{l}\text { HARD- } \\
\text { MESS } \\
\text { (HG/L } \\
\text { AS } \\
\text { CACD3) } \\
(00900)\end{array}$ & $\begin{array}{c}\text { HARD- } \\
\text { NESS, } \\
\text { MONCAR- } \\
\text { BONATE } \\
\text { (MG/L } \\
\text { CACO3) } \\
(00902)\end{array}$ & $\begin{array}{l}\text { CALCIUM } \\
\text { DIS- } \\
\text { SOLVED } \\
\text { (MG/L } \\
\text { AS CA) } \\
(00915)\end{array}$ & $\begin{array}{c}\text { HAGNE- } \\
\text { SIUH, } \\
\text { DIS- } \\
\text { SOLVED } \\
\text { (MG/L } \\
\text { AS HG) } \\
(00925)\end{array}$ & $\begin{array}{l}\text { SODIUH, } \\
\text { DIS- } \\
\text { SOLVED } \\
\text { (MG/L } \\
\text { AS NA) } \\
\text { (00930) }\end{array}$ & $\begin{array}{c}\text { SODIUH } \\
\text { AD- } \\
\text { SORP- } \\
\text { TION } \\
\text { RATIO } \\
\text { (00931) }\end{array}$ & $\begin{array}{l}\text { PERCENT } \\
\text { SODIUH } \\
(00932)\end{array}$ & $\begin{array}{c}\text { SODIUH+ } \\
\text { POTAS- } \\
\text { SIUH } \\
\text { DIS- } \\
\text { SOLVED } \\
\text { (HE/L } \\
\text { AS HA) } \\
\text { (00933) }\end{array}$ & $\begin{array}{l}\text { POTAS- } \\
\text { SIUH, } \\
\text { DIS- } \\
\text { SOLVED } \\
\text { (HG/L } \\
\text { AS K) } \\
\text { (00935) }\end{array}$ & $\begin{array}{l}\text { CHLO- } \\
\text { RIDE, } \\
\text { DIS- } \\
\text { SOLVE } \\
\text { IMG/L } \\
\text { AS CL } \\
100940\end{array}$ \\
\hline $03-28-74$ & -- & 2500 & 2100 & 640 & 230 & 1900 & 17 & 62 & -- & 26 & 3300 \\
\hline $03-05-75$ & -- & 2000 & 1600 & 520 & 170 & 1600 & 16 & 63 & -- & 32 & 2600 \\
\hline $05-04-76$ & -- & 1800 & 1400 & 420 & 190 & 1400 & 15 & 63 & -- & 17 & 2200 \\
\hline $01-06-69$ & - & -- & -- & - & - & -- & -- & -- & -- & - & -- \\
\hline $10-01-69$ & -- & 1300 & 860 & 300 & 140 & 1800 & 22 & 74 & -- & -- & 2100 \\
\hline $01-02-70$ & - & -- & -- & -- & -- & -- & -- & -- & - & -- & -- \\
\hline $10-01-70$ & -- & 1100 & 600 & 240 & 110 & 1500 & 21 & 75 & - & 18 & 1700 \\
\hline $10-07-71$ & -- & 920 & 490 & 240 & 80 & 1400 & 20 & 76 & -- & 15 & 1400 \\
\hline $10-03-72$ & -- & 860 & 440 & 260 & 49 & 1200 & 18 & 75 & -- & 16 & 1200 \\
\hline $10-04-73$ & -- & 800 & 350 & 210 & 66 & 1100 & 18 & 75 & -- & 16 & 1100 \\
\hline $10-01-74$ & -- & 760 & 190 & 180 & 72 & 1100 & 18 & 76 & -- & 23 & 1100 \\
\hline $10-06-75$ & - & 780 & 340 & 180 & 79 & 1000 & 16 & 74 & -- & 10 & 970 \\
\hline $08-28-64$ & -- & 1900 & 1600 & 400 & 230 & 2400 & 25 & -- & -- & -- & 3700 \\
\hline $03-30-65$ & -- & 1700 & 1400 & 350 & 210 & 2300 & 25 & - & -- & -- & 3400 \\
\hline $07-07-65$ & -- & 1600 & 1300 & 330 & 190 & 2200 & 25 & -- & -- & -- & 3200 \\
\hline $06-20-66$ & -- & 1400 & 1100 & 280 & 170 & 2000 & 24 & -- & -- & -- & 2700 \\
\hline $09-19-67$ & -- & 1300 & 950 & 270 & 160 & 1900 & 23 & - & - & -- & 2500 \\
\hline $10-24-68$ & - & 1100 & 770 & 230 & 130 & 1800 & 24 & -- & - & -- & 2200 \\
\hline $10-02-69$ & -- & 980 & 620 & 210 & 110 & 1600 & 23 & - & -- & -- & 2000 \\
\hline $10-05-70$ & -- & 730 & 360 & 190 & 62 & 1300 & 22 & 79 & - & 15 & 1400 \\
\hline $10-08-71$ & -- & 820 & 470 & 200 & 79 & 1500 & 24 & 80 & - & 14 & 1700 \\
\hline $02-02-72$ & -- & 960 & 600 & 260 & 77 & 1700 & 24 & 79 & -- & 12 & 1900 \\
\hline $02-05-73$ & -- & 980 & 610 & 220 & 100 & 1700 & 24 & 78 & -- & 15 & 1900 \\
\hline $03-01-74$ & -- & 680 & 300 & 150 & 72 & 1400 & 23 & 81 & -- & 11 & 1500 \\
\hline $05-01-75$ & -- & 820 & 440 & 170 & 95 & 1600 & 24 & 80 & -- & 10 & 1800 \\
\hline $06-03-76$ & -- & 710 & 310 & 150 & 82 & 1500 & 24 & 81 & -- & 11 & 1500 \\
\hline $12-05-63$ & - & 1100 & 780 & 290 & 100 & 410 & 5 & -- & -- & -- & 570 \\
\hline $02-27-64$ & -- & 1400 & 980 & 340 & 120 & 440 & 5 & -- & -- & -- & 770 \\
\hline $08-28-64$ & -- & 1400 & 1000 & 350 & 130 & 470 & 6 & -- & -- & - & 790 \\
\hline $03-01-65$ & -- & 1400 & 1100 & 390 & 110 & 490 & $b$ & -- & -- & -- & 860 \\
\hline $08-30-65$ & -- & 1400 & 1000 & 340 & 120 & 480 & 6 & -- & -- & -- & 770 \\
\hline $12-01-65$ & -- & 1400 & 1000 & 350 & 130 & 490 & $b$ & -- & -- & - & 810 \\
\hline $02-28-66$ & -- & 1500 & 1100 & 370 & 130 & 520 & 6 & -- & -- & - & 860 \\
\hline $07-01-66$ & -- & 1400 & 1000 & 360 & 130 & 510 & $b$ & -- & -- & -- & 830 \\
\hline $07-03-67$ & -- & 1300 & 1000 & 330 & 130 & 530 & 7 & -- & -- & -- & 820 \\
\hline
\end{tabular}




\begin{tabular}{|c|c|c|c|c|c|c|c|c|c|c|c|}
\hline DATE & $\begin{array}{l}\text { SULFATE } \\
\text { DIS- } \\
\text { SOLVED } \\
\text { (HG/L } \\
\text { AS SO4) } \\
\text { (00945) }\end{array}$ & $\begin{array}{l}\text { FLUO- } \\
\text { RIDE, } \\
\text { DIS- } \\
\text { SOLVED } \\
(\text { HG/L } \\
\text { AS F) } \\
(00950)\end{array}$ & $\begin{array}{l}\text { SILICA, } \\
\text { DIS- } \\
\text { SOLVED } \\
\text { IMG/L } \\
\text { AS } \\
\text { SI02) } \\
(00955)\end{array}$ & $\begin{array}{l}\text { BORON, } \\
\text { DIS- } \\
\text { SOLVED } \\
\text { (UG/L } \\
\text { AS B) } \\
(01020)\end{array}$ & $\begin{array}{c}\text { IRON, } \\
\text { DIS- } \\
\text { SOLVED } \\
\text { (U6/L } \\
\text { AS FE) } \\
\text { (01046) }\end{array}$ & $\begin{array}{l}\text { MANGA- } \\
\text { NESE, } \\
\text { DIS- } \\
\text { SOLVED } \\
\text { (U6/L } \\
\text { AS HW) } \\
(01056)\end{array}$ & $\begin{array}{l}\text { SOLIDS, } \\
\text { RESIDUE } \\
\text { AT 1BO } \\
\text { DEE. C } \\
\text { DIS- } \\
\text { SOLVED } \\
\text { (HE/L) } \\
(70300)\end{array}$ & $\begin{array}{c}\text { SOLIDS, } \\
\text { SUH OF } \\
\text { CONSTI- } \\
\text { TUENTS, } \\
\text { DIS- } \\
\text { SOLVED } \\
\text { (HG/L) } \\
\text { (7030!) }\end{array}$ & $\begin{array}{c}\text { SOLIDS, } \\
\text { DIS- } \\
\text { SOLVED } \\
\text { (TONS } \\
\text { PER } \\
\text { DAY) } \\
(70302)\end{array}$ & $\begin{array}{c}\text { SOLIDS, } \\
\text { DIS- } \\
\text { SOLVED } \\
\text { (TDMS } \\
\text { PER } \\
\text { AC-FT) } \\
(70303)\end{array}$ & $\begin{array}{r}\text { NITRO } \\
\text { GEN, } \\
\text { AMHONI } \\
\text { DIS- } \\
\text { SOLVE } \\
\text { IMG/L } \\
\text { AS NHA } \\
\text { (71846 }\end{array}$ \\
\hline $03-28-74$ & 1500 & - & 26 & -- & -- & - & -- & 7900 & -- & 10.7 & -- \\
\hline $03-05-75$ & 1400 & - & 25 & -- & -- & -- & -- & 6500 & -- & 8.9 & -- \\
\hline $05-04-76$ & 1400 & - & 25 & - & -- & -- & -- & 5900 & -- & 8.0 & -- \\
\hline $01-06-69$ & -- & -- & -- & - & - & -- & -- & 6500 & -- & 8.9 & -- \\
\hline $10-01-69$ & 1700 & -- & -- & -- & -- & -- & -- & 6200 & -- & 9.0 & -- \\
\hline $01-02-70$ & -- & -- & -- & -- & -- & - & - & 5900 & -- & B.0 & -- \\
\hline $10-01-70$ & 1600 & -- & -- & - & -- & -- & -- & 5400 & -- & 7.1 & -- \\
\hline $10-07-71$ & 1300 & -- & -- & -- & -- & - & -- & 4700 & -- & 6.5 & -- \\
\hline $10-03-72$ & 1200 & -- & -- & - & -- & -- & -- & 4200 & -- & 5.7 & - \\
\hline $10-04-73$ & 1200 & -- & 28 & -- & -- & - & -- & 4000 & -- & 5.5 & -- \\
\hline $10-01-74$ & 1100 & - & 29 & -- & -- & -- & -- & 4000 & -- & 5.4 & -- \\
\hline $10-06-75$ & 1100 & -- & 29 & -- & -- & -- & -- & 3600 & -- & 5.0 & - \\
\hline $08-28-64$ & 1600 & - & -- & -- & -- & -- & -- & 8500 & -- & -- & -- \\
\hline $03-30-65$ & 1600 & -- & -- & -- & -- & -- & -- & 8000 & - & -- & -- \\
\hline $07-07-65$ & 1500 & - & -- & -- & -- & -- & -- & 7600 & -- & - & -- \\
\hline $0 b-20-66$ & 1400 & -- & -- & - & -- & - & -- & 6800 & -- & -- & -- \\
\hline $09-19-67$ & 1500 & -- & -- & -- & -- & -- & -- & 6500 & -- & - & -- \\
\hline $10-24-68$ & 1400 & - & - & -- & -- & -- & -- & 6000 & -- & - & -- \\
\hline $10-02-69$ & 1300 & - & - & -- & -- & - & -- & 5500 & -- & -- & -- \\
\hline $10-05-70$ & 1200 & - & -- & -- & -- & - & - & 4400 & -- & -- & -- \\
\hline $10-08-71$ & 1300 & -- & -- & -- & -- & -- & -- & 5000 & -- & -- & -- \\
\hline $02-02-72$ & 1500 & -- & - & -- & -- & -- & -- & 5600 & -- & -- & -- \\
\hline $02-05-73$ & 1400 & -- & -- & -- & - & -- & -- & 5400 & -- & -- & -- \\
\hline $03-01-74$ & 1100 & -- & 48 & - & -- & - & -- & 4400 & -- & 6.1 & -- \\
\hline $05-01-75$ & 1300 & -- & 46 & -- & -- & - & -- & 5200 & -- & 7.0 & -- \\
\hline $06-03-76$ & 1200 & -- & 47 & - & - & -- & -- & 4700 & -- & 6.4 & -- \\
\hline $12-05-63$ & 830 & -- & -- & - & -- & -- & -- & 2400 & -- & -- & -- \\
\hline $02-27-64$ & 880 & - & -- & - & -- & -- & -- & 2800 & -- & -- & -- \\
\hline $08-28-64$ & 910 & - & -- & -- & -- & -- & -- & 2900 & -- & -- & -- \\
\hline $03-01-65$ & 930 & -- & - & - & - & -- & -- & 3000 & -- & -- & -- \\
\hline $08-30-65$ & 910 & - & -- & -- & - & -- & -- & 2800 & -- & -- & - \\
\hline $12-01-65$ & 920 & -- & - & -- & -- & -- & -- & 2900 & -- & -- & -- \\
\hline $02-28-66$ & 950 & - & -- & - & -- & - & -- & 3100 & -- & -- & -- \\
\hline $07-01-66$ & 950 & -- & -- & -- & -- & -- & -- & 3000 & -- & -- & -- \\
\hline $07-03-67$ & 970 & - & -- & - & -- & -- & -- & 3000 & -- & -- & - \\
\hline
\end{tabular}




\begin{tabular}{|c|c|c|c|c|c|c|c|c|c|c|c|}
\hline DATE & $\begin{array}{c}\text { NITRO- } \\
\text { GEN, } \\
\text { NITRATE } \\
\text { TOTAL } \\
\text { (HG/L } \\
\text { AS NOJ) } \\
(71850)\end{array}$ & $\begin{array}{c}\text { NITRO- } \\
\text { GEN, } \\
\text { NITRATE } \\
\text { DIS- } \\
\text { SDLVED } \\
\text { (HIG/L } \\
\text { AS NO3) } \\
\text { (71851) }\end{array}$ & $\begin{array}{c}\text { NITRO- } \\
\text { GEM, } \\
\text { NITRITE } \\
\text { DIS- } \\
\text { SOLVED } \\
\text { (MG/L } \\
\text { AS NO2) } \\
\text { (71856) }\end{array}$ & $\begin{array}{c}\text { NITRO- } \\
\text { GEN, } \\
\text { TOTAL } \\
\text { (HG/L } \\
\text { AS NO3) } \\
\text { (71887) }\end{array}$ & $\begin{array}{c}\text { ELEV. } \\
\text { OF LAND } \\
\text { SURFACE } \\
\text { DATUH } \\
\text { (FT. } \\
\text { ABOVE } \\
\text { NGUD) } \\
(72000)\end{array}$ & $\begin{array}{c}\text { DEPTH } \\
\text { OF } \\
\text { MELL, } \\
\text { TOTAL } \\
\text { (FEET) } \\
\text { (72008) }\end{array}$ & $\begin{array}{l}\text { DEPTH } \\
\text { TO TOP } \\
\text { OF } \\
\text { SAMPLE } \\
\text { INTER- } \\
\text { VAL } \\
\text { (FT) } \\
(72015)\end{array}$ & $\begin{array}{c}\text { DEPTH } \\
\text { TO BOT- } \\
\text { TOH OF } \\
\text { SAMPLE } \\
\text { INTER- } \\
\text { VAL } \\
\text { (FT) } \\
(72016)\end{array}$ & $\begin{array}{c}\text { SEDI- } \\
\text { MENT, } \\
\text { DIS- } \\
\text { CHARGE, } \\
\text { SUS- } \\
\text { PENDED } \\
\text { (T/DAY) } \\
\text { (B0155) }\end{array}$ & $\begin{array}{l}\text { SEDI- } \\
\text { MENT, } \\
\text { DISCH, } \\
\text { SUSP. + } \\
\text { BED HA- } \\
\text { TERIAL } \\
\text { (T/DAY) } \\
\text { (80156) }\end{array}$ & $\begin{array}{c}\text { DRAIN- } \\
\text { AGE } \\
\text { AREA } \\
\text { (SQ. } \\
\text { MI.) } \\
\text { (81024) }\end{array}$ \\
\hline $03-28-74$ & -- & -- & -- & -- & 275 & 89.00 & -- & -- & -- & - & -- \\
\hline $03-05-75$ & -- & -- & -- & -- & 275 & 89.00 & -- & -- & -- & -- & -- \\
\hline $05-04-76$ & -- & - & - & -- & 275 & 89.00 & -- & - & -- & -- & -- \\
\hline $01-06-69$ & -- & -- & -- & -- & 279 & 90.00 & -- & -- & -- & -- & -- \\
\hline $10-01-69$ & -- & - & -- & -- & 279 & 90.00 & -- & $-\infty$ & -- & -- & -- \\
\hline $01-02-70$ & -- & -- & -- & - & 279 & 90.00 & -- & -- & -- & - & -- \\
\hline $10-01-70$ & -- & - & -- & - & 279 & 90.00 & -- & -- & -- & -- & -- \\
\hline $10-07-71$ & -- & - & -- & - & 279 & 90.00 & -- & -- & -- & -- & -- \\
\hline $10-03-72$ & -- & - & -- & - & 279 & 90.00 & -- & -- & -- & -- & -- \\
\hline $10-04-73$ & -- & -- & -- & -- & 279 & 90.00 & -- & -- & -- & -- & -- \\
\hline $10-01-74$ & -- & -- & - & -- & 279 & 92.00 & -- & -- & -- & -- & -- \\
\hline $10-0 b-75$ & -- & -- & - & -- & 279 & 92.00 & -- & -- & -- & -- & -- \\
\hline $08-28-64$ & -- & -- & -- & -- & 266 & 96.00 & -- & -- & -- & -- & -- \\
\hline $03-30-65$ & -- & -- & -- & - & 266 & 96.00 & -- & -- & -- & -- & -- \\
\hline $07-07-65$ & -- & -- & -- & -- & 266 & 96.00 & -- & -- & -- & - & -- \\
\hline $06-20-66$ & -- & -- & -- & -- & 266 & 96.00 & -- & - & -- & -- & -- \\
\hline $09-19-67$ & -- & - & -- & - & 266 & 96.00 & -- & -- & -- & -- & -- \\
\hline $10-24-68$ & -- & -- & -- & - & 266 & 96.00 & -- & -- & -- & -- & -- \\
\hline $10-02-69$ & -- & -- & -- & -- & 266 & 96.00 & -- & - & -- & - & -- \\
\hline $10-05-70$ & -- & - & -- & - & 266 & 96.00 & -- & -- & -- & -- & -- \\
\hline $10-08-71$ & -- & - & -- & - & 266 & 96.00 & -- & -- & -- & -- & -- \\
\hline $02-02-72$ & - & -- & -- & - & 266 & 96.00 & -- & -- & -- & -- & -- \\
\hline $02-05-73$ & -- & - & -- & - & 266 & 96.00 & -- & -- & -- & -- & -- \\
\hline $03-01-74$ & -- & -- & -- & - & 266 & 96.00 & -- & -- & -- & -- & -- \\
\hline $05-01-75$ & -- & -- & -- & -- & 266 & 96.00 & -- & -- & -- & -- & -- \\
\hline $06-03-76$ & -- & -- & -- & $-\rightarrow$ & $26 b$ & 96.00 & -- & -- & -- & -- & -- \\
\hline $12-05-63$ & -- & - & -- & -- & 283 & 103.00 & -- & -- & -- & -- & -- \\
\hline $02-27-64$ & -- & - & - & -- & 283 & 103.00 & -- & - & - & $-\cdots$ & -- \\
\hline $08-28-64$ & -- & -- & -- & -- & 283 & 103.00 & -- & -- & -- & - & -- \\
\hline $03-01-65$ & -- & -- & -- & - & 283 & 103.00 & -- & - & -- & -- & -- \\
\hline $08-30-65$ & -- & - & -- & -- & 283 & 103.00 & -- & -- & -- & -- & -- \\
\hline $12-01-65$ & -- & -- & -- & -- & 283 & 103.00 & -- & -- & -- & -- & -- \\
\hline $02-28-66$ & -- & -- & -- & - & 283 & 103.00 & -- & -- & -- & -- & -- \\
\hline $07-01-66$ & -- & - & -- & -- & 283 & 103.00 & -- & -- & -- & -- & -- \\
\hline $07-03-67$ & -- & - & -- & -- & 283 & 103.00 & -- & -- & -- & -- & -- \\
\hline
\end{tabular}


LOCAL

IDENT-

I-

FIER
C-08-16 01BCC

C-08-16 01BCC

C-08-16 01BCC

C-08-16 01BCC

C-08-16 01BCC

C-08-16 01BCC

C-08-16 04BAA

C-08-16 04BAA

C-08-16 04BAA

C-08-16 04BAA

C-08-16 09BDD

C $-08-16 \quad 09 B D D$

C-08-16 09BDD

C-08-16 09BDD

C-08-16 09BDD

C- $-08-16 \quad 098 D D$

C-08-16 09BDD

C-08-16 $118 B B$

C $-08-16 \quad 11 \mathrm{BBB}$

C-08-16 11BBB

C-08-16 11BBB

C-08-16 11BBB

C $-08-16$ 11BBB

C $-08-16 \quad 118 B B$

C-08-16 11BBB

C- $08-16 \quad 118 B B$

C $-08-16 \quad 11 B B B$

C $-08-16 \quad 118 B B$

C-08-16 22BBA

C-08-16 22BBA

C-08-16 22BBA

C-08-16 22BBA

C-08-16 22BBA

C-08-16 22BBA

C-08-16 22BBA

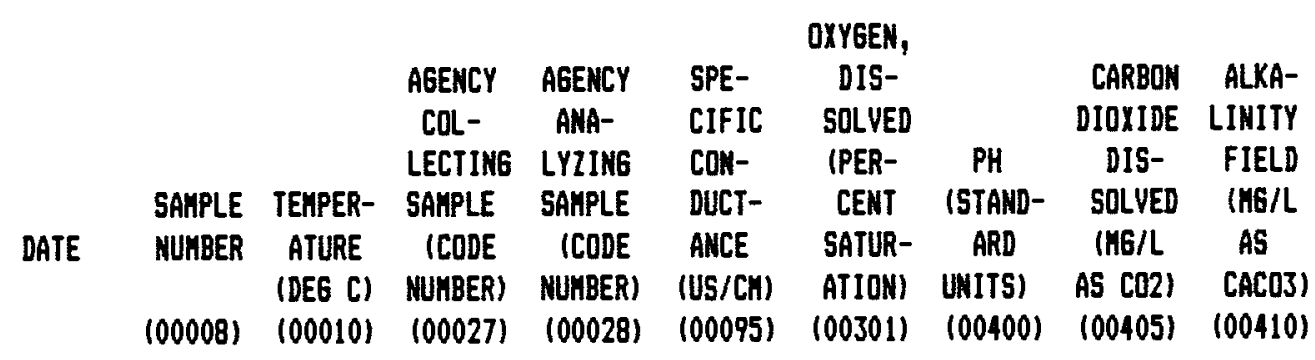

$\begin{array}{rlllllllll}07-02-68 & 1230 & -- & -- & -- & 4690 & -- & -- & - & 353 \\ 07-18-69 & 1230 & -- & -- & -- & 4980 & -- & - & -- & 399 \\ 08-04-70 & 1230 & - & -- & -- & 4440 & -- & 8.1 & 6.0 & 390 \\ 02-01-72 & 1230 & -- & - & -- & 4730 & -- & 7.7 & 15 & 400 \\ 02-01-73 & 1230 & -- & -- & -- & 4640 & -- & 7.8 & 12 & 405 \\ & & & & & & & & & \\ 01-02-74 & 1230 & -- & -- & -- & 4410 & -- & 7.7 & 15 & 382 \\ 03-03-69 & 1230 & -- & -- & 1076 & 5150 & -- & -- & -- & -- \\ 07-02-69 & 1230 & -- & -- & 1076 & 5060 & -- & -- & -- & 383 \\ 11-30-70 & 1230 & -- & -- & 1076 & 5080 & -- & -- & -- & 410 \\ 01-29-76 & 1230 & -- & -- & -- & 5730 & -- & 7.4 & 36 & 465 \\ & & & & & & & & & \\ 08-07-69 & 1230 & -- & -- & -- & 5870 & -- & -- & - & 365 \\ 09-02-70 & 1230 & -- & -- & -- & 5920 & -- & 7.8 & 12 & 400 \\ 01-03-72 & 1230 & -- & -- & -- & 5490 & -- & 7.7 & 16 & 403 \\ 01-03-73 & 1230 & -- & -- & -- & 5330 & -- & 7.7 & 18 & 463 \\ 05-07-74 & 1230 & -- & -- & -- & 4890 & -- & 7.6 & 23 & 464 \\ 06-02-75 & 1230 & -- & -- & -- & 4580 & -- & 7.5 & 27 & 446 \\ 05-04-76 & 1230 & -- & -- & -- & 4810 & -- & 7.5 & 26 & 426 \\ 12-05-63 & 1230 & -- & -- & -- & 8530 & -- & -- & - & 586 \\ 02-27-64 & 1230 & -- & -- & -- & 7940 & -- & -- & -- & 616 \\ 08-28-64 & 1230 & -- & -- & -- & 7350 & -- & -- & - & 551 \\ & & & -- & & & & & & \\ 10-24-68 & 1230 & -- & -- & -- & 6030 & -- & -- & -- & 398 \\ 07-02-69 & 1230 & -- & -- & -- & 5890 & -- & -- & -- & 532 \\ 09-29-70 & 1230 & -- & -- & -- & 5560 & -- & 8.0 & 10 & 521 \\ 06-10-71 & 1230 & -- & -- & -- & 5480 & -- & 8.0 & 8.1 & 418 \\ 05-01-72 & 1230 & -- & -- & -- & 5650 & -- & 7.7 & 19 & 490 \\ & & & & & & & & & \\ 04-30-73 & 1230 & -- & -- & -- & 5420 & - & 7.8 & 17 & 541 \\ 11-05-74 & 1230 & -- & -- & -- & 5520 & -- & 7.7 & 14 & 358 \\ 10-03-75 & 1230 & -- & -- & -- & 5130 & -- & 7.6 & 20 & 402 \\ 01-03-68 & 1230 & -- & -- & 1076 & 5370 & -- & -- & -- & -- \\ 01-05-68 & 1230 & -- & -- & 1076 & 5030 & -- & -- & - & 270 \\ & & & -- & & & & & & \\ 07-02-68 & 1230 & -- & -- & 1076 & 5250 & -- & -- & -- & 253 \\ 01-07-69 & 1230 & -- & -- & 1076 & 5380 & -- & -- & - & -- \\ 07-02-69 & 1230 & -- & -- & 1076 & 5320 & -- & -- & -- & 239 \\ 01-05-70 & 1230 & -- & - & 1076 & 5180 & -- & -- & -- & -- \\ 09-02-70 & 1230 & -- & -- & 1076 & 4750 & -- & 7.9 & 5.4 & 220\end{array}$




\begin{tabular}{|c|c|c|c|c|c|c|c|c|c|c|c|c|}
\hline DATE & $\begin{array}{c}\text { ACIDITY } \\
\text { (MG/L } \\
\text { AS } \\
\text { CACO3) } \\
(00435)\end{array}$ & $\begin{array}{c}\text { BICAR- } \\
\text { BONATE } \\
\text { FET-FLD } \\
\text { (MG/L } \\
\text { AS } \\
\text { HCO3) } \\
(00440)\end{array}$ & $\begin{array}{c}\text { CAR- } \\
\text { BONATE } \\
\text { FET-FLD } \\
\text { (MG/L } \\
\text { AS CO3) } \\
(00445)\end{array}$ & $\begin{array}{l}\text { NITRO- } \\
\text { GEN, } \\
\text { TOTAL } \\
\text { (MG/L } \\
\text { AS N) } \\
\text { (00600) }\end{array}$ & $\begin{array}{l}\text { NITRO- } \\
\text { GEN, } \\
\text { ORGANIC } \\
\text { TOTAL } \\
\text { (HG/L } \\
\text { AS N) } \\
(00605)\end{array}$ & $\begin{array}{l}\text { NITRO- } \\
\text { GEN, } \\
\text { ORGANIC } \\
\text { DIS- } \\
\text { SOLVED } \\
\text { (MG/L } \\
\text { AS N) } \\
\text { (00607) }\end{array}$ & $\begin{array}{c}\text { NITRO- } \\
\text { GEN, } \\
\text { MITRATE } \\
\text { DIS- } \\
\text { SOLVED } \\
\text { (MG } / L \\
\text { AS N) } \\
\text { (00618) }\end{array}$ & $\begin{array}{c}\text { NITRO- } \\
\text { GEN, } \\
\text { NITRATE } \\
\text { TOTAL } \\
\text { (HG/L } \\
\text { AS N) } \\
(00620)\end{array}$ & $\begin{array}{c}\text { NITRO- } \\
\text { GEN, } \\
\text { NO2+NO3 } \\
\text { DIS- } \\
\text { SOLVED } \\
\text { (MG/L } \\
\text { AS N) } \\
(00631)\end{array}$ & $\begin{array}{c}\text { PHOS- } \\
\text { PHATE, } \\
\text { ORTHO, } \\
\text { DIS- } \\
\text { SOLVED } \\
\text { (MG/L } \\
\text { AS PO4) } \\
\text { (00660) }\end{array}$ & $\begin{array}{c}\text { PHOS- } \\
\text { PHORUS, } \\
\text { ORGANIC } \\
\text { TOTAL } \\
\text { (NG/L } \\
\text { AS P) } \\
(00670)\end{array}$ & $\begin{array}{c}\text { PHDS- } \\
\text { PHORUS, } \\
\text { ORTHD } \\
\text { DIS- } \\
\text { SOLVED } \\
\text { (MG/L } \\
\text { AS P) } \\
(00671)\end{array}$ \\
\hline $07-02-68$ & -- & 430 & -- & - & -- & -- & -- & -- & -- & -- & -- & -- \\
\hline $07-18-69$ & -- & 490 & -- & -- & -- & -- & -- & -- & -- & -- & -- & -- \\
\hline $08-04-70$ & -- & 480 & -- & -- & -- & -- & -- & - & -- & -- & - & -- \\
\hline $02-01-72$ & -- & 490 & -- & -- & - & -- & -- & -- & -- & -- & -- & -- \\
\hline $02-01-73$ & -- & 490 & -- & - & -- & -- & -- & -- & -- & -- & -- & -- \\
\hline $01-02-74$ & -- & 470 & -- & -- & -- & - & -- & - & -- & -- & -- & -- \\
\hline $03-03-69$ & -- & -- & -- & -- & -- & - & -- & -- & -- & -- & -- & - \\
\hline $07-02-69$ & -- & 470 & 0 & - & -- & - & -- & -- & -- & -- & -- & -- \\
\hline $11-30-70$ & - & 500 & 0 & - & -- & -- & - & -- & -- & -- & - & -- \\
\hline $01-29-76$ & -- & 570 & -- & -- & - & - & -- & -- & -- & -- & -- & -- \\
\hline $08-07-69$ & -- & 450 & -- & -- & -- & -- & -- & - & -- & -- & -- & - \\
\hline $09-02-70$ & -- & 490 & -- & -- & -- & -- & -- & -- & -- & -- & -- & -- \\
\hline $01-03-72$ & - & 490 & -- & - & -- & -- & - & -- & -- & -- & -- & -- \\
\hline $01-03-73$ & -- & 560 & -- & -- & -- & -- & -- & -- & - & -- & -- & -- \\
\hline $05-07-74$ & -- & 570 & -- & - & -- & -- & - & -- & -- & -- & -- & - \\
\hline $06-02-75$ & -- & 540 & -- & -- & - & -- & -- & -- & -- & -- & -- & -- \\
\hline $05-04-76$ & -- & 520 & -- & -- & -- & -- & -- & -- & -- & - & -- & - \\
\hline $12-05-63$ & -- & 710 & -- & -- & -- & - & -- & -- & -- & - & -- & -- \\
\hline $02-27-64$ & -- & 750 & -- & - & -- & -- & - & -- & -- & -- & -- & -- \\
\hline $08-28-64$ & -- & 670 & -- & -- & -- & -- & -- & -- & -- & -- & -- & -- \\
\hline $10-24-68$ & -- & 490 & -- & - & -- & -- & -- & -- & -- & - & -- & -- \\
\hline $07-02-69$ & -- & 650 & - & - & -- & -- & -- & -- & -- & -- & -- & -- \\
\hline $09-29-70$ & -- & 640 & -- & -- & -- & -- & -- & -- & -- & -- & -- & -- \\
\hline $06-10-71$ & -- & 510 & - & -- & -- & -- & -- & -- & -- & -- & -- & -- \\
\hline $05-01-72$ & -- & 600 & -- & -- & -- & -- & -- & -- & -- & - & -- & -- \\
\hline $04-30-73$ & -- & 660 & -- & -- & -- & -- & -- & -- & -- & - & -- & -- \\
\hline $11-05-74$ & -- & 440 & -- & - & -- & -- & -- & - & -- & -- & - & -- \\
\hline $10-03-75$ & -- & 490 & -- & -- & -- & - & -- & - & -- & -- & -- & -- \\
\hline $01-03-68$ & -- & - & -- & - & -- & -- & -- & -- & -- & - & -- & -- \\
\hline $01-05-68$ & -- & 330 & 0 & -- & -- & -- & -- & -- & -- & -- & -- & -- \\
\hline $07-02-68$ & - & 310 & -- & - & -- & - & -- & -- & -- & -- & -- & -- \\
\hline $01-07-69$ & -- & -- & -- & -- & -- & -- & -- & -- & -- & -- & -- & -- \\
\hline $07-02-69$ & -- & 290 & 0 & - & - & -- & -- & -- & -- & -- & -- & -- \\
\hline $01-05-70$ & -- & -- & -- & -- & -- & -- & -- & -- & -- & -- & -- & -- \\
\hline $09-02-70$ & - & 270 & 0 & -- & -- & -- & -- & -- & -- & - & -- & -- \\
\hline
\end{tabular}




\begin{tabular}{|c|c|c|c|c|c|c|c|c|c|c|c|}
\hline DATE & $\begin{array}{c}\text { PHOS- } \\
\text { PHORUS, } \\
\text { ORGANIC } \\
\text { DIS- } \\
\text { SOLVED } \\
\text { (MG/L } \\
\text { AS P) } \\
(00673)\end{array}$ & $\begin{array}{l}\text { HARD- } \\
\text { NESS } \\
\text { (HG/L } \\
\text { AS } \\
\text { CACO3) } \\
\text { (00900) }\end{array}$ & $\begin{array}{c}\text { HARD- } \\
\text { NESS, } \\
\text { NONCAR- } \\
\text { BONATE } \\
\text { (MG/L } \\
\text { CACO3) } \\
(00902)\end{array}$ & $\begin{array}{l}\text { CALCIUH } \\
\text { DIS- } \\
\text { SOLVED } \\
\text { (M6/L } \\
\text { AS CA) } \\
\text { (00915) }\end{array}$ & $\begin{array}{c}\text { MAGHE- } \\
\text { SIUM, } \\
\text { DIS- } \\
\text { SOLVED } \\
\text { (MG/L } \\
\text { A5 MG) } \\
\text { (00925) }\end{array}$ & $\begin{array}{c}\text { SODIUH, } \\
\text { DIS- } \\
\text { SOLVED } \\
\text { (MG/L } \\
\text { AS NA) } \\
\text { (00930) }\end{array}$ & $\begin{array}{l}\text { SODIUH } \\
\text { AD- } \\
\text { SORP- } \\
\text { TION } \\
\text { RATIO } \\
\text { (00931) }\end{array}$ & $\begin{array}{c}\text { PERCENT } \\
\text { SODIUH } \\
(00932)\end{array}$ & $\begin{array}{c}\text { SODIUHA } \\
\text { POTAS- } \\
\text { SIUH } \\
\text { DIS- } \\
\text { SOLVED } \\
\text { (MG/L } \\
\text { AS NA) } \\
\text { (00933) }\end{array}$ & $\begin{array}{c}\text { POTAS- } \\
\text { SIUH, } \\
\text { DIS- } \\
\text { SOLVED } \\
\text { (NGG/L } \\
\text { AS X) } \\
\text { (00935) }\end{array}$ & $\begin{array}{l}\text { CHLD } \\
\text { RIDE, } \\
\text { DIS- } \\
\text { SOLV } \\
\text { IMG/L } \\
\text { AS CL } \\
10094 C\end{array}$ \\
\hline $07-02-68$ & -- & 1400 & 1000 & 340 & 130 & 550 & 7 & -- & -- & -- & 860 \\
\hline $07-18-69$ & -- & 1400 & 1000 & 360 & 120 & 610 & 7 & -- & -- & -- & 940 \\
\hline $08-04-70$ & -- & 1400 & 1000 & 380 & 110 & 650 & 8 & 50 & -- & 13 & 860 \\
\hline $02-01-72$ & -- & 1300 & 920 & 370 & 94 & 660 & 8 & 52 & -- & 13 & 840 \\
\hline $02-01-73$ & -- & 1300 & 900 & 340 & 110 & 610 & 8 & 50 & -- & 16 & 780 \\
\hline $01-02-74$ & -- & 1100 & 750 & 300 & 91 & 600 & 8 & 53 & -- & 15 & 740 \\
\hline $03-03-69$ & -- & - & -- & - & -- & -- & -- & -- & -- & -- & -- \\
\hline $07-02-69$ & -- & 1300 & 920 & 320 & 120 & 680 & 8 & 53 & -- & -- & 850 \\
\hline $11-30-70$ & -- & 1300 & 890 & 370 & 92 & 710 & 9 & 65 & -- & -- & 820 \\
\hline $01-29-76$ & -- & 1500 & 1100 & 380 & 140 & 800 & 9 & 53 & -- & 14 & 1000 \\
\hline $08-07-69$ & -- & 1500 & 1100 & 380 & 130 & 780 & 9 & -- & -- & -- & 1300 \\
\hline $09-02-70$ & -- & 1600 & 1200 & 410 & 140 & 770 & 9 & 51 & -- & 16 & 1300 \\
\hline $01-03-72$ & -- & 1300 & 940 & 370 & 100 & 820 & 10 & 57 & -- & 12 & 1100 \\
\hline $01-03-73$ & -- & 1400 & 890 & 380 & 100 & 740 & 9 & 54 & - & 14 & 950 \\
\hline $05-07-74$ & -- & 1200 & 740 & 320 & 97 & 710 & 9 & 56 & -- & 15 & 840 \\
\hline $06-02-75$ & - & 1000 & 550 & 260 & 86 & 700 & 10 & 60 & -- & 10 & 730 \\
\hline $05-04-76$ & - & 1200 & 730 & 280 & 110 & 630 & 8 & 54 & -- & 11 & 700 \\
\hline $12-05-63$ & -- & 1700 & 1100 & 400 & 170 & 1500 & 16 & -- & $\cdots$ & - & 2000 \\
\hline $02-27-64$ & -- & 1500 & 920 & 350 & 160 & 1300 & 15 & -- & -- & - & 1700 \\
\hline $08-28-64$ & -- & 1400 & 900 & 320 & 160 & 1200 & 14 & - & -- & -- & 1600 \\
\hline $10-24-68$ & -- & 1100 & 690 & 240 & 120 & 960 & 13 & -- & -- & -- & 1200 \\
\hline $07-02-69$ & -- & 1000 & 500 & 250 & 100 & 970 & 14 & -- & -- & - & 1100 \\
\hline $09-29-70$ & -- & 990 & 470 & 250 & 90 & 910 & 13 & 66 & -- & 15 & 1000 \\
\hline $06-10-71$ & -- & 930 & 510 & 300 & 46 & 880 & 13 & 67 & -- & 14 & 1000 \\
\hline $05-01-72$ & -- & 1000 & 550 & 250 & 100 & 900 & 13 & 65 & -- & 12 & 960 \\
\hline $04-30-73$ & -- & 1000 & 510 & 290 & 77 & 890 & 12 & 65 & -- & 15 & 940 \\
\hline $11-05-74$ & -- & 890 & 540 & 200 & 99 & 900 & 14 & 68 & -- & 23 & 930 \\
\hline $10-03-75$ & -- & 900 & 500 & 200 & 98 & 860 & 13 & 67 & -- & 11 & 930 \\
\hline $01-03-68$ & -- & -- & -- & -- & - & - & -- & -- & -- & -- & -- \\
\hline $01-05-68$ & -- & 450 & 180 & 110 & 46 & 990 & 21 & 83 & -- & - & 960 \\
\hline $07-02-68$ & -- & 550 & 300 & 130 & 55 & 970 & 19 & 79 & -- & - & 1000 \\
\hline $01-07-69$ & -- & - & -- & -- & -- & -- & - & -- & -- & -- & -- \\
\hline $07-02-69$ & -- & 570 & 330 & 140 & 55 & 960 & 18 & 7900 & -- & -- & 1000 \\
\hline $01-05-70$ & -- & -- & -- & - & -- & -- & $-\infty$ & -- & -- & - & -- \\
\hline $09-02-70$ & -- & 520 & 300 & 150 & 36 & 840 & 17 & 78 & -- & 10 & 860 \\
\hline
\end{tabular}




\begin{tabular}{|c|c|c|c|c|c|c|c|c|c|c|c|}
\hline DATE & $\begin{array}{l}\text { SULFATE } \\
\text { DIS- } \\
\text { SOLVED } \\
\text { (MG/L } \\
\text { AS SO4) } \\
\text { (00945) }\end{array}$ & $\begin{array}{l}\text { FLUO- } \\
\text { RIDE, } \\
\text { DIS- } \\
\text { SOLVED } \\
\text { (NG/L } \\
\text { AS F) } \\
(00950)\end{array}$ & $\begin{array}{l}\text { SILICA, } \\
\text { DIS- } \\
\text { SOLVED } \\
\text { (MG/L } \\
\text { AS } \\
\text { SIO2) } \\
(00955)\end{array}$ & $\begin{array}{c}\text { BOROH, } \\
\text { DIS- } \\
\text { SOLVED } \\
\text { (US/L } \\
\text { AS B) } \\
\text { (01020) }\end{array}$ & $\begin{array}{l}\text { IRON, } \\
\text { DIS- } \\
\text { SOLVED } \\
\text { (UG/L } \\
\text { AS FE) } \\
\text { (01046) }\end{array}$ & $\begin{array}{l}\text { MANGA- } \\
\text { NESE, } \\
\text { DIS- } \\
\text { SDLVED } \\
\text { (UG/L } \\
\text { AS MM) } \\
\text { (01056) }\end{array}$ & $\begin{array}{c}\text { SOLIDS, } \\
\text { RESIDUE } \\
\text { AT } 180 \\
\text { DEG. C } \\
\text { DIS- } \\
\text { SOLVED } \\
\text { (MG/L) } \\
(70300)\end{array}$ & $\begin{array}{l}\text { SOLIDS, } \\
\text { SUH OF } \\
\text { CONSTI- } \\
\text { TUENTS, } \\
\text { DIS- } \\
\text { SOLVED } \\
\text { (IHG/L) } \\
\text { (70301) }\end{array}$ & $\begin{array}{c}\text { SOLIDS, } \\
\text { DIS- } \\
\text { SOLVED } \\
\text { (TONS } \\
\text { PER } \\
\text { DAY) } \\
\text { (70302) }\end{array}$ & $\begin{array}{c}\text { SOLIDS, } \\
\text { DIS- } \\
\text { SOLVED } \\
\text { (TONS } \\
\text { PER } \\
\text { AC-FT) } \\
(70303)\end{array}$ & $\begin{array}{r}\text { NITRO } \\
\text { GEN, } \\
\text { AMMONI } \\
\text { DIS- } \\
\text { SOLVE } \\
\text { IMG/L } \\
\text { AS NH4 } \\
\text { (71846 }\end{array}$ \\
\hline $07-02-68$ & 990 & - & -- & -- & -- & -- & -- & 3100 & -- & -- & - \\
\hline $07-18-69$ & 1000 & -- & -- & - & - & -- & -- & 3300 & -- & -- & -- \\
\hline $08-04-70$ & 980 & - & -- & - & -- & - & -- & 3200 & -- & -- & -- \\
\hline $02-01-72$ & 1100 & -- & - & - & -- & -- & -- & 3300 & -- & -- & -- \\
\hline $02-01-73$ & 1100 & -- & -- & -- & -- & -- & - & 3200 & -- & -- & -- \\
\hline $01-02-74$ & 910 & - & 26 & -- & - & -- & -- & 2900 & -- & 4.0 & -- \\
\hline $03-03-69$ & -- & -- & -- & -- & -- & -- & - & 3700 & -- & 5.0 & -- \\
\hline $07-02-69$ & 1200 & - & -- & -- & -- & - & -- & 3400 & -- & 4.9 & -- \\
\hline $11-30-70$ & 1200 & -- & -- & - & -- & -- & -- & 3500 & -- & 5.1 & -- \\
\hline $01-29-76$ & 1300 & - & 26 & - & - & -- & -- & 3900 & -- & 5.3 & -- \\
\hline $08-07-69$ & 1000 & -- & -- & - & -- & -- & - & 3800 & -- & -- & -- \\
\hline $.09-02-70$ & 1000 & -- & -- & -- & -- & - & -- & 3900 & -- & -- & -- \\
\hline $01-03-72$ & 1100 & -- & -- & - & -- & -- & -- & 3800 & -- & -- & -- \\
\hline $01-03-73$ & 1000 & - & -- & -- & -- & -- & -- & 3500 & -- & -- & -- \\
\hline $05-07-74$ & 1000 & -- & 30 & -- & -- & -- & -- & 3300 & -- & 4.5 & -- \\
\hline $06-02-75$ & 920 & -- & 29 & -- & -- & -- & -- & 3000 & -- & 4.1 & - \\
\hline $05-04-76$ & 1000 & -- & 29 & -- & -- & -- & -- & 3100 & -- & 4.2 & -- \\
\hline $12-05-63$ & 1600 & -- & -- & - & - & -- & -- & 5900 & -- & -- & -- \\
\hline $02-27-64$ & 1400 & -- & -- & -- & -- & -- & -- & 5300 & -- & -- & -- \\
\hline $08-28-64$ & 1200 & -- & -- & - & -- & -- & -- & 4900 & -- & $\cdots$ & -- \\
\hline $10-24-68$ & 1100 & -- & - & -- & -- & -- & -- & 3800 & -- & -- & -- \\
\hline $07-02-69$ & 1000 & -- & -- & - & -- & -- & -- & 3800 & -- & -- & -- \\
\hline $09-29-70$ & 1000 & -- & -- & -- & -- & -- & -- & 3700 & -- & -- & -- \\
\hline $06-10-71$ & 950 & -- & -- & - & -- & -- & -- & 3500 & -- & -- & -- \\
\hline $05-01-72$ & 1100 & -- & -- & -- & -- & -- & -- & 3600 & -- & -- & -- \\
\hline $04-30-73$ & 1000 & -- & 28 & -- & -- & -- & -- & 3600 & -- & 4.9 & -- \\
\hline $11-05-74$ & 1000 & -- & 27 & -- & -- & -- & -- & 3400 & -- & 4.7 & -- \\
\hline $10-03-75$ & 950 & -- & 28 & - & -- & -- & -- & 3300 & -- & 4.5 & - \\
\hline $01-03-68$ & -- & -- & -- & -- & -- & -- & -- & 3500 & -- & 4.7 & -- \\
\hline $01-05-68$ & 960 & -- & -- & -- & -- & -- & -- & 3200 & -- & 4.5 & -- \\
\hline $07-02-68$ & 950 & -- & -- & - & -- & -- & -- & 3300 & -- & 4.6 & -- \\
\hline $01-07-69$ & -- & -- & -- & -- & -- & -- & -- & 3400 & -- & 4.7 & -- \\
\hline $07-02-69$ & 950 & -- & -- & -- & -- & -- & -- & 3300 & -- & 4.7 & -- \\
\hline $01-05-70$ & -- & -- & - & -- & -- & -- & -- & 3400 & -- & 4.6 & -- \\
\hline $09-02-70$ & 900 & - & -- & -- & -- & -- & -- & 2900 & -- & 4.2 & -- \\
\hline
\end{tabular}




\begin{tabular}{|c|c|c|c|c|c|c|c|c|c|c|c|}
\hline DATE & $\begin{array}{c}\text { NITRO- } \\
\text { GEN, } \\
\text { NITRATE } \\
\text { TOTAL } \\
\text { (MG/L } \\
\text { AS NOJ) } \\
\text { (71850) }\end{array}$ & $\begin{array}{c}\text { NITRO- } \\
\text { GEN, } \\
\text { HITRATE } \\
\text { DIS- } \\
\text { SOLVED } \\
\text { (MG/L } \\
\text { AS NO3) } \\
\text { (71851) }\end{array}$ & $\begin{array}{c}\text { NITRO- } \\
\text { GEN, } \\
\text { HITRITE } \\
\text { DIS- } \\
\text { SOLVED } \\
\text { (MGIL } \\
\text { AS NO2) } \\
\text { (7I856) }\end{array}$ & $\begin{array}{c}\text { NITRO- } \\
\text { GEN, } \\
\text { TOTAL } \\
\text { (MG/L } \\
\text { AS NO3) } \\
\text { (71887) }\end{array}$ & $\begin{array}{l}\text { ELEV. } \\
\text { OF LAND } \\
\text { SURFACE } \\
\text { DATUA } \\
\text { (FT. } \\
\text { ABOVE } \\
\text { NGVD) } \\
\text { (72000) }\end{array}$ & $\begin{array}{c}\text { DEPTH } \\
\text { OF } \\
\text { HELL, } \\
\text { TOTAL } \\
\text { (FEET) } \\
(72008)\end{array}$ & $\begin{array}{c}\text { DEPTH } \\
\text { TO TOP } \\
\text { OF } \\
\text { SAMPLE } \\
\text { INTER- } \\
\text { VAL } \\
\text { (FT) } \\
(72015)\end{array}$ & $\begin{array}{c}\text { DEPTH } \\
\text { TO BOT- } \\
\text { TOM OF } \\
\text { SAMPLE } \\
\text { INTER- } \\
\text { VAL } \\
\text { (FT) } \\
(72016)\end{array}$ & $\begin{array}{c}\text { SEDI- } \\
\text { MENT, } \\
\text { DIS- } \\
\text { CHARGE, } \\
\text { SUS- } \\
\text { PENDED } \\
\text { (T/DAY) } \\
\text { (80155) }\end{array}$ & $\begin{array}{l}\text { SEDI- } \\
\text { MENT, } \\
\text { DISCH, } \\
\text { SUSP. + } \\
\text { BED HA- } \\
\text { TERIAL } \\
\text { (T/DAY) } \\
\text { (80156) }\end{array}$ & $\begin{array}{c}\text { DRAIN } \\
\text { AGE } \\
\text { AREA } \\
\text { (SQ. } \\
\text { MI.) } \\
\text { (81024) }\end{array}$ \\
\hline $07-02-68$ & -- & -- & -- & -- & 283 & 103.00 & -- & -- & -- & -- & -- \\
\hline $07-18-69$ & - & -- & -- & -- & 283 & 103.00 & -- & -- & -- & -- & -- \\
\hline $08-04-70$ & -- & -- & -- & -- & 283 & 103.00 & -- & -- & -- & -- & -- \\
\hline $02-01-72$ & -- & -- & -- & -- & 283 & 103.00 & -- & -- & -- & -- & -- \\
\hline $02-01-73$ & -- & -- & -- & -- & 283 & 103.00 & -- & -- & -- & -- & -- \\
\hline $01-02-74$ & -- & -- & -- & -- & 283 & 103.00 & -- & - & -- & -- & -- \\
\hline $03-03-69$ & -- & -- & -- & -- & 276 & 97.00 & -- & -- & -- & -- & -- \\
\hline $07-02-69$ & -- & -- & -- & -- & 276 & 97.00 & -- & -- & -- & -- & -- \\
\hline $11-30-70$ & -- & -- & -- & -- & 276 & 97.00 & -- & -- & -- & -- & -- \\
\hline $01-29-76$ & -- & -- & - & - & 276 & 97.00 & -- & -- & -- & -- & -- \\
\hline $08-07-69$ & -- & -- & -- & -- & 270 & 109.00 & -- & -- & -- & -- & -- \\
\hline $09-02-70$ & -- & -- & -- & -- & 270 & 109.00 & -- & -- & -- & -- & -- \\
\hline $01-03-72$ & -- & -- & -- & -- & 270 & 109.00 & -- & -- & -- & -- & -- \\
\hline $01-03-73$ & -- & -- & -- & -- & 270 & 109.00 & -- & -- & -- & -- & -- \\
\hline $05-07-74$ & -- & -- & -- & -- & 270 & 109.00 & -- & -- & -- & -- & -- \\
\hline $06-02-75$ & -- & -- & -- & -- & 270 & 107.00 & -- & -- & -- & -- & -- \\
\hline $05-04-76$ & -- & - & -- & -- & 270 & 109.00 & -- & -- & -- & -- & -- \\
\hline $12-05-63$ & -- & -- & -- & -- & 281 & 63.00 & -- & -- & -- & -- & -- \\
\hline $02-27-64$ & -- & - & -- & -- & 281 & 63.00 & -- & -- & -- & -- & -- \\
\hline $08-28-64$ & -- & -- & -- & -- & 281 & 63.00 & -- & -- & -- & -- & -- \\
\hline $10-24-68$ & -- & -- & -- & -- & 281 & 63.00 & -- & -- & -- & -- & -- \\
\hline $07-02-69$ & -- & -- & -- & -- & 281 & 63.00 & -- & - & -- & -- & -- \\
\hline $09-29-70$ & -- & -- & -- & -- & 281 & 63.00 & -- & -- & -- & -- & -- \\
\hline $06-10-71$ & -- & -- & -- & -- & 281 & 63.00 & -- & -- & -- & -- & -- \\
\hline $05-01-72$ & -- & -- & -- & -- & 281 & 63.00 & -- & -- & -- & -- & -- \\
\hline $04-30-73$ & -- & -- & -- & -- & 281 & 63.00 & -- & -- & -- & -- & -- \\
\hline $11-05-74$ & -- & -- & -- & -- & 281 & 63.00 & -- & -- & -- & -- & -- \\
\hline $10-03-75$ & -- & - & -- & -- & 281 & 63.00 & -- & -- & -- & -- & -- \\
\hline $01-03-68$ & -- & -- & -- & - & 294 & 72.00 & -- & -- & -- & -- & -- \\
\hline $01-05-68$ & -- & -- & -- & - & 294 & 72.00 & -- & -- & -- & -- & -- \\
\hline $07-02-68$ & -- & -- & -- & -- & 294 & 72.00 & -- & -- & -- & -- & -- \\
\hline $01-07-69$ & -- & -- & -- & -- & 294 & 72.00 & -- & -- & -- & -- & -- \\
\hline $07-02-69$ & -- & -- & -- & -- & 294 & 72.00 & -- & -- & -- & -- & -- \\
\hline $01-05-70$ & -- & -- & -- & -- & 294 & 72.00 & -- & -- & -- & -- & -- \\
\hline $09-02-70$ & -- & -- & - & -- & 294 & 72.00 & -- & -- & -- & -- & -- \\
\hline
\end{tabular}


LOCAL

IDENT-

I-

FIER
C-08-16 22BBA

C-0B-16 22BBA

C-08-16 22BBA

C-08-16 22BBA

C- $08-16$ 22BBA

C-0B-16 228BA

C-08-17 01BBC

C-08-17 01BBC

C-08-17 01BBC

C-08-17 01BBC

C-08-17 01BBC

C-08-17 01BBC

C-08-17 01BBC

C-08-17 08BBB

[-08-17 08BBB

C-08-17 08BBB

C-08-17 08BBB

C $-08-1708 B 8 B$

C-08-17 0888B

C-08-17 08B8B

C-08-17 08BBB

C $-08-17$ 08BBB

C $-08-17$ 13BBB

C-08-17 13BBB

C-08-17 $13 B B B$

C-08-17 13BBB

C-08-17 $138 B 8$

C-08-17 13BBB

C-08-17 138BB

C-08-17 13BBB

C-08-17 13BBB

[-08-17 138BB

C-08-18 14AAA

C-08-18 I4AAA

C-08-18 14AAA

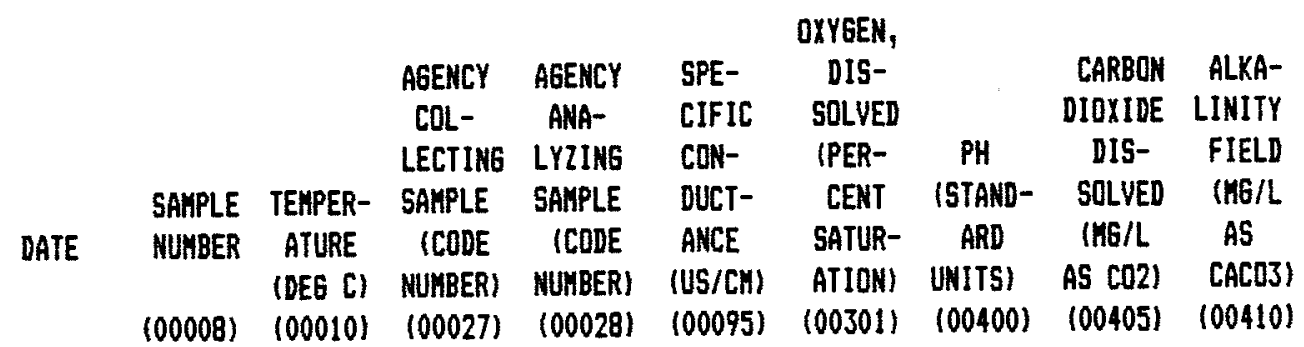

\begin{tabular}{|c|c|c|c|c|c|c|c|c|}
\hline $06-01-71$ & 1230 & -- & - & 1076 & 4710 & -- & 7.9 & 5.6 \\
\hline $05-01-72$ & 1230 & -- & - & 1076 & 4650 & -- & 7.8 & 7.5 \\
\hline $04-30-73$ & 1230 & -- & -- & 1076 & 5010 & -- & 7.7 & 10 \\
\hline $03-28-74$ & 1230 & -- & - & -- & 4430 & -- & 7.7 & 10 \\
\hline $03-04-75$ & 1230 & -- & -- & -- & 4260 & -- & 7.3 & 26 \\
\hline $03-04-76$ & 1230 & -- & -- & -- & 4170 & -- & 7.8 & 8.5 \\
\hline $10-01-69$ & 1230 & -- & -- & -- & 12400 & -- & -- & -- \\
\hline $10-05-70$ & 1230 & -- & - & -- & 12300 & -- & 8.1 & 7.0 \\
\hline $10-08-71$ & 1230 & -- & -- & -- & 11800 & -- & 7.6 & 21 \\
\hline $10-04-72$ & 1230 & -- & -- & -- & 10600 & -- & 7.6 & 22 \\
\hline $10-04-73$ & 1230 & -- & -- & -- & 10100 & -- & 7.6 & 24 \\
\hline $01-06-75$ & 1230 & -- & -- & -- & 8950 & -- & 7.7 & 18 \\
\hline $01-28-76$ & 1230 & -- & -- & -- & 8800 & -- & 7.6 & 23 \\
\hline $08-28-64$ & 1230 & -- & -- & -- & 14300 & -- & -- & -- \\
\hline $03-30-65$ & 1230 & -- & -- & -- & 14100 & -- & -- & -- \\
\hline $08-02-68$ & 1230 & -- & -- & -- & 10100 & -- & -- & -- \\
\hline $10-02-69$ & 1230 & -- & -- & - & 7830 & -- & -- & -- \\
\hline $08-04-70$ & 1230 & -- & -- & -- & 7300 & -- & 8.2 & 4.9 \\
\hline $01-03-72$ & 1230 & -- & -- & -- & 7390 & -- & 7.9 & 10 \\
\hline $01-04-73$ & 1230 & -- & -- & -- & 7480 & -- & 7.9 & 10 \\
\hline $01-03-74$ & 1230 & -- & -- & -- & 7150 & -- & 8.0 & 8.5 \\
\hline $06-02-75$ & 1230 & -- & - & -- & 5600 & -- & 8.0 & 7.5 \\
\hline $07-03-67$ & 1230 & -- & -- & -- & 5780 & -- & - & -- \\
\hline $07-02-68$ & 1230 & -- & - & -- & 5720 & -- & -- & -- \\
\hline $07-03-69$ & 1230 & -- & -- & - & 5610 & -- & -- & -- \\
\hline $08-04-70$ & 1230 & -- & -- & -- & 5650 & -- & 7.6 & 18 \\
\hline $05-04-71$ & 1230 & -- & -- & -- & 5330 & -- & 7.9 & 6.5 \\
\hline $03-02-72$ & 1230 & -- & - & -- & 5600 & -- & 7.8 & 11 \\
\hline $03-02-73$ & 1230 & -- & -- & -- & 5900 & -- & 7.6 & 18 \\
\hline $03-28-74$ & 1230 & -- & - & -- & 5200 & -- & 7.5 & 21 \\
\hline $03-04-75$ & 1230 & -- & -- & -- & 4860 & -- & 7.4 & 24 \\
\hline $04-06-76$ & 1230 & -- & -- & -- & 4940 & -- & 7.4 & 27 \\
\hline $02-28-64$ & 1230 & -- & - & -- & 23800 & -- & -- & -- \\
\hline $03-01-65$ & 1230 & -- & - & -- & 16600 & -- & -- & -- \\
\hline $07-07-65$ & 1230 & -- & -- & -- & 15600 & -- & -- & -- \\
\hline
\end{tabular}




\begin{tabular}{|c|c|c|c|c|c|c|c|c|c|c|c|c|}
\hline DATE & $\begin{array}{c}\text { ACIDITY } \\
\text { (ME/L } \\
\text { AS } \\
\text { CACOZ) } \\
\text { (00435) }\end{array}$ & $\begin{array}{c}\text { BICAR- } \\
\text { BONATE } \\
\text { FET-FLD } \\
\text { (HG/L } \\
\text { AS } \\
\text { HCO3) } \\
(00440)\end{array}$ & $\begin{array}{c}\text { CAR- } \\
\text { BONATE } \\
\text { FET-FLD } \\
\text { (MG/L } \\
\text { AS CO3) } \\
\text { (00445) }\end{array}$ & $\begin{array}{c}\text { NITRO- } \\
\text { GEN, } \\
\text { TOTAL } \\
\text { (HG/L } \\
\text { AS M) } \\
(00600)\end{array}$ & $\begin{array}{l}\text { MITRO- } \\
\text { GEN, } \\
\text { ORGANIC } \\
\text { TOTAL } \\
\text { (MG/L } \\
\text { AS N) } \\
\text { (00605) }\end{array}$ & $\begin{array}{c}\text { NITRO- } \\
\text { GEN, } \\
\text { ORGANIC } \\
\text { DIS- } \\
\text { SOLVED } \\
\text { (MG/L } \\
\text { AS N) } \\
(00607)\end{array}$ & $\begin{array}{c}\text { NITRO- } \\
\text { GEN, } \\
\text { MITRATE } \\
\text { DIS- } \\
\text { SOLVED } \\
\text { (MG/L } \\
\text { AS N) } \\
\text { (00618) }\end{array}$ & $\begin{array}{l}\text { NITRO- } \\
\text { GEN, } \\
\text { MITRATE } \\
\text { TOTAL } \\
\text { (MG/L } \\
\text { AS N) } \\
\text { (00620) }\end{array}$ & $\begin{array}{c}\text { NITRO- } \\
\text { GEN, } \\
\text { NO2+NO3 } \\
\text { DIS- } \\
\text { SOLVED } \\
\text { (NG/L } \\
\text { AS N) } \\
(00631)\end{array}$ & $\begin{array}{c}\text { PHOS- } \\
\text { PHATE, } \\
\text { ORTHD, } \\
\text { DIS- } \\
\text { SOLVED } \\
\text { (MG/L } \\
\text { AS PO4) } \\
(00660)\end{array}$ & $\begin{array}{c}\text { PHOS- } \\
\text { PHORUS, } \\
\text { ORGANIC } \\
\text { TOTAL } \\
\text { (MG/L } \\
\text { AS P) } \\
(00670)\end{array}$ & $\begin{array}{c}\text { PHOS- } \\
\text { PHORUS, } \\
\text { ORTHO, } \\
\text { DIS- } \\
\text { SOLVED } \\
\text { (MG/L } \\
\text { AS P) } \\
\text { (00671) }\end{array}$ \\
\hline $06-01-71$ & -- & 280 & 0 & -- & -- & -- & -- & -- & -- & -- & -- & -- \\
\hline $05-01-72$ & - & 300 & 0 & -- & -- & -- & -- & $\because$ & -- & -- & -- & -- \\
\hline $04-30-73$ & -- & 330 & 0 & -- & -- & -- & -- & $\therefore$ & -- & -- & -- & -- \\
\hline $03-28-74$ & -- & 330 & -- & -- & -- & -- & -- & -- & -- & -- & - & -- \\
\hline $03-04-75$ & -- & 330 & -- & -- & -- & - & -- & - & -- & -- & -- & -- \\
\hline $03-04-76$ & -- & 340 & -- & -- & -- & -- & -- & -- & -- & -- & -- & -- \\
\hline $10-01-69$ & -- & 560 & -- & - & -- & -- & - & -- & -- & -- & -- & -- \\
\hline $10-05-70$ & -- & 560 & -- & -- & -- & -- & -- & -- & -- & -- & -- & -- \\
\hline $10-08-71$ & -- & 540 & -- & - & -- & -- & -- & -- & -- & -- & -- & -- \\
\hline $10-04-72$ & -- & 550 & -- & -- & -- & -- & -- & -- & -- & -- & -- & -- \\
\hline $10-04-73$ & -- & 600 & -- & -- & -- & -- & -- & - & -- & -- & -- & -- \\
\hline $01-06-75$ & -- & 560 & -- & -- & -- & -- & -- & -- & -- & -- & -- & -- \\
\hline $01-28-76$ & -- & 580 & -- & -- & -- & -- & -- & -- & -- & -- & -- & -- \\
\hline $08-28-64$ & -- & 390 & -- & -- & -- & -- & -- & -- & -- & -- & -- & - \\
\hline $03-30-65$ & - & 400 & -- & -- & -- & -- & -- & -- & -- & -- & - & -- \\
\hline $08-02-68$ & -- & 480 & -- & -- & -- & -- & -- & -- & -- & -- & - & -- \\
\hline $10-02-69$ & -- & 480 & -- & -- & -- & -- & -- & -- & -- & -- & -- & -- \\
\hline $08-04-70$ & -- & 490 & -- & -- & -- & -- & -- & -- & -- & -- & -- & -- \\
\hline $01-03-72$ & -- & 500 & -- & -- & -- & -- & -- & -- & -- & -- & -- & -- \\
\hline $01-04-73$ & -- & 510 & -- & -- & -- & -- & - & -- & -- & -- & -- & -- \\
\hline $01-03-74$ & -- & 540 & -- & -- & -- & -- & -- & -- & - & -- & - & -- \\
\hline $06-02-75$ & -- & 470 & -- & -- & -- & -- & -- & -- & -- & -- & -- & -- \\
\hline $07-03-67$ & -- & 430 & -- & - & -- & -- & -- & -- & -- & -- & -- & -- \\
\hline $07-02-68$ & -- & 450 & -- & -- & -- & -- & -- & -- & -- & -- & -- & -- \\
\hline $07-03-69$ & -- & 440 & -- & -- & -- & -- & -- & -- & -- & -- & - & -- \\
\hline $08-04-70$ & -- & 450 & -- & -- & -- & -- & -- & -- & -- & -- & -- & -- \\
\hline $05-04-71$ & -- & 330 & -- & - & -- & -- & -- & -- & -- & -- & -- & -- \\
\hline $03-02-72$ & -- & 420 & -- & -- & -- & -- & -- & -- & -- & -- & -- & -- \\
\hline $03-02-73$ & -- & 450 & -- & -- & -- & -- & -- & -- & -- & -- & -- & -- \\
\hline $03-28-74$ & -- & 420 & -- & -- & -- & -- & -- & -- & -- & -- & -- & -- \\
\hline $03-04-75$ & -- & 390 & -- & -- & -- & -- & -- & -- & -- & -- & -- & -- \\
\hline $04-06-76$ & -- & 430 & -- & -- & -- & -- & -- & -- & -- & -- & -- & -- \\
\hline $02-28-64$ & -- & 380 & -- & -- & -- & -- & -- & -- & -- & -- & -- & -- \\
\hline $03-01-65$ & -- & 380 & -- & - & -- & -- & -- & -- & -- & -- & -- & -- \\
\hline $07-07-65$ & -- & 380 & -- & -- & -- & -- & -- & -- & -- & -- & -- & -- \\
\hline
\end{tabular}




\begin{tabular}{|c|c|c|c|c|c|c|c|c|c|c|c|}
\hline DATE & $\begin{array}{c}\text { PHDS- } \\
\text { PHDRUS, } \\
\text { ORGAMIC } \\
\text { DIS- } \\
\text { SOLVED } \\
\text { (MG/L } \\
\text { AS P) } \\
(00673)\end{array}$ & $\begin{array}{l}\text { HARD- } \\
\text { HESS } \\
\text { (HG/L } \\
\text { AS } \\
\text { CACO3) } \\
(00900)\end{array}$ & $\begin{array}{c}\text { HARD- } \\
\text { NESS, } \\
\text { NONCAR- } \\
\text { BONATE } \\
\text { (MG/L } \\
\text { CACD3) } \\
(00902)\end{array}$ & $\begin{array}{l}\text { CALCIUM } \\
\text { DIS- } \\
\text { SDLVED } \\
\text { (ME/L } \\
\text { AS CA) } \\
\text { (00915) }\end{array}$ & $\begin{array}{c}\text { MAGNE- } \\
\text { SIUH, } \\
\text { DIS- } \\
\text { SOLVED } \\
\text { (MG/L } \\
\text { AS MG) } \\
(00925)\end{array}$ & $\begin{array}{c}\text { SODIUH, } \\
\text { DIS- } \\
\text { SOLVED } \\
\text { (HG/L } \\
\text { AS NA) } \\
(00930)\end{array}$ & $\begin{array}{c}\text { SODIUH } \\
\text { AD- } \\
\text { SORP- } \\
\text { TION } \\
\text { RATID } \\
(00931)\end{array}$ & $\begin{array}{c}\text { PERCENT } \\
\text { SODIUH } \\
(00932)\end{array}$ & $\begin{array}{c}\text { SODIUHH } \\
\text { POTAS- } \\
\text { SIUH } \\
\text { DIS- } \\
\text { SOLVED } \\
\text { (MG/L } \\
\text { AS NA) } \\
\text { (00933) }\end{array}$ & $\begin{array}{l}\text { POTAS- } \\
\text { SIUH, } \\
\text { DIS- } \\
\text { SOLVED } \\
\text { (MG/L } \\
\text { AS K) } \\
(00935)\end{array}$ & $\begin{array}{l}\text { CHLO- } \\
\text { RIDE, } \\
\text { DIS- } \\
\text { SOLVE } \\
\text { (MG/L } \\
\text { AS CL } \\
\text { (00940 }\end{array}$ \\
\hline $06-01-71$ & -- & 490 & 260 & 130 & 41 & 890 & 18 & 80 & -- & 9.0 & 840 \\
\hline $05-01-72$ & -- & 430 & 180 & 120 & 32 & 870 & 19 & 81 & -- & 7.0 & 770 \\
\hline $04-30-73$ & -- & 590 & 320 & 190 & 26 & 950 & 18 & 77 & -- & 10 & 960 \\
\hline $03-28-74$ & -- & 440 & 170 & 120 & 32 & 830 & 18 & 80 & -- & 7.8 & 770 \\
\hline $03-04-75$ & -- & 450 & 180 & 130 & 32 & 770 & 16 & 78 & -- & 13 & 710 \\
\hline $03-04-76$ & -- & 410 & 130 & 100 & 38 & 790 & 18 & 80 & -- & 6.3 & 650 \\
\hline $10-01-69$ & -- & 2400 & 1900 & 590 & 220 & 2100 & 19 & -- & -- & -- & 3300 \\
\hline $10-05-70$ & -- & 2300 & 1900 & 590 & 210 & 2100 & 19 & 66 & -- & 13 & 3200 \\
\hline $10-08-71$ & -- & 2000 & 1600 & 470 & 200 & 2000 & 20 & 68 & -- & 21 & 3000 \\
\hline $10-04-72$ & -- & 1800 & 1400 & 460 & 160 & 1800 & 18 & 67 & -- & 23 & 2500 \\
\hline $10-04-73$ & -- & 1800 & 1300 & 420 & 180 & 1700 & 19 & 68 & -- & 23 & 2500 \\
\hline $01-06-75$ & -- & 1400 & 980 & 170 & 250 & 1500 & 18 & 69 & -- & 32 & 2000 \\
\hline $01-28-76$ & -- & 1500 & 990 & 330 & 150 & 1600 & 18 & 70 & -- & 15 & 2000 \\
\hline $08-28-64$ & -- & 1900 & 1500 & 380 & 220 & 2800 & 29 & -- & -- & -- & 4100 \\
\hline $03-30-65$ & -- & 1800 & 1500 & 360 & 220 & 2900 & 30 & -- & -- & -- & 4100 \\
\hline $08-02-68$ & -- & 930 & 540 & 190 & 110 & 1900 & 28 & -- & -- & -- & 2200 \\
\hline $10-02-69$ & -- & 630 & 240 & 140 & 69 & 1600 & 28 & -- & -- & -- & 1700 \\
\hline $08-04-70$ & -- & 660 & 260 & 150 & 73 & 1500 & 26 & 83 & -- & 5.9 & 1500 \\
\hline $01-03-72$ & - & 680 & 270 & 210 & 41 & 1500 & 26 & 83 & -- & 8.6 & 1500 \\
\hline $01-04-73$ & -- & 730 & 320 & 180 & 71 & 1500 & 25 & 81 & -- & 11 & 1500 \\
\hline $01-03-74$ & -- & 650 & 210 & 160 & 61 & 1400 & 25 & 83 & -- & 9.4 & 1400 \\
\hline $06-02-75$ & -- & 360 & 0 & 73 & 43 & 1200 & 27 & 87 & -- & 5.5 & 1000 \\
\hline $07-03-67$ & -- & 1700 & 1400 & 420 & 170 & 690 & 7 & -- & -- & -- & 1200 \\
\hline $07-02-68$ & -- & 1700 & 1400 & 430 & 160 & 680 & 7 & -- & -- & -- & 1100 \\
\hline $07-03-69$ & -- & 1700 & 1300 & 420 & 150 & 670 & 7 & -- & -- & -- & 1100 \\
\hline $08-04-70$ & -- & 1600 & 1300 & 420 & 150 & 700 & 8 & 48 & -- & 12 & 1100 \\
\hline $05-04-71$ & -- & 1600 & 1300 & 400 & 150 & 680 & 8 & 48 & -- & 15 & 1100 \\
\hline $03-02-72$ & -- & 1600 & 1300 & 450 & 120 & 670 & 7 & 47 & -- & 16 & 1100 \\
\hline $03-02-73$ & -- & 1700 & 1400 & 450 & 150 & 650 & 7 & 45 & - & 16 & 1000 \\
\hline $03-28-74$ & -- & 1600 & 1200 & 420 & 120 & 600 & 7 & 46 & -- & 14 & 990 \\
\hline $03-04-75$ & - & 1400 & 1100 & 380 & 120 & 580 & 7 & 46 & -- & 24 & 910 \\
\hline $04-0 b-7 b$ & -- & 1400 & 1100 & 360 & 130 & 590 & 7 & 47 & -- & 11 & 920 \\
\hline $02-28-64$ & -- & 3200 & 2900 & 670 & 380 & 4600 & 37 & -- & -- & - & 7200 \\
\hline $03-01-65$ & -- & 2100 & 1800 & 440 & 250 & 3400 & 33 & - & -- & -- & 4900 \\
\hline $07-07-65$ & -- & 1900 & 1600 & 400 & 220 & 3100 & 32 & -- & -- & -- & 4400 \\
\hline
\end{tabular}




\begin{tabular}{|c|c|c|c|c|c|c|c|c|c|c|c|}
\hline DATE & $\begin{array}{l}\text { SULFATE } \\
\text { DIS- } \\
\text { SOLVED } \\
\text { (MG/L } \\
\text { AS SO4) } \\
\text { (00945) }\end{array}$ & $\begin{array}{l}\text { FLUO- } \\
\text { RIDE, } \\
\text { DIS- } \\
\text { SOLVED } \\
\text { (HG/L } \\
\text { AS F) } \\
(00950)\end{array}$ & $\begin{array}{l}\text { SILICA, } \\
\text { DIS- } \\
\text { SOLVED } \\
\text { (MGG/L } \\
\text { AS } \\
\text { SI02) } \\
(00955)\end{array}$ & $\begin{array}{l}\text { BOROK, } \\
\text { DIS- } \\
\text { SOLVED } \\
\text { (UG/L } \\
\text { AS B) } \\
(01020)\end{array}$ & $\begin{array}{l}\text { IRON, } \\
\text { DIS- } \\
\text { SOLVED } \\
\text { (UG/L } \\
\text { AS FE) } \\
\text { (01046) }\end{array}$ & $\begin{array}{l}\text { MANGA- } \\
\text { HESE, } \\
\text { DIS- } \\
\text { SOLVED } \\
\text { (UG/L } \\
\text { AS MN) } \\
(01056)\end{array}$ & $\begin{array}{c}\text { SOLIDS, } \\
\text { RESIDUE } \\
\text { AT } 180 \\
\text { DEG. C } \\
\text { DIS- } \\
\text { SOLVED } \\
\text { (MG/L) } \\
(70300)\end{array}$ & $\begin{array}{l}\text { SOLIDS, } \\
\text { SUH OF } \\
\text { CONSTI- } \\
\text { TUENTS, } \\
\text { DIS- } \\
\text { SOLVED } \\
\text { (HG /L) } \\
\text { (70301) }\end{array}$ & $\begin{array}{c}\text { SOLIDS, } \\
\text { DIS- } \\
\text { SOLVED } \\
\text { (TONS } \\
\text { PER } \\
\text { DAY) } \\
\text { (70302) }\end{array}$ & $\begin{array}{c}\text { SOLIDS, } \\
\text { DIS- } \\
\text { SOLVED } \\
\text { (TONS } \\
\text { PER } \\
\text { AC-FT) } \\
(70303)\end{array}$ & $\begin{array}{r}\text { NITRO } \\
\text { GEN, } \\
\text { AMHONI } \\
\text { DIS- } \\
\text { SOLVE } \\
\text { IHE/L } \\
\text { AS NH4 } \\
\text { (71B46 }\end{array}$ \\
\hline $06-01-71$ & 940 & -- & -- & - & -- & -- & -- & 3000 & -- & 4.2 & -- \\
\hline $05-01-72$ & 870 & - & -- & - & -- & -- & -- & 2800 & -- & 4.0 & -- \\
\hline $04-30-73$ & 940 & -- & -- & -- & -- & - & -- & 3200 & - & 4.5 & -- \\
\hline $03-28-74$ & 830 & -- & 37 & - & -- & -- & -- & 2800 & -- & 3.8 & -- \\
\hline $03-04-75$ & 790 & -- & 34 & - & -- & -- & -- & 2600 & -- & 3.6 & -- \\
\hline $03-04-76$ & 820 & -- & 37 & - & -- & -- & -- & 2600 & -- & 3.5 & -- \\
\hline $10-01-69$ & 1800 & - & -- & -- & -- & - & -- & 9400 & - & -- & -- \\
\hline $10-05-70$ & 1700 & -- & -- & -- & -- & -- & -- & 8000 & -- & -- & -- \\
\hline $10-08-71$ & 1700 & -- & - & -- & -- & -- & -- & 7600 & -- & -- & -- \\
\hline $10-04-72$ & 1500 & -- & -- & - & -- & - & -- & 6700 & -- & - & -- \\
\hline $10-04-73$ & 1600 & - & 31 & - & - & -- & - & 6700 & -- & 9.1 & -- \\
\hline $01-06-75$ & 1400 & -- & 30 & - & -- & -- & -- & 5700 & -- & 7.7 & -- \\
\hline $01-28-76$ & 1500 & -- & 33 & -- & -- & -- & -- & 5800 & -- & 7.9 & -- \\
\hline $08-28-64$ & 1900 & -- & -- & -- & -- & - & -- & 9600 & -- & -- & -- \\
\hline $03-30-65$ & 1900 & -- & -- & -- & -- & -- & -- & 9600 & -- & -- & -- \\
\hline $08-02-68$ & 1500 & -- & -- & - & -- & -- & -- & 6200 & -- & -- & -- \\
\hline $10-02-69$ & 1200 & -- & -- & -- & -- & - & -- & 5000 & -- & -- & -- \\
\hline $08-04-70$ & 1200 & -- & -- & - & -- & -- & -- & 4700 & -- & -- & - \\
\hline $01-03-72$ & 1300 & -- & -- & -- & -- & -- & -- & 4900 & -- & -- & -- \\
\hline $01-04-73$ & 1300 & -- & -- & - & -- & -- & -- & 4800 & -- & -- & -- \\
\hline $01-03-74$ & 1200 & -- & 51 & -- & -- & - & -- & 4600 & -- & 6.3 & -- \\
\hline $06-02-75$ & 920 & - & 41 & - & -- & -- & -- & 3500 & -- & 4.7 & -- \\
\hline $07-03-67$ & 1200 & -- & - & -- & -- & - & -- & 3800 & -- & -- & -- \\
\hline $07-02-68$ & 1200 & -- & -- & -- & -- & - & -- & 3800 & -- & -- & -- \\
\hline $07-03-69$ & 1200 & -- & -- & - & -- & - & -- & 3800 & -- & -- & -- \\
\hline $08-04-70$ & 1200 & -- & -- & -- & -- & -- & -- & 3800 & -- & - & -- \\
\hline $05-04-71$ & 1200 & -- & -- & -- & -- & - & -- & 3600 & -- & -- & -- \\
\hline $03-02-72$ & 1200 & -- & -- & - & -- & -- & -- & 3700 & -- & -- & -- \\
\hline $03-02-73$ & 1200 & -- & -- & -- & -- & -- & -- & 3700 & -- & -- & -- \\
\hline $03-28-74$ & 1000 & -- & 26 & -- & -- & -- & -- & 3400 & -- & 4.7 & -- \\
\hline $03-04-75$ & 990 & - & 25 & -- & -- & -- & -- & 3200 & -- & 4.4 & -- \\
\hline $04-06-76$ & 1100 & - & 27 & -- & -- & -- & -- & 3300 & -- & 4.5 & -- \\
\hline $02-28-64$ & 2800 & -- & -- & -- & -- & -- & -- & 16000 & -- & -- & -- \\
\hline $03-01-65$ & 2300 & -- & -- & - & -- & -- & -- & 12000 & -- & -- & -- \\
\hline $07-07-65$ & 2200 & -- & -- & -- & -- & -- & -- & 11000 & -- & -- & -- \\
\hline
\end{tabular}




\begin{tabular}{|c|c|c|c|c|c|c|c|c|c|c|c|}
\hline DATE & $\begin{array}{c}\text { NITRO- } \\
\text { GEH, } \\
\text { NITRATE } \\
\text { TOTAL } \\
\text { ( }(\text { G6/L } \\
\text { AS NOJ) } \\
\text { (71850) }\end{array}$ & $\begin{array}{c}\text { NITRO- } \\
\text { GEN, } \\
\text { NITRATE } \\
\text { DIS- } \\
\text { SOLVED } \\
\text { (IHG/L } \\
\text { AS MO3) } \\
\text { (71851) }\end{array}$ & $\begin{array}{c}\text { NITRO- } \\
\text { GEN, } \\
\text { NITRITE } \\
\text { DIS- } \\
\text { SOLVED } \\
\text { (HE/L } \\
\text { AS NO2) } \\
\text { (71856) }\end{array}$ & $\begin{array}{c}\text { NITRO- } \\
\text { GEN, } \\
\text { TOTAL } \\
\text { (H6/L } \\
\text { AS NOJ) } \\
\text { (71887) }\end{array}$ & $\begin{array}{l}\text { ELEV. } \\
\text { OF LAND } \\
\text { SURFACE } \\
\text { DATUH } \\
\text { (FT. } \\
\text { ABDVE } \\
\text { NGVD) } \\
(72000)\end{array}$ & $\begin{array}{c}\text { DEPTH } \\
\text { OF } \\
\text { MELL, } \\
\text { TOTAL } \\
\text { (FEET) } \\
\text { (72008) }\end{array}$ & $\begin{array}{l}\text { DEPTH } \\
\text { TO TOP } \\
\text { OF } \\
\text { SAMPLE } \\
\text { INTER- } \\
\text { VAL } \\
\text { (FT) } \\
\text { (72015) }\end{array}$ & $\begin{array}{c}\text { DEPTH } \\
\text { TO BOT- } \\
\text { TOH OF } \\
\text { SAMPLE } \\
\text { INTER- } \\
\text { VAL } \\
\text { (FT) } \\
(72016)\end{array}$ & $\begin{array}{c}\text { SEDI- } \\
\text { HENT, } \\
\text { DIS- } \\
\text { CHARGE, } \\
\text { SUS- } \\
\text { PEMDED } \\
\text { (T/DAY) } \\
\text { (80155) }\end{array}$ & $\begin{array}{c}\text { SEDI- } \\
\text { MENT, } \\
\text { DISCH, } \\
\text { SUSP. + } \\
\text { BED HA- } \\
\text { TERIAL } \\
\text { (T/DAY) } \\
\text { (80156) }\end{array}$ & $\begin{array}{c}\text { DRAIH } \\
\text { AGE } \\
\text { AREA } \\
\text { (SQ. } \\
\text { MI.) } \\
\text { (B1024 }\end{array}$ \\
\hline $06-01-71$ & -- & -- & -- & -- & 294 & 72.00 & -- & -- & - & -- & -- \\
\hline $05-01-72$ & -- & -- & -- & - & 294 & 72.00 & - & -- & -- & - & -- \\
\hline $04-30-73$ & -- & -- & - & - & 294 & 72.00 & -- & - & - & -- & -- \\
\hline $03-28-74$ & -- & -- & - & -- & 294 & 84.00 & -- & -- & -- & -- & -- \\
\hline $03-04-75$ & -- & - & -- & -- & 294 & 84.00 & -- & -- & -- & -- & -- \\
\hline $03-04-76$ & -- & -- & -- & -- & 294 & 84.00 & -- & - & -- & -- & -- \\
\hline $10-01-69$ & -- & -- & -- & -- & 263 & 94.00 & -- & -- & -- & -- & -- \\
\hline $10-05-70$ & -- & -- & -- & -- & 263 & 94.00 & -- & -- & -- & - & -- \\
\hline $10-08-71$ & -- & -- & -- & -- & 263 & 94.00 & -- & - & -- & -- & -- \\
\hline $10-04-72$ & -- & -- & -- & -- & 263 & 94.00 & -- & - & -- & -- & -- \\
\hline $10-04-73$ & -- & -- & -- & -- & 263 & 94.00 & -- & - & -- & - & -- \\
\hline $01-06-75$ & -- & -- & -- & - & 263 & 94.00 & -- & -- & - & -- & -- \\
\hline $01-28-76$ & -- & -- & -- & -- & 263 & 94.00 & -- & -- & -- & -- & -- \\
\hline $08-28-64$ & -- & -- & -- & -- & 249 & 83.00 & -- & -- & -- & -- & -- \\
\hline $03-30-65$ & -- & -- & -- & -- & 249 & 83.00 & -- & -- & -- & -- & -- \\
\hline $08-02-68$ & -- & -- & -- & -- & 249 & 83.00 & -- & -- & -- & -- & -- \\
\hline $10-02-69$ & -- & -- & -- & - & 249 & 83.00 & -- & - & -- & -- & -- \\
\hline $08-04-70$ & -- & -- & -- & -- & 249 & 83.00 & -- & - & -- & -- & -- \\
\hline $01-03-72$ & -- & - & -- & -- & 249 & 83.00 & -- & - & -- & -- & -- \\
\hline $01-04-73$ & -- & -- & -- & - & 249 & 83.00 & -- & - & -- & - & -- \\
\hline $01-03-74$ & -- & -- & -- & - & 249 & 83.00 & -- & -- & -- & -- & -- \\
\hline $06-02-75$ & -- & -- & -- & -- & 249 & 83.00 & -- & -- & -- & -- & -- \\
\hline $07-03-67$ & -- & -- & -- & -- & 259 & 97.00 & -- & -- & -- & -- & -- \\
\hline $07-02-68$ & -- & -- & -- & -- & 259 & 97.00 & -- & -- & -- & -- & -- \\
\hline $07-03-69$ & -- & - & -- & -- & 259 & 97.00 & -- & -- & -- & -- & -- \\
\hline $08-04-70$ & -- & - & -- & -- & 259 & 97.00 & -- & -- & -- & -- & -- \\
\hline $05-04-71$ & -- & -- & -- & - & 259 & 97.00 & -- & -- & -- & -- & -- \\
\hline $03-02-72$ & -- & -- & -- & - & 259 & 97.00 & -- & -- & -- & -- & -- \\
\hline $03-02-73$ & -- & -- & -- & -- & 259 & 97.00 & -- & -- & -- & -- & -- \\
\hline $03-28-74$ & -- & -- & - & -- & 259 & 97.00 & -- & -- & -- & -- & -- \\
\hline $03-04-75$ & -- & -- & -- & -- & 259 & 97.00 & -- & -- & -- & -- & -- \\
\hline $04-06-76$ & -- & -- & -- & - & 259 & 97.00 & -- & -- & -- & -- & -- \\
\hline $02-28-64$ & -- & -- & - & -- & 234 & 83.00 & -- & -- & -- & -- & -- \\
\hline $03-01-65$ & -- & -- & -- & -- & 234 & 83.00 & -- & -- & -- & -- & -- \\
\hline $07-07-65$ & -- & -- & -- & -- & 234 & 83.00 & -- & -- & -- & -- & -- \\
\hline
\end{tabular}


LOCAL

IDENT-

I-

FIER

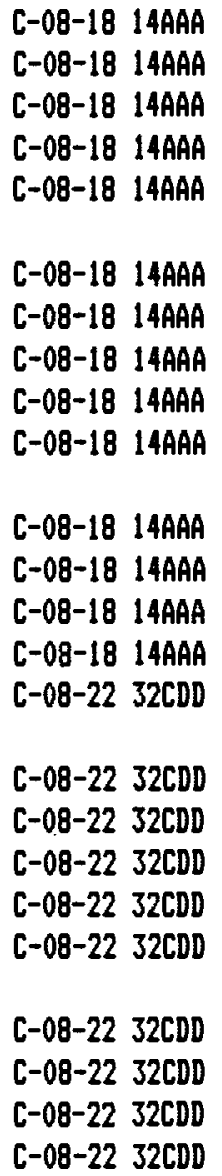

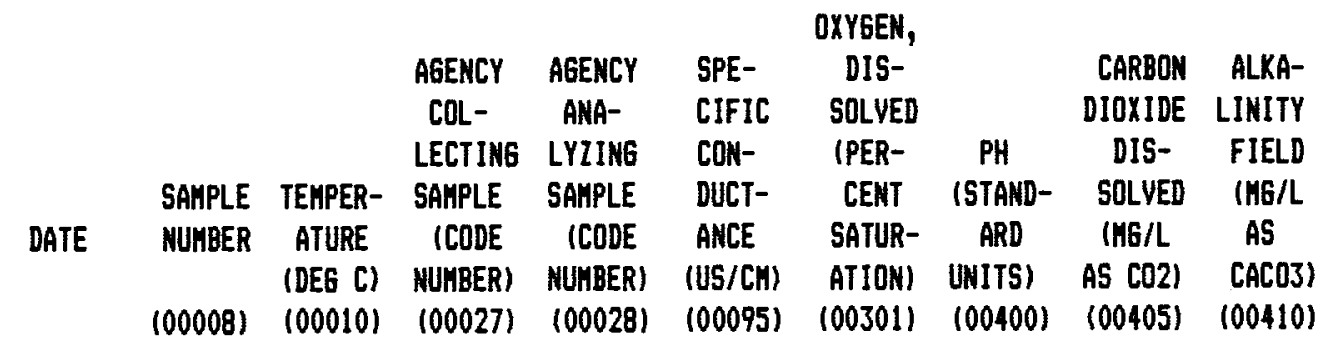

\begin{tabular}{|c|c|c|c|c|c|c|c|c|c|}
\hline $08-31-65$ & 1230 & -- & -- & -- & 13900 & -- & -- & -- & 305 \\
\hline $12-01-65$ & 1230 & -- & -- & -- & 13600 & -- & -- & -- & 315 \\
\hline $03-01-66$ & 1230 & -- & -- & -- & 15000 & -- & -- & -- & 321 \\
\hline $07-01-66$ & 1230 & -- & -- & -- & 12500 & -- & -- & -- & 338 \\
\hline $07-05-67$ & 1230 & -- & -- & -- & 12200 & -- & -- & -- & 360 \\
\hline $07-02-68$ & 1230 & -- & -- & -- & 11700 & -- & -- & -- & 353 \\
\hline $07-03-69$ & 1230 & -- & -- & -- & 10700 & - & -- & -- & 350 \\
\hline $10-05-70$ & 1230 & -- & -- & -- & 10600 & -- & 7.9 & 8.2 & 335 \\
\hline $11-02-71$ & 1230 & -- & -- & -- & 11500 & -- & 7.7 & 12 & 308 \\
\hline $10-04-72$ & 1230 & -- & -- & -- & 9820 & -- & 7.7 & 12 & 323 \\
\hline $03-27-73$ & 1230 & - & -- & -- & 9940 & - & 7.8 & 11 & 344 \\
\hline $03-01-74$ & 1230 & -- & -- & -- & 8040 & -- & 7.6 & 16 & 338 \\
\hline $03-04-75$ & 1230 & -- & -- & -- & 7480 & -- & 7.8 & 10 & 335 \\
\hline $03-04-76$ & 1230 & -- & -- & -- & 8480 & -- & 7.9 & 8.7 & 355 \\
\hline $09-05-61$ & -- & -- & 1028 & 1028 & 4320 & -- & 7.6 & 11 & 223 \\
\hline $01-02-62$ & -- & -- & 1028 & 1028 & 4600 & -- & 7.8 & 6.8 & 221 \\
\hline $03-30-62$ & -- & -- & 1028 & 1028 & 6230 & -- & 7.4 & 17 & 224 \\
\hline $04-24-62$ & -- & -- & 1028 & 1028 & 5220 & -- & 7.5 & 14 & 223 \\
\hline $11-08-62$ & -- & -- & 1028 & 1028 & 4670 & -- & 7.7 & 8.8 & 228 \\
\hline $04-24-63$ & -- & -- & 1028 & 1028 & 5320 & -- & 7.3 & 22 & 230 \\
\hline $11-19-63$ & -- & - & 1028 & 1028 & 4380 & -- & 7.6 & 11 & 231 \\
\hline $02-19-64$ & -- & -- & 1028 & 1028 & 4330 & -- & 7.4 & 18 & 233 \\
\hline $01-28-65$ & - & -- & 1028 & 1028 & 4240 & -- & 7.5 & 14 & 231 \\
\hline $01-24-66$ & -- & - & 1028 & 1028 & 4140 & -- & 7.7 & 9.3 & 239 \\
\hline
\end{tabular}




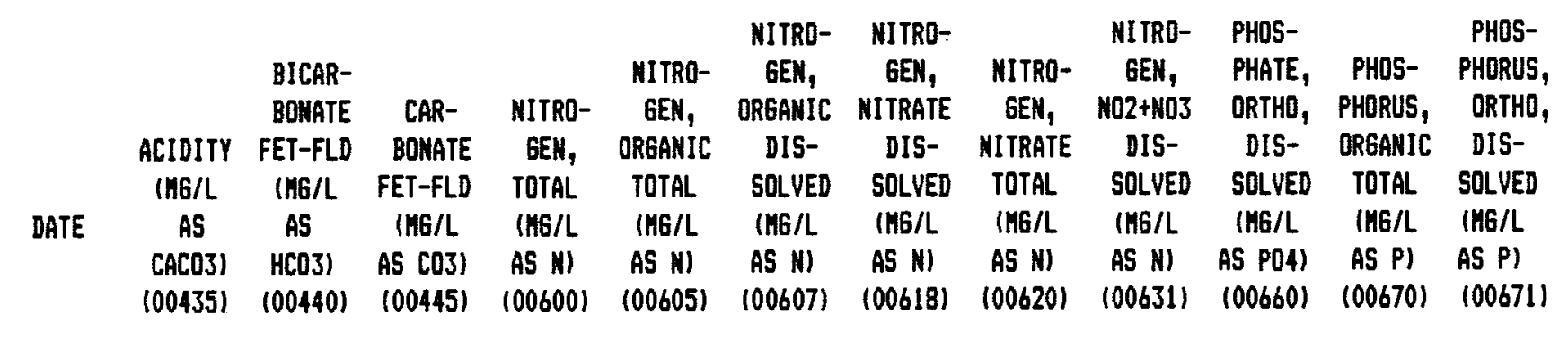

\begin{tabular}{|c|c|c|c|c|c|c|c|c|c|c|c|c|}
\hline $08-31-65$ & -- & 370 & -- & - & -- & -- & -- & -- & -- & -- & -- & -- \\
\hline $12-01-65$ & -- & 380 & -- & -- & -- & -- & -- & -- & -- & -- & -- & -- \\
\hline $03-01-66$ & -- & 390 & -- & -- & -- & -- & -- & -- & -- & -- & -- & -- \\
\hline $07-01-66$ & - & 410 & -- & -- & -- & -- & -- & -- & -- & -- & -- & -- \\
\hline $07-05-67$ & -- & 440 & -- & -- & -- & -- & -- & - & -- & -- & -- & - \\
\hline $07-02-68$ & -- & 430 & -- & - & -- & -- & -- & -- & -- & -- & -- & - \\
\hline $07-03-69$ & -- & 430 & -- & - & -- & -- & -- & - & -- & -- & -- & -- \\
\hline $10-05-70$ & -- & 410 & -- & -- & -- & -- & -- & -- & - & -- & -- & -- \\
\hline $11-02-71$ & -- & 380 & -- & - & - & -- & -- & -- & -- & -- & -- & -- \\
\hline $10-04-72$ & -- & 390 & - & -- & -- & -- & -- & -- & -- & -- & -- & -- \\
\hline $03-27-73$ & - & 420 & -- & -- & -- & -- & -- & -- & -- & -- & -- & -- \\
\hline $03-01-74$ & -- & 410 & -- & -- & -- & -- & -- & -- & -- & -- & -- & -- \\
\hline $03-04-75$ & -- & 410 & -- & -- & -- & -- & -- & -- & -- & -- & -- & -- \\
\hline $03-04-76$ & -- & 430 & -- & - & -- & -- & -- & -- & -- & -- & -- & -- \\
\hline $09-05-61$ & -- & 270 & - & -- & -- & -- & -- & -- & -- & -- & -- & -- \\
\hline $01-02-62$ & -- & 270 & -- & -- & -- & -- & -- & -- & -- & -- & -- & -- \\
\hline $03-30-62$ & - & 270 & -- & - & -- & - & -- & - & -- & -- & -- & -- \\
\hline $04-24-62$ & -- & 270 & -- & -- & -- & - & -- & -- & -- & -- & $\rightarrow$ & -- \\
\hline $11-08-62$ & -- & 280 & -- & -- & -- & - & -- & -- & -- & -- & -- & -- \\
\hline $04-24-63$ & - & 280 & -- & -- & -- & -- & - & -- & -- & -- & -- & -- \\
\hline $11-19-63$ & -- & 280 & -- & -- & -- & -- & -- & -- & -- & -- & -- & -- \\
\hline $02-19-64$ & -- & 280 & -- & -- & -- & -- & - & -- & -- & - & -- & -- \\
\hline $01-28-65$ & -- & 280 & -- & -- & -- & -- & -- & -- & -- & - & -- & -- \\
\hline $01-24-66$ & -- & 290 & -- & -- & -- & -- & -- & -- & -- & -- & -- & -- \\
\hline
\end{tabular}




\begin{tabular}{|c|c|c|c|c|c|c|c|c|c|c|c|}
\hline DATE & $\begin{array}{l}\text { PHOS- } \\
\text { PHORUS, } \\
\text { ORGANIC } \\
\text { DIS- } \\
\text { SOLVED } \\
\text { (MG/L } \\
\text { AS P) } \\
\text { (00673) }\end{array}$ & $\begin{array}{l}\text { HARD- } \\
\text { MESS } \\
\text { (MG/L } \\
\text { AS } \\
\text { CACO3) } \\
(00900)\end{array}$ & $\begin{array}{c}\text { HARD- } \\
\text { NESS, } \\
\text { NONCAR- } \\
\text { BONATE } \\
\text { (MG/L } \\
\text { CACO3) } \\
\text { (00902) }\end{array}$ & $\begin{array}{l}\text { CALCIUH } \\
\text { DIS- } \\
\text { SOLVED } \\
\text { (MG/L } \\
\text { AS CA) } \\
(00915)\end{array}$ & $\begin{array}{l}\text { MAGNE- } \\
\text { SIUH, } \\
\text { DIS- } \\
\text { SOLVED } \\
\text { (MG/L } \\
\text { AS MG) } \\
(00925)\end{array}$ & $\begin{array}{l}\text { SODIUH, } \\
\text { DIS- } \\
\text { SOLVED } \\
\text { (MG/L } \\
\text { AS NA) } \\
(00930)\end{array}$ & $\begin{array}{c}\text { SODIUM } \\
\text { AD- } \\
\text { SORP- } \\
\text { TION } \\
\text { RATIO } \\
\text { (00931) }\end{array}$ & $\begin{array}{c}\text { PERCENT } \\
\text { SODIUM } \\
(00932)\end{array}$ & $\begin{array}{c}\text { SODIUHA } \\
\text { POTAS- } \\
\text { SIUH } \\
\text { DIS- } \\
\text { SOLVED } \\
\text { (MG/L } \\
\text { AS NA) } \\
\text { (00933) }\end{array}$ & $\begin{array}{l}\text { POTAS- } \\
\text { SIUH, } \\
\text { DIS- } \\
\text { SOLVED } \\
\text { (MG/L } \\
\text { AS K) } \\
(00935)\end{array}$ & $\begin{array}{l}\text { CHLO- } \\
\text { RIDE, } \\
\text { DIS- } \\
\text { SOLVEI } \\
\text { IHG/L } \\
\text { AS CLI } \\
1009401\end{array}$ \\
\hline $08-31-65$ & -- & 1700 & 1400 & 360 & 180 & 2800 & 31 & -- & -- & -- & 3800 \\
\hline $12-01-65$ & -- & 1700 & 1400 & 360 & 190 & 2800 & 31 & -- & -- & - & 3800 \\
\hline $03-01-66$ & - & 1900 & 1500 & 380 & 220 & 3100 & 32 & -- & -- & -- & 4000 \\
\hline $07-01-66$ & -- & 1600 & 1200 & 330 & 180 & 2700 & 30 & -- & -- & -- & 3300 \\
\hline $07-05-67$ & -- & 1400 & 1000 & 300 & 160 & 2500 & 30 & - & -- & -- & 3100 \\
\hline $07-02-68$ & -- & 1200 & 840 & 250 & 140 & 2200 & 29 & -- & -- & -- & 2700 \\
\hline $07-03-69$ & -- & 1100 & 720 & 230 & 120 & 2200 & 30 & -- & -- & -- & 2600 \\
\hline $10-05-70$ & -- & 1100 & 730 & 270 & 92 & 2100 & 29 & 81 & -- & 6.6 & 2700 \\
\hline $11-02-71$ & -- & 1100 & 770 & 240 & 120 & 2200 & 30 & 81 & - & 14 & 2700 \\
\hline $10-04-72$ & - & 940 & 620 & 220 & 92 & 1900 & 28 & 82 & -- & 13 & 2300 \\
\hline $03-27-73$ & -- & 950 & 610 & 220 & 100 & 2000 & 29 & 82 & -- & 14 & 2400 \\
\hline $03-01-74$ & -- & 690 & 350 & 190 & 51 & 1500 & 27 & 83 & -- & 11 & 1800 \\
\hline $03-04-75$ & -- & 730 & 390 & 170 & 73 & 1500 & 24 & 81 & -- & 13 & 1700 \\
\hline $03-04-76$ & -- & 860 & 500 & 180 & 97 & 1600 & 25 & 80 & -- & 7.8 & 1900 \\
\hline $09-05-61$ & -- & 1000 & 820 & 250 & 100 & - & -- & 51 & 500 & -- & 1000 \\
\hline $01-02-62$ & -- & 1100 & 880 & 260 & 110 & - & -- & 54 & 600 & - & 1100 \\
\hline $03-30-62$ & - & 1300 & 1000 & 290 & 130 & -- & -- & 59 & 860 & -- & 1600 \\
\hline $04-24-62$ & -- & 1100 & 900 & 260 & 110 & -- & -- & 55 & 640 & -- & 1200 \\
\hline $11-08-62$ & -- & 1000 & 810 & 250 & 99 & - & -- & 59 & 640 & -- & 1100 \\
\hline $04-24-63$ & -- & 1100 & 850 & 250 & 110 & -- & -- & 59 & 710 & -- & 1300 \\
\hline $11-19-63$ & -- & 960 & 730 & 240 & 90 & - & -- & 57 & 580 & -- & 1000 \\
\hline $02-19-64$ & -- & 940 & 710 & 220 & 96 & -- & - & 57 & 580 & -- & 970 \\
\hline $01-28-65$ & -- & 860 & 630 & 200 & 87 & -- & -- & 61 & 610 & - & 960 \\
\hline $01-24-66$ & -- & 780 & 540 & 190 & 77 & -- & -- & 63 & 610 & - & 890 \\
\hline
\end{tabular}




\begin{tabular}{|c|c|c|c|c|c|c|c|c|c|c|c|}
\hline DATE & $\begin{array}{l}\text { SULFATE } \\
\text { DIS- } \\
\text { SOLVED } \\
\text { (ASG/L } \\
\text { AS SO4) } \\
\text { (00945) }\end{array}$ & $\begin{array}{l}\text { FLUD- } \\
\text { RIDE, } \\
\text { DIS- } \\
\text { SOLVED } \\
\text { (HG/L } \\
\text { AS F) } \\
(00950)\end{array}$ & $\begin{array}{l}\text { SILICA, } \\
\text { DIS- } \\
\text { SOLVED } \\
\text { (HG/L } \\
\text { AS } \\
\text { SI02) } \\
(00955)\end{array}$ & $\begin{array}{l}\text { BORON, } \\
\text { DIS- } \\
\text { SOLVED } \\
(U 6 / L \\
\text { AS B) } \\
(01020)\end{array}$ & $\begin{array}{c}\text { IRON, } \\
\text { DIS- } \\
\text { SOLVED } \\
\text { (UG/L } \\
\text { AS FE) } \\
\text { (01046) }\end{array}$ & $\begin{array}{l}\text { MANGA- } \\
\text { NESE, } \\
\text { DIS- } \\
\text { SOLVED } \\
\text { (UG/L } \\
\text { AS MN) } \\
\text { (01056) }\end{array}$ & $\begin{array}{c}\text { SOLIDS, } \\
\text { RESIDUE } \\
\text { AT } 180 \\
\text { DEG. C } \\
\text { DIS- } \\
\text { SOLVED } \\
\text { (MG/L) } \\
(70300)\end{array}$ & $\begin{array}{c}\text { SOLIDS, } \\
\text { SUH OF } \\
\text { CONSTI- } \\
\text { TUENTS, } \\
\text { DIS- } \\
\text { SOLVED } \\
\text { (HG/L) } \\
\text { (70301) }\end{array}$ & $\begin{array}{c}\text { SOLIDS, } \\
\text { DIS- } \\
\text { SOLVED } \\
\text { (TONS } \\
\text { PER } \\
\text { DAY) } \\
\text { (70302) }\end{array}$ & $\begin{array}{c}\text { SOLIDS, } \\
\text { DIS- } \\
\text { SOLVED } \\
\text { (TONS } \\
\text { PER } \\
\text { AC-FT) } \\
(70303)\end{array}$ & $\begin{array}{c}\text { NITRO } \\
\text { GEN, } \\
\text { AHHONI } \\
\text { DIS- } \\
\text { SOLVEI } \\
\text { (HG/L } \\
\text { AS NH4) } \\
(71846)\end{array}$ \\
\hline $08-31-65$ & 2100 & - & -- & -- & -- & -- & -- & 9400 & - & -- & -- \\
\hline $12-01-65$ & 2200 & -- & -- & -- & -- & -- & -- & 9500 & -- & -- & -- \\
\hline $03-01-66$ & 2500 & -- & -- & -- & -- & -- & -- & 10000 & -- & - & -- \\
\hline $07-01-66$ & 2200 & -- & -- & -- & -- & - & -- & 8900 & -- & -- & -- \\
\hline $07-05-67$ & 2000 & - & -- & -- & - & -- & -- & 8200 & -- & -- & -- \\
\hline $07-02-68$ & 1800 & -- & -- & -- & -- & -- & -- & 7400 & -- & -- & -- \\
\hline $07-03-69$ & 1700 & -- & -- & - & -- & - & -- & 6900 & -- & -- & -- \\
\hline $10-05-70$ & 1600 & - & -- & -- & -- & -- & -- & 6900 & -- & -- & -- \\
\hline $11-02-71$ & 1600 & - & -- & -- & -- & -- & -- & 7000 & -- & -- & - \\
\hline $10-04-72$ & 1400 & -- & -- & -- & -- & -- & -- & 6100 & -- & -- & -- \\
\hline $03-27-73$ & 1400 & - & 40 & -- & -- & -- & -- & 6400 & -- & 8.7 & -- \\
\hline $03-01-74$ & 1100 & - & 39 & -- & -- & -- & -- & 5000 & -- & 6.8 & - \\
\hline $03-04-75$ & 1100 & -- & 40 & -- & -- & -- & -- & 4800 & -- & 6.5 & -- \\
\hline $03-04-76$ & 1300 & -- & 42 & -- & -- & - & -- & 5400 & -- & 7.3 & -- \\
\hline $09-05-61$ & 480 & - & 28 & 1 & -- & -- & -- & 2500 & -- & -- & -- \\
\hline $01-02-62$ & 600 & -- & 31 & -- & -- & - & -- & 2800 & -- & -- & -- \\
\hline $03-30-62$ & 630 & -- & 19 & -- & - & -- & -- & 3700 & -- & -- & -- \\
\hline $04-24-62$ & 530 & -- & 21 & -- & $\therefore$ & -- & -- & 2900 & -- & - & -- \\
\hline $11-08-62$ & 630 & -- & 23 & -- & -- & -- & -- & 2900 & -- & -- & -- \\
\hline $04-24-63$ & 580 & - & 21 & -- & -- & -- & -- & 3100 & -- & -- & -- \\
\hline $11-19-63$ & 540 & -- & 23 & -- & -- & -- & -- & 2600 & -- & -- & -- \\
\hline $02-19-64$ & 580 & -- & 18 & - & -- & -- & -- & 2600 & -- & -- & -- \\
\hline $01-28-65$ & 580 & - & 24 & -- & -- & -- & -- & 2600 & -- & -- & -- \\
\hline $01-24-66$ & 580 & -- & 22 & -- & -- & -- & -- & 2500 & -- & -- & -- \\
\hline
\end{tabular}




\begin{tabular}{|c|c|c|c|c|c|c|c|c|c|c|c|}
\hline DATE & $\begin{array}{c}\text { NITRO- } \\
\text { GEN, } \\
\text { NITRATE } \\
\text { TOTAL } \\
\text { (HG/L } \\
\text { AS NO3) } \\
\text { (71850) }\end{array}$ & $\begin{array}{c}\text { NITRO- } \\
\text { GEN, } \\
\text { NITRATE } \\
\text { DIS- } \\
\text { SOLVED } \\
\text { (NG/L } \\
\text { AS NO3) } \\
\text { (71851) }\end{array}$ & $\begin{array}{c}\text { NITRO- } \\
\text { GEN, } \\
\text { NITRITE } \\
\text { DIS- } \\
\text { SDLVED } \\
\text { (MG/L } \\
\text { AS ND2) } \\
\text { (71856) }\end{array}$ & $\begin{array}{c}\text { NITRO- } \\
\text { GEN, } \\
\text { TOTAL } \\
\text { (MG/L } \\
\text { AS NO3) } \\
\text { (71887) }\end{array}$ & $\begin{array}{c}\text { ELEY. } \\
\text { OF LAND } \\
\text { SURFACE } \\
\text { DATUM } \\
\text { (FT. } \\
\text { ABOVE } \\
\text { NGVD) } \\
(72000)\end{array}$ & $\begin{array}{c}\text { DEPTH } \\
\text { OF } \\
\text { WELL, } \\
\text { TOTAL } \\
\text { (FEET) } \\
\text { (72008) }\end{array}$ & $\begin{array}{c}\text { DEPTH } \\
\text { TO TOP } \\
\text { OF } \\
\text { SAMPLE } \\
\text { INTER- } \\
\text { VAL } \\
\text { (FT) } \\
\text { (72015) }\end{array}$ & $\begin{array}{c}\text { DEPTH } \\
\text { TO BOT- } \\
\text { TOH OF } \\
\text { SAMPLE } \\
\text { INTER- } \\
\text { VAL } \\
\text { (FT) } \\
(72016)\end{array}$ & $\begin{array}{c}\text { SEDI- } \\
\text { MENT, } \\
\text { DIS- } \\
\text { CHARGE, } \\
\text { SUS- } \\
\text { PENDED } \\
\text { (T/DAY) } \\
\text { (80155) }\end{array}$ & $\begin{array}{c}\text { SEDI- } \\
\text { MENT, } \\
\text { DISCH, } \\
\text { SUSP. + } \\
\text { BED HA- } \\
\text { TERIAL } \\
\text { (T/DAY) } \\
\text { (B0156) }\end{array}$ & $\begin{array}{c}\text { DRAIN } \\
\text { AGE } \\
\text { AREA } \\
\text { (SQ. } \\
\text { MI.) } \\
(81024\end{array}$ \\
\hline $08-31-65$ & -- & - & -- & - & 234 & 83.00 & -- & -- & -- & - & -- \\
\hline $12-01-65$ & -- & -- & -- & -- & 234 & 83.00 & -- & -- & -- & -- & -- \\
\hline $03-01-66$ & - & -- & -- & -- & 234 & 83.00 & - & -- & -- & -- & -- \\
\hline $07-01-66$ & -- & -- & -- & - & 234 & 83.00 & -- & - & -- & -- & -- \\
\hline $07-05-67$ & - & -- & -- & - & 234 & 83.00 & -- & - & -- & -- & -- \\
\hline $07-02-68$ & -- & - & -- & -- & 234 & 83.00 & -- & - & - & -- & -- \\
\hline $07-03-69$ & - & -- & -- & - & 234 & 83.00 & -- & -- & -- & -- & -- \\
\hline $10-05-70$ & -- & -- & -- & -- & 234 & 83.00 & -- & -- & -- & -- & -- \\
\hline $11-02-71$ & -- & - & -- & -- & 234 & 83.00 & -- & -- & -- & -- & -- \\
\hline $10-04-72$ & -- & -- & -- & - & 234 & 83.00 & -- & - & -- & -- & - \\
\hline $03-27-73$ & - & -- & -- & -- & 234 & 83.00 & -- & -- & -- & -- & -- \\
\hline $03-01-74$ & -- & -- & - & -- & 234 & 83.00 & -- & - & -- & -- & -- \\
\hline $03-04-75$ & -- & -- & -- & - & 234 & 83.00 & -- & -- & -- & -- & -- \\
\hline $03-04-76$ & -- & -- & -- & -- & 234 & 83.00 & -- & -- & -- & -- & -- \\
\hline $09-05-61$ & 2.8 & - & -- & -- & 144 & 200.00 & 90 & 200 & -- & -- & -- \\
\hline $01-02-62$ & -- & -- & -- & - & 144 & 200.00 & 90 & 200 & -- & -- & -- \\
\hline $03-30-62$ & -- & - & -- & - & 144 & 200.00 & 90 & 200 & - & -- & -- \\
\hline $04-24-62$ & -- & - & - & -- & 144 & 200.00 & 90 & 200 & -- & -- & -- \\
\hline $11-08-62$ & -- & -- & -- & -- & 144 & 200.00 & 90 & 200 & -- & -- & -- \\
\hline $04-24-63$ & -- & - & -- & -- & 144 & 200.00 & 90 & 200 & -- & -- & -- \\
\hline $11-19-63$ & -- & - & -- & - & 144 & 200.00 & 90 & 200 & -- & -- & -- \\
\hline $02-19-64$ & - & -- & - & - & 144 & 200.00 & 90 & 200 & -- & -- & -- \\
\hline $01-28-65$ & -- & -- & -- & -- & 144 & 200.00 & 90 & 200 & -- & -- & -- \\
\hline $01-24-66$ & -- & -- & -- & -- & 144 & 200.00 & 90 & 200 & -- & -- & -- \\
\hline
\end{tabular}


CHEMICAL ANALYSES FOR SELECTED WELLS IN AREA III

(The following information was obtained fron the U.S. Geological Survey, Tucson, Arizona)

LOCAL

IDENT-

I-

FIER
B-01-01 09DAB

B-01-01 090AB

B-01-02 $140 D B$

B-01-02 1400B

$B-01-022900 B$

B-01-03 32BAA

B-01-03 32BAA

B-01-03 35ACB

B-01-03 35ACB

B-01-03 35ACB

B-01-04 33ADA

B-01-04 33ADA

B-01-04 36ABB

B-01-09 17ABB

B-02-09 14BBB

B-02-09 14B8B

B-02-09 14BBB

B-02-09 14BBB

B-02-09 14BBB

B-02-09 148BB

B-02-09 14BBB

B-02-09 26B8B

C-01-03 06CDB

C-01-04 11CBC

C-01-04 18ABB

C-01-04 18ABB

C-01-05 34DBD

C-01-05 34DBD

C-01-05 340BD

C-02-05 03AAA

C-02-05 03AAA

C-02-05 16DAA

C-02-05 I6DAA

C-04-04 32BBA

C-04-04 32BBA

C-04-04 32BBA

C-04-08 31DCC

[-04-08 3400D

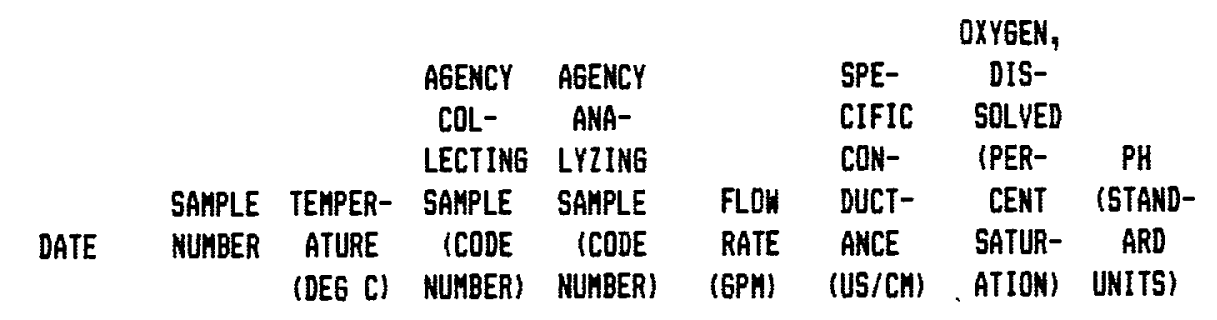

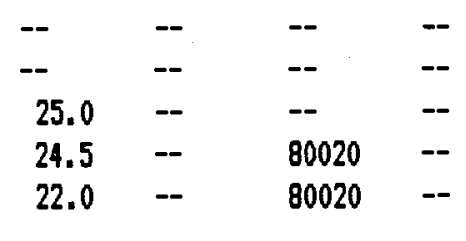

04-14-42 --

05-03-79 1460

07-06-37 --

$09-19-37 \quad--$

05-03-79 $\quad 1460$

09-09-61 --

05-02-79 1460

05-03-79 $\quad 1460$

09-26-79 1250

$07-16-52 \quad 1250$

09-26-52 1250

03-25-55 1250

12-06-66 1250

09-19-72 1250

08-08-74 1250

12-11-79 1250

09-20-79 1250

05-03-79 1460

05-03-79 1460

$07-18-51 \quad--$

05-03-79 1460

07-18-74 --

06-29-77 --

$06-24-81 \quad 1340$

07-18-74 --

06-29-77 --

07-30-74 --

06-28-77 --

$06-16-65 \quad 1200$

$11-22-73 \quad 1200$

$08-13-79 \quad--$

$11-08-72 \quad--$

$\begin{array}{llll}-- & -- & - & -- \\ 23.5 & -- & 80020 & -- \\ -- & -- & -- & -- \\ -- & -- & -- & -- \\ 23.0 & -- & 80020 & --\end{array}$

$\begin{array}{llrr}-- & - & - & - \\ 24.0 & -- & 80020 & -- \\ 24.0 & -- & 80020 & -- \\ -- & -- & 9704 & - \\ 31.5 & 1028 & 1028 & 3150\end{array}$

$31.5 \quad 1028$

$32.0 \quad 1028$

$33.0 \quad 1028$

$32.0 \quad--\quad--\quad 2200$

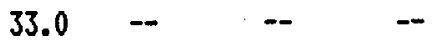

$\begin{array}{llll}-- & -- & 9704 \quad--\end{array}$

$--$

$23.5 \quad-$

$22.0 \quad-$

23.5

$22.0 \quad--\quad 80020 \quad--$

$\begin{array}{llll}22.0 & - & - & -\end{array}$

$23.0 \quad--\quad--\quad$--

$23.5 \quad--\quad 80020 \quad--$

$26.0 \quad--\quad--\quad--$

$25.0 \quad--\quad--\quad-$

$23.0 \quad--\quad--$

$\begin{array}{cccc}22.0 & - & -- & - \\ 26.0 & 1028 & 1028\end{array}$

$--$

$$
26 .
$$

25. $\begin{array}{lll}-- & -- & - \\ -- & -- & -- \\ 5500 & -- & -- \\ 4800 & -- & -- \\ 4900 & -- & --\end{array}$

$8150 \quad--\quad--$

$5450 \quad--\quad 7.3$

$3380 \quad--\quad 7.5$

$3580 \quad--\quad 7.7$

$4700 \quad--\quad 7.1$

$\begin{array}{rrr}-- & -- & -- \\ 5800 & -- & 7.3 \\ 7100 & -- & 7.4 \\ 4000 & -- & 7.8 \\ 728 & -- & --\end{array}$

709 -- --

$738 \quad--\quad 7.1$

$966 \quad--\quad 7.4$

$1180 \quad--\quad 8.0$

$1010 \quad--$

7.8

7.7

9.1

7.3

$\begin{array}{lll}5950 & - & 7.3 \\ 5000 & - & 7.1\end{array}$

$5700 \quad--\quad 7.0$

$\begin{array}{lll}5900 & -- & 7.7\end{array}$

$7700 \quad--\quad--$

$5000 \quad--\quad 7.3$

$\begin{array}{lll}7100 & -- & 7.8\end{array}$

$6900 \quad--\quad--$

$7550 \quad--\quad 7.4$

$7500 \quad--\quad--$

$2500 \quad--\quad-$

$4580 \quad--\quad 7.6$

$4950 \quad--\quad--$

8380 -- -- 


\begin{tabular}{|c|c|c|c|c|c|c|c|c|c|c|c|}
\hline DATE & $\begin{array}{c}\text { PH } \\
\text { LAB } \\
\text { (STAND- } \\
\text { ARD } \\
\text { UNITS) }\end{array}$ & $\begin{array}{c}\text { CARBOW } \\
\text { OIOXIDE } \\
\text { DIS- } \\
\text { SOLVED } \\
\text { (MG/L } \\
\text { AS CO2) }\end{array}$ & $\begin{array}{c}\text { ALKA- } \\
\text { LINITY } \\
\text { FIELD } \\
\text { (IIG/L } \\
\text { AS } \\
\text { CACO3) }\end{array}$ & $\begin{array}{c}\text { ACIDITY } \\
\text { (MG/L } \\
\text { AS } \\
\text { CACO3) }\end{array}$ & $\begin{array}{c}\text { BICAR- } \\
\text { BONATE } \\
\text { FET-FLD } \\
\text { (MG/L } \\
\text { AS } \\
\text { HCOZ) }\end{array}$ & $\begin{array}{c}\text { CAR- } \\
\text { BONATE } \\
\text { FET-FLD } \\
\text { (MG/L } \\
\text { AS CO3) }\end{array}$ & $\begin{array}{l}\text { NITRO- } \\
\text { GEN, } \\
\text { TOTAL } \\
\text { (MG/L } \\
\text { AS N) }\end{array}$ & $\begin{array}{l}\text { NITRO- } \\
\text { GEN, } \\
\text { ORGANIC } \\
\text { TOTAL } \\
\text { (MG/L } \\
\text { AS N) }\end{array}$ & $\begin{array}{c}\text { GEN, } \\
\text { ORGANIC } \\
\text { DIS- } \\
\text { SOLVED } \\
\text { (NG/L } \\
\text { AS N) }\end{array}$ & $\begin{array}{c}\text { GEN, } \\
\text { NITRITE } \\
\text { DIS- } \\
\text { SOLVED } \\
\text { (HG/L } \\
\text { AS N) }\end{array}$ & $\begin{array}{c}\text { GEN, } \\
\text { NITRATE } \\
\text { DIS- } \\
\text { SOLVEI } \\
\text { (MG/L } \\
\text { AS N) }\end{array}$ \\
\hline $09-01-59$ & -- & -- & 196 & -- & 240 & 0 & -- & -- & -- & -- & 3.60 \\
\hline $04-30-63$ & -- & -- & -- & -- & 220 & 0 & - & -- & -- & - & -- \\
\hline $07-14-76$ & -- & -- & -- & - & -- & -- & -- & -- & -- & - & -- \\
\hline $08-22-80$ & -- & -- & 170 & -- & -- & - & -- & -- & -- & - & -- \\
\hline $08-22-80$ & -- & -- & 260 & -- & -- & -- & -- & -- & -- & -- & -- \\
\hline $04-14-42$ & -- & -- & -- & -- & 160 & 0 & -- & -- & -- & -- & -- \\
\hline $05-03-79$ & -- & 21 & 210 & -- & 260 & 0 & -- & -- & - & -- & -- \\
\hline $07-06-37$ & -- & 12 & -- & - & 240 & 0 & -- & -- & -- & -- & -- \\
\hline $09-19-37$ & -- & 8.2 & -- & - & 260 & 0 & -- & -- & -- & - & -- \\
\hline $05-03-79$ & -- & 34 & 250 & -- & 300 & 0 & -- & -- & - & -- & -- \\
\hline $09-09-61$ & -- & -- & 176 & -- & 220 & 0 & -- & $\therefore$ & -- & -- & 32.0 \\
\hline $05-02-79$ & -- & 20 & 180 & - & 220 & 0 & -- & -- & -- & -- & -- \\
\hline $05-03-79$ & -- & 14 & 180 & - & 220 & 0 & -- & -- & -- & -- & -- \\
\hline $09-26-79$ & -- & 4.4 & 142 & -- & 170 & 0 & -- & -- & -- & -- & 210 \\
\hline $07-16-52$ & -- & - & 125 & -- & 150 & -- & -- & -- & -- & -- & 2.10 \\
\hline $09-26-52$ & -- & -- & 123 & -- & 150 & 0 & -- & -- & -- & -- & -- \\
\hline $03-25-55$ & -- & 19 & 126 & - & 150 & 0 & -- & - & - & -- & -- \\
\hline $12-06-66$ & -- & 9.1 & 118 & -- & 140 & 0 & -- & -- & -- & -- & -- \\
\hline $09-19-72$ & -- & 2.2 & 115 & -- & 140 & 0 & -- & -- & -- & -- & -- \\
\hline $08-08-74$ & -- & 3.5 & 115 & -- & 140 & - & -- & -- & -- & -- & -- \\
\hline $12-11-79$ & -- & 3.2 & 84 & -- & 100 & 0 & -- & -- & -- & -- & 19.0 \\
\hline $09-20-79$ & -- & 0.5 & 403 & -- & 370 & 62 & -- & -- & -- & -- & 34.0 \\
\hline $05-03-79$ & -- & 20 & 210 & -- & 250 & 0 & -- & -- & -- & -- & -- \\
\hline $05-03-79$ & -- & 40 & 260 & -- & 320 & 0 & -- & -- & $=-$ & -- & -- \\
\hline $07-18-51$ & -- & - & -- & -- & 270 & 0 & -- & -- & -- & -- & -- \\
\hline $05-03-79$ & -- & 54 & 280 & -- & 340 & 0 & -- & -- & -- & -- & -- \\
\hline $07-18-74$ & -- & - & -- & -- & -- & -- & -- & -- & -- & -- & -- \\
\hline $06-29-77$ & -- & -- & -- & -- & -- & -- & -- & -- & -- & -- & -- \\
\hline $06-24-81$ & 7.4 & 22 & -- & -- & -- & -- & -- & -- & -- & -- & -- \\
\hline $07-18-74$ & -- & 3.9 & 126 & -- & 150 & -- & -- & -- & -- & -- & -- \\
\hline $06-29-77$ & -- & -- & -- & -- & -- & -- & -- & -- & -- & -- & -- \\
\hline $07-30-74$ & -- & 34 & 441 & -- & 540 & -- & -- & -- & -- & -- & -- \\
\hline $06-28-77$ & -- & -- & -- & -- & -- & -- & -- & -- & -- & -- & -- \\
\hline $06-16-65$ & -- & -- & -- & -- & -- & -- & -- & -- & -- & -- & -- \\
\hline $11-22-73$ & -- & 7.3 & 151 & - & 180 & 0 & -- & -- & -- & 0.13 & 7.17 \\
\hline $08-13-79$ & -- & -- & -- & -- & -- & -- & -- & -- & -- & -- & -- \\
\hline $11-08-72$ & -- & -- & 345 & -- & 420 & 0 & - & -- & -- & -- & -- \\
\hline $07-12-77$ & -- & -- & -- & -- & -- & - & -- & -- & -- & -- & -- \\
\hline
\end{tabular}




\begin{tabular}{|c|c|c|c|c|c|c|c|c|c|c|c|}
\hline DATE & $\begin{array}{c}\text { NITRO- } \\
\text { GEN, } \\
\text { NITRATE } \\
\text { TOTAL } \\
\text { (MG/L } \\
\text { AS N) }\end{array}$ & $\begin{array}{l}\text { NITRO- } \\
\text { GEN, } \\
\text { NO2+NO3 } \\
\text { DIS- } \\
\text { SOLVED } \\
\text { (MG } / L \\
\text { AS N) }\end{array}$ & $\begin{array}{c}\text { PHOS- } \\
\text { PHATE, } \\
\text { ORTHO, } \\
\text { DIS- } \\
\text { SOLVED } \\
\text { (MG/L } \\
\text { AS PO4) }\end{array}$ & $\begin{array}{c}\text { PHOS- } \\
\text { PHORUS, } \\
\text { ORGANIC } \\
\text { TOTAL } \\
\text { (MG/L } \\
\text { AS P) }\end{array}$ & $\begin{array}{l}\text { PHOS- } \\
\text { PHORUS, } \\
\text { ORTHO, } \\
\text { DIS- } \\
\text { SOLVED } \\
\text { (MG/L } \\
\text { AS P) }\end{array}$ & $\begin{array}{c}\text { PHOS- } \\
\text { PHORUS, } \\
\text { ORGANIC } \\
\text { DIS- } \\
\text { SOLVED } \\
\text { (HG/L } \\
\text { AS P) }\end{array}$ & $\begin{array}{l}\text { HARD- } \\
\text { NESS } \\
\text { (HG/L } \\
\text { AS } \\
\text { CACO3) }\end{array}$ & $\begin{array}{l}\text { HARD- } \\
\text { MESS, } \\
\text { NONCAR- } \\
\text { BONATE } \\
\text { (MG/L } \\
\text { CACO3) }\end{array}$ & $\begin{array}{l}\text { CALCIUH } \\
\text { DIS- } \\
\text { SOLVED } \\
\text { (MG/L } \\
\text { AS CA) }\end{array}$ & $\begin{array}{l}\text { MAGNE- } \\
\text { SIUH, } \\
\text { DIS- } \\
\text { SOLVED } \\
\text { (HG/L } \\
\text { AS NG) }\end{array}$ & $\begin{array}{c}\text { SODIUH } \\
\text { DIS- } \\
\text { SOLYED } \\
\text { IMG/L } \\
\text { AS NA }\end{array}$ \\
\hline $09-01-59$ & -- & - & -- & - & -- & -- & 2000 & 1800 & 490 & 190 & 420 \\
\hline $04-30-63$ & -- & -- & -- & -- & -- & -- & 2200 & -- & 540 & 210 & 290 \\
\hline $07-14-76$ & -- & -- & -- & -- & -- & -- & -- & -- & - & - & -- \\
\hline $08-22-80$ & -- & 2.20 & 0.15 & - & 0.05 & -- & 1600 & 1400 & 390 & 150 & 750 \\
\hline $08-22-80$ & -- & 1.70 & 0.09 & - & 0.03 & - & 1200 & 910 & 270 & 120 & 860 \\
\hline $04-14-42$ & -- & -- & -- & -- & -- & -- & 2300 & - & 500 & 250 & 970 \\
\hline $05-03-79$ & -- & 23.0 & -- & -- & -- & -- & 1200 & 1000 & 240 & 150 & 850 \\
\hline $07-06-37$ & -- & - & -- & -- & -- & -- & 700 & - & 170 & 70 & 450 \\
\hline $09-19-37$ & -- & -- & -- & -- & -- & -- & 750 & -- & 180 & 73 & 480 \\
\hline $05-03-79$ & -- & 17.0 & -- & -- & -- & -- & 1100 & 890 & 260 & 120 & 650 \\
\hline $09-09-61$ & -- & - & -- & - & -- & -- & 1500 & 1400 & 380 & 140 & 800 \\
\hline $05-02-79$ & -- & - & -- & -- & -- & -- & 1200 & 970 & 280 & 110 & 950 \\
\hline $05-03-79$ & -- & 37.0 & -- & -- & -- & -- & 1100 & 890 & 290 & 85 & 1300 \\
\hline $09-26-79$ & -- & -- & -- & -- & -- & -- & 700 & 550 & 130 & 88 & 760 \\
\hline $07-16-52$ & -- & -- & -- & - & -- & -- & 130 & 7 & 28 & 15 & -- \\
\hline $09-26-52$ & -- & -- & -- & -- & -- & - & -- & -- & -- & -- & -- \\
\hline $03-25-55$ & -- & -- & -- & -- & -- & -- & 150 & 23 & 25 & 21 & -- \\
\hline $12-06-66$ & -- & -- & -- & -- & -- & -- & 130 & 11 & 32 & 12 & -- \\
\hline $09-19-72$ & -- & 6.30 & 0.03 & -- & 0.01 & -- & 150 & 33 & 38 & 13 & 170 \\
\hline $08-08-74$ & -- & 4.80 & 0.06 & - & 0.02 & -- & 140 & 23 & 32 & 14 & 140 \\
\hline $12-11-79$ & -- & -- & -- & -- & -- & - & 550 & 470 & 190 & 20 & 710 \\
\hline $09-20-79$ & -- & -- & -- & -- & -- & -- & 45 & 0 & 13 & 3.0 & 1100 \\
\hline $05-03-79$ & -- & 24.0 & -- & -- & -- & -- & 1200 & 990 & 250 & 140 & 950 \\
\hline $05-03-79$ & -- & 22.0 & -- & -- & -- & -- & 1200 & 900 & 250 & 130 & 1000 \\
\hline $07-18-51$ & -- & -- & -- & -- & -- & -- & -- & -- & -- & -- & -- \\
\hline $05-03-79$ & -- & 16.0 & -- & -- & -- & -- & 1100 & 820 & 260 & 110 & 900 \\
\hline $07-18-74$ & -- & -- & -- & - & -- & -- & -- & -- & -- & -- & -- \\
\hline $06-29-77$ & -- & -- & -- & -- & -- & -- & -- & -- & -- & -- & -- \\
\hline $06-24-81$ & -- & 5.10 & 0.0 & -- & 0.00 & -- & 830 & 600 & 210 & 73 & 730 \\
\hline $07-18-74$ & -- & 7.10 & 0.18 & -- & 0.06 & -- & 1200 & 1100 & 320 & 95 & 1000 \\
\hline $06-29-77$ & -- & - & -- & -- & -- & -- & -- & -- & -- & -- & -- \\
\hline $07-30-74$ &.- & 8.40 & 0.09 & -- & 0.03 & -- & 1300 & 860 & 340 & 110 & 1200 \\
\hline $06-28-77$ & -- & - & -- & -- & -- & -- & -- & -- & -- & -- & -- \\
\hline $06-16-65$ & -- & -- & -- & -- & -- & -- & -- & -- & -- & -- & -- \\
\hline $11-22-73$ & -- & 7.30 & 0.25 & -- & 0.08 & -- & 1200 & 1100 & 340 & 90 & 480 \\
\hline $08-13-79$ & -- & -- & -- & -- & - & - & -- & -- & -- & -- & -- \\
\hline $11-08-72$ & -- & 1.20 & 0.09 & -- & 0.03 & -- & 1400 & 1100 & 410 & 91 & 1400 \\
\hline $07-12-77$ & -- & -- & -- & -- & -- & - & -- & -- & -- & -- & -- \\
\hline
\end{tabular}




\begin{tabular}{|c|c|c|c|c|c|c|c|c|c|c|c|}
\hline DATE & $\begin{array}{l}\text { SODIUH } \\
\text { AD- } \\
\text { SORP- } \\
\text { TIOH } \\
\text { RATIO }\end{array}$ & $\begin{array}{l}\text { PERCENT } \\
\text { SODIUH }\end{array}$ & $\begin{array}{c}\text { SODIUH+ } \\
\text { POTAS- } \\
\text { SIUH } \\
\text { DIS- } \\
\text { SOLVED } \\
\text { (HG/L } \\
\text { AS NA) }\end{array}$ & $\begin{array}{l}\text { POTAS- } \\
\text { SIUH, } \\
\text { DIS- } \\
\text { SOLVED } \\
\text { (MG/L } \\
\text { AS K) }\end{array}$ & $\begin{array}{l}\text { CHLO- } \\
\text { RIDE, } \\
\text { DIS- } \\
\text { SOLVED } \\
\text { (HG/L } \\
\text { AS CL) }\end{array}$ & $\begin{array}{c}\text { SULFATE } \\
\text { DIS- } \\
\text { SOLVED } \\
\text { (MG/L } \\
\text { AS SO4) }\end{array}$ & $\begin{array}{l}\text { FLUD- } \\
\text { RIDE, } \\
\text { DIS- } \\
\text { SOLVED } \\
\text { (NG6/L } \\
\text { AS F) }\end{array}$ & $\begin{array}{l}\text { SILICA, } \\
\text { DIS- } \\
\text { SOLVED } \\
\text { (NIG/L } \\
\text { AS } \\
\text { SI02) }\end{array}$ & $\begin{array}{l}\text { BORON, } \\
\text { DIS- } \\
\text { SOLVED } \\
\text { (UG/L } \\
\text { AS B) }\end{array}$ & $\begin{array}{c}\text { CHRO- } \\
\text { MIUH, } \\
\text { HEXA- } \\
\text { VALENT, } \\
\text { DIS. } \\
\text { (UG/L } \\
\text { AS CR) }\end{array}$ & $\begin{array}{l}\text { IRON, } \\
\text { TOTAL } \\
\text { RECOU } \\
\text { ERABL } \\
\text { IUE/L } \\
\text { AS FE }\end{array}$ \\
\hline $09-01-59$ & 4 & -- & -- & - & 400 & 1400 & -- & -- & -- & - & -- \\
\hline $04-30-63$ & 3 & - & -- & - & 550 & 1700 & -- & -- & -- & -- & - \\
\hline $07-14-76$ & -- & -- & -- & -- & -- & - & -- & -- & -- & -- & -- \\
\hline $08-22-80$ & 8 & 50 & -- & 12 & 1200 & 1300 & 0.3 & 22 & 2700 & - & -- \\
\hline $08-22-80$ & 11 & 61 & -- & 10 & 1400 & 700 & 1.2 & 33 & 2000 & -- & -- \\
\hline $04-14-42$ & 9 & 48 & -- & 0.0 & 2100 & 1100 & -- & -- & -- & -- & -- \\
\hline $05-03-79$ & 11 & 60 & - & 7.8 & 1100 & 1200 & 2.1 & 24 & 5200 & -- & -- \\
\hline $07-06-37$ & 8 & 58 & -- & 0.0 & 660 & 470 & - & -- & -- & -- & -- \\
\hline $09-19-37$ & 8 & 59 & -- & 0.0 & 720 & 500 & -- & -- & -- & -- & -- \\
\hline $05-03-79$ & 9 & 55 & - & 7.3 & 1000 & 770 & 1.2 & 33 & 2000 & -- & -- \\
\hline $09-09-61$ & 9 & -- & -- & -- & 1000 & 1500 & -- & -- & -- & -- & -- \\
\hline $05-02-79$ & 13 & 64 & 960 & 7.8 & 1300 & 1100 & 2.0 & 26 & 5500 & -- & -- \\
\hline $05-03-79$ & 18 & 72 & -- & 11 & 1400 & 1600 & 2.1 & 25 & 6800 & - & -- \\
\hline $09-26-79$ & 13 & -- & -- & - & 800 & 660 & 3.2 & - & -- & $-\dot{~}$ & -- \\
\hline $07-16-52$ & 4 & 63 & 100 & - & 73 & 120 & 1.4 & 38 & -- & -- & -- \\
\hline $09-26-52$ & -- & -- & - & - & 69 & -- & -- & -- & -- & -- & $-\infty$ \\
\hline $03-25-55$ & 4 & 59 & 98 & - & 780 & 110 & 1.3 & 41 & -- & -- & -- \\
\hline $12-06-66$ & 6 & -- & 140 & -- & 120 & 140 & 1.9 & 44 & -- & -- & -- \\
\hline $09-19-72$ & 6 & 71 & -- & 4.3 & 130 & 210 & 2.2 & 38 & 390 & -- & -- \\
\hline $08-08-74$ & 5 & 68 & -- & 3.7 & 120 & 150 & 1.6 & 37 & 340 & 26 & -- \\
\hline $12-11-79$ & 14 & -- & -- & -- & 630 & 1000 & 4.4 & -- & -- & -- & -- \\
\hline $09-20-79$ & 77 & -- & -- & -- & 850 & 810 & 180 & -- & -- & - & -- \\
\hline $05-03-79$ & 12 & 63 & 960 & 7.6 & 1100 & 1500 & 1.7 & 26 & 5800 & -- & -- \\
\hline $05-03-79$ & 13 & 65 & 1000 & 5.9 & 1300 & 1100 & 3.2 & 44 & 5700 & -- & -- \\
\hline $07-18-51$ & -- & -- & -- & -- & 1200 & -- & -- & -- & -- & -- & -- \\
\hline $05-03-79$ & 12 & 64 & -- & 4.5 & 1200 & 980 & 3.5 & 40 & $<20$ & -- & -- \\
\hline $07-18-74$ & -- & -- & -- & -- & -- & -- & 3.6 & -- & -- & -- & - \\
\hline $06-29-77$ & -- & -- & -- & -- & -- & -- & 2.9 & -- & -- & - & -- \\
\hline $06-24-81$ & 11 & 66 & -- & 8.7 & 1100 & 680 & 2.5 & 52 & 2100 & -- & -- \\
\hline $07-18-74$ & 13 & 64 & -- & 11 & 1800 & 720 & 3.2 & 51 & 2100 & -- & -- \\
\hline $06-29-77$ & -- & -- & -- & -- & -- & -- & 3.8 & -- & -- & - & -- \\
\hline $07-30-74$ & 15 & 66 & -- & 14 & 1800 & 940 & 2.8 & 31 & 2700 & -- & -- \\
\hline $06-28-77$ & $-\infty$ & -- & -- & -- & -- & -- & 2.8 & -- & -- & -- & - \\
\hline $06-16-65$ & -- & -- & -- & - & -- & -- & -- & -- & -- & -- & - \\
\hline $11-22-73$ & 6 & 46 & - & 15 & 1200 & 310 & 0.9 & 25 & 100 & -- & -- \\
\hline $08-13-79$ & -- & -- & -- & -- & - & -- & 1.3 & -- & -- & -- & -- \\
\hline $11-08-72$ & 17 & 68 & -- & 9.2 & 2300 & 960 & 3.4 & 36 & 6000 & -- & -- \\
\hline $07-12-77$ & -- & -- & - & -- & - & -- & 5.0 & -- & -- & -- & -- \\
\hline
\end{tabular}




\begin{tabular}{|c|c|c|c|c|c|c|c|c|c|c|c|}
\hline DATE & $\begin{array}{l}\text { IRON, } \\
\text { DIS- } \\
\text { SOLVED } \\
\text { (UG/L } \\
\text { AS FE) }\end{array}$ & $\begin{array}{l}\text { MANGA- } \\
\text { NESE, } \\
\text { DIS- } \\
\text { SOLVED } \\
\text { (UG/L } \\
\text { AS HN) }\end{array}$ & $\begin{array}{l}\text { SOLIDS, } \\
\text { RESIDUE } \\
\text { AT } 180 \\
\text { DEG. C } \\
\text { DIS- } \\
\text { SOLVED } \\
\text { (MG/L) }\end{array}$ & $\begin{array}{l}\text { SOLIDS, } \\
\text { SUH OF } \\
\text { CONSTI- } \\
\text { TUENTS, } \\
\text { DIS- } \\
\text { SOLVED } \\
\text { (MG/L) }\end{array}$ & $\begin{array}{c}\text { SOLIDS, } \\
\text { DIS- } \\
\text { SOLVED } \\
\text { ITONS } \\
\text { PER } \\
\text { DAY) }\end{array}$ & $\begin{array}{c}\text { SOLIDS, } \\
\text { DIS- } \\
\text { SOLVED } \\
\text { (TONS } \\
\text { PER } \\
\text { AC-FT) }\end{array}$ & $\begin{array}{c}\text { NITRO- } \\
\text { GEN, } \\
\text { AMMONIA } \\
\text { DIS- } \\
\text { SQLVED } \\
\text { (MG/L } \\
\text { AS NH4) }\end{array}$ & $\begin{array}{c}\text { NITRO- } \\
\text { GEN, } \\
\text { NITRATE } \\
\text { DIS- } \\
\text { SOLVED } \\
\text { (MG/L } \\
\text { AS NOZ) }\end{array}$ & $\begin{array}{c}\text { NITRO- } \\
\text { GEN, } \\
\text { MITRITE } \\
\text { DIS- } \\
\text { SOLVED } \\
\text { IMG/L } \\
\text { AS NO2) }\end{array}$ & $\begin{array}{c}\text { NITRO- } \\
\text { GEN, } \\
\text { TOTAL } \\
\text { IMG/L } \\
\text { A5 NO3) }\end{array}$ & $\begin{array}{c}\text { ELEV. } \\
\text { OF LAND } \\
\text { SURFACE } \\
\text { DATUH } \\
\text { (FT. } \\
\text { ABOVE } \\
\text { NGVD) }\end{array}$ \\
\hline $09-01-59$ & -- & - & -- & 3600 & -- & -- & -- & 16 & -- & -- & 983 \\
\hline $04-30-63$ & -- & -- & - & 3600 & -- & -- & -- & 53 & -- & - & 983 \\
\hline $07-14-76$ & -- & -- & -- & -- & -- & -- & -- & -- & -- & -- & 950 \\
\hline $08-22-80$ & 60 & 10 & -- & 3900 & -- & 5.3 & -- & -- & -- & -- & 950 \\
\hline $08-22-80$ & 40 & 10 & - & 3600 & -- & 4.8 & -- & -- & -- & -- & -- \\
\hline $04-14-42$ & -- & -- & - & 5200 & -- & -- & -- & 240 & -- & -- & 924 \\
\hline $05-03-79$ & 60 & 20 & -- & 3700 & -- & 5.0 & -- & -- & -- & -- & 924 \\
\hline $07-06-37$ & -- & - & 2110 & 2000 & -- & -- & -- & 68 & -- & -- & 884 \\
\hline $09-19-37$ & -- & - & 2320 & 2100 & -- & -- & -- & 60 & -- & -- & 884 \\
\hline $05-03-79$ & 60 & $<10$ & -- & 3000 & -- & 4.1 & -- & -- & -- & -- & 884 \\
\hline $09-09-61$ & - & -- & -- & 4100 & - & - & -- & 140 & -- & -- & -- \\
\hline $05-02-79$ & 40 & 20 & -- & 3900 & -- & 5.3 & -- & -- & -- & -- & -- \\
\hline $05-03-79$ & 50 & 20 & -- & 4800 & -- & 6.6 & -- & -- & -- & -- & 929 \\
\hline $09-26-79$ & - & -- & 3570 & - & -- & -- & -- & 930 & -- & -- & 1157 \\
\hline $07-16-52$ & -- & - & -- & 460 & -- & 0.62 & -- & 9.3 & -- & -- & 1192 \\
\hline $09-26-52$ & -- & -- & -- & - & -- & -- & -- & -- & -- & -- & 1192 \\
\hline $03-25-55$ & -- & -- & -- & 460 & - & 0.63 & -- & -- & -- & -- & 1192 \\
\hline $12-0 b-6 b$ & - & - & -- & -- & -- & -- & -- & - & -- & -- & 1192 \\
\hline $09-19-72$ & 10 & -- & 780 & 670 & - & 1.1 & -- & -- & -- & -- & 1192 \\
\hline $08-08-74$ & 20 & $\langle 10$ & -- & 570 & - & 0.77 & -- & -- & -- & - & 1192 \\
\hline $12-11-79$ & -- & -- & 3130 & - & -- & -- & -- & 84 & -- & - & 1192 \\
\hline $09-20-79$ & -- & - & 3230 & -- & -- & -- & - & 150 & -- & -- & 1153 \\
\hline $05-03-79$ & 40 & $<10$ & -- & 4100 & -- & 5.6 & -- & -- & -- & -- & 878 \\
\hline $05-03-79$ & 40 & $<10$ & - & 4000 & -- & 5.4 & -- & -- & -- & -- & 829 \\
\hline $07-18-51$ & -- & -- & - & -- & -- & -- & - & -- & -- & -- & -- \\
\hline $05-03-79$ & 30 & $<10$ & -- & 3700 & -- & 5.0 & - & -- & - & -- & -- \\
\hline $07-18-74$ & -- & -- & -- & -- & -- & -- & -- & -- & -- & -- & 774 \\
\hline $06-29-77$ & -- & -- & -- & -- & -- & - & -- & - & -- & -- & 774 \\
\hline $06-24-81$ & 20 & 10 & -- & 3000 & -- & 4.1 & - & -- & - & -- & 774 \\
\hline $07-18-74$ & 20 & $<10$ & -- & 4100 & -- & 5.5 & -- & -- & -- & -- & 783 \\
\hline $06-29-77$ & -- & -- & -- & - & -- & -- & -- & -- & -- & -- & 783 \\
\hline $07-30-74$ & 20 & 290 & -- & 4700 & -- & 6.4 & -- & -- & -- & -- & 762 \\
\hline $06-28-77$ & -- & -- & -- & -- & -- & -- & -- & -- & - & -- & 762 \\
\hline $0 b-16-65$ & -- & -- & -- & -- & -- & -- & -- & -- & -- & -- & 670 \\
\hline $11-22-73$ & $<10$ & 70 & -- & 2600 & -- & 3.5 & -- & 32 & 0.43 & - & 670 \\
\hline $08-13-79$ & -- & -- & -- & -- & -- & -- & -- & -- & -- & -- & 670 \\
\hline $11-08-72$ & 20 & 30 & -- & 5400 & -- & 7.4 & -- & -- & -- & -- & 503 \\
\hline $07-12-77$ & -- & -- & - & -- & -- & -- & -- & -- & -- & -- & 534 \\
\hline
\end{tabular}




\begin{tabular}{|c|c|c|c|c|c|c|c|c|c|c|}
\hline DATE & $\begin{array}{l}\text { DEPTH } \\
\text { OF } \\
\text { NELL, } \\
\text { TOTAL } \\
\text { (FEET) }\end{array}$ & $\begin{array}{c}\text { DEPTH } \\
\text { TO BOT- } \\
\text { TOH OF } \\
\text { SAHPLE } \\
\text { INTER- } \\
\text { VAL } \\
\text { (FT) }\end{array}$ & $\begin{array}{c}\text { DEPTH } \\
\text { BELOH } \\
\text { LAND } \\
\text { SURFACE } \\
\text { (HATER } \\
\text { LEVEL) } \\
\text { (FEET) }\end{array}$ & $\begin{array}{c}\text { SEDI- } \\
\text { MENT, } \\
\text { DIS- } \\
\text { CHARGE, } \\
\text { SUS- } \\
\text { PENDED } \\
\text { (T/DAY) }\end{array}$ & $\begin{array}{l}\text { SEDI- } \\
\text { HENT, } \\
\text { DISCH, } \\
\text { SUSP. + } \\
\text { BED HA- } \\
\text { TERIAL } \\
\text { (T/DAY) }\end{array}$ & $\begin{array}{l}\text { DRAIN- } \\
\text { AGE } \\
\text { AREA } \\
\text { (SQ. } \\
\text { HI.) }\end{array}$ & $\begin{array}{l}\text { POTAS- } \\
\text { SIUH } 40 \\
\text { DIS- } \\
\text { SOLVED } \\
\text { (PCI/L } \\
\text { AS K40) }\end{array}$ & $\begin{array}{c}\text { SPE- } \\
\text { CIFIC } \\
\text { CON- } \\
\text { DUCT- } \\
\text { ANCE } \\
\text { LAB } \\
\text { (US/CM) }\end{array}$ & $\begin{array}{c}\text { ALKA- } \\
\text { LINITY } \\
\text { LAB } \\
\text { (MG/L } \\
\text { AS } \\
\text { CACO3) }\end{array}$ & $\begin{array}{l}\text { HARD- } \\
\text { MESS } \\
\text { NONCAR- } \\
\text { BONATE } \\
\text { (HE/L } \\
\text { AS } \\
\text { CACOJ) }\end{array}$ \\
\hline $09-01-59$ & 218.00 & 218 & - & - & -- & -- & - & -- & -- & 2000 \\
\hline $04-30-63$ & 218.00 & 218 & -- & -- & -- & -- & -- & -- & -- & 2180 \\
\hline $07-14-76$ & 354.00 & -- & -- & -- & -- & -- & -- & -- & -- & -- \\
\hline $08-22-80$ & 354.00 & - & - & -- & - & -- & -- & -- & -- & 1590 \\
\hline $08-22-80$ & -- & -- & - & -- & -- & -- & -- & -- & -- & 1170 \\
\hline $04-14-42$ & 206.00 & 206 & - & -- & -- & - & -- & -- & -- & 2290 \\
\hline $05-03-79$ & 206.00 & -- & -- & - & -- & -- & -- & -- & -- & 1220 \\
\hline $07-06-37$ & 132.00 & 132 & -- & - & -- & -- & -- & -- & -- & 700 \\
\hline $09-19-37$ & 132.00 & 132 & -- & -- & -- & -- & -- & -- & -- & 745 \\
\hline $05-03-79$ & 132.00 & -- & -- & -- & -- & -- & - & -- & -- & 1140 \\
\hline $09-09-61$ & 268.00 & -- & 69.00 & -- & -- & -- & -- & -- & -- & 1540 \\
\hline $05-02-79$ & 268.00 & -- & -- & -- & -- & -- & - & - & -- & 1150 \\
\hline $05-03-79$ & 1152.00 & -- & -- & -- & - & -- & - & -- & -- & 1070 \\
\hline $09-26-79$ & 1216.00 & -- & - & -- & -- & -- & - & -- & -- & 697 \\
\hline $07-16-52$ & 1530.00 & -- & 200.00 & -- & -- & -- & -- & -- & -- & 132 \\
\hline $09-26-52$ & 1530.00 & -- & - & $-\infty$ & -- & -- & -- & -- & -- & -- \\
\hline $03-25-55$ & 1530.00 & - & 200.00 & -- & -- & -- & -- & -- & - & 149 \\
\hline $12-06-66$ & 1530.00 & -- & - & -- & -- & - & - & -- & -- & 129 \\
\hline $09-19-72$ & 1530.00 & -- & - & -- & - & - & - & -- & - & 148 \\
\hline $08-08-74$ & 1530.00 & - & - & -- & -- & -- & -- & -- & -- & 138 \\
\hline $12-11-79$ & 1530.00 & -- & - & - & -- & -- & -- & -- & -- & 554 \\
\hline $09-20-79$ & 1820.00 & - & -- & -- & - & -- & - & -- & -- & 45 \\
\hline $05-03-79$ & 184.00 & -- & - & -- & -- & - & -- & -- & -- & 1200 \\
\hline $05-03-79$ & 146.00 & -- & -- & -- & -- & -- & -- & -- & -- & 1160 \\
\hline $07-18-51$ & 186.00 & -- & -- & -- & -- & -- & -- & -- & -- & -- \\
\hline $05-03-79$ & 186.00 & -- & -- & -- & -- & -- & -- & -- & -- & 1100 \\
\hline $07-18-74$ & 532.00 & -- & -- & -- & -- & -- & - & -- & -- & -- \\
\hline $06-29-77$ & 532.00 & -- & - & -- & -- & -- & -- & -- & -- & -- \\
\hline $06-24-81$ & 532.00 & -- & -- & -- & -- & -- & 6.5 & 4950 & 230 & 825 \\
\hline $07-18-74$ & 501.00 & -- & -- & -- & -- & -- & -- & -- & -- & 1190 \\
\hline $06-29-77$ & 501.00 & - & -- & -- & -- & -- & -- & -- & -- & -- \\
\hline $07-30-74$ & 590.00 & -- & -- & -- & -- & -- & - & -- & -- & 1300 \\
\hline $06-28-77$ & 590.00 & -- & -- & -- & - & -- & -- & -- & -- & -- \\
\hline $06-16-65$ & 260.00 & -- & -- & -- & -- & -- & -- & -- & -- & -- \\
\hline $11-22-73$ & 260.00 & - & -- & -- & -- & -- & -- & -- & -- & 1220 \\
\hline $08-13-79$ & 260.00 & - & -- & -- & -- & -- & -- & -- & -- & -- \\
\hline $11-08-72$ & 487.00 & - & -- & -- & - & -- & -- & -- & -- & 1400 \\
\hline $07-12-77$ & 438.00 & -- & -- & -- & -- & -- & -- & -- & -- & -- \\
\hline
\end{tabular}




\begin{tabular}{|c|c|c|c|c|c|c|c|c|c|c|c|}
\hline & $\begin{array}{l}\text { LOCAL } \\
\text { IDENT- } \\
\text { I- } \\
\text { FIER }\end{array}$ & & DATE & $\begin{array}{l}\text { SAMPLEE } \\
\text { NUMBER }\end{array}$ & $\begin{array}{l}\text { TEMPER- } \\
\text { ATURE } \\
\text { (DEG C) }\end{array}$ & $\begin{array}{l}\text { AGENCY } \\
\text { COL- } \\
\text { LECTING } \\
\text { SAMPLE } \\
\text { (CODE } \\
\text { NUMBER) }\end{array}$ & $\begin{array}{l}\text { AGENCY } \\
\text { ANA- } \\
\text { LYZING } \\
\text { SANPLE } \\
\text { (CODE } \\
\text { NUMBER) }\end{array}$ & $\begin{array}{l}\text { FLOH } \\
\text { RATE } \\
\text { (GPM) }\end{array}$ & $\begin{array}{l}\text { SPE- } \\
\text { CIFIC } \\
\text { CON- } \\
\text { DUCT- } \\
\text { ANCE } \\
\text { (US/CMI) }\end{array}$ & $\begin{array}{l}\text { OXYGEN, } \\
\text { DIS- } \\
\text { SOLVED } \\
\text { (PER- } \\
\text { CENT } \\
\text { SATUR- } \\
\text { ATION) }\end{array}$ & $\begin{array}{l}\text { PH } \\
\text { (STAND- } \\
\text { ARD } \\
\text { UNITS) }\end{array}$ \\
\hline$C-04-0834$ & $100 D$ & & $07-12-77$ & 1210 & 27.0 & -- & -- & - & 3440 & -- & -- \\
\hline$[-04-10 \quad 33$ & $B B D$ & & $09-10-52$ & -- & 25.5 & 1028 & 1028 & 711 & 2900 & -- & -- \\
\hline$C-04-10 \quad 33$ & $3 B D D$ & & $08-27-54$ & -- & 25.5 & 1028 & 1028 & 500 & 4170 & -- & -- \\
\hline C-04-10 33 & $B B D$ & & $06-15-55$ & -- & -- & 1028 & 1028 & 600 & 5800 & -- & 6.8 \\
\hline$[-04-10 \quad 33$ & $B B D D$ & & $08-23-56$ & - & 25.5 & 1028 & 1028 & 570 & 6170 & -- & 8.0 \\
\hline$[-04-1033$ & $B D D$ & & $08-08-57$ & -- & 25.5 & 1028 & 1028 & 1070 & 6300 & -- & 8.0 \\
\hline DATE & $\begin{array}{l}\text { PH } \\
\text { LAB } \\
\text { (STAHD- } \\
\text { ARD } \\
\text { UNITS) }\end{array}$ & $\begin{array}{c}\text { CARBON } \\
\text { DIOXIDE } \\
\text { DIS- } \\
\text { SOLVED } \\
\text { (MG/L } \\
\text { AS CO2) }\end{array}$ & $\begin{array}{l}\text { ALKA- } \\
\text { LINITY } \\
\text { FIELD } \\
\text { (MG/L } \\
\text { AS } \\
\text { CACO3) }\end{array}$ & $\begin{array}{c}\text { ACIDITY } \\
\text { (MG/L } \\
\text { AS } \\
\text { CACO3) }\end{array}$ & $\begin{array}{l}\text { BICAR- } \\
\text { BONATE } \\
\text { FET-FLD } \\
\text { (MG/L } \\
\text { AS } \\
\text { HCO3) }\end{array}$ & $\begin{array}{c}\text { CAR- } \\
\text { BONATE } \\
\text { FET-FLD } \\
\text { (NG/L } \\
\text { AS COJ) }\end{array}$ & $\begin{array}{l}\text { NITRO- } \\
\text { GEN, } \\
\text { TOTAL } \\
\text { (MG/L } \\
\text { AS H) }\end{array}$ & $\begin{array}{l}\text { NITRO- } \\
\text { GEN, } \\
\text { ORGANIC } \\
\text { TOTAL } \\
\text { (HG/L } \\
\text { AS N) }\end{array}$ & $\begin{array}{l}\text { NITRO- } \\
\text { GEN, } \\
\text { ORGANIC } \\
\text { DIS- } \\
\text { SOLVED } \\
\text { (MG/L } \\
\text { AS N) }\end{array}$ & $\begin{array}{l}\text { NITRD- } \\
\text { GEN, } \\
\text { NITRITE } \\
\text { DIS- } \\
\text { SOLVED } \\
\text { (MIG/L } \\
\text { AS N) }\end{array}$ & $\begin{array}{c}\text { HITRO- } \\
\text { GEN, } \\
\text { NITRATE } \\
\text { DIS- } \\
\text { SOLVED } \\
\text { (MG/L } \\
\text { AS N) }\end{array}$ \\
\hline $07-12-77$ & -- & -- & -- & -- & -- & - & -- & -- & -- & -- & -- \\
\hline $09-10-52$ & -- & -- & 94 & - & 110 & 0 & -- & -- & - & -- & 9.50 \\
\hline $08-27-54$ & - & -- & 93 & - & 110 & 0 & -- & -- & -- & -- & 13.0 \\
\hline $06-15-55$ & -- & 30 & 97 & - & 120 & 0 & -- & -- & -- & -- & 19.0 \\
\hline $08-23-56$ & -- & 2.0 & 104 & - & 130 & 0 & -- & -- & -- & -- & -- \\
\hline $08-08-57$ & -- & 0.9 & 45 & - & 55 & 0 & -- & -- & -- & -- & -- \\
\hline DATE & $\begin{array}{l}\text { NITRO- } \\
\text { GEN, } \\
\text { NITRATE } \\
\text { TOTAL } \\
\text { (MG/L } \\
\text { AS N) }\end{array}$ & $\begin{array}{l}\text { NITRO- } \\
\text { GEN, } \\
\text { NO2+NO3 } \\
\text { DIS- } \\
\text { SOLVED } \\
\text { (MG/L } \\
\text { AS N) }\end{array}$ & $\begin{array}{c}\text { PHOS- } \\
\text { PHATE, } \\
\text { ORTHO, } \\
\text { DIS- } \\
\text { SOLVED } \\
\text { (MG/L } \\
\text { AS POA) }\end{array}$ & $\begin{array}{l}\text { PHOS- } \\
\text { PHORUS, } \\
\text { ORGANIC } \\
\text { TOTAL } \\
\text { (HG/L } \\
\text { AS P) }\end{array}$ & $\begin{array}{l}\text { PHOS- } \\
\text { PHORUS, } \\
\text { ORTHO, } \\
\text { DIS- } \\
\text { SOLVED } \\
\text { (MG/L } \\
\text { AS P) }\end{array}$ & $\begin{array}{l}\text { PHOS- } \\
\text { PHORUS, } \\
\text { ORGAMIC } \\
\text { DIS- } \\
\text { SOLVED } \\
\text { (HG/L } \\
\text { AS P) }\end{array}$ & $\begin{array}{l}\text { HARD- } \\
\text { NESS } \\
\text { (MGG/L } \\
\text { AS } \\
\text { CACO3) }\end{array}$ & $\begin{array}{l}\text { HARD- } \\
\text { NESS, } \\
\text { NONCAR- } \\
\text { BONATE } \\
\text { (MG/L } \\
\text { CACO3) }\end{array}$ & $\begin{array}{l}\text { CALCIUM } \\
\text { DIS- } \\
\text { SOLVED } \\
\text { (MG/L } \\
\text { AS CA) }\end{array}$ & $\begin{array}{l}\text { MAGNE- } \\
\text { SIUH, } \\
\text { DIS- } \\
\text { SOLVED } \\
\text { (HG/L } \\
\text { AS MG) }\end{array}$ & $\begin{array}{l}\text { SODIUH, } \\
\text { DIS- } \\
\text { SOLVED } \\
\text { (MG/L } \\
\text { AS NA) }\end{array}$ \\
\hline $07-12-77$ & -- & -- & -- & -- & -- & $\cdot-\cdot$ & -- & -- & -- & -- & -- \\
\hline $09-10-52$ & -- & -- & -- & -- & -- & -- & 530 & 140 & 190 & 14 & -- \\
\hline $08-27-54$ & -- & -- & -- & -- & -- & - & 820 & 730 & 300 & 16 & -- \\
\hline $06-15-55$ & -- & -- & -- & -- & -- & -- & 1300 & 1200 & 440 & 50 & -- \\
\hline $08-23-56$ & -- & -- & -- & - & -- & - & 1400 & 1300 & -- & -- & -- \\
\hline $08-08-57$ & -- & -- & -- & -- & -- & -- & 1100 & 1100 & -- & - & -- \\
\hline
\end{tabular}




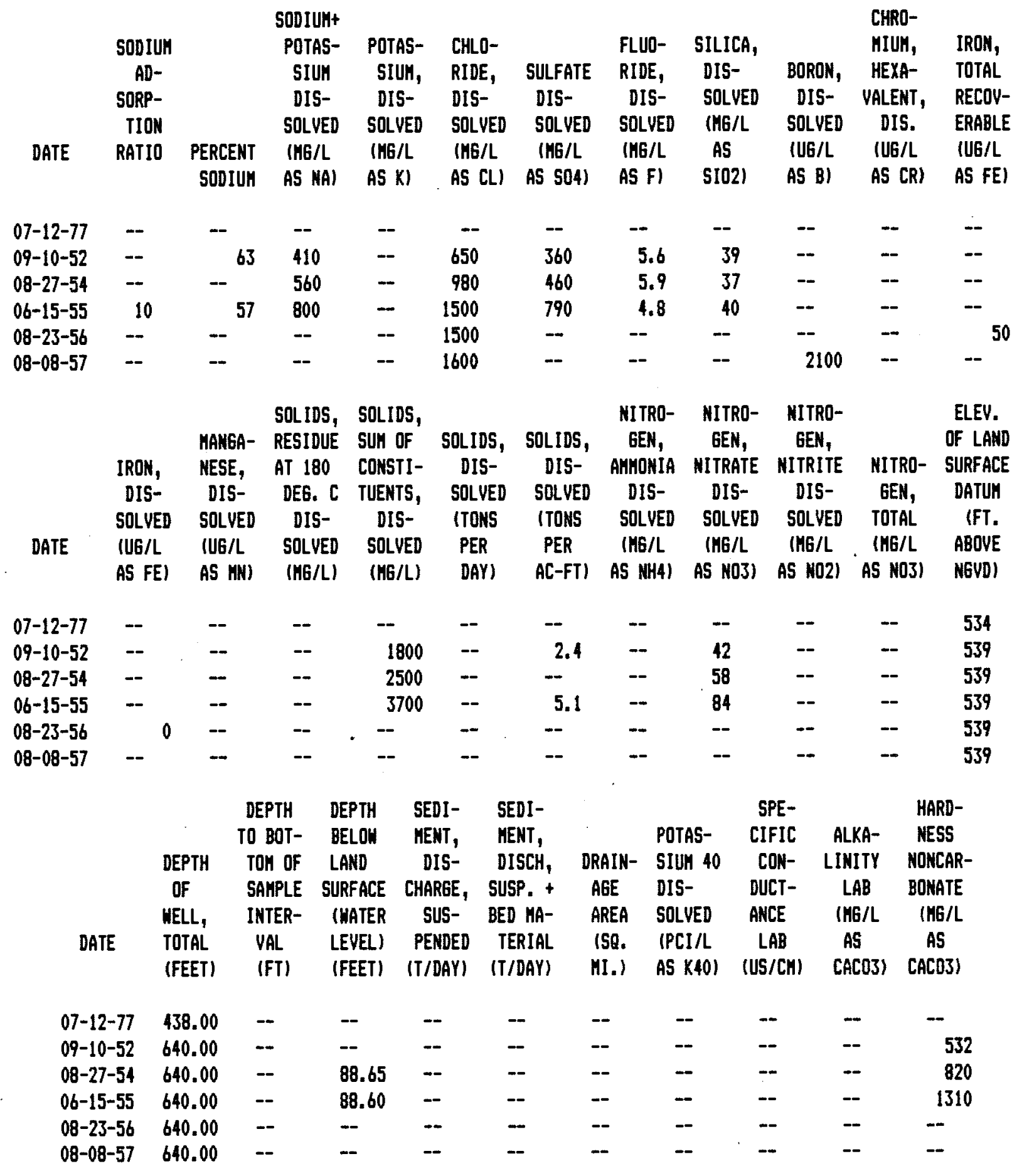


LOCAL

IDENT-

I-

FIER
C-05-04 08BDD1

C-05-04 08BDD2

C-05-04 08BDD2

C-05-05 13CBA2

C-05-05 18DCD2

C-05-05 18DCD2

C-05-05 $180 \mathrm{CD} 2$

C-05-05 1800C3

C-05-05 18DDC3

C- $-05-05$ 18DDC3

C-05-06 1600D

C-05-06 1600D

C-05-06 16000

C-05-06 16000

C-05-06 34CCD

C-05-06 34CCD

C-05-06 34CCD

C-05-06 34CCD

C $-05-06$ 34CCD

C-05-06 34CCD

C-05-09 12ACDI

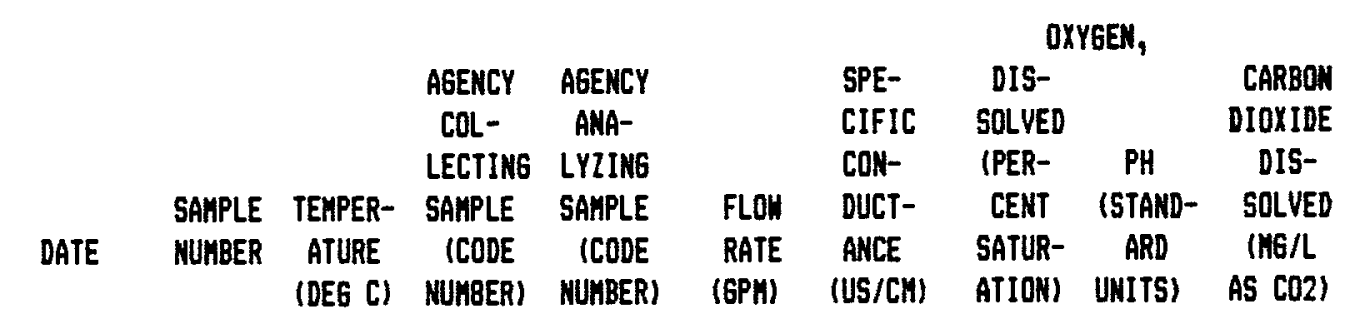

\begin{tabular}{|c|c|c|c|c|c|c|c|c|c|}
\hline $05-28-53$ & -- & 23.5 & 1028 & 1028 & -- & 19500 & -- & -- & -- \\
\hline $06-02-54$ & 1200 & 22.0 & 1028 & 1028 & -- & 18900 & -- & -- & - \\
\hline $06-02-54$ & 1200 & 22.0 & 1028 & 1028 & 1.0 & 17800 & -- & -- & -- \\
\hline $06-03-54$ & 1200 & 23.5 & 1028 & 1028 & 1.0 & 14200 & -- & - & - \\
\hline $08-15-79$ & 1200 & -- & 9999 & 9704 & - & -- & -- & -- & - \\
\hline $08-15-79$ & -- & 25.5 & -- & -- & - & 8500 & -- & -- & -- \\
\hline $08-15-79$ & 1200 & -- & - & 9704 & -- & -- & -- & 7.8 & 6.1 \\
\hline $04-01-74$ & 1200 & 24.0 & - & -- & - & 6730 & -- & 7.5 & 15 \\
\hline $04-27-76$ & -- & -- & - & - & -- & 6000 & - & -- & -- \\
\hline $06-23-77$ & 1200 & 24.5 & -- & -- & -- & 3800 & -- & - & -- \\
\hline $01-08-74$ & 1200 & -- & - & -- & - & 7960 & - & 7.6 & 7.8 \\
\hline $04-27-76$ & -- & -- & -- & -- & - & 9700 & -- & -- & -- \\
\hline $03-24-80$ & 1200 & -- & 9999 & 9704 & -- & -- & -- & -- & -- \\
\hline $03-24-80$ & 1200 & 26.5 & -- & 9704 & - & -- & -- & 7.2 & 15 \\
\hline $06-16-55$ & 1200 & 25.5 & 1028 & 1028 & 3000 & 7160 & -- & 7.8 & 4.5 \\
\hline $04-27-76$ & -- & -- & -- & -- & - & 4900 & -- & -- & -- \\
\hline $06-21-77$ & 1200 & 26.5 & -- & -- & -- & 5500 & -- & -- & -- \\
\hline $08-16-79$ & -- & 26.0 & -- & -- & -- & 6500 & -- & -- & -- \\
\hline $03-24-80$ & 1200 & -- & 9999 & 9704 & -- & -- & -- & -- & - \\
\hline $03-24-80$ & 1200 & 26.5 & -- & 9704 & -- & -- & -- & -- & - \\
\hline $11-08-72$ & -- & 24.0 & - & - & - & 31800 & -- & -- & -- \\
\hline
\end{tabular}




\begin{tabular}{|c|c|c|c|c|c|c|c|c|c|c|c|c|}
\hline DATE & $\begin{array}{l}\text { ALKA- } \\
\text { LINITY } \\
\text { FIELD } \\
\text { (HE/L } \\
\text { AS } \\
\text { CACO3) } \\
(00410)\end{array}$ & $\begin{array}{c}\text { ACIDITY } \\
\text { (ME/L } \\
\text { AS } \\
\text { CACO3) } \\
\text { (00435) }\end{array}$ & $\begin{array}{c}\text { BICAR- } \\
\text { BONATE } \\
\text { FET-FLD } \\
\text { (HG/L } \\
\text { AS } \\
\text { HCO3) } \\
(00440)\end{array}$ & $\begin{array}{r}\text { CAR- } \\
\text { BONATE } \\
\text { FET-FLD } \\
\text { (M6/L } \\
\text { AS CO3) } \\
\text { (00445) }\end{array}$ & $\begin{array}{l}\text { MITRO- } \\
\text { GEN, } \\
\text { TOTAL } \\
\text { (ME/L } \\
\text { AS N) } \\
(00600)\end{array}$ & $\begin{array}{l}\text { MITRO- } \\
\text { GEN, } \\
\text { ORGANIC } \\
\text { TOTAL } \\
\text { (MG/L } \\
\text { AS N) } \\
\text { (00605) }\end{array}$ & $\begin{array}{c}\text { NITRO- } \\
\text { GEN, } \\
\text { ORGANIC } \\
\text { DIS- } \\
\text { SOLVED } \\
\text { (NG/L } \\
\text { AS N) } \\
(00607)\end{array}$ & $\begin{array}{l}\text { NITRO- } \\
\text { GEN, } \\
\text { NITRITE } \\
\text { DIS- } \\
\text { SOLVED } \\
\text { (MG/L } \\
\text { AS N) } \\
\text { (00613) }\end{array}$ & $\begin{array}{l}\text { MITRO- } \\
\text { GEN, } \\
\text { MITRATE } \\
\text { DIS- } \\
\text { SOLVED } \\
\text { (HG/L } \\
\text { AS N) } \\
\text { (00618) }\end{array}$ & $\begin{array}{c}\text { NITRO- } \\
\text { GEN, } \\
\text { NITRATE } \\
\text { TOTAL } \\
\text { (HG/L } \\
\text { AS N) } \\
\text { (00620) }\end{array}$ & $\begin{array}{c}\text { NITRO- } \\
\text { GEN, } \\
\text { NO2+ND3 } \\
\text { DIS- } \\
\text { SOLYED } \\
\text { (MG/L } \\
\text { AS H) } \\
(00631)\end{array}$ & $\begin{array}{c}\text { PHOS- } \\
\text { PHATE, } \\
\text { ORTHO, } \\
\text { DIS- } \\
\text { SOLVED } \\
\text { (MG/L } \\
\text { AS PO4) } \\
\text { (00660) }\end{array}$ \\
\hline $05-28-53$ & 456 & -- & 560 & 0 & -- & -- & -- & -- & -- & -- & -- & -- \\
\hline $06-02-54$ & 316 & -- & 390 & 0 & -- & -- & -- & - & -- & - & -- & -- \\
\hline $06-02-54$ & 408 & -- & 500 & 0 & -- & -- & -- & -- & -- & -- & -- & - \\
\hline $06-03-54$ & 323 & -- & 390 & 0 & -- & -- & -- & -- & -- & -- & -- & -- \\
\hline $08-15-79$ & 198 & -- & -- & 0 & -- & -- & -- & -- & -- & - & -- & -- \\
\hline $08-15-79$ & -- & -- & -- & -- & -- & - & -- & -- & -- & -- & -- & -- \\
\hline $08-15-79$ & 198 & -- & 240 & -- & -- & -- & - & -- & 6.80 & -- & -- & -- \\
\hline $04-01-74$ & 238 & -- & 290 & 0 & -- & - & - & $<0.01$ & 6.50 & -- & 6.50 & 0.21 \\
\hline $04-27-76$ & -- & -- & -- & -- & -- & - & -- & -- & -- & -- & -- & -- \\
\hline $06-23-77$ & - & -- & -- & - & -- & -- & -- & -- & -- & -- & -- & -- \\
\hline $01-08-74$ & 161 & -- & 200 & 0 & -- & -- & - & $<0.01$ & 11.0 & -- & 11.0 & 0.0 \\
\hline $04-27-76$ & -- & -- & -- & - & -- & - & -- & -- & -- & -- & -- & - \\
\hline $03-24-80$ & 120 & -- & - & 0 & -- & -- & -- & -- & -- & -- & -- & -- \\
\hline $03-24-90$ & 120 & - & 150 & -- & -- & -- & -- & -- & 0.90 & -- & -- & - \\
\hline $06-16-55$ & 147 & -- & 180 & 0 & - & -- & -- & -- & 12.0 & - & -- & - \\
\hline $04-27-76$ & -- & - & - & -- & -- & -- & - & -- & - & -- & -- & - \\
\hline $0 b-21-77$ & - & - & -- & -- & -- & - & -- & -- & -- & -- & -- & - \\
\hline $08-16-79$ & -- & -- & -- & - & -- & - & - & -- & -- & -- & -- & -- \\
\hline $03-24-80$ & 124 & -- & -- & 0 & -- & -- & -- & -- & -- & -- & -- & - \\
\hline $03-24-80$ & 102 & -- & 120 & -- & -- & -- & -- & -- & 11.0 & -- & -- & -- \\
\hline $11-08-72$ & 544 & - & 660 & 0 & -- & -- & -- & -- & -- & -- & 0.02 & 0.15 \\
\hline
\end{tabular}




\begin{tabular}{|c|c|c|c|c|c|c|c|c|c|c|c|c|}
\hline DATE & $\begin{array}{c}\text { PHOS- } \\
\text { PHORUS, } \\
\text { ORGAMIC } \\
\text { TOTAL } \\
\text { (MG/L } \\
\text { AS P) } \\
(00670)\end{array}$ & $\begin{array}{l}\text { PHOS- } \\
\text { PHORUS, } \\
\text { ORTHO, } \\
\text { DIS- } \\
\text { SOLVED } \\
\text { (HE/L } \\
\text { AS P) } \\
\text { (O0671) }\end{array}$ & $\begin{array}{c}\text { PHOS- } \\
\text { PHORUS, } \\
\text { ORGANIC } \\
\text { DIS- } \\
\text { SOLVED } \\
\text { (HG/L } \\
\text { AS P) } \\
\text { (00673) }\end{array}$ & $\begin{array}{l}\text { HARD- } \\
\text { NESS } \\
\text { (HE/L } \\
\text { AS } \\
\text { CACO3) } \\
(00900)\end{array}$ & $\begin{array}{c}\text { HARD- } \\
\text { NESS, } \\
\text { NONCAR- } \\
\text { BONATE } \\
\text { (MG/L } \\
\text { CACO3) } \\
(00902)\end{array}$ & $\begin{array}{l}\text { CALCIUM } \\
\text { DIS- } \\
\text { SOLVED } \\
\text { (HG /L } \\
\text { AS CA) } \\
\text { (00915) }\end{array}$ & $\begin{array}{c}\text { MAGNE- } \\
\text { SIUH, } \\
\text { DIS- } \\
\text { SOLVED } \\
\text { (MG/L } \\
\text { AS MG) } \\
(00925)\end{array}$ & $\begin{array}{l}\text { SODIUH, } \\
\text { DIS- } \\
\text { SOLVED } \\
\text { (MG/L } \\
\text { AS NA) } \\
\text { (00930) }\end{array}$ & $\begin{array}{c}\text { SODIUH } \\
\text { AD- } \\
\text { SORP- } \\
\text { TION } \\
\text { RATIO } \\
1009311\end{array}$ & $\begin{array}{l}\text { PERCENT } \\
\text { SODIUH } \\
(00932)\end{array}$ & $\begin{array}{c}\text { SODIUM+ } \\
\text { POTAS- } \\
\text { SIUH } \\
\text { DIS- } \\
\text { SOLVED } \\
\text { (ME/L } \\
\text { AS NA) } \\
\text { (00933) }\end{array}$ & $\begin{array}{c}\text { POTAS- } \\
\text { SIUH, } \\
\text { DIS- } \\
\text { SOLVED } \\
\text { (MG/L } \\
\text { AS K) } \\
(00935)\end{array}$ \\
\hline $05-28-53$ & -- & -- & -- & 4400 & 3900 & 1000 & 450 & - & -- & 61 & 3200 & -- \\
\hline $06-02-54$ & -- & -- & -- & 4100 & 3700 & 940 & 420 & -- & 22 & 63 & 3200 & -- \\
\hline $06-02-54$ & -- & -- & - & 3700 & 3300 & 870 & 380 & - & 22 & 64 & 3000 & -- \\
\hline $06-03-54$ & -- & -- & -- & 4000 & 3600 & 1000 & 350 & -- & 13 & 51 & 1900 & - \\
\hline $08-15-79$ & -- & -- & -- & 1600 & 1400 & 540 & 70 & 1300 & 15 & -- & -- & -- \\
\hline $08-15-79$ & -- & -- & -- & -- & -- & -- & -- & -- & -- & -- & -- & -- \\
\hline $08-15-79$ & -- & -- & - & 1600 & 1400 & 540 & 70 & 1300 & 15 & -- & -- & -- \\
\hline $04-01-74$ & -- & 0.07 & -- & 970 & 730 & 240 & 90 & 1100 & 16 & 71 & -- & 13 \\
\hline $04-27-76$ & -- & - & -- & -- & -- & -- & -- & -- & -- & -- & -- & -- \\
\hline $06-23-77$ & -- & -- & -- & - & -- & -- & -- & -- & -- & -- & -- & -- \\
\hline $01-08-74$ & -- & $<0.01$ & -- & 2000 & 1900 & 550 & 160 & 1500 & 15 & 61 & -- & 18 \\
\hline $04-27-76$ & -- & -- & -- & -- & -- & -- & -- & -- & -- & -- & -- & -- \\
\hline $03-24-80$ & -- & -- & -- & 2100 & 2000 & 550 & 170 & 1600 & 16 & - & -- & -- \\
\hline $03-24-80$ & -- & -- & -- & 2100 & 2000 & 550 & 170 & 1600 & 16 & -- & -- & -- \\
\hline $06-16-55$ & -- & -- & -- & 1000 & 860 & 290 & 69 & -- & 17 & 73 & 1300 & -- \\
\hline $04-27-76$ & -- & -- & -- & -- & -- & -- & -- & -- & -- & -- & -- & -- \\
\hline $06-21-77$ & -- & -- & -- & -- & -- & - & -- & -- & -- & -- & -- & -- \\
\hline $08-16-79$ & -- & -- & -- & -- & -- & -- & -- & -- & -- & - & -- & -- \\
\hline $03-24-80$ & -- & - & -- & 830 & 710 & 280 & 35 & 1100 & 17 & - & -- & -- \\
\hline $03-24-80$ & - & -- & -- & 830 & 730 & 280 & 35 & 1100 & 17 & - & -- & -- \\
\hline $11-08-72$ & -- & 0.05 & -- & 5500 & 4900 & 1500 & 420 & 5800 & 35 & 70 & -- & 37 \\
\hline
\end{tabular}




\begin{tabular}{|c|c|c|c|c|c|c|c|c|c|c|c|}
\hline DATE & $\begin{array}{l}\text { CHLO- } \\
\text { RIDE, } \\
\text { DIS- } \\
\text { SOLVED } \\
\text { (MIG/L } \\
\text { AS CL) } \\
(00940)\end{array}$ & $\begin{array}{c}\text { SULFATE } \\
\text { DIS- } \\
\text { SOLVED } \\
\text { (MiG/L } \\
\text { AS SO4) } \\
\text { (00945) }\end{array}$ & $\begin{array}{c}\text { FLUO- } \\
\text { RIDE, } \\
\text { DIS- } \\
\text { SOLVED } \\
\text { (MG/L } \\
\text { AS F) } \\
(00950)\end{array}$ & $\begin{array}{c}\text { SILICA, } \\
\text { DIS- } \\
\text { SOLVED } \\
\text { (MG/L } \\
\text { AS } \\
\text { SIO2) } \\
(00955)\end{array}$ & $\begin{array}{c}\text { ARSENIC } \\
\text { TOTAL } \\
\text { (UG/L } \\
\text { AS AS) } \\
(01002)\end{array}$ & $\begin{array}{c}\text { BORON, } \\
\text { DIS- } \\
\text { SOLVED } \\
\text { (UG/L } \\
\text { AS B) } \\
\text { (01020) }\end{array}$ & $\begin{array}{l}\text { CADMIUH } \\
\text { TOTAL } \\
\text { RECOV- } \\
\text { ERABLE } \\
\text { (UG/L } \\
\text { AS CD) } \\
\text { (01027) }\end{array}$ & $\begin{array}{l}\text { CHRO- } \\
\text { MIUH, } \\
\text { TOTAL } \\
\text { RECOV- } \\
\text { ERABLE } \\
\text { (UG/L } \\
\text { AS CR) } \\
(01034)\end{array}$ & $\begin{array}{c}\text { COPPER, } \\
\text { TOTAL } \\
\text { RECOU- } \\
\text { ERABLE } \\
\text { (UG } / L \\
\text { AS CU) } \\
\text { (O1042) }\end{array}$ & $\begin{array}{c}\text { IROH, } \\
\text { TOTAL } \\
\text { RECON- } \\
\text { ERABLE } \\
\text { (UG/L } \\
\text { AS FE) } \\
\text { (01045) }\end{array}$ & $\begin{array}{c}\text { IROH, } \\
\text { DIS- } \\
\text { SOLVED } \\
\text { (U6/L } \\
\text { AS FE) } \\
(01046)\end{array}$ \\
\hline $05-28-53$ & 6000 & 2300 & 1.1 & 33 & -- & -- & -- & -- & -- & -- & - \\
\hline $06-02-54$ & 6000 & 2100 & -- & 19 & -- & -- & - & -- & $\rightarrow$ & -- & - \\
\hline $06-02-54$ & 5500 & 2100 & -- & 37 & -- & -- & -- & -- & -- & -- & -- \\
\hline $06-03-54$ & 4500 & 1300 & 0.5 & 30 & - & -- & -- & -- & -- & -- & -- \\
\hline $08-15-79$ & 2300 & 900 & 1.0 & -- & 0 & -- & $<0$ & $<0$ & 0 & 3 & -- \\
\hline $08-15-79$ & -- & -- & 1.0 & -- & -- & - & -- & -- & -- & -- & -- \\
\hline $08-15-79$ & 2300 & 900 & -- & - & -- & - & -- & -- & -- & -- & -- \\
\hline $04-01-74$ & 1800 & 610 & 2.1 & $4 !$ & -- & 1600 & -- & -- & -- & -- & 70 \\
\hline $04-27-76$ & -- & -- & 2.4 & -- & -- & -- & -- & -- & -- & -- & -- \\
\hline $06-23-77$ & -- & - & 2.0 & -- & - & -- & -- & -- & -- & -- & - \\
\hline $01-08-74$ & 2000 & 2400 & 2.1 & 32 & -- & 460 & -- & -- & -- & -- & $<10$ \\
\hline $04-27-76$ & -- & -- & 3.0 & -- & -- & -- & -- & -- & -- & -- & -- \\
\hline $03-24-80$ & 2400 & 2400 & 2.1 & -- & 0 & -- & $<0$ & $<0$ & 0 & 6 & -- \\
\hline $03-24-80$ & 2400 & 2400 & -- & -- & -- & -- & -- & -- & -- & -- & -- \\
\hline $06-16-55$ & 1800 & 980 & 4.0 & 44 & -- & -- & -- & -- & -- & -- & -- \\
\hline $04-27-76$ & - & -- & 5.3 & -- & -- & -- & -- & -- & -- & -- & -- \\
\hline $06-21-77$ & -- & -- & 3.1 & -- & -- & -- & -- & -- & -- & -- & -- \\
\hline $08-16-79$ & - & -- & 3.1 & -- & -- & -- & -- & -- & -- & - & -- \\
\hline $03-24-80$ & 1500 & 850 & 3.0 & - & 0 & -- & $<0$ & $<0$ & 0 & 0 & -- \\
\hline $03-24-80$ & 1500 & 850 & -- & - & - & -- & -- & -- & -- & -- & $\cdots$ \\
\hline $11-08-7$ & 11000 & 3200 & 4.4 & 27 & -- & 26000 & -- & -- & $=-$ & - & $<10$ \\
\hline
\end{tabular}




\begin{tabular}{|c|c|c|c|c|c|c|c|c|c|c|c|}
\hline DATE & $\begin{array}{l}\text { LEAD, } \\
\text { TOTAL } \\
\text { RECON- } \\
\text { ERABLE } \\
\text { (UG/L } \\
\text { AS PB) } \\
\text { (01051) }\end{array}$ & $\begin{array}{l}\text { MANGA- } \\
\text { NESE, } \\
\text { TOTAL } \\
\text { RECOV- } \\
\text { ERABLE } \\
\text { (UG/L } \\
\text { AS MN) } \\
\text { (01055) }\end{array}$ & $\begin{array}{l}\text { HANGA- } \\
\text { NESE, } \\
\text { DIS- } \\
\text { SOLVED } \\
\text { (UG/L } \\
\text { AS HN) } \\
\text { (01056) }\end{array}$ & $\begin{array}{l}\text { SILVER, } \\
\text { TOTAL } \\
\text { RECOV- } \\
\text { ERABLE } \\
\text { (UG/L } \\
\text { AS AG) } \\
\text { (01077) }\end{array}$ & $\begin{array}{c}\text { ZINC, } \\
\text { TOTAL } \\
\text { RECON- } \\
\text { ERABLE } \\
\text { (UG/L } \\
\text { AS IN) } \\
(01092)\end{array}$ & $\begin{array}{c}\text { SELE- } \\
\text { NIUH, } \\
\text { TOTAL } \\
\text { (UG/L } \\
\text { AS SE) } \\
\text { (01147) }\end{array}$ & $\begin{array}{c}\text { SOLIDS, } \\
\text { RESIDUE } \\
\text { AT } 180 \\
\text { DEG. C } \\
\text { DIS- } \\
\text { SDLVED } \\
\text { (AG/L) } \\
\text { (70300) }\end{array}$ & $\begin{array}{l}\text { SOLIDS, } \\
\text { SUM OF } \\
\text { CONSTI- } \\
\text { TUENTS, } \\
\text { DIS- } \\
\text { SOLVED } \\
\text { (MG/L) } \\
\text { (70301) }\end{array}$ & $\begin{array}{c}\text { SOLIDS, } \\
\text { DIS- } \\
\text { SOLVED } \\
\text { (TONS } \\
\text { PER } \\
\text { DAY) } \\
\text { (70302) }\end{array}$ & $\begin{array}{c}\text { SOLIDS, } \\
\text { DIS- } \\
\text { SOLVED } \\
\text { (TONS } \\
\text { PER } \\
\text { AC-FT) } \\
(70303)\end{array}$ & $\begin{array}{c}\text { NITRO- } \\
\text { GEN, } \\
\text { AMHONI } \\
\text { DIS- } \\
\text { SOLVEI } \\
\text { (HG/L } \\
\text { AS NH4) } \\
\text { (7I846) }\end{array}$ \\
\hline $05-28-53$ & -- & -- & -- & -- & -- & -- & -- & 13000 & - & 18.0 & -- \\
\hline $06-02-54$ & -- & - & -- & -- & -- & -- & -- & 13000 & - & 17.7 & -- \\
\hline $06-02-54$ & -- & -- & -- & - & - & -- & -- & 12000 & - & 16.6 & -- \\
\hline $06-03-54$ & -- & - & -- & - & -- & -- & -- & 9300 & -- & 12.7 & - \\
\hline $08-15-79$ & $<0$ & 1 & -- & $<0$ & 0 & 0 & 5280 & -- & -- & -- & -- \\
\hline $08-15-79$ & -- & -- & -- & -- & -- & -- & -- & -- & -- & -- & -- \\
\hline $08-15-79$ & -- & - & -- & - & - & -- & 5280 & -- & -- & -- & -- \\
\hline $04-01-74$ & -- & -- & $<10$ & -- & - & -- & -- & 4100 & - & 5.5 & -- \\
\hline $04-27-76$ & -- & - & -- & - & -- & - & -- & -- & -- & -- & -- \\
\hline $06-23-77$ & -- & -- & -- & - & -- & -- & -- & - & - & -- & -- \\
\hline $01-08-74$ & -- & -- & 40 & - & - & -- & - & 6800 & -- & 9.3 & -- \\
\hline $04-27-76$ & -- & -- & -- & -- & -- & - & -- & -- & -- & -- & -- \\
\hline $03-24-80$ & 0 & 1 & -- & $<0$ & 2 & 1 & 7020 & -- & -- & -- & -- \\
\hline $03-24-80$ & -- & -- & -- & -- & -- & -- & 7110 & -- & -- & -- & -- \\
\hline $06-16-55$ & -- & -- & -- & -- & -- & -- & -- & 4600 & -- & 6.3 & -- \\
\hline $04-27-76$ & -- & -- & -- & -- & -- & - & -- & -- & - & - & -- \\
\hline $06-21-77$ & - & -- & -- & -- & -- & -- & -- & -- & -- & -- & -- \\
\hline $08-16-79$ & -- & -- & -- & -- & -- & -- & -- & - & -- & -- & -- \\
\hline $03-24-80$ & 0 & $<0$ & -- & $<0$ & 0 & 0 & 3830 & -- & -- & -- & -- \\
\hline $03-24-80$ & -- & -- & -- & -- & -- & -- & 3830 & - & -- & -- & -- \\
\hline $11-08-72$ & -- & - & 6900 & -- & -- & -- & -- & 22000 & -- & 30.3 & -- \\
\hline
\end{tabular}




\begin{tabular}{|c|c|c|c|c|c|c|c|c|c|c|c|}
\hline DATE & $\begin{array}{c}\text { NITRO- } \\
\text { GEN, } \\
\text { NITRATE } \\
\text { TOTAL } \\
\text { (HG/L } \\
\text { AS NO3) } \\
\text { (71850) }\end{array}$ & $\begin{array}{c}\text { NITRO- } \\
\text { GEN, } \\
\text { MITRATE } \\
\text { OIS- } \\
\text { SOLVED } \\
\text { (HG/L } \\
\text { AS ND3) } \\
\text { (71851) }\end{array}$ & $\begin{array}{c}\text { NITRO- } \\
\text { GEN, } \\
\text { NITRITE } \\
\text { DIS- } \\
\text { SOLVED } \\
\text { IIRG/L } \\
\text { AS NO2) } \\
\text { (71856) }\end{array}$ & $\begin{array}{l}\text { NITRO- } \\
\text { GEN, } \\
\text { TOTAL } \\
\text { (HGG/L } \\
\text { AS NO3) } \\
\text { (71887) }\end{array}$ & $\begin{array}{c}\text { MERCURY } \\
\text { TOTAL } \\
\text { RECOU- } \\
\text { ERABLE } \\
\text { (UG/L } \\
\text { AS HG) } \\
(71900)\end{array}$ & $\begin{array}{l}\text { ELEV. } \\
\text { OF LAND } \\
\text { SURFACE } \\
\text { DATUK } \\
\text { (FT. } \\
\text { ABOVE } \\
\text { NGVD) } \\
\text { (72000) }\end{array}$ & $\begin{array}{c}\text { DEPTH } \\
\text { OF } \\
\text { HELL, } \\
\text { TOTAL } \\
\text { (FEET) } \\
\text { (72008) }\end{array}$ & $\begin{array}{c}\text { DEPTH } \\
\text { BELOW } \\
\text { LAND } \\
\text { SURFACE } \\
\text { (WATER } \\
\text { LEVEL) } \\
\text { (FEET) } \\
\text { (72019) }\end{array}$ & $\begin{array}{c}\text { SEDI- } \\
\text { MENT, } \\
\text { DIS- } \\
\text { CHARGE, } \\
\text { SUS- } \\
\text { PENDED } \\
\text { (T/DAY) } \\
\text { (BO155) }\end{array}$ & $\begin{array}{l}\text { SEDI- } \\
\text { MENT, } \\
\text { DISCH, } \\
\text { SUSP. + } \\
\text { BED HA- } \\
\text { TERIAL } \\
\text { (T/DAY) } \\
\text { (80156) }\end{array}$ & $\begin{array}{c}\text { DRAIN } \\
\text { AGE } \\
\text { AREA } \\
\text { (SQ. } \\
\text { HI.) } \\
(81024)\end{array}$ \\
\hline $05-28-53$ & -- & - & -- & -- & -- & -- & 11.91 & 10.31 & -- & -- & -- \\
\hline $06-02-54$ & 14 & - & -- & -- & -- & 640 & 17.30 & 11.54 & -- & -- & -- \\
\hline $06-02-54$ & 38 & -- & -- & -- & -- & 640 & 17.30 & 11.54 & -- & -- & -- \\
\hline $06-03-54$ & 55 & -- & -- & - & -- & 635 & 20.80 & 17.18 & -- & -- & -- \\
\hline $08-15-79$ & 30 & -- & -- & - & $<0$ & 640 & 960.00 & -- & -- & -- & -- \\
\hline $08-15-79$ & - & -- & -- & - & -- & 640 & 960.00 & -- & -- & -- & -- \\
\hline $08-15-79$ & -- & 30 & -- & - & -- & 640 & 960.00 & - & -- & - & -- \\
\hline $04-01-74$ & -- & 29 & 0.0 & -- & -- & 645 & 708.00 & - & -- & -- & -- \\
\hline $04-27-76$ & -- & - & - & -- & - & 645 & 708.00 & - & -- & - & -- \\
\hline $06-23-77$ & -- & -- & -- & -- & -- & 645 & 708.00 & -- & -- & - & -- \\
\hline $01-08-74$ & - & 49 & 0.0 & -- & -- & 660 & 1672.00 & -- & -- & - & -- \\
\hline $04-27-76$ & -- & -- & - & -- & -- & 660 & 1672.00 & -- & -- & -- & -- \\
\hline $03-24-80$ & 4.0 & -- & -- & - & $<0$ & 660 & 1672.00 & -- & -- & -- & -- \\
\hline $03-24-80$ & -- & 4.0 & -- & - & -- & 660 & 1672.00 & -- & -- & - & -- \\
\hline $06-16-55$ & -- & 53 & -- & -- & -- & 736 & 1000.00 & -- & -- & - & -- \\
\hline $04-27-76$ & - & -- & - & - & -- & 736 & 1000.00 & - & -- & -- & -- \\
\hline $06-21-77$ & -- & - & - & -- & -- & 736 & 1000.00 & -- & -- & -- & -- \\
\hline $08-16-79$ & -- & -- & - & -- & -- & 736 & 1000.00 & -- & -- & - & -- \\
\hline $03-24-80$ & 47 & - & -- & -- & $<0$ & 736 & 1000.00 & -- & - & -- & -- \\
\hline $03-24-80$ & -- & 49 & -- & -- & -- & 736 & 1000.00 & -- & -- & -- & -- \\
\hline $11-08-72$ & -- & -- & -- & - & -- & 518 & 1346.00 & - & -- & -- & -- \\
\hline
\end{tabular}


CHEMICAL ANALYSES FOR SELECTED HELLS IN AREA IN

(The following information was obtained from the U. S. Geological Survey, Tucson, Arizona)

LOCAL

IDENT-

I-

FIER
D-01-01 36AAA

D-01-01 उ6AAA

D-01-01 36AAA

D-01-01 36AAA

D-01-01 36AAA

D-01-01 36AAA

D-01-01 36AAA

D-01-01 उ6AAA

D-01-01 उ6AAA

D-01-01 36AAA

D-01-01 उ6AAA

D-0I-0I उ6AAA

D-01-01 36AAA

D-01-01 36AAA

D-01-01 36AAA

D-01-01 36AAA

D-01-01 36AAA

D-01-01 36AAA

D-01-05 3IAAA

D-01-05 31AAA

D-01-05 31AAA

D-01-05 3LAAA

D-01-05 JIAAA

D-0I-05 JIAAA

D-01-05 JIAAA

D-01-05 31AAA

D-01-05 J1AAA

D-01-05 31AAA

D-0I-05 JIAAA

D-01-05 31AAA

D-01-05 3IAAA

D-02-03 01BDA

D-02-03 01BDA

D-02-04 01AAA

D-02-04 11CAB

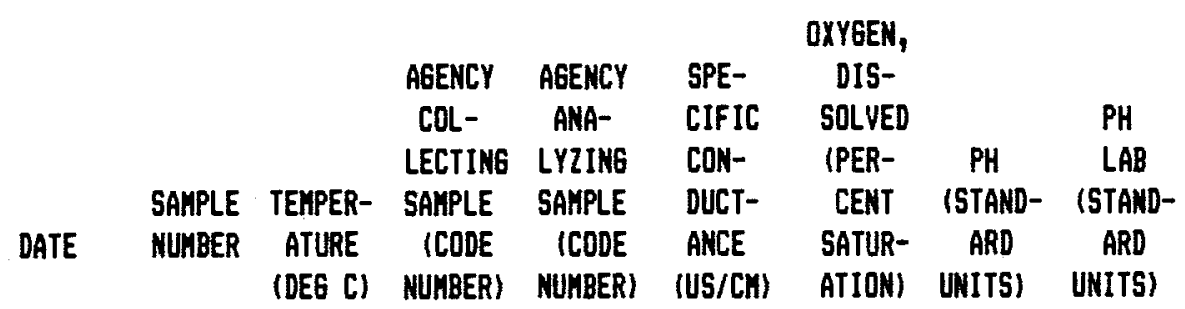

$\begin{array}{lllll}12-29-33 & - & - & - & - \\ 10-27-34 & - & - & - & - \\ 05-31-35 & - & - & - & - \\ 10-19-35 & -- & - & - & - \\ 05-09-36 & -- & 22.0 & -- & -\end{array}$

$\begin{array}{lllll}10-28-36 & - & 22.0 & -- & -- \\ 04-12-37 & -- & 22.0 & -- & -- \\ 04-07-38 & - & - & - & - \\ 09-20-38 & - & -- & -- & - \\ 09-23-42 & - & -- & - & -\end{array}$

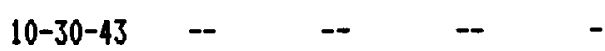

10-04-44 -- $\quad--\quad--$

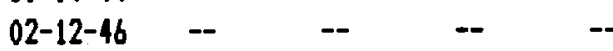

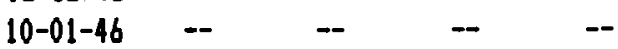

09-30-47

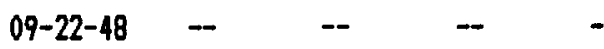

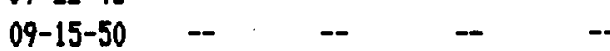

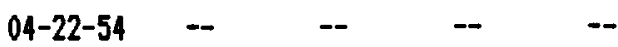

$\begin{array}{lllll}12-22-33 & - & -- & -- & -\end{array}$

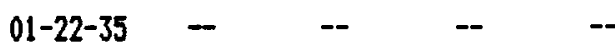

10-10-37 $\quad--\quad---\quad--$

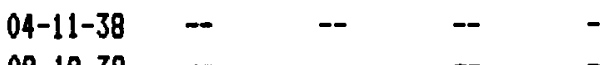

$\begin{array}{ccccc}09-19-38 & - & -- & - & - \\ 04-06-39 & - & -- & - & -\end{array}$

$\begin{array}{lllll}04-06-39 & - & -- & - & - \\ 09-27-39 & -- & -- & -- & -\end{array}$

11-07-39 $\quad-\quad-\quad--\quad--$

$\begin{array}{llll}04-23-40 & - & - & - \\ 10-08-40 & - & - & -\end{array}$

$\begin{array}{ccccc}10-08-40 & -- & -- & -- & - \\ 04-29-48 & -- & -- & -- & -\end{array}$

04-16-53 -- $\quad--\quad$--

04-09-57 -

09-16-75 --

08-04-82 --

08-05-80 1460

$08-01-80 \quad 1460$
$--$

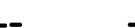

$-\infty$

$-$

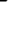

$4050 \quad--$

$4040 \quad--$

$4180 \quad--\quad \begin{array}{lll}4.4 & --\end{array}$

$4170 \quad--\quad 7.4 \quad-$

$4480 \quad--\quad 0 \quad 7.5 \quad--$

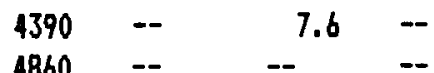

4860

$4560 \quad--\quad---\quad--$

$4590 \quad--\quad$-- $\quad$--

$4700 \quad--\quad---\quad--$

$4640 \quad--\quad---\quad--$

$\begin{array}{rrrr}4550 & -- & - & - \\ 4660 & - & 7.1 & -\end{array}$

$5140 \quad--\quad 7.4 \quad--$

7070

$8.1 \quad--$

$6900 \quad--\quad .7 .6 \quad--$

$6040 \quad--\quad 7.5 \quad-$

$5780 \quad--\quad 7.4 \quad--$

$\begin{array}{llll}7160 & - & -- & -- \\ 7090 & -- & -- & --\end{array}$

$-7080$

$7080 \quad--\quad---\quad--$

$5970 \quad--\quad---\quad--$

$7230 \quad--\quad---\quad-$

$4500 \quad--\quad--$

$5850 \quad--\quad 7.3 \quad-$

$5600 \quad--\quad 7.3 \quad-$

$5700 \quad--\quad--\quad-$

$\begin{array}{llll}6400 & -- & 6.9 & 7.4\end{array}$

$23.5 \quad 80020 \quad 80020$

3780

4990
$6.9 \quad--$

$7.0 \quad-$
$4620 \quad--\quad--$

$--$

$23.0 \quad--\quad 80020$ 


\begin{tabular}{|c|c|c|c|c|c|c|c|c|c|c|c|}
\hline DATE & $\begin{array}{c}\text { CARBON } \\
\text { DIOXIDE } \\
\text { DIS- } \\
\text { SOLVED } \\
\text { (MG/L } \\
\text { AS CO2) }\end{array}$ & $\begin{array}{l}\text { ALKA- } \\
\text { LINITY } \\
\text { FIELD } \\
\text { (MG/L } \\
\text { AS } \\
\text { CACO3) }\end{array}$ & $\begin{array}{c}\text { ACIDITY } \\
\text { (HGG/L } \\
\text { AS } \\
\text { CACO3) }\end{array}$ & $\begin{array}{l}\text { BICAR- } \\
\text { 8ONATE } \\
\text { FET-FLD } \\
\text { (MG/L } \\
\text { AS } \\
\text { HCO3) }\end{array}$ & $\begin{array}{c}\text { CAR- } \\
\text { BONATE } \\
\text { FET-FLD } \\
\text { (MG /L } \\
\text { AS COZ) }\end{array}$ & $\begin{array}{l}\text { SOLIDS, } \\
\text { RESIDUE } \\
\text { AT 105 } \\
\text { DEG. C, } \\
\text { SUS- } \\
\text { PENDED } \\
\text { (MG/L) }\end{array}$ & $\begin{array}{l}\text { NITRO- } \\
\text { GEN, } \\
\text { TOTAL } \\
\text { (MG/L } \\
\text { AS N) }\end{array}$ & $\begin{array}{c}\text { NITRO- } \\
\text { GEN, } \\
\text { ORGANIC } \\
\text { TOTAL } \\
\text { (MG/L } \\
\text { AS MI }\end{array}$ & $\begin{array}{c}\text { NITRO- } \\
\text { GEN, } \\
\text { ORGANIC } \\
\text { DIS- } \\
\text { SOLVED } \\
\text { IMG/L } \\
\text { AS NI }\end{array}$ & $\begin{array}{c}\text { MITRO- } \\
\text { GEN, } \\
\text { NITRATE } \\
\text { DIS- } \\
\text { SOLVED } \\
\text { MMG/L } \\
\text { AS NI }\end{array}$ & $\begin{array}{c}\text { MITRO- } \\
\text { GEN, } \\
\text { NITRATE } \\
\text { TOTAL } \\
\text { (MG/L } \\
\text { AS N) }\end{array}$ \\
\hline $12-29-33$ & -- & -- & -- & 590 & 0 & -- & -- & -- & -- & - & -- \\
\hline $10-27-34$ & 31 & -- & -- & 500 & 0 & -- & -- & -- & -- & - & -- \\
\hline $05-31-35$ & 32 & -- & -- & 500 & 0 & -- & -- & - & -- & -- & -- \\
\hline $10-19-35$ & 31 & - & -- & 490 & 0 & -- & -- & - & -- & -- & -- \\
\hline $05-09-36$ & 31 & -- & -- & 490 & 0 & -- & -- & -- & -- & -- & -- \\
\hline $10-28-36$ & 30 & -- & -- & 470 & 0 & - & -- & - & -- & -- & -- \\
\hline $04-12-37$ & 30 & -- & -- & 470 & 0 & -- & - & -- & - & - & -- \\
\hline $04-07-38$ & 24 & $-\infty$ & -- & 480 & 0 & -- & -- & - & -- & -- & -- \\
\hline $09-20-38$ & 19 & - & -- & 460 & 0 & -- & -- & -- & -- & -- & -- \\
\hline $09-23-42$ & -- & - & -- & 480 & 0 & -- & -- & - & -- & - & -- \\
\hline $10-30-43$ & -- & -- & - & 480 & 0 & -- & - & -- & -- & -- & -- \\
\hline $10-04-44$ & -- & -- & -- & 490 & 0 & -- & -- & -- & -- & -- & -- \\
\hline $02-12-46$ & -- & -- & -- & 500 & 0 & -- & -- & -- & -- & -- & $:-$ \\
\hline $10-01-46$ & - & -- & -- & 470 & 0 & -- & -- & -- & -- & -- & - \\
\hline $09-30-47$ & -- & -- & - & 460 & 0 & - & -- & -- & -- & -- & -- \\
\hline $09-22-48$ & -- & - & - & 460 & 0 & -- & -- & -- & -- & -- & -- \\
\hline $09-15-50$ & 58 & -- & -- & 460 & 0 & - & -- & -- & -- & -- & -- \\
\hline $04-22-54$ & 31 & -- & -- & 500 & 0 & -- & -- & -- & -- & - & -- \\
\hline $12-22-33$ & -- & -- & - & 410 & 0 & -- & -- & -- & -- & -- & -- \\
\hline $01-22-35$ & 5.8 & - & -- & 460 & 0 & -- & -- & -- & -- & -- & -- \\
\hline $10-10-37$ & 20 & -- & -- & 510 & 0 & -- & -- & - & -- & -- & -- \\
\hline $04-11-38$ & 21 & - & -- & 410 & 0 & -- & -- & - & -- & -- & -- \\
\hline $09-19-38$ & 24 & $\because$ & -- & 390 & 0 & -- & -- & -- & -- & -- & -- \\
\hline $04-06-39$ & -- & -- & -- & 570 & 0 & -- & -- & -- & -- & -- & -- \\
\hline $09-27-39$ & -- & -- & - & 520 & 0 & - & -- & -- & -- & - & -- \\
\hline $11-07-39$ & -- & -- & -- & $510^{\circ}$ & 0 & -- & -- & -- & -- & -- & -- \\
\hline $04-23-40$ & -- & - & -- & 390 & 0 & - & -- & -- & -- & -- & -- \\
\hline $10-08-40$ & -- & - & -- & 480 & 0 & -- & -- & -- & -- & -- & -- \\
\hline $04-29-48$ & -- & -- & -- & 490 & 0 & -- & -- & -- & -- & -- & -- \\
\hline $04-16-53$ & 34 & -- & -- & 420 & 0 & -- & -- & -- & -- & -- & -- \\
\hline $04-09-57$ & 34 & -- & -- & 430 & 0 & -- & -- & -- & -- & - & -- \\
\hline $09-16-75$ & -- & - & -- & -- & -- & -- & -- & -- & -- & -- & -- \\
\hline $08-04-82$ & 37 & -- & -- & -- & -- & -- & -- & -- & -- & -- & -- \\
\hline $08-05-80$ & 20 & 81 & -- & -- & -- & -- & -- & -- & -- & -- & -- \\
\hline $08-01-80$ & 21 & 110 & -- & -- & -- & -- & -- & - & -- & -- & - \\
\hline
\end{tabular}




\begin{tabular}{|c|c|c|c|c|c|c|c|c|c|c|c|}
\hline DATE & $\begin{array}{c}\text { NITRO- } \\
\text { GEM, } \\
\text { MO2+NO3 } \\
\text { DIS- } \\
\text { SOLVED } \\
\text { (MG/L } \\
\text { AS N) }\end{array}$ & $\begin{array}{c}\text { PHOS- } \\
\text { PHATE, } \\
\text { ORTHO, } \\
\text { DIS- } \\
\text { SOLVED } \\
\text { (MG/L } \\
\text { AS PO4) }\end{array}$ & $\begin{array}{c}\text { PHOS- } \\
\text { PHORUS, } \\
\text { ORGANIC } \\
\text { TOTAL } \\
\text { (MGG/L } \\
\text { AS P) }\end{array}$ & $\begin{array}{l}\text { PHOS- } \\
\text { PHORUS, } \\
\text { ORTHO, } \\
\text { DIS- } \\
\text { SOLVED } \\
\text { (MG/L } \\
\text { AS P) }\end{array}$ & $\begin{array}{l}\text { PHOS- } \\
\text { PHORUS, } \\
\text { ORGANIC } \\
\text { DIS- } \\
\text { SOLVED } \\
\text { (HG/L } \\
\text { AS P) }\end{array}$ & $\begin{array}{l}\text { CARBON, } \\
\text { ORGANIC } \\
\text { DIS- } \\
\text { SOLVED } \\
\text { (MG/L } \\
\text { AS C) }\end{array}$ & $\begin{array}{l}\text { HARD- } \\
\text { MESS } \\
\text { (MG/L } \\
\text { AS } \\
\text { CACO3) }\end{array}$ & $\begin{array}{c}\text { HARD- } \\
\text { MESS, } \\
\text { NONCAR- } \\
\text { BONATE } \\
\text { (MG/L } \\
\text { CACO3) }\end{array}$ & $\begin{array}{l}\text { CALCIUM } \\
\text { DIS- } \\
\text { SOLVED } \\
\text { (MG/L } \\
\text { AS CA) }\end{array}$ & $\begin{array}{l}\text { MAGNE- } \\
\text { SIUH, } \\
\text { DIS- } \\
\text { SOLVED } \\
\text { (MG/L } \\
\text { AS MG) }\end{array}$ & $\begin{array}{l}\text { SODIUH, } \\
\text { DIS- } \\
\text { SOLVED } \\
\text { (MG/L } \\
\text { AS MA) }\end{array}$ \\
\hline $12-29-33$ & -- & -- & -- & -- & -- & -- & 1100 & -- & 290 & 83 & 600 \\
\hline $10-27-34$ & -- & -- & -- & -- & -- & -- & 860 & -- & 200 & 84 & 570 \\
\hline $05-31-35$ & -- & -- & -- & -- & -- & -- & 860 & -- & 210 & 84 & 570 \\
\hline $10-19-35$ & -- & - & -- & -- & -- & -- & 890 & -- & 210 & 88 & 580 \\
\hline $05-09-36$ & -- & -- & -- & - & -- & -- & 860 & -- & 210 & 83 & 580 \\
\hline $10-28-36$ & -- & -- & -- & - & -- & -- & 870 & -- & 210 & 84 & 590 \\
\hline $04-12-37$ & -- & -- & -- & - & -- & -- & 860 & -- & 210 & 84 & 580 \\
\hline $04-07-38$ & -- & -- & -- & - & -- & -- & 940 & -- & 220 & 94 & 620 \\
\hline $09-20-38$ & -- & -- & -- & -- & -- & -- & 900 & -- & 210 & 89 & 620 \\
\hline $09-23-42$ & -- & -- & -- & -- & -- & -- & 1000 & -- & 240 & 110 & 680 \\
\hline $10-30-43$ & -- & - & -- & -- & -- & -- & 940 & -- & 220 & 95 & 640 \\
\hline $10-04-44$ & -- & -- & -- & -- & -- & -- & 950 & -- & 220 & 97 & 650 \\
\hline $02-12-46$ & -- & -- & -- & -- & -- & -- & 970 & -- & 230 & 97 & 670 \\
\hline $10-01-46$ & -- & -- & -- & -- & -- & -- & 950 & -- & 230 & 94 & 650 \\
\hline $09-30-47$ & -- & -- & -- & -- & -- & -- & 950 & -- & 220 & 95 & 640 \\
\hline $09-22-48$ & -- & -- & -- & - & -- & -- & 970 & - & 230 & 95 & 620 \\
\hline $09-15-50$ & -- & -- & -- & - & -- & -- & 1000 & -- & 250 & 100 & 670 \\
\hline $04-22-54$ & -- & -- & -- & - & -- & -- & 1200 & -- & 270 & 120 & 710 \\
\hline $12-22-33$ & -- & -- & -- & -- & -- & - & 530 & -- & 150 & 38 & 150 \\
\hline $01-22-35$ & -- & -- & -- & -- & $\because$ & -- & 1300 & -- & 320 & 120 & 1100 \\
\hline $10-10-37$ & -- & -- & -- & -- & -- & -- & 1100 & -- & 260 & 100 & 1100 \\
\hline $04-11-38$ & -- & -- & -- & - & -- & -- & 1200 & -- & 330 & 100 & 840 \\
\hline $09-19-38$ & -- & -- & -- & - & -- & -- & 1200 & -- & 340 & 98 & 790 \\
\hline $04-06-39$ & -- & -- & -- & - & -- & -- & 990 & - & 230 & 100 & 1200 \\
\hline $09-27-39$ & -- & -- & -- & -- & -- & - & 1000 & -- & 250 & 100 & 1200 \\
\hline $11-07-39$ & -- & -- & -- & -- & -- & -- & 1000 & -- & 250 & 100 & 1200 \\
\hline $04-23-40$ & -- & -- & -- & -- & -- & -- & 1200 & -- & 330 & 100 & 820 \\
\hline $10-08-40$ & -- & -- & -- & - & - & -- & 1100 & -- & 270 & 110 & $1200^{\circ}$ \\
\hline $04-29-48$ & -- & -- & -- & -- & -- & -- & 700 & -- & 180 & 60 & 700 \\
\hline $04-16-53$ & -- & -- & -- & - & -- & -- & 1300 & -- & 340 & 100 & 810 \\
\hline $04-09-57$ & -- & -- & -- & - & -- & - & 1300 & -- & 340 & 98 & 750 \\
\hline $09-16-75$ & -- & -- & -- & -- & -- & -- & -- & -- & -- & -- & -- \\
\hline $08-04-82$ & 13.0 & 0.03 & -- & 0.01 & -- & -- & 1400 & 1200 & 340 & 130 & 870 \\
\hline $08-05-80$ & 10.0 & 0.0 & -- & 0.00 & -- & 1.4 & 1100 & 1000 & 300 & 83 & 880 \\
\hline $08-01-80$ & 7.40 & 0.0 & -- & 0.00 & -- & 1.7 & 2100 & 2000 & 590 & 160 & 600 \\
\hline
\end{tabular}




\begin{tabular}{|c|c|c|c|c|c|c|c|c|c|c|c|}
\hline DATE & $\begin{array}{l}\text { SODIUM } \\
\text { AD- } \\
\text { SORP- } \\
\text { TION } \\
\text { RATIO }\end{array}$ & $\begin{array}{l}\text { PERCENT } \\
\text { SODIUH }\end{array}$ & $\begin{array}{c}\text { SODIUNA } \\
\text { POTAS- } \\
\text { SIUH } \\
\text { DIS- } \\
\text { SOLVED } \\
\text { (MG/L } \\
\text { AS NAI }\end{array}$ & $\begin{array}{l}\text { POTAS- } \\
\text { SIUH, } \\
\text { DIS- } \\
\text { SOLVED } \\
\text { (MG/L } \\
\text { AS K) }\end{array}$ & $\begin{array}{l}\text { CHLO- } \\
\text { RIDE, } \\
\text { DIS- } \\
\text { SOLVED } \\
\text { (MG/L } \\
\text { AS CL) }\end{array}$ & $\begin{array}{l}\text { SULFATE } \\
\text { DIS- } \\
\text { SOLVED } \\
\text { (MG/L } \\
\text { AS SO4) }\end{array}$ & $\begin{array}{l}\text { FLUO- } \\
\text { RIDE, } \\
\text { DIS- } \\
\text { SOLVED } \\
\text { (HIG/L } \\
\text { AS F) }\end{array}$ & $\begin{array}{l}\text { SILICA, } \\
\text { DIS- } \\
\text { SOLVED } \\
\text { (M6/L } \\
\text { AS } \\
\text { SI02) }\end{array}$ & $\begin{array}{c}\text { ARSENIC } \\
\text { DIS- } \\
\text { SOLVED } \\
\text { (UG/L } \\
\text { AS AS) }\end{array}$ & $\begin{array}{l}\text { ARSENIC } \\
\text { SUS- } \\
\text { PENDED } \\
\text { TOTAL } \\
\text { (UG/L } \\
\text { AS AS) }\end{array}$ & $\begin{array}{l}\text { ARSENI } \\
\text { TOTAL } \\
\text { IUG/L } \\
\text { AS AS }\end{array}$ \\
\hline $12-29-33$ & 8 & 55 & -- & 0.0 & 970 & 500 & -- & -- & -- & -- & -- \\
\hline $10-27-34$ & 9 & 59 & -- & 0.0 & 870 & 400 & -- & - & -- & -- & -- \\
\hline $05-31-35$ & 9 & 59 & - & 11 & 880 & 400 & -- & -- & -- & -- & -- \\
\hline $10-19-35$ & 9 & 59 & -- & 0.0 & 910 & 410 & -- & -- & -- & -- & -- \\
\hline $05-09-36$ & 9 & 60 & - & 0.0 & 890 & 410 & -- & -- & -- & -- & -- \\
\hline $10-28-36$ & 9 & 60 & - & 0.0 & 910 & 430 & -- & -- & -- & -- & -- \\
\hline $04-12-37$ & 9 & 59 & -- & 1.0 & 900 & 430 & -- & -- & -- & $-\infty$ & -- \\
\hline $04-07-38$ & 9 & 59 & -- & 4.0 & 990 & 470 & -- & -- & -- & -- & -- \\
\hline $09-20-38$ & 9 & 60 & -- & 0.0 & 960 & 470 & -- & -- & -- & - & -- \\
\hline $09-23-42$ & 9 & 59 & -- & 0.0 & 110 & 530 & -- & -- & -- & -- & -- \\
\hline $10-30-43$ & 9 & 60 & -- & 0.0 & 1000 & 480 & -- & -- & -- & -- & -- \\
\hline $10-04-44$ & 9 & 60 & -- & 0.0 & 1000 & 500 & -- & -- & -- & -- & -- \\
\hline $02-12-46$ & 10 & 60 & -- & 0.0 & 1000 & 520 & -- & -- & - & -- & -- \\
\hline $10-01-46$ & 9 & 60 & -- & 0.0 & 1000 & 520 & -- & -- & -- & -- & -- \\
\hline $09-30-47$ & 9 & 60 & -- & 0.0 & 1000 & 510 & -- & -- & -- & - & -- \\
\hline $09-22-48$ & 9 & 58 & -- & 0.0 & 970 & 510 & -- & -- & -- & -- & -- \\
\hline $09-15-50$ & 9 & -- & -- & -- & 1000 & 550 & -- & -- & -- & - & -- \\
\hline $04-22-54$ & 9 & -- & -- & -- & 1200 & 620 & -- & -- & -- & -- & -- \\
\hline $12-22-33$ & 3 & -- & -- & -- & 1800 & 900 & -- & -- & -- & - & -- \\
\hline $01-22-35$ & 14 & 65 & -- & 0.0 & 1800 & 760 & -- & -- & -- & -- & -- \\
\hline $10-10-37$ & 16 & 70 & - & 0.0 & 1700 & 730 & - & -- & -- & -- & - \\
\hline $04-11-38$ & 11 & 60 & -- & 4.0 & 1500 & 600 & -- & -- & -- & -- & $-\infty$ \\
\hline $09-19-38$ & 10 & 58 & -- & 0.0 & 1500 & 560 & -- & -- & -- & -- & -- \\
\hline $04-06-39$ & 18 & 73 & -- & 0.0 & 1700 & 790 & -- & -- & -- & -- & -- \\
\hline $09-27-39$ & 17 & 72 & -- & 0.0 & 1700 & 780 & -- & -- & -- & -- & -- \\
\hline $11-07-39$ & 16 & 71 & -- & 5.0 & 1700 & 760 & -- & -- & -- & -- & -- \\
\hline $04-23-40$ & 10 & 59 & -- & 0.0 & 1500 & 590 & -- & -- & -- & -- & -- \\
\hline $10-08-40$ & 16 & 70 & -- & 1.0 & 1800 & 800 & -- & -- & -- & -- & -- \\
\hline $04-29-48$ & 12 & 68 & -- & 1.0 & 950 & 450 & -- & - & -- & -- & -- \\
\hline $04-16-53$ & 10 & -- & -- & -- & 1400 & 620 & -- & -- & -- & -- & -- \\
\hline $04-09-57$ & 9 & -- & -- & - & 1300 & 580 & - & -- & -- & -- & -- \\
\hline $09-16-75$ & -- & - & -- & -- & -- & -- & 0.8 & -- & -- & -- & -- \\
\hline $08-04-82$ & 11 & 58 & -- & 8.4 & 1600 & 900 & 0.1 & 25 & -- & -- & -- \\
\hline $08-05-80$ & 12 & 63 & -- & 13 & 1500 & 630 & 0.5 & 21 & 3 & -- & -- \\
\hline $08-01-80$ & 6 & 38 & -- & 13 & 2000 & 640 & 0.4 & 34 & 5 & -- & -- \\
\hline
\end{tabular}




\begin{tabular}{|c|c|c|c|c|c|c|c|c|c|c|c|}
\hline DATE & $\begin{array}{l}\text { BARIUH, } \\
\text { DIS- } \\
\text { SOLVED } \\
\text { (UG/L } \\
\text { AS BA) }\end{array}$ & $\begin{array}{l}\text { BERYL- } \\
\text { LIUH, } \\
\text { DIS- } \\
\text { SOLVED } \\
\text { (UG/L } \\
\text { AS BE) }\end{array}$ & $\begin{array}{l}\text { BERYL- } \\
\text { LIUH, } \\
\text { TOTAL } \\
\text { RECOU- } \\
\text { ERABLE } \\
\text { (UG/L } \\
\text { AS BE) }\end{array}$ & $\begin{array}{l}\text { BORON, } \\
\text { DIS- } \\
\text { SOLVED } \\
\text { \{UG/L } \\
\text { AS BI }\end{array}$ & $\begin{array}{c}\text { CADHIUM } \\
\text { DIS- } \\
\text { SOLVED } \\
\text { (UG/L } \\
\text { AS CD) }\end{array}$ & $\begin{array}{c}\text { CADMIUH } \\
\text { SUS- } \\
\text { PENDED } \\
\text { RECOU- } \\
\text { ERABLE } \\
\text { (UG/L } \\
\text { AS CD) }\end{array}$ & $\begin{array}{l}\text { CADHIUH } \\
\text { TOTAL } \\
\text { RECOV- } \\
\text { ERABLE } \\
\text { (UG/L } \\
\text { AS CDI }\end{array}$ & $\begin{array}{c}\text { CHRO- } \\
\text { MIUH, } \\
\text { HEXA- } \\
\text { VALENT, } \\
\text { DIS. } \\
\text { (UG/L } \\
\text { AS CR) }\end{array}$ & $\begin{array}{l}\text { CHRO- } \\
\text { MIUH, } \\
\text { TOTAL } \\
\text { RECOV- } \\
\text { ERABLE } \\
\text { (UG/L } \\
\text { AS CR) }\end{array}$ & $\begin{array}{l}\text { COBALT, } \\
\text { DIS- } \\
\text { SOLLED } \\
\text { (UG/L } \\
\text { AS CO) }\end{array}$ & $\begin{array}{l}\text { COPPER, } \\
\text { DIS- } \\
\text { SOLVED } \\
\text { (UG/L } \\
\text { AS CU) }\end{array}$ \\
\hline $12-29-33$ & -- & - & -- & - & -- & -- & -- & -- & -- & -- & -- \\
\hline $10-27-34$ & -- & - & -- & -- & -- & -- & -- & -- & -- & - & -- \\
\hline $05-31-35$ & -- & - & -- & -- & -- & -- & -- & - & -- & -- & - \\
\hline $10-19-35$ & - & -- & -- & - & -- & -- & -- & -- & -- & -- & -- \\
\hline $05-09-36$ & -- & -- & -- & -- & -- & -- & -- & - & -- & -- & -- \\
\hline $10-28-36$ & -- & - & -- & -- & - & -- & -- & -- & -- & -- & -- \\
\hline $04-12-37$ & -- & -- & -- & -- & -- & -- & -- & -- & -- & -- & -- \\
\hline $04-07-38$ & -- & - & -- & 530 & -- & -- & -- & -- & -- & -- & -- \\
\hline $09-20-38$ & - & -- & -- & -- & -- & -- & -- & - & -- & -- & -- \\
\hline $09-23-42$ & -- & -- & -- & -- & -- & -- & -- & -- & -- & -- & - \\
\hline $10-30-43$ & -- & - & -- & -- & -- & -- & -- & -- & -- & -- & -- \\
\hline $10-04-44$ & -- & -- & -- & - & - & -- & -- & -- & -- & -- & -- \\
\hline $02-12-46$ & -- & -- & -- & -- & -- & - & -- & -- & -- & -- & -- \\
\hline $10-01-46$ & - & -- & -- & -- & -- & -- & -- & -- & -- & -- & -- \\
\hline $09-30-47$ & -- & -- & -- & -- & -- & -- & -- & -- & - & -- & -- \\
\hline $09-22-48$ & -- & - & -- & -- & -- & -- & -- & -- & -- & -- & -- \\
\hline $09-15-50$ & -- & -- & -- & -- & -- & -- & -- & -- & -- & -- & -- \\
\hline $04-22-54$ & -- & - & - & -- & -- & -- & -- & - & -- & -- & -- \\
\hline $12-22-33$ & -- & - & -- & -- & -- & -- & -- & - & - & -- & -- \\
\hline $01-22-35$ & -- & -- & -- & -- & -- & - & -- & - & -- & -- & -- \\
\hline $10-10-37$ & -- & -- & -- & 1800 & -- & - & -- & - & -- & -- & -- \\
\hline $04-11-38$ & -- & -- & -- & 1100 & -- & -- & -- & -- & -- & -- & - \\
\hline $09-19-38$ & -- & -- & -- & -- & - & -- & -- & -- & -- & -- & - \\
\hline $04-06-39$ & -- & - & -- & 2700 & -- & -- & -- & -- & -- & - & -- \\
\hline $09-27-39$ & -- & -- & -- & -- & -- & -- & -- & -- & -- & -- & -- \\
\hline $11-07-39$ & -- & -- & -- & -- & -- & - & -- & -- & -- & -- & - \\
\hline $04-23-40$ & -- & -- & -- & -- & -- & -- & -- & -- & -- & -- & -- \\
\hline $10-08-40$ & -- & - & -- & -- & -- & -- & -- & -- & -- & -- & -- \\
\hline $04-29-48$ & -- & -- & -- & -- & -- & - & -- & - & -- & -- & -- \\
\hline $04-16-53$ & -- & - & -- & - & -- & -- & -- & - & -- & -- & -- \\
\hline $04-09-57$ & - & -- & -- & -- & -- & -- & -- & - & -- & -- & -- \\
\hline $09-16-75$ & -- & -- & -- & -- & -- & -- & -- & -- & -- & -- & -- \\
\hline $08-04-82$ & -- & -- & -- & 2400 & -- & - & -- & -- & -- & -- & -- \\
\hline $08-05-80$ & 50 & $<1$ & -- & 1700 & $<1$ & -- & -- & 3 & -- & $\langle 3$ & $<10$ \\
\hline $08-01-80$ & 170 & $<1$ & -- & 940 & $<1$ & -- & -- & 10 & -- & $<3$ & $<10$ \\
\hline
\end{tabular}




\begin{tabular}{|c|c|c|c|c|c|c|c|c|c|c|c|}
\hline DATE & $\begin{array}{l}\text { COPPER, } \\
\text { SUS- } \\
\text { PENDED } \\
\text { RECOV- } \\
\text { ERABLE } \\
\text { IUG/L } \\
\text { AS CUI }\end{array}$ & $\begin{array}{l}\text { COPPER, } \\
\text { TOTAL } \\
\text { RECOV- } \\
\text { ERABLE } \\
\text { (UG/L } \\
\text { AS CU) }\end{array}$ & $\begin{array}{l}\text { IRON, } \\
\text { DIS- } \\
\text { SOLVED } \\
\text { (UG/L' } \\
\text { AS FE) }\end{array}$ & $\begin{array}{l}\text { LEAD, } \\
\text { DIS- } \\
\text { SOLVED } \\
\text { (UG/L } \\
\text { AS PB) }\end{array}$ & $\begin{array}{l}\text { LEAD, } \\
\text { TOTAL } \\
\text { RECOU- } \\
\text { ERABLE } \\
\text { (UG/L } \\
\text { AS PB) }\end{array}$ & $\begin{array}{l}\text { MANGA- } \\
\text { NESE, } \\
\text { DIS- } \\
\text { SOLVED } \\
\text { (UG/L } \\
\text { AS MN) }\end{array}$ & $\begin{array}{l}\text { MOLYB- } \\
\text { DENUH, } \\
\text { DIS- } \\
\text { SOLVED } \\
\text { (UG/L } \\
\text { AS MO) }\end{array}$ & $\begin{array}{l}\text { NICKEL, } \\
\text { DIS- } \\
\text { SOLVED } \\
\text { (UE/L } \\
\text { AS NI) }\end{array}$ & $\begin{array}{l}\text { NICKEL, } \\
\text { TOTAL } \\
\text { RECOV- } \\
\text { ERABLE } \\
\text { (UE/L } \\
\text { AS NI) }\end{array}$ & $\begin{array}{l}\text { STRON- } \\
\text { TIUK, } \\
\text { DIS- } \\
\text { SOLVED } \\
\text { (UG/L } \\
\text { AS SR) }\end{array}$ & $\begin{array}{l}\text { VANA- } \\
\text { DIUH, } \\
\text { DIS- } \\
\text { SOLVED } \\
\text { (UG/L } \\
\text { AS VI }\end{array}$ \\
\hline $12-29-33$ & -- & -- & -- & -- & -- & -- & -- & -- & -- & -- & -- \\
\hline $10-27-34$ & -- & - & -- & -- & -- & -- & -- & -- & -- & -- & -- \\
\hline $05-31-35$ & -- & -- & -- & -- & -- & -- & -- & - & -- & -- & -- \\
\hline $10-19-35$ & -- & -- & - & - & -- & - & -- & -- & -- & -- & -- \\
\hline $05-09-36$ & -- & -- & -- & - & -- & -- & -- & -- & -- & -- & -- \\
\hline $10-28-36$ & -- & - & -- & -- & -- & -- & -- & -- & - & -- & -- \\
\hline $04-12-37$ & -- & -- & -- & -- & -- & -- & -- & -- & -- & -- & -- \\
\hline $04-07-38$ & -- & - & -- & -- & - & -- & -- & -- & -- & -- & -- \\
\hline $09-20-38$ & -- & -- & -- & - & -- & -- & -- & -- & -- & -- & -- \\
\hline $09-23-42$ & -- & -- & -- & -- & -- & -- & -- & -- & -- & -- & -- \\
\hline $10-30-43$ & -- & -- & -- & - & -- & -- & -- & -- & -- & -- & -- \\
\hline $10-04-44$ & -- & -- & -- & -- & -- & -- & -- & -- & -- & -- & -- \\
\hline $02-12-46$ & -- & -- & -- & -- & -- & -- & -- & -- & -- & -- & -- \\
\hline $10-01-46$ & -- & -- & -- & -- & -- & -- & -- & -- & -- & -- & -- \\
\hline $09-30-47$ & - & -- & -- & -- & -- & -- & -- & -- & -- & -- & -- \\
\hline $09-22-48$ & -- & -- & -- & -- & -- & -- & -- & -- & - & -- & -- \\
\hline $09-15-50$ & -- & - & -- & -- & -- & -- & -- & -- & -- & -- & -- \\
\hline $04-22-54$ & -- & -- & -- & - & -- & - & -- & -- & -- & -- & -- \\
\hline $12-22-33$ & -- & -- & -- & -- & -- & -- & -- & -- & -- & -- & -- \\
\hline $01-22-35$ & -- & -- & -- & -- & -- & -- & -- & -- & -- & -- & -- \\
\hline $10-10-37$ & -- & -- & -- & -- & -- & -- & -- & -- & -- & -- & -- \\
\hline $04-11-38$ & -- & -- & -- & -- & -- & -- & -- & -- & -- & -- & -- \\
\hline $09-19-38$ & -- & - & -- & - & -- & -- & -- & -- & -- & -- & -- \\
\hline $04-06-39$ & - & - & -- & -- & -- & -- & -- & -- & -- & -- & -- \\
\hline $09-27-39$ & -- & - & -- & -- & - & -- & -- & -- & -- & -- & -- \\
\hline $11-07-39$ & -- & - & -- & - & -- & - & -- & -- & -- & -- & -- \\
\hline $04-23-40$ & -- & - & -- & -- & -- & -- & - & -- & -- & -- & -- \\
\hline $10-08-40$ & -- & -- & -- & - & -- & -- & -- & -- & -- & -- & -- \\
\hline $04-29-48$ & -- & -- & -- & -- & -- & -- & -- & - & - & -- & -- \\
\hline $04-16-53$ & -- & -- & - & - & -- & -- & -- & -- & -- & -- & -- \\
\hline $04-09-57$ & -- & -- & -- & - & $\cdots$ & -- & -- & -- & -- & -- & -- \\
\hline $09-16-75$ & -- & - & -- & -- & -- & -- & -- & -- & -- & -- & -- \\
\hline $08-04-82$ & -- & -- & 120 & -- & -- & 10 & -- & - & -- & -- & -- \\
\hline $08-05-80$ & -- & - & $<10$ & $<10$ & -- & $<1$ & $<10$ & -- & -- & 5800 & <b \\
\hline $08-01-80$ & -- & -- & 36 & $<10$ & -- & $<1$ & $<10$ & -- & - & 7600 & $<3$ \\
\hline
\end{tabular}




\begin{tabular}{|c|c|c|c|c|c|c|c|c|c|c|c|}
\hline DATE & $\begin{array}{l}\text { ZINC, } \\
\text { DIS- } \\
\text { SOLVED } \\
\text { (UG/L } \\
\text { AS IN) }\end{array}$ & $\begin{array}{l}\text { ZINC, } \\
\text { SUS- } \\
\text { PENDED } \\
\text { RECOV- } \\
\text { ERABLE } \\
\text { (US/L } \\
\text { AS ZN) }\end{array}$ & $\begin{array}{l}\text { ZINC, } \\
\text { TOTAL } \\
\text { RECON- } \\
\text { ERABLE } \\
\text { (UG/L } \\
\text { AS IN) }\end{array}$ & $\begin{array}{l}\text { ALUH- } \\
\text { INUH, } \\
\text { DIS- } \\
\text { SOLVED } \\
\text { (UG/L } \\
\text { AS AL) }\end{array}$ & $\begin{array}{c}\text { LITHIUM } \\
\text { DIS- } \\
\text { SOLVED } \\
\text { IUG/L } \\
\text { AS LI) }\end{array}$ & $\begin{array}{l}\text { SELE- } \\
\text { NIUH, } \\
\text { DIS- } \\
\text { SOLVED } \\
\text { (U6/L } \\
\text { AS SE) }\end{array}$ & $\begin{array}{l}\text { SELE- } \\
\text { NIUH, } \\
\text { SUS- } \\
\text { PENDED } \\
\text { TOTAL } \\
\text { (UG/L } \\
\text { AS SE) }\end{array}$ & $\begin{array}{l}\text { SELE- } \\
\text { NIUH, } \\
\text { TOTAL } \\
\text { (UG/L } \\
\text { AS SE) }\end{array}$ & $\begin{array}{l}\text { SOLIDS, } \\
\text { RESIDUE } \\
\text { AT } 180 \\
\text { DEG. C } \\
\text { DIS- } \\
\text { SOLVED } \\
\text { (MG/L) }\end{array}$ & $\begin{array}{l}\text { SOLIDS, } \\
\text { SUH OF } \\
\text { CONSTI- } \\
\text { TUENTS, } \\
\text { DIS- } \\
\text { SOLVED } \\
\text { (MG/L) }\end{array}$ & $\begin{array}{c}\text { SOLIDS } \\
\text { DIS- } \\
\text { SOLVE } \\
\text { (TONS } \\
\text { PER } \\
\text { DAY) }\end{array}$ \\
\hline $12-29-33$ & - & -- & -- & - & -- & -- & -- & -- & -- & 2700 & -- \\
\hline $10-27-34$ & -- & -- & -- & - & -- & - & -- & -- & 2640 & 2400 & -- \\
\hline $05-31-35$ & -- & -- & -- & -- & -- & - & -- & -- & 2620 & 2500 & -- \\
\hline $10-19-35$ & -- & -- & -- & -- & -- & -- & -- & - & 2640 & 2500 & -- \\
\hline $05-09-36$ & -- & -- & -- & - & -- & -- & -- & - & 2600 & 2500 & -- \\
\hline $10-28-36$ & -- & -- & -- & - & -- & -- & $\therefore$ & -- & 2630 & 2500 & -- \\
\hline $04-12-37$ & -- & -- & -- & - & -- & -- & -- & - & 2650 & 2500 & -- \\
\hline $04-07-38$ & -- & -- & -- & -- & -- & -- & -- & -- & -- & 2300 & -- \\
\hline $09-20-38$ & -- & -- & -- & - & -- & -- & -- & -- & -- & 2600 & -- \\
\hline $09-23-42$ & -- & -- & -- & -- & -- & -- & -- & - & -- & 1900 & -- \\
\hline $10-30-43$ & -- & -- & -- & -- & -- & -- & -- & -- & -- & 2700 & -- \\
\hline $10-04-44$ & -- & -- & -- & - & -- & - & -- & -- & -- & 2700 & -- \\
\hline $02-12-46$ & - & -- & -- & -- & -- & -- & -- & -- & -- & 2800 & -- \\
\hline $10-01-46$ & -- & -- & -- & - & -- & -- & -- & -- & -- & 2800 & -- \\
\hline $09-30-47$ & -- & -- & -- & - & -- & -- & -- & -- & -- & 2700 & -- \\
\hline $09-22-48$ & -- & - & -- & - & -- & - & -- & -- & -- & 2700 & - \\
\hline $09-15-50$ & -- & -- & -- & - & -- & -- & -- & -- & -- & 2900 & -- \\
\hline $04-22-54$ & -- & - & -- & -- & -- & -- & -- & -- & -- & 3200 & -- \\
\hline $12-22-33$ & -- & -- & -- & -- & -- & -- & -- & - & -- & 3400 & -- \\
\hline $01-22-35$ & -- & -- & -- & - & -- & - & -- & -- & 4780 & 4400 & -- \\
\hline $10-10-37$ & -- & - & -- & - & -- & -- & -- & - & 4330 & 4200 & -- \\
\hline $04-11-38$ & -- & -- & -- & -- & -- & -- & -- & -- & -- & 3600 & -- \\
\hline $09-19-38$ & -- & -- & -- & -- & -- & -- & -- & - & -- & 3500 & -- \\
\hline $04-06-39$ & -- & -- & -- & -- & -- & -- & -- & -- & -- & 4400 & -- \\
\hline $09-27-39$ & -- & -- & -- & -- & -- & -- & -- & -- & -- & 4300 & -- \\
\hline $11-07-39$ & -- & - & -- & - & -- & -- & -- & -- & -- & 4300 & -- \\
\hline $04-23-40$ & - & -- & -- & - & -- & -- & -- & -- & -- & 3500 & -- \\
\hline $10-08-40$ & -- & -- & -- & - & -- & -- & -- & -- & -- & 4400 & -- \\
\hline $04-29-48$ & - & - & -- & -- & -- & -- & -- & -- & -- & 2600 & -- \\
\hline $04-16-53$ & -- & -- & -- & - & -- & -- & -- & -- & -- & 3500 & -- \\
\hline $04-09-57$ & -- & -- & -- & -- & -- & -- & -- & -- & -- & 3300 & -- \\
\hline $09-16-75$ & -- & -- & -- & -- & -- & -- & -- & - & -- & - & -- \\
\hline $08-04-82$ & -- & - & -- & -- & -- & -- & -- & -- & -- & 4000 & -- \\
\hline $08-05-80$ & 10 & -- & -- & 20 & 580 & 6 & -- & -- & -- & 3500 & -- \\
\hline $08-01-80$ & 8 & -- & -- & 20 & 500 & 5 & -- & -- & -- & 4100 & -- \\
\hline
\end{tabular}




\begin{tabular}{|c|c|c|c|c|c|c|c|c|c|c|}
\hline DATE & $\begin{array}{c}\text { SOLIDS, } \\
\text { DIS- } \\
\text { SOLVED } \\
\text { (TONS } \\
\text { PER } \\
\text { AC-FT) }\end{array}$ & $\begin{array}{c}\text { NITRO- } \\
\text { GEN, } \\
\text { AMHONIA } \\
\text { DIS- } \\
\text { SOLVED } \\
\text { (HE/L } \\
\text { AS NH4) }\end{array}$ & $\begin{array}{c}\text { NITRO- } \\
\text { GEH, } \\
\text { NITRATE } \\
\text { TOTAL } \\
\text { (ME/L } \\
\text { AS NO3) }\end{array}$ & $\begin{array}{c}\text { NITRO- } \\
\text { GEN, } \\
\text { NITRATE } \\
\text { DIS- } \\
\text { SOLVED } \\
\text { (MG/L } \\
\text { AS MOZ) }\end{array}$ & $\begin{array}{c}\text { NITRO- } \\
\text { GEN, } \\
\text { NITRITE } \\
\text { DIS- } \\
\text { SOLVED } \\
\text { (HE/L } \\
\text { AS ND2) }\end{array}$ & $\begin{array}{c}\text { NITRO- } \\
\text { GEN, } \\
\text { TOTAL } \\
\text { (MG/L } \\
\text { AS NOS) }\end{array}$ & $\begin{array}{c}\text { MERCURY } \\
\text { DIS- } \\
\text { SOLVED } \\
\text { (UG/L } \\
\text { AS HG) }\end{array}$ & $\begin{array}{c}\text { MERCURY } \\
\text { SUS- } \\
\text { MPENDED } \\
\text { RECOV- } \\
\text { ERABLE } \\
\text { (UG/L } \\
\text { AS HE) }\end{array}$ & $\begin{array}{l}\text { MERCURY } \\
\text { TOTAL } \\
\text { RECOV- } \\
\text { ERABLE } \\
\text { (UG/L } \\
\text { AS HG) }\end{array}$ & $\begin{array}{c}\text { ELEV. } \\
\text { OF LAND } \\
\text { SURFACE } \\
\text { DATUH } \\
\text { (FT. } \\
\text { ABOVE } \\
\text { NGUD) }\end{array}$ \\
\hline $12-29-33$ & -- & -- & -- & 0.0 & -- & -- & -- & -- & - & -- \\
\hline $10-27-34$ & -- & -- & -- & 35 & - & -- & - & -- & -- & - \\
\hline $05-31-35$ & -- & -- & -- & 47 & -- & -- & - & - & -- & -- \\
\hline $10-19-35$ & -- & -- & -- & 43 & - & -- & - & -- & - & -- \\
\hline $05-09-36$ & -- & -- & -- & 34 & -- & -- & - & - & -- & -- \\
\hline $10-28-36$ & -- & -- & - & 31 & -- & -- & - & -- & -- & -- \\
\hline $04-12-37$ & - & - & - & 33 & -- & -- & - & -- & -- & -- \\
\hline $04-07-38$ & - & -- & -- & 29 & - & -- & - & -- & -- & -- \\
\hline $09-20-38$ & - & -- & -- & 29 & - & -- & - & -- & -- & -- \\
\hline $09-23-42$ & -- & -- & -- & 37 & -- & -- & - & -- & -- & -- \\
\hline $10-30-43$ & -- & -- & -- & 27 & -- & -- & -- & -- & -- & -- \\
\hline $10-04-44$ & -- & -- & -- & 24 & -- & -- & -- & -- & -- & -- \\
\hline $02-12-46$ & - & -- & -- & 22 & -- & -- & -- & -- & -- & -- \\
\hline $10-01-46$ & - & -- & - & 37 & -- & -- & - & -- & -- & -- \\
\hline $09-30-47$ & -- & -- & -- & 36 & -- & -- & - & -- & -- & -- \\
\hline $09-22-48$ & -- & - & -- & $3 !$ & -- & -- & -- & -- & -- & -- \\
\hline $09-15-50$ & - & -- & -- & 37 & -- & -- & - & -- & -- & -- \\
\hline $04-22-54$ & -- & -- & - & 34 & - & -- & - & -- & -- & -- \\
\hline $12-22-33$ & -- & -- & -- & - & -- & - & -- & -- & -- & 1193 \\
\hline $01-22-35$ & -- & -- & -- & 36 & -- & -- & -- & -- & - & 1193 \\
\hline $10-10-37$ & - & -- & -- & 26 & -- & -- & -- & -- & -- & 1193 \\
\hline $04-11-38$ & -- & -- & -- & 22 & -- & -- & -- & -- & -- & 1193 \\
\hline $09-19-38$ & -- & -- & -- & 31 & -- & -- & -- & -- & - & 1193 \\
\hline $04-06-39$ & -- & -- & -- & 29 & - & -- & -- & -- & -- & 1193 \\
\hline $09-27-39$ & -- & -- & - & 40 & -- & -- & -- & -- & -- & 1193 \\
\hline $11-07-39$ & - & - & -- & 33 & -- & -- & -- & - & -- & 1193 \\
\hline $04-23-40$ & -- & -- & -- & 27 & -- & -- & -- & -- & -- & 1193 \\
\hline $10-0 B-40$ & - & -- & - & 40 & -- & -- & -- & -- & -- & 1193 \\
\hline $04-29-48$ & -- & -- & -- & 28 & -- & -- & -- & -- & -- & 1193 \\
\hline $04-16-53$ & -- & -- & -- & 34 & -- & -- & -- & -- & -- & 1193 \\
\hline $04-09-57$ & -- & -- & -- & 34 & -- & -- & - & -- & -- & 1193 \\
\hline $09-16-75$ & -- & -- & -- & -- & -- & -- & -- & -- & -- & 1154 \\
\hline $08-04-82$ & 5.4 & -- & -- & -- & -- & -- & -- & -- & -- & 1154 \\
\hline$O B-05-B O$ & 4.7 & -- & -- & -- & -- & -- & 0 & -- & -- & -- \\
\hline $08-01-80$ & 5.6 & -- & -- & -- & -- & -- & 0 & -- & -- & -- \\
\hline
\end{tabular}




\begin{tabular}{|c|c|c|c|c|c|c|c|c|c|c|}
\hline DATE & $\begin{array}{l}\text { DEPTH } \\
\text { OF } \\
\text { MELL, } \\
\text { TOTAL } \\
\text { (FEET) }\end{array}$ & $\begin{array}{c}\text { DEPTH } \\
\text { TO BOT- } \\
\text { TOM OF } \\
\text { SAMPLE } \\
\text { INTER- } \\
\text { VAL } \\
\text { (FT) }\end{array}$ & $\begin{array}{c}\text { SEDI- } \\
\text { MENT, } \\
\text { DIS- } \\
\text { CHARGE, } \\
\text { SUS- } \\
\text { PENDED } \\
\text { (T/DAY) }\end{array}$ & $\begin{array}{c}\text { SEDI- } \\
\text { MENT, } \\
\text { DISCH, } \\
\text { SUSP. + } \\
\text { BED MA- } \\
\text { TERIAL } \\
\text { (T/DAY) }\end{array}$ & $\begin{array}{l}\text { DRAIN- } \\
\text { AGE } \\
\text { AREA } \\
\text { (SR. } \\
\text { HI.) }\end{array}$ & $\begin{array}{l}\text { H-2I } \\
\text { H-1/ } \\
\text { STABLE } \\
\text { ISOTOPE } \\
\text { RATIO } \\
\text { PER } \\
\text { HILL }\end{array}$ & $\begin{array}{l}0-18 / \\
0-16 \\
\text { STABLE } \\
\text { ISOTOPE } \\
\text { RATIO } \\
\text { PER } \\
\text { HIL }\end{array}$ & $\begin{array}{c}\text { SPE- } \\
\text { CIFIC } \\
\text { CON- } \\
\text { DUCT- } \\
\text { ANCE } \\
\text { LAB } \\
\text { (US/CH) }\end{array}$ & $\begin{array}{c}\text { ALKA- } \\
\text { LINITY } \\
\text { LAB } \\
\text { (HE/L } \\
\text { AS } \\
\text { CACO3) }\end{array}$ & $\begin{array}{l}\text { HARD- } \\
\text { NESS } \\
\text { MONCAR- } \\
\text { BONATE } \\
\text { (NG/L } \\
\text { AS } \\
\text { CACOS) }\end{array}$ \\
\hline $12-29-33$ & 700.00 & - & -- & -- & -- & -- & -- & - & - & 1070 \\
\hline $10-27-34$ & 700.00 & -- & - & -- & - & - & -- & - & - & 855 \\
\hline $05-31-35$ & 700.00 & -- & -- & - & -- & -- & - & - & -- & 860 \\
\hline $10-19-35$ & 700.00 & -- & - & -- & - & - & - & - & - & 887 \\
\hline $05-09-36$ & 700.00 & -- & -- & - & -- & -- & -- & -- & -- & 856 \\
\hline $10-28-36$ & 700.00 & -- & - & - & -- & -- & - & -- & - & 865 \\
\hline $04-12-37$ & 700.00 & -- & -- & -- & - & -- & -- & - & -- & 860 \\
\hline $04-07-38$ & 700.00 & - & - & - & - & -- & -- & -- & - & 941 \\
\hline $09-20-38$ & 700.00 & -- & - & -- & - & -- & -- & - & - & 901 \\
\hline $09-23-42$ & 700.00 & -- & -- & -- & - & - & -- & - & - & 1040 \\
\hline $10-30-43$ & 700.00 & -- & - & - & -- & -- & -- & -- & - & 936 \\
\hline $10-04-44$ & 700.00 & -- & -- & -- & -- & -- & - & -- & -- & 954 \\
\hline $02-12-46$ & 700.00 & -- & -- & -- & -- & - & - & -- & -- & 969 \\
\hline $10-01-46$ & 700.00 & -- & -- & -- & -- & -- & -- & -- & -- & 951 \\
\hline $09-30-47$ & 700.00 & -- & -- & -- & -- & -- & -- & -- & -- & 951 \\
\hline $09-22-48$ & 700.00 & -- & - & - & -- & -- & -- & -- & - & 966 \\
\hline $09-15-50$ & 700.00 & $\therefore$ & -- & - & -- & -- & - & -- & -- & 1030 \\
\hline $04-22-54$ & 700.00 & -- & -- & - & -- & -- & - & -- & -- & 1150 \\
\hline $12-22-33$ & 245.00 & 245 & -- & -- & -- & - & - & -- & -- & 531 \\
\hline $01-22-35$ & 245.00 & 245 & -- & -- & - & -- & - & -- & -- & 1300 \\
\hline $10-10-37$ & 245.00 & 245 & - & - & -- & -- & -- & -- & -- & 1080 \\
\hline $04-11-38$ & 245.00 & 245 & - & - & -- & -- & - & - & -- & 1240 \\
\hline $09-19-38$ & 245.00 & 245 & - & -- & -- & -- & - & -- & -- & 1250 \\
\hline $04-06-39$ & 245.00 & 245 & -- & -- & -- & -- & - & -- & - & 986 \\
\hline $09-27-39$ & 245.00 & 245 & -- & -- & - & - & -- & -- & -- & 1030 \\
\hline $11-07-39$ & 245.00 & 245 & - & -- & -- & -- & -- & -- & -- & 1050 \\
\hline $04-23-40$ & 245.00 & 245 & -- & - & -- & - & - & -- & - & 1250 \\
\hline $10-08-40$ & 245.00 & 245 & -- & -- & -- & -- & -- & -- & - & 1120 \\
\hline $04-29-48$ & 245.00 & 245 & -- & -- & - & -- & -- & -- & - & 704 \\
\hline $04-16-53$ & 245.00 & 245 & - & -- & - & -- & - & - & - & 1260 \\
\hline $04-09-57$ & 245.00 & 245 & - & -- & -- & -- & -- & -- & - & 1250 \\
\hline $09-16-75$ & 800.00 & - & -- & -- & -- & -- & -- & - & -- & -- \\
\hline $08-04-82$ & 800.00 & -- & -- & -- & -- & -- & -- & 6280 & 152 & 1380 \\
\hline $08-05-80$ & -- & -- & - & - & -- & -- & -- & -- & -- & 1100 \\
\hline $08-01-80$ & - & -- & - & -- & - & -6.9 & -0.9 & -- & -- & 2140 \\
\hline
\end{tabular}




$$
\begin{gathered}
\text { LOCAL } \\
\text { IDENT- } \\
\text { I- }
\end{gathered}
$$

FIER
D-02-04 I3ADA
$D-02-04$ 13ADA
$D-02-04$ 14AAD
$D-02-05$ 17CAA
$D-02-05$ 17CAA

$D-02-05$ 17CAA
$D-02-05$ 18AAA
$D-02-05$ 18AAA
$D-02-05$ 20BCC
$D-05-07$ 23DAA
D-05-08 20ADD

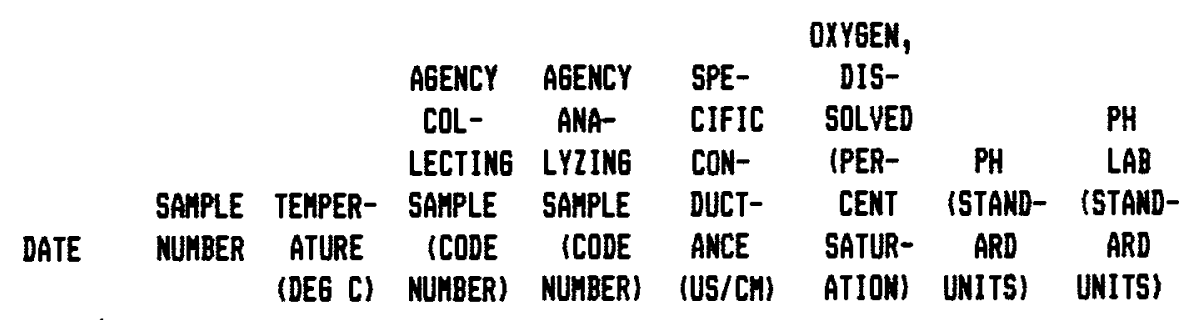

$08-04-80 \quad 1460$

08-05-82 --

$07-31-80 \quad 1460$

$07-03-75 \quad-$

07-25-79 -

07-26-80 1460

$07-02-75 \quad--$

07-15-80 1460

$07-25-80 \quad 1460$

08-30-82 --

$29.5 \quad-$

$28.5 \quad 8002$

24.5 , --

$25.0 \quad-$

--

80020

80020

4600

$6650 \quad--$

$6.9 \quad--$

09-04-41 -- $\begin{array}{lllllll}24.5 & -- & 80020 & 4350 & -- & 6.5 & -- \\ 24.0 & -- & -- & 5900 & -- & -- & -- \\ 23.5 & -- & 80020 & 4520 & - & 6.7 & -- \\ 24.5 & -- & 80020 & 4950 & -- & 6.8 & - \\ 24.0 & 80020 & 80020 & 5960 & -- & 7.2 & 8.1\end{array}$

$\begin{array}{lllll}24.5 & 80020 & 80020 & 4660 & --\end{array}$ $\begin{array}{ll}7.0 & 7.5\end{array}$

$7.0 \quad--$

$-$
SOLIDS, NITRO- NITRO-

RESIDUE NITRO- GEN, GEN, NITRO-

CARBON ALKA-

DIOXIDE LINITY

DIS- FIELD

SOLVED (MG/L

DATE IHG/L AS

\begin{tabular}{|c|c|c|c|c|c|c|c|c|c|c|c|}
\hline $08-04-80$ & 24 & 99 & -- & -- & -- & - & -- & -- & -- & - & - \\
\hline $08-05-82$ & 17 & -- & -- & -- & -- & -- & -- & -- & -- & -- & - \\
\hline $07-31-80$ & 27 & 140 & -- & -- & -- & -- & -- & -- & - & - & - \\
\hline $07-03-75$ & -- & - & -- & - & - & - & - & -- & -- & - & -- \\
\hline $07-25-79$ & -- & -- & - & -- & -- & - & - & - & - & - & -- \\
\hline $07-26-80$ & 40 & 66 & -- & -- & -- & - & -- & -- & -- & -- & -- \\
\hline $07-02-75$ & - & -- & -- & -- & -- & - & -- & - & -- & -- & -- \\
\hline $07-15-80$ & 73 & 190 & -- & - & -- & -- & -- & -- & -- & -- & -- \\
\hline $07-25-80$ & 49 & 160 & -- & -- & -- & -- & -- & -- & -- & -- & -- \\
\hline $08-30-82$ & 16 & - & -- & -- & -- & -- & -- & - & $=$ & -- & -- \\
\hline $09-04-41$ & - & 198 & -- & 240 & & - & -- & - & -- & -- & -- \\
\hline
\end{tabular}

AS $\mathrm{CO21}$ CACO3)

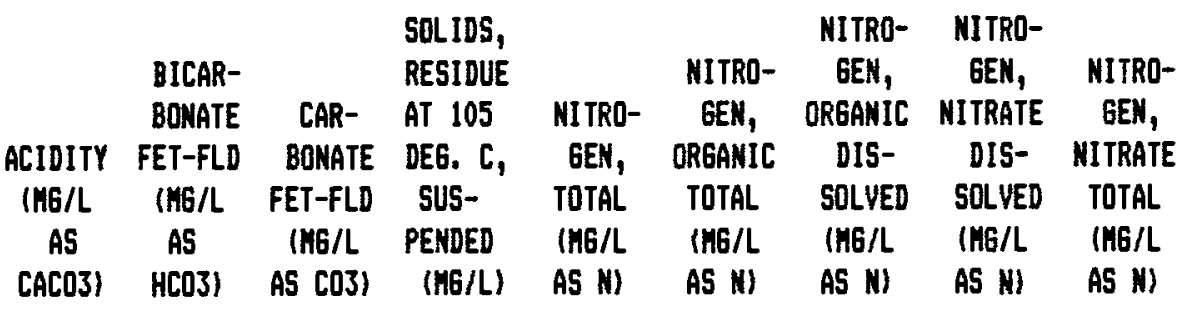




\begin{tabular}{|c|c|c|c|c|c|c|c|c|c|c|c|}
\hline DATE & $\begin{array}{l}\text { MITRO- } \\
\text { GEN, } \\
\text { MO2+NOZ } \\
\text { DIS- } \\
\text { SOLVED } \\
\text { (MG/L } \\
\text { AS NI }\end{array}$ & $\begin{array}{c}\text { PHOS- } \\
\text { PHATE, } \\
\text { ORTHO, } \\
\text { DIS- } \\
\text { SOLVED } \\
\text { (NG/L } \\
\text { AS PO4) }\end{array}$ & $\begin{array}{c}\text { PHOS- } \\
\text { PHORUS, } \\
\text { ORGANIC } \\
\text { TOTAL } \\
\text { (MG/L } \\
\text { AS P) }\end{array}$ & $\begin{array}{l}\text { PHOS- } \\
\text { PHORUS, } \\
\text { ORTHO, } \\
\text { DIS- } \\
\text { SOLVED } \\
\text { (MG/L } \\
\text { AS P) }\end{array}$ & $\begin{array}{l}\text { PHOS- } \\
\text { PHORUS, } \\
\text { ORGANIC } \\
\text { DIS- } \\
\text { SOLVED } \\
\text { (HG/L } \\
\text { AS P) }\end{array}$ & $\begin{array}{c}\text { CARBON, } \\
\text { ORGANIC } \\
\text { DIS- } \\
\text { SOLVED } \\
\text { (MG/L } \\
\text { AS C) }\end{array}$ & $\begin{array}{l}\text { HARD- } \\
\text { MESS } \\
\text { (MG/L } \\
\text { AS } \\
\text { CACO3) }\end{array}$ & $\begin{array}{c}\text { HARD- } \\
\text { NESS, } \\
\text { NONCAR- } \\
\text { BONATE } \\
\text { (HE/L } \\
\text { CACOZ) }\end{array}$ & $\begin{array}{l}\text { CALCIUM } \\
\text { DIS- } \\
\text { SOLVED } \\
\text { (HG/L } \\
\text { AS CA) }\end{array}$ & $\begin{array}{l}\text { MAGNE- } \\
\text { SIUM, } \\
\text { DIS- } \\
\text { SOLVED } \\
\text { (MG/L } \\
\text { AS MG) }\end{array}$ & $\begin{array}{l}\text { SODIUH, } \\
\text { DIS- } \\
\text { SOLVED } \\
\text { (MG/L } \\
\text { AS NA) }\end{array}$ \\
\hline $08-04-80$ & 13.0 & 0.0 & -- & 0.00 & -- & 4.6 & 2000 & 1900 & 520 & 160 & 570 \\
\hline $08-05-82$ & 14.0 & - & -- & $<0.01$ & -- & -- & 2000 & 1900 & 520 & 160 & 530 \\
\hline $07-31-80$ & 20.0 & 0.0 & -- & 0.00 & -- & -- & 3500 & 3400 & 1000 & 250 & 710 \\
\hline $07-03-75$ & -- & -- & -- & - & - & -- & -- & -- & - & -- & -- \\
\hline $07-25-79$ & - & -- & - & - & -- & -- & -- & -- & -- & -- & -- \\
\hline $07-26-80$ & 17.0 & 0.0 & -- & 0.00 & -- & - & 2200 & 2100 & 590 & 170 & 390 \\
\hline $07-02-75$ & - & -- & - & - & -- & - & -- & -- & -- & - & - \\
\hline $07-15-80$ & 20.0 & 0.0 & -- & 0.00 & -- & 11 & 2100 & 1900 & 600 & 150 & 420 \\
\hline $07-25-80$ & 18.0 & 0.0 & -- & 0.00 & -- & 1.1 & 1500 & 1400 & 410 & 120 & 680 \\
\hline $08-30-82$ & 17.0 & 0.03 & -- & 0.01 & - & - & 1200 & 1000 & 370 & 58 & 790 \\
\hline $09-04-41$ & -- & - & -- & - & -- & -- & 1600 & 1400 & 490 & 100 & -- \\
\hline DATE & $\begin{array}{l}\text { SODIUH } \\
\text { AD- } \\
\text { SORP- } \\
\text { TION } \\
\text { RATIO }\end{array}$ & $\begin{array}{l}\text { PERCENT } \\
\text { SODIUM }\end{array}$ & $\begin{array}{l}\text { SODIUM+ } \\
\text { POTAS- } \\
\text { SIUH } \\
\text { DIS- } \\
\text { SOLVED } \\
\text { (MG/L } \\
\text { AS NAI }\end{array}$ & $\begin{array}{l}\text { POTAS- } \\
\text { SIUM, } \\
\text { DIS- } \\
\text { SOLVED } \\
\text { (MG/L } \\
\text { AS K) }\end{array}$ & $\begin{array}{l}\text { CHLO- } \\
\text { RIDE, } \\
\text { DIS- } \\
\text { SOLVED } \\
\text { (MG/L } \\
\text { AS CL) }\end{array}$ & $\begin{array}{l}\text { SULFATE } \\
\text { DIS- } \\
\text { SOLVED } \\
\text { (MG/L } \\
\text { AS S04) }\end{array}$ & $\begin{array}{l}\text { FLUO- } \\
\text { RIDE, } \\
\text { DIS- } \\
\text { SOLVED } \\
\text { (MG/L } \\
\text { AS F) }\end{array}$ & $\begin{array}{l}\text { SILICA, } \\
\text { DIS- } \\
\text { SOLVED } \\
\text { (HG /L } \\
\text { AS } \\
\text { SIO2) }\end{array}$ & $\begin{array}{l}\text { ARSENIC } \\
\text { DIS- } \\
\text { SOLVED } \\
\text { (U6/L } \\
\text { AS AS) }\end{array}$ & $\begin{array}{l}\text { ARSENIC } \\
\text { SUS- } \\
\text { PENDED } \\
\text { TOTAL } \\
\text { (U6/L } \\
\text { AS AS) }\end{array}$ & $\begin{array}{l}\text { ARSENIC } \\
\text { TOTAL } \\
\text { (UG/L } \\
\text { AS AS) }\end{array}$ \\
\hline $08-04-80$ & 6 & 39 & -- & 12 & 1700 & 600 & 0.2 & 28 & 3 & - & - \\
\hline $08-05-82$ & 5 & 37 & -- & 10 & 1700 & 640 & 0.2 & 29 & -- & -- & -- \\
\hline $07-31-80$ & 5 & 30 & - & 14 & 2800 & 630 & 0.2 & 45 & - & - & -- \\
\hline $07-03-75$ & -- & - & -- & - & -- & -- & 0.7 & -- & -- & -- & -- \\
\hline $07-25-79$ & -- & -- & -- & -- & - & - & 0.8 & -- & -- & -- & -- \\
\hline $07-26-80$ & 4 & 28 & -- & 8.9 & $\cdot 1700$ & 540 & 0.2 & 4.7 & -- & -- & -- \\
\hline $07-02-75$ & -- & -- & -- & -- & - & - & 0.8 & -- & -- & -- & - \\
\hline $07-15-80$ & 4 & 30 & $\therefore$ & 10 & 1500 & 640 & 0.2 & 54 & 1 & -- & -- \\
\hline $07-25-80$ & 8 & 49 & - & 12 & 1700 & 650 & 0.4 & 49 & 2 & -- & -- \\
\hline $08-30-82$ & 11 & 59 & -- & 7.7 & 1100 & 1200 & 1.0 & 37 & - & -- & -- \\
\hline $09-04-41$ & -- & -- & 460 & -- & 970 & 980 & 1.4 & - & -- & -- & - \\
\hline
\end{tabular}




\begin{tabular}{|c|c|c|c|c|c|c|c|c|c|c|c|}
\hline DATE & $\begin{array}{l}\text { BARIUH, } \\
\text { DIS- } \\
\text { SOLVED } \\
\text { (UG/L } \\
\text { AS BA) }\end{array}$ & $\begin{array}{l}\text { BERYL- } \\
\text { LIUK, } \\
\text { DIS- } \\
\text { SOLVED } \\
\text { (UG/L } \\
\text { AS BE) }\end{array}$ & $\begin{array}{l}\text { BERYL- } \\
\text { LIUH, } \\
\text { TOTAL } \\
\text { RECOV- } \\
\text { ERABLE } \\
\text { (UG/L } \\
\text { AS BE) }\end{array}$ & $\begin{array}{l}\text { BORON, } \\
\text { DIS- } \\
\text { SOLVED } \\
\text { (UG/L } \\
\text { AS B) }\end{array}$ & $\begin{array}{c}\text { CADMIUH } \\
\text { DIS- } \\
\text { SOLVED } \\
\text { (UG/L } \\
\text { AS CD) }\end{array}$ & $\begin{array}{c}\text { CADHIUH } \\
\text { SUS- } \\
\text { PENDED } \\
\text { RECOV- } \\
\text { ERABLE } \\
\text { (UG/L } \\
\text { AS CD) }\end{array}$ & $\begin{array}{l}\text { CADHIUH } \\
\text { TOTAL } \\
\text { RECOU- } \\
\text { ERABLE } \\
\text { (UG/L } \\
\text { AS CD) }\end{array}$ & $\begin{array}{c}\text { CHRO- } \\
\text { MIUH, } \\
\text { HEXA- } \\
\text { VALENT, } \\
\text { DIS. } \\
\text { (UG/L } \\
\text { AS CR) }\end{array}$ & $\begin{array}{l}\text { CHRO- } \\
\text { MIUH, } \\
\text { TOTAL } \\
\text { RECOY- } \\
\text { ERABLE } \\
\text { (UG/L } \\
\text { AS CR) }\end{array}$ & $\begin{array}{l}\text { COBALT, } \\
\text { DIS- } \\
\text { SOLVED } \\
\text { (US/L } \\
\text { AS CO) }\end{array}$ & $\begin{array}{l}\text { COPPER, } \\
\text { DIS- } \\
\text { SOLVED } \\
\text { (UG/L } \\
\text { AS CU) }\end{array}$ \\
\hline $08-04-80$ & 220 & $<1$ & -- & 560 & $<1$ & -- & -- & 6 & -- & <3 & $\langle 1$ \\
\hline $08-05-82$ & -- & -- & -- & 630 & -- & -- & -- & -- & -- & - & -- \\
\hline $07-31-80$ & -- & - & -- & 910 & -- & - & -- & - & -- & -- & - \\
\hline $07-03-75$ & -- & -- & -- & -- & -- & -- & - & - & -- & -- & -- \\
\hline $07-25-79$ & -- & -- & -- & -- & - & -- & -- & - & - & -- & - \\
\hline $07-26-80$ & -- & - & -- & 970 & - & -- & -- & -- & -- & - & -- \\
\hline $07-02-75$ & -- & -- & -- & -- & - & -- & -- & - & - & - & -- \\
\hline $07-15-80$ & -- & -- & -- & 600 & -- & - & $-\cdots$ & 0 & -- & -- & - \\
\hline $07-25-80$ & 80 & $<1$ & - & 1400 & $<1$ & -- & -- & 0 & - & $\langle 3$ & \\
\hline $08-30-82$ & -- & - & - & 1600 & -- & -- & - & -- & - & - & -- \\
\hline $09-04-41$ & -- & -- & -- & -- & -- & -- & -- & - & - & -- & -- \\
\hline
\end{tabular}

COPPER,

SUS- COPPER, LEAD, MANGA- MOLYB- NICKEL, STRON- VANAPENDED TOTAL IRON, LEAD, TOTAL NESE, DENUH, NICKEL, TOTAL TIUH, DIUH, RECOV- RECOV- DIS- DIS- RECOV- DIS- DIS- DIS- RECOU- DIS- DISERABLE ERABLE SOLVED SOLVED ERABLE SOLVED SOLVED SOLVED ERABLE SOLVED SOLVED DATE IUG/L IUG/L IUG/L IUG/L IUG/L IUG/L IUG/L IUG/L IUG/L IUG/L IUG/L AS CUI AS CUI AS FE) AS PBI AS PB) AS NM) AS MOI AS NII AS NI) AS SRI AS V)

\begin{tabular}{|c|c|c|c|c|c|c|c|c|c|c|c|}
\hline $08-04-80$ & -- & -- & 57 & $<10$ & -- & 2 & <10 & - & -- & 7800 & \\
\hline $08-05-82$ & -- & -- & 60 & -- & -- & 20 & -- & -- & -- & -- & -- \\
\hline $07-31-80$ & -- & -- & 350 & -- & -- & 30 & -- & - & -- & -- & -- \\
\hline $07-03-75$ & -- & - & -- & -- & -- & -- & -- & -- & - & -- & -- \\
\hline $07-25-79$ & - & -- & - & - & -- & - & - & - & -- & - & - \\
\hline $07-26-80$ & - & -- & 70 & - & - & 10 & -- & - & -- & -- & $-\infty$ \\
\hline $07-02-75$ & -- & -- & -- & -- & - & -- & -- & + & -- & - & -- \\
\hline $07-15-80$ & -- & - & 80 & 3 & - & 20 & -- & -- & - & -- & -- \\
\hline $07-25-80$ & -- & -- & $<10$ & $<10$ & -- & $<1$ & $<10$ & -- & -- & 5000 & \\
\hline $08-30-82$ & -- & - & 90 & -- & - & 20 & -- & - & - & - & -- \\
\hline $09-04-41$ & -- & - & -- & - & - & -- & -- & -- & - & - & -- \\
\hline
\end{tabular}




\begin{tabular}{|c|c|c|c|c|c|c|c|c|c|c|c|c|c|c|c|}
\hline $\begin{array}{l}\text { ZINO } \\
\text { DIS } \\
\text { SOLV } \\
\text { IU6/ } \\
\text { AS ? }\end{array}$ & $\begin{array}{l}\text { INC, } \\
\text { DIS- } \\
\text { OLVED } \\
\text { U6/L } \\
S(H)\end{array}$ & $\begin{array}{l}\text { INC, } \\
\text { SUS- } \\
\text { ENDED } \\
\text { ECOV- } \\
\text { RABLE } \\
\text { UG/L } \\
\text { S INI }\end{array}$ & $\begin{array}{l}\text { ZINC } \\
\text { TOTA } \\
\text { RECO } \\
\text { ERABI } \\
\text { (UG/ } \\
\text { AS ZI }\end{array}$ & $\begin{array}{l}\text { ALI } \\
\text { INI } \\
\text { D. } \\
\text { SOL } \\
\text { IUE } \\
\text { AS }\end{array}$ & $\begin{array}{ll}\text { I- } & \\
\text { II, } & \text { LITH } \\
\text { S- } & \text { DI } \\
\text { VED } & \text { SOL } \\
\text { LL } & \text { IUE } \\
\text { AL) } & \text { AS }\end{array}$ & $\begin{array}{l}\text { IUH } \\
\text { S- } \\
\text { UED } \\
\text { IL } \\
\text { LII }\end{array}$ & $\begin{array}{l}\text { SELE } \\
\text { NIUH } \\
\text { DIS } \\
\text { SOLVI } \\
\text { UUG/L } \\
\text { AS St }\end{array}$ & & $\begin{array}{l}\text { SELE- } \\
\text { NIUH } \\
\text { SUS- } \\
\text { PENDS } \\
\text { TOTAL } \\
\text { IUG/L } \\
\text { AS SE }\end{array}$ & & $\begin{array}{l}\text { SELE- } \\
\text { NIUM, } \\
\text { TOTAL } \\
\text { (UG/L } \\
\text { AS SE) }\end{array}$ & $\begin{array}{r}\text { SOLID } \\
\text { RESID } \\
\text { AT } 18 \\
\text { DEG. } \\
\text { DIS } \\
\text { SOLV } \\
\text { (MG) }\end{array}$ & $\begin{array}{ll}\text { DS, } & \text { SOLI } \\
\text { DUE } & \text { SUH } \\
\text { BO } & \text { CONS } \\
\text { C } & \text { TUEN } \\
\text { S- } & \text { DI } \\
\text { UED } & \text { SOL } \\
\text { IL) } & \text { (ME }\end{array}$ & & $\begin{array}{c}\text { SOLIDS, } \\
\text { DIS- } \\
\text { SOLVED } \\
\text { (TONS } \\
\text { PER } \\
\text { DAY) }\end{array}$ \\
\hline $08-04-80$ & 9 & -- & -- & & 10 & 360 & & 3 & - & & -- & - & & 700 & -- \\
\hline $08-05-82$ & - & - & -- & - & - & & -- & & -- & & - & -- & & 600 & -- \\
\hline $07-31-80$ & - & -- & -- & - & - & & -- & & -- & & -- & - & & 500 & $\rightarrow$ \\
\hline $07-03-75$ & - & - & -- & - & - & & -- & & -- & & -- & -- & -- & & -- \\
\hline $07-25-79$ & - & -- & -- & - & - & & -- & & -- & & - & -- & - & & -- \\
\hline $07-26-80$ & -- & - & -- & - & - & & -- & & - & & -- & -- & & 100 & -- \\
\hline $07-02-75$ & - & - & -- & $\ldots$ & - & & - & & -- & & -- & -- & - & & -- \\
\hline $07-15-80$ & - & - & -- & & 10 & & & 0 & -- & & -- & -- & & 500 & - \\
\hline $07-25-80$ & 5 & - & -- & & 10 & 250 & & 4 & -- & & -- & -- & & 700 & -- \\
\hline $08-30-82$ & - & - & -- & - & - & & -- & & -- & & -- & -- & & 600 & - \\
\hline $09-04-41$ & - & - & -- & - & - & & -- & & -- & & -- & -- & & 200 & -- \\
\hline DATE & $\begin{array}{c}\text { SOLIDS, } \\
\text { DIS- } \\
\text { SOLVED } \\
\text { (TONS } \\
\text { PER } \\
\text { AC-FT) }\end{array}$ & $\begin{array}{r}\text { NITR } \\
\text { GEN } \\
\text { AHMON } \\
\text { DIS } \\
\text { SOLV } \\
\text { AS WH }\end{array}$ & & $\begin{array}{c}\text { NITRO- } \\
\text { GEN, } \\
\text { NITRATE } \\
\text { TOTAL } \\
\text { (MG/L } \\
\text { AS NO3) }\end{array}$ & $\begin{array}{c}\text { NITRD- } \\
\text { GEN, } \\
\text { NITRATE } \\
\text { DIS- } \\
\text { SOLVED } \\
\text { (MG/L } \\
\text { AS NOZ) }\end{array}$ & $\begin{array}{r}\text { NITR } \\
\text { GEN } \\
\text { NITRI } \\
\text { DIS } \\
\text { SOLV } \\
\text { MUGI } \\
\text { AS NO }\end{array}$ & $\begin{array}{l}\text { RO- } \\
\text { N, } \\
\text { ITE } \\
\text { S- } \\
\text { UED } \\
\text { LL } \\
\text { 2I }\end{array}$ & $\begin{array}{r}\text { NITRO } \\
\text { GEN, } \\
\text { TOTAL } \\
\text { (MG/L } \\
\text { AS NOS }\end{array}$ & & $\begin{array}{l}\text { HERCURY } \\
\text { DIS- } \\
\text { SOLVED } \\
\text { (UG/L } \\
\text { AS HG) }\end{array}$ & $\begin{array}{rr}\text { MERC } \\
\text { SU } \\
\text { MPEN } \\
\text { REC } \\
\text { D ERA } \\
\text { IUG } \\
\text { I) AS }\end{array}$ & $\begin{array}{l}\text { URY } \\
\text { IS- } \\
\text { IDED } \\
\text { OOV- } \\
\text { IBLE } \\
\text { BLL } \\
\text { HGI }\end{array}$ & $\begin{array}{l}\text { MERCURY } \\
\text { TOTAL } \\
\text { RECOV- } \\
\text { ERABLE } \\
\text { (UG/L } \\
\text { AS HG) }\end{array}$ & $\begin{array}{r}\text { ELE } \\
\text { OF L } \\
\text { SURF } \\
\text { OAT } \\
\text { IF } \\
\text { ABO } \\
\text { NGV }\end{array}$ & $\begin{array}{l}\text { EV. } \\
\text { LAND } \\
\text { AACE } \\
\text { TUH } \\
\text { ET. } \\
\text { OUE } \\
\text { VDI }\end{array}$ \\
\hline $08-04-80$ & 5.0 & - & & -- & - & -- & & -- & & 0 & -- & & -- & -- & \\
\hline $08-05-82$ & 5.0 & -- & & -- & -- & -- & & -- & & -- & -- & & -- & -- & \\
\hline $07-31-80$ & 7.5 & -- & & - & -- & -- & & -- & & -- & -- & & -- & -- & \\
\hline $07-03-75$ & -- & -- & & -- & -- & -- & & -- & & -- & -- & & -- & 119 & \\
\hline $07-25-79$ & -- & -- & & -- & - & -- & & -- & & - & -- & & -- & 119 & \\
\hline $07-2 b-80$ & 4.7 & -- & & - & -- & -- & & -- & & -- & -- & & -- & 119 & \\
\hline $07-02-75$ & -- & -- & & -- & -- & -- & & - & & -- & -- & & -- & - & \\
\hline $07-15-80$ & 4.7 & -- & & - & -- & -- & & -- & & 0 & -- & & -- & -- & \\
\hline $07-25-80$ & 5.1 & -- & & -- & -- & -- & & -- & & 0 & -- & & -- & -- & \\
\hline $08-30-82$ & 5.0 & -- & & -- & -- & -- & & -- & & -- & - & & -- & 138 & \\
\hline $09-04-41$ & - & -- & & 39 & -- & -- & & -- & & -- & - & & -- & 141 & \\
\hline
\end{tabular}




\begin{tabular}{|c|c|c|c|c|c|c|c|c|c|c|}
\hline DATE & $\begin{array}{l}\text { DEPTH } \\
\text { OF } \\
\text { HELL, } \\
\text { TOTAL } \\
\text { (FEET) }\end{array}$ & $\begin{array}{c}\text { DEPTH } \\
\text { TO BOT- } \\
\text { TOH DF } \\
\text { SAAPLE } \\
\text { IMTER- } \\
\text { VAL } \\
\text { (FT) }\end{array}$ & $\begin{array}{c}\text { SEDI- } \\
\text { MENT, } \\
\text { DIS- } \\
\text { CHARGE, } \\
\text { SUS- } \\
\text { PENDED } \\
\text { (T/DAY) }\end{array}$ & $\begin{array}{l}\text { SEDI- } \\
\text { MENT, } \\
\text { DISCH, } \\
\text { SUSP. + } \\
\text { BED HA- } \\
\text { TERIAL } \\
\text { (T/DAY) }\end{array}$ & $\begin{array}{l}\text { DRAIN- } \\
\text { AGE } \\
\text { AREA } \\
\text { (SQ. } \\
\text { HI.) }\end{array}$ & $\begin{array}{l}\text { H-2I } \\
\text { H-1/ } \\
\text { STABLE } \\
\text { ISOTOPE } \\
\text { RATIO } \\
\text { PER } \\
\text { HILL }\end{array}$ & $\begin{array}{l}0-18 / \\
0-16 \\
\text { STABLE } \\
\text { ISOTOPE } \\
\text { RATIO } \\
\text { PER } \\
\text { HIL }\end{array}$ & $\begin{array}{c}\text { SPE- } \\
\text { CIFIC } \\
\text { CON- } \\
\text { DUCT- } \\
\text { ANCE } \\
\text { LAB } \\
\text { (US/CH) }\end{array}$ & $\begin{array}{c}\text { ALKA- } \\
\text { LINITY } \\
\text { LAB } \\
\text { (M6/L } \\
\text { AS } \\
\text { CACO3) }\end{array}$ & $\begin{array}{c}\text { HARD- } \\
\text { MESS } \\
\text { MDNCAR- } \\
\text { BOHATE } \\
\text { (MG/L } \\
\text { AS } \\
\text { CACO3) }\end{array}$ \\
\hline $8-04-80$ & - & -- & - & -- & - & -- & - & -- & - & 1970 \\
\hline $08-05-82$ & -- & -- & - & - & - & -- & - & 6150 & 88 & 1960 \\
\hline $07-31-80$ & - & - & - & -- & - & - & - & - & - & 3530 \\
\hline $07-03-75$ & 500.00 & - & - & - & - & -- & -- & -- & - & -- \\
\hline $07-25-79$ & 500.00 & - & - & - & - & -- & - & - & - & -- \\
\hline $07-26-80$ & 500.00 & - & - & -- & - & - & - & -- & - & 2170 \\
\hline $07-02-75$ & 350.00 & - & - & -- & -- & - & -- & - & - & -- \\
\hline $07-15-80$ & 350.00 & - & - & - & -- & -- & - & -- & - & 2120 \\
\hline $07-25-80$ & - & - & - & - & -- & - & - & -- & - & 1530 \\
\hline $08-30-82$ & 212.00 & - & - & -- & - & - & -- & 5420 & 132 & 1160 \\
\hline $09-04-41$ & 160.00 & -- & -- & -- & - & -- & -- & -- & -- & 1630 \\
\hline
\end{tabular}


CHEHICAL ANALYSES FOR SELECTED WELLS IN AREA $V$

\begin{tabular}{|c|c|c|c|c|c|c|c|c|c|c|c|c|}
\hline LOCATION & DATE & $\begin{array}{l}\text { DEPTH } \\
\text { OF WELL } \\
\text { (FEET) }\end{array}$ & $\begin{array}{c}\mathrm{HCOS} \\
(\mathrm{HG} / \mathrm{L})\end{array}$ & $\begin{array}{c}\cos \\
(n 6 / L)\end{array}$ & $\begin{array}{c}C L \\
(M G / L)\end{array}$ & $\begin{array}{c}504 \\
\text { (M6/L) }\end{array}$ & $\begin{array}{l}M A+K \\
(M 6 / L)\end{array}$ & $\begin{array}{c}\text { CA } \\
\text { (MG/L) }\end{array}$ & $\begin{array}{c}\text { MG } \\
\text { (MG/L) }\end{array}$ & $\begin{array}{l}\text { NITRO- } \\
\text { GEN } \\
\text { AS NO3 } \\
\text { (NG/L) }\end{array}$ & $\begin{array}{l}\text { PHOS- } \\
\text { POROUS } \\
\text { (MG/L) }\end{array}$ & $\begin{array}{c}\text { TDS } \\
\text { (NG/L) }\end{array}$ \\
\hline$D-4-23 \quad 17 D C$ & $04-06-43$ & 18 & 177 & - & 1570 & 522 & 1053 & 190 & 34 & 1 & - & 3460 \\
\hline $0-4-23 \quad 17 C D$ & $08-06-43$ & - & 613 & - & 1990 & 1049 & 1412 & 381 & 93 & 2 & - & 5230 \\
\hline$D-4-23 \quad 17 C D$ & $04-17-44$ & - & 211 & - & 1690 & 576 & 1140 & 210 & 37 & .5 & - & 3760 \\
\hline$D-5-24 \quad 06 C D$ & $09-12-41$ & - & 411 & - & 3690 & 1147 & 2486 & 381 & 91 & - & - & 8010 \\
\hline$D-5-24 \quad 06 C D$ & $09-09-43$ & - & 131 & - & 1980 & 802 & 1470 & 167 & 33 & 2 & - & 4520 \\
\hline$D-6-24 \quad 02 C D$ & $08-16-43$ & - & 934 & - & 1355 & 989 & 1547 & 145 & 45 & 1 & - & 4450 \\
\hline $0-5-230100$ & $03-25-43$ & 18 & 578 & - & 1750 & 702 & 1002 & 415 & 112 & 1 & - & 4270 \\
\hline \multicolumn{13}{|c|}{ Source: Hea, 1950} \\
\hline $0-3-22 \quad 29$ & $06-00-55$ & 102 & 366 & - & 1528 & 560 & 717 & 450 & 90 & - & - & 3711 \\
\hline $0-4-23 \quad 11$ & $08-00-55$ & so & 476 & - & 2800 & 750 & 1672 & 365 & 149 & - & - & 6212 \\
\hline $0-4-23 \quad 17$ & $04-00-58$ & 120 & 434 & - & 1903 & 944 & 1369 & 223 & 121 & - & - & 4994 \\
\hline $0-6-24 \quad 07$ & $07-00-61$ & 48 & 503 & - & 954 & 525 & 761 & 160 & 61 & - & - & 2964 \\
\hline $0-7-26 \quad 05$ & $11-00-58$ & 200 & 49 & - & 8275 & 1740 & 5879 & 185 & 64 & - & - & 16191 \\
\hline $0-7-26 \quad 06$ & $12-00-59$ & - & 547 & - & 1184 & 633 & 878 & 244 & 63 & - & - & 3549 \\
\hline $0-8-26 \quad 06$ & $04-00-59$ & 65 & 215 & - & 1400 & 720 & 489 & 521 & 135 & - & - & 3501 \\
\hline
\end{tabular}


CHEMICAL ANALYSES FOR SELECTED MELLS IN AREA VI

(The following information was obtained fron the U.S. Geological Survey, Tucson, Arizona)

$$
\begin{aligned}
& \text { LOCAL } \\
& \text { IDENT- } \\
& \text { I- } \\
& \text { FIER }
\end{aligned}
$$

\begin{tabular}{|c|c|c|c|c|c|c|c|c|c|}
\hline ATE & $\begin{array}{l}\text { SAHPLE } \\
\text { NUMBER }\end{array}$ & $\begin{array}{l}\text { TEMPER- } \\
\text { ATURE } \\
\text { (DEG C) }\end{array}$ & $\begin{array}{l}\text { A6ENCY } \\
\text { ANA- } \\
\text { LYZING } \\
\text { SAMPLE } \\
\text { (CODE } \\
\text { MUMBER) }\end{array}$ & $\begin{array}{l}\text { SPE- } \\
\text { CIFIC } \\
\text { CON- } \\
\text { DUCT- } \\
\text { ANCE } \\
\text { (US/CH) }\end{array}$ & $\begin{array}{c}\text { DIS- } \\
\text { SOLVED } \\
\text { (PER- } \\
\text { CENT } \\
\text { SATUR- } \\
\text { ATIOH) }\end{array}$ & $\begin{array}{l}\text { PH } \\
\text { (STAMD- } \\
\text { ARD } \\
\text { UNITS) }\end{array}$ & $\begin{array}{c}\text { CARBOH } \\
\text { DIDXIDE } \\
\text { DIS- } \\
\text { SOLVED } \\
\text { (HG/L } \\
\text { AS CO2) }\end{array}$ & $\begin{array}{c}\text { ALKA- } \\
\text { LINITY } \\
\text { FIELD } \\
\text { (MG/L } \\
\text { A5 } \\
\text { CACOZ) }\end{array}$ & $\begin{array}{c}\text { ACIDITY } \\
\text { (MG/L } \\
\text { A5 } \\
\text { CACO3) }\end{array}$ \\
\hline
\end{tabular}

$\begin{array}{rrrrrrrrrr}07-02-75 & - & 15.0 & 1028 & 8800 & - & 6.9 & 87 & 356 & -- \\ 12-22-71 & -- & 19.5 & 1028 & 6390 & - & 7.5 & 17 & 271 & -- \\ 09-12-47 & -- & -- & 9902 & -- & -- & -- & -- & 356 & -- \\ 08-22-57 & 1280 & 15.0 & 1028 & 8330 & -- & 8.5 & 1.2 & 218 & -- \\ 12-22-71 & -- & 18.0 & 1028 & 90400 & - & 7.0 & 84 & 435 & -- \\ & & & & & & & & & \\ 02-27-79 & 1120 & 14.0 & 1028 & 6650 & -- & 7.7 & 6.0 & 160 & - \\ 02-20-79 & 1120 & 13.0 & 1028 & 6100 & -- & 7.6 & 8.0 & 160 & - \\ 06-16-72 & 1280 & 17.0 & 1028 & 5870 & - & 7.5 & 13 & 220 & - \\ 05-02-66 & 1280 & 18.0 & 1028 & 12100 & -- & 11.1 & -- & -- & - \\ 06-18-75 & -- & 15.0 & 1028 & 5500 & -- & - & - & 402 & -\end{array}$

A-14-27 15BDC

$A-16-23 \quad 158 A D$

A-16-30 190BC1

A-18-17 05CAA

A-18-24 OBBCB

$A-19-16 \quad 20 B C D$

A-19-16 $28 C C C$

A-19-16 3608B

$A-19-1705000$

A-19-23 190CB 


\begin{tabular}{|c|c|c|c|c|c|c|c|c|c|c|c|}
\hline DATE & $\begin{array}{l}\text { PHOS- } \\
\text { PHORUS, } \\
\text { ORTHO, } \\
\text { DIS- } \\
\text { SOLVED } \\
\text { (NG/L } \\
\text { AS P) }\end{array}$ & $\begin{array}{c}\text { PHOS- } \\
\text { PHORUS, } \\
\text { ORGANIC } \\
\text { DIS- } \\
\text { SOLVED } \\
\text { (MG/L } \\
\text { AS P) }\end{array}$ & $\begin{array}{l}\text { HARD- } \\
\text { MESS } \\
\text { MGG/L } \\
\text { AS } \\
\text { CACO3) }\end{array}$ & $\begin{array}{l}\text { HARD- } \\
\text { NESS, } \\
\text { NONCAR- } \\
\text { BONATE } \\
\text { (HG/L } \\
\text { CACO3) }\end{array}$ & $\begin{array}{l}\text { CALCIUH } \\
\text { DIS- } \\
\text { SOLVED } \\
\text { (MG/L } \\
\text { AS CA) }\end{array}$ & $\begin{array}{l}\text { MAGNE- } \\
\text { SIUH, } \\
\text { DIS- } \\
\text { SOLVED } \\
\text { (MG/L } \\
\text { AS MG) }\end{array}$ & $\begin{array}{l}\text { SODIUH, } \\
\text { DIS- } \\
\text { SOLVED } \\
\text { (HG/L } \\
\text { AS NA) }\end{array}$ & $\begin{array}{l}\text { SODIUM } \\
\text { AD- } \\
\text { SORP- } \\
\text { TION } \\
\text { RATIO }\end{array}$ & $\begin{array}{l}\text { PERCENT } \\
\text { SODIUN }\end{array}$ & $\begin{array}{l}\text { SODIUAH } \\
\text { POTAS- } \\
\text { SIUH } \\
\text { DIS- } \\
\text { SOLVED } \\
\text { (HG/L } \\
\text { AS NAI }\end{array}$ & $\begin{array}{l}\text { POTAS- } \\
\text { SIUH, } \\
\text { DIS- } \\
\text { SOLVED } \\
\text { (MG/L } \\
\text { AS K) }\end{array}$ \\
\hline $07-02-75$ & $<0.01$ & -- & 2400 & 2100 & 600 & 230 & 1200 & 11 & 51 & - & 15 \\
\hline $12-22-71$ & 0.02 & -- & 330 & 63 & 96 & 23 & 1200 & 30 & 88 & - & 12 \\
\hline $09-12-47$ & - & - & 640 & 280 & 230 & 19 & 1300 & 23 & -- & -- & -- \\
\hline $08-22-57$ & -- & - & 460 & 240 & 96 & 53 & -- & 34 & 89 & 1700 & -- \\
\hline $12-22-71$ & 0.15 & - & 3000 & 2500 & 880 & 190 & 24000 & 200 & 95 & -- & 37 \\
\hline $02-27-79$ & $<0.01$ & - & 440 & 280 & 79 & 60 & 1200 & 25 & 85 & - & 12 \\
\hline $02-20-79$ & 0.03 & -- & 440 & 280 & 93 & 51 & 1200 & 26 & 85 & - & 11 \\
\hline $06-16-72$ & 0.01 & - & 640 & 420 & 150 & 64 & 1000 & 18 & 77 & -- & 7.5 \\
\hline $05-02-66$ & - & - & 500 & -- & 200 & 0.8 & -- & - & -- & 1300 & - \\
\hline $06-18-75$ & 0.03 & - & 220 & 0 & 81 & 5.4 & 1200 & 37 & 92 & -- & 4.5 \\
\hline
\end{tabular}

\begin{tabular}{|c|c|c|c|c|c|c|c|c|c|c|c|}
\hline DATE & $\begin{array}{l}\text { CHLO- } \\
\text { RIDE, } \\
\text { DIS- } \\
\text { SOLVED } \\
\text { (MG/L } \\
\text { AS CL) }\end{array}$ & $\begin{array}{c}\text { SULFATE } \\
\text { DIS- } \\
\text { SOLVED } \\
(\mathrm{HG} / \mathrm{L} \\
\text { AS SO4) }\end{array}$ & $\begin{array}{l}\text { FLUD- } \\
\text { RIDE, } \\
\text { DIS- } \\
\text { SOLVED } \\
\text { (MG/L } \\
\text { AS F) }\end{array}$ & $\begin{array}{l}\text { SILICA, } \\
\text { DIS- } \\
\text { SOLVED } \\
\text { (MG/L } \\
\text { AS } \\
\text { SI02) }\end{array}$ & $\begin{array}{l}\text { BOROH, } \\
\text { DIS- } \\
\text { SOLVED } \\
\text { (UG/L } \\
\text { AS B) }\end{array}$ & $\begin{array}{l}\text { IRON, } \\
\text { TOTAL } \\
\text { RECOV- } \\
\text { ERABLE } \\
\text { (UG/L } \\
\text { AS FE) }\end{array}$ & $\begin{array}{l}\text { IRON, } \\
\text { DIS- } \\
\text { SOLVED } \\
\text { (UG/L } \\
\text { AS FE) }\end{array}$ & $\begin{array}{l}\text { HANGA- } \\
\text { NESE, } \\
\text { DIS- } \\
\text { SOLVED } \\
\text { IUG/L } \\
\text { AS NN) }\end{array}$ & $\begin{array}{c}\text { SOLIDS, } \\
\text { RESIDUE } \\
\text { AT } 180 \\
\text { DEG. C } \\
\text { DIS- } \\
\text { SOLVED } \\
\text { (MG/L) }\end{array}$ & $\begin{array}{c}\text { SOLIDS, } \\
\text { SUH OF } \\
\text { CONSTI- } \\
\text { TUENTS, } \\
\text { DIS- } \\
\text { SOLVED } \\
\text { (HG/L) }\end{array}$ & $\begin{array}{c}\text { SOLIDS, } \\
\text { DIS- } \\
\text { SOLVED } \\
\text { (TOHS } \\
\text { PER } \\
\text { DAY) }\end{array}$ \\
\hline $07-02-75$ & 2200 & 1700 & 1.1 & 13 & 640 & -- & $<10$ & -- & 6330 & $6200^{\circ}$ & -- \\
\hline $12-22-71$ & 1800 & 270 & 1.7 & 10 & -- & 40 & -- & 130 & -- & 3600 & - \\
\hline $09-12-47$ & 1700 & 300 & 1.2 & -- & -- & -- & - & -- & -- & 3800 & -- \\
\hline $08-22-57$ & 2500 & 380 & 0.8 & - & -- & -- & - & -- & -- & 4800 & -- \\
\hline $12-22-71$ & 37000 & 1700 & 3.2 & 8.3 & - & -- & 20 & 310 & -- & 64000 & -- \\
\hline $02-27-79$ & 1800 & 300 & 0.2 & 5.8 & 230 & - & 80 & $<10$ & -- & 3600 & -- \\
\hline $02-20-79$ & 1800 & 320 & 0.3 & 9.8 & 250 & -- & $<10$ & $<10$ & -- & 3600 & -- \\
\hline $06-16-72$ & 1500 & 52 & 0.2 & 10 & -- & -- & 10 & 18 & -- & 2900 & -- \\
\hline $05-02-66$ & 3800 & 490 & 0.5 & - & -- & -- & -- & -- & -- & 6600 & -- \\
\hline $06-18-75$ & 890 & 1100 & 1.9 & 10 & 1200 & -- & $<10$ & -- & 3560 & 3500 & - \\
\hline
\end{tabular}




\begin{tabular}{|c|c|c|c|c|c|c|c|c|c|c|c|}
\hline DATE & $\begin{array}{c}\text { SOLIDS, } \\
\text { DIS- } \\
\text { SOLVED } \\
\text { (TONS } \\
\text { PER } \\
\text { AC-FT) }\end{array}$ & $\begin{array}{c}\text { HY- } \\
\text { DROXIDE } \\
\text { ION } \\
\text { FET-FLD } \\
\text { (HG/L } \\
\text { AS OH) }\end{array}$ & $\begin{array}{c}\text { NITRO- } \\
\text { GEN, } \\
\text { AMMONIA } \\
\text { DIS- } \\
\text { SOLVED } \\
\text { (MG/L } \\
\text { AS NHA) }\end{array}$ & $\begin{array}{c}\text { NITRO- } \\
\text { GEN, } \\
\text { MITRATE } \\
\text { DIS- } \\
\text { SOLVED } \\
\text { (HG/L } \\
\text { AS NO3) }\end{array}$ & $\begin{array}{c}\text { NITRD- } \\
\text { GEN, } \\
\text { NITRITE } \\
\text { DIS- } \\
\text { SOLVED } \\
\text { (HG/L } \\
\text { AS NO2) }\end{array}$ & $\begin{array}{l}\text { NITRO- } \\
\text { GEN, } \\
\text { TOTAL } \\
\text { (MG/L } \\
\text { AS NOJ) }\end{array}$ & $\begin{array}{c}\text { ELEV. } \\
\text { OF LAND } \\
\text { SURFACE } \\
\text { DATUH } \\
\text { (FT. } \\
\text { ABOVE } \\
\text { NGVD) }\end{array}$ & $\begin{array}{l}\text { DEPTH } \\
\text { OF } \\
\text { WELL, } \\
\text { TOTAL } \\
\text { (FEET) }\end{array}$ & $\begin{array}{c}\text { SEDI- } \\
\text { MENT, } \\
\text { DIS- } \\
\text { CHARGE, } \\
\text { SUS- } \\
\text { PENDED } \\
\text { (T/DAY) }\end{array}$ & $\begin{array}{l}\text { SEDI- } \\
\text { MEMT, } \\
\text { DISCH, } \\
\text { SUSP. + } \\
\text { BED MA- } \\
\text { TERIAL } \\
\text { IT/DAY) }\end{array}$ & $\begin{array}{l}\text { DRAIN- } \\
\text { AGE } \\
\text { AREA } \\
\text { (SQ. } \\
\text { MI.) }\end{array}$ \\
\hline $07-02-75$ & 8.6 & -- & -- & 1.9 & 0.2 & -- & 5565 & 105.00 & -- & - & -- \\
\hline $12-22-71$ & 4.9 & - & -- & - & -- & -- & 5395 & 500.00 & -- & - & -- \\
\hline $09-12-47$ & -- & - & -- & -- & -- & -- & 5798 & 1360.00 & - & -- & -- \\
\hline $08-22-57$ & 6.6 & -- & - & 1.1 & - & -- & 4885 & 409.00 & -- & -- & - \\
\hline $12-22-71$ & 87.1 & -- & -- & -- & - & -- & 5299 & 600.00 & -- & -- & \\
\hline$-27-79$ & 4.8 & - & - & - & -- & - & 4845 & 198.00 & -- & -- & - \\
\hline $02-20-79$ & 4.9 & - & -- & -- & -- & -- & 4860 & 198.00 & -- & -- & \\
\hline $06-16-72$ & 4.0 & -- & -- & - & -- & -- & 4890 & 610.00 & -- & -- & $\cdots$ \\
\hline & -- & 50 & -- & -- & -- & -- & 5165 & 680.00 & -- & -- & $\cdots$ \\
\hline $06-18-75$ & 4.8 & -- & -- & 1.8 & 0.03 & -- & 5375 & 33.00 & -- & - & \\
\hline
\end{tabular}


APPENDI CES 